\title{
Program Evaluation:
} Weatherization Residential Assistance Partnership (WRAP)
Program

\section{Volume III}

Appendices D, E, F, and G

Prepared for

Northeast Utilities

WRAP Task Force

Prepared by

ICF Resources Incorporated

December 1991

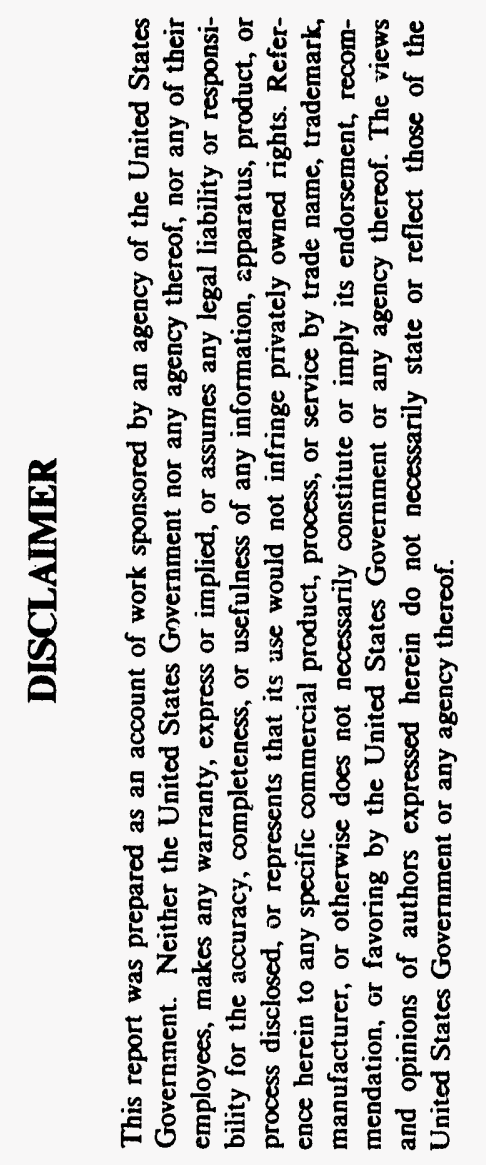


this evaluation report is dedicated to the memory of

\section{Charles R. "Tom" Dunklee}


The complete program evaluation comprises five documents:

Principal evaluation document:

Program Evaluation: Weatherization Residential Assistance Partnership (WRAP) Program, ICF Resources Incorporated, December 1991.

Volume I: Final Report

Volume II: Appendices A, B, and C

Volume III: Appendices D, E, F, and G

Companion documents:

WRAP Program Evaluation, Steven Ferrey \& Associates, 1990.

Process Evaiuation, Weatherization Residential Assistance Partnership (WRAP Program), Technical Development Corporation, October 1990.

Key conclusions and documentation from both companion documents have been incorporated into the principal report.

Key Investigators:

ICF Resources Incorporated 9300 Lee Highway

Fairfax, Virginia 22031

(703) 934-3000

Steven Ferrey \& Associates

Technical Development Corporation
Bonnie B. Jacobson, Vice President

Barbara Lundien, Analyst Jeffrey Kaufman, Analyst

Adam Kreczko, Associate

Steven Ferrey

Stephen Morgan

ICF Resources would like to recognize the following organizations and individuals for their invaluable assistance to this evaluation:

Northeast Utilities

Sara S. Ellison

Alice Kelley

Pearl Bouchard

Marlene Martino

Steven Waite

CHIF/WRAP Unit

Jan Barnard

Dean Sandstrom 


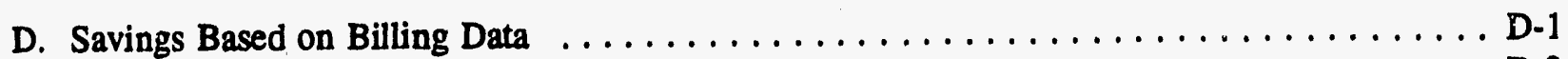

D1. PRISM Documentation $\ldots \ldots \ldots \ldots \ldots \ldots \ldots \ldots \ldots \ldots \ldots \ldots \ldots, D, 3$

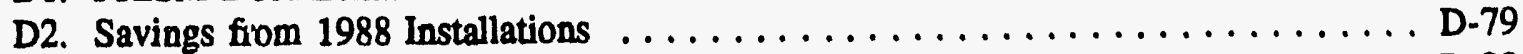

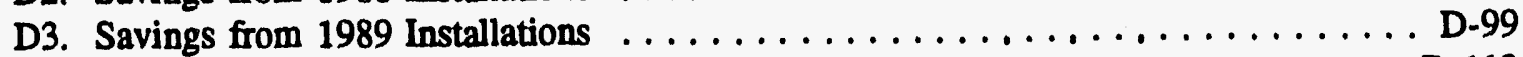

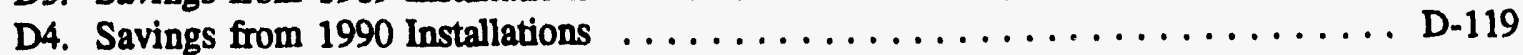

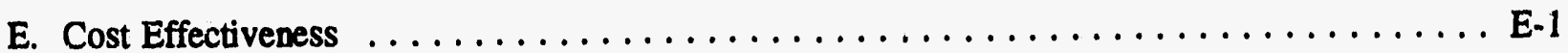

F. Arrearage Impacts $\ldots \ldots \ldots \ldots \ldots \ldots \ldots \ldots \ldots \ldots \ldots \ldots \ldots \ldots \ldots \ldots \ldots \ldots \ldots \ldots \ldots \ldots, 1$

F1. 1988 Installations $\ldots \ldots \ldots \ldots \ldots \ldots \ldots \ldots \ldots \ldots \ldots \ldots \ldots \ldots \ldots \ldots, F-3$

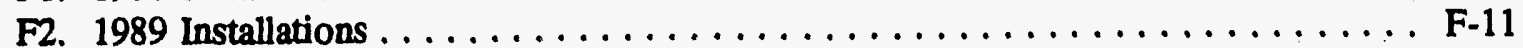

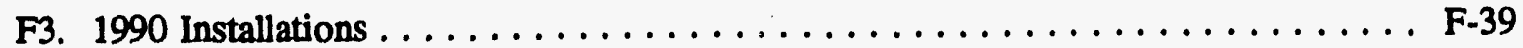

G. Process Evaluation Documentation $\ldots \ldots \ldots \ldots \ldots \ldots \ldots \ldots \ldots \ldots \ldots \ldots \ldots$, G-1

G1. Audit Invoice Forms $\ldots \ldots \ldots \ldots \ldots \ldots \ldots \ldots \ldots \ldots \ldots \ldots$, G-3

G2. Literature Review Bilbliography $\ldots \ldots \ldots \ldots \ldots \ldots \ldots \ldots \ldots \ldots \ldots$, G-9

G3. Customer Survey Forms $\ldots \ldots \ldots \ldots \ldots \ldots \ldots \ldots \ldots \ldots \ldots \ldots \ldots$, G-13

G4. List of Interviewees $\ldots \ldots \ldots \ldots \ldots \ldots \ldots \ldots \ldots \ldots \ldots \ldots \ldots \ldots \ldots$, G-19

G5. Customer Records Analysis $\ldots \ldots \ldots \ldots \ldots \ldots \ldots \ldots \ldots \ldots \ldots \ldots \ldots \ldots \ldots$, G-23 


\section{Appendix D: Savings Based on Billing Data}

Appendix $D$ provides supporting documentation and analysis for savings estimates based on actual participant billing data. Key findings are summarized in chapter 4 of the main report.

Table of Contents:

D1. PRISM Documentation $\ldots \ldots \ldots \ldots \ldots \ldots \ldots \ldots \ldots \ldots \ldots \ldots \ldots \ldots \ldots$

Section 1 is Princeton University's documentation for the PRISM model, used by ICF to weather-normalize consumption.

D2. Savings from 1988 Installations $\ldots \ldots \ldots \ldots \ldots \ldots \ldots \ldots \ldots \ldots \ldots \ldots$

Section 2 presents the statistical analysis of savings from 1988 installations.

D3. Savings from 1989 Installations $\ldots \ldots \ldots \ldots \ldots \ldots \ldots \ldots \ldots \ldots \ldots$

Section 3 comprises tables of pre- and post-weatherization normalized annual consumption (NAC), with standard deviation, standard error, and t-tests, for 1989 participants.

D4. Savings from 1990 Installations $\ldots \ldots \ldots \ldots \ldots \ldots \ldots \ldots \ldots \ldots \ldots$ D-119

Section 4 comprises tables of pre- and post-weatherization normalized annual consumption (NAC), with standard deviation, standard error, and t-tests, for 1990 participants. In addition to the standard participant categories analyzed for 1989 installations, participant pre- and postinstallation NAC was calculated by the relative magnitude of electricity consumption and by the $R$-squared level of the account. 


\section{Appendix D: Savings Based on Billing Data}

\section{Section 1: PRISM Documentation}




\section{FOREWORD}

The Princeton Scorekeeping Method, or "PRISM", is a statistical procedure which uses avallable billing and weather data to produce accurate estimates of saved energy. Derived from simple physical principles, the method provides physical descriptors as well as a weather-normalized index of consumption for each house analyzed. The long-range objective is a standardized approach which is equally applicable to all fuels, and which can be used over a wide range of climetes and bullding types.

Until recently, the emphasis of PRISM development was on houses heated by natural gas: the individual-house approach was developed for the Modular Retrofit Experiment under funding by the Buildings Systems Division of the U.S. Department of Energy, while the aggregate approach, funded by the Ford Foundation and the New Jersey Department of Energy, was developed to monitor statewide conservation trends in New Jersey. We have explored the applicability of the nethod to oil-heated houses, and are currently working to extend it to houses heated and cooled by electricity (Electric Power Research Institute Project RP 2034-4; see EPRI Report No. EM-4358). Our most recent source of funding is the gas and electric utilities in New Jersey, through the establishment of the New Jersey Energy Conservation Laboratory. PRISM research to date and selected applications are summarized in the Scorekeeping Issue of Energy and Bulldings (Vol. 9, \#1-2, 1986); the sixteen papers are listed in the Blbilography.

None of this work would have been possible without the continued guidance and enthusiasm of Robart Socolow. The scorekeeping approach originated more than - decade ago when, under his direction, Thomas Schrader, Yoav Benjamini, Lawrence Mayer and Thomas Woteki gave the methodology its first Inspiration. Special thanks go to Miriam Goldberg and Michael Lavine for bringing new ldas and statistical rigor to the approach, and to Clifford Hurvich and James Rachlin for contributing to recent advances of the nethodology.

History of documentation : Version 1.0 (March 1984)
Version 2.1 (October 1984)
Version 2.2 (January 1985)
Version 3.0 (February 1986)
Version 4.0 (October 1986)




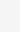




\section{Table of Contants}

PART I. PRISM Documentation (for Mainframe PRISM and for PRISMonPC)

$$
\text { Introduction }
$$

1. Data Preparation 5

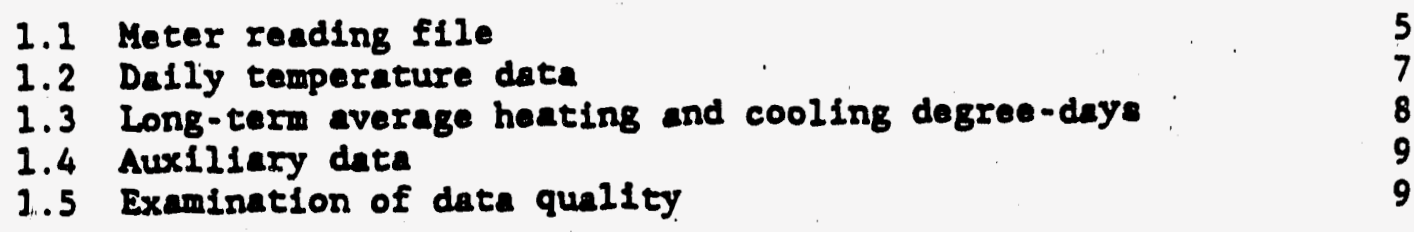

2. The Input Files : 13

3. The Output F1les 19

4. Command Syntax 23

4.1 The STATUS command 23

4.2 The MODEL HO/CO comand 24

4.3 The SET command 24

4.4 The RUN comand 28

4.5 The FIND comand 28

4.6 The NEXI comand 28

4.7 The USE comand 28

4.8 The REWIND COmand 30

4.9 The RERUN command 30

4.10 The QUIT command 30

5. A Typical Run 31

6. Programing Notes 32

Tables and Figures 33

Appendix 1. Technical Codes for PRISM Program A-I

Appendix 2. Supplementary Programs A-2

A. DDCAIC $A-2$

B. WDY A-3

Appendix 3. Description of NOMA Date Series A-5

Appendix 4. Blbllography of Scorekeeping Publications A-7 
Table of Contents. (contd.)

PART II. Docunentation for PC APplication (for PRISMonPC)

1. Getting Set Up $\quad$ PC-1

1.1 What you w111 need

PC-1

1.2 Making a beck-up copy

PC- 1

1.3 Installation

PC- 1

1.4 Input data

PC-2

2. To run PRISM $\quad$ PC-2

2.1 Start

2.2 Specify I/O files

2.3 Run

2.4 End

PC-2

PC-2

PC- 3

PC-3

3. The Output . PC-3

3.1 On the scrien $\quad$ PC-3

\begin{tabular}{l}
3.2 On the printer $\quad$ PC -4 \\
\hline .3 Space
\end{tabular}

3.3 Space linitations
PC -4

4. Auxiliary programs
PC -4

4.1 To run DDGALC
PC.5

$\begin{array}{ll}4.2 \text { To } \operatorname{run} \text { IDY } & \text { PC-5 }\end{array}$

5. Additional details concerning a hard-disk configuration PC-6

$\begin{array}{ll}5.1 \text { Before installing PRISM PC-6 } & \end{array}$

5.2 Installation on the hard disk
PC-6

5.3 To run PRISY on the hard disk
PC-7 


\section{List of Tables and Figures}

Part I:

Table 1: Example of neter file 34

Table 2: Example of file of dally average texperatures 36

Table 3a: Example of normalized-year heating degree-day file 37

Table 3b: Example of normalized-year cooling degree-day fil3 37

Table 4: Examplo of LONG output file. 38

Table 5: Example of COMPARE file 39

Table 6: Example of LOK summary file 39

Table 7: Example of RESIDUALS file 40

Table 8: Example of COMPARE file for set of "good" houses 41

Figure 1: Schematic showing Inputs required for PRISM 2

Figure 2: Sample date from NOMA 42

Figure 3: Plots produced by PRISM program 43

Part II:

Exhibit 1: Sample FORIRAN file definitions from autoexecs PC-9

Exhib1: 2: Sample PRISki sun
PC-10

Exhibit 3: Semple ousput printed in CONDENSED mode PC-11 


\section{-}




\section{PRISM Documentation}

(Documentation for Scorekeeplng Heating-only (HO) or Cooling-only (CO) Estimation Program)

M. Fels, C. Reynolds and D. Stram

Center for Energy and Environmental Studies Princeton University

October 1986 for Version 4.0

\section{Introduction}

This report provides documentation noeded to set up and run the Heating Only (HO) or Cooling Only (CO) scorekeeping model estimation program, based on the PRInceton Scorekeeping Method (PRISM).* The estimation method used by this program is extensively discussed in PRISM: An Introduction (Fels, 1986) as well as other reports listed in the Blbliography. We recommend that the reader become famlliar with the aethod before attempting to follow the procedure outlined here.

Briefly, from moter readings for each house analyze and daily temperature data from a nearby weather station, the program produces the Normalized Annual Consumption (NAC) Index for that house and time period, the corresponding physical descriptors (base level, heating (or cooling] slope, reference temperature, and heating [or cooling] estimate derived from them) and accurate standard errors for each estimate. Savings may then be computed as the diffarence in NAC between a pre- and post-retrofit period. Running the program for the two perlods for each of the houses being monitored, one may obtain everage savings and distributions of savings across houses for each group of interest (e.g., non-participant, audit-plus-loan, etc.). In addition, the program outputs may provide input to subsequent analyses, to determine key factors influencing consumpeion, for example, or the cost-effectiveness of the conservation measures being tried. Thus the PRISM analysis depicted in Figure 1 constitutes a standardized stage one of an evaluation, while subsequent analyses constituting stage two must be designed to meet the specific needs of the project being evalueted.

Version 4.0 of PRISM differs from earlier versions in the addition of an option to run the cooling-only (CO) model instead of the heating-only (HO) model (see Stram and Fels, 1986). The Co model is rigorously a mathematical analogue of the ho model, wherein heating variables (e.g., degree-days) have been replaced by their cooling analogues. Similar performance of the two nodels should not be expected, however. The HO model applied to the heating fuel has been shown to work extremely well on

«PRISM Program copyrighted (C) 1984. 


\section{- INPUTS:}

OUTPUTS:

a)

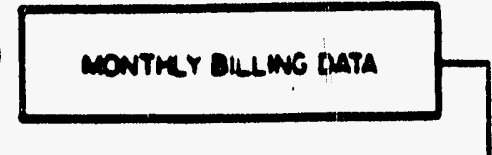

ouKr TEMPERATURE oATA

LONO-TERM DEGREE-DAYS

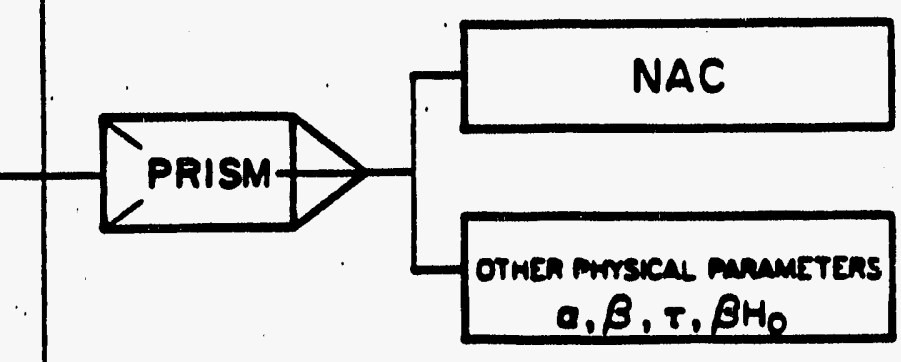

b) montmer guL mo oata

Oni ANO nOST

montur ays ome oata

ron conthol mevess.

me ano nOST
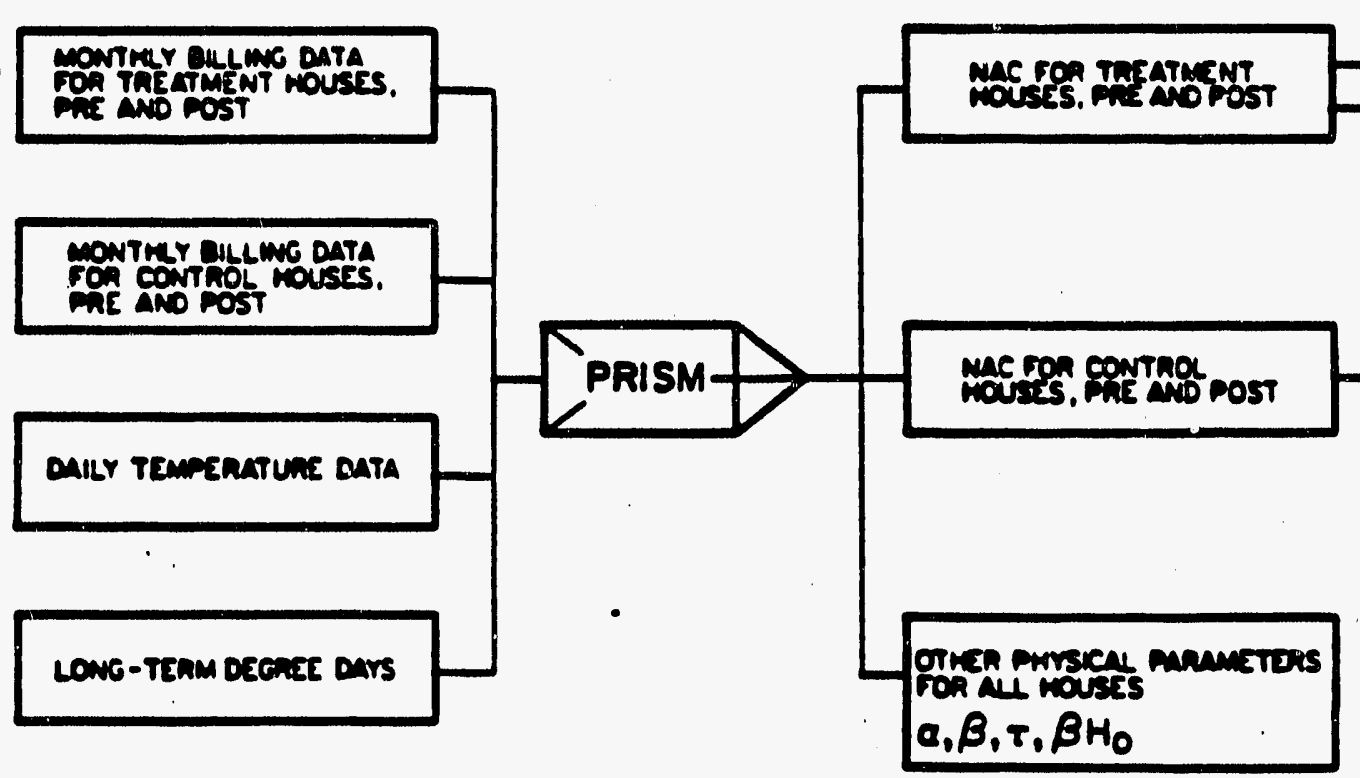

Figure 1. Scheantic showing the Imputs required for the Princetpn Scorekeeping Method (PRISK) and the estimates that result fron 1:: a) the basic procedure for one house; and b) the procedure for calculating control-adjusted savings for a group of treated houses. 
average on houses in heating-dominated climates (to model total natural gas consumption in a gas-heated house, for exaüple, or electricity consumption in a house heatid but not extensively cooled by electricity). The succes's of the $\mathrm{CO}$ model, on the other hand, is much less well documented. In our experience, its performance on houses in a single climate varies enormously (for consumption of electricity used for cooling in gas-heated house, for example, or for electricity consumpeion in an all-electric house in a cooling-dominated climate). We include the $C O$ option here as an aid to exploratory analysis, and look to the experience of other PRISM users to teach us whet level of success, under certeain conditions, may be expected with the $C O$ model. Because we expect that the primary application of this program will be to heating fuels, this documentation emphasizes the HO option and 1ts output.

The software for Mainframe PRISM and PRISMonPC is identical, as are the auxiliary programs and data files. The only difference is the manner in which the software is provided: source code, on tape, for Mainframe PRISM, and complled code, on floppy disk, for PRISMonPC. The same general documentation applies, and is grovided in Part I of this documentation.

The purpose of Part I is to help other 'scorekeepers' use PRISM on their computer systems. The documeritation discusses preparation of the required data (Section 1), the format of input and output filus (Secs. 2 and 3 , respectively), and the command syntax accepted by the program (Sec. 4). In addition, it provides inseructions for typical run (Sec. 5) to go with the sample data provided with the PRISM software. Documentation for auxiliary programs that are also provided is given in Appendix 2.

Note concerning PRISMonPC: special documentation for running PRISM on an IBM PC is provided at the end of this documentation, in Fart II.

We welcome comments from ali PRISM users. We are partictiarly eager to hear how the program (Including this documentation) could serve the user better. 



\section{Deta Preparation}

Three data. flles are needed to run PRISM: 1) consumption data añd , corresponding time perlods for eech house, extracted from metmr readings; 2) daily average temperatures from a nearby weather station for $\bullet$ long-run period plus the pariod encompassed by the meter reading periods, for compuration of heatipg (or cooling] degree-days, and 3) long-term average heating (or cooling] degree-days for each possible (integer) reference temperature, for computation of NAC, the Normalized Annual Consumption index. A brief description of each data file is given below (Secs. 1.1-1.4). Sample tables mentionad in the text appear after. sec. 6 . In addition, several important date quality conslderations are addressed (Sec. 1.5).

\subsection{Meter reading Elle}

The required format is described in this document under unit number 10 in Sec. 2, and 1llustrated in Table 1 . See also note concerning data validation in See. 1.5 .

The data file contains consumption computed from each successive pair of (non-estimated) meter readings. Each line of date contains the meter reading date and the consumption for the neter reading period ending with that date. The first line, which also includes the house ID and three descriptive labels, contains the date indicating the beginning of the first consumption period. Several specific points are important:

A. Do not use estimated readings. If an estimated reading is indicated, Ignore the reading and combine the two readings on either side of it as one (- two-month) period. Thus, the following meter reading data:

$$
\text { date meter reading consumption }
$$

\begin{tabular}{ll|l} 
Feb 16, 1983 & 9936 & 1 \\
Mar 15, 1983 & 0068 & 132 \\
Apr 15, 1983 & 0197 (est'd) & 129 (est'd) \\
Mey 15, 1983 & 0270 & 73 \\
Jun 15, 1983 & 0322 & 52
\end{tabular}

should be entered as follows:

$\begin{array}{rlll}132 & 2 & 16 & 83 \\ 202 & 3 & 15 & 83 \\ 52 & 5 & 15 & 83 \\ & 6 & 15 & 83\end{array}$

so that the two-month period between March 15 and May 15 becomes a single consumption pariod, with consumption of $202(-0270-0068)$ units. Note: an estimated weter reading for the flret or last date, for any house, should be avolded.

*This documentation 1s written primarily for the HO option. Substitution of

"cooling" for "heating" yields documentation for the CO option. 
B. It is preferable to have access to the raw neter readings as well

as the consumption data derived from tham, because of the ...

Intermal consistency checks avaliable (e.g., cum of consumption.

over the time perlods comprising a year must equal the difference between neter readings for the end points of the year) and

because transcription and subtraction errors can then be checked. W1th meter readings as the primary data source, "missing" data (whlch would be entered as negative consumption, 1.e. -1, for the relevant tine period) should occur very infrequently.

In the following example:

\begin{tabular}{|c|c|c|}
\hline $\begin{array}{l}: \\
2320 \\
-1 \\
1272\end{array}$ & $\begin{array}{l}: \\
2 \\
3 \\
4\end{array}$ & 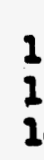 \\
\hline : & : & \\
\hline
\end{tabular}

PRISM w1ll assign a period of $3 / 13 / 81$ to $4 / 14 / 81$ to the consumption 1272 and will treat the period from $2 / 12 / 81$ to $3 / 13 / 81$ as a miseing point.

C. Enter the dares in this f110 in the standard comvontion: 31583 for March 15, 2983, etc. [Now with Version 3.0; date formats from meter flles created for Version 2.2 (or lower) may be converted to new format using WDY program described in Appendix 2.]

D. Use -9 to Indicate the end of data for one house, and -99 to Indicate the end of the neter reading file.

E. Since the house ID for each house gets printed in the COAPARE file and other outputs, you may want to choose a comvenlent (nonproprletary) numbering schome.

F. If you have nore than one year of consecutive date for each house, and a treatment (retrofit) was done within the begimning and ending dates, thare are two options for the organization of the data:

1) Store all data under on house ID/Label; and with the USE comand (Sec. 4.7) specify the starting and anding dates for all houses. Thus you would $\operatorname{run}$ all houses for the pre-period, and repeat for the post-period.

2) Store the date for each house in approxinately $12-$ month oegents, separating, for example, the pre- and postperlods. The data would be oxganized as follows: 


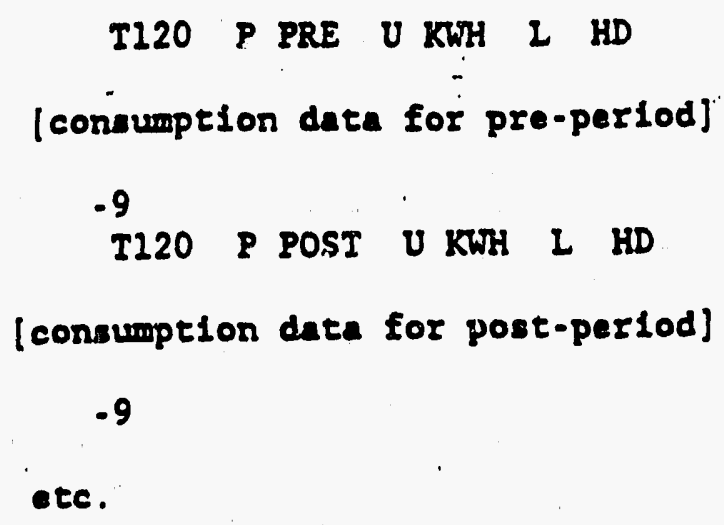

\subsection{Dafly temperature data}

The required format is described under unit number 12 in Sec. 2, and 11lustrated in Table 2.

We recommend the following procedure for obtalning the nacessary temperature date (see also Appendix 3):

A. Select a NOMA (National Oceanic and Atmospheric Administration) prinary weather station near the set of houses to be analyzed. Some variation of weather across the region can be tolerated; for example, PRISM has worked well for houses throughout nost of New Jersey with temperature data from the Newark station.

B. For that station, obtain fros the National Climatic Data Center (Federal Building, Asheville, NC 28801; phone 704-259-0682) the weather tape contalning the historical temperature (anong other useful) data. This tape is called Series TD-3210: Sumanary of the Day First Order (for dally rather thun hourly observations), for the primary weather station in question. Data are also avallable on floppy diak.

C. For that etation, obtain (also from the National Climatic Data Centar) a copy of the Local Climatological Data (ICD) Montsily Sumary for the months subsequent to the final month on the tape, and obtain a subscription for monthly updates if continued analyses are to be performed. (Sample is shown in Figure 2.) 
D. Starting from the artlest possible date neaded (e.g., the beginning of the normalization perlod, as defined in

Sec. 1.3, Step B), extract minimum and anximum tomperatures from the tape for each date and compute dally average tomperature as

$$
T_{1}-\text { dally } t-(\operatorname{minimum}+\max 1 \text { mum }) / 2 \text {, }
$$

rounding 0.5 (as NOAM does) to the next highest Integer. For your convenlence, the NOM documentation for the weather data Includes a typical FORIRAN program to read a tape formatted in Series 3210.

E. Continue the series wfth the monthly LCD's, using colum 4 labeled "Tomperature "F: everage". Note discussion in Sec. 1.5 concerning data validation.

F. Update the file as neoded.

See also the description of undt 12 in Sec. 2 and the note with the SET MIND command in Sec. 4.3.

\subsection{Long-term average heating and cooling degree-days}

The required format is described undar unit numbers 15 and 21 in Sec. 2 , and 1llustrated in Table 3. The FORIRAN progran DDCAIC produces the normalization flles in the required format from a PRISM dally tomperature file. (The program is included on the tape and documented in Appendix 2.) Note that use of DDCALC ensures the nocessary consistency between the longterm degree-day data used in MC and the dally temperature data used in the regression.

Long-term averages of heating and cooling degree-days for the desired weather station are computed once for each possible reference tomperature (Integers only), and retrleved for each computation of MAC.

Specific points follow:

A. Establish alnimm (MINB) and naximum (MNXB) values well outside the range of likely tamperatures. For Nawark, we we KINB - $-10^{\circ} \mathrm{F}$ and $\mathrm{KNXB}-+120^{\circ} \mathrm{F}$; these are the default seteings of DDCNIC.

B. Choose recent 10- to 12-year perlod for the normalisation period. Our favorite 1s the 12-year period from Jan. 1, 1970 through Dec. 31, 1981; these are used as the default in DDCAIC.

C. For each integer value $T$ between (and including) MINB and MUXB, DDCAIC computes the average per-day heating and cooling degree-days as follows: 


$$
\begin{aligned}
& H_{0}(T)=\sum_{1=1}^{N}\left[\max \left(0 ; T-T_{1}\right)\right] / N \\
& C_{0}(T)=\sum_{i=1}^{N}\left[\max \left(0 ; T_{1}-T\right)\right] / N
\end{aligned}
$$

where $I$ is the average dally temperature for the $1^{\text {th }}$ day (from the tomperature file), and the summation extends over all N days comprising the normalization period.

See also description of untes 15 and 21 in Sec. 2.

\subsection{Auxiliary data}

Additional household data, though not required by PRISM, may be useful. for subsequent analysis, and, if available, might be profitably computerized as the metef reading data are entered. Examples Include:

- house area

- whether water is heated by space heating fuel

- conservation program participation status

- primary/secondary heating fuels

- alr conditioning ownershlp (central, room units, none)

- type of heating and/or alr conditloning equipment

- typo of unit (single-family detachad, multi. famlly with $2,3, \geq 4$ units, etc.)

- date soved in.

Note that these date any be stored in the neter file as comants (see sec. 2 , unit 10), not read by PRISM but readable by other programs written by the user.

\subsection{Examination of date guality}

In order to obtain reliable scorakeeping results, considerable attention must be given to the quality of the input data. In our experience, the improvement in the reliability and credibility of the results well warrants the extra time invested in the beginning. In the 
words of PRISM users Rick Goeltz and Eric Hirst at Oak Ridge National Laboratery:

We think that andysts too often manipulate data using high-speed computers and sophisticated statistical coftware packages without taking sufficient time to carefully examine the data beforchand. The old adage .. garbage in, garbage out .. applies here. ... Thls requires a comituent to date quallty and to the Investment of the resources necessary to achieve it.

The Elrst step to assuring data quailty is to Idantify anowelles in the consumption data at the Individual-house lavel. Vse of the plotting routine (see Sec. 4.3 and F1g. 3) can be very helpful here. For example, you way detect outliers (1.e.. anonalously hlgh or low b1118) by plotting consumption against heating degroo-days, computed at begt tau or, for comparison, at a Elxed reference tamperature such as $60^{\circ} \mathrm{F}$. If (and only if) the model is greatly lmproved by doing so, It may be reasonable to remove a single extrans outiler or, nore comonly, to combine two outlier b111s which are of opposite sign and consecutive. Such changes in the data should be well documented. (Note that, if you are starting with raw meter readings, an isolated consumption outlier should reflect high or low consumption that actually occurred, for example, due to visit from Grandwother or a vacation.)

The temperature data deserve careful chacking, particularly if thay are entered manually from LCD'. (see Sec. 1.2 and F1g. 2). A good check on the input data is to compute total hoating and cooling degree-days to base $65^{\circ} \mathrm{F}$ for each month and compare with the printed total givan on the month's LCD. You may use the FORTRAN program DDCALC for this (see Apperdix 2).

Another way to detect Imput data probleas 1s to vary the time period for estimation. If changen in heating consumption are of prinary interest, the preferred estiantion perlod is July-through-June. Sinilarly, Januarythrough-Decenber nay be used for estinations of cooling consumption. Wherever possible, simllar boundarles should be chosen for the pre- and post-periods. Obviously, data evallablilty in the pre-perlod and the deslre for early completion of data collection for the post-pariod ay interfere with these ideals. The model results should not be overly sensitive to the exact cholce of estination period, and, if they are, the Imput date should be carefully exaninad (see stablilty study: Rachlin et al., 1986).

In general, it is Important to Identify anoanalies in the PRISM outputs. The most maningful Indlcators of problems are the nodel $R^{2}$ values and the standard errors of the estinntes. The standard arror of the referenee temperature, which any be very large or Infinite (indicated by -9.0) for a reference temperature naar the boundarles of allowed temperatures, 1s a particularly good Indicator. In subsequent analysis, you way want to eliminate houses for which a -9.0 has appeared; this is particularly important if you are roporting wean rather than sadian 
results. (See also description of LOOK file in Sec. 3.) In addition, examination of outliers in.the individual parameters -. base level, heating slope and reference temperature.. and the relative magnitude of the physical estimates derived from them .. the heating consumption estimate, NAC (pre and post) and the resulting savings estimates -. can be very informative.

With the benefit of other users' experiences, we are currently trying to establish hard-and-fast rules for determining when adjustments in elther the consumption data or the set of houses in the data set are warranted. Meanwhile, in the absence of such rules, we urge extrome caution in making any changes so as not to interfere with the credibility of the results.

The reliability of MAC 1s PRISH's nost important feature. For most applications of the HO model, the standerd error of NAC is usually within 3 or 48 of the MAC estivante, even when the Individual peraneters are much less vell. determined. These parametors doserve careful physical interpretation: generally the base lovel estimate (365*alpha) is rigorously the temperature-1ndependent component of NAC, while the remainder of NAC, the temperature-dependent component, provides a slight overestimate of the energy consumed for heating in the heating-only model (roughly by approximately 10s, because of some seasonal dependence of energy usage for appliances, etc.; see seasonallty study: Fels et al., 1986).

After an extensive examination of the results at the Individual-house level, you way want to explore different cuts of the entire sample, reflecting, for example, raported wood use (e.g., those roporting <l cord vs. $\geq 1$ cord per year), or the ratio of heating consumption to MAC. Such examples of different cross-sections of the data can provide useful insights in the savings analysis.

PRISM research findings and selected applications are summarized in. the Scorekeeping Issue of Energy and Bulldings (Fels; ed., 1986). The stablilty and enesonality studies are particularly relevant to the Interpretation of PRISM results. The analysis of the Hodular Retrofit Experiment is presented as a prototype PRISM application. Additional studies of the use of specific fuels (natural gas, electricity, oll, and the effect af wood une on olectricity consumption) as well as real-world applications of PRISM provide a wide range of experiences from which each PRISM user may benefit. A complete 11st of references is provided in the Blbliography (Appendix 4). 


\section{The Input Files}

This section gives complete Information about the contents of the four Input files required by PRISM. These are disined in the program as FORTRAN unit numbers $10,22,15$ and 21 . In addition, unit 5 is dafined to be connected to a terminal for the input of user commands.

To run this program in batch mode, unit 5 mast be defined to the operating system so that it refers to a file contsaining user comands. There is a simple technique, discussed in Sec. 4, to change the unit which contains user commands so that in the courule of a session with the program, commands way be raad from a flle and thisn control given back to the user at the terminul. This feature is helpliul in reducing typing requirements; comonly used comands way be plated in a file, and the user may tell the program to execute those comands and then to raturn back to unit 5 for nore input.

If your computer system requires OPEN/CLOSE statements, see special notes in Sec. 6.4 .

The remainder of this rection gives detalled information for aach of the input files, referrad to by FORTRAN unit number.

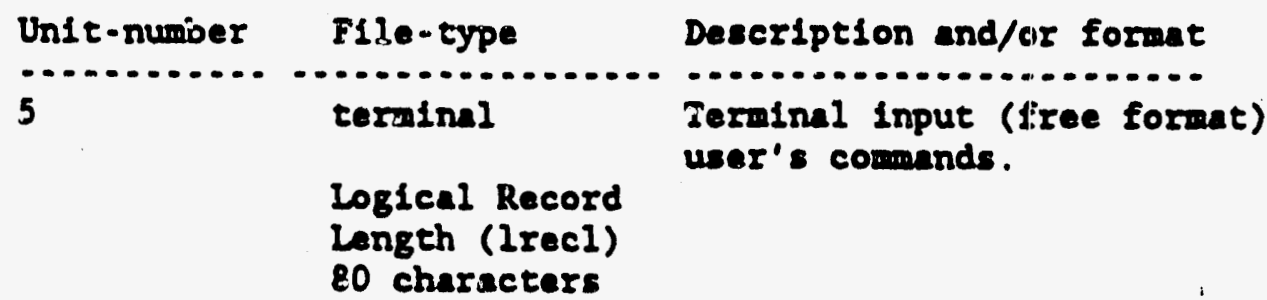

Meter file Consumption data, house Identifiers,

$2 x \operatorname{ecc} 80^{*}$

Sce Table 1 for example.

House-Id in dd yy $P$ prepost $I$ label $U$ units E(1) $E(2)$ ind dy and $y y$

$E(x) \quad$ and $y y$

$-9$

House-1d an dd yy $P$ prepost $I$ label $v$ undts E(1)

$E(2)$ r... dd $y$ in dd yy

E(X) $-99$ non dd yy.

* Recomended record lengths ara given for Input files. User way wish to decrease them to save space. 
The consumption data for different houses are separated by a -9 while the end of data is flagged by a -99 . The first line of each set of house data starts with 15 alphanumeric characters (without spaces). This is inediately followed by a space and the date of the beginning of the first consumption poriod.

There are three optforal 1abels that may be entered in any order following the date:

$P$ Indicates a pre- or post-ratrofit period; up to 8 characters, the first 4 of which are printed in COMPARE file. Recomended values: PRE, POST.

v Indicates units of consumption data In Eeter flle; up to 8 characters, the flrst of which is printed in the COSTPARE f1le. Suggested values: CCF, MirRYs, MBTU, KWH, GAI, etc.

1 provides an extra dascriptor needed to distingulish between houses; up to 8 characters, the first 2 of which are printed in the COAPARE file. Suggested values: IP (non-particlpant), AO (audit only), AI (audit plus locn), HD (howe doctor), etc.

Each subsequent line consists of a single consumption figure and the flrst date of the following aeter reading period .. unt1l a -9 or a -99 is reached. The program does not require that the dates or consumption figures be entered on any specific colum mimbers (1.e., the program accepts free format input).

See example in Table 1, which Includes problex as well as vell-bohaved houses.

Important Notes:

Missing data on the ecter file are signified by a negative consumption flgure; we prefer -1. If an actual reading 1 s zero, code the consumption as 0 . (This is a change with Version 3.0 of PRISM.) 


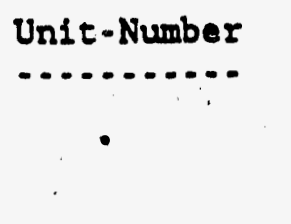

File-type

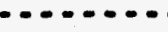

12

Temperature

EIle

lrecl 80

See Table 2.

15

Normalized

heating year

1recl 80

Soe Table $3 a$.
Description and/or format

Estimated readings should not be included. In the event of an estimated roading the consumption for the two perlods on elther side should be combined, to form one actual reading period. (See example in Sec. 1.1).

Comment statements may now be included In the meter file (a now feature of Version 3.0; see example in Table 1). An asterisk must be placed in the firat colum to Indicate that the line should be 1gnored as Input. Th1s is particularly useful for including auxiliary data (see sec. 1.4).

File of average dally temperatures. Each month consists of a separate logical record, though not necessarlily on a single

ine in the file. The formst is:

YEAR MONTH DAYS. II T2 ... TDAYS

Here YEAR is typed as a full four-diglt number, MONTH as two digits, and DAYS is this number of days in the month, 1.e., 31 3029 or 28. T1 T2 ... TDAYS are the average dally tomperatures, typed as Integers. At least one space sepurates exch item. See example in Table 2.

We strongly recomend that your tomperature f1le predate any possible meter readings you might use. This will avold the ceveat connected with the SEI MIND command (see Sec. 4). We think the safest procedure is to keep your entire temperature file that you used to create the long-term noranlization files and periodically add updates to 1t. (Our temperature files go back to January 1, 1970.)

File of normal yoar heating degree-dayz for a range of base tamperatures. A normal year heating degree-day value is an everage (usually over approximately 10 years) of observed heating degree-days reported on a per day basis. 
Unit-Number

F11e-type

-.........

.

21

Nornalized

cooling yeer

Irecl 80

See Table 3b.
Description and/or format

The format 1s:

MINB MAXB

$H_{0}(M I N B) H_{0}(M I N B+1) \ldots$

...

‥ $H_{0}(\operatorname{MAXB})$

and is specifled in FORTRAN as: (2I4) for MINB and MAXB and (starting on a now line) $(10(F 6.3,2 X))$ for the $H$ values. Here MINB and KNXB specify the minimum and naximum base tomperatures for which normalyear heating degree-days are calculated.

The program DDGAlC produces the file in this format (unlt 14) from the dally temperature f11. (unit 12): Note that you must copy this output f1le from DDCALC to an input f11. for PRISM, 1.e., from unst 14 to unit 15. (Two differant unit numbers are used so that a DDAlC run does not unintentionally write over an existing normalization f1I0 used by PRISM.) We strongly urge you to use DDCNIC to prepare this file for PRISK, In order to ensure consistency between your dally tomperature and long-term degree-day data.

Comments any be Inserted after MINB and MNBB on the same line. Nottce in Table 3 that we use an extromely large range $(-10$ to $120^{\circ} \mathrm{F}$ ) of base tomperatures in the normalization. This large range is incorporated as the default in DDCAIC. Since PRISM requires the range of the normalization file to exceed the range of temperature data for the tine perlod studied (for the purposes of Interpolating dagree-days), we etrongly recomend that this default range be used.

F1le of noraal year cooling degree-days for a range of base tameratures. Sae description under unlt is (above).

Th1s f1le is produced as an output f1lo of DDCAIC (unit 20). 
Note regarding undts 15 and 21 (normalized heating and cooling year files): Although user may be interested in running only one of the two possible models (HO or CO), PRISM requires that a flle definition for both normialization flies be listed in any exec. To avold confusion, we suggest always creating both heating and cooling degree-day files (using DDCAIC) and defining both in your PRISM exec. 


\section{The Output Files}

- This section describes the contents of five files which are produced as output from the estimation program. Only one of these files, the 'LONG OUTPUT', is produced by default. This default setting is easily changed when running the program. Other output flles are generated optionally according to user command specifications. The commands needed to create the optional output files are discussed below and in Sec. 4. Appropriare "heating" labels from the HO model appear as "cooling" labels when the CO option is used (new with Version 4.0). (Example outputs are given only for the HO model.)

Please note that there are some IImitations on the size of some fields. For most systems, if an output value exceeds the space allotted, the fleld is filled by a ' This is not to be confused with the PRISM value of -9.0 , which Indicates a standard error that 1s approeching infinity. (Note to pre-version 3.0 users: this is an Improved convention, new with Version 4.0, for consistently indicating infinite standard errors, previously indicated by -9.9 or -99.0. )

If your computer system requires OPEN/CLOSE statements or a change in the unlt numbers, seeciel notes in Sec. 6.4 .

This section discusses each output file in turn, agein referred to by FORTRAN unit number.

$\begin{array}{ll}\text { Unit-Number } & \text { F1le-type } \\ 6 & \text { terminal } \\ & \text { 1recl } 80 \\ 77 & \text { LoNG OUTPur } \\ & \text { Irecl } 130 \\ & \text { See Table 4. }\end{array}$

Dascription and/or format

Output to user; prompts for comends, exror messages, etc.

The default output f1l produced for each house. Gives complete output for the estination run. See example in Table 4. If this is not destred, use the comand 'SET LONG OFF'. See Sec. 4.3. If the wer has 1ssued the additional cosmands 'SET PLIUSE ON' and/Or 'SET PLIRSD ON', then IIno printer plots of energy uage and/or residuals are produced on this file. Sae sample plote in FIgs. $3 a$ and $3 b$, as well as the description of the SET cosmand given below. Note that record longth (Irecl) for this file mest be set at 130 ovin $1 f$ plots are not requested.

An addad feature (new with Version 3.0) is the SET PLT80 ON command. The same plots 


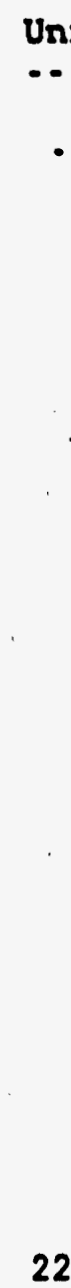

22
File-type

COAPARE

(short summary of scorekeeping results)

Irec1 230

Sae Tables 588 .
Description and/or format

described above are produced in an 80 . column width for easier viewing on terminal sereens.

An additional feature (now with Version 4.0) 1s the option to display the Correlation satrix. The default is ofi To receive this information use the command 'SET CORR ON'. (See Table 4.)

The coefficiont of variation for each parainter (excluding tau) has been added beneath each standard error, Indlcated by '(CV)' (new with Version 4.0). This value represents [se(estimate)/estimate] x100.

Whether the HO or CO model was selected is Indicated in the header to the LONG output.

Error messages are printed for houses which did not run.

Technical Codes, explained in Appandix 1 , are included to give further detalls about the way the estination procedure behaved for the specific run.

Th1s output file gives a short summary for a set of houses (one line per house), and is produced if the user has Issued the comand 'SET COMPAR ON'. (Note new notation; prior to Version 4.0, PRTCIP was used.) It cons lsts of a standardized table patterned after those produced for Princeton': Hodular Retrofit Experinent; see exnoples in Tables 5 and 8 . Numbers in parentheses are eccurate standard errors of the estinate.

Note: R-field 1s truncated to 4 characters and printed under 'PRE or POST'. I-fleld is trunceted to 2 characters and printed under 'SAYP TYPE'. U.field is truncated to 1 character and printed undar ' $X$ ' (new with version 4.0).

Whether HO or CO model was selected is Indicated in the header to the COKPARE file. 


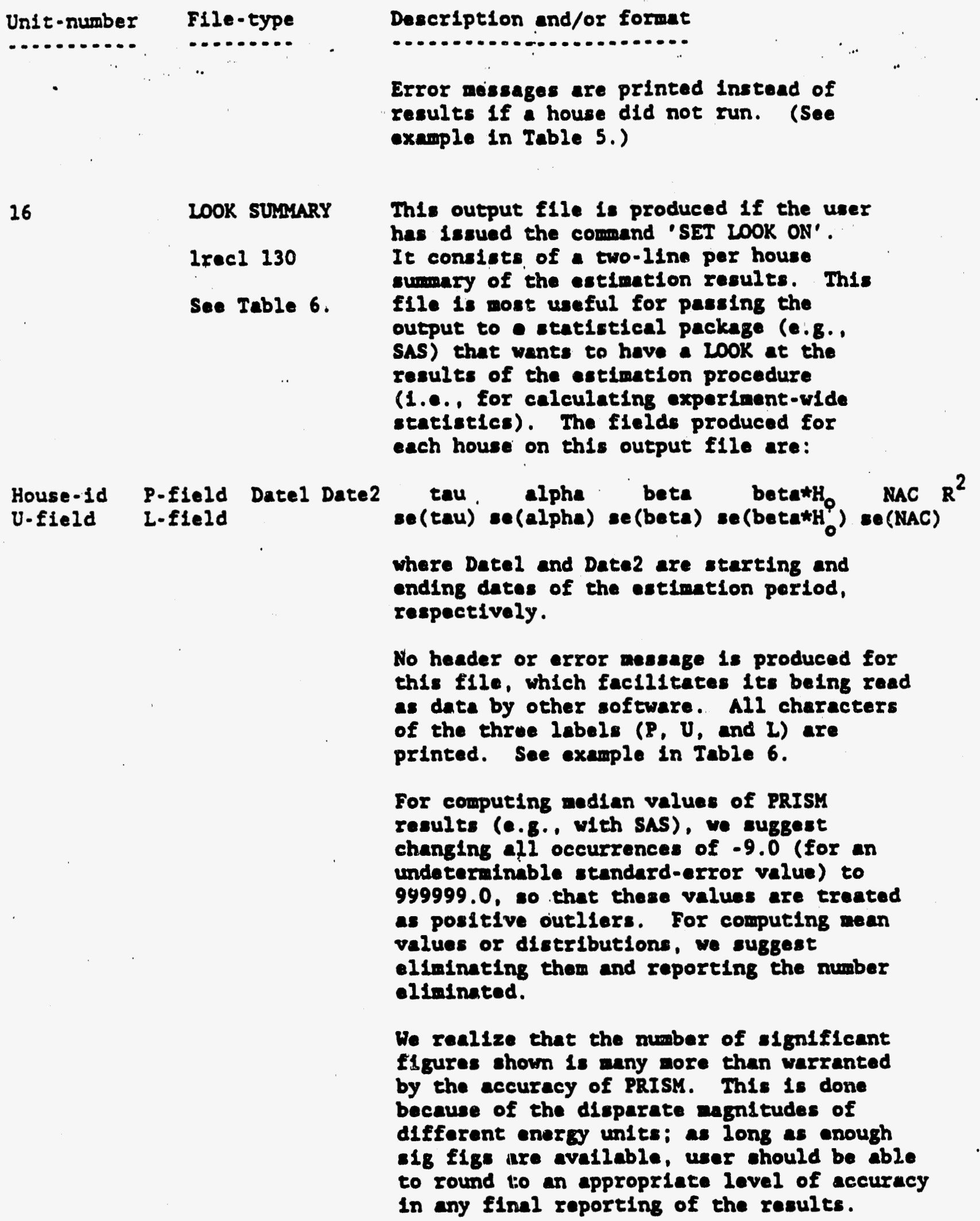


92.

V̈ERY SHORI

SUMRARY

Irecl 80

41
RESIDUAIS

Irecl 80

See Table 7 .

PD* DATE
Description and/or format

This output file gives a minimal summary of the results for each house. We use this f1l. to control the operation of sev ral other of our programs whlch need to know the estination results. File is produced from the command 'SET CNIREC ON' . (Mainly for our research purposes; no example shown.)

This file gives a sumary of consumption and residuals by poriod. If the user 1ssues. the comand 'SET RESIDS ON' (a new comand notation; was PRTSAT prior to Version 4.0 ), then the following output is produced for every meter reading period:

NDAYS/PD CONS/DAY HDD(TAU)/DAY RESID/DAY

$$
\begin{aligned}
& \text { whice - perlod number - } 1 \\
& \text { DATE - ending date of period } 1 \\
& \text { WDAYS/PD - number of days in perlod } 1 \\
& \text { CONS/DAY - raw consumption per day for } 1 \\
& \text { HDD(TAU)/DAY - hearing degree-days per } \\
& \text { day at best eau for } 1 \\
& \text { RESID/DAY - residual per day for } 1
\end{aligned}
$$

For the CO option, CDD (cooling degree-days)

are given instead of HDD.

Note to non-statisticians: the residual computed for each consumption period is the difference between the value predicted by the aodel and the acturl consuruption per day for that perlod; the least-squares regression essures that the oum of the residuals over all periods is zero.

Note that, $1 f$ a subset of the date in the neter file is used (1.e., lssulng a USE DAT corande), all periods in the aeter file are produced in the residual 111. Parlods not used in the regression are Indicatad by a '-1' for consumption per day and. ' for residual per day.

The plots produced from the comand 'SET PLIRSD ON' (Sec. 4.3) Include data from the estination period only. See F1g. 3b. 


\section{Command Syntax}

The basic user commands which control the operation of the program are as. fcllows:
1) The STATUS command
2) The MODEL HO/CO command
3) The SET command
4) The RUN command
5) The FIND command
6) The NEXI command
7) The USE command
8) The REWIND command
9) The RERUN comand
10) The QUIT command.

User commands are raad from unit 5 , unless the user has given the command 'SET KEYBRD $n$ ' where $n$ is the unit number of a flle containing additional user commands. The last ltem in the flle should be the command, 'SET KEXBRD 5', to return control of the program to the user.

A complete description of the syntax and the meaning of the user commands is given below.

\subsection{The STATUS command}

Typing the word 'STATUS' (without quotes and followed by a carriage return) prints out a page of information concerning the current settings of number of Internal variables which you may then manipulate with the SET command. Manipulating these status variables is the primary mathod of controlling the program. Below is the output produced at the terminal by the STATUS command. It is designed to flt on one screen.

STATUS

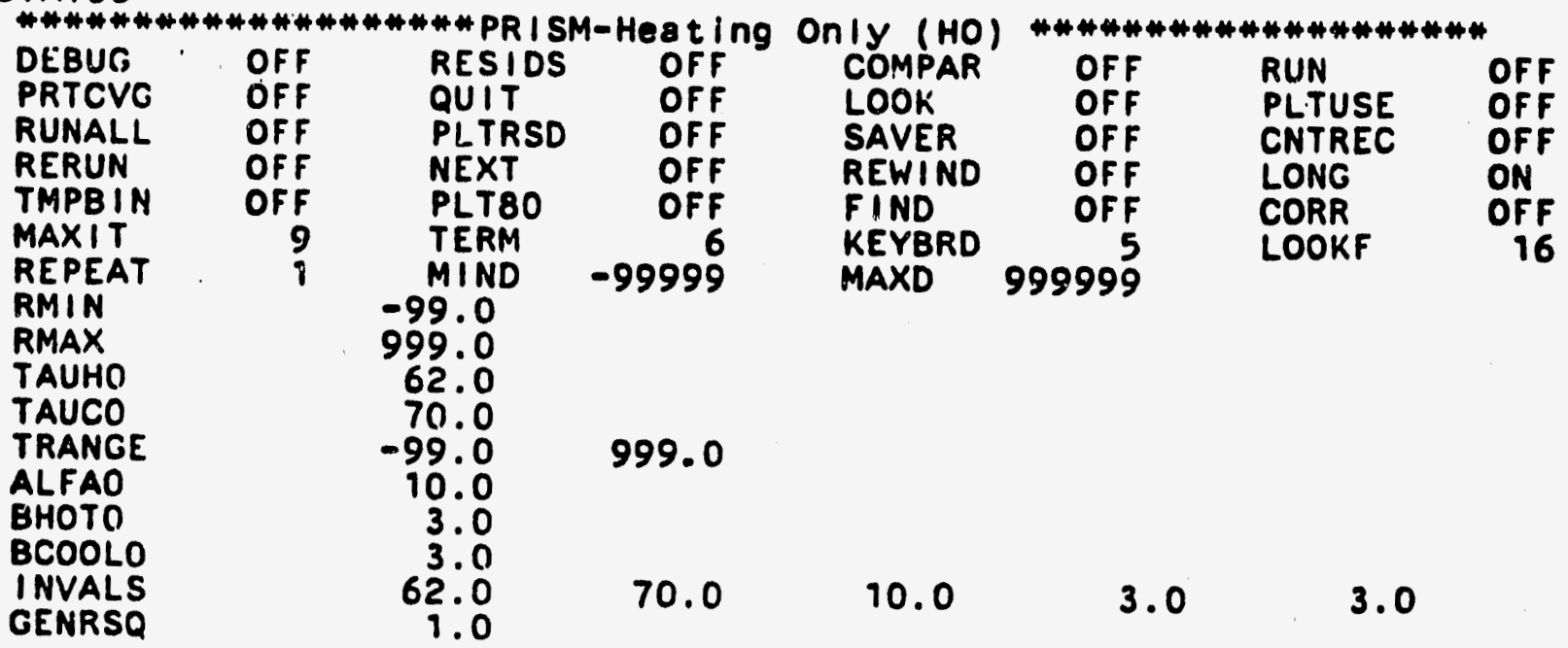




\subsection{The MODEL HO/CO command}

- A new feature of Version 4.0 is the option to run a cooling-only model of PRISM. In order to do this, type 'MODEL CO' before running PRISM. . (The default is MODEL HO for heating-only.) All appropriate changes to output have been made to accommodate the cooling option (especially cosmetic changes from 'heating' to 'cooling').

Note 1: Once one or more houses have been run using elther the MODEL CO Or MODEL HO COmand, the uner cannot ewitch models in the middle of a run. If attempted, the user will recelve an error meseage at the terminal.

Note 2: The co option requires a normalized cooling degree-day flle (unit 21) just as the HO option requires a normalized heating degreeday f1le (unlt 15).

\subsection{The SET command}

The SET command manipulates the internal variables shown by the STATUS comand. The SET comand Itself does not produce any output unt1l the RUN cosmand is 1ssued. Note that, with the excoption of the 'LONG' comand, the following variables are all set to 'OFF' by default. The possible forms and the meanings of the SET command are:

SET PLTUSE ON - Causes the program to produce two plots for each house, 130 columns wide. The flxet plot is of onergy usage by neter reading perlod; note that reading perlods are "sceled" es $1 f$ of equal length. The second plot is energy usage egainst heating lor cooling] degree-days caleulated at the ostinated value of the heating [or cooling] reference tanperature (TAU). On the latter, symbols (\$) are providad to Indicate location of the bast-fit line resulting from the regression. See F1g. $3 \mathrm{a}$.

OFF - Turns off the consumption plots.

SET PLTRSD ON - Gauses the program to produce two graphs of the residuals of the regression for each house, 130 colume wide. The residuals are ploteed by neter reading perlod and against hoating [or cooling] degree-days celculated at the estimated value of best TAU. Sae Fig. 3b.

OFF - Turns off the residunl plots. 


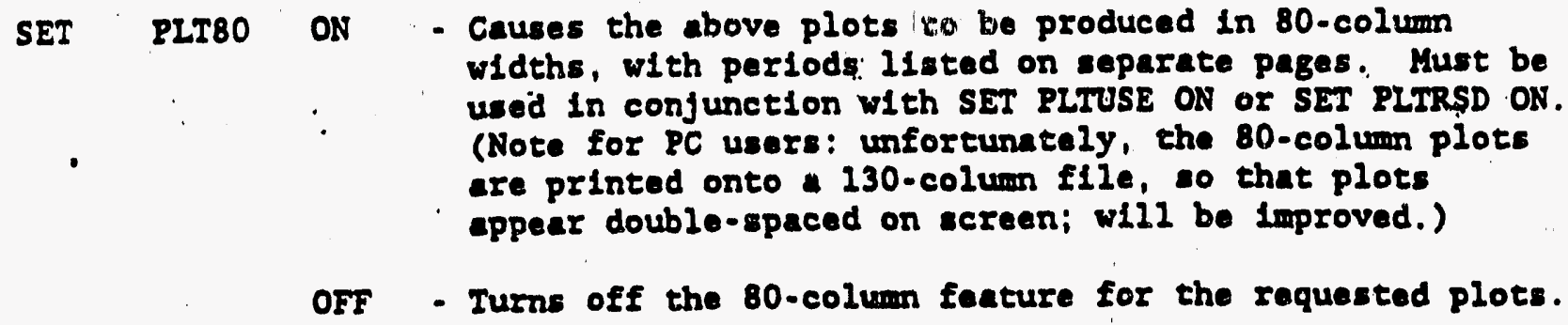
widths, with periods. 11sted on separate pages. Must be used in conjunction with SET RLIUSE ON or SET PIIRSD ON. (Note for PC users: unfortunately, the 80-colum plots are printed onto a 130-colum file, so that plots appear double-spaced on screen; will be improved.)

OFF - Turns off the 80-column feature for the raquested plots.

NOTE: These graphs are produced as IIne printer plots. They are written to unit 77 along with the LONG OUTPUr for each house. If 'SET LONG OFF' is used (see below) the output will contain only the plots.

SET COMPAR ON - Produces the COMPARE f11a, a standardized short summary of scorakeeping results (unlt 22). (Note now notation; wes PRTCip prior to Varsion 4.0.)

See Tables 5 and 8 .

OFF - No such output is produced.

SEI LONG ON - Produces the LONG output flle (unit 77): default 1s ON. See Iable 4 .

OFF - No such output is prodused.

SET RESIDS ON - Te11s the program to print the RESIDUAIS f110 (unit 41). (Note now notation; was PRTMA prior to Version 4.0.) See Table 7.

OFF - No such output is produced.

SET LOOK ON - Produces the LOOK sumary f1le (untt 16). See Table 6. OFF - No such output is produced.

SEI PRICVG ON - Raquests that the progran print out, on the terininal, corverzence information at ench stop of the lecrative search for best $\mathrm{IAU}$.

OTE - No such output is produced.

SEI RUIAIL ON - Tells the program to $2 \mathrm{~m}$ all houses on the eter f110 when the RUN comand is Issued.

OFF - When the RUN comand is givan the progran w112 $2 \mathrm{~mm}$ one house, and then pause for nore uner comands. 
Note: PRISM w1ll produce output for all houses on the meter file, ., including houses that did-not run due to data problems. Error messages for those houses are printed on the LONG and COMPARE files, along with estimates for all other houses. This assures that PRISM will not terminate after encountering an error-ridden house's data (new feature of version 3.0 ).

SET CNTREC ON - Program produces the 'very short summary' file (unlt 92) when RUN command is 1ssued.

OFF - No such output produced.

SET RMIN thow Sets the lower bound on the search for best heating reference tomperature to the value $t_{\text {low. }}$ (Default setting 1\% -99.0.$)$

SET RYAX t up - Sets the upper bound on the search for best heating reference tomperature to the value $t_{\text {up }}$. (Default setting is +999.0 .)

SEI TRANCE tow tup - Equivalent to the Ewo SET commands: 'SET RMIN tiow' and 'SET RHAX tup'

Note concerning fixed tau: If you want the program to use a epecific reference temperature (axy $65^{\circ} \mathrm{F}$ ) rather than trying to find the 'best' reference tamperature, use the comands:

SET RMIN 65

SET RMAX 65

or alternatively, before the RUN command:

SET TRANGE 6565

Fixed tau may be set at non-1nteger values (a now feature of Version 3.0).

SEI TAUHO $t_{0}$

- Sets the Initial value for the search for best TAU to the value $t_{0}$. (Default setting is 62.0.)

SET MNIT $n$

- Sots the anximum number of iterations in the Iterative portion of the search for best heating reference temperature, to the integer $n$. (Default soteing is 9.)

SET KIND mom/dd/yy - Tells the program that the firet day for whlch tomperature data are avallable (on un1t 12) is the date $\mathrm{m} / \mathrm{dd} / \mathrm{y} y$. Thls setting is used to check the validity of dates on the nater flle. (Default setting 1s -99999.)

SET KAXD m/dd/yy - Tells the program that the last day for which 
temperature data are avallable $1 \mathrm{~s} \mathrm{~mm} / \mathrm{dd} / \mathrm{yy}$.

(Default setting is +1999999.$)$

NOTE (including caveat): The SET MIND and MAXD commands deserve extra discussion, alded by the folsawing definitions:

$$
\begin{aligned}
& \text { MIN - beginning date in the temperature file } \\
& \text { MAX - ending date in the teaperature file } \\
& \text { DATE1 - earliest date in meter file } \\
& \text { DATE2 - latest dace in meter flle }
\end{aligned}
$$

a) It is preforable to sat KIND - TMIN and MNXD - TMNX.

(even though leaving them at thelr default values is usually ok). You may went to include SET MIND and MAXD comands in a file of user commands (see explanation of SET KEYBRD $n$ at beginninig of section).

b) Always set up files so that TMIN < DATEI

(otherwise, program may go into a tallspin).

c) Never SET MIND > DATEI

(otherwise, program way go into a tallspin).

d) It is ok to set up files so that THAX < DATE2:

(for example, when the most recent tamperature update hasn't yet

\begin{tabular}{|c|c|c|c|}
\hline SET & TMPBIN & ON & $\begin{array}{l}\text { Tells the program to read temperatures in binary } \\
\text { rather than character format (for Princeton } \\
\text { use). OFF default should be meintained in } \\
\text { distributed version of flrogram. }\end{array}$ \\
\hline SEI & TERM & $n$ & $\begin{array}{l}\text { - Sets unit nubber for teiminal output. If } \mathrm{n} \text { is } \\
\text { different from } 6 \text {, terminal output goes to a file } \\
\text { which wust be dafined to the operating system as } \\
\text { unit } n \text {. }\end{array}$ \\
\hline SET & KEYBRD & $n$ & 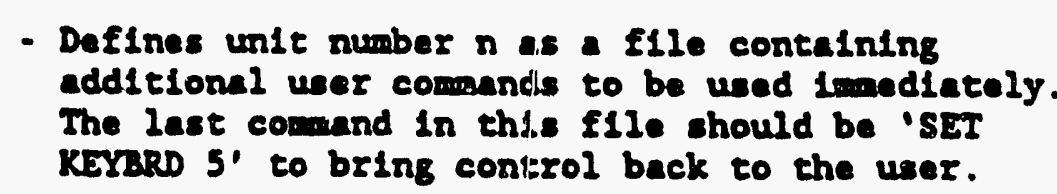 \\
\hline
\end{tabular}
arrived). PRISM correctiy truncates the estimation perlod as long as you have set MAXD - TMAX. If MAXD is left at 1Es default value, PRISM will not run the house, but will give an error message.

NOTE: The ruanining STATUS variables not discussed in the context of the SET comand are not used by this version of the program; thay should be left at their defaule values. 


\subsection{The RUN command}

Issuing the command 'RUN' tells the program to estimate the PRISM " madel using the current STATUS settings. If RUNAIl has been set to ON then all houses on unit 10 are run. Otherwlse a single house 18 run and the program pauses for more user commands. This command is equivalent to the command 'SET RUN ON'.

\subsection{The FIND comand (a new feature with Version 3.0)}

When running PRISY, the user any Input the 'comand 'FIND house-1d,' and the program will put the pointer before the house indicatad (1f $1 \mathrm{e}$ exists in the aeter f12e).

Important notes about the FIND comand:

a) The FIND comand any be used as many times as desired in a noter flle. However, it is luportant to ronaber that PRISY only noves forward in the meter file. If the desired house is positioned before the point where the FIND command is given, then PRISM will first search to the bottom of the neter file, REWIND. the file, and position the pointer at the beginning of the file. At this point, the user may input the FIND comand a second time to locate the desired house.

b) House-1d must be entered exactly as it is typed on the neter flle (no spaces separating characters are allowed).

c) The PRISM FIND command does not distinguish capltal from lower case letters; it recognizes only caps. (This is because of the way the computer reads the terminal.) Therefore, if a house-1d is typed in the meter file with lower case letters, the PRISM FIND comand will not locate the house. Note that this upper case restriction applies only to the FIND comand; PRISM run on any house-1d w111 st111 run as before and will falthfully print out upper and lower case.

\subsection{The NExT comand}

Typing the command 'NEXT' causes the program to skip over one house on the meter file and to position the aeter file at the start of the data for the next house. This differs from a RUN comand in that no output is produced for the house which is oktpped over. Th1s comand 1s especially useful for browsing; the FIND comand is preferable if the exact house-1d 1s known. After ach NEXT comand is lssued, the progran writes a mesage to the terninal (unlt 6) giving the house-1d of the next house on the file.

\subsection{The USE comand (improved for Version 3.0)}

In many application, the neter flle my lnclude nore weter reading perlods than the user wishes to use in the analysis. For exanple, the neter file alght be set up so that pre- and post-periods are not soparated 
on the file. The USE command enables the user to run the pre- and postperiods separately without racraating the weter file. Another Importarit. applieation is the sliding analysis, wherein ane-year estimation period. is sild forward one month at time [see PRISM: An Introduction (Fels, 1986)].

There are two ways in which the user can specify the meter readings to be used for each run. Both ways way be displayed in STATUS after the commands are issued.

a) The first form of the USE command is to give baginning and ending dates of the meter readings used for the estimation perlod. The format of the command 1s:

USE DAT 1

Then the program will respond with the prompt:

Input periods

The user then types:

KEEP $m l / d 1 / y 1$ TO $m 2 / d 2 / y 2$

where $\mathrm{ml} / \mathrm{d} 1 / \mathrm{yl}$ and $\mathrm{m} 2 / \mathrm{d} 2 / \mathrm{y}^{2}$ specify the beginning and anding dates, respectively, which are to be uned in the estimation period. After the RUN command is lasued, the user may specify now dates and the RERUN comand. For example, if the post-period is to consist of all meter reading periods with beginning dates between July 11, 1981 and July 10, 1982, the user will type:

USE DAT 1

KEEP $7 / 11 / 81$ TO $7 / 10 / 82$

If the user has typed:

USE DAT 2

then the computer w1ll request that two perlods be input as in:

KEEP $m 1 / d 1 / y 1$ TO $m 2 / d 2 / y^{2}$

KEEP $\mathrm{m} 3 / \mathrm{d} 3 / \mathrm{y}^{3}$ TO $/ 4 / \mathrm{d} 4 / \mathrm{y} 4$

Note: These two Intervals together constitute one estimation period, and all meter readings which are in elther of the two intervals are used in a single run.

b) The second form of the USE command ellows the user to specify period numbers rather than dates to indicate which meter reading periods are to be used. The format of the comand is:

USE NUM 1

followed by: 
KEEP n1 TO n2

Th1s form of the USE cominand is used whan dates vary from house to house but the order of the readings for each house is the same. Thus if the user always wants to have the 23 th to the 24 th consumption readings be a single estimation period he or she would type:

USE NUY 1

KEEP 13 TO 24

If a USE comand was issued and it is destred for the remalning houses to 80 back to the default of zunning all positive meter readings, then the comand 'USE AIl' should be typed.

If the USE command 1s. not epecified, then all positive neter raadings are included in the estimation.

\subsection{The REWIND comand}

Issuing the command 'REWIND' causps the aeter file (unit 10) to be reset at 1 ts beginning. The first house on the meter flle 1 s then ready to be processed. Th1s command may be used together with the USE command to define pre- and post-periods for a number of houses. For example, the USE command any be Imoked to define the 'pre-period' for all houses on the neter flle. Then after running all houses for the pre-perlod the user may REWIND the neter f1le, lasue now USE comand for the post-period and run the houses again.

\subsection{The RERUN comand}

Th1s cosmand tells the program to rerun the last house with any now settings changed since the last RUN comand was lssued. It is equivalent to the comand 'SET RERUN ON'.

\subsection{The QUIT command}

Terminates the program. Equivalent to 'SET QUIT ON'. 
5. A Typical Run

A typical rin of the estimation program consists of setting up the input files (units 10, 12, 15, and 21), compiling, and executing the program. You might then enter the commands:

command

MODEL HO

SET MIND $2 / 2 / 69$

SET MAXD $12 / 31 / 85$

SEI PLTUSE ON

SET PLTRSD ON

SET COMPAR ON

SET LOOK ON

SET RUNAII ON

USE DAT 1 .

REEP $7 / 1 / 80$ TO $6 / 30 / 81$

RUN

QUIT explenction

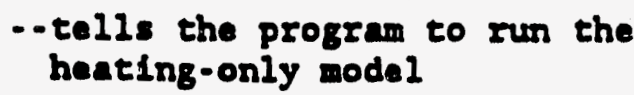

--indicates the beginning date for whlch tomperature date are avallable (note cavest in Sec. 4:3).

- Indlcates the last date for which temp data are present.

- tells the program to gonerate plots of energy usage (unit 77).

- tells the program to generate rasidual plots (unit 77).

--tells the program to produce the COATARE file (unit 22).

--tells the program to produce the 200K file (unit 16).

- says to run all the houses on the MEIER f1le (unit 10).

- specifies the estimation period (example)

- -begins execution of the program.

-stops axecution of the program.

NOTE: If you are ruming in batch mode, the QUIT command is essential to avold getting into an infinite loop.

The output of the estimation w111 be printed on units 16, 22 and 77 .

* With Input date from the mater f1le, tamparature f1le, and normalization file found on the tape (or disk), use of only the atarred comands will produce the LONG output on the tape. Note also that the date on the tables and figures in this documentation are consistent with the data on the tape. 


\section{Programing Notes (EÖr Hainfran: PRISM)}

6:1. Thare is a maximum number of meter reading periods which can be usad for \& ingle house. This aximum 1s currently set at 400 . The maximum is dafined by the use of a FORIRAN 77 PARAKETER statement. To change the maxinum from 400 to sone other ( $\$ 1 x e d)$ number, it is necessary to change all occurrences of the

$$
\text { PARALETER( MAXPD - } 400 \text { ) }
$$

statanent in the program to set MAXPD to sose other aaximum. The program must then be recomplied.

6.2. Similarly, there is a naximu number of dally average temperatures (hence days in the estination perlod) which can be read into mamory at one time. The current aximum is set to 3660 , or ten years of dally data, which is generally ample olnce a usual run requires approximately one year of data. If for some reason you want to run more than this asount of aeter reading date at one time for a oingle house, you will have to change all occurrences of the FORTRAN 77 PARAVIETER statement:

PARAVETER (RAXTEAS-366*10)

to set MAXIEY to sose other anximum, and recomplle the program. Note that the dally touperature flle ltself any contaln as wuch data as required.

6.3. Sowe systens have 11mitations on the size of the flle unlt numbers for Input/output. These mubers can be altered in the PARANETER stateants at the beginning of the progran.

6.4. If your computer system requires OPEN/CLOSE statenonts, these way be inserted in the duman subroutines OPENF and CLOSEF provided in the PRINM program. These subroutines are called at the appropriate places in the program. 


\section{Tables and Figures}


Table 1. Example of meter file

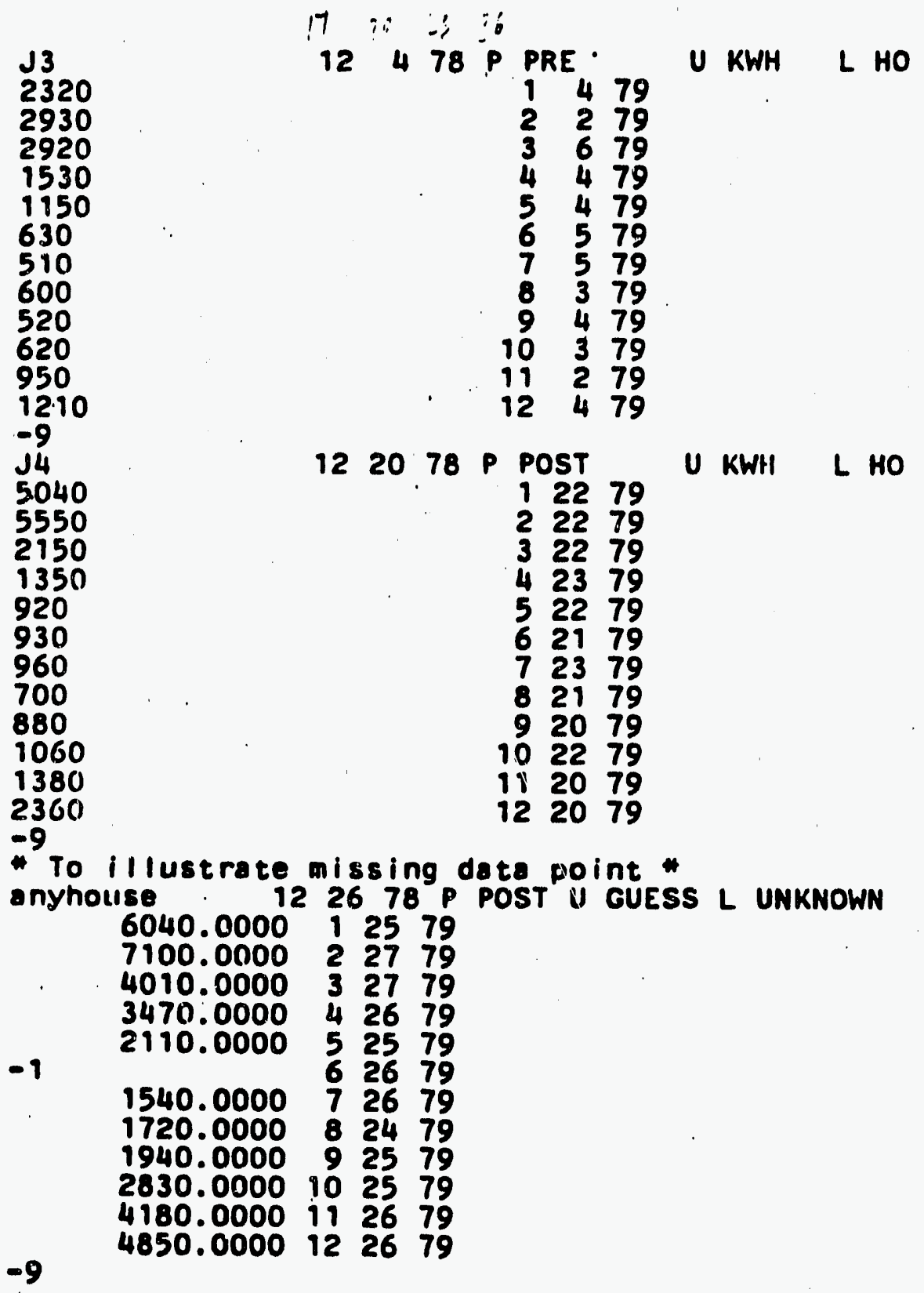


Table 1. Example of meter file (cont'd.)

- Similar to house $J 3$ but with a zero consumption point J23456789012345 12 478 P PRE L HO U KWH

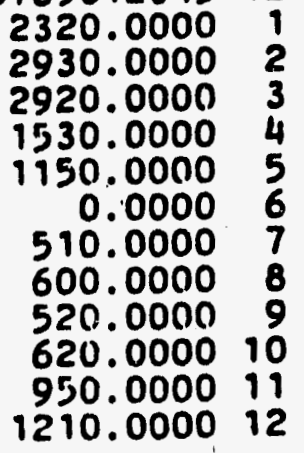

479

279

6.79

479

479

579

579

379

479

$\begin{array}{lll}4 & 79 \\ 3 & 79\end{array}$

279

$1210.000012 \quad 479$

-9 This is b bad house--Too few meter reading periods BADHOUSE

$\begin{array}{llll}3850.0000 & 1 & 19 & 79 \\ 4640.0000 & 2 & 21 & 79 \\ 2950.0000 & 3 & 21 & 79\end{array}$

* This is a bad house--mixed dates in July

J6PICKUPSTICKS 12478 P MIXED L WRONG U BAD 2320.0000 i 479

$2930.000022 \quad 279$

$2920.0000 \quad 3 \quad 679$

1530.00004479

1150.00005479

$0.0000 \quad 6 \quad 579$

510.00007579

600.00007379

520.0000 9 479

$620.0000 \quad 10 \quad 379$

950.000011279

E105

$1210.000012 \quad 479$

\section{6.}

374 .

182 .

143.

53.

45.

39.

37.

48.

107.

195.

255.

$-99$

\section{P PRE U CCF L CONTROL}

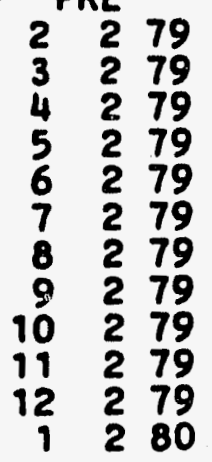


Table 2. Example of file of dafly uverage, temperatures

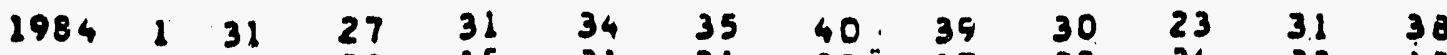
$22 \quad 15 \cdot 21 \quad 31 \quad 23 \% 17 \quad 23,26 \quad 22,12$

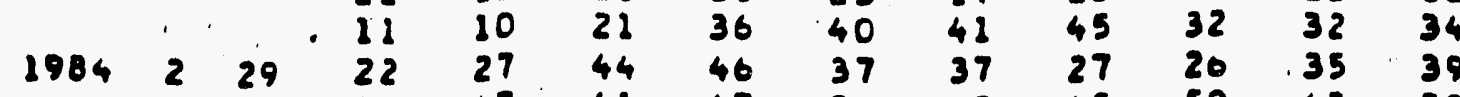

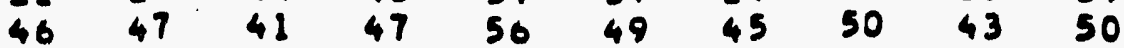

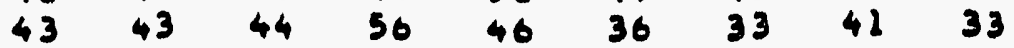

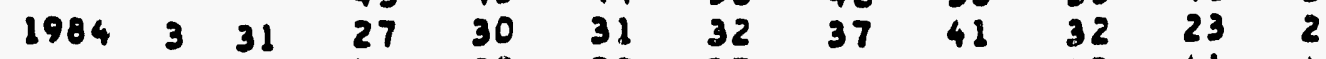
$\begin{array}{llllllllll}27 & 30 & 31 & 32 & 37 & 41 & 32 & 23 & 23 & 19 \\ 30 & 22 & 29 & 37 & 41 & 44 & 43 & 41 & 44 & 46\end{array}$

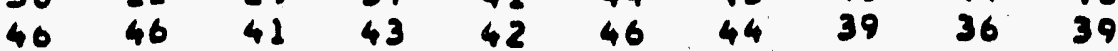

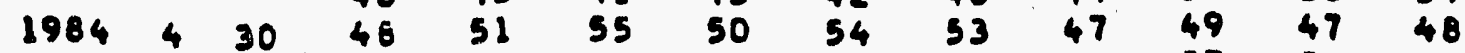

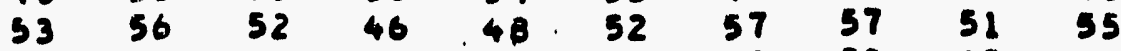

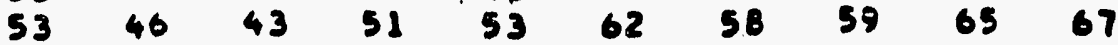

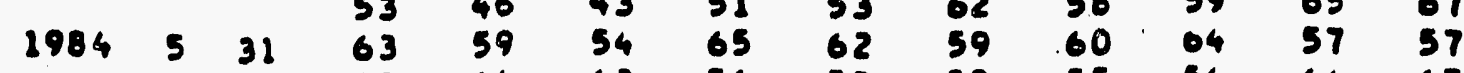

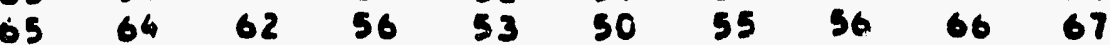
$\begin{array}{lllllllllllll}1984 & 6 & 30 & 68 & 69 & 75 & 68 & 71 & 78 & 69 & 60 & 66 & 59 \\ & & 65 & 66 & 61 & 71 & 75 & 78 & 63 & 66 & 85 & 67 \\ & & 67 & 76 & 64 & 79 & 69 & 66 & 69 & 71 & 81 & 77\end{array}$ $\begin{array}{lllllllllll}1904 & 74 & 72 & 75 & 73 & 77 & 71 & 77 & 78 & 70 & 71\end{array}$ $\begin{array}{lllllllllllll}1904 & 7 & 31 & 72 & 76 & 00 & 80 & 82 & 79 & 73 & 71 & 72 & 73\end{array}$ $\begin{array}{llllllllll}84 & 81 & 61 & 63 & 64 & 81 & 79 & 74 & 74 & 76\end{array}$

$\begin{array}{llll}72 & 77 & 80\end{array}$

198463180 84

\section{4} $77 \quad 77$ $\begin{array}{llllll}82 & 83 & 77 & 00 & 81 & 83 \\ 01 & 83 & 84 & 83 & 78 & 73\end{array}$ $\begin{array}{lllll}83 & 75 & 74 & 69 & 70\end{array}$

$73 \cdot 74$

7976

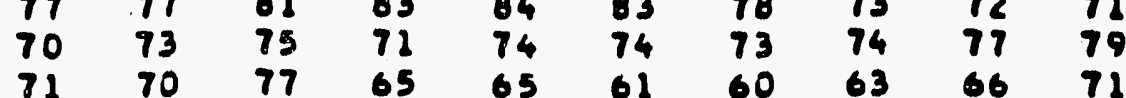

$\begin{array}{llll}75 & 73 & 68 & 73 \\ 68 & 65 & 72 & 78\end{array}$

$\begin{array}{lllllll}1984 & 10 & 31 & 56 & 52 & 50 & 58\end{array}$

$\begin{array}{llllll}59 & 55 & 60 & 59 & 63 & 71\end{array}$

$\begin{array}{llllll}79 & 62 & 52 & 49 & 00 & 59\end{array}$

$\begin{array}{llllll}79 & 62 & 52 & 49 & 00 & 59 \\ 68 & 50 & 53 & 61 & 66 & 63\end{array}$ $66 \quad 65$

$\begin{array}{llll}1984 & 1130 \quad 58\end{array}$ 6771 $63 \quad 02$

6261

6107

6268

6672 $\begin{array}{llll}1984 & 11 \quad 30 \quad 58\end{array}$ 58.52 4351

65

$\begin{array}{lllll}1984 & 12 & 31 & 34 & 33\end{array}$
3944

$1984 \quad 22 \quad 31$

$47 \quad 43$

$44 \quad 35$

5145

4 e 48

6573

68

$44 \quad 42$

48

$\begin{array}{llll}43 & 45 & 48 & 54\end{array}$

35

60

61

29

3950

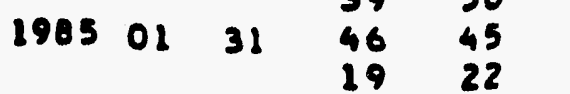

$31 \quad 39$

3842

31

3645

$39 \quad 35 \quad 32 \quad 30$

51

39

$\begin{array}{llll}28 & 29 & 38 & 25\end{array}$

5850

$\begin{array}{lllll}31 & 24 & 16 & 23 & 26\end{array}$

16

$\begin{array}{llll}19 & 22 & 27 & 3 \\ -2 & 15 & 24 & 2\end{array}$

$\begin{array}{llll}1985 & 02 \quad 28 \quad 32\end{array}$

32

$24 \quad 28$

32

23

23

29

$\begin{array}{llll}22 & 24 & 22 & 13\end{array}$

2

$28-26$

20

26
28
35

$\begin{array}{llll}1985 & 03 \quad 31 \quad 4\end{array}$

$40 \quad 33 \quad 31$

$36 \quad 50 \quad 60 \quad 60$

29

$\begin{array}{lll}26 & 34 & 36 \\ 43 & 41 & 32\end{array}$

$\begin{array}{lllll}39 & 33 & 48 & 29 & 31\end{array}$

41

47
32

42

35

$\begin{array}{llll}47 & 49 & 51 & 46\end{array}$

$\begin{array}{llll}1985 & 04 \quad 30 \quad 49\end{array}$

$49 \quad 43 \quad 42 \quad 53$

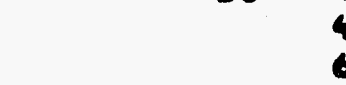

$\begin{array}{lllll}1985 & 05 & 31 & 72 & 55\end{array}$

565

58.52

43

$\begin{array}{llll}43 & 46 & 57\end{array}$

4544

$32 \quad 32 \quad 49$

687356

$\begin{array}{llllll}67 & 63 & 55 & 46 & 41 & 40\end{array}$

$\begin{array}{llllll}55 & 66 & 53 & 60 & 77 & 60\end{array}$

$\begin{array}{llllll}58 & 72 & 65 & 61 & 63 & 71\end{array}$

$52 \quad 56$

$\begin{array}{llll}68 & 71 & 65 & 60\end{array}$

$\begin{array}{llll}79 & 76 & 78 & 71\end{array}$

$\begin{array}{llll}59 & 65 & 70 & 63\end{array}$

5672

$\begin{array}{llll}73 & 69 & 65 & 69 \\ 73 & 72 & 76 & 70\end{array}$

$7174 \quad 7971$

0073

$\begin{array}{lllllll}1985 & 06 & 30 & 73 & 72 & 76 & 70 \\ & & & 70 & 73 & 62 & 62\end{array}$

$\begin{array}{llll}61 & 60 & 64 & 65 \\ 66 & 70 & 71 & 76\end{array}$

6502

6978

7271

29

45

57

76

7.7

64

36

26

46

68

36

bno2a27.3MppDI 
Table 3a. Example of normallzed-year heating degree-day flle



Table 3b. Example of normalized-year cooling degree-day file

\begin{tabular}{|c|c|c|c|c|c|c|c|c|c|}
\hline $\begin{array}{l}10120 \\
.8706 \\
.870 \\
.879 \\
.979 \\
.568 \\
.188 \\
.430 \\
.300 \\
.804 \\
.172 \\
.000 \\
.000\end{array}$ & $\begin{array}{l}4.003 \\
4.675 \\
16.435 \\
9.844 \\
4.877 \\
1.545 \\
0.117 \\
0.000 \\
0.000 \\
0.000\end{array}$ & $\begin{array}{l}\text { D. JAN } \\
62.870 \\
52.870 \\
42.888 \\
33.032 \\
23.792 \\
15.700 \\
9.274 \\
4.467 \\
1.308 \\
0.076 \\
0.000 \\
0.000 \\
0.000\end{array}$ & $\begin{array}{r}11970 \\
61.870 \\
51.870 \\
41.893 \\
32.070 \\
22.919 \\
14.981 \\
8.722 \\
4.076 \\
1.090 \\
0.049 \\
0.000\end{array}$ & $\begin{array}{r}- \text { DEC } \\
60.870 \\
50.870 \\
40.899 \\
31.115 \\
22.058 \\
14.282 \\
8.183 \\
3.700 \\
0.895 \\
0.031 \\
0.000 \\
0.000 \\
0.000\end{array}$ & $\begin{array}{l}31.981 \\
59.870 \\
49.871 \\
39.907 \\
30.167 \\
21.210 \\
13.600 \\
7.666 \\
3.342 \\
0.721 \\
0.020 \\
0.000 \\
0.000 \\
0.000\end{array}$ & $\begin{array}{r}58.870 \\
48.871 \\
38.917 \\
29.230 \\
20.375 \\
12.935 \\
7.162 \\
3.000 \\
0.570 \\
0.012 \\
0.000 \\
0.000 \\
0.000\end{array}$ & $\begin{array}{r}57.870 \\
47.872 \\
37.929 \\
28.300 \\
19.556 \\
12.288 \\
6.673 \\
2.677 \\
0.440 \\
0.006 \\
0.000 \\
0.000 \\
0.000\end{array}$ & $\begin{array}{r}56.870 \\
46.873 \\
36.943 \\
27.382 \\
18.750 \\
11.653 \\
6.200 \\
2.369 \\
0.329 \\
0.003 \\
0.000 \\
0.000 \\
0.000\end{array}$ & $\begin{array}{r}55.870 \\
45.876 \\
35.959 \\
26.471 \\
17.960 \\
11.033 \\
5.741 \\
2.080\end{array}$ \\
\hline
\end{tabular}


Table 4. Example of LONG output f1le (frow first house in Table $1^{*}$ ).

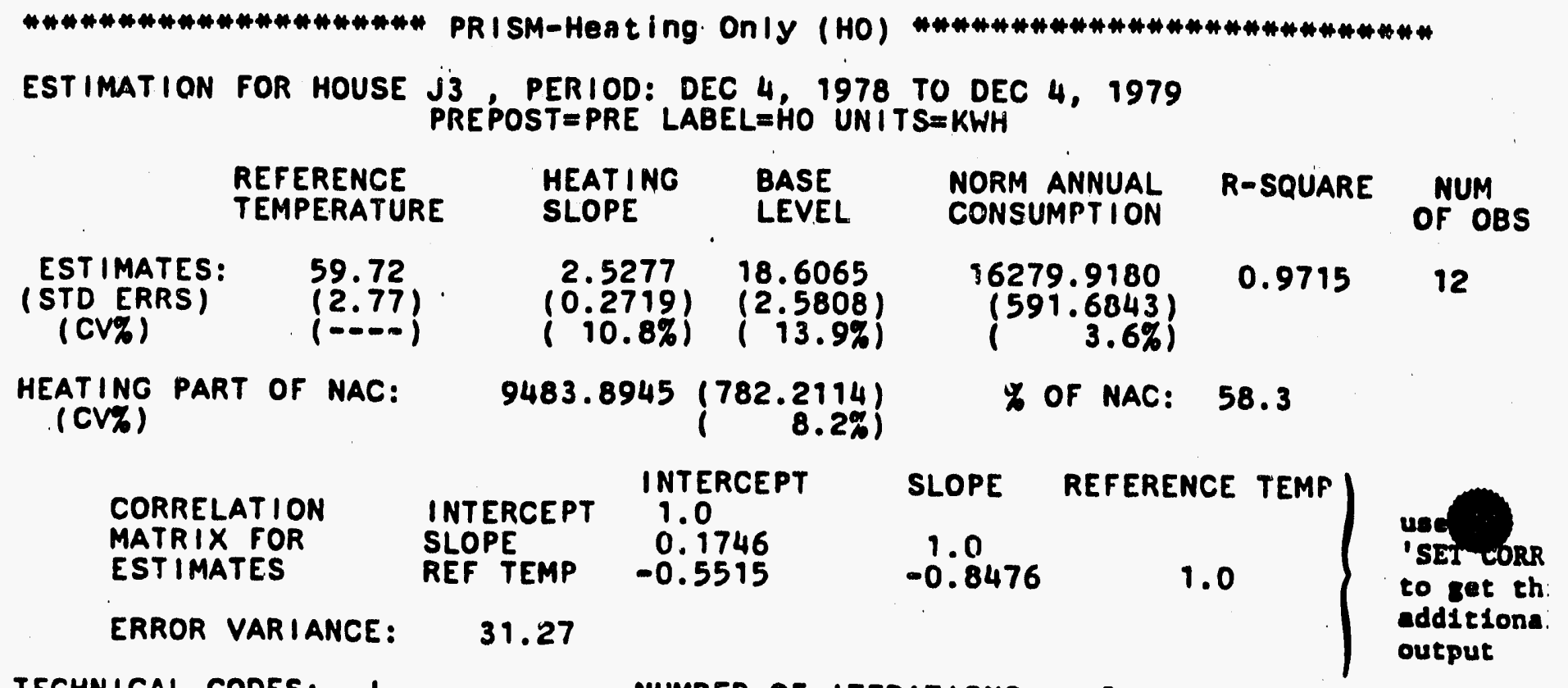

TECHNICAL CODES: J NUMBER OF ITERATIONS: 3

*Plots in F1gs. 3a and 3b correspond with this output. 


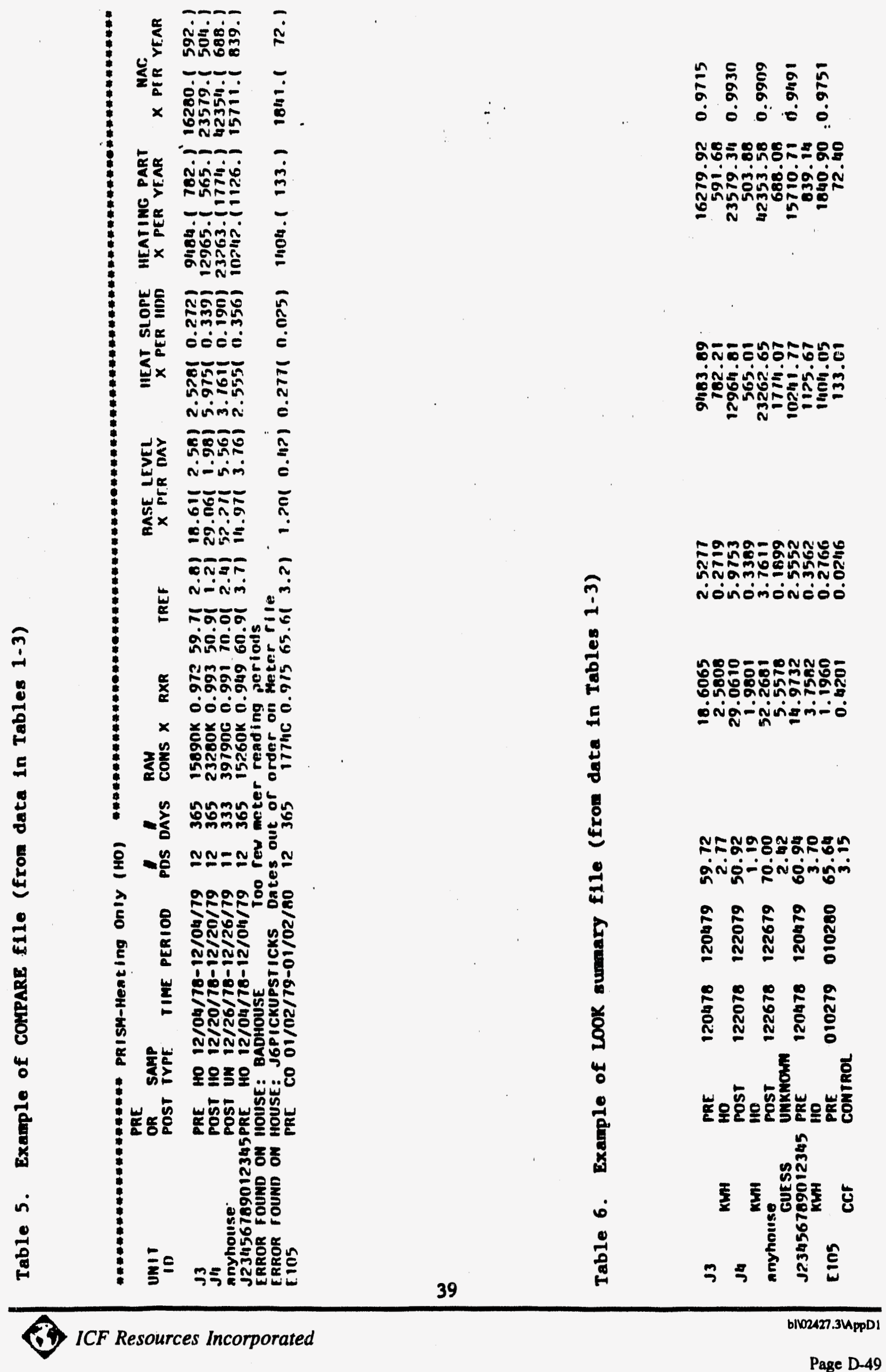


Table 7. Example of RESIDUALs fite (from data in Tables 1-3)

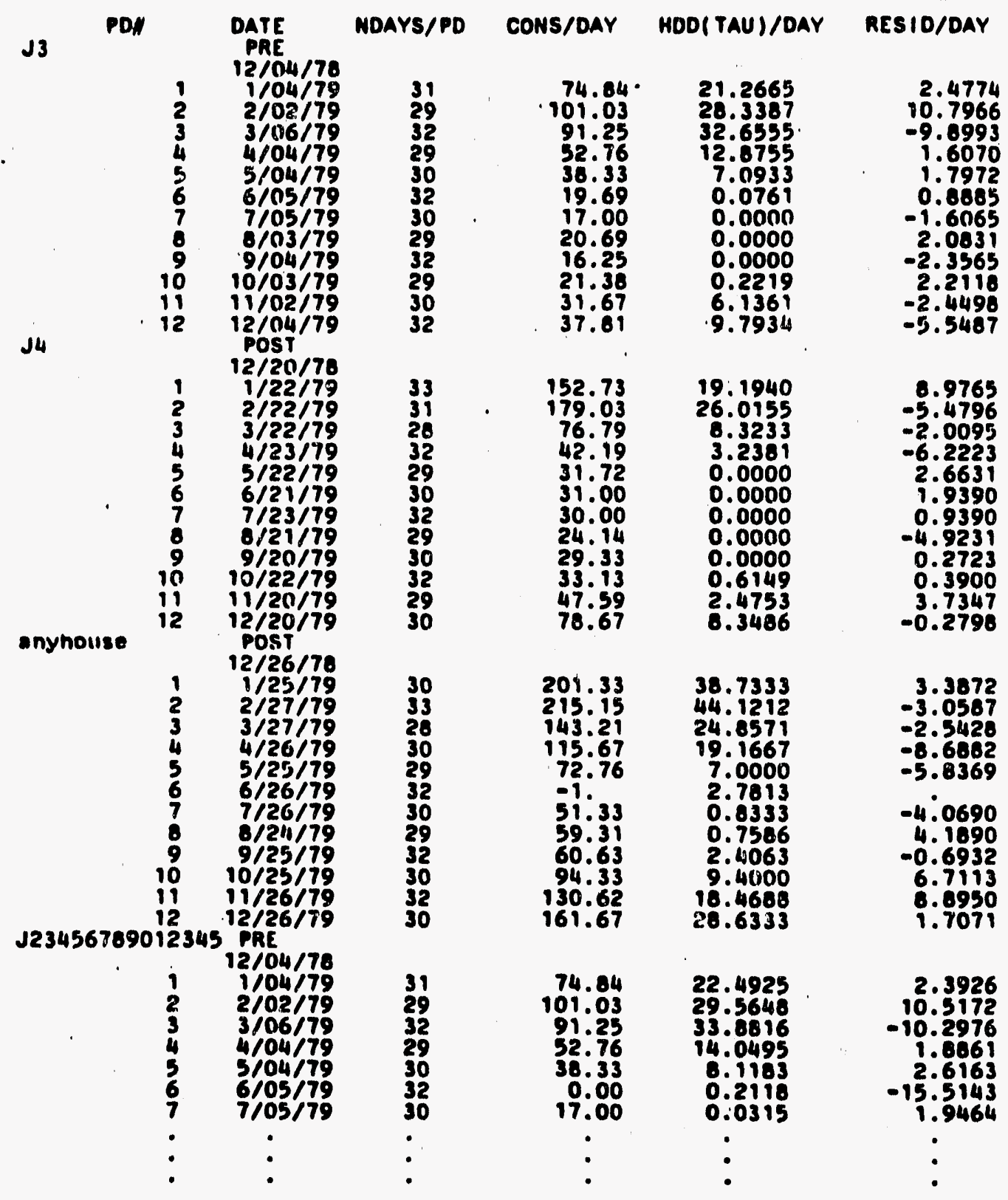


¿́⿴囗十் 象

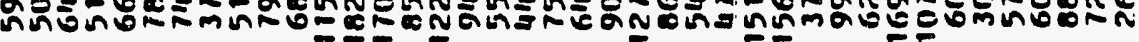

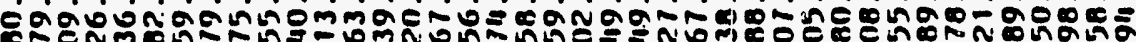
Gกำ

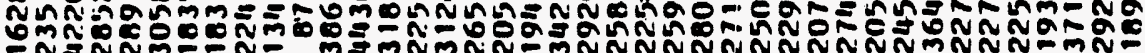

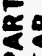

$\sum$

a Niñ -

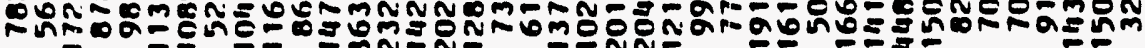

Co

$=w$

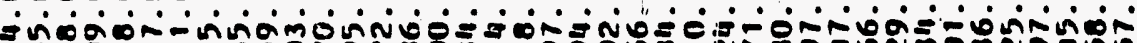
OCHEm- - me

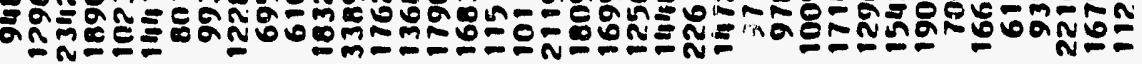

능를

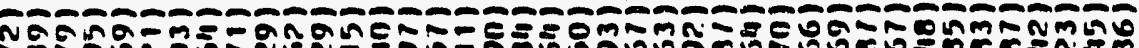
NMํํํำ

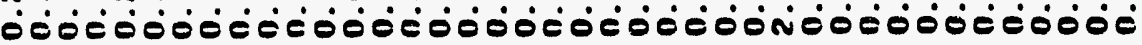

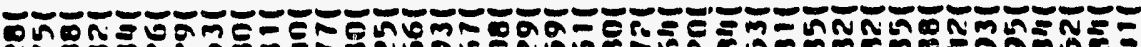

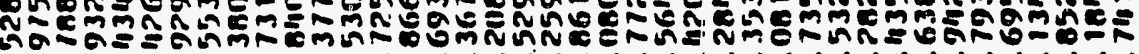

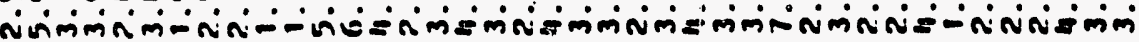

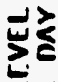

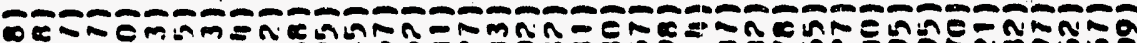

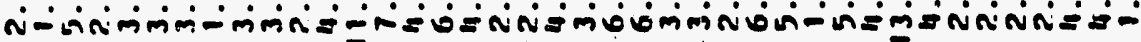

we

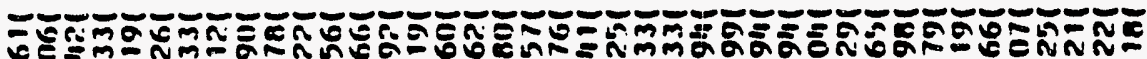

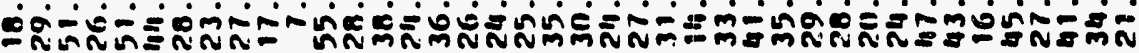

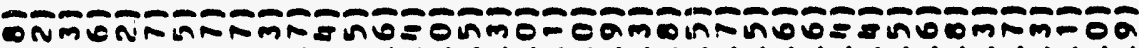

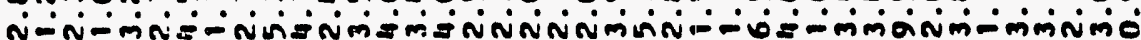

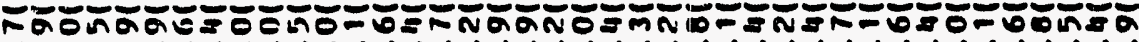

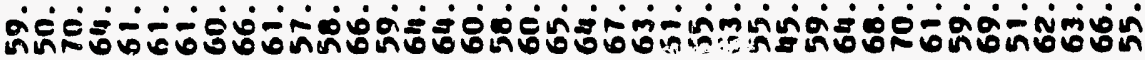

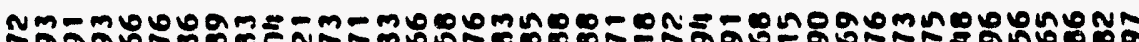

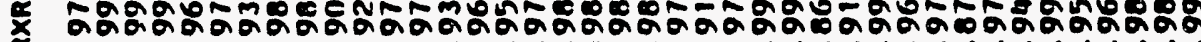

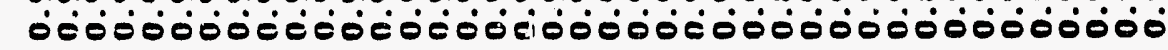

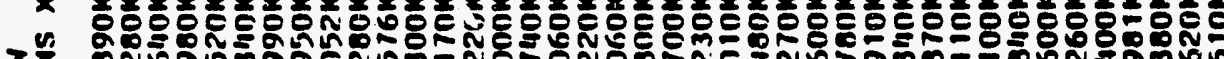
ว

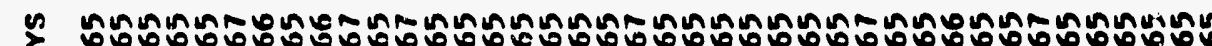

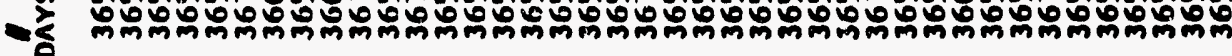

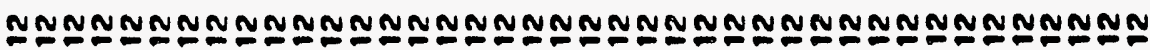

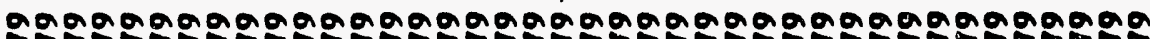

\& జ

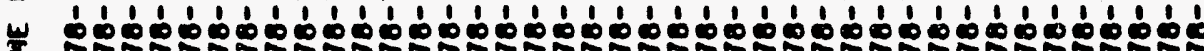

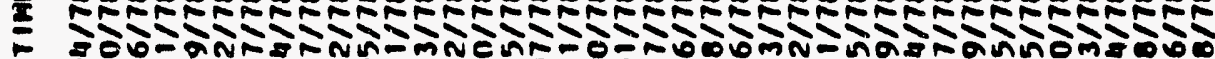

อกำด

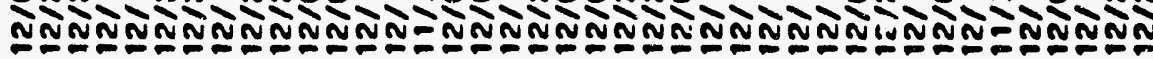

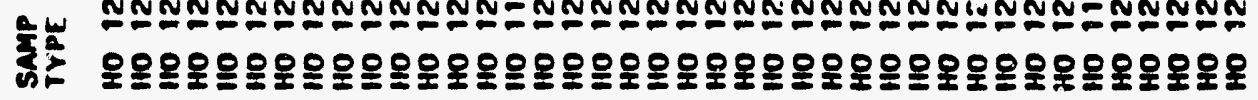

这㓠宫

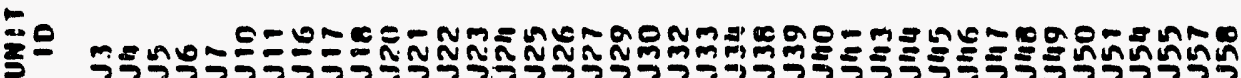





\section{Monthly Summery}

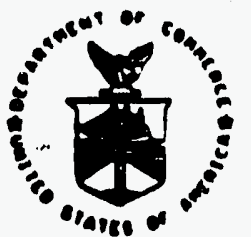

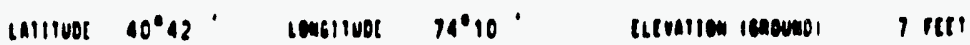

IInt reat castenn

1493

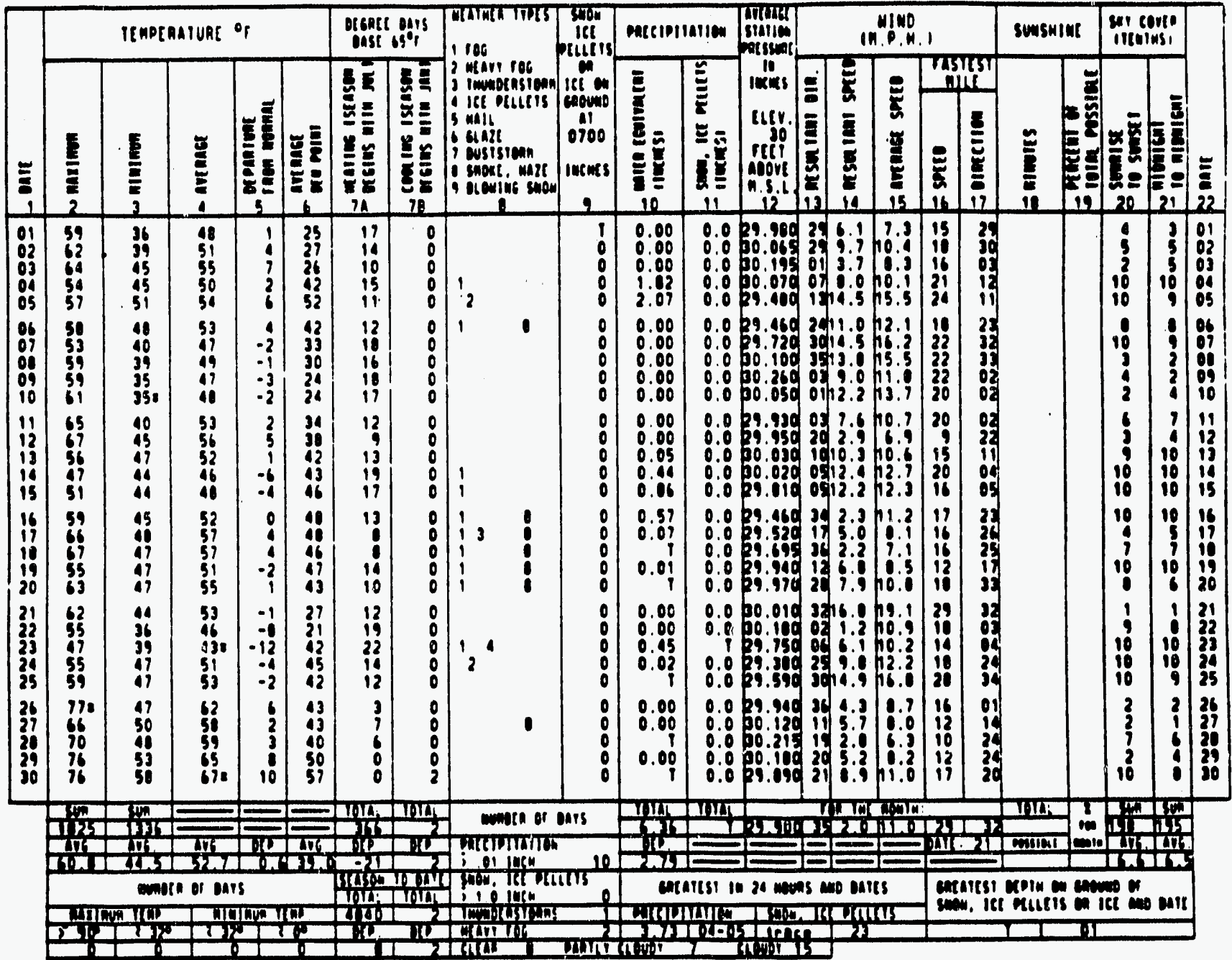

- Exinene con ine nowin - Lasi occunnence if mone iwan owe inder anoum?

- also on tantich oate is

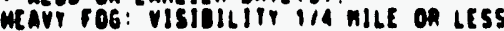

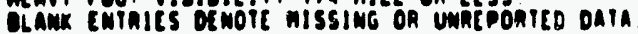

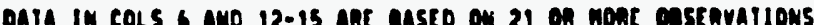
at moinh

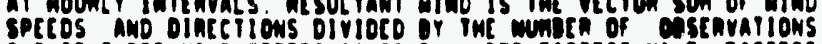

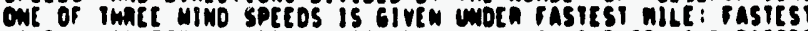

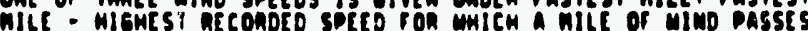

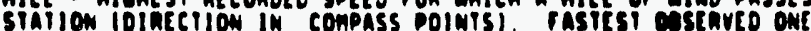

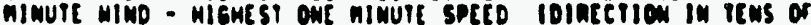

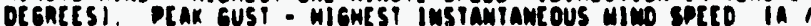

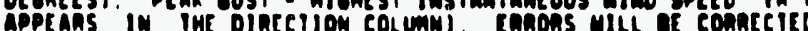

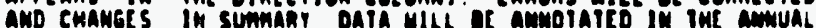
PulieAtion.

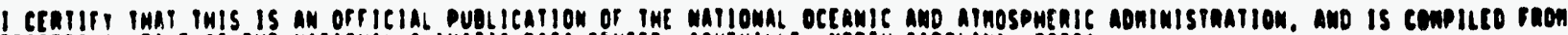

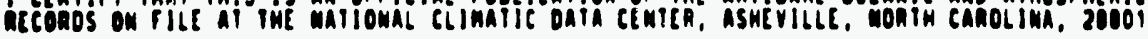

ariste

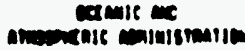

milea:

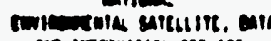

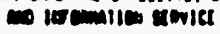

milinen

araile cura amo

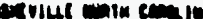

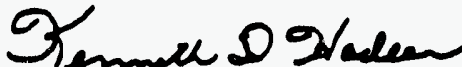

olaterion

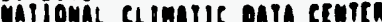

Figure 2. Sample data from NOA Local Climatological Data, the data source for monthly temperature updaces 

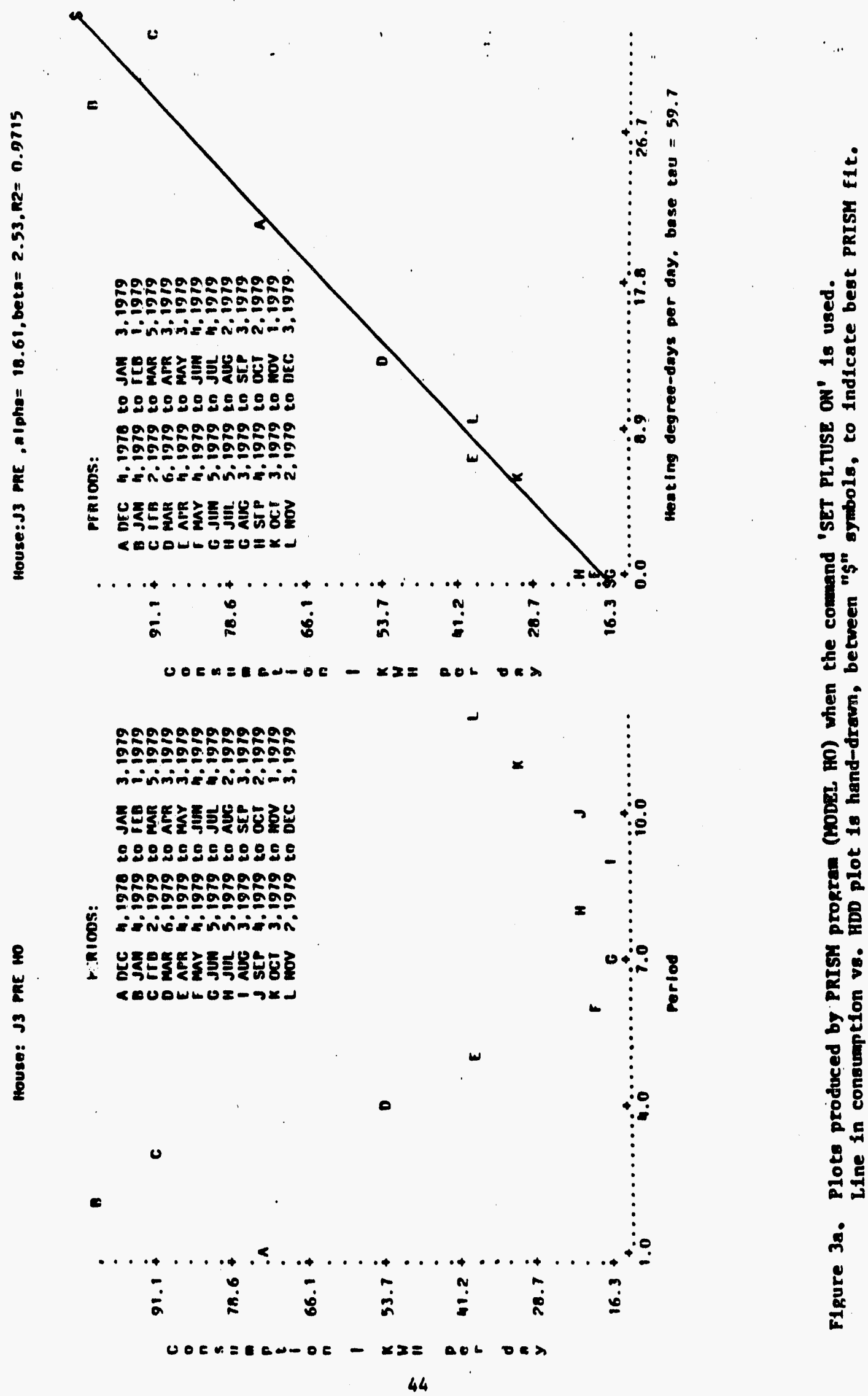


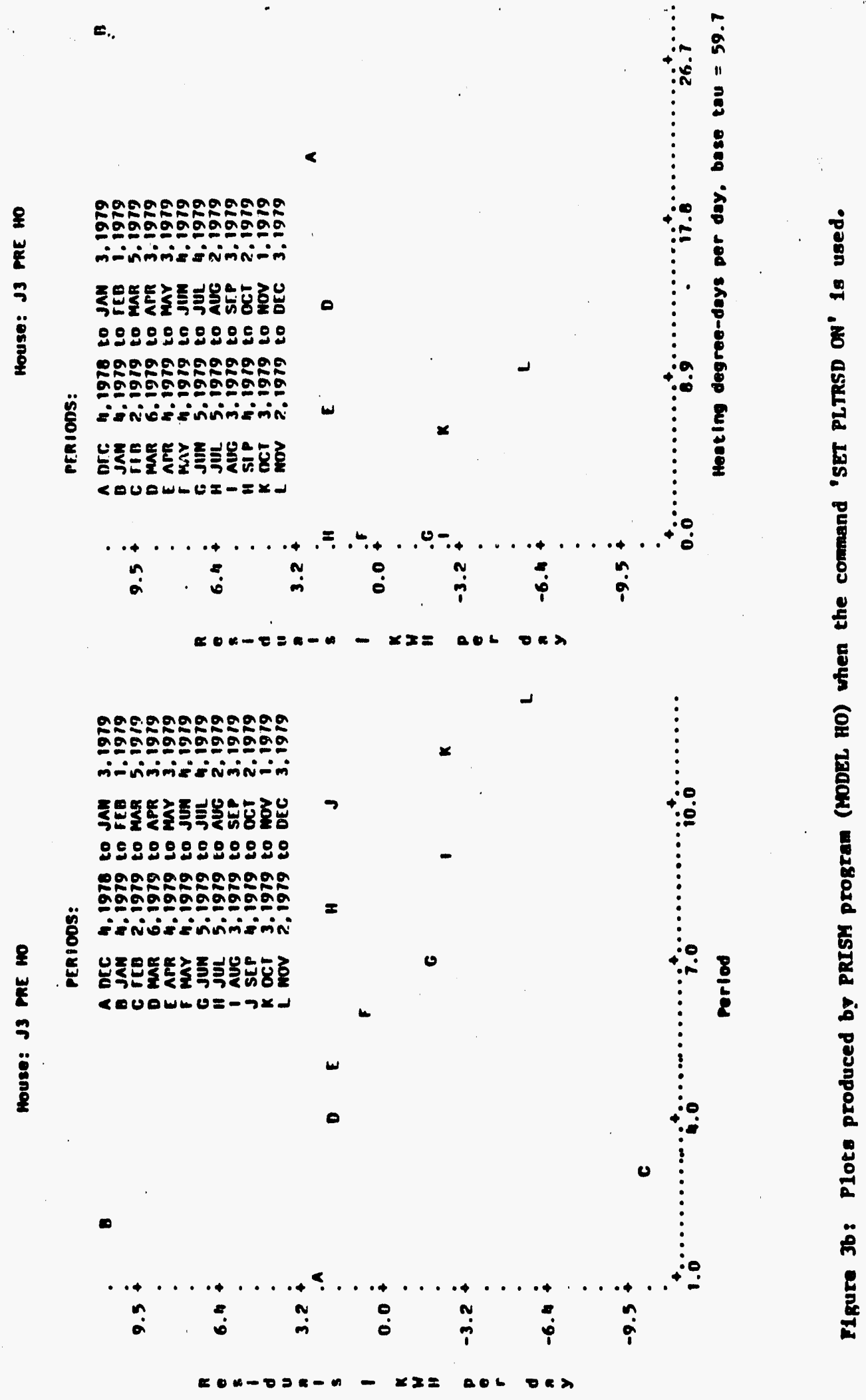

45 

Appendix 1. Technical Codes for PRISM Program

\begin{tabular}{|c|c|}
\hline Code: & Explenation \\
\hline Blank & $\begin{array}{l}\text { Normal convergence. Iterative procedure found best } \\
\text { estimates in less than MAXIT iterations. }\end{array}$ \\
\hline B & $\begin{array}{l}\text { Iterative procedure tried to } 80 \text { above MAXIAU in } \\
\text { search for best TAU. }\end{array}$ \\
\hline C & - Iterative procedure tried to go below MINTAU. \\
\hline D & $\begin{array}{l}\text { Oscillation around values for more than one } \\
\text { Integer ("double star orblt"). }\end{array}$ \\
\hline $\boldsymbol{E}$ & $\begin{array}{l}\text { - Oscillation around one Integar value ("single } \\
\text { star orbit"). }\end{array}$ \\
\hline$F$ & - No convergence in MAXIT 1terations. \\
\hline G & $\begin{array}{l}R^{2} \operatorname{maximized} \text { in gridsearch rather than in } \\
\text { 1terative procedure. }\end{array}$ \\
\hline $\mathbf{H}$ & - Value for taU set to maXrau. \\
\hline$I$ & $\begin{array}{l}\text { Bast TAU found within one integer above best } \\
\text { value found in integer gridsearch. }\end{array}$ \\
\hline $\mathrm{J}$ & $\begin{array}{l}\text { - Best TAU found within one Integer below best } \\
\text { velue found in integer gridsearch. }\end{array}$ \\
\hline 0 & $\begin{array}{l}\text { Heating slope too close to zero to calculate } \\
\text { standard error for TAU. In this case, the } \\
\text { standard error for MAC is set to }-9.0 \text {. }\end{array}$ \\
\hline$x$ & $\begin{array}{l}\text { Iteriative procedure terminated because } R^{2} \\
\text { docreased (rather than Increased) twice in a row } \\
\text { during 1terative portion of estination procedure. } \\
\text { Gridsearch was uged to complete estimations. }\end{array}$ \\
\hline$A, K, L, M, N$ & $\begin{array}{l}\text { - All used to flag zero divide errora in various } \\
\text { aections of the program. }\end{array}$ \\
\hline
\end{tabular}

Note to user: Gridearch refars to the fallback routine uned when the Iterative procedure falls to find best TAU.

$A-1$ 
Appendix 2. Supplamentary Programs

Three additional programs are providad on the tape for users of the PRISM software. These are:

A. A FORTRAN 77 program, called DDCALC, which can be used to generate the normalized year heating and cooling degree-day files for PRISM fron the imput dally tamperature data (In PRISM format). The progran reads the comparature f1le (unit 12) described in sec. 2 and creates the normalized hoating year file (untt 14) and cooling year file (untt 20). Degree-days are computed on a per-day basis. The user specifies the normalization perlod dates and the deslred range of lnteger reference touperatures. This progran is also useful for computing degree-days for other periods (e.g.. for each nonth at base $65^{\circ} \mathrm{F}$, to validate the temperature data entered; see Sec. 1.5).

B. A FORIRAN 77 program, called VDY, which reads aeter flles used for PRISM Version 2.2 and rowrites thom into now flle in the format required by ERISM Verisions 3.0 and higher. The program assumes that. the original aeter flle has no errors and is already PRISM-usable.

A. DDCALC

The program DDGAlC requires five files. These are (by FORTRAN unit number):

Unit 5 - Terminel Input of commands (see below)

6 - Terminal output of messages

12 - Input tomperature f1le (Sec. 2)

14 - Output f1le of normalized heating degree-days (was 15 prior to Version 3.0)

20 - Output flle of nornalized coollng degree-days

To $\operatorname{sun}$ DDGAIC:

1. Prepare the temperature file and define this file as unlt 12 to your computer's operating aystam.

2. Complie and execute program.

$A=2$ 
3. Type the following commands from the terminal

: SET STARTD mom/dd/yy -. to define the beginning of the normalization period. Default is $1 / 1 / 70$.

SET ENDD m/dd/yy -. to dafine the end of the normalization period. Default 1s $12 / 31 / 81$.

SET TRANGE minb maxb -. to define the minimum and naximem reforence tomperatures for the calculation of henting (and cooling) degree-days. The default values are minb - -10 and paxb $=220^{\circ} \mathrm{F}$.

STATUS

-. to vlew current settings of Intarmal variables that are anipulated with the SET commands.

RUN

-. to begin the calculations and create the normalizetion fllos.

If you desire only heating degree-days (un1t 14) then type

SET CDD OFF

before the RUN command. (PrLor to version 4.0, SET CDD ON was not a default.)

B. WDY (for pre-Version 3.0 upers only)

The KDY program uses two files. Thase are (by FORTRN unlt muber):

Unit 9 - Meter f1le used in PRISM Version 2.2 (or earlier).

Unte 10 - Comverted nater file to be used in PRISY Version 3.0 or higher.

Error nessages are printed on the terminal, unit 6.

A-3 
The following example 1llustrates the differences between the old format read by $\mathrm{kDY}$ and the now format generrated by the program:

METER FILE (Version 2.2)

METER FILE (Versions 3.0 or higher)

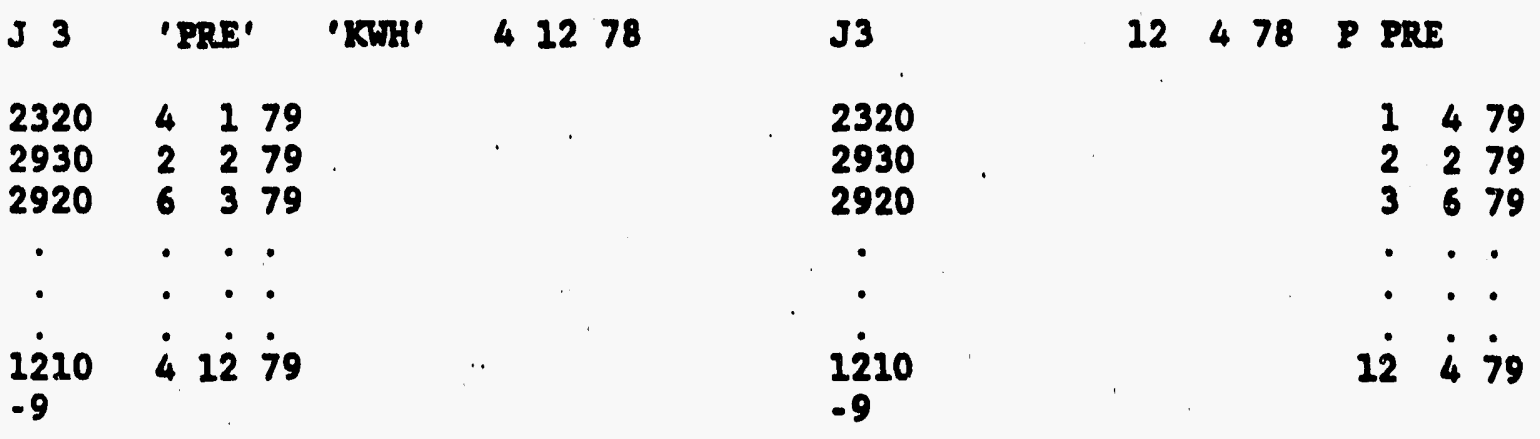

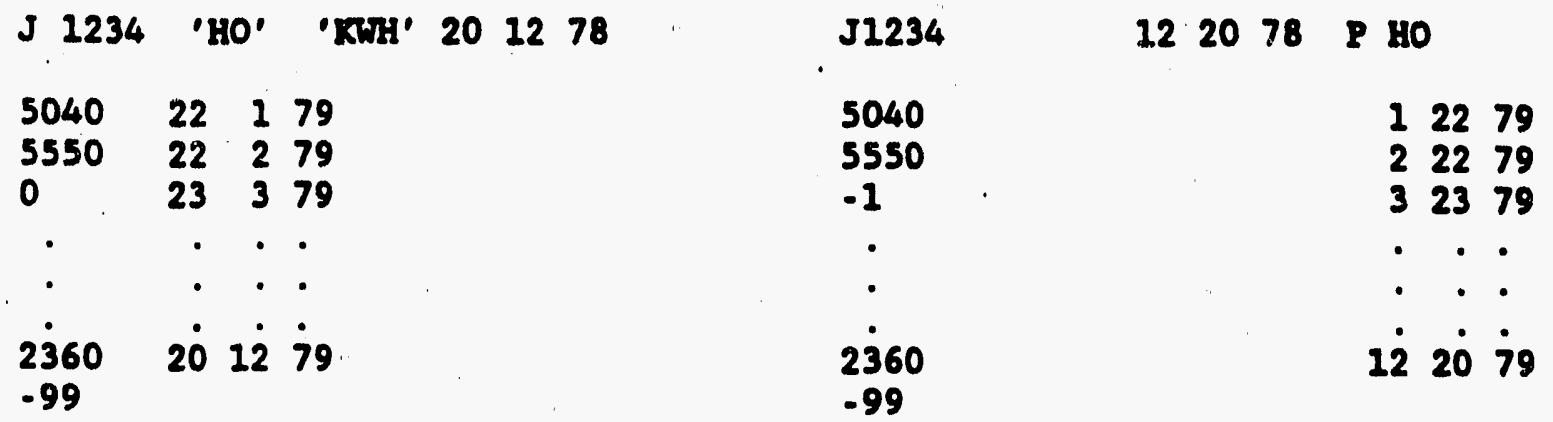

บ KWH

Please note the following differences:

1. The header card of the meter file consists now of a house idantifier which way be up to 15 alphanuwerlc characters (no spaces are allowed), the date with the now format waY DD YY, and three label flelds described in Sec. 2 (unit 10).

2. PRISY Version 2.2 allowed only 2 descriptive flelds in the heador card. With the BDY progran these two flelds are copled to the now format as the PREPOST (P) Eleld and the ONITS (U) field. You way wiah to change the WDY format stitonent which opecifles the fleld (e.8., If you used 'HD' 'In the PREPOST fleld of an old neter file to descrlbe a house doctor tractont, you way wish to change the field from $P$ to I for this set of houses).

3. In order to accomodate those cases when consumption is actually zero, PRISM Version 3.0 or higher w1ll accopt 0 as a consumption point. Therefore, the IDY progran converts all 0 readings, praviously Indicating a alssing data polnt, to a - I reading. This is the now convention for alssing readings. 
Appendix 3. Description of NOM Date Series

Following is a goneral description of the weather data obtalned from the National Climatic Data Center in Asheville, NC (see also Sec. 1.2):

a) data for over 400 primary weather stations are avallable (Including navy bases and 1slands)

b) years Included range from 1940 to 1983 (any number of yearly data may be requestad) with updates on a separate reel or on hard copy

c) format is Series 3210: variable length ASCII; can be converted to ASCII flxed length or EBCDIC fixed or variable length for an additional fee*

d) Local Climatological Data (LCD) updates are avallable on a permonth basis and also as an annual aubscription of monthly updates. Thare is usually a 2-gonth lag in recelving the most recent update.

The following list describes the Individual components that determine the total cost of any data request:

a) minimum charge

b) cost per starion selected

c) conversion to a different tape format*

d) \# of input tape mounts**

-) of output tape mounts

f) fixed tape cost

g) merge of pre-1984 data with more recent data

h) LCD updetes

1) shipping and handling.

The metaorologists are very helpful and ancourage people to call for a cost estimate. Payment may be made in several ways: by VISA or MASTERCARD (1f one wishes to speed things up), as well as with normal purchasing procedures. Dellvery detes may be as long as 3 to 4 weoks from time of order. The NCDC will take rush orders and Federal Express orders (at extra cost).

\footnotetext{
*The comversion cost 1s the same whether one whohes to have the data formatted In the 3210 serles ASCII flxed length or converted to the 9750 series variable or flxed langth (the old roM tape format for weather data). This cost results from having to put the data through a software program first before belng output to tape.

the number of Imput tape nounts 1s deternined by the number of selected weather stations. Frequently, date from many weather stations in the same geographical location are on the sane roel, in which case only one tape mount is charged.
}

A -5 

Appendix 4. Bibliography of Scorakaeping Publications

About the Scorekeeping Methodology:

M. F. Fels (1986) "RRISM: An Introduction", Energy and Buildings, 9. 11, PP. 5-18; previously avallablo as PU/CEES No. 263.

(the description of the method)

M. F. Fels, ed. (1986) Measuring Energy Savings: the Scorekeeping Approach, A special isaue of Energy and Buildinge, 9, \#1-2, Elsevier, Lausanne, Swltzerland.

(sixteen papers providing a comprahenalve summary of PRISM research and applications; see specific references in list below)

M. L. Goldberg (1982) "A geometrical approsch to nondifferentlable regression models as related to methods for assessing residential energy conservation", Ph.D. Thesis for Dept. of Statistics, Princeton University, PU/CEES Report No. 142, Princeton, NJ.

(derivation of rigorous statistics underlying PRISH, Including wathod for computing standard errors of the estimates)

\section{Prototype application}

G. S. Dutt, M. L. Lavine and B. G. Lev1 (2986) "The Modular Retrofit Experiment: Design, corekeeping and ovaluation", Energy and Bulidings, 2, \#1, pp. 21-33.

(the retrofit experimant of 140 gas-heated houses for whlch the scorekeeping method was developed)

\section{Interpretation of PRISy results}

M. F. Fels, J. Rachlin and R. H. Socolow (1986) "Seasonality of non-heating consumption and 1ts effect on PRISM results". Enargy and Bulldinge, 2, \#2, Pp. 139-148.

(an analysis of hasting ve. non-heating consumption, with an Improved understanding of the physical

meaning of the model estimates)

J. Rachlin, K. F. Fels and R. H. Socolow (1986) "The stabll1ty of PRISM ostimates", Energy and Bulldings, 9, \#2, PP. 149-157.

(an analysis of the data requirements of the scorekeeping model and the stabllity of nodel rosults)

\section{A-7}


Other studies

E. Hirst, R. Goeltz and D. White (August 1984) wee of electriclty bliling date to determine household energy use 'Elngetprints" " Oak Ridge National Laboratory Raport No. ORNL/CON-164, Oak Ridge, TN.

(an exploration of differenis ways to use PRISM estimates to categorize houses)

Application to different fuels

M. F. Fols, R. H. Socolow, J. Rachlin and D. O. Stram (1985) "PRISM: A conservation scorekeaping wethod applied to electrically heated houses". Electric Power Research Instltute Report No. Ey-4358, Palo Alto, CA.

(sumary of research to extend PRISM from gas-heated to electrlcally heated houses)

D. O. Stram and M. F. Fels (1986) "The applicabll1ty of PRISM to electric heating and cooling", Energy and Bulldings, 9. \#2, Pp. $101-110$.

(application of the scorokeeping approach to electrically heated houses, including an exploration of how cooling alght be Included in the model)

M. F. Fels and D. O. Stran (1986) "The effect of burning rood on saving electrieley", Eneryy and Bulldinge, 9, "2, Pp. 119-126.

(an assessant of the rellability of scorakeepling results when wood is supplenenting alectricity used for heating; the benefits of separating woodusers from non-woodusers for the analysis)

M. F. Fols and D. O. Stran (1986) "Does PRISM distort the ervergy signature of heat-pump houses?", Energy and Bulldinse, 9, "2, pp. 111-128.

(exploration of the application of FRISY to houses hoatod by heat-pump oystans)

M. F. Fels, M. L. Goldberg and M. L. Lavine (1986) "Exploratory scorakeoping for o11-heated houses", Energy and Bulldings. 9. \#2. Pp. $127-136$.

(an assassent of how well the nodel works on 011 delivery date in eingle-family houses) 
Application to multifamily buildings

J. M. DeCleco, G. S. Dute, D. T. Harrje and R. H. Socolow (1986)" "PRISM applied to a mitifamily bullding: the Lemley Homes case study", Energy and Bulldings, 9, 1, Pp. 77-88.

(a pilot application of PRISM to a multifamily building; gore detalled analysis using instrumented date)

C. A. Goldman and R. L. Ritschard (1986) "Energy conservation in public housing: - case study of the San Francisco Housing Author1ty", Energy and Bulldings, 9, "1, PP. 89-98.

(application of PRISY to several multifamliy bulldings)

Evaluation of energy conservation programs

M. L. Goldberg (1986) "A Hidwest low-1ricome weatherization program seen through PRISM", Energy and Buildings. 9, 11, Pp. 37-44.

(scorakeeping for a low-incone weatherization project; good accounting of date problans ancounterad)

M. J. Hewert, I. S. Dunwworth, I. A. Miller and M. J. Koehler (1986) "Measured vs. predicted savings fron elngle retrofits: * sample study". Energy and Butldings, 9, "1, Pp. 65-73.

(use of PRISM to essess the acisuracy of savings predictions)

E. Hirst (1986) "Electricity savings oine, two, and three years after participation in the BPA Residential Weatherization P1lot Program", Enr sky and Bulldings, 2."1, Pp. 45-53.

(a couplete evaluntion, based on MAC's fron PRISK; 1lluetrates two-stage approach)

L. S. Rodberg (1986) "Energy conservation in low-Income homes in New York C1ty: the effectivaness of house doctoring", Energy and Bulldinge. 2, 11, Pp. 55-64.

(successful upplication of PRISM to data set with considerable data probleas)

A-9 


\section{Monitoring aggregate consumption}

M. F. Fals and M. i. Goldberg (2986) "Using the scorekeeping appröach to nonltor aggregate energy conservation". Energy and Bulldings, 9, \#2, Pp. $161-168$.

(the eothodology applied to aggregate gas bliling data in Now Jersey, to understand post-embargo conservation)

M. L. Goldberg and M. F. Fels (1986) "Refraction of PRISM results into components of saved onergy", Enersy and Bufldinge, 2, "2, Pp. $169-180$.

(a now extension of PRI8H to decompose the enercy sevings into physically maningful compononts; Includes estimates of Interlor tomperature changes and the takeback effoct)

M. F. Fels and M. L. Goldberg (1982) "Measuring houschold fuel consumption on the standard IIving cyclo", Energy, I, \#6.

(earlier version of Fals and Goldberg (1986))

M. F. FeIs and $M$. I. Goldbers (1984) "Using b1lling and wather date to separate thermostat fron invulation effects". Energy, 2, \#5.

(precursor of refraction approach)

\section{Foundations for PRISY}

T. F. Schrader (1978) "A two-paraneter model for asseseing the determinants of resldential epace heating"., kS Thesis for Dept. of Mech. and Aer. Engineering. Princeton Univarelty, PU/CEES Report No. 69, Princeton, IN.

(the physical underploning of the sodel)

R. H. Socolow, ed. (1978) Seving Energy in the Home, Ballinger Publishing Co., Cambridge, BA.

(original PU/CESS studies of energy consumption in housing; early formulation of scorakeeping approach) 
PART II

\section{Documentation for PC Application}

October 1986

These instructions are for PRISMonPC, the PC version of PRISM (the PRInceton Scorekeeping Method). They are to be ured along with the regular PRISM documentation found in Part I of this report. In what follows, the user types what is indicated after $A$ (the $A$ prompt) and presses. RETURN at the end of each line.

1. Getting Set Up

1.1. What you will need
a) an IBM PC with $256 \mathrm{~K}$ memory and two disk drives*
b) a math coprocessor (an 8087 chip)
c) the PRISM disk and the sample data disk, from CEES
d) DOS 2.1 (or higher) disk
e) blank disk' formatted in DOS 2.1 (or higher) using /S option
f) your input data files on a floppy disk (see 1.4 below).

1.2. Making a back-up copy

We recomend that you back up both disks that were sent. Current output flles are immediately replaced when the programs are run if a new fliename is not specified beforahand (see section 2.2 below).

1.3. Installation (one time only)

To install PRISM, follow these steps:

a) Place your DOS diak in the $A$ drive and your blank formatted disk in the $B$ drive

b) Turn on PC

c) Type

A COPY PRINT. COM B:

d) Replace DOS disk (In A drive) with the PRTSM disk

c) Type

$$
A C O O F Y * B:
$$

All the programs you need are now on the disk in the B drive. Remove the disk, affix the extra PRISM label to the disk, and place a writeprevent tape over the noten.

*These Instructions can be easily adapted to a PC wlth a hard disk, as described in Section.5. 


\subsection{Input data}

For preparation of the four required input data files, see Part I; Section 2 of documentation. For the PC version, we recommend the following naming convention:

$$
\begin{array}{ll}
\text { TEMPS.xyz } & \text { the dally temperature file } \\
\text { HNORY.xyz } & \text { the normalized heating degree-day file } \\
\text { CNORY.xyz } & \text { the normallzed cooling degree-day file } \\
\text { METER.abc } & \text { the coneumption date }
\end{array}
$$

where xyz represents the wather station (e.g. NWK for Newark), and abc represents the set of houves/years to be analyzed.

2. To run PRISM

\subsection{Start}

Put now PRISY disk in A drive and disk with Input data in B drive (see 2.2 below).

Reboot (control-alt-delete) or turn PC on.

Set CAPS IOCK on.

An AUTOEXEC program invokes a progran in BASIC, and providas a complete set of SET comands for PRISY Input and output (I/O) f1les, using default names given in Exhibit ia. To see these filenames on the scroen, type

A>TYPE A:AUTOEXEC, BAT

\subsection{Specify I/O Elles}

At the beginning of each session (1.e., after turning PC on or after robooting), It is nacessary to set $I / 0$ flles, to correspond with the FRISY documentation in Part I: Section 2 for Input and section 3 for output files.

If you wish to change the default velues, type now set commands. For example,

$$
\begin{aligned}
& \text { ASSET FORT10-B : METER. MRE } \\
& \text { ASET FORT12-B:TEYPS. NWK } \\
& \text { ASET FORT15-B : HNORY. NWK }
\end{aligned}
$$

would specify the Newark tamperature and normalization files, and the consumption date for Modular Retrofit Bxperiment (KRE) houses.

Hote 1: This needs to be done only once at the beginning of the session unless you change an input file to be used or respecify an output file. Please remanber that output flles will be repleced each tine the program is run. If you wish to save a previous run, renane the old flle.

PC-2 
Note 2: Depending on your system, you may encounter an error message while running the AUTOEXEC which reads "Out of eivifonment space". This feature of DOS may IImi't the number of characters used in the SET commands for the PRISM FORTRAN file definitions. If this occurs, quick fix is to use shorter length flle names.

2.3. Run

W1th system configured as in 2.1, type

A PRISM

Screen w111 respond:

Next house.......

Enter PRISM commands (e.g., SET PLTUSE ON, RUNALI, etc.; see Part I, Section 4.3 of documentation).

Type

RUN

Walt for PRISM to run (be patient!).

2.4. End

After you have finished the run:

Type

QUIT

System will return to A., after giving message "Execution terminated: ON. See example run in Exhiblt 2.

3. The output

3.1. On the screen

To look at output on the screen, type

A TYPE B:fllename

For example,

A TYPE B:LONG

w111 give the LONG output.

For an output wider than 80 characters (e.g.. the plots in the LONG output, or the COXPARE file), the TYPE command will show two 80 . character lines for each line of output. A wordprocessor can roed it correctly (e.g., use non-document mode of WordStar). 


\subsection{On the printer}

If you have a narrow (80-character) printer such as amall Epson, and want to print aore than 80 characters per IIne, first type

\section{A CONDENSE}

to get condensed output. (To return to regular type, turn printer off and on.) Printer will ask for printer nane ("name of list device"); respond LPTI (unless you know otherwise). See Exhibit 3 for example of condensed output.

Set paper in corract position for form feads.

Type

\section{APRIVI B:E1lonamo}

to get a printout of the file you desire.

\subsection{Space 11mitations}

The LONG output takes up approxinately 900 bytes of disk space for each house, and an additional 15,000 bytes per house if elther SET PLTUSE ON or SET PLTRSD ON 1s uned, 1.e., a total of about 30,000 bytes per house. In contrast, the COxPARE flle takes up only 550 bytes for the first house and 130 bytes for each subsequent house. If many houses are being run, you may want first to produce the COMPARE Elle only for all the houves (use SET LONG OFF and SET COMPAR ON), and then request the LONG output (for example, use SET LONG ON and SET PLTUSE ON) for Individual houses that naed a closer look.

\section{Auxillary prograne}

Before running the autoexec for elther DDCArC or MDY, you will need to run the 2APAUTO progran as described below. This clears previous FORTRAN flle definition to make room for the new ones that are defined in DDAUTO or MDYAUTO. (See Note 2 under Sec. 2.2).

Whenever you swlech from one progran to another (e.g., from DDGAlC back to PRISY). It is important firat to run ZAPAUTO followed by the approprlate autoexec: AUTOEREC for PRISK, DDAUTO for DDCALC, and MDYAUTO for BDY. For example, to run PRISY after running DDGALC or MDY, elther raboot, or type

\section{A>ZAPAUTO}

ADAUTOEXEC

Note: To check the status of your flle definitions at any tine, sioply type

ASET 


\subsection{To run DDCALC}

With PRISM disk in A drive, type

$$
\begin{aligned}
& \text { A ZZAPAUTO } \\
& \text { ADDAUTO }
\end{aligned}
$$

This will define the necessary FORIRAN files (see Exhibit Ib).

Type

ADDDCAIC

Enter any necessary SET commands (e.8., SET STARTD ER/DD/YY; see Appendix 2, Section A in Part I).

Type

$$
\text { RUN }
$$

The heating degree-days will be written to the file specified as unit number 14 called HDD on the B disk. The output file for cooling degree-days is specified as unit number 20 called CDD on the B disk.

\subsection{To run MDY (pre-Version 3.0 urers only)}

As described in Appendix 2 , Section B in Part $I$, in order to run any pre-Version 3.0 meter flles through PRISM they must first be converted to the new format using the program IDY.

The input meter file should be assigned to unit 9. To do this, type

$$
\begin{aligned}
& \text { ADZAPAUTO } \\
& \text { AXIDYAUTO }
\end{aligned}
$$

Next, copy the old meter file to a file called METER.OLD on the B drive. The converted output file is assigned to unit 10 on the $B$ drive, with filename METER (aee Exhibit 1c). If you want to change the output filename then type

A SET FORTIO-

With the PRISY disk in the A drive, type

$$
A>B: \text { MDY }
$$

(Because of Insufficient space on the PRISM disk, the MDY program is on the DATA disk.) After execution, you should be able to run the converted meter file through PRISM imediately. 
5. Additional detalls concerting a hard-disk configuration

\section{5:1. Before Iristalling PRISM}

a) Because the PRISY program may open and close more files than the default settings for DOS allow, you must add a FILES-20 statement to the CONFIG.SYS file that resides in the root directory of the hard disk. If you do not have a CONFIG.SYS already, copy the file on the PRISM disk into the root directory.

b) The PATH comand must be appendid to search for the subdirectory where the PRINT.COA file can be located. For example, if PRINT.CON is in a subdirectory called PRGis and the current PATH command reads

\section{CPATH C:IFIRST}

then the PATH command should be modified to read

CPPATH C:\FIRST;C:\PRGMS

5.2. Installation on the hard diek (one time only)

To install PRISM on the hard disk, follow these steps:

a) Craate a now subdirectory (call it PRISM):

\section{CXND IPRISY}

b) Create a batch file in the root directory called PRISM.BAT (use a word processing software or EDLIN). In this file, input the following:
CD \PRISY
SET FORT10-AIETER
SET FORT12-TEMPS
SET FORT15-HWORY
SEI FORT21-CNORY
SET FORT16-LOOK
SET FORT77-LONG
SET FORT22-COAPARE
SET FORT41-RESIDS
PRITITLE

Th1s is essentially equivalent to the AUTOEXEC.BAT file found on the PRISM disk with "B:" renoved before each filenane, and with the first line added to direct the computer to the PRISM subdirectory. 

c) Type
to go into the PRISM subdirectory.
d) Insert PRISM disk in A drive.
e) Type

$$
\text { C COPYN A:*.* C: }
$$
f) Insert sample file disk in A drivo.
8) Type

$$
\text { CSCOPY N A:*.* C: }
$$
h) Edit the autoexec files DDAUTO.BAT and NDYAUTO.BAT (using word processing software) to eliminate "B:" before each filename. For example, in DDAUTO.BAT, the statemant
SET FORT12-B: TEMPS
should be changed to
SET FORT12-TENPS

\subsection{To Iun PRISM on the hard disk}

Reboot on the hard disk.

Set CAPS IOCK on and type

\section{CSPRISY}

This will put you in the PRISM subdirectory and run the AUTOEXEC file.

Make any changes in flle definitions by typing

$$
\text { CSET FORT_- }
$$

(See Sec. 2.2.)

Type

$$
\text { CPRISY }
$$

Follow directions beginning with sec. 2.3.

GOOD LUCK!! 


\section{PC. 8}


Exhibit 1. Sample FORTRAN file definitions for a) AUTOEXEC.BAT for PRISM execution, b) DDAUTO.BAT for DDCAIC execution, and c) MDYAUTO.BAT for MDY execution.

в)

BET FOFT 1ORE:METEF

SET FOFTI =E: TEMFIS

SET PORT 15: E: HNDFW

SET FOFTII I E: CNMFM

SFT FOTS 16 $6=$ E: LOO::

CET FOFT TT=E: LONG

ERT FOFT22=E: COMT'AAE

STT FOFT T1 =E: FIESIIS

b)

SET FOFT 12:=E: TEMFS

SET FOFTI-A =E:HDS

SET FOETQONE:CDD

c)

SET FOFTQ $=$ E:METER. OLD

SET FORT 1 $O=E$ : METER

Pa. 9 
Exhibit 2. Sample PRISM run.

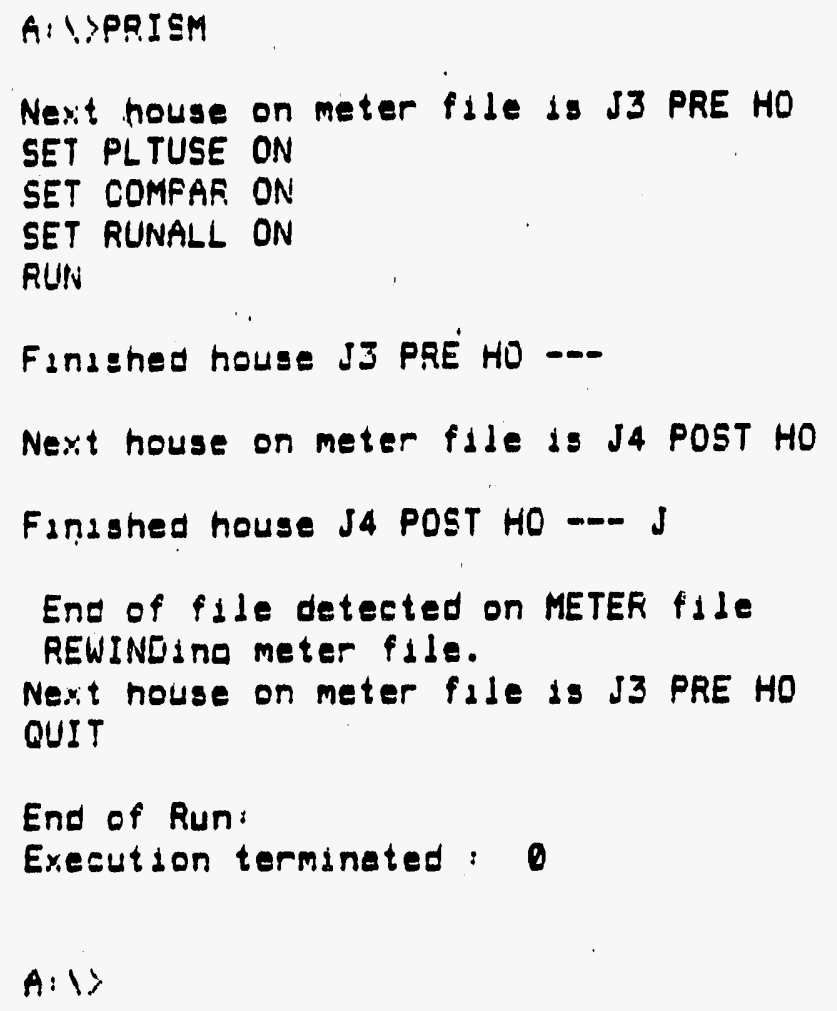

PC. 10 
Exhib1t 3. Sample output printed in CONDENSED mode. (Plot results from using SET PLTUSE ON when running PRISM; see Figure 3 in Part I. for other plots produced in the LONG output.)

Houses 13 PPC WI

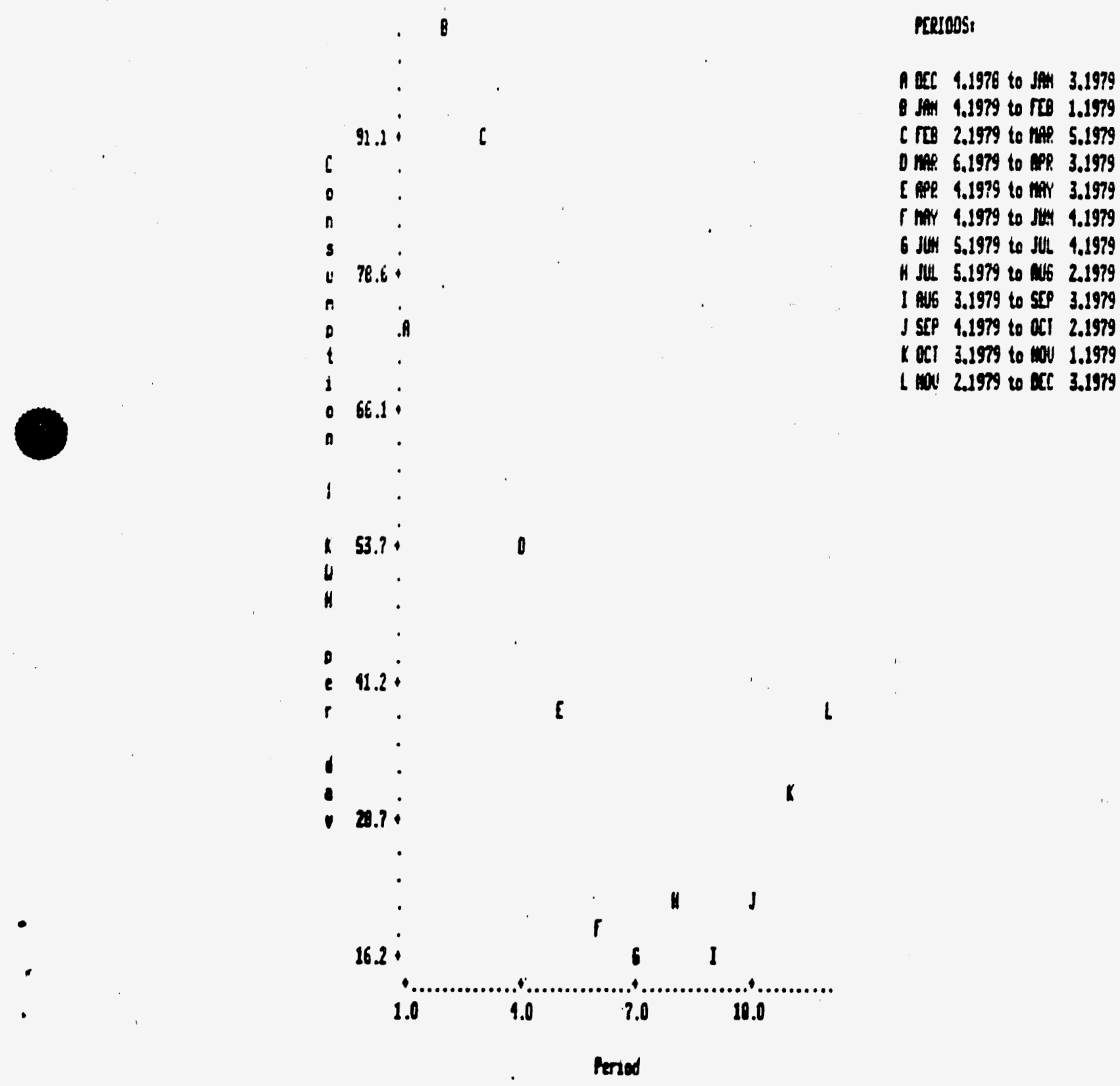




\section{Appendix D: Savings Based on Billing Data \\ Section 2: Statistical Analysis}


The Princeton Scorekeeping Method, or PRISM, is a computer program that takes weather sensitive billing data and normalizes the data for weather conditions. The program computes a normal annualized consumption (NAC) estimate for each household. PRISM provides this estimate by calculating degree-days for the consumption period, then estimating a straight line regression equation to best fit the data. PRISM also provides statistical estimates for goodness of fit (R-squared tests) and reliability estimates (coefficient of variance tests) for each household. Additional information on this model is presented in secion 1 of this appendix.

Tie goodness of fit test, R-squared, indicates how accurately the regression line fits the data. Specifically, the R-squared measures the proportion of total variation about the mean explained by the regression; or, in other words, the percent of the data that is explained by the regression equation. When a regression equation fits a data set well, the estimators in that equation are accurate predictors of the data. An R-squared close to 100 percent indicates that the regression equation predicts the data with perfect accuracy.

The coefficient of variance test, or $\mathrm{CV}$, measures the reliability of estimates made by the regression equation. It is calculated by dividing the standard error of an estimate by the estimate itself. A lower CV percent indicates a more reliable estimate; a perfectly reliable estimate will have a CV of zero percent.

ICF used PRISM to estimate actual consumption, both for the year prior to installation and for the year after installation. The difference between the two consumption estimates yielded estimates of actual savings. This analysis was calculated for various sub-groups, including urban and rural participants, electric heat customers, and consumption quartiles. ICF compared the savings of the various groups to analyze the effects of werattherization on usage patterns.

\section{Drta Reliability and Goodness of Fit}

Northeast Utilities provided ICF with data for 373 homes, weatherized in 1988 through the WRAP program, to be evaluated by PRISM. Of the 373, not all of whom are primary electric us $\%$ rs, 47 were not analyzed through PRISM because of various anomalies found within the data. Of the "emaining 326 accounts, 57 (17 percent) had R-squareds greater than 50 percent. This indicates that tive regression equations calculated by FRISM are nnt highly accurate in predicting the data for these low fit 1 -articipants.

Each account was also analyzed for its coefficient of variance, in order to determine the riliability of PRISM's estimates of energy consumption. The analysis showed that the "reliable" accounts ithose possessing low CV percents) are concentrated among the "gond fitting" (those possessing high Rsquareds). In table D-1, the accounts are grouped based on their R-squareds. Those accounts with high CV percents (low reliability) were also broken out from each group. ICF divided the number of high CV percent accounts by the total number of accounts in each group to determine if a correlation existed between accounts that fit the PRISM model well and those with reliable estimates. These calculations showed that a correlation does exist. Over 52 percent of the 326 total accounts have a CV percent greater than 6 percent, while only 21 percent of the accounts with R-squareds greater than 70 percent have a CV percent greater than 6 percent. Thus, this indicates that those participants with good fit are also reliable for analysis of energy savings. 


\begin{tabular}{|c|c|c|c|c|c|}
\hline \multicolumn{7}{|c|}{ TABLE D-1 } \\
\hline & \multicolumn{5}{|c|}{ Data Reliability and Goodness of Fit } \\
\hline ALL & 171 & 154 & 326 & $52 \%$ & $47 \%$ \\
\hline$>50 \%$ & 19 & 17 & 57 & $33 \%$ & $30 \%$ \\
\hline$>60 \%$ & 9 & 7 & 39 & $23 \%$ & $18 \%$ \\
\hline$>70 \%$ & 5 & 3 & 24 & $21 \%$ & $13 \%$ \\
\hline$>75 \%$ & 4 & 2 & 19 & $21 \%$ & $11 \%$ \\
\hline$>80 \%$ & 4 & 2 & 12 & $33 \%$ & $17 \%$ \\
\hline$>85 \%$ & 3 & 1 & 9 & $33 \%$ & $11 \%$ \\
\hline$>90 \%$ & 0 & 0 & 5 & $0 \%$ & $0 \%$ \\
\hline
\end{tabular}

ICF used the R-squared calculations to determine whether PRISM over or underestimated energy consumption. Since the most accurate and reliable accounts were used, the estimated amount of consumption is considered close to reality. However, for the less accurate accounts, PRISM underestimated heating and cooliug consumption, especially in the year after installation. Thus, overall saving estimates for heating and cooling with these data included may be overstated.

Due to this possible source of inaccuracy, the remainder of the analyses presented in this appendix focus primarily on the accurate and reliable estimates (those accounts with high R-equareds).

\section{Savings By End Use Category}

Based on the normal annualized consumption (NAC) estimates from PRISM, the electric accounts experienced a savings of 0.5 percent (table D-2). However, estimates of savings increased with the accuracy of the data. For the reasonably accurate accounts (R-squareds greater than 75 percent), PRISM estimated a 6 percent savings. For an even more accurate level (greater than 85 percent), PRISM estimated savings of 7.7 percent. Based $\leq n$ hese figures, the WRAP effort should be credited with approximately 6.5 percent savings in general electricity consumption. Again it should be noted that these estimates are for all customers with electricity, not only those having electricity as the primary heating or water heating fuel. 


\begin{tabular}{|c|c|c|c|c|c|c|}
\hline \multicolumn{7}{|c|}{$\begin{array}{l}\text { TABLE D-2 } \\
\text { Estimated Actual Consumption and Savings }\end{array}$} \\
\hline \multirow[b]{2}{*}{ 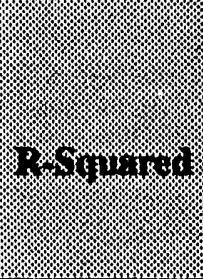 } & \multicolumn{3}{|c|}{ 3. } & \multirow[b]{2}{*}{ 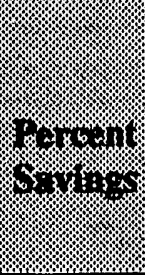 } & \multirow[b]{2}{*}{ \%) } & \multirow[b]{2}{*}{ 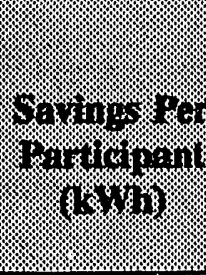 } \\
\hline & 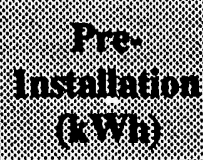 & 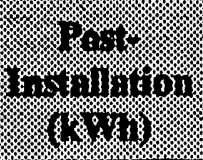 & $8 \%$ & & & \\
\hline ALL & $2,794,304$ & $2,781,490$ & 12,814 & $0.5 \%$ & 326 & 39 \\
\hline$>50 \%$ & 390,196 & 384,390 & 5,806 & $1.5 \%$ & 57 & 102 \\
\hline$>60 \%$ & 273,945 & 270,101 & 3,844 & $1.4 \%$ & 39 & 99 \\
\hline$>70 \%$ & 207,344 & 199,076 & 8,268 & $4.0 \%$ & 24 & 345 \\
\hline$>75 \%$ & 159,008 & 149,443 & 9,565 & $6.0 \%$ & 19 & 503 \\
\hline$>80 \%$ & 120,077 & 112,609 & 7,468 & $6.2 \%$ & 12 & 622 \\
\hline$>85 \%$ & 98,965 & 91,390 & 7,575 & $7.7 \%$ & 9 & 842 \\
\hline$>90 \%$ & 40,002 & 37,261 & 2,741 & $6.9 \%$ & 5 & 548 \\
\hline
\end{tabular}

Estimating the savings for heating/cooling consumption was more difficult. No clear level of savings was established among the more accurate accounts (those with higher R-squareds). Among those accounts with R-squareds greater than 75 percent, PRISM estimated actual savings of 5.5 percent; among all accounts with R-squareds greater than 85 percent, PRISM estimated an increase in consumption of 2.8 percent (table D-3). 


\begin{tabular}{|c|c|c|c|c|c|c|}
\hline \multicolumn{7}{|c|}{ TABLE D-3 } \\
Estimated Actual Consumption and Savings for Heating and Cooling \\
\hline$>0$
\end{tabular}

Table D-4 shows the breakdown of energy savings between heating and cooling and other end uses. Among the more accurate accounts with higher $\mathrm{K}$-squareds, most of the energy savings came from the non-space-conditioning measures. Low R-squared accounts exhibited the opposite pattern. As discussed later in this chapter, the high R-squared accounts tended to be primary electric users and the low R-squared accounts tended to heat primarily with other fuels. This implies that space conditioning measures were more effective in residences with non-electric primary heat. 


\begin{tabular}{|c|c|c|c|c|c|c|c|c|}
\hline \multirow{3}{*}{ 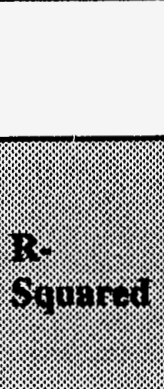 } & \multicolumn{7}{|c|}{ Energy Savings by Category of End Use } & \multirow{3}{*}{ 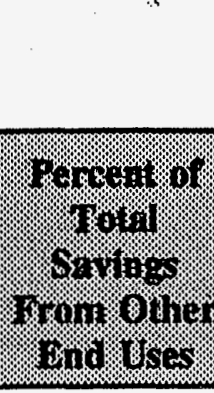 } \\
\hline & \multirow{2}{*}{ r. } & \multicolumn{2}{|c|}{ 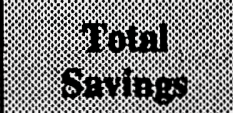 } & \multicolumn{2}{|c|}{ 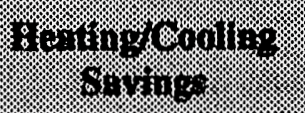 } & \multicolumn{2}{|c|}{ 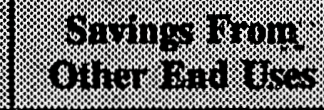 } & \\
\hline & & $8 \%$ & 8. & $3 \%$ & i. & 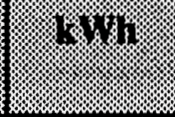 & 8 & \\
\hline All & 326 & 12,814 & 0.5 & 144,763 & 38.4 & $(131,949)$ & (5.5) & N/A \\
\hline$>50 \%$ & 57 & 5,806 & 1.5 & $(2,282)$ & $(2.3)$ & 8,088 & 2.8 & $139.3 \%$ \\
\hline$>60 \%$ & 39 & 3,844 & 1.4 & 1,872 & 2.0 & 1,972 & 1.1 & $51.3 \%$ \\
\hline$>70 \%$ & 24 & 8,268 & 4.0 & 1,379 & 1.9 & 6,889 & 5.1 & $83.3 \%$ \\
\hline$>75 \%$ & 19 & 9,565 & 6.0 & 3,274 & 5.5 & 6,291 & 6.3 & $65.7 \%$ \\
\hline$>80 \%$ & 12 & 7,468 & 6.2 & 1,263 & 2.4 & 6,205 & 9.2 & $83.1 \%$ \\
\hline$>85 \%$ & 9 & 7,575 & 7.7 & $(1,197)$ & $(2.8)$ & 8,772 & 15.7 & $115.8 \%$ \\
\hline$>90 \%$ & 5 & 2,741 & 6.9 & (82) & $(0.4)$ & 2,823 & 13.2 & $103.0 \%$ \\
\hline
\end{tabular}

In summation, the data suggests that participants consumed about 6.5 percent less total energy due to participation in the WRAP program. For electric general service use accounts, the heating/cooling energy usage declined approximately 3 percent. For participants with electric heat, end uses other than space-conditioning accounted for the majority of the savings. The data is more reliable for higher $\mathbf{R}$ squareds than for lower $\mathbf{R}$-squareds and the total annual consumption figures are more consistent in their claimed savings than are the heating/cooling figures.

\section{Quartile Analysis}

ICF also analyzed the PRISM data based on base consumption quartiles. The purpose of this analysis was twofold: (1) to determine if high energy consumption was correlated with high energy savings, and (2) to determine if high energy consumption was correlated with high R-squared values.

The pre-installation quartile analysis showed that high consumption was associated with high savings (table D-5). The highest consumption quartile accounted for over $70,000 \mathrm{kWh}$ in savings, while savings for all four quartiles were less than $13,000 \mathrm{kWh}$. 


\begin{tabular}{|l|c|c|c|}
\hline \multicolumn{4}{|c|}{ TABLE D-5 } \\
\multicolumn{4}{|c|}{ Savings by Pre-Installation Consumption Quartiles } \\
\hline
\end{tabular}

As discussed previously, much of the billing data could not be included for analysis with the PRISM model. Only 17 percent of the accounts had R-squareds higher than 50 percent. ICF's analysis shows that the most accurate accounts are concentrated among the highest 25 percent quartile of preinstallation base energy consumption (table D-6). Over half of the most accurate accounts (with Rsquareds of 70 percent or higher) fell in the top pre-installation consumption quartile.

Since previous analysis showed that the highest quartile was also associated with higher savings, this analysis implies that the higher savings are associated with more accurate accounts. This supports the conclusion that the lower overall estimates of actual savings may have been underestimated by PRISM. 


\begin{tabular}{|c|c|c|c|c|c|c|c|}
\hline \multirow[b]{3}{*}{ 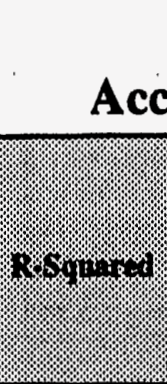 } & \multirow{3}{*}{ 4.7. } & \multirow{2}{*}{\multicolumn{2}{|c|}{$\frac{\text { TAI }}{\text { Tunis by Pre }}$}} & \multirow{2}{*}{\multicolumn{2}{|c|}{ 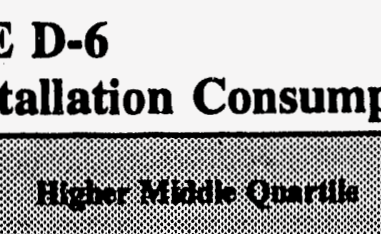 }} & \multirow{2}{*}{\multicolumn{2}{|c|}{ 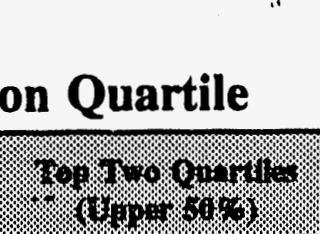 }} \\
\hline & & & & & & & \\
\hline & & $\begin{array}{l}1 \% 1 \\
1.8 \%\end{array}$ & 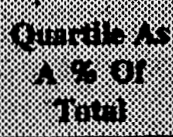 & (2) & \% & 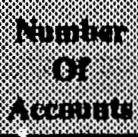 & 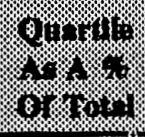 \\
\hline$>50 \%$ & 57 & 19 & $33 \%$ & 15 & $26 \%$ & 34 & $60 \%$ \\
\hline$>60 \%$ & 39 & 14 & $36 \%$ & 9 & $23 \%$ & 23 & $59 \%$ \\
\hline$>70 \%$ & 24 & 12 & $50 \%$ & 4 & $17 \%$ & 16 & $67 \%$ \\
\hline$>75 \%$ & 19 & 10 & $53 \%$ & 2 & $11 \%$ & 12 & $63 \%$ \\
\hline$>80 \%$ & 12 & 8 & $67 \%$ & 1 & $8 \%$ & 9 & $75 \%$. \\
\hline$: 85 \%$ & 9 & 6 & $67 \%$ & 1 & $11 \%$ & 7 & $78 \%$ \\
\hline$>90 \%$ & 5 & 3 & $60 \%$ & 0 & $0 \%$ & 3 & $60 \%$ \\
\hline
\end{tabular}

\section{Urban/Rural Analysis}

ICF analyzed PRISM's electricity consumption estimates for urban and rural participants. Total consumption and savings for each R-squared level are shown in table D-7 for urban accounts, and in table D-8 for rural accounts. Both tables reflect that the estimates of percent savings vary positively with the accuracy level of the data. The exception to this is in the greater than 90 percent R-squared level; this inconsistency may be due to the very small sample size at this level. The correlation between accuracy and savings implies that overall savings may be underestimated for both groups. The relatively accurate estimates, those with R-squareds higher than 70 percent, show savings of between 6 percent and 8 percent for urban participants, and between 4.5 percent and 10 percent for rural participants.

A more detailed examination of $\mathbf{R}$-squared level distribution shows that consumption estimates for urban accounts are more accurate than for rural accounts (table D-9). Urban accounts are more likely to have higher $\mathbf{R}$-squared values than rural accounts.

The distribution of reliable accounts (those with CVs lower than 7 percent) indicates that PRISM's consumption estimates for urban accounts may be more reliable than those for rural accounts (table D-10, "Reliable Accounts"). An examination of the percentage of accounts that are reliable at each R-squared level (table D-10, "All Accounts") show that the more accurate accounts tend to be more reliable as well. 


\begin{tabular}{|c|c|c|c|c|}
\hline \multirow[b]{3}{*}{ 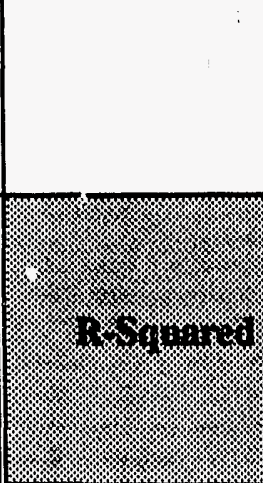 } & Estimated A & $\begin{array}{l}\text { ABLE D- } \\
\text { Consump } \\
\text { ban Partic }\end{array}$ & ad Savi & \multirow[b]{3}{*}{ 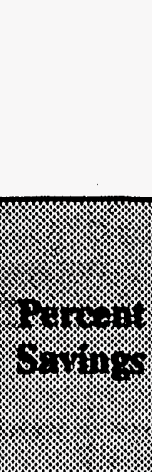 } \\
\hline & \multicolumn{3}{|c|}{ 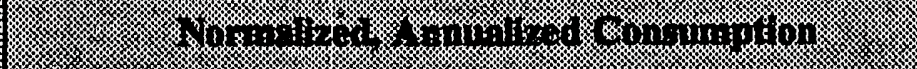 } & \\
\hline & א. & 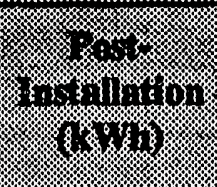 & 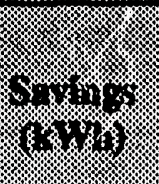 & \\
\hline ALL & 751,736 & 740,750 & 10,986 & $1.5 \%$ \\
\hline$>50 \%$ & 176,473 & 172,871 & 3,601 & $2.0 \%$ \\
\hline$>60 \%$ & 142,025 & 135,938 & 6,087 & $4.3 \%$ \\
\hline$>70 \%$ & 124,423 & 116,929 & 7,494 & $6.0 \%$ \\
\hline$>75 \%$ & 85,269 & 79,534 & 5,735 & $6.7 \%$ \\
\hline$>80 \%$ & 82,822 & 76,944 & 5,878 & $7.1 \%$ \\
\hline$>85 \%$ & 68,989 & 63,511 & 5,479 & $7.9 \%$ \\
\hline$>90 \%$ & 38,389 & 35,607 & 2,782 & $7.3 \%$ \\
\hline
\end{tabular}




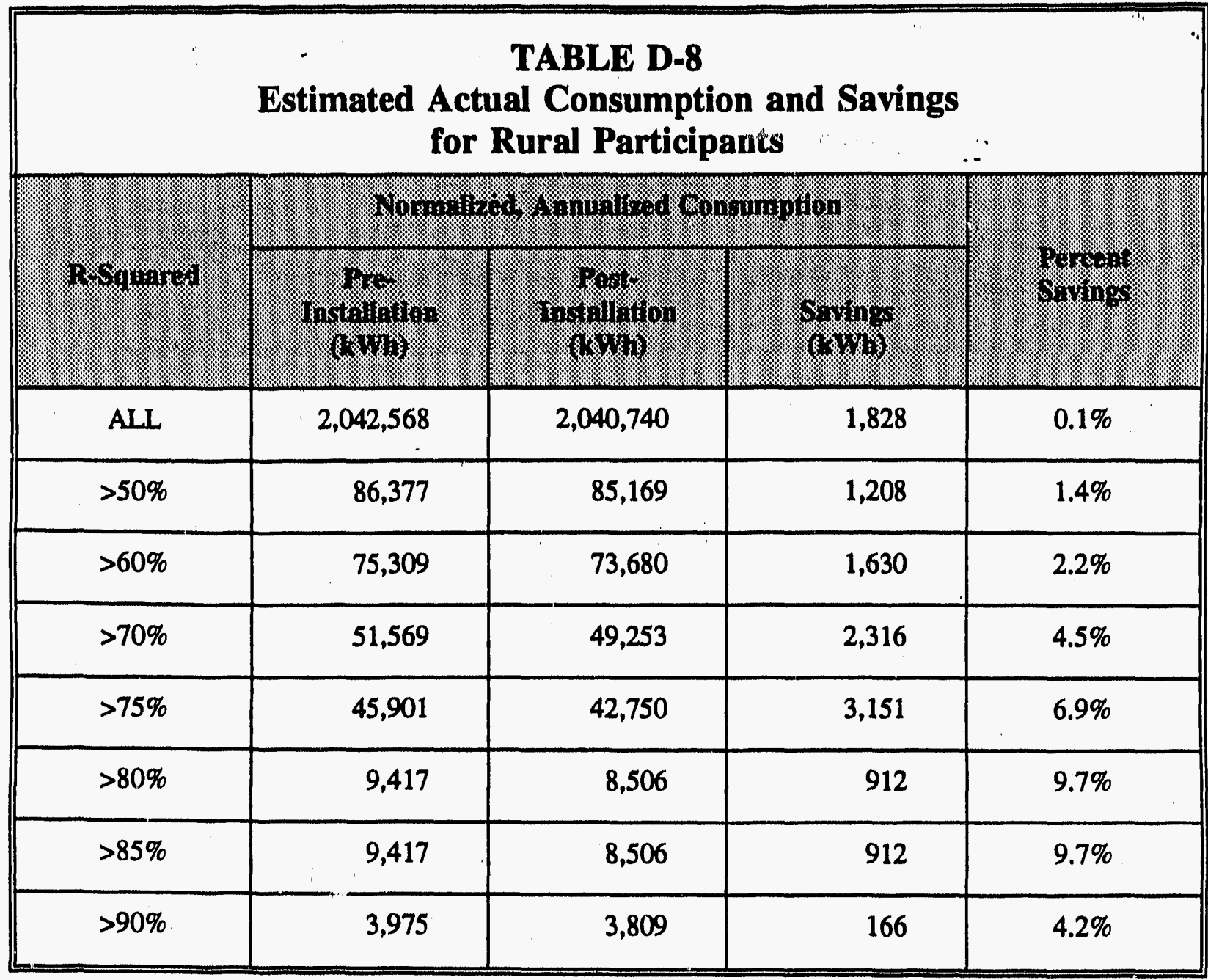




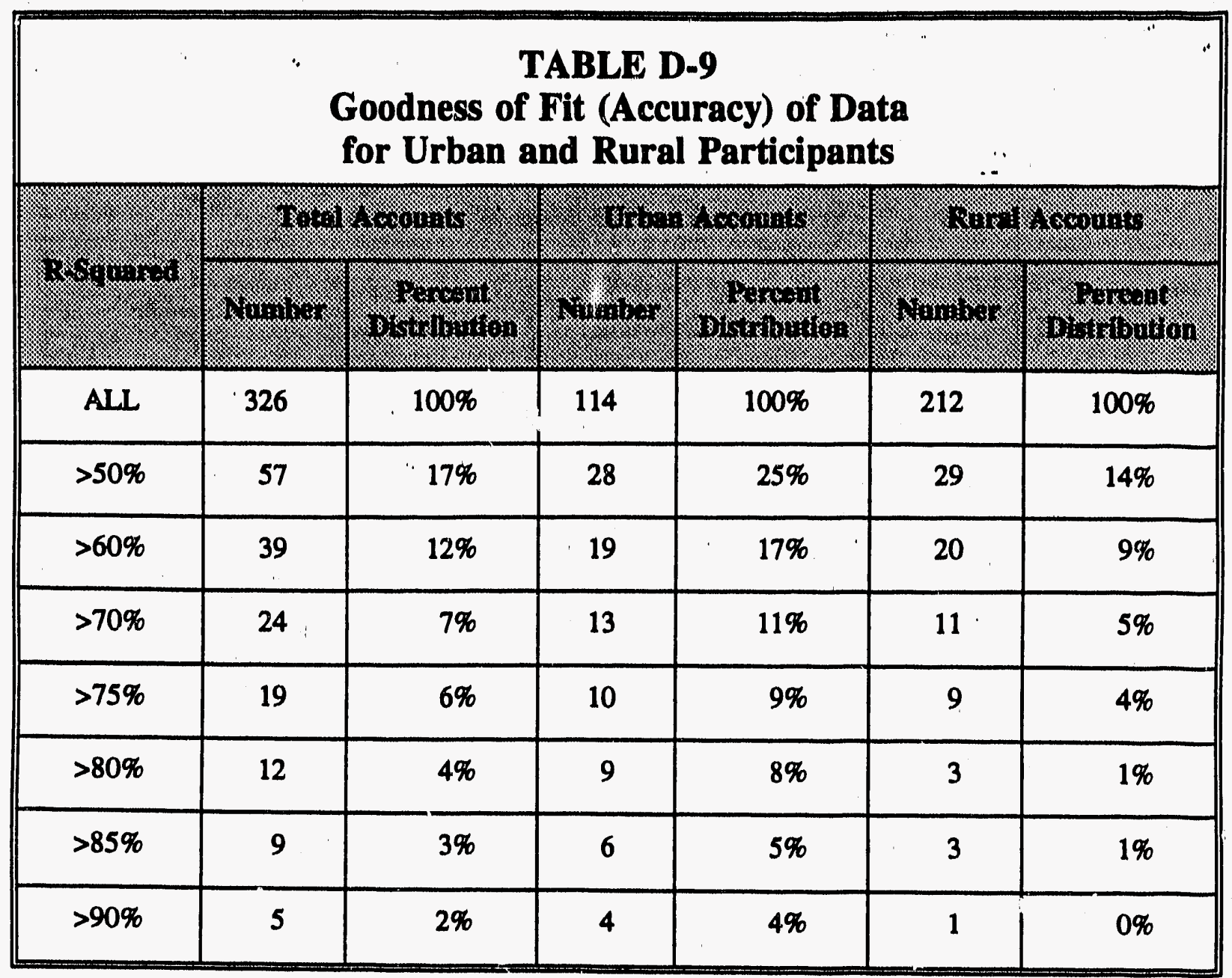




\begin{tabular}{|c|c|c|c|c|c|c|c|c|}
\hline \multirow{4}{*}{ 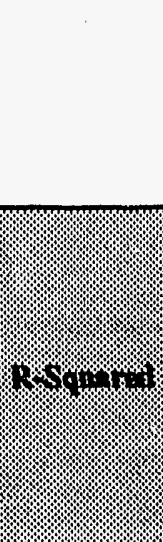 } & \multicolumn{6}{|c|}{$\begin{array}{c}\text { TABLE D-10 } \\
\text { Reliability of Data } \\
\text { for Urban and Rural Participants }\end{array}$} & \multicolumn{2}{|c|}{. } \\
\hline & \multicolumn{4}{|c|}{ 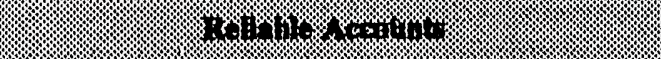 } & \multicolumn{4}{|c|}{ 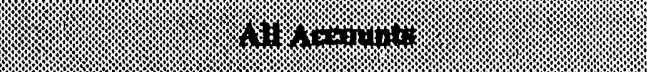 } \\
\hline & \multicolumn{2}{|c|}{ 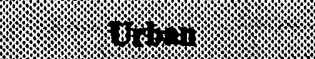 } & \multicolumn{2}{|c|}{ 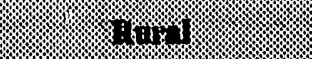 } & \multicolumn{2}{|c|}{48} & \multicolumn{2}{|c|}{ x.1.8, } \\
\hline & 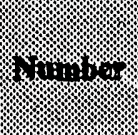 & $9 \%$ & yin & 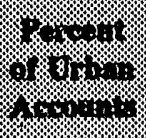 & $4 y^{2}$ & 48 & inini. & 48 \\
\hline ALL & 72 & $63 \%$ & 100 & $47 \%$ & 114 & $63 \%$ & 212 & $47 \%$ \\
\hline$>50 \%$ & 21 & $18 \%$ & 19 & $9 \%$ & 28 & $75 \%$ & 29 & $66 \%$ \\
\hline$>60 \%$ & 16 & $14 \%$ & 16 & $8 \%$ & 19 & $84 \%$ & 20 & $80 \%$ \\
\hline$>70 \%$ & 12 & $11 \%$ & 9 & $4 \%$ & 13 & $92 \%$ & 11 & $82 \%$ \\
\hline$>75 \%$ & 8 & $7 \%$ & 8 & $4 \%$ & 10 & $80 \%$ & 9 & $89 \%$ \\
\hline$>80 \%$ & 7 & $6 \%$ & 2 & $1 \%$ & 9 & $78 \%$ & 3 & $67 \%$ \\
\hline$>85 \%$ & 5 & $4 \%$ & 2 & $1 \%$ & 6 & $83 \%$ & 3 & $67 \%$ \\
\hline$>90 \%$ & 3 & $3 \%$ & 1 & $0 \%$ & 4 & $75 \%$ & 1 & $100 \%$ \\
\hline
\end{tabular}

More detailed information on the energy consumption characteristics of urban and rura! participants was obtained by computing average consumption and savings per participant (tables D-11 and D-12). The results of this analysis indicate that higher levels of accuracy are related to higher levels of consumption, as well as to larger percent savings. In addition, the more accurate estimates show that urban participants used electricity far more intensively than rural participants; for the very accurate accounts, up to three times more per year. This implies that urban participants may use electricity for a wider range of end-uses, and may also have a higher incidence of primary electric space heating. If PRISM is more accurate for accounts with higher consumption, as the data may indicate, this may explain why PRISM's estimates were generally more accurate for urban accounts than for rural. 


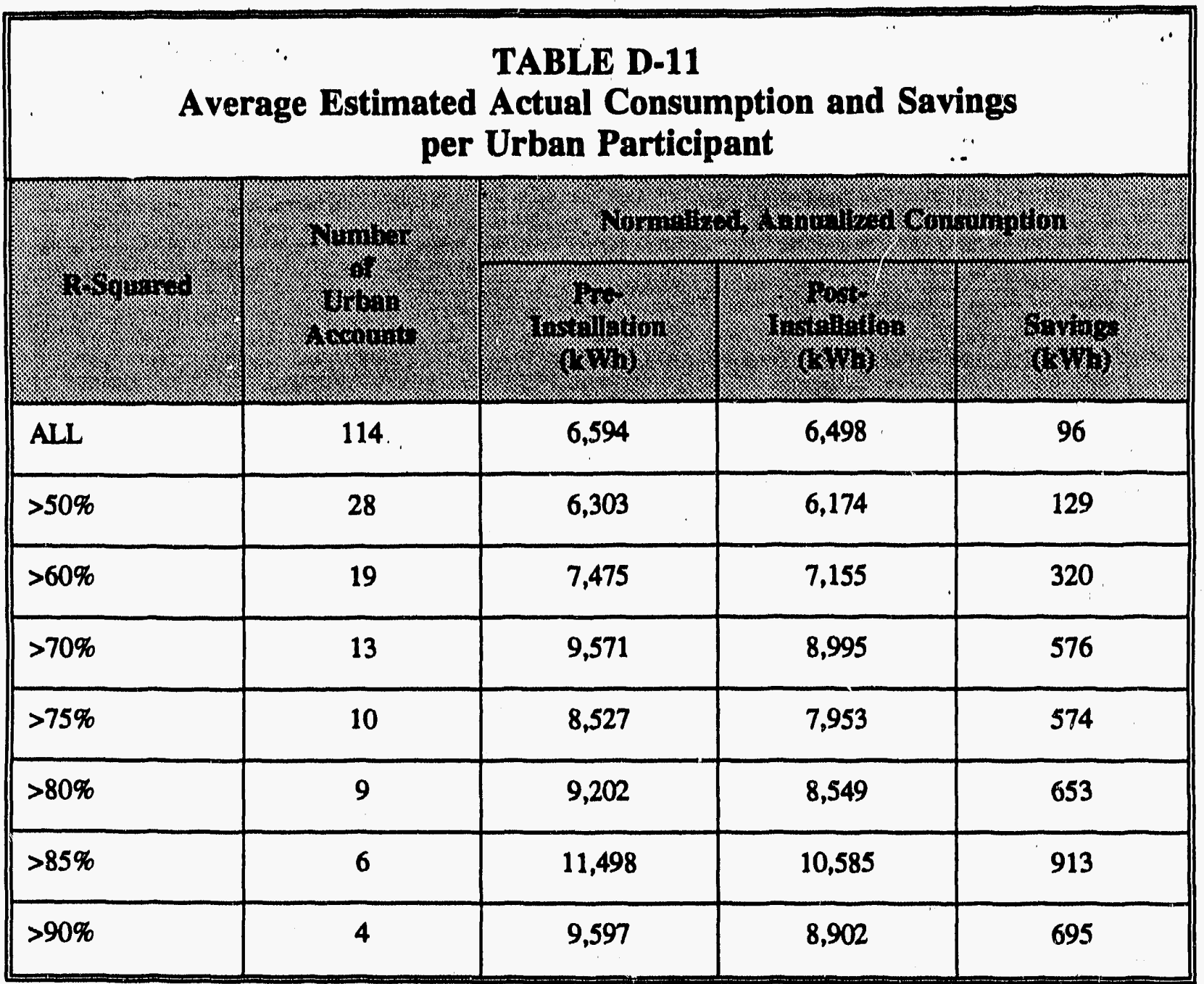

To determine the relationship between accuracy and the use of electricity as the primary heating fuel, ICF separated primary electric heat users from the urban and rural categories. Fifteen participants in the sample set used electricity as their primary heating fuel, thirteen urban and two rural. (This supports the earlier inference that urban customers have a higher incidence of primary electric heat.) No further examination of the rural group was performed because of the statistical insignificance of the sample size. 


\begin{tabular}{|c|c|c|c|c|}
\hline \multirow[b]{3}{*}{ 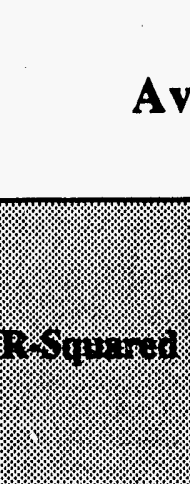 } & \multicolumn{4}{|c|}{$\begin{array}{l}\text { TABLE D-12 } \\
\text { Estimated Actual Consumption and Savings } \\
\text { per Rural Participant }\end{array}$} \\
\hline & \multirow{2}{*}{ 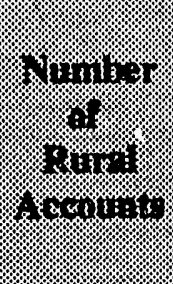 } & \multicolumn{3}{|c|}{ 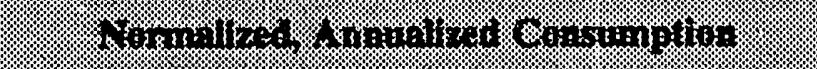 } \\
\hline & & : & 2. & \% \\
\hline ALL & 212 & 9,635 & 9,626 & 9 \\
\hline$>50 \%$ & 29 & 2,979 & 2,937 & 42 \\
\hline$>60 \%$ & 20 & 3,765 & 3,684 & 81 \\
\hline$>70 \%$ & 11 & 4,688 & 4,478 & 210 \\
\hline$>75 \%$ & 9 & 5,100 & 4,750 & 350 \\
\hline$>80 \%$ & 3 & 3,139 & 2,835 & 304 \\
\hline$>85 \%$ & 3 & 3,139 & 2,835 & 304 \\
\hline$>90 \%$ & 1 & 3,975 & 3,809 & 166 \\
\hline
\end{tabular}

For urban participants, this analysis showed a marked difference in goodness of fit (accuracy) between primary electric heat users and all urban participants (table D-13). Urban accounts with primary electric heat also showed significantly better results for their reliability of the estimates (table D-14). These results are as anticipated because PRISM was designed to adjust weather-sensitive energy consumption for weather variations. Thus, consumption that is not weather sensitive would not fit the model as well. 


\begin{tabular}{|c|c|c|c|c|}
\hline \multicolumn{5}{|c|}{$\begin{array}{l}\text { TABLE D-13 } \\
\text { Goodness of Fit (Accuracy) of Data } \\
\text { for Urban Participants With and Without Primary Electric Heat }\end{array}$} \\
\hline \multirow{2}{*}{ 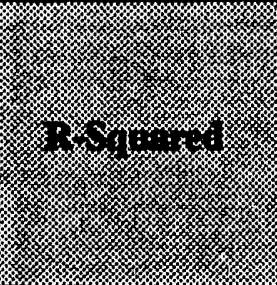 } & \multicolumn{2}{|c|}{ 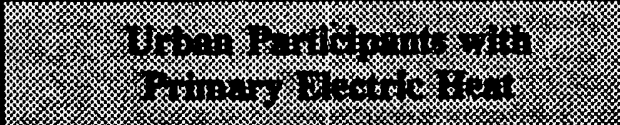 } & \multicolumn{2}{|c|}{ 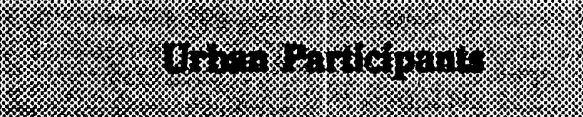 } \\
\hline & If & 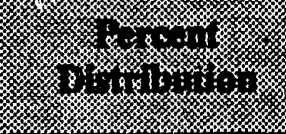 & (2) & 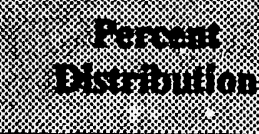 \\
\hline ALL & 13 & $100 \%$ & 114 & $100 \%$ \\
\hline$>50 \%$ & 8 & $62 \%$ & 28 & $25 \%$ \\
\hline$>60 \%$ & 7 & $54 \%$ & 19 & $17 \%$ \\
\hline$>70 \%$ & 5 & $38 \%$ & 13 & $11 \%$ \\
\hline$>75 \%$ & 4 & $31 \%$ & 10 & $9 \%$ \\
\hline$>80 \%$ & 4 & $31 \%$ & 9 & $8 \%$ \\
\hline$>85 \%$ & 4 & $31 \%$ & 6 & $5 \%$ \\
\hline$>90 \%$ & 3 & $23 \%$ & 4 & $4 \%$ \\
\hline
\end{tabular}




\begin{tabular}{|c|c|c|c|c|c|c|c|c|}
\hline \multirow[b]{4}{*}{ i: } & Urban & articip & $\begin{array}{r}\mathbf{T} \\
\text { Reli } \\
\text { ats Wit }\end{array}$ & $\begin{array}{l}\text { BEE D } \\
\text { illity } 0 \\
\text { and } \mathrm{K}\end{array}$ & $\begin{array}{l}4 \\
\text { Data } \\
\text { hout I }\end{array}$ & mary & ectric & eat \\
\hline & \multicolumn{4}{|c|}{ অ. } & \multicolumn{4}{|c|}{ 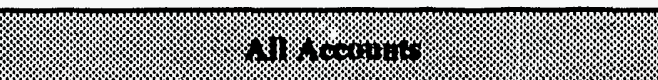 } \\
\hline & \multicolumn{2}{|c|}{$874.17 \cdot 1+1$} & \multicolumn{2}{|c|}{40.1494.} & \multicolumn{2}{|c|}{ 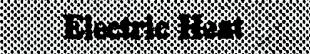 } & \multicolumn{2}{|c|}{ 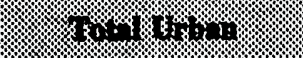 } \\
\hline & 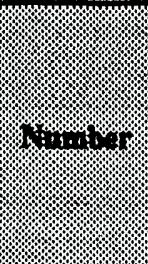 & 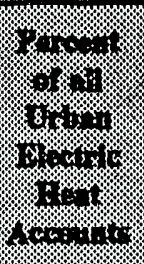 & 4 & \% & in..1.7. & 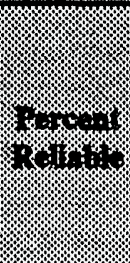 & 4 & 8 \\
\hline ALL & 9 & $69 \%$ & 72 & $63 \%$ & 13 & $69 \%$ & 114 & $63 \%$ \\
\hline$>50 \%$ & 5 & $38 \%$ & 21 & $18 \%$ & 8 & $63 \%$ & 28 & $75 \%$ \\
\hline$>60 \%$ & 5 & $38 \%$ & 16 & $14 \%$ & 7 & $71 \%$ & 19 & $84 \%$ \\
\hline$>70 \%$ & 5 & $38 \%$ & 12 & $11 \%$ & 5 & $100 \%$ & 13 & $92 \%$ \\
\hline$>75 \%$ & 4 & $31 \%$ & 8 & $7 \%$ & 4 & $100 \%$ & 10 & $80 \%$ \\
\hline$>80 \%$ & 4 & $31 \%$ & 7 & $6 \%$ & 4 & $100 \%$ & 9 & $78 \%$ \\
\hline$>85 \%$ & 4 & $31 \%$ & 5 & $4 \%$ & 4 & $100 \%$ & 6 & $83 \%$ \\
\hline$>90 \%$ & 3 & $23 \%$ & 3 & $3 \%$ & 3 & $100 \%$ & 4 & $75 \%$ \\
\hline
\end{tabular}

Tables D-15 and D-16 display heating and cooling consumption and savings data for urban and rural participants. For urban accounts, the data showed no significant savings or losses within the space conditioning end-uses. Rural accounts, however, showed substantial heating and cooling electricity savings, between 31 percent and 36 percent among the higher R-syuared levels. Comparing these figures to the overall urban and rural savings shown in tables D-7 and D-8 indicates that urban savings were driven primarily by non-space conditioning end-uses, while rural savings were driven by heating and cooling end-use savings. 


\begin{tabular}{|c|c|c|c|c|}
\hline \multicolumn{5}{|c|}{$\begin{array}{l}\text { TABLE D-15 } \\
\text { Estimated Actual Heating and Cooling } \\
\text { Consumption and Savings for Urban Participants }\end{array}$} \\
\hline ৷ ১ & \multicolumn{3}{|c|}{ (2) } & \multirow{2}{*}{ 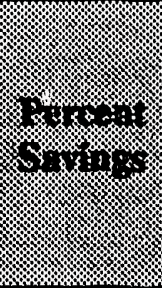 } \\
\hline 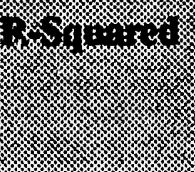 & 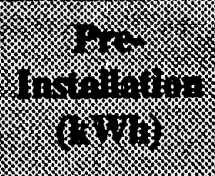 & 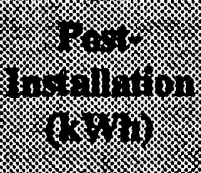 & (1) & \\
\hline All & 124,542 & 123,850 & 692 & $0.6 \%$ \\
\hline$>50 \%$ & 51,843 & 53,202 & $(1,359)$ & (2.6) \\
\hline$>60 \%$ & 47,610 & 47,496 & 114 & $0.2 \%$ \\
\hline$>70 \%$ & 43,437 & 44,594 & $(1,157)$ & $(2.7 \%)$ \\
\hline$>75 \%$ & 34,260 & 34,337 & (77) & $(0.2 \%)$ \\
\hline$>80 \%$ & 33,729 & 33,688 & 41 & $0.1 \%$ \\
\hline$>85 \%$ & 30,317 & 31,175 & (858) & $(2.8 \%)$ \\
\hline$>90 \%$ & 15,131 & 14,537 & 594 & $3.9 \%$ \\
\hline
\end{tabular}

One possible explanation for this relies on the premise that many participants have more than one type of heat available to them. If they are more likely to reduce consumption of secondary heating fuels when temperature conditions improve as a result of weatherization, then weatherization will show little effect on the consumption of the primary heating fuel. Because urban participants may be more likely to have primary electric heat, they may show lower electricity savings from heating and cooling, which appears to be the case. 


\begin{tabular}{|c|c|c|c|c|}
\hline \multicolumn{5}{|c|}{$\begin{array}{c}\text { TABLE D-16 } \\
\text { Estimated Actual Heating and Cooling } \\
\text { Consumption and Savings for Rural Participants }\end{array}$} \\
\hline \multirow{2}{*}{ 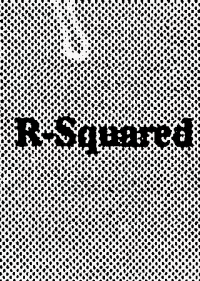 } & \multicolumn{3}{|c|}{ 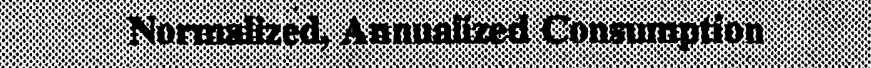 } & \multirow[b]{2}{*}{ 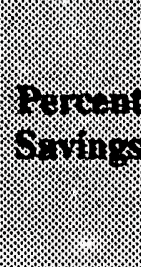 } \\
\hline & 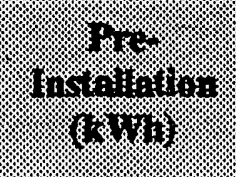 & 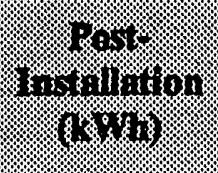 & s.m. & \\
\hline ALL & 252,047 & 107,976 & 144,071 & $57.2 \%$ \\
\hline$>50 \%$ & 12,701 & 12,400 & 302 & $2.4 \%$ \\
\hline$>60 \%$ & 11,619 & 11,567 & 52 & $0.5 \%$ \\
\hline$>70 \%$ & 11,507 & 7,944 & 3,563 & $31.0 \%$ \\
\hline$>75 \%$ & 10,769 & 7,193 & 3,576 & $33.2 \%$ \\
\hline$>80 \%$ & 4,189 & 2,742 & 1,447 & $34.5 \%$ \\
\hline$>85 \%$ & 4,189 & 2,742 & 1,447 & $34.5 \%$ \\
\hline$>90 \%$ & 854 & 546 & 308 & $36.0 \%$ \\
\hline
\end{tabular}

This concept is further supported by examining data on heating and cooling electricity consumption as a percent of total consumption (table D-17). Heating and cooling account for a larger share of urban consumption than rural consumption, implying that urban participants may use more electricity as a primary space heating fuel. 


\begin{tabular}{|c|c|c|c|c|}
\hline \multicolumn{5}{|c|}{$\begin{array}{c}\text { Heating and Cooling Electricity Consumption as a Percent of } \\
\text { Total Electricity Consumption }\end{array}$} \\
\hline \multirow[b]{2}{*}{ is } & \multicolumn{2}{|c|}{3} & \multicolumn{2}{|c|}{ 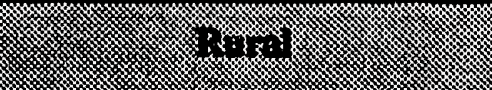 } \\
\hline & 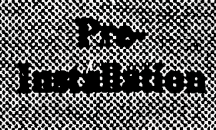 & 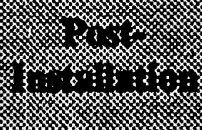 & 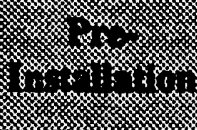 & 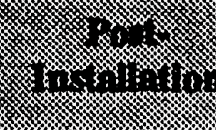 \\
\hline ALL & $16.57 \%$ & $16.72 \%$ & $12.34 \%$ & $5.29 \%$ \\
\hline$>50 \%$ & $29.38 \%$ & $30.78 \%$ & $14.70 \%$ & $14.56 \%$ \\
\hline$>60 \%$ & $33.52 \%$ & $34.94 \%$ & $15.43 \%$ & $15.70 \%$ \\
\hline$>70 \%$ & $34.91 \%$ & $38.14 \%$ & $22.31 \%$ & $16.13 \%$ \\
\hline$>75 \%$ & $40.18 \%$ & $43.17 \%$ & $23.46 \%$ & $16.83 \%$ \\
\hline$>80 \%$ & $40.72 \%$ & $43.78 \%$ & $44.49 \%$ & $32.24 \%$ \\
\hline$>85 \%$ & $43.94 \%$ & $49.09 \%$ & $44.49 \%$ & $32.24 \%$ \\
\hline$>90 \%$ & $39.42 \%$ & $40.83 \%$ & $21.49 \%$ & $14.34 \%$ \\
\hline
\end{tabular}

\section{Conclusions}

Preliminary PRISM results showed overall electricity savings of only 0.5 percent; this included savings of 38.4 percent in heating and cooling consumption and an increase of 5.5 percent in the electricity consumption of other end-uses. However, additional statistical analysis showed that the PRISM estimates did not have a high level of accuracy or reliability. Examination of only the more accurate accounts provided different, but more accurate results.

Analysis of the most accurate and reliable accounts showed that 1988 WRAP participants reduced their electricity consumption by about 6.5 percent overall. Savings from non-space conditioning end-uses were probably between 6 percent and 15 percent. Heating and cooling consumption reductions for urban participants were close to zero; however, rural participants showed savings between 31 percent and 36 percent. This may be due to the higher incidence of primary electric space heating in urban residences. Primary heating fuels may be less affected by weatherization than secondary fuels. For all end-uses, urban participants saved approximately 6 percent to 8 percent, and rural participants approximately 4.5 percent to 10 percent. 


\section{Appendix D: Savings Based on Billing Data}

\section{Section 3: Savings from 1989 Installations}

Table of Contents:

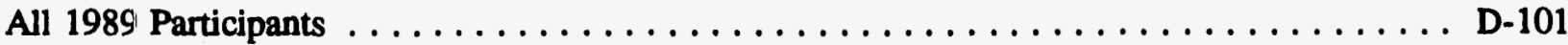

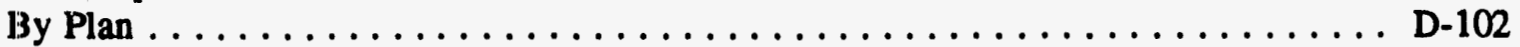

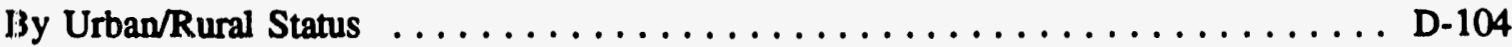

By Urban/Rural Status and Plan . . . . . . . . . . . . . . . . D-105

By Owner/Renter Status $\ldots \ldots \ldots \ldots \ldots \ldots \ldots \ldots \ldots \ldots \ldots \ldots \ldots \ldots$ D-108

By Owner/Renter Status and Plan . . . . . . . . . . . . . . . . . D-109

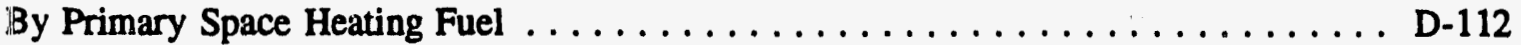

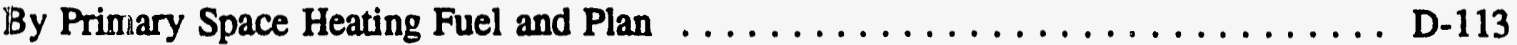




\section{Normalized Annual Consumption of 1989 Participants}

$+$

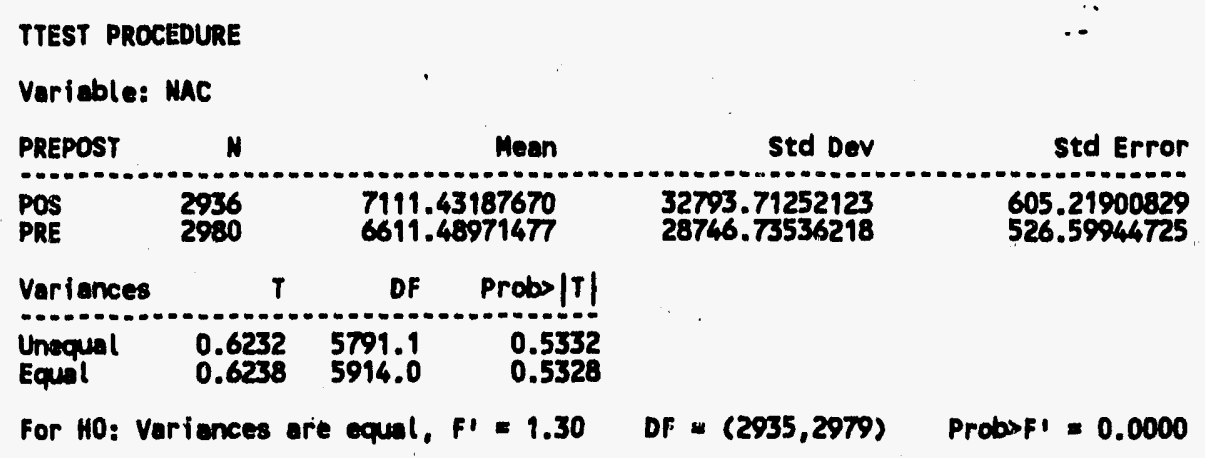




\section{Normalized Annual Consumption of 1989 Participants (by plan)}

EPLAN=1

Variable: MC

\begin{tabular}{llllll} 
PREPOST & $N$ & Moen & Std Dev & Std Error \\
\hline POS & 893 & 7920.08684211 & 34758.56772018 & 1163.15111927 \\
PRE & 910 & 7907.81868132 & 33203.61621195 & 1100.60915952
\end{tabular}

\begin{tabular}{llll} 
Variances & $T$ & DF & Probs $|T|$ \\
\hline Unequal & 0.0077 & 1793.5 & 0.9939
\end{tabular}

$\begin{array}{llll}\text { Unequal } & 0.0077 & 1793.5 & 0.9939 \\ \text { Equal } & 0.0077 & 1801.0 & 0.9939\end{array}$

For HO: Variences are equal, FI $=1.10 \quad$ DF $=(892,909) \quad$ Probsf' $=0.1697$

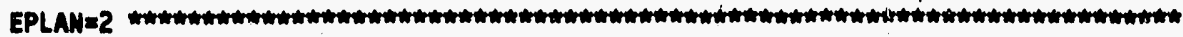
Voriable: MAC

\begin{tabular}{lllll} 
PREPOST & $N$ & Mean & Std DuV & Std Error \\
\hline POS & 172 & 6612.20802326 & 4132.46540282 & 315.09783794 \\
PRE & 175 & 6850.05205714 & 4877.98811813 & 368.74124168
\end{tabular}

$\begin{array}{llll}\text { Variences } & T & \text { DF Probs/T! } \\ \text { Uneoual } & -0.4904 & 337.7 & 0.6242\end{array}$

Equal $\quad-0.4697 \quad 345.0 \quad 0.6267$

For HO: Veriances are equal, FI $=1.39$ DF $=(174,171) \quad$ ProbsFt $=0.0301$

EPLAN=3 Variable: MaC

\begin{tabular}{llllll} 
PREPOST & $N$ & Meen & Std Dev & Std Error \\
\hline POS & 1468 & $\mathbf{6 6 7 8 . 9 6 7 8 7 4 6 6}$ & $\mathbf{3 7 3 4 5 . 0 0 6 3 2 3 2 1}$ & 974.69673104 \\
PRE & 1488 & 5420.25680780 & $\mathbf{3 0 7 0 0 . 7 7 2 3 0 6 4 8}$ & $\mathbf{7 9 5 . 8 8 0 4 4 6 8 2}$
\end{tabular}

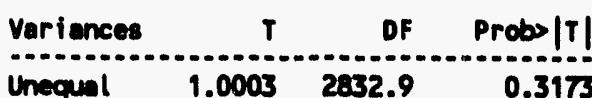

$\begin{array}{llll}\text { Unequal } & 1.0003 & 2832.9 & 0.3173 \\ \text { Equal } & 1.0016 & 2954.0 & 0.3166\end{array}$

For HO: Variances are equal, F' $=1.48$ DF $=(1467,1487) \quad$ Probsfl $=0.0000$

EPLANal Variable: MAC

\begin{tabular}{|c|c|c|c|c|c|}
\hline PREPOST & $N$ & & Mean & Std Dev & Std Error \\
\hline $\begin{array}{l}\text { POS } \\
\text { PRE }\end{array}$ & $\begin{array}{l}223 \\
227\end{array}$ & $\begin{array}{l}6596 . \\
8032 .\end{array}$ & 0062780 & $\begin{array}{r}4637.84833710 \\
12633.22078261\end{array}$ & $\begin{array}{l}310.57329600 \\
838.49631340\end{array}$ \\
\hline Variances & $T$ & DF & Probs |T| & & \\
\hline $\begin{array}{l}\text { Unequal } \\
\text { Equal }\end{array}$ & $\begin{array}{l}-1.6052 \\
-1.5943\end{array}$ & $\begin{array}{l}286.8 \\
448.0\end{array}$ & $\begin{array}{l}0.1096 \\
0.1116\end{array}$ & & \\
\hline
\end{tabular}




\section{Normalized Annual Consumption of 1989 Participants (by plan)}

EPLAN=5

Variable: MAC

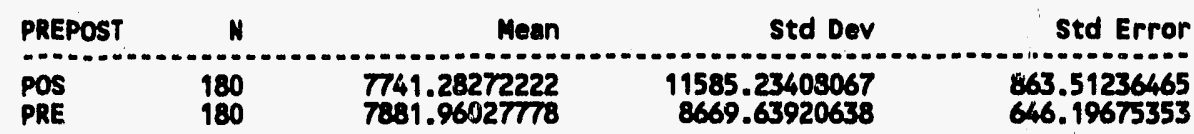

\begin{tabular}{llll} 
Variances & $T$ & DF & Probs|T| \\
\hline Unequal & -0.1304 & 331.6 & 0.8963
\end{tabular}

$\begin{array}{llll}\text { Unequal } & -0.1304 & 331.6 & 0.8963 \\ \text { Equal } & -0.1304 & 358.0 & 0.8963\end{array}$

For HO: Variances are equal, FI $=1.79 \quad$ DF $=(179,179) \quad$ ProbsFl $=0.0001$ 


\section{Normalized Annual Consumption of 1989.Participants (by urban/rural status)}

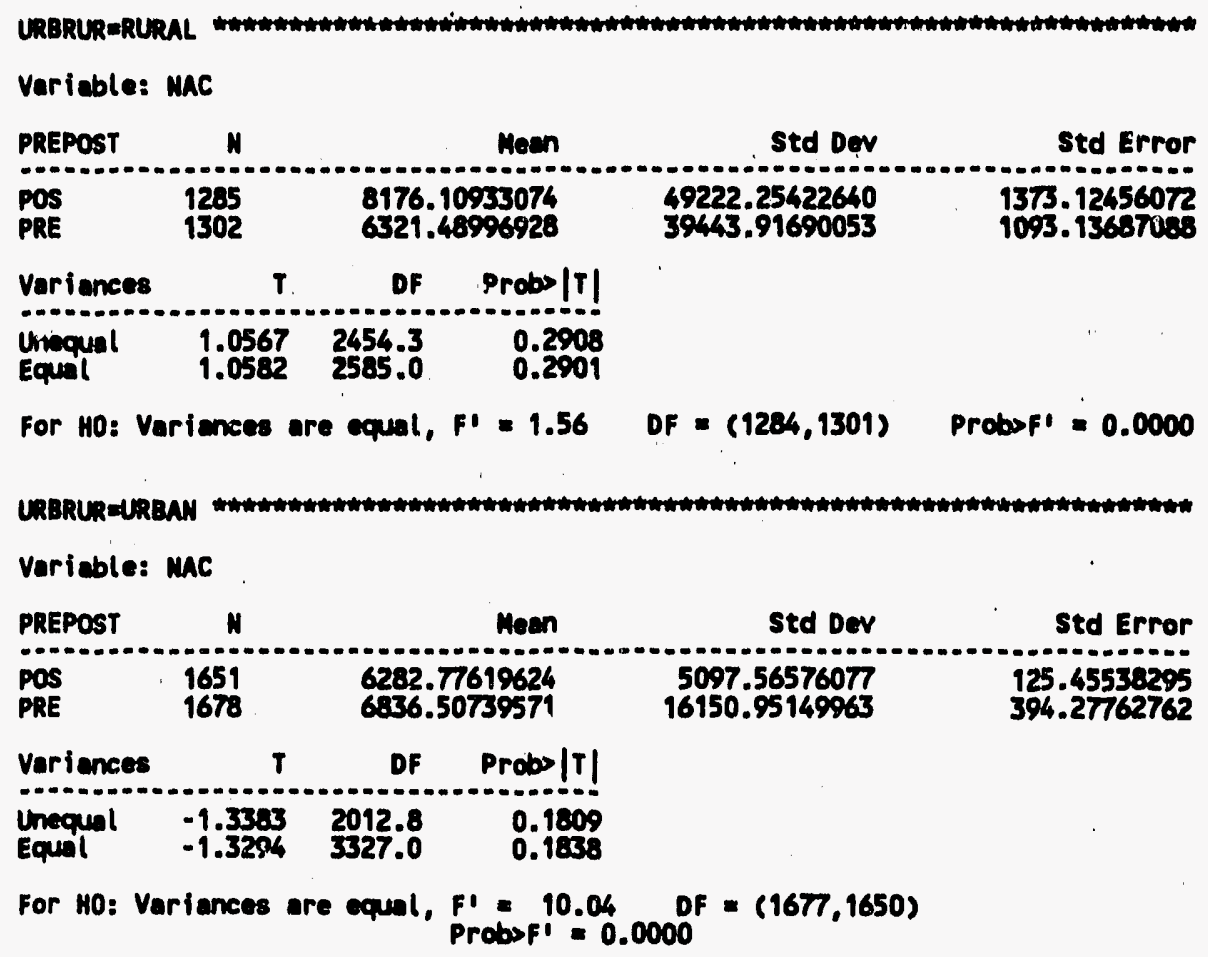




\section{Normalized Annual Consumption of 1989 Participants (by urban/rural status and plan)}

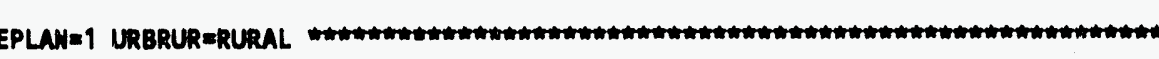
Variable: MAC

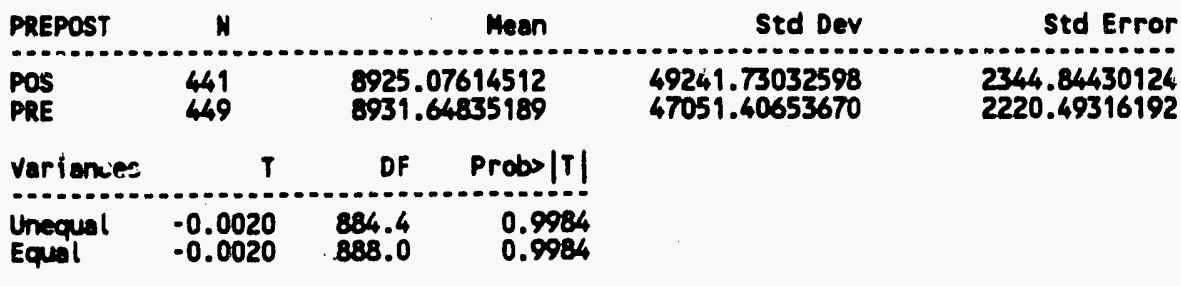

For HO: Variances are equal, F' $=1.10 \quad$ OF $=(440,448) \quad$ ProbsF' $=0.3378$

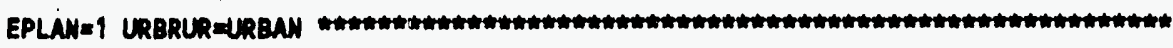
Varicble: MAC

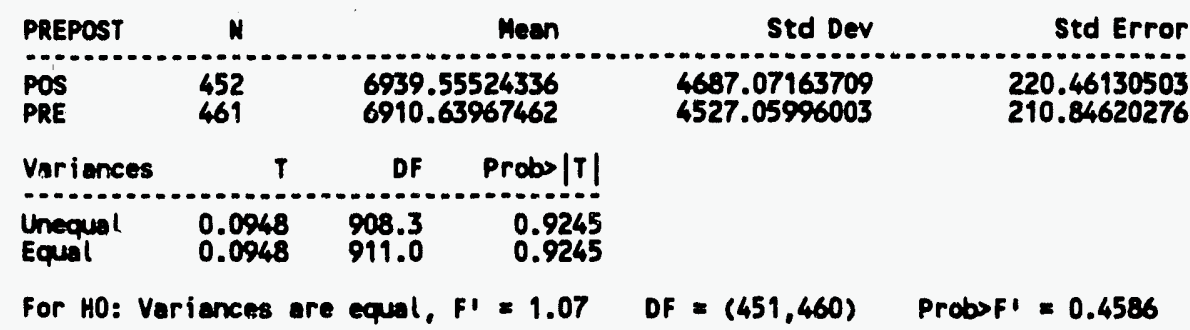

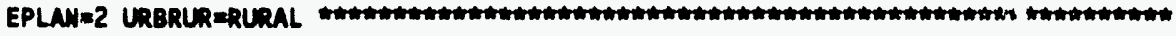
Variable: MAC

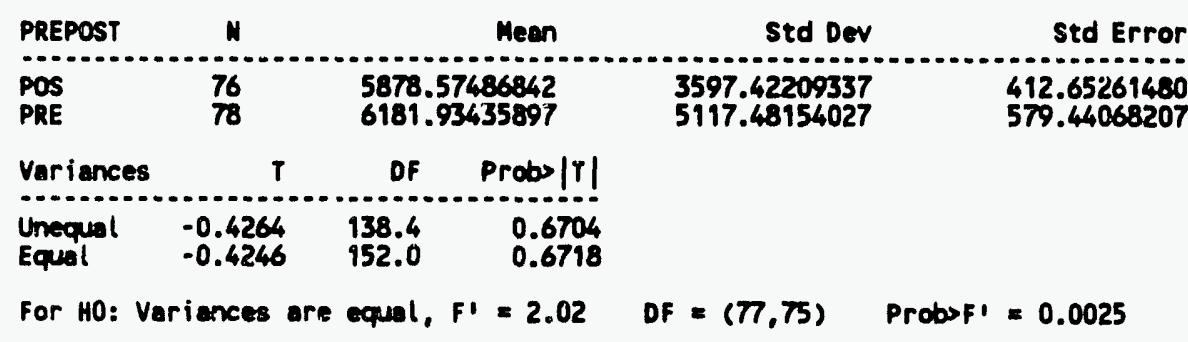

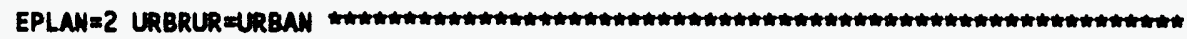
Variable: HAC

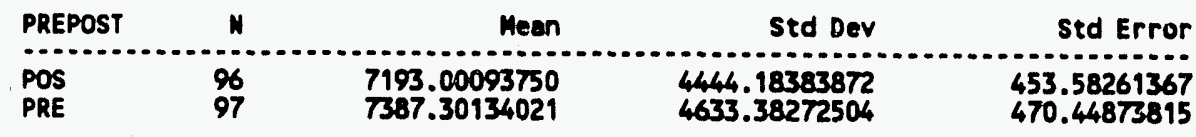

\begin{tabular}{lllr} 
Variances & $T$ & DF & Probs|T| \\
\hline Unequal & -0.2973 & 190.8 & 0.7665 \\
Equal & -0.2973 & 191.0 & 0.7666
\end{tabular}

For HO: Veriances are equal, F'= 1.09 DF $=(96,95) \quad$ ProbsFI $=0.6848$ 


\section{Normalized Annual Consumption of 1989 Participants (by urban/rural status and plan)}

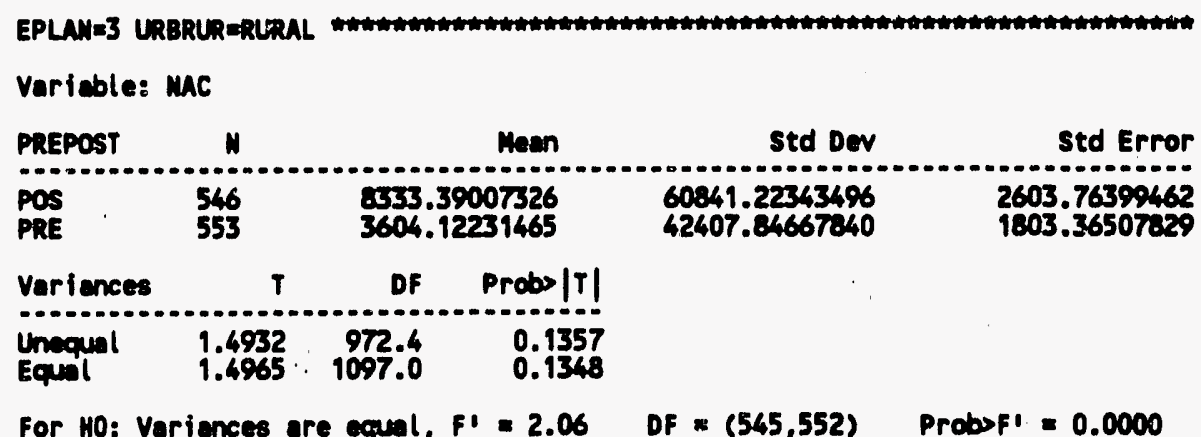

For HO: Variences are equal, F' $=2.06 \quad$ DF $:(545,552) \quad$ Probsfl $=0.0000$

EPLAN=3 URBRUR=URBAN Varicble: MAC

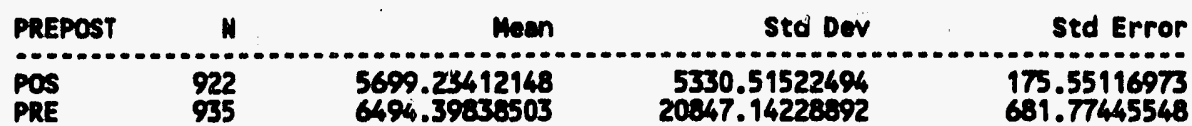

\begin{tabular}{lll} 
Variences & $T$ & DF Probs $|T|$ \\
\hline
\end{tabular}

Equal $\quad-1.1226 \quad 9855.0 \quad 0.2618$

For HO: Variences are equal, FI $=15.30 \quad$ DF $=(934,921) \quad$ Probsf $=0.0000$

EPLAN=4 URBRLR=RLRAL Vericble: MaC

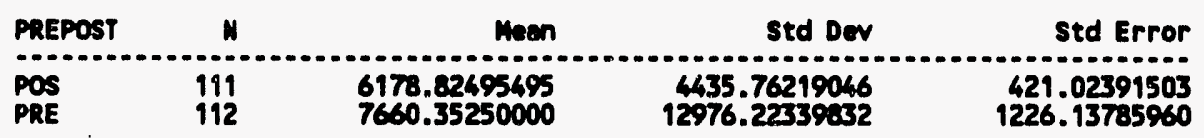

\begin{tabular}{llll} 
Variences & T & DF & Probs $|T|$ \\
\hdashline Unequal & -1.1428 & 136.8 & 0.2551
\end{tabular}

$\begin{array}{llll}\text { Equal } & -1.1428 & 136.8 & 0.2551 \\ & -1.1387 & 221.0 & 0.2560\end{array}$

For HO: Variunces ore equal, F' $=8.56$ DF $=(191,110)$ ProbsFI $=0.0000$

EPLANEL URBRURURBAN Varicble: MAC

\begin{tabular}{l|lllr} 
PREPOST & $N$ & Meen & Std Dev & Std Error \\
\hline POS & 112 & 7010.90500000 & 4813.81536327 & 454.86279674 \\
PRE & 115 & $83 \% 4.00678261$ & 12336.02080741 & 1150.33987175
\end{tabular}

Variances DF Probs/T|

Unequal $-1.1181 \quad 148.7 \quad 0.2653$

Equal $\quad-1.1072 \quad 225.0 \quad 0.2694$

For HO: Variences are equal, FI $=6.57 \quad$ OF $=(114,111) \quad$ ProbsFI $=0.0000$ 


\section{Normalized Annual Consumption of 1989 Participants (by urban/rural status and plan)}

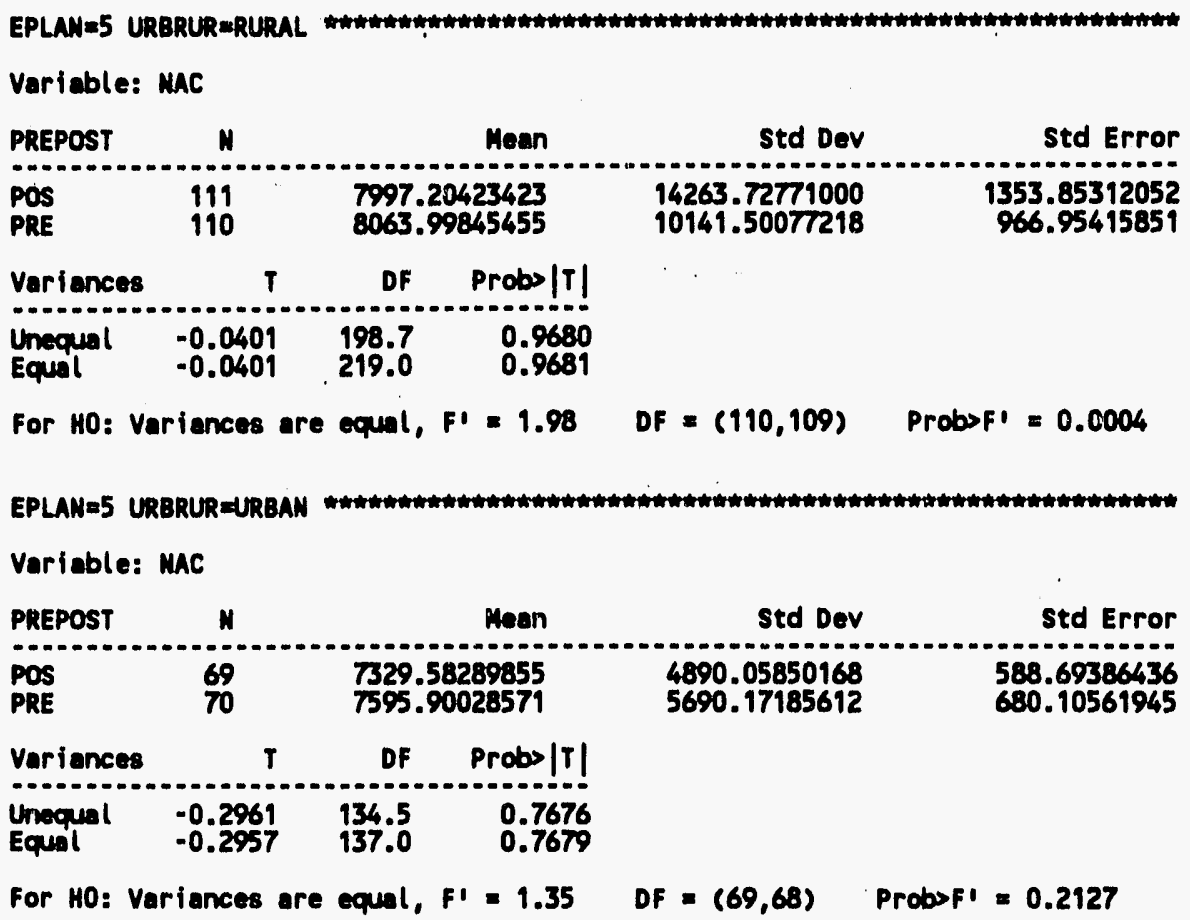




\section{Normalized Annual Consumption of 1989 Participants (by owner/renter status)}

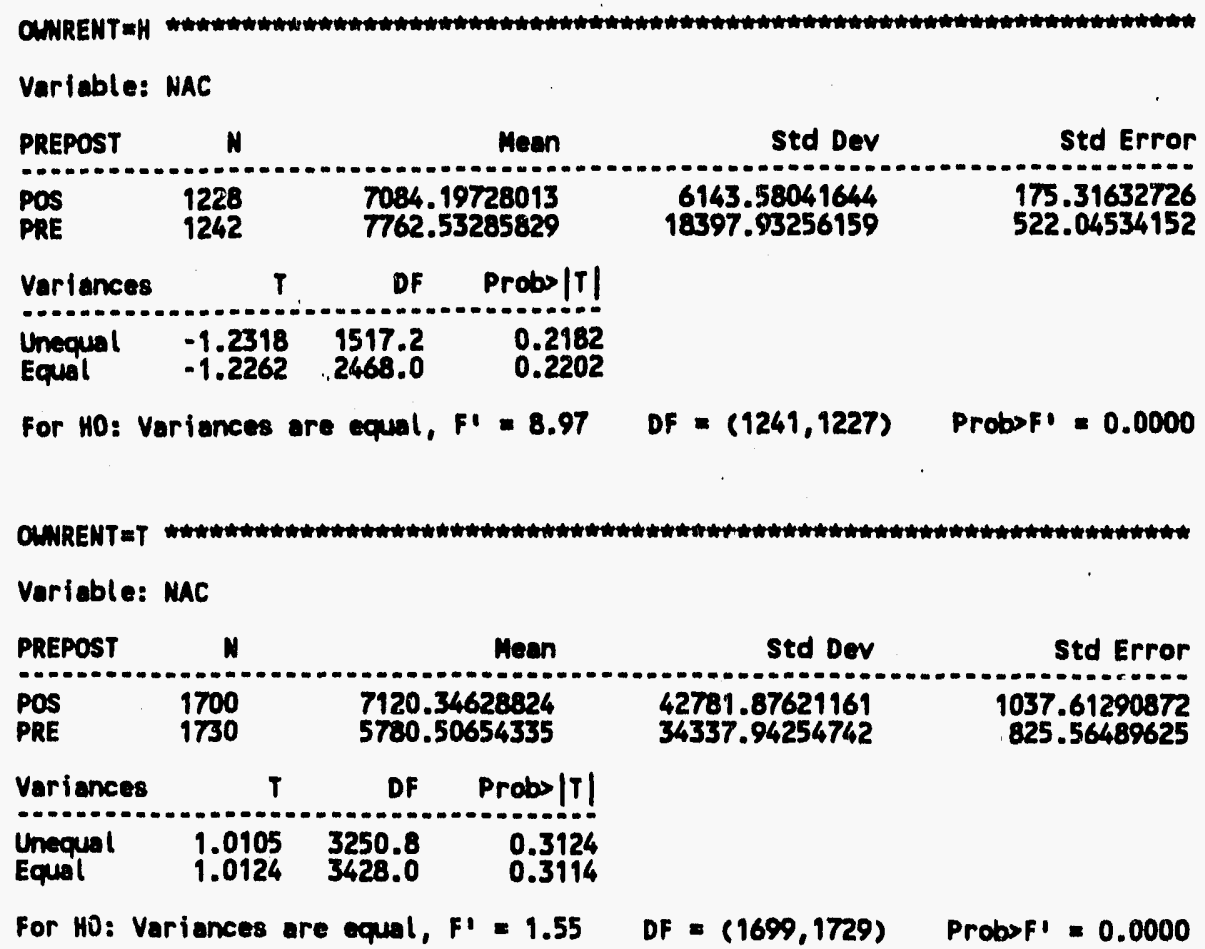




\section{Normalized Annual Consumption of 1989 Participants (by owner/renter status and plan)}

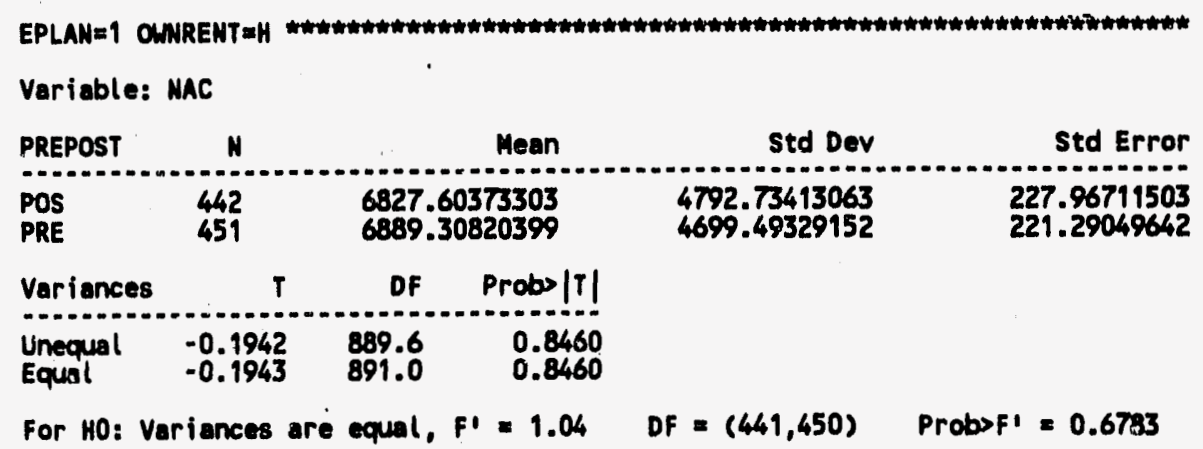

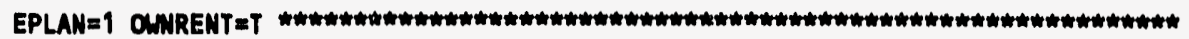
Variable: MAC

\begin{tabular}{|c|c|c|c|c|c|}
\hline PREPOST & N & & Mean & Std Dev & Std Error \\
\hline $\begin{array}{l}\text { POS } \\
\text { PRE }\end{array}$ & $\begin{array}{l}450 \\
458\end{array}$ & $\begin{array}{l}8985 \\
8902\end{array}$ & $\begin{array}{l}066667 \\
373362\end{array}$ & $\begin{array}{l}48736.77462803 \\
46573.65362590\end{array}$ & $\begin{array}{l}2297.47358884 \\
2176.24391577\end{array}$ \\
\hline Variances & $T$ & DF & Probs $|T|$ & & \\
\hline $\begin{array}{l}\text { Unequal } \\
\text { Equal }\end{array}$ & $\begin{array}{l}0.0263 \\
0.0263\end{array}$ & $\begin{array}{l}902.4 \\
906.0\end{array}$ & $\begin{array}{l}0.9790 \\
0.9790\end{array}$ & & \\
\hline
\end{tabular}

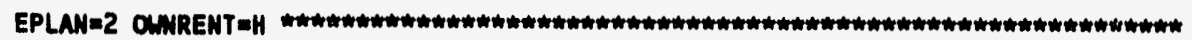
Variable: MAC

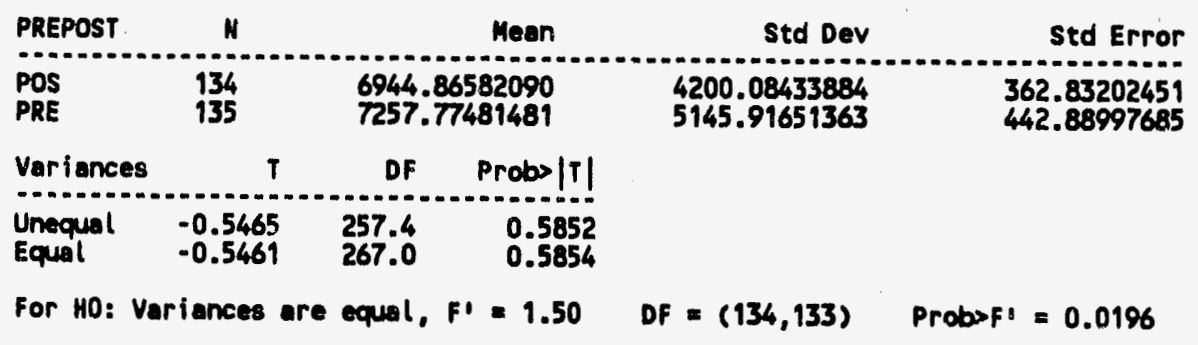

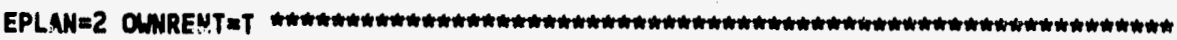
Variable: MAC

\begin{tabular}{|c|c|c|c|c|}
\hline REPOST & $N$ & Mean & Std Dev & std Error \\
\hline PRE & $\begin{array}{l}20 \\
40\end{array}$ & $\begin{array}{l}5439.15757895 \\
5473.98775000\end{array}$ & $\begin{array}{l}3707.29895004 \\
3558.03248366\end{array}$ & $\begin{array}{l}600.4299 \\
562.5743\end{array}$ \\
\hline
\end{tabular}

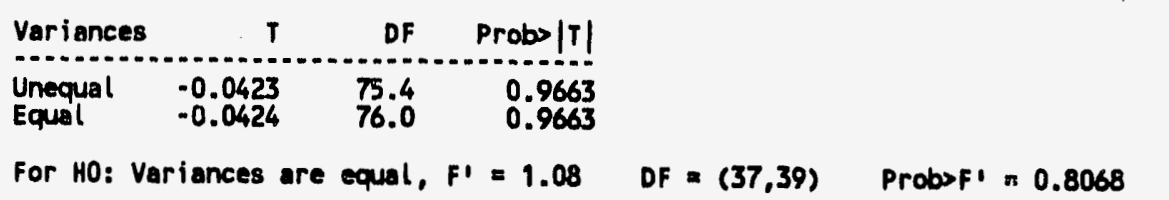




\section{Normalized Annual Consumption of 1989 Participants (by owner/renter status and plan)}

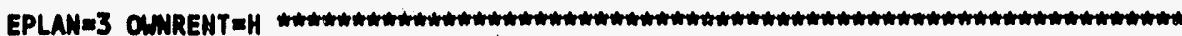
Variable: MAC

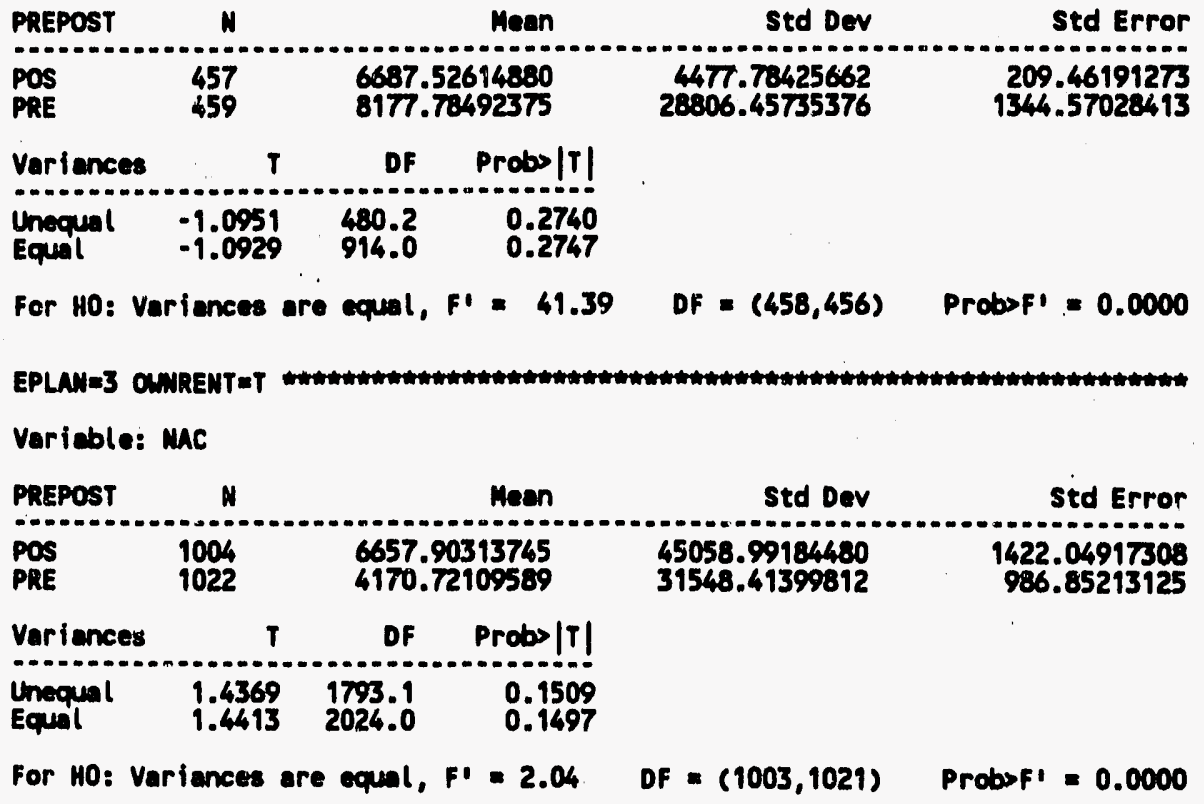

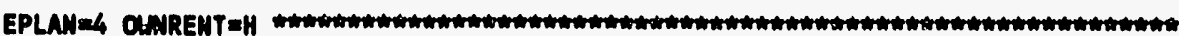
Variable: MC

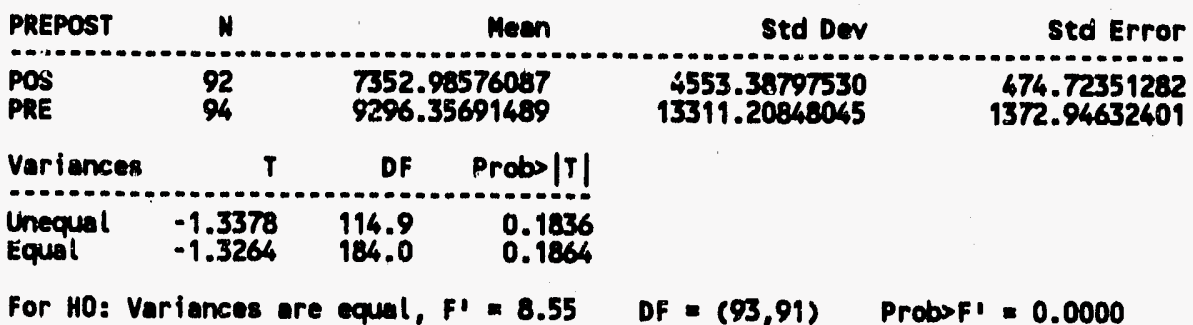

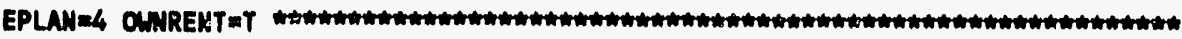
Variable: MAC

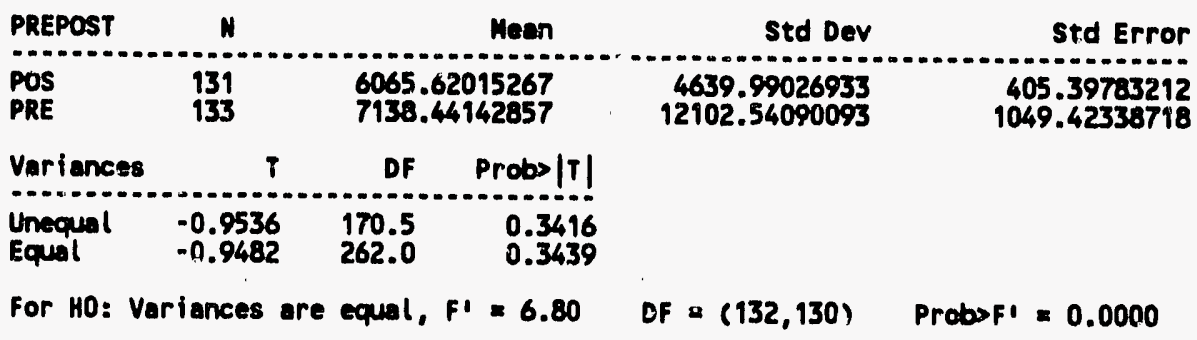




\section{Normalized Annual Consumption of 1989 Participants (by owner/renter status and plan)}

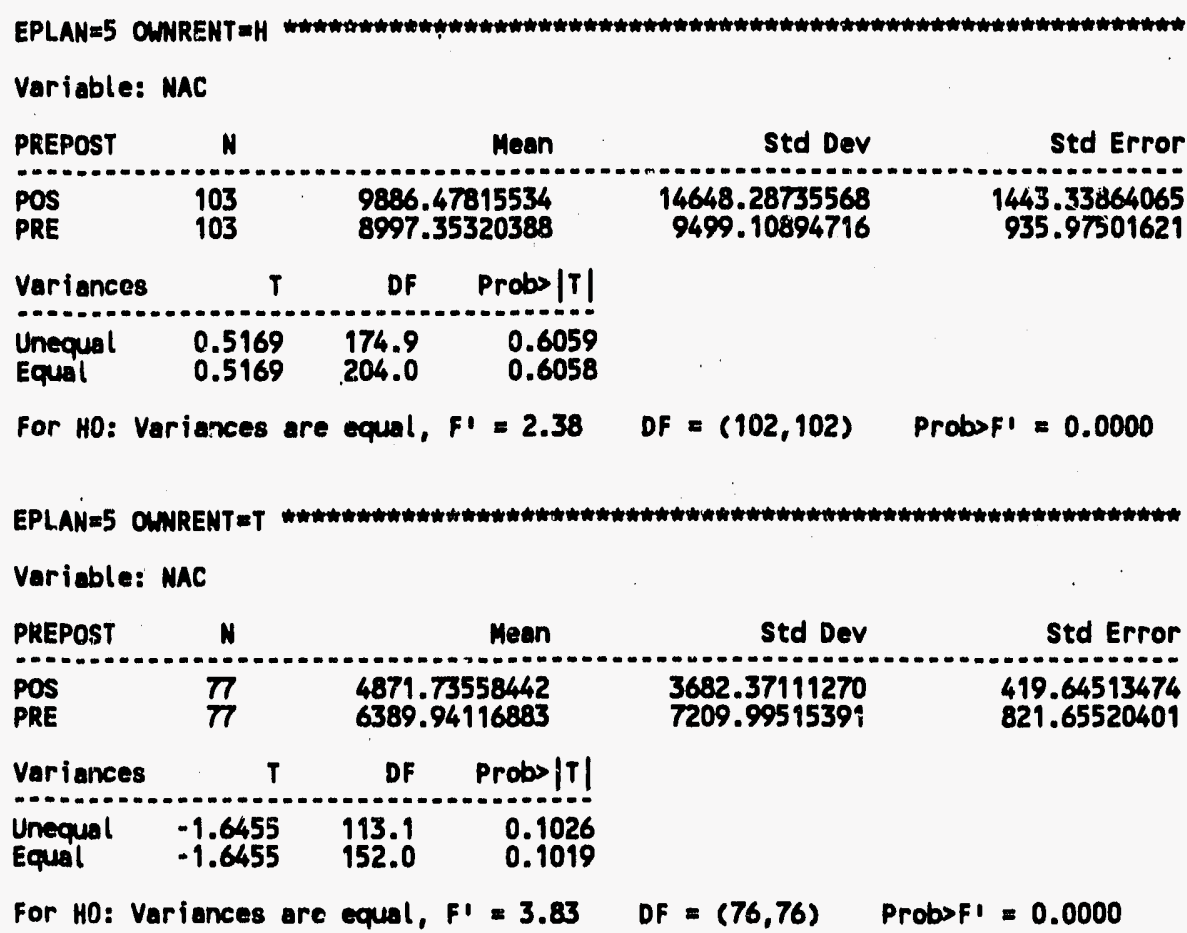




\section{Normalized Annual Consumption of 1989 Participants (by primary space heating fuel)}

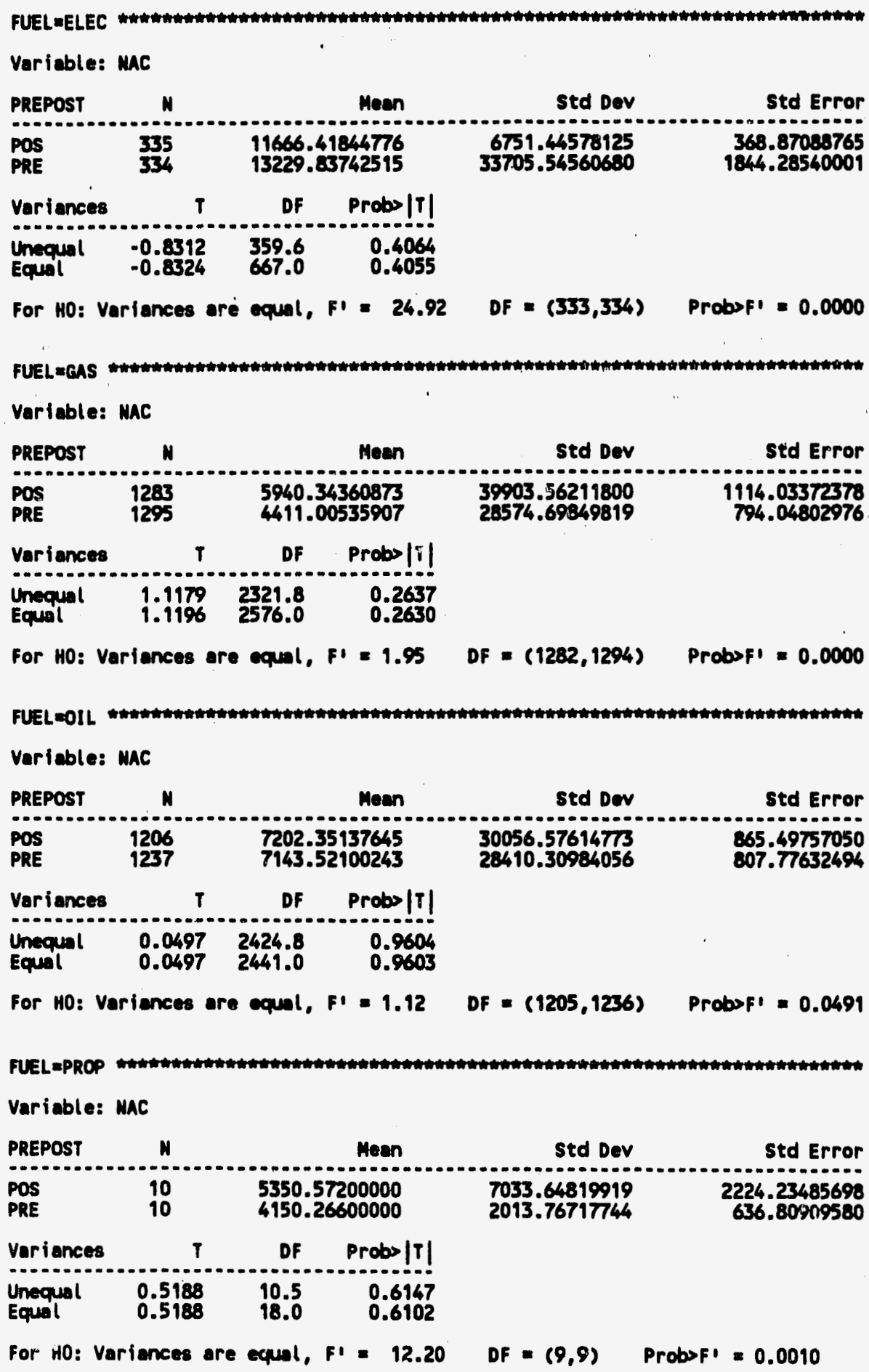




\section{Normalized Annual Consumption of 1989 Participants (by primary space heating fuel and plan)}

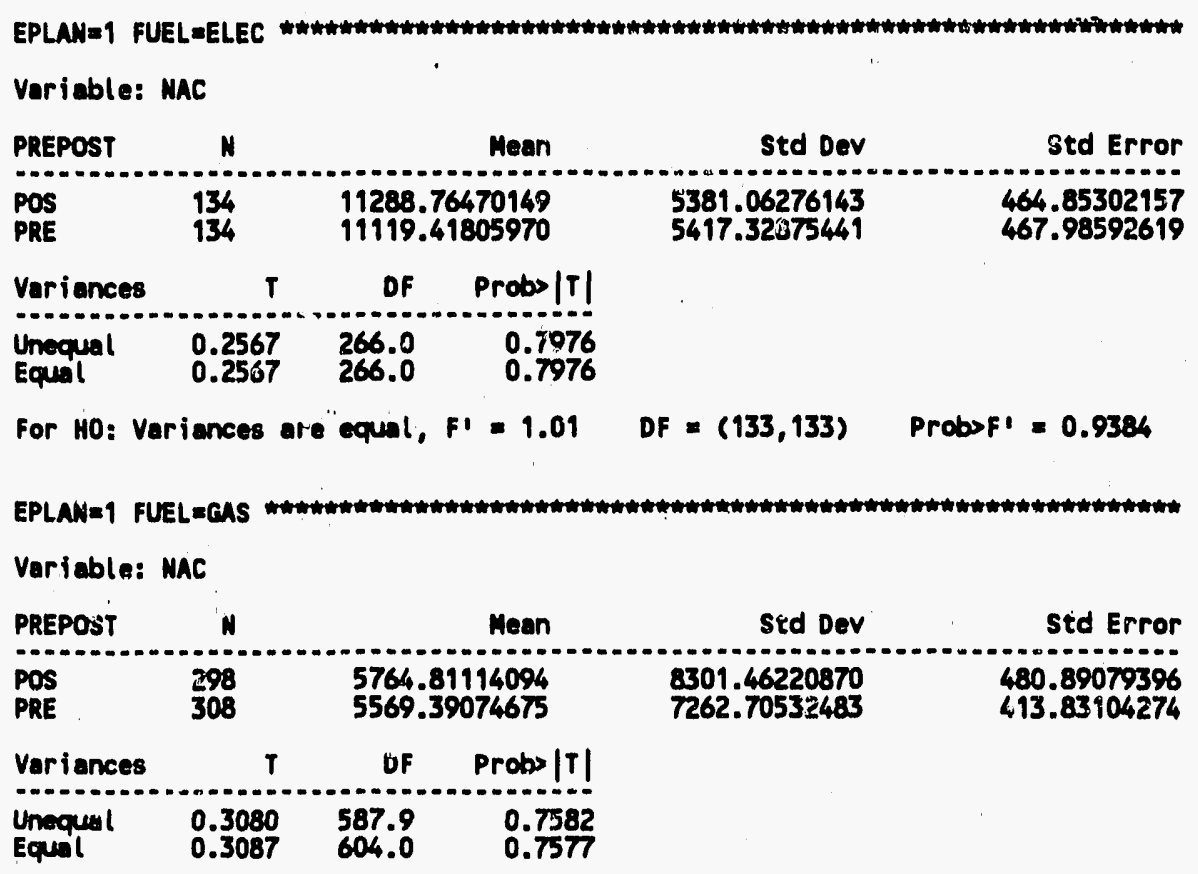

For HO: Variances are equal, FI $=1.31 \quad$ DF $=(297,307) \quad$ ProbsF' $=0.0204$

EPLAN=1 FUEL=OIL Variable: MAC

\begin{tabular}{|c|c|c|c|c|c|}
\hline PREPOST & $N$ & & Mean & Std Dev & std Error \\
\hline $\begin{array}{l}\text { POS } \\
\text { PRE }\end{array}$ & $\begin{array}{l}421 \\
426\end{array}$ & $\begin{array}{l}8498 \\
8737\end{array}$ & $\begin{array}{l}434679 \\
880282\end{array}$ & $\begin{array}{l}49988.78683289 \\
47964.37792290\end{array}$ & $\begin{array}{l}2436.30439782 \\
2323.88170366\end{array}$ \\
\hline Variances & $T$ & DF & Probs $|T|$ & & \\
\hline $\begin{array}{l}\text { Unequal } \\
\text { Equal }\end{array}$ & $\begin{array}{l}-0.0709 \\
-0.0709\end{array}$ & $\begin{array}{l}842.6 \\
845.0\end{array}$ & $\begin{array}{l}0.9435 \\
0.9435\end{array}$ & & \\
\hline
\end{tabular}

For HO: Variances are equal, F' $=1.09 \quad$ DF $=(420,425) \quad$ ProbsF' $=0.3957$

EPLAN=1 FUELAPROP Variable: MAC

\begin{tabular}{lllll} 
PREPOST & $N$ & Mean & Std Dev & Std Error \\
\hline POS & 1 & 1031.60000000 & & \\
PRE & 1 & 1104.60000000 & . &
\end{tabular}

\begin{tabular}{lll} 
Variances & T & DF Probs|T! \\
\hdashline Unequal & : & :
\end{tabular}

MOTE: All values are the same for one CLASS level. 


\section{Normalized Annual Consumption of 1989 Participants}

(by primary space heating fuel and plan)

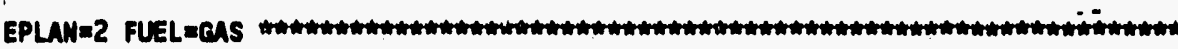
Variable: MAC

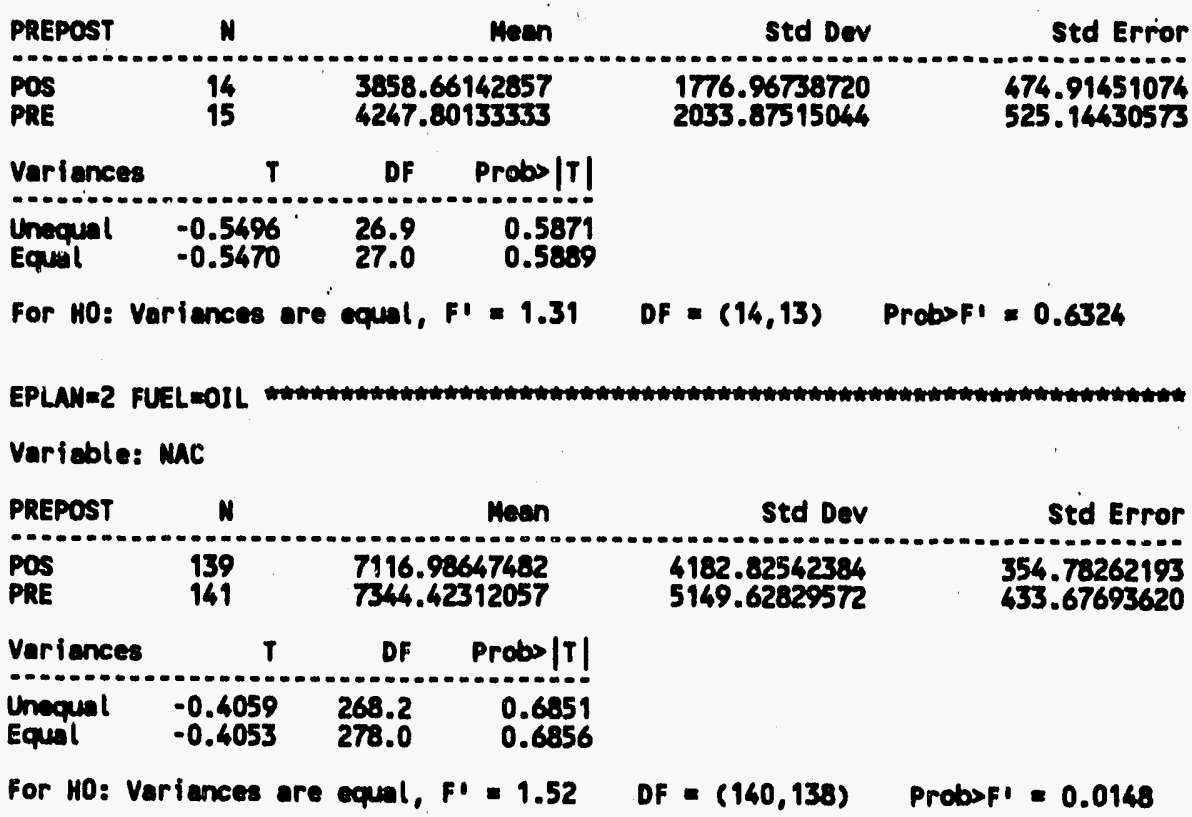




\section{Normalized Annual Consumption of 1989 Participants (by primary space heating fuel and plan)}

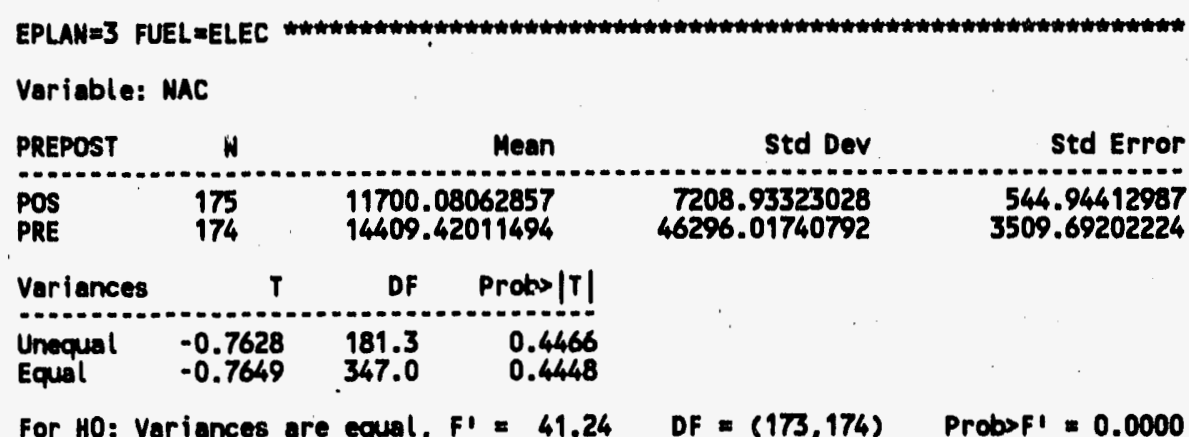

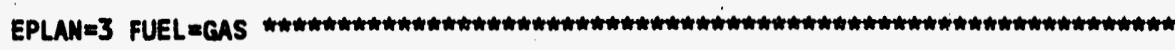
Veriable: MAC

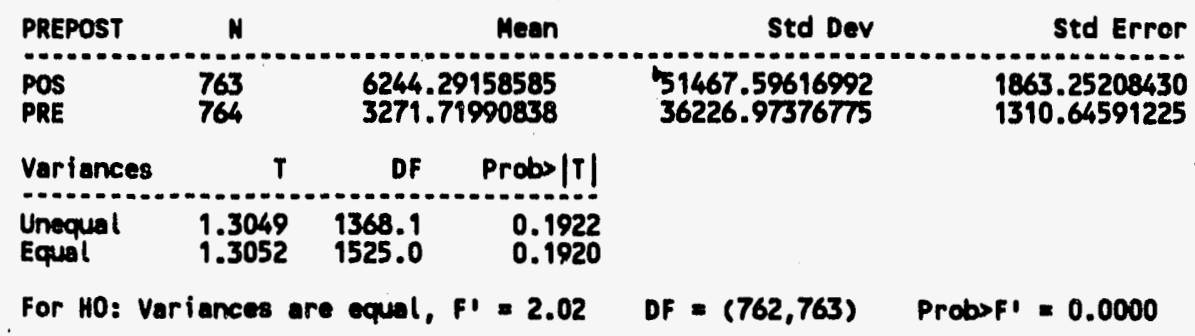

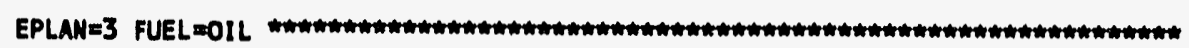
Variable: MAC

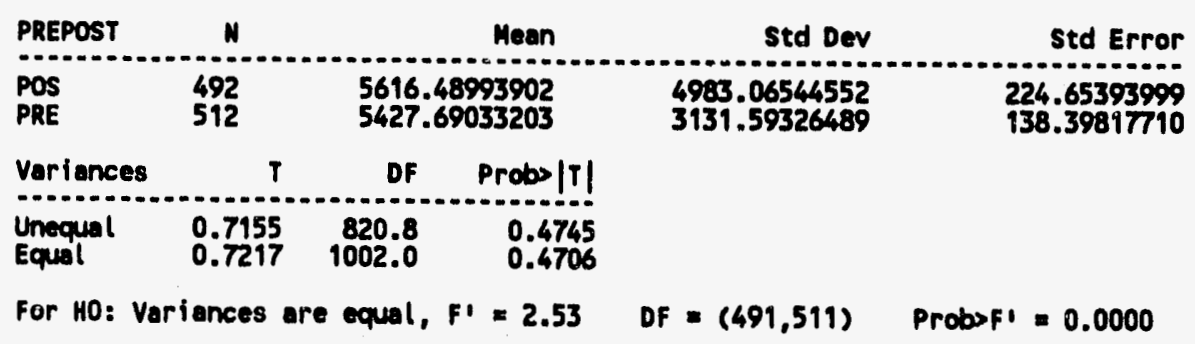




\section{Normalized Annual Consumption of 1989 Participants (by primary space heating fuel and pian)}

EPLAN=4 FUEL=ELEC

Variable: MAC

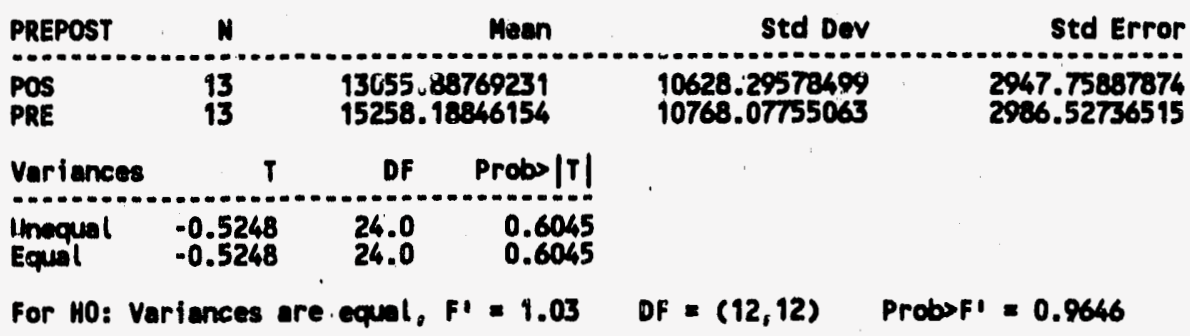

EPLANE4 FUELECAS Hom Variable: MAC

\begin{tabular}{llllrr} 
PREPOST & $N$ & & Mean & Std Dev & Std Error \\
\hline POS & 133 & 5612.36338346 & 3090.64224341 & 267.99267015 \\
PRE & 134 & 7632.80805970 & 15652.22727503 & 1352.14649329
\end{tabular}

Variences T PF Probs|T!

Equal $\quad-1.4607 \quad 265.0 \quad 0.1453$

For HO: Variances are equal, FI = $25.65 \quad$ DF $=(133,132) \quad$ ProbsFI $=0.0000$

EPLANEL FUEL=OIL Variable: MAC

\begin{tabular}{l|cccc} 
PREPOST & $N$ & Mean & Std Dev & std Error \\
\hline POS & 75 & 7266,61733333 & 403.35763603 & 508.65596330 \\
PRE & 78 & 7579.43192308 & 4975.18442558 & 472.74654384
\end{tabular}

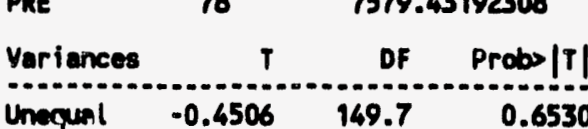

Equal $\quad-0.4510 \quad 159.0 \quad 0.6526$

For HO: Variances are equal, FI $=1.11 \quad$ DF $=(74,77) \quad$ ProbsFI $=0.6439$

EPLANEL FUELEPROP Veriable: MAC

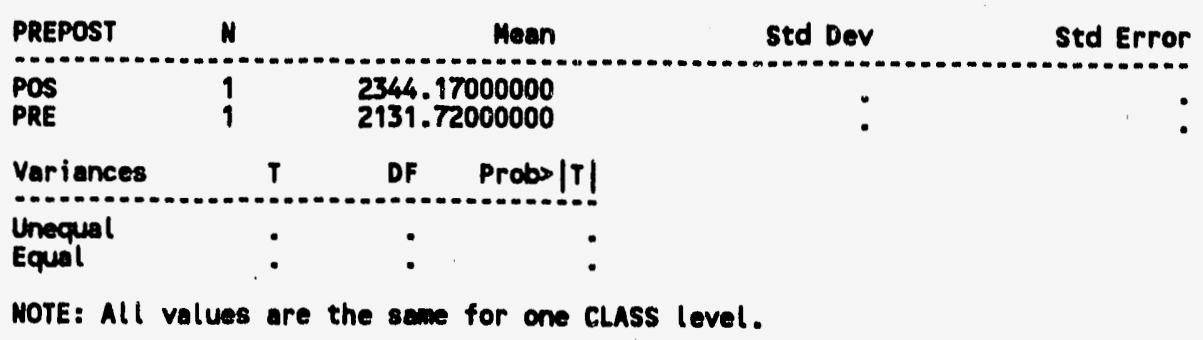




\section{Normalized Annual Consumption of 1989 Participants (by primary space heating fuel and plan)}

EPLAN=5 FUEL=ELEC Variabla: MAC

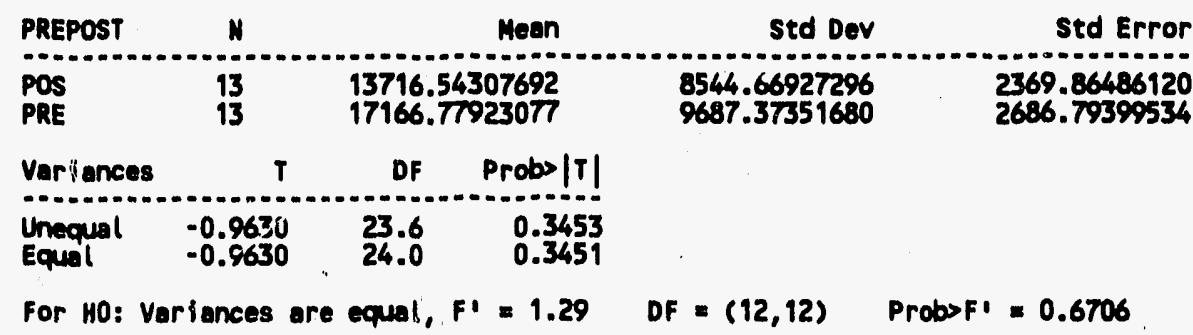

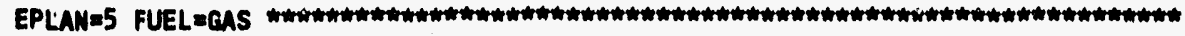
Variable: MAC

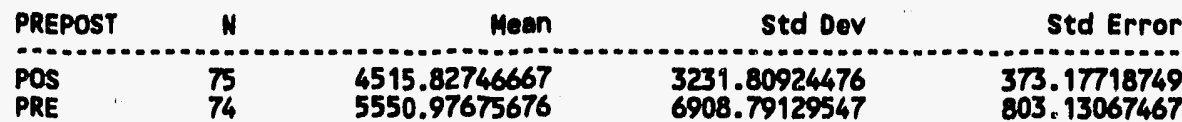

\begin{tabular}{llll|} 
Variances & $T$ & DF & Probs $|T|$ \\
\hdashline Unequal & -1.1689 & 103.2 & 0.2451 \\
Equal & -1.1739 & 147.0 & 0.2623
\end{tabular}

For HO: Variances are equal, FI $=4.57 \quad$ DF $=(73,74) \quad$ ProbsFI $=0.0000$

EPLANE5 FUEL=OIL Variable: MAC

\begin{tabular}{|l|c|ccc} 
PREPOST & $N$ & Mean & Std Dev & Std Error \\
\hline POS & 79 & 10260.69569620 & 16147.97385313 & 1816.78900066 \\
PRE & 80 & 8858.81412500 & 9395.23404033 & 1050.41909894
\end{tabular}

\begin{tabular}{llll} 
Variances & $T$ & DF & Probs $|T|$ \\
\hline Unequal & 0.6680 & 125.1 & 0.5054 \\
Equal & 0.6701 & 157.0 & 0.5038
\end{tabular}

For HO: Variances are equal, $F^{\prime}=2.95 \quad$ DF $=(78,79) \quad$ Probsfl $=0.0000$

EPLAN=5 FUELAPROP Variable: MAC

\begin{tabular}{|c|c|c|c|c|}
\hline PREPOST & $N$ & Mean & Std Dev & Std Error \\
\hline $\begin{array}{l}\text { POS } \\
\text { PRE }\end{array}$ & $\begin{array}{l}3 \\
3\end{array}$ & $\begin{array}{l}3240.29000000 \\
4542.10666667\end{array}$ & $\begin{array}{l}2051.77442191 \\
1865.72533673\end{array}$ & $\begin{array}{l}1184.59251481 \\
1077.17702540\end{array}$ \\
\hline
\end{tabular}

\begin{tabular}{llll} 
Variances & $T$ & DF & Probs $|T|$ \\
\hline Unequal & -0.8131 & 4.0 & 0.4623 \\
Equal & -0.8131 & 4.0 & 0.4618
\end{tabular}

For HO: Variances are equal, $F^{\prime}=1.21 \quad$ DF $=(2,2) \quad$ Probs $F^{\prime}=0.9052$ 



\section{Appendix D: Savings Based on Billing Data}

\section{Section 4: Savings from 1990 Installations}

Table of Contents:

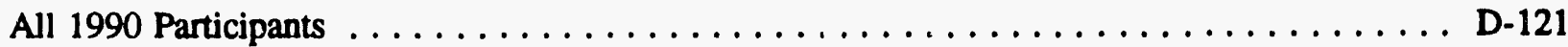

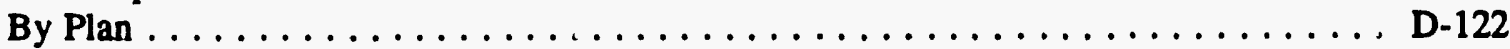

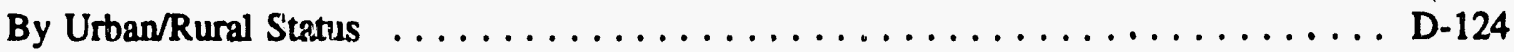

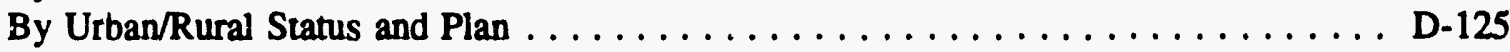

By Owner/Renter Status $\ldots \ldots \ldots \ldots \ldots \ldots \ldots \ldots \ldots \ldots \ldots$. . . . . . . . . . . . . . . . . .

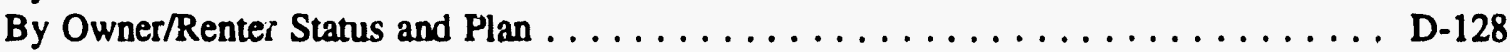

By Primary Space Heating Fuel $\ldots \ldots \ldots \ldots \ldots \ldots \ldots \ldots \ldots \ldots$. . . . . . . . . . . . . . . . . .

By Primary Space Heating Fuel and Plan $\ldots \ldots \ldots \ldots \ldots \ldots \ldots \ldots$ D-131

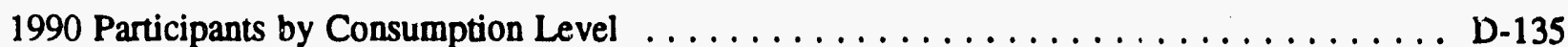

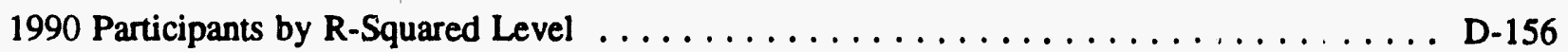





\section{Normalized Annual Consumption of 1990 Participants}

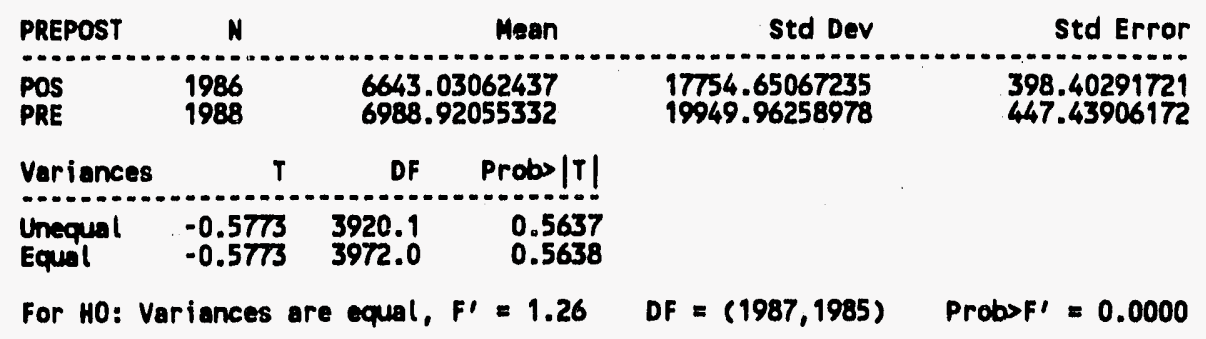




\section{Normalized Annual Consumption of 1990 Participants (by plan)}

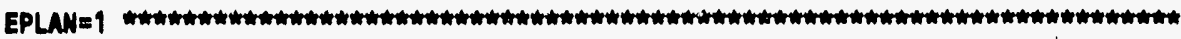
Variable: MAC

\begin{tabular}{|c|c|c|c|c|c|}
\hline PREPOST & $N$ & & Mean & Std Dev & Std Error \\
\hline $\begin{array}{l}\text { POS } \\
\text { PRE }\end{array}$ & $\begin{array}{l}334 \\
338\end{array}$ & $\begin{array}{l}6152 \\
6319\end{array}$ & $\begin{array}{l}862275 \\
647929\end{array}$ & $\begin{array}{l}5062.40421215 \\
5156.18178769\end{array}$ & $\begin{array}{l}277.00243415 \\
280.45931593\end{array}$ \\
\hline Variance & $T$ & DF & Probs|T| & & \\
\hline $\begin{array}{l}\text { Unequal } \\
\text { Equal }\end{array}$ & $\begin{array}{l}-0.4232 \\
-0.4231 .\end{array}$ & $\begin{array}{l}670.0 \\
670.0\end{array}$ & $\begin{array}{l}0.6723 \\
0.6723\end{array}$ & & \\
\hline
\end{tabular}

For HO: Variances are equal, F' $=1.04 \quad$ OF $=(337,333) \quad$ Probof' $=0.7373$

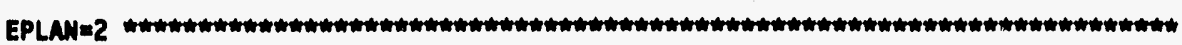
Variable: MAC

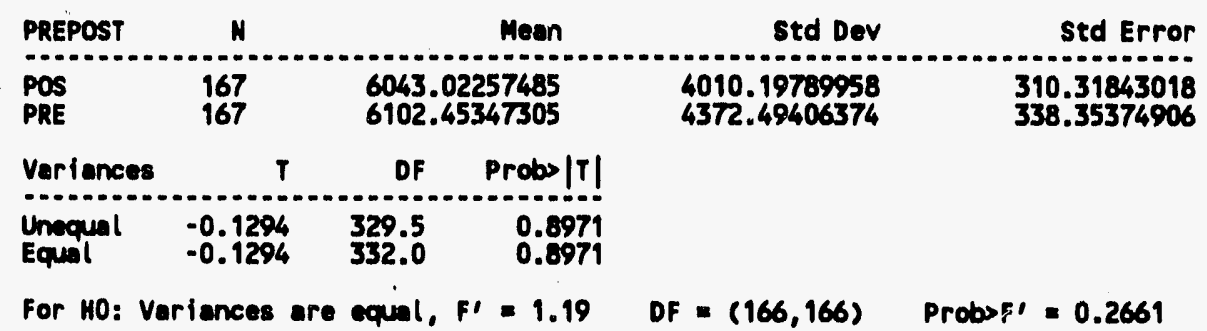

EPLANE3 How Variable: MAC

\begin{tabular}{|c|c|c|c|c|c|}
\hline PREPOST & N & & Mean & std Dev & std Error \\
\hline $\begin{array}{l}\text { POS } \\
\text { PRE }\end{array}$ & $\begin{array}{l}841 \\
836\end{array}$ & $\begin{array}{l}7384 \\
8029\end{array}$ & $\begin{array}{l}115339 \\
593301\end{array}$ & $\begin{array}{l}26772.82761538 \\
30239.41800707\end{array}$ & $\begin{array}{r}923.20095225 \\
1045.85214072\end{array}$ \\
\hline Variance & $T$ & DF & Probs $|T|$ & & \\
\hline $\begin{array}{l}\text { Unequal } \\
\text { Equal }\end{array}$ & $\begin{array}{l}-0.4621 \\
-0.4622\end{array}$ & $\begin{array}{l}1648.4 \\
1675.0\end{array}$ & $\begin{array}{l}0.6441 \\
0.6440\end{array}$ & & \\
\hline
\end{tabular}

For HO: Variances are equal, FI $=1.28 \quad$ DF $=(835,840) \quad$ ProbsF' $=0.0004$

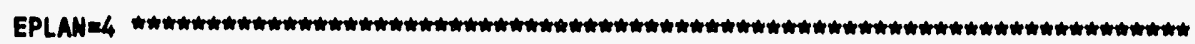
Variable: HAC

\begin{tabular}{|c|c|c|c|c|c|}
\hline PREPOST & N & & Mean & std Dev & std Error \\
\hline $\begin{array}{l}\text { POS } \\
\text { PRE }\end{array}$ & $\begin{array}{l}321 \\
322\end{array}$ & $\begin{array}{l}7088 \\
7314\end{array}$ & $\begin{array}{l}778816 \\
475155\end{array}$ & $\begin{array}{l}4805.63585151 \\
5120.14768410\end{array}$ & $\begin{array}{l}268.22443721 \\
285.33467495\end{array}$ \\
\hline Variances & $T$ & DF & Prabs $|T|$ & & \\
\hline $\begin{array}{l}\text { Unequal } \\
\text { Equal }\end{array}$ & $\begin{array}{l}-0.5769 \\
-0.5769\end{array}$ & $\begin{array}{l}638.7 \\
641.0\end{array}$ & $\begin{array}{l}0.5642 \\
0.5642\end{array}$ & & \\
\hline
\end{tabular}


Normalized Annual Consumption of 1990 Participants

(by plan)

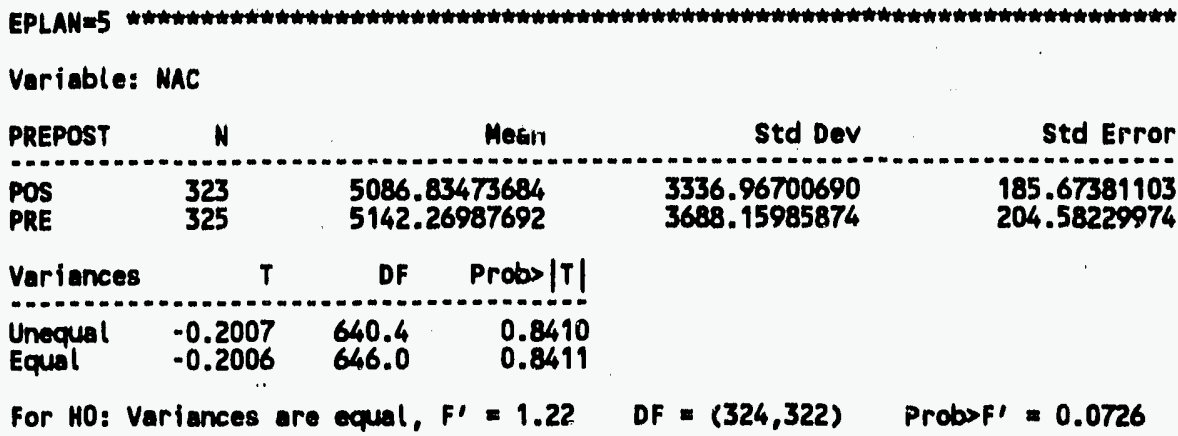




\section{Normalized Annual Consumption of 1990 Participants (by urban/rural status)}

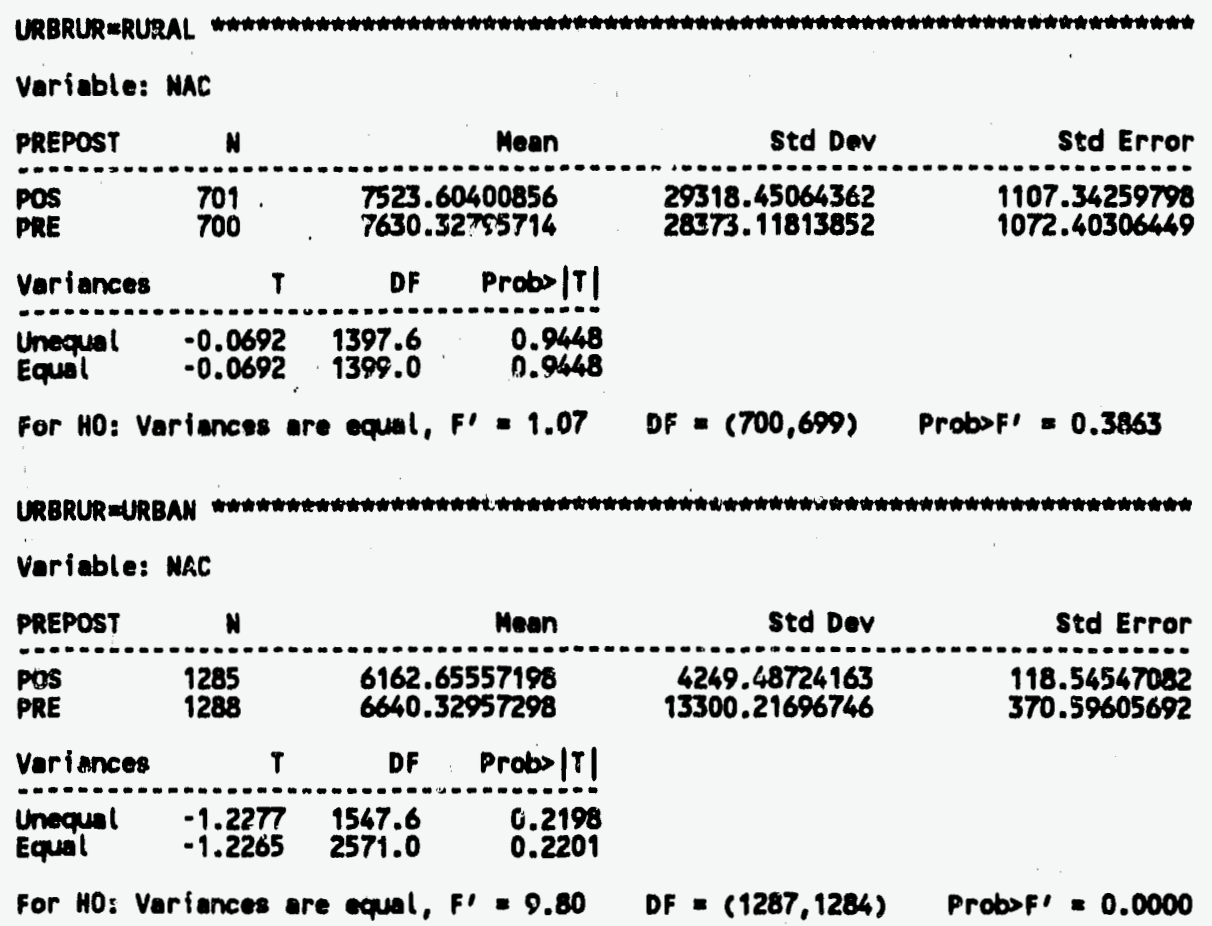




\section{Normalized Annual Consumption of 1990 Participants}

\section{(by urban/rural status and plan)}

EPLAN=1 URBRUR=RURAL

- Variable: NAC

$\begin{array}{lllllll}\text { PREPUST } & N & \text { Mean } & \text { Std Dev } & \text { Std Error } & \text { Minimum } & \text { Maximm } \\ \text { POS } & 140 & 5699.9400714 & 5087.0908471 & 429.93764736 & 33.47000000 & 3000.130000 \\ \text { PRE } & 143 & 6015.6202098 & 5278.3328605 & 441.39636808 & 16.88000000 & 30745.080000\end{array}$

\begin{tabular}{llll} 
Variances & $T$ & DF & Probs $|T|$ \\
\hdashline Unequal & -0.5123 & 280.9 & 0.6088 \\
Equal & -0.5121 & 281.0 & 0.6090
\end{tabular}

For HO: Variances are equal, F' $=1.08 \quad$ DF $\equiv(142,139) \quad$ Probs $F^{\prime}=0.6629$

EPLAN=1 URBRUR=URBAY Variable: NAC

\begin{tabular}{|c|c|c|c|c|c|c|c|c|c|c|}
\hline & N & Mean. & std Dev & std Error & Minimm & Maximum & ariances & $\mathbf{T}$ & DF & Pro \\
\hline & $\begin{array}{l}194 \\
195\end{array}$ & $\begin{array}{l}6479.6381959 \\
6542.5644103\end{array}$ & $\begin{array}{l}5032.3085992 \\
5066.7767185\end{array}$ & $\begin{array}{l}361.29870153 \\
362.83941716\end{array}$ & $\begin{array}{l}229.51000000 \\
554.55000000\end{array}$ & $\begin{array}{l}40884.720000 \\
37960.540000\end{array}$ & $\begin{array}{l}\text { Unequal } \\
\text { Equal }\end{array}$ & $\begin{array}{l}-0.1229 \\
-0.1229\end{array}$ & $\begin{array}{l}387.0 \\
387.0\end{array}$ & $\begin{array}{l}0.9023 \\
0.9023\end{array}$ \\
\hline
\end{tabular}

For HO: Variances are equal, FI $=1.01 \quad$ DF $=(194,193) \quad$ Probs $F 1=0.9245$

EPLAN=2 URBRUR=RURAL Variable: MAC

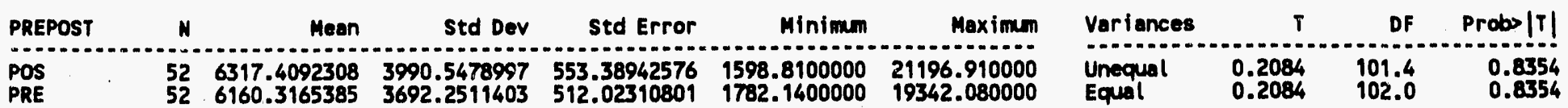

Fol' HO: Variances ore equal, $F^{\prime}=1.17 \quad$ DF $=(51,51) \quad$ ProbsF' $=0.5811$

EPLAN=2 URBRUR=URBAN Variable: MAC

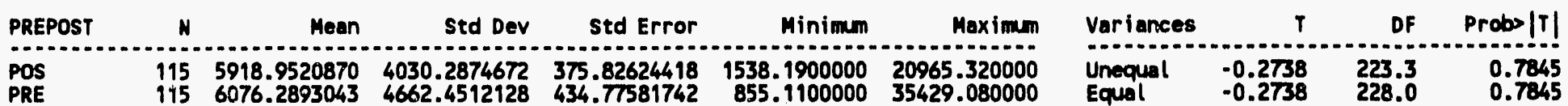

For HO: Variances are equal, $F^{\prime}=1.34 \quad$ DF $=(114,114) \quad$ ProbsFl $=0.1212$

EPLAN=3 URBRUR=RURAL Variable: NAC

\begin{tabular}{|c|c|c|c|c|c|c|c|c|c|c|}
\hline REP & N & Mean & Std Dev & std Error & Minimm & Maximum & Variances & $T$ & DF & Probs $|\mathrm{T}|$ \\
\hline E & $\begin{array}{l}245 \\
239\end{array}$ & $\begin{array}{r}10030.809469 \\
9836.969163\end{array}$ & $\begin{array}{l}49167.659538 \\
48049.937043\end{array}$ & $\begin{array}{l}3141.2065435 \\
3108.0920501\end{array}$ & $\begin{array}{l}706.03000000 \\
344.58000000\end{array}$ & $\begin{array}{l}771375.19000 \\
743902.44000\end{array}$ & $\begin{array}{l}\text { Unequal } \\
\text { Equal }\end{array}$ & 0.0439 & 482.0 & \\
\hline
\end{tabular}

For HO: Variances are equal, $F^{\prime}=1.05 \quad$ OF $=(244,238) \quad$ Prob>FI $=0.7218$

EPLAN=3 URBRUR=URBAN

Variable: NAC

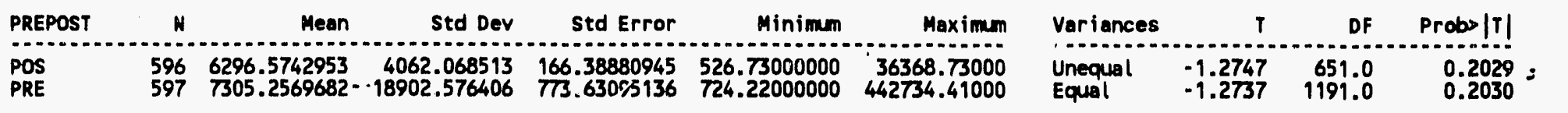

For HO: Variances are equal, $F^{\prime}=21.65 \quad D F=(596,595) \quad$ Prob>F' $=0.0000$ 


\section{Normalized Annual Consumption of 1990 Participants \\ (by urban/rural status and plan)}

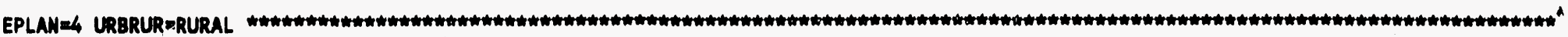
Variable: MAC

\begin{tabular}{l|cccccc} 
PREPOST & $N$ & Mean & Std Dev & Std Error & Minimm & Maximm \\
\hdashline POS & 145 & 7162.3542759 & 4595.8674054 & 381.66601403 & 348.82000000 & 28129.400000 \\
PRE & 146 & 7624.7580822 & 5074.8797855 & 420.00003945 & 586.15000000 & 33594.530000
\end{tabular}

For HO: Variances are equal, FI $=1.22 \quad$ DF $=(145,144) \quad$ ProbsFI $=0.2347$

\begin{tabular}{llll} 
Variances & $T$ & DF & Probs|T! \\
\hline Unoqual & -0.8148 & 286.6 & 0.4159 \\
Equal & -0.8145 & 289.0 & 0.4160
\end{tabular}

EPLANE4 URBRUR=URBAN Variable: MAC

\begin{tabular}{|c|c|c|c|c|c|c|c|c|c|c|}
\hline PREPOST & $N$ & Mean & Std Dev & Std Error & Minimm & Maximum & Variances & $T$ & DF & Probs $|\mathrm{T}|$ \\
\hline $\begin{array}{l}\text { POS } \\
\text { PRE }\end{array}$ & $\begin{array}{l}176 \\
176\end{array}$ & $\begin{array}{l}7028.0513636 \\
7057.4099432\end{array}$ & $\begin{array}{l}4984.0442045 \\
5157.6475330\end{array}$ & $\begin{array}{l}375.68646739 \\
388.77231064\end{array}$ & $\begin{array}{r}567.9700000 \\
1437.2100000\end{array}$ & $\begin{array}{l}32378.030000 \\
35479.410000\end{array}$ & $\begin{array}{l}\text { Unequal } \\
\text { Equal }\end{array}$ & $\begin{array}{l}-0.0543 \\
-0.0543\end{array}$ & $\begin{array}{l}349.6 \\
350.0\end{array}$ & $\begin{array}{l}0.9567 \\
0.9567\end{array}$ \\
\hline
\end{tabular}

For HO: Variances are equal, FI $=1.07 \quad$ DF $=(175,175) \quad$ ProbsFI $=0.6511$

EPLAN=5 URBRUR=RURAL Variable: MAC

\begin{tabular}{lllllll} 
PREPOST & $N$ & Mean & Std Dev & Std Error & Minimm & Maximm \\
\hdashline POS & 119 & 5474.4523529 & 3894.1153733 & 356.97297900 & 187.7800000 & 24240.730000 \\
PRE & 120 & 5803.4092500 & 4841.7988931 & 441.99374544 & 1085.0500000 & 40544.000000
\end{tabular}

\begin{tabular}{llll} 
Variances & $T$ & DF & Probs $\mid$ T! \\
\hline Unequal & -0.5790 & 227.3 & 0.5632 \\
Equal & -0.5785 & 237.0 & 0.5635
\end{tabular}

For HO: Variances are equal, F' $=1.55 \quad$ DF $=(119,118) \quad$ Prob>FI $=0.0185$

EPLAN=5 URBRUROURBAN Variable: MAC

\begin{tabular}{llllllll} 
PREPOST & $N$ & & Mean & Std Dev & Std Error & Minimum & Maximum \\
\hline POS & 204 & 4860.7244608 & 2951.0833964 & 206.61716531 & 805.5200000 & 20294.520000 \\
PRE & 205 & 4755.2614634 & 2742.4959292 & 191.54422430 & 1400.5800000 & 15251.510000
\end{tabular}

For HO: Variances are equal, FI $=1.16 \quad$ DF $=(203,204) \quad$ Probsfl $=0.2964$

\begin{tabular}{llll} 
Variances & $T$ & DF & Probs|T! \\
\hline Unaqual & 0.3743 & 404.5 & 0.7084 \\
Equal & 0.3744 & 407.0 & 0.7083
\end{tabular}




\section{Normalized Annual Consumption of 1990 Participants (by owner/renter status)}

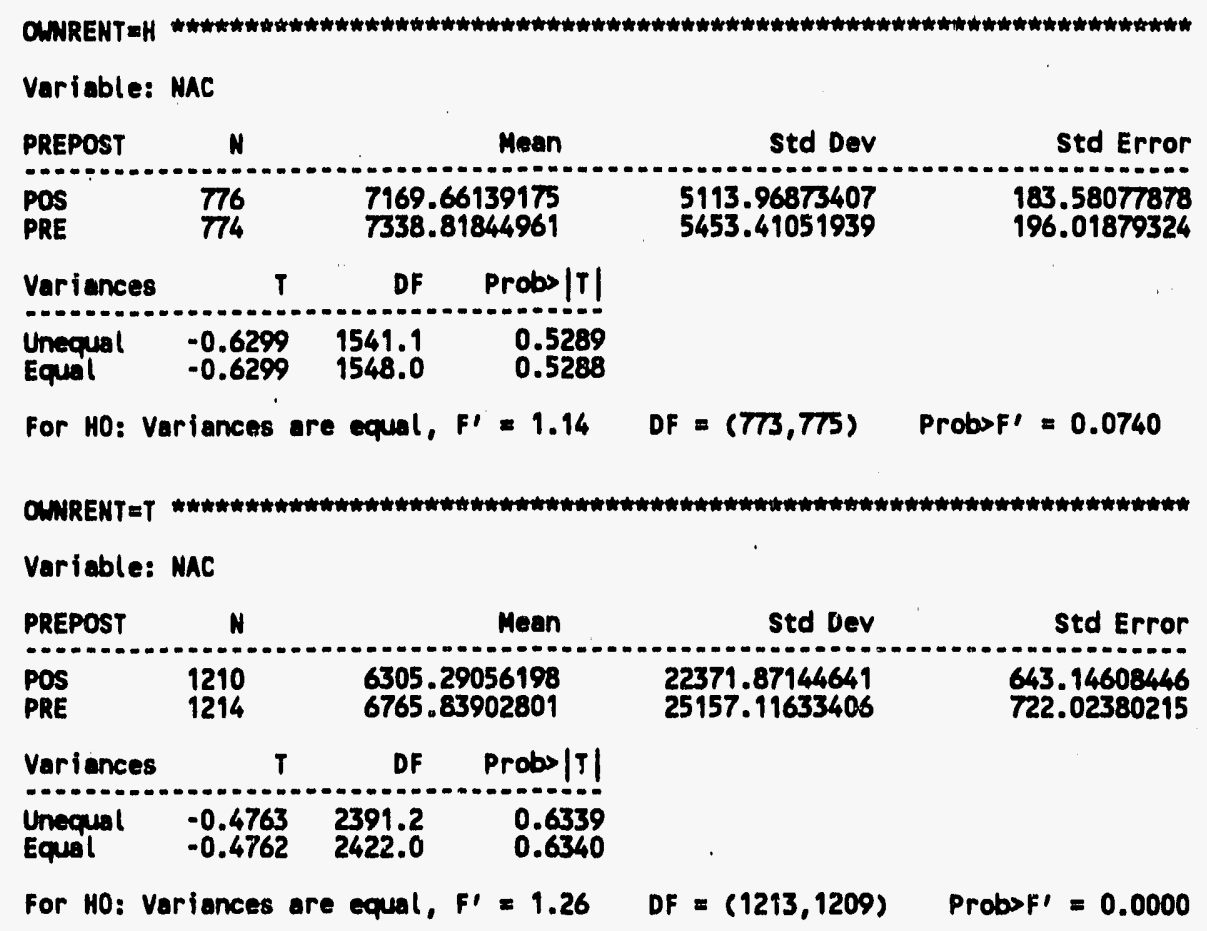




\section{Normalized Annual Consumption of 1990 Participants (by owner/renter status and plan)}

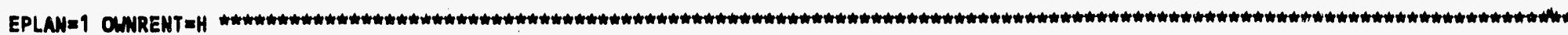
Variable: MAC

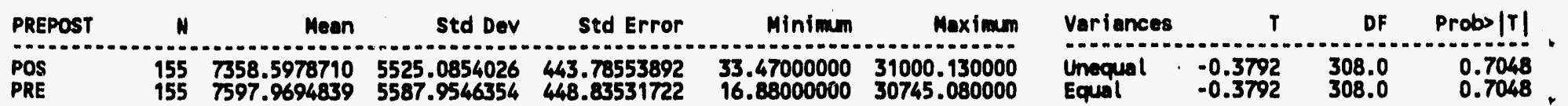

For HO: Variances are equal, FI $=1.02 \quad$ DF $=(154,154) \quad$ ProbsFl $=0.8885$

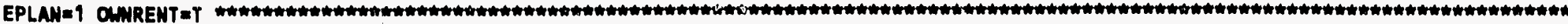
Variable: MAC

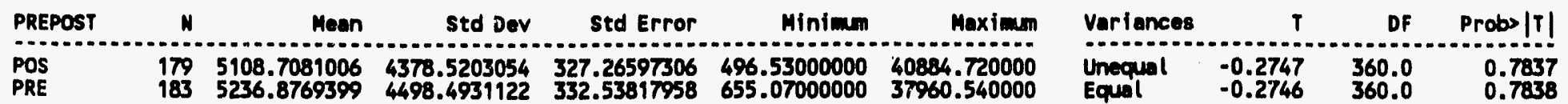

For HO: Variances are equal, FI $=1.06 \quad$ DF $=(182,178) \quad$ ProbsFl $=0.7177$

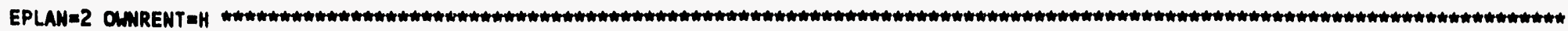
Variable: MAC

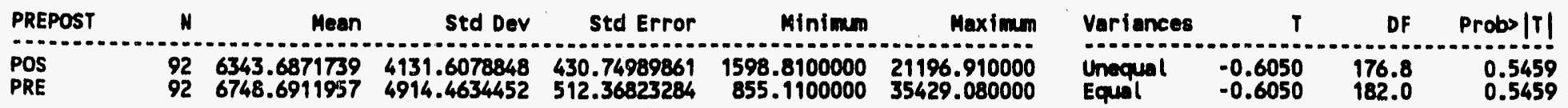

For HO: Variances are equal, F' $=1.41 \quad$ DF $=(91,91) \quad$ ProbsF' $=0.0996$

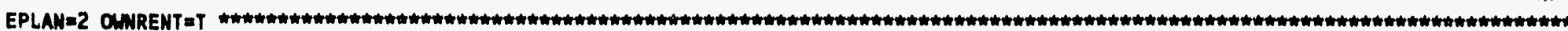
Variable: NAC

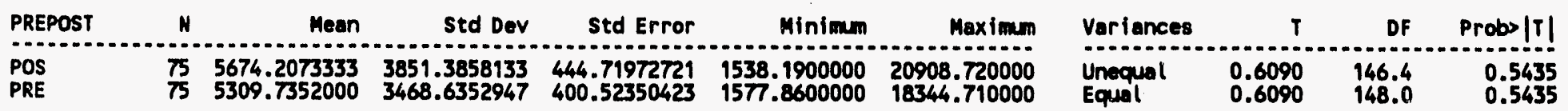

For HO: Variances are equal, FI $=1.23$ DF $=(74,74) \quad$ ProbsF1 $=0.3699$

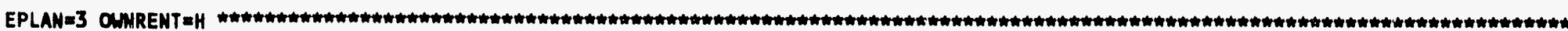
Variable: NAC

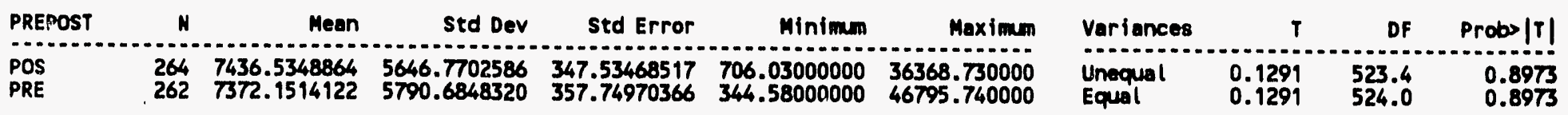

For HO: Variances are equal, F' $=1.05 \quad$ DF $=(261,263)$ Probs.51 $=0.6839$

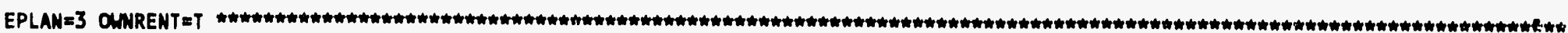
Variable: MAC

\begin{tabular}{lcccccc} 
PREPOST & $N$ & \multicolumn{1}{c}{ Mean } & Std Dev & Std Error & Minimum & Maximum \\
\hline POS & 577 & 7360.5916638 & 32105.288601 & 1336.5606526 & 526.73000000 & 771375.19000 \\
PRE & 574 & 8328.8682404 & 36290.138531 & 1514.7211163 & 724.22000000 & 743902.44000
\end{tabular}

For HO: Variances are equal, F' $=1.28 \quad$ DF $=(573,576) \quad$ Probs $F^{\prime}=0.0034$

\begin{tabular}{llll} 
Variances & $T$ & DF & Probs|T! \\
\hline Unequal & -0.4793 & 1130.7 & 0.6318 \\
Equal & -0.4795 & 1149.0 & 0.6317
\end{tabular}




\section{Normalized Annual Consumption of 1990 Participants \\ (by owner/renter status and plan)}

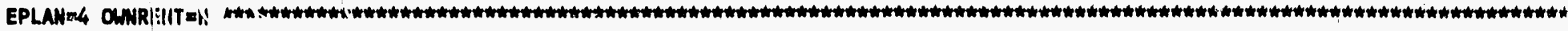
Variable: MAC

PREPOST N Mean Std Dev Std Error Minimum Maximm

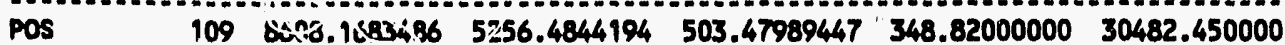

PRE $\quad 109 \quad 9074.0333028 \quad 3857.8543780 \quad 561.08068982 \quad 586.15000000 \quad 35479.410000$

\begin{tabular}{llll} 
Variances & $T$ & DF & Probs $\mid T !$ \\
\hline Unequal & -0.6180 & 213.5 & 0.5372 \\
Equal & -0.6180 & 216.0 & 0.5372
\end{tabular}

For HO: Variances are equal, FI $=1.24 \quad$ DF $=(108,108) \quad$ ProbsFI $=0.2619$

EPLAN=4 ONRENT=T Veriable: WAC

\begin{tabular}{llllllll} 
PREPOST & $N$ & & Mean & Std Dev & Std Error & Minimum & Maximum \\
\hline POS & 212 & 6307.4908491 & 4367.5761192 & 299.96635941 & 567.9700000 & 32378.030000
\end{tabular}

For HO: Variances are equal, FI $=1.04 \quad$ DF $=(212,211) \quad$ Probsfl $=0.7845$

\begin{tabular}{llll} 
Variances & $T$ & DF & Probs $|T|$ \\
\hline Unequal & -0.2497 & 422.9 & 0.8030 \\
Equal & -0.2497 & 423.0 & 0.8030
\end{tabular}

EPLAN=5 OWRENT=H Variable: NAC

\begin{tabular}{llllllll} 
PREPOST & $N$ & & Mean & Std Dev & Std Error & Minimm & Maximun \\
\hdashline POS & 156 & 6012.3063462 & 3700.1340594 & 296.24781789 & 1368.8100000 & 24240.730000 \\
PRE & 156 & 6160.9094231 & 4353.0057733 & 348.51938899 & 1085.0500000 & 40544.0000000
\end{tabular}

For HO: Veriances are equal, F' $=1.38 \quad$ DF $=(155,155) \quad$ Probsfl $=0.0439$

\begin{tabular}{llll} 
Variances & $T$ & DF & Probs/T| \\
\hdashline Unequal & -0.3249 & 302.2 & 0.7455 \\
Equal & -0.3249 & 310.0 & 0.7455
\end{tabular}

EPLAN=5 OWRENT=T Variable: MAC

\begin{tabular}{|c|c|c|c|c|c|c|c|c|c|c|}
\hline I & $N$ & Mean & Std Dev & std Error & imm & Maximn & Variances & $T$ & DF & Probs $|T|$ \\
\hline & $\begin{array}{l}167 \\
169\end{array}$ & 420 & $\begin{array}{l}2694.3181654 \\
2626.4308519\end{array}$ & $\begin{array}{l}208 . \\
202 .\end{array}$ & 800000 & $\begin{array}{l}21774.460000 \\
21759.750000\end{array}$ & $\begin{array}{l}\text { Unequal } \\
\text { Equal }\end{array}$ & 0.0701 & & \\
\hline
\end{tabular}

For HO: Variances are equal, $F r=1.05 \quad$ OF $=(166,168) \quad$ ProbsF' $=0.7417$ 


\section{Normalized Annual Consumption of 1990 Participants (by primary space heating fuel)}

FUELEELEC Variable: MAC

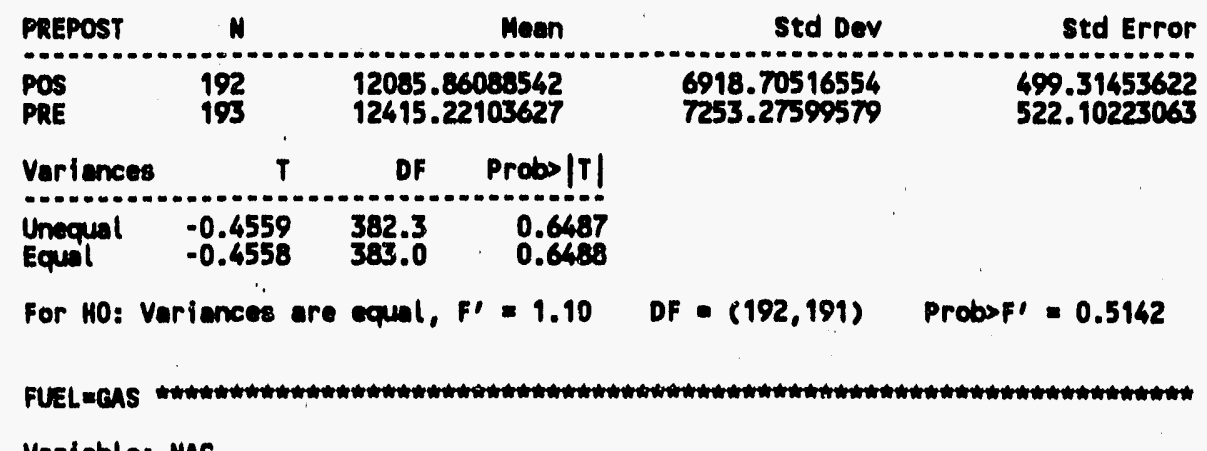

Variable: MAC

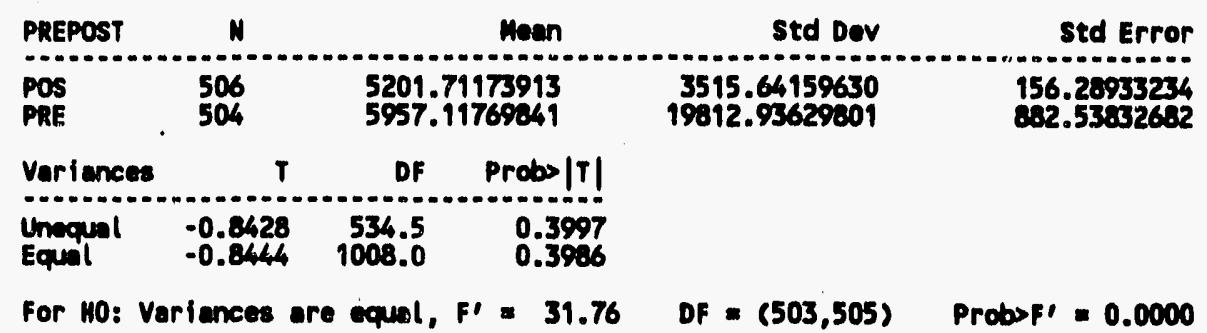

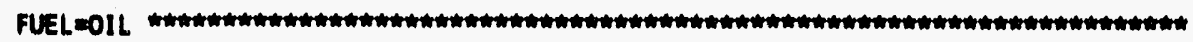
Varfable: WAC

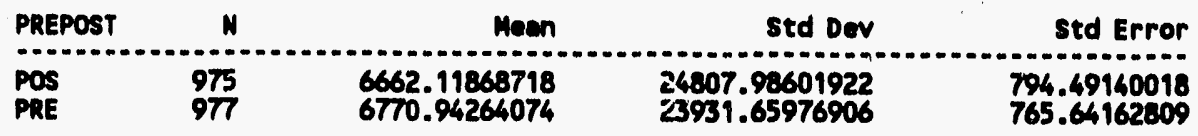

\begin{tabular}{llll} 
Variences & $T$ & DF & Probs|T| \\
\hline Unequal & -0.0986 & 1947.2 & 0.9214 \\
Equil & -0.0986 & 1950.0 & 0.9214
\end{tabular}

For HO: Variances are equal, F' = 1.07 DF - $(974,976)$ Probsf' 0.2616

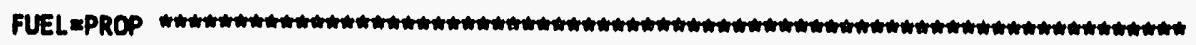
Variable: NAC

\begin{tabular}{llllr} 
PREPOST & $N$ & Mean & Std Dev & Std Error \\
\hline POS & 14 & 6700.02142857 & 4456.41808325 & 1191.02783141 \\
PRE & 14 & 6489.70642857 & 4264.08197100 & 1139.62384319
\end{tabular}

\begin{tabular}{llll} 
Variences & $T$ & DF & Probs $|\mathrm{T}|$ \\
\hline Unequal & 0.1276 & 25.9 & 0.8995 \\
Equal & 0.1276 & 26.0 & 0.8995
\end{tabular}

For HO: Variances are equal, F' $=1.09 \quad$ OF $=(13,13) \quad$ ProbsF' $=0.8760$ 


\section{Normalized Annual Consumption of 1990 Participants (by primary space heating fuel and plan)}

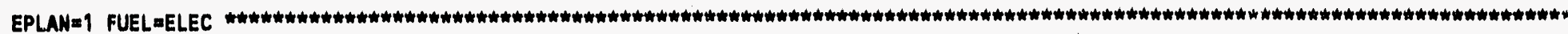

- Variable: NAC

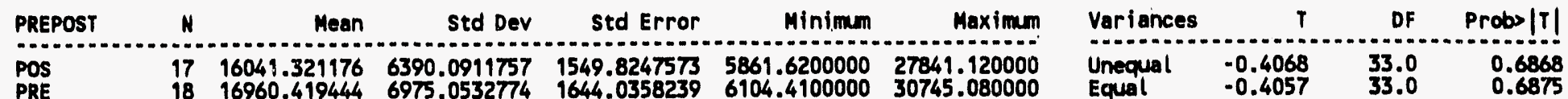

For HO: Variances are equal, FI $=1.19 \quad$ DF $=(17,16) \quad$ ProbsFI $=0.7303$

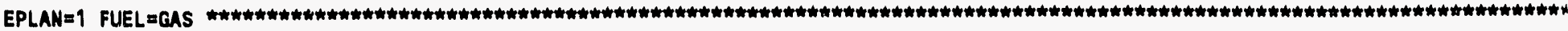

Variable: NAC

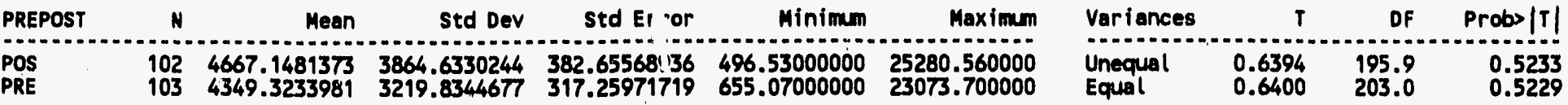

For HO: Variances are equal, FI $=1.44 \quad$ DF $=(101,102) \quad$ ProbsFI $=0.0672$

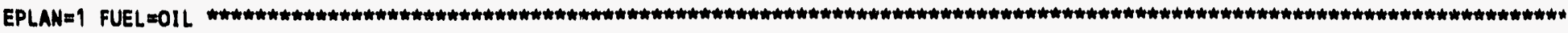
Variable: NAC

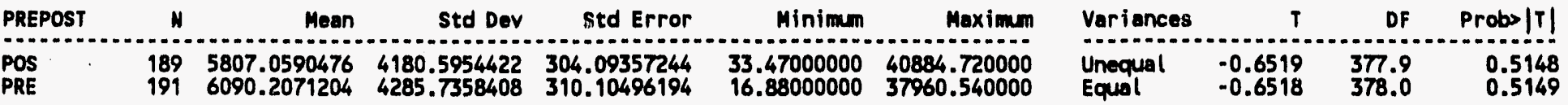

PRE $\quad 191 \quad 6090.2071204 \quad 4285.7358408 \quad 310.104 \% 6194 \quad 16.88000000 \quad 37960.540000$

For HO: Variances are equal, $F^{\prime}=1.05 \quad$ OF $=(190,188) \quad$ Probs $=0.7333$

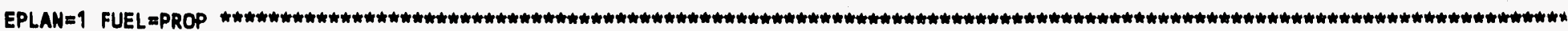
Variable: NAC

\begin{tabular}{|c|c|c|c|c|c|c|c|c|c|c|}
\hline PREPOST & $\mathbf{N}$ & Mean & std Dev & std Error & Minimum & Maximum & Variances & $T$ & DF & Probs $|\mathrm{T}|$ \\
\hline PRE & $\begin{array}{l}2 \\
2\end{array}$ & $\begin{array}{l}11447.920000 \\
10747.380000\end{array}$ & $\begin{array}{l}3419.9360893 \\
4195.7029390\end{array}$ & $\begin{array}{l}2418.2600000 \\
2966.8100000\end{array}$ & $\begin{array}{l}9029.6600000 \\
7780.5700000\end{array}$ & $\begin{array}{l}13866.180000 \\
13714.190000\end{array}$ & $\begin{array}{l}\text { Unequal } \\
\text { Equal }\end{array}$ & $\begin{array}{l}0.1830 \\
0.1830\end{array}$ & $\begin{array}{l}1.9 \\
2.0\end{array}$ & 0.1 \\
\hline
\end{tabular}

For HO: Variances are equal, $F^{\prime}=1.51 \quad$ DF $=(1,1) \quad$ ProbsF' $=0.8707$

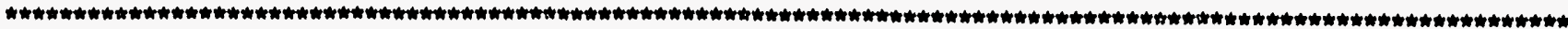

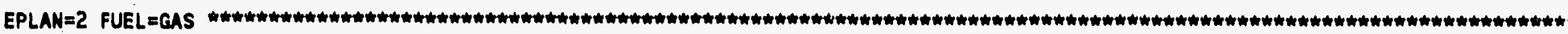
Variable: NAC

\begin{tabular}{lcccccc} 
PREPOST & N & Mean & Std Dev & Std Error & Minimm & Maximum \\
\hline POS & 21 & 8357.6000000 & 4636.7052729 & 1011.8120423 & 2644.1100000 & 20908.720000
\end{tabular}

POS $\quad 21 \quad 8357.6000000 \quad 4636.7052729 \quad 1011.8120423 \quad 2644.1100000 \quad 20908.720000$

$\begin{array}{llllllll}\text { PRE } & 21 & 7926.8390476 & 5038.1830366 & 1099.4216729 & 3125.6900000 & 23339.620000\end{array}$

\begin{tabular}{lccc} 
Variances & $T$ & DF & Probs|T| \\
\hline Unequal & 0.2883 & 39.7 & 0.7746 \\
Equal & 0.2883 & 40.0 & 0.7746
\end{tabular}

For HO: Variances are equal, $F^{\prime}=1.18 \quad$ DF $=(20,20) \quad$ Probs $>1=0.7140$ 


\section{Normalized Annual Consumption of 1990 Participants (by primary space heating fuel and plan)}

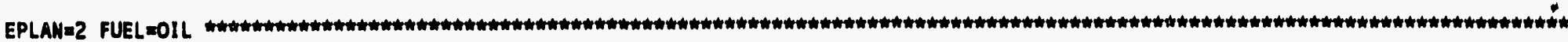
Variable: MAC

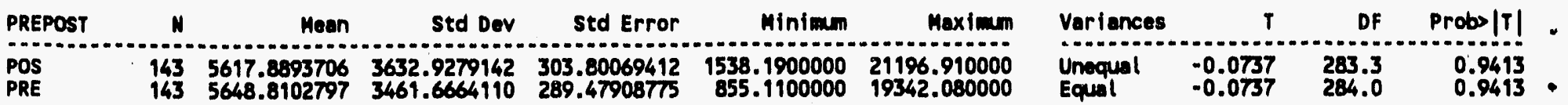

For HO: Variances are equal, F' $=1.10 \quad$ DF $=(142,142) \quad$ ProbsF' $=0.5658$

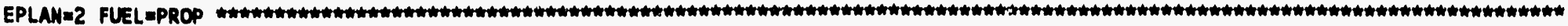
Variable: MAC

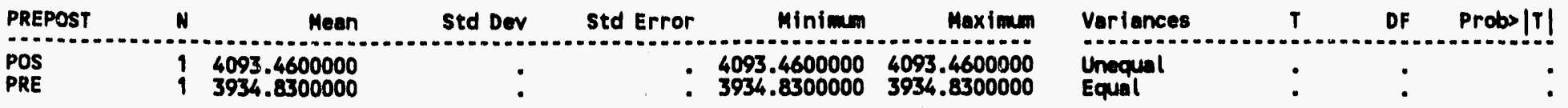

NOTE: All values ore the same for one Class level.

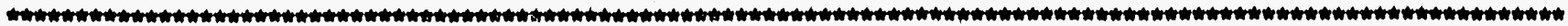

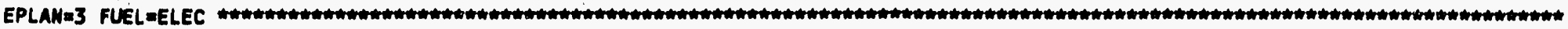
Variable: MAC

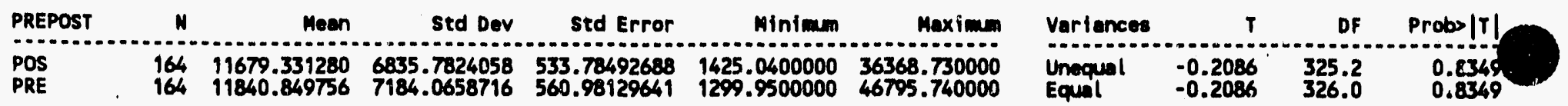

For HO: Variances are equal, FI $=1.10$ DF $=(163,163)$ Probs' $=0.5265$

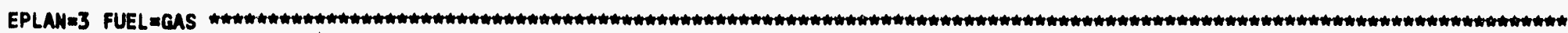
Variable: NAC

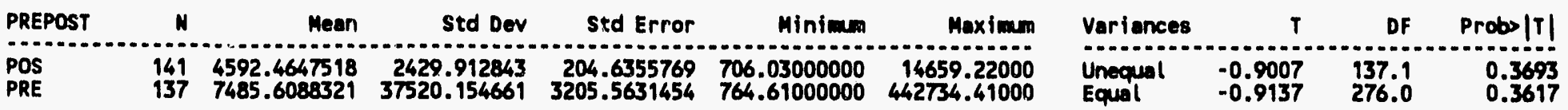

For HO: Variances are equal, FI $=238.42 \quad$ OF $=(136,140) \quad$ ProbsF' $=0.0000$

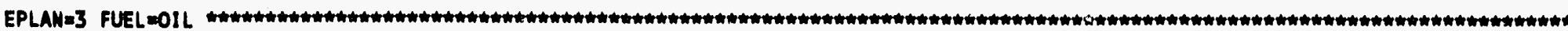
Variable: MAC

\begin{tabular}{lllllll} 
PREPOST & $N$ & \multicolumn{1}{c}{ Moan } & Std Dov & Std Error & Minimm & Maximm \\
\hline POS & 345 & 7599.2317101 & 41318.043848 & 2224.4887036 & 526.73000000 & 771375.19000 \\
PRE & 343 & 7576.6031487 & 39957.014210 & 2157.4739741 & 344.58000000 & 743902.44000
\end{tabular}

For HO: Variances are equal, F' $=1.07 \quad$ DF $=(344,342) \quad$ ProbsF' $=0.5355$

\begin{tabular}{llll} 
Variances & $T$ & DF & Probs|T| \\
\hline Unequal & 0.0073 & 685.5 & 0.9942 \\
Equal & 0.0073 & 686.0 & 0.9942
\end{tabular}

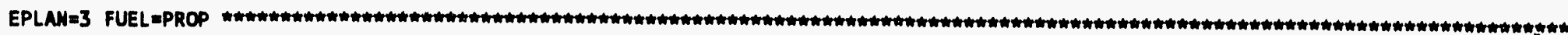
Variable: MAC

\begin{tabular}{lllllll} 
PREPOST & $N$ & \multicolumn{1}{c}{ Mean } & ..Std Dev & Std Error & Minimm & Maximm \\
\hline POS & 5 & 6562.1860000 & 5602.0913581 & 2505.3314186 & 3148.6600000 & 16468.160000 \\
PRE & 5 & 6165.2380000 & 5655.7607294 & 2529.3330911 & 827.0300000 & 15698.260000
\end{tabular}

$\begin{array}{lllllll}\text { PRE } & 5 & 6165.2380000 & 5655.7607294 & 2529.3330911 & 827.0300000 & 15698.260000\end{array}$

For HO: Variances are equal, FI $=1.02 \quad$ DF $=(4,4) \quad$ Prob>FI $=0.9857$

\begin{tabular}{llll} 
Variances & $T$ & DF & Probs|T! \\
\hline Unequal & 0.1115 & 8.0 & 0.9140 \\
Equal & 0.1115 & 8.0 & 0.9140
\end{tabular}




\section{Normalized Annual Consumption of 1990 Participants (by primary space heating fuel and plan)}

EPLAN=4 FUELEGS Variable: MAC

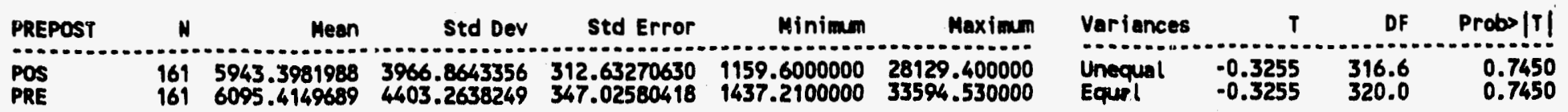

For KO: Variances are equal, $F 1=1.23 \quad$ DF $=(160,160) \quad$ ProbsF' $=0.1879$

EPLANEL FUELOOIL Voriable: MAC

\begin{tabular}{|c|c|c|c|c|c|c|c|c|c|c|}
\hline REP & N & Mean & Std Dev & Std Error & Minimm & Maximum & Variances & $T$ & DF & Prol \\
\hline 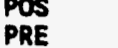 & $\begin{array}{l}123 \\
124\end{array}$ & 8486.9545968 & $\begin{array}{l}5124.4761018 \\
5243.4993460\end{array}$ & $\begin{array}{l}462.05844 \pi 46 \\
470.87295765\end{array}$ & $\begin{array}{r}567.9700000 \\
1147.5500000\end{array}$ & 35479.410000 & Equa! & -0.3147 & 245.0 & \\
\hline
\end{tabular}

For HO: Variances are equal, FI $=1.05 \quad$ DF $=(123,122) \quad$ ProbsFI $=0.8001$

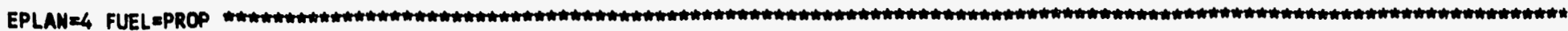
Variable: MAC

\begin{tabular}{l|cccccc} 
PREPOST & $N$ & \multicolumn{1}{c}{ Mean } & Std Dev & Std Error & Minimm & Maximm \\
\hline POS & 5 & 6297.8600000 & 3557.1477595 & 1590.8048392 & 2569.0800000 & 10884.000000 \\
PRE & 5 & 6322.5720000 & 2962.2822023 & 1324.7728746 & 2914.5900000 & 9827.190000
\end{tabular}

\begin{tabular}{lllr} 
Variances & $T$ & DF & Frobs|T! \\
\hline Jnequal & -0.0119 & 7.7 & 0.9908 \\
Equal & -0.0190 & 8.0 & 0.9908
\end{tabular}

For HO: Variances ore equal, F' 2 1.44 $\quad$ DF $=(4,4) \quad$ ProbsFl $=0.7315$ 


\section{Normalized Annual Consumption of 1990 Participants (by primary space heating fuel and plan)}

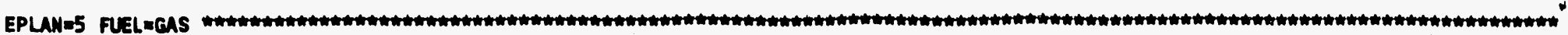
Variable: Mac

\begin{tabular}{llllllll} 
PREPOST & $N$ & & Meen & Std Dev & Std Error & Minimm & Maximm \\
\hline POS & 81 & 4642.9974074 & 2632.3366233 & 292.48184703 & 1374.2600000 & 14049.160000 \\
PRE & 82 & 4646.9898780 & 2531.9849614 & 279.61096328 & 1205.3500000 & 12522.030000
\end{tabular}

For HO: Variences are equal, FI $=1.08$ DF $=(80,81) \quad$ Probsfl $=0.7278$

\begin{tabular}{llll} 
Veriences & $T$ & OF & Probs |T! \\
\hdashline Unequal & -0.0099 & 160.6 & 0.9921 \\
Equal & -0.0099 & 161.0 & 0.9921
\end{tabular}

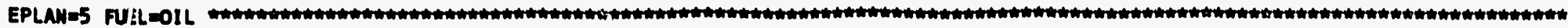
Variable: MAC

\begin{tabular}{lllllll} 
PREPOST & $N$ & \multicolumn{1}{c}{ Meen } & Std Dev & Std Error & Minimm & Maximum \\
\hline POS & 175 & 5454.7584571 & 38.55 .6831515 & 293.73003693 & 187.7000000 & 24240.730000 \\
PRE & 176 & 5642.2970455 & 4342.9654650 & 327.36333920 & 1055.0500000 & 40544.000000
\end{tabular}

\begin{tabular}{llll} 
Variances & $T$ & DF & Probs/T! \\
\hline Unequal & -0.4264 & 345.2 & 0.6701 \\
Equal & -0.4263 & 349.0 & 0.6702
\end{tabular}

For HO: Variences are equal, F' $=1.25$ DF $=(175,174) \quad$ Probsfl $=0.1427$

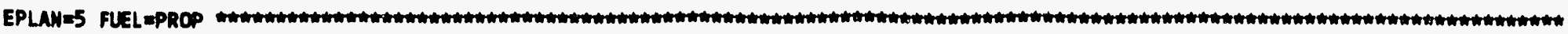
Variable:

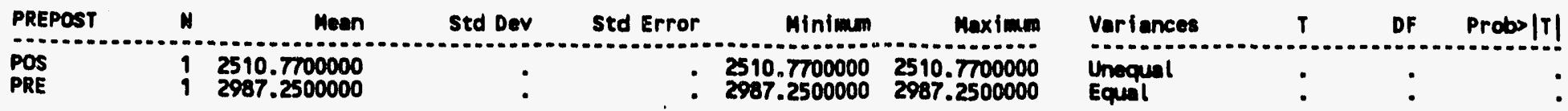

MOTE: All values ore the same for one CLASS level. 


\section{Normalized Annual Consumption of 1990 Participants}

(by consumption level)

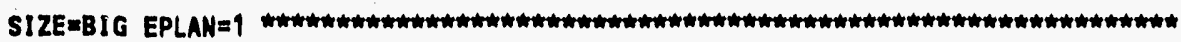
Variable: $M A C$

\begin{tabular}{llllr} 
PREPOST & $N$ & Mean & Std Dev & Std Error \\
\hline POS & 66 & 14064.65575758 & 5987.55069015 & 737.01654177 \\
PRE & 62 & 14889.35967742 & 6019.00106382 & 764.41389952
\end{tabular}

\begin{tabular}{llll} 
Variances & $T$ & DF & Probs|T| \\
\hline Unequal & -0.7767 & 125.4 & 0.4388
\end{tabular}

Equal $\quad-0.7768 \quad 126.0 \quad 0.4387$

For HO: Variances are equal, $F^{\prime}=1.01 \quad$ DF $=(61,65) \quad$ ProbsF' $=0.9648$

SIZE=BIG EPLAN=2 Variable: NAC

\begin{tabular}{llllr} 
PREPOST & N & \multicolumn{1}{c}{ Mean } & Std Dev & Std Error \\
\hline POS & 32 & 12611.06562500 & 3875.26144085 & 685.05591092 \\
PRE & 30 & 13112.63533333 & 5422.42771027 & 989.99532445
\end{tabular}

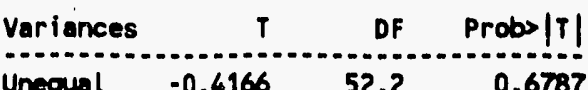

$\begin{array}{llll}\text { Unequal } & -0.4166 & 52.2 & 0.6787 \\ \text { Equal } & -0.4211 & 60.0 & 0.6752\end{array}$

For HO: Variances are equal, F' $=1.96 \quad$ DF $=(29,31) \quad$ ProbsF' $=0.0691$

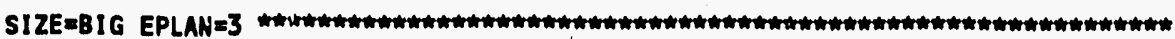
Variable: NAC

\begin{tabular}{|c|c|c|c|c|c|}
\hline PREPOST & N & & Mean & std Dev & Std Error \\
\hline $\begin{array}{l}\text { POS } \\
\text { PRE }\end{array}$ & $\begin{array}{l}129 \\
131\end{array}$ & $\begin{array}{l}21024 \\
24871\end{array}$ & $\begin{array}{l}232558 \\
000000\end{array}$ & $\begin{array}{l}66812.98814572 \\
74266.16585037\end{array}$ & $\begin{array}{l}5882.55559672 \\
6488.66503761\end{array}$ \\
\hline Variances & $T$ & DF & Probs $|T|$ & & \\
\hline $\begin{array}{l}\text { Unequal } \\
\text { Equal }\end{array}$ & $\begin{array}{l}-0.4393 \\
-0.4389\end{array}$ & $\begin{array}{l}255.9 \\
258.0\end{array}$ & $\begin{array}{l}0.6608 \\
0.6611\end{array}$ & & \\
\hline
\end{tabular}

SIZE Variable: NAC

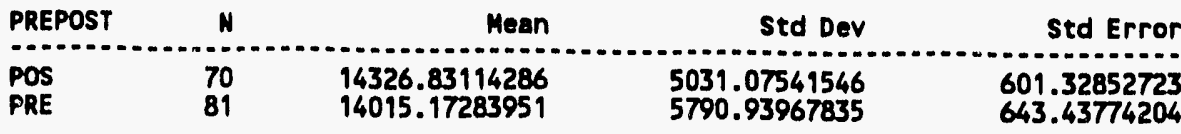

\begin{tabular}{lccr} 
Variances & $T$ & DF & Probs|T| \\
\hline Unequal & 0.3539 & 149.0 & 0.7239 \\
Equal & 0.3503 & 149.0 & 0.7266
\end{tabular}

For HO: Variances are equal, F' $=1.32$ DF $=(80,69) \quad$ ProbsF' $=0.2321$ 


\section{Normalized Annual Consumption of 1990 Participants (by consumption level)}

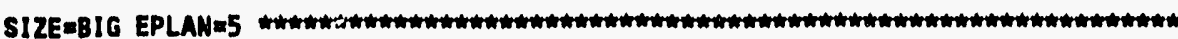
Voriable: MAC

\begin{tabular}{|c|c|c|c|c|c|}
\hline PREPOST & N & & Mean & Std Dev & Std Error \\
\hline $\begin{array}{l}\text { POS } \\
\text { PRE }\end{array}$ & $\begin{array}{l}32 \\
37\end{array}$ & $\begin{array}{l}12913 . \\
12714 .\end{array}$ & $\begin{array}{l}031250 \\
513514\end{array}$ & $\begin{array}{l}3696.34638165 \\
5511.55356490\end{array}$ & $\begin{array}{l}653.42789802 \\
906.09382455\end{array}$ \\
\hline Variances & $T$ & DF & Probs $|T|$ & & \\
\hline $\begin{array}{l}\text { Unequal } \\
\text { Equal }\end{array}$ & $\begin{array}{l}0.1778 \\
0.1729\end{array}$ & $\begin{array}{l}63.3 \\
67.0\end{array}$ & $\begin{array}{l}0.8595 \\
0.8633\end{array}$ & & \\
\hline
\end{tabular}

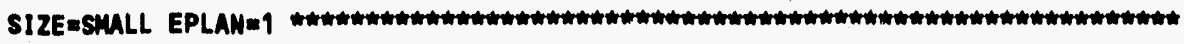
Voriable: NAC

\begin{tabular}{|c|c|c|c|c|c|}
\hline PREPOST & N & & Mean & Std Dev & Std Error \\
\hline $\begin{array}{l}\text { POS } \\
\text { PRE }\end{array}$ & $\begin{array}{l}268 \\
276\end{array}$ & $\begin{array}{l}4204 . \\
4394 .\end{array}$ & $\begin{array}{l}311940 \\
148551\end{array}$ & $\begin{array}{l}1987.74585455 \\
2065.71940676\end{array}$ & $\begin{array}{l}121.42090329 \\
124.34169651\end{array}$ \\
\hline Variances & $T$ & DF & Probs|T| & & \\
\hline $\begin{array}{l}\text { Unequal } \\
\text { Equal }\end{array}$ & $\begin{array}{l}-1.0942 \\
-1.0936\end{array}$ & $\begin{array}{l}542.0 \\
542.0\end{array}$ & $\begin{array}{l}0.2744 \\
0.2746\end{array}$ & & \\
\hline
\end{tabular}

SIZE=SMALL EPLANE2 Variable: MAC

\begin{tabular}{|c|c|c|c|c|c|}
\hline PREPOST & $N$ & & Mean & Std Dev & std Error \\
\hline $\begin{array}{l}\text { POS } \\
\text { PRE }\end{array}$ & $\begin{array}{l}135 \\
137\end{array}$ & $\begin{array}{l}4486 \\
4567\end{array}$ & $\begin{array}{l}311111 \\
715328\end{array}$ & $\begin{array}{l}1924.58578689 \\
1962.72536650\end{array}$ & $\begin{array}{l}165.64197113 \\
167.68694469\end{array}$ \\
\hline Variances & $T$ & DF & Probs $|T|$ & & \\
\hline $\begin{array}{l}\text { Unequal } \\
\text { Equal }\end{array}$ & $\begin{array}{l}-0.3446 \\
-0.3446\end{array}$ & $\begin{array}{l}270.0 \\
270.0\end{array}$ & $\begin{array}{l}0.7307 \\
0.7307\end{array}$ & & . \\
\hline
\end{tabular}

SIZE =SEALL EPLAN=3 How Voriable: NAC

\begin{tabular}{|c|c|c|c|c|c|}
\hline PREPOST & $N$ & & Mean & Std Dev & std Error \\
\hline $\begin{array}{l}\text { POS } \\
\text { PRE }\end{array}$ & $\begin{array}{l}712 \\
705\end{array}$ & $\begin{array}{l}4913 . \\
4899 .\end{array}$ & $\begin{array}{l}0946629 \\
2659574\end{array}$ & $\begin{array}{l}1822.96358387 \\
1871.73608381\end{array}$ & $\begin{array}{l}68.31844870 \\
70.49365916\end{array}$ \\
\hline Variances & $\begin{array}{l}T \\
-.\end{array}$ & DF & Probs|T| & & \\
\hline $\begin{array}{l}\text { Unequal } \\
\text { Equal }\end{array}$ & $\begin{array}{l}0.1404 \\
0.1404\end{array}$ & $\begin{array}{l}1413.1 \\
1415.0\end{array}$ & $\begin{array}{l}0.8884 \\
0.8883\end{array}$ & & \\
\hline
\end{tabular}




\section{Normalized Annual Consumption of 1990 Participants (by consumption level)}

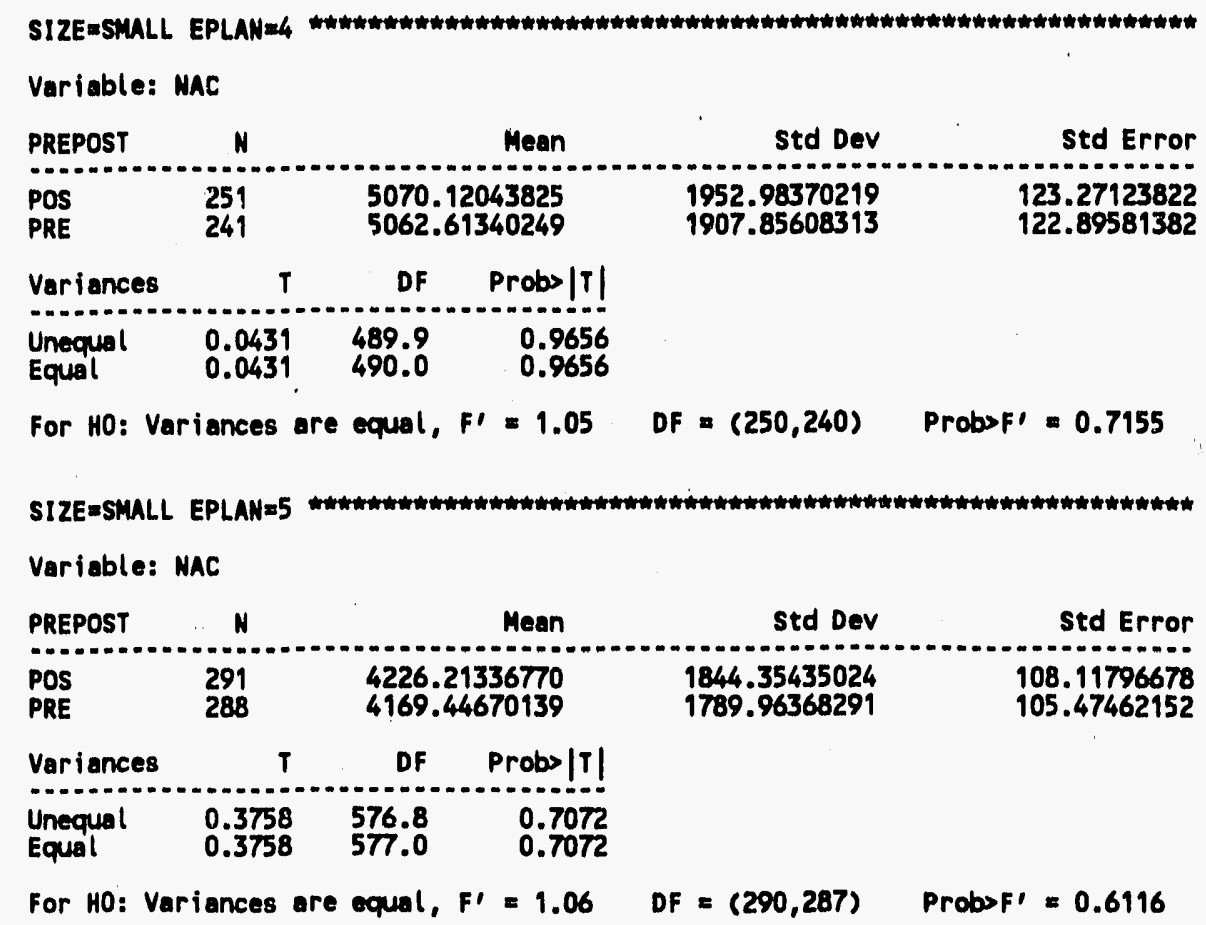




\section{Normalized Annual Consumption of 1990 Participants (by consumption level)}

SIZE=BIG URBRUR=RURAL

Variable: MAC

\begin{tabular}{|c|c|c|c|c|c|}
\hline PREPOST & N & & Mean & Std Dev & Std Error \\
\hline $\begin{array}{l}\text { POS } \\
\text { PRE }\end{array}$ & $\begin{array}{l}127 \\
133\end{array}$ & $\begin{array}{l}20932 \\
20828\end{array}$ & $\begin{array}{l}322835 \\
789474\end{array}$ & $\begin{array}{l}67358.45442894 \\
63489.03579992\end{array}$ & $\begin{array}{l}5977.09630017 \\
5505.19758976\end{array}$ \\
\hline Variance & $T$ & DF & Probs $|T|$ & & \\
\hline $\begin{array}{l}\text { Unequal } \\
\text { Equal }\end{array}$ & $\begin{array}{l}0.0128 \\
0.0128\end{array}$ & $\begin{array}{l}255.2 \\
258.0\end{array}$ & $\begin{array}{l}0.9898 \\
0.9898\end{array}$ & & \\
\hline
\end{tabular}

For HO: Variances are equal, F' $=1.13 \quad$ DF $=(126,132) \quad$ Probof' $=0.5016$

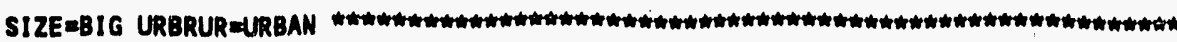
Variable: MAC

\begin{tabular}{|c|c|c|c|c|c|}
\hline PREPOST & N & & Meen & std Dev & Std Error \\
\hline $\begin{array}{l}\text { POS } \\
\text { PRE }\end{array}$ & $\begin{array}{l}202 \\
208\end{array}$ & $\begin{array}{l}13869 \\
16394\end{array}$ & $\begin{array}{l}044554 \\
711538\end{array}$ & $\begin{array}{r}5005.74617153 \\
31003.31162024\end{array}$ & $\begin{array}{r}352.20307158 \\
2155.23988188\end{array}$ \\
\hline Variance & $T$ & DF & Probs $|T|$ & & \\
\hline $\begin{array}{l}\text { Unequal } \\
\text { Equal }\end{array}$ & $\begin{array}{l}-1.1566 \\
-1.1406\end{array}$ & $\begin{array}{l}218.0 \\
408.0\end{array}$ & $\begin{array}{l}0.2487 \\
0.2547\end{array}$ & & \\
\hline
\end{tabular}

For HO: Variances are equal, F' $=38.56 \quad$ DF $=(207,201) \quad$ ProbsF' $=0.0000$

SIZE=SMALL URBRUR=RURAL Variable: MAC

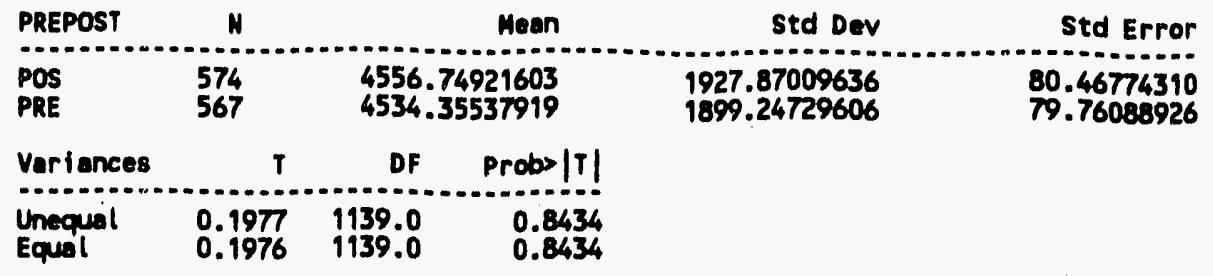

For HO: Variances are equal, $F^{\prime}=1.03 \quad$ DF $=(573,566) \quad$ ProbsF' $=0.7214$

SIZE=SHALL URBRUR=URBAN Variable: MAC

\begin{tabular}{|c|c|c|c|c|c|}
\hline PREPOST & N & & Mean & Std Dev & Std Error \\
\hline $\begin{array}{l}\text { POS } \\
\text { PRE }\end{array}$ & $\begin{array}{l}1083 \\
1080\end{array}$ & $\begin{array}{l}4725 \\
4761\end{array}$ & $\begin{array}{l}5705448 \\
5523148\end{array}$ & $\begin{array}{l}1902.43674622 \\
1940.86534409\end{array}$ & $\begin{array}{l}57.80907198 \\
59.05865167\end{array}$ \\
\hline Variances & $T$ & DF & Probs $|T|$ & & \\
\hline $\begin{array}{l}\text { Unequal } \\
\text { Equal }\end{array}$ & $\begin{array}{l}-0.4408 \\
-0.4408\end{array}$ & $\begin{array}{l}2159.9 \\
2161.0\end{array}$ & $\begin{array}{l}0.6594 \\
0.6594\end{array}$ & & \\
\hline
\end{tabular}




\section{Normalized Annual Consumption of 1990 Participants (by consumption level)}

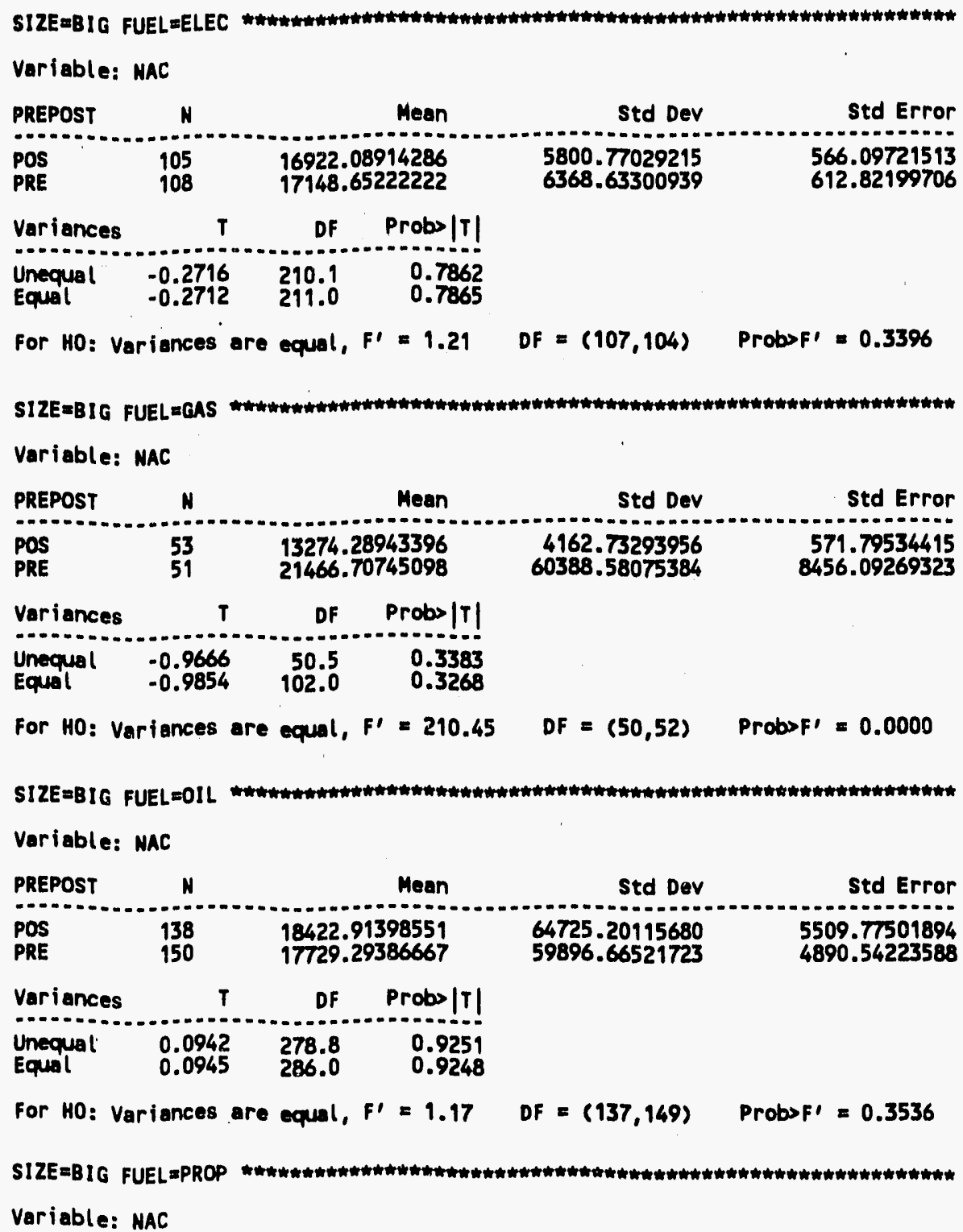

\begin{tabular}{|l|ccccr} 
PREPOST & $N$ & & Mean & Std Dev & Std Error \\
\hline POS & 4 & 12562.00000000 & 3278.82505854 & 1639.41252927 \\
PRE & 3 & 13079.88000000 & 2986.49085354 & 1724.25129823
\end{tabular}

\begin{tabular}{llll} 
Variances & $T$ & DF & Probs |T \\
\hline Unequal & -0.2177 & 4.7 & 0.8369 \\
Equal & -0.2142 & 5.0 & 0.8388
\end{tabular}

For HO: Variances are equal, $F^{\prime}=1.21 . \quad D F=(3,2) \quad$ Probs. $F^{\prime}=0.9667$ 


\section{Normalized Annual Consumption of 1990 Participants (by consumption level)}

SIZE=SMALL FUELEELEC Voriable: MAC

\begin{tabular}{|c|c|c|c|c|c|}
\hline PREPOST & N & & Mean & std Dev & Std Error \\
\hline $\begin{array}{l}\text { POS } \\
\text { PRE }\end{array}$ & $\begin{array}{l}87 \\
85\end{array}$ & $\begin{array}{l}6249 \\
6400\end{array}$ & $\begin{array}{l}367816 \\
905882\end{array}$ & $\begin{array}{l}1612.34574005 \\
1782.63209536\end{array}$ & $\begin{array}{l}172.86160784 \\
193.35359828\end{array}$ \\
\hline Variances & $T$ & DF & Probs $|T|$ & & \\
\hline $\begin{array}{l}\text { Unequal } \\
\text { Equal }\end{array}$ & $\begin{array}{l}-0.5859 \\
-0.5865\end{array}$ & $\begin{array}{l}167.5 \\
170.0\end{array}$ & $\begin{array}{l}0.5588 \\
0.5583\end{array}$ & & \\
\hline
\end{tabular}

For HO: Variances are equal, $F^{\prime}=1.22 \quad$ DF $=(84,86) \quad$ Probsf' $=0.3558$

SIZE=SWMLL. FUEL=CAS Variable: MAC

\begin{tabular}{l|ccccc} 
PREPOST & $N$ & & Mean & Std Dev & Std Error \\
\hline POS & 453 & 4257.23796909 & 1811.14889015 & 85.09519799 \\
PRE & 453 & 4211.00494481 & 1800.79458293 & 84.60871019
\end{tabular}

\begin{tabular}{llll} 
Variances & $T$ & DF & Probs $|T|$ \\
\hline Unequal & 0.3853 & 904.0 & 0.7009
\end{tabular}

$\begin{array}{llll}\text { Unequal } & 0.3853 & 904.0 & 0.7001 \\ \text { Equal } & 0.3853 & 904.0 & 0.7001\end{array}$

For HO: Variances are equal, $F^{\prime}=1.01 \quad$ DF $=(452,452) \quad$ Probsf' $=0.9030$

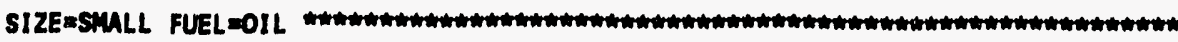
Variable: MAC

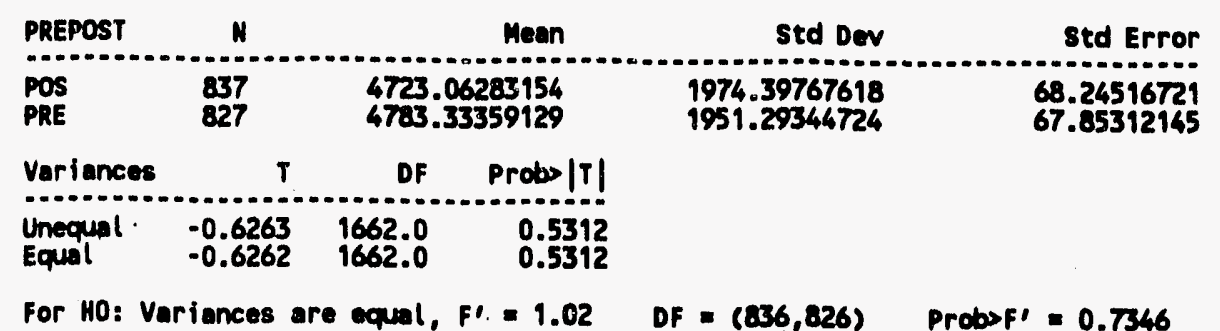

SIZE=SHALL FUELPROP Variable: MAC

\begin{tabular}{l|lllll} 
PREPOST & $N$ & & Mean & Std Dev & Std Error \\
\hline POS & 10 & 4355.23000000 & 1929.07251487 & 610.02629186 \\
PRE & 11 & 4692.38636364 & 2295.81714876 & 692.21491543
\end{tabular}

\begin{tabular}{llll} 
Voriances & $T$ & DF & Probs $|T|$ \\
\hline Unequal & -0.3654 & 18.9 & 0.7189
\end{tabular}

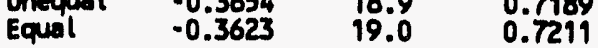

For HO: Variances are equal, F' $=1.42 \quad$ DF $=(10,9) \quad$ ProbsF' $=0.6119$ 


\section{Normalized Annual Consumption of 1990 Participants (by consumption level)}

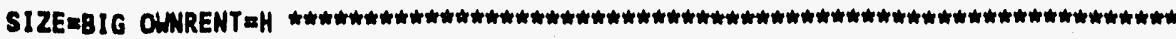
Variable: MAC

\begin{tabular}{|c|c|c|c|c|}
\hline & $N$ & Mean & Std Dev & std Error \\
\hline $\begin{array}{l}\text { POS } \\
\text { PRE }\end{array}$ & $\begin{array}{l}187 \\
186\end{array}$ & $\begin{array}{l}14461.12844920 \\
14861.33376344\end{array}$ & $\begin{array}{l}5212.10353011 \\
6114.99033528\end{array}$ & \\
\hline
\end{tabular}

Variances $T$ T DF Probs $\mid \mathrm{T}$ |

Unequal $\quad-0.6801 \quad 361.3 \quad 0.4969$

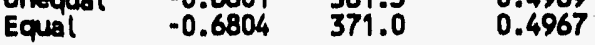

For HO: Variances 'are equal, $F^{\prime}=1.38 \quad$ DF $=(185,186) \quad$ Prob>F' $=0.0301$

SIZE=BIG OWNRETT=T Variable: HAC

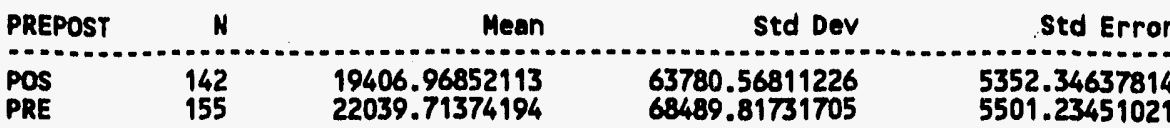

\begin{tabular}{llll} 
Variances & $T$ & DF & Probs $|T|$ \\
\hline Unequal & -0.3430 & 294.9 & 0.7318
\end{tabular}

Equal $\quad-0.3419 \quad 295.0 \quad 0.7326$

For HO: Variances are equal, $F^{\prime}=1.15 \quad$ DF $=(154,141) \quad$ ProbsF' $=0.3902$

SIZE=SMALL OWRENT=H Variable: NAC

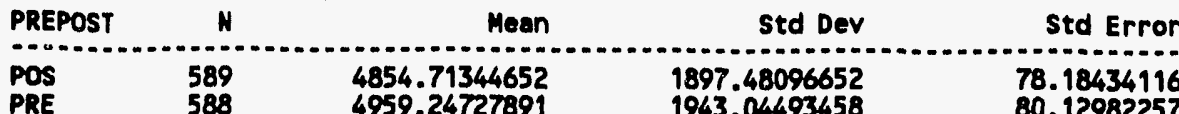

Variances $\quad T \quad$ OF Probs |T!

Unequal. $\quad-0.9337 \quad 1174.2 \quad 0.3506$

Equal $\quad-0.9337 \quad 1175.0 \quad 0.3506$

For HO: Variances ore equal, $F^{\prime}=1.05 \quad D_{F}=(587,588) \quad$ Probs $F^{\prime}=0.5654$

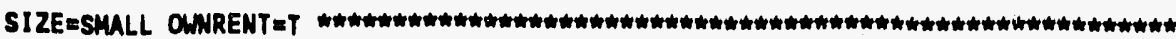
Variable: NAC

\begin{tabular}{|c|c|c|c|c|}
\hline & $N$ & Mean & Std Dev & Std \\
\hline $\mathbf{E}$ & $\begin{array}{l}1068 \\
1059\end{array}$ & $\begin{array}{l}4563.30716292 \\
4530.28607177\end{array}$ & $\begin{array}{l}1913.56474736 \\
1905.03828962\end{array}$ & \\
\hline
\end{tabular}

\begin{tabular}{llll} 
Variances & $T$ & DF & Probs $|T|$ \\
\hline Unequal & 0.3988 & 2125.0 & 0.6901 \\
Equal & 0.3988 & 2125.0 & 0.6901
\end{tabular}

For HO: Variances are equal, $F^{\prime}=1.01 \quad$ DF $=(1067,1058) \quad$ Prob>F' $=0.8844$ 


\section{Normalized Annual Consumption of 1990 Participants (by consumption level)}

SIZE=BIG EPLAH=1 FUELEELEC Variable: MAC

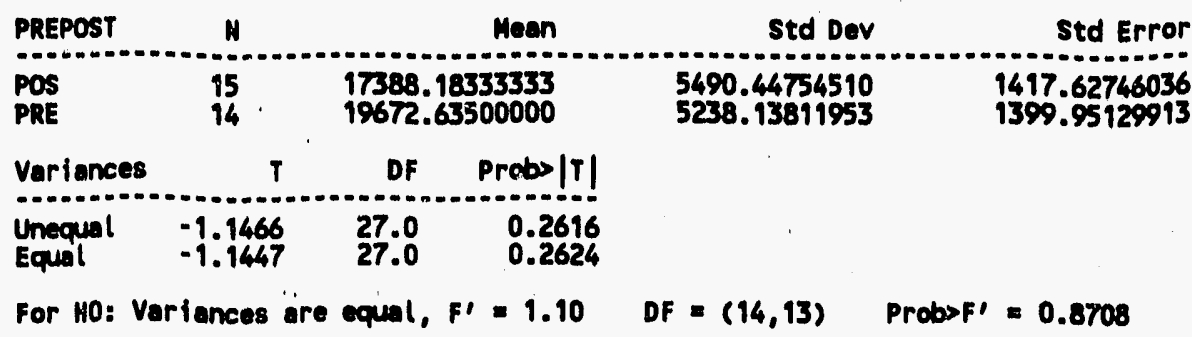

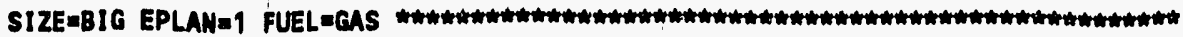
Variable: NAC

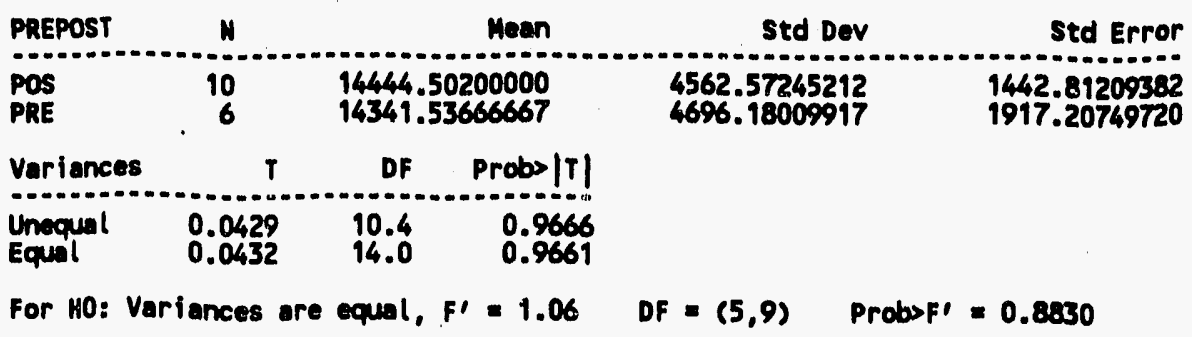

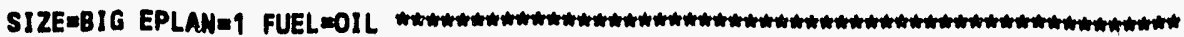
Variable: MAC

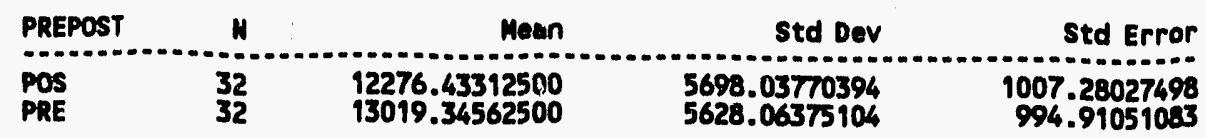

\begin{tabular}{llll} 
Variances & $T$ & DF & Probs|T| \\
\hline Unequal & -0.5247 & 62.0 & 0.6016 \\
Equal & -0.5247 & 62.0 & 0.6016
\end{tabular}

For HO: Variances are equal, F' $=1.03 \quad$ DF $=(31,31) \quad$ ProbsF' $=0.9456$

SIZEXBIG EPLAN=1 FUELEPROP Variable: NAC

\begin{tabular}{lcccc} 
PREPOST & $N$ & Mean & Std Dev & Std Error \\
\hline POS & 2 & 11447.92000000 & 3419.93608934 & 2418.26000000 \\
PRE & 1 & 13714.19000000 & 0 &
\end{tabular}

\begin{tabular}{llll} 
Variances & $T$ & DF & Probs |T! \\
\hline $\begin{array}{l}\text { Unequal } \\
\text { Equal }\end{array}$ & -0.5411 & $1 . \dot{0}$ & $0.684 \dot{3}$
\end{tabular}

MOTE: All values ore the same for one CLASS level." 


\section{Normalized Annual Consumption of 1990 Participants (by consumption level)}

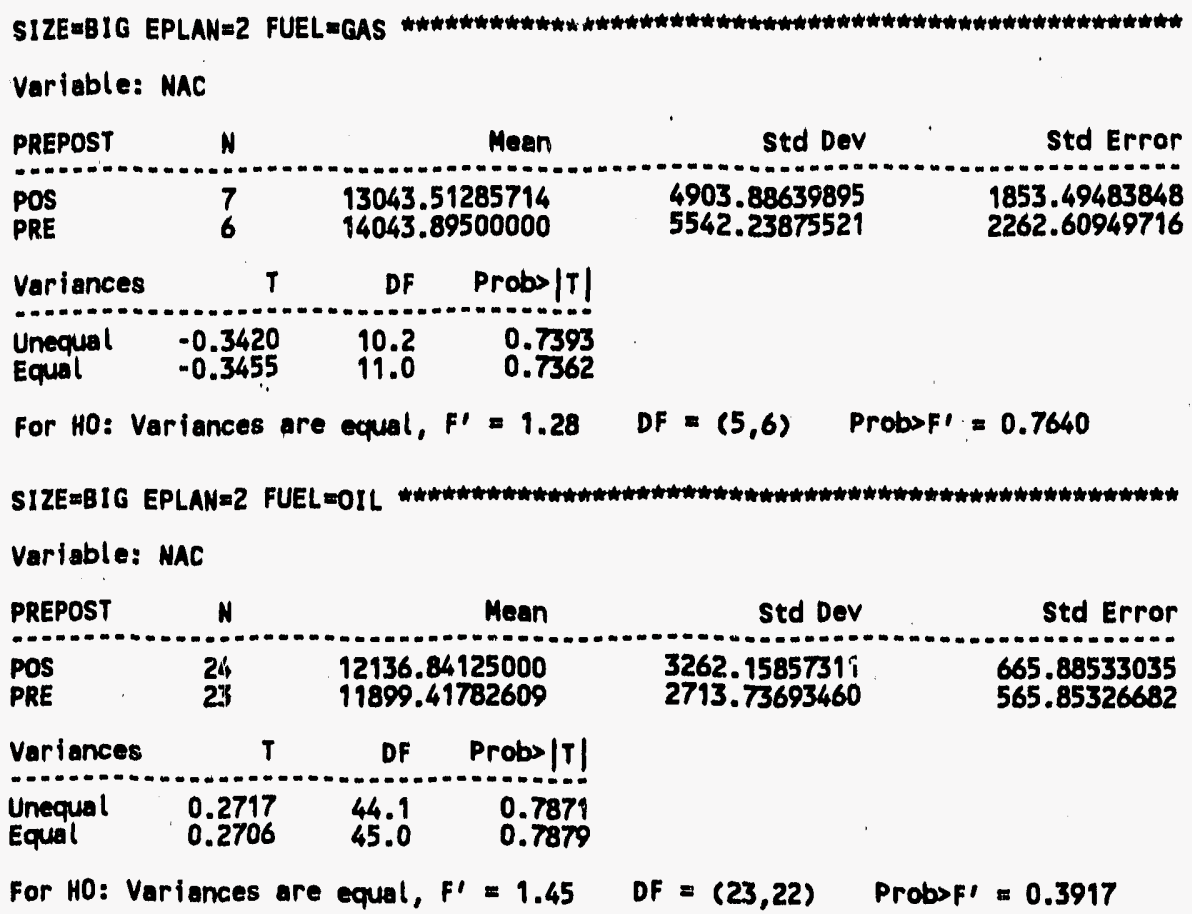




\section{Normalized Annual Consumption of 1990 Participants (by consumption level)}

SIZE=BIG EPLANE3 FUEL=ELEC Variable: MAC

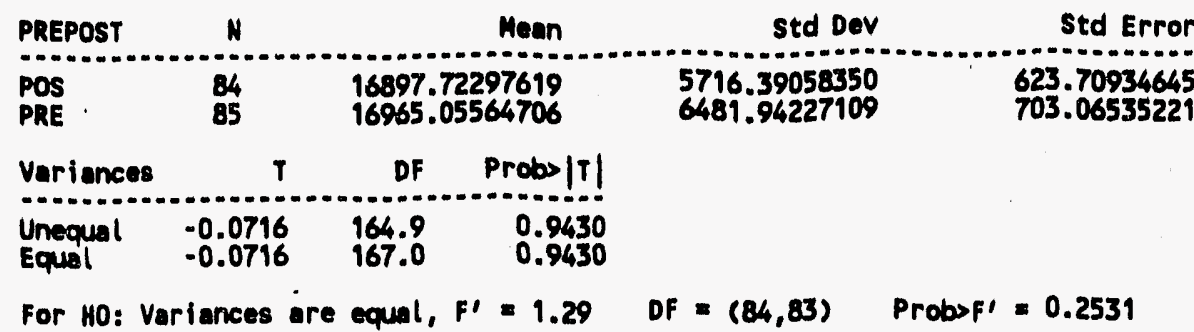

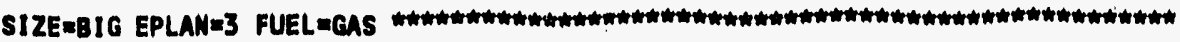
Variable: MAC

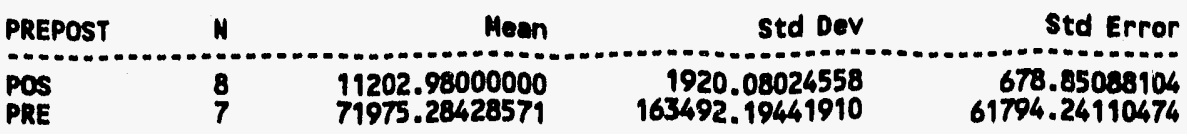

$\begin{array}{llrr}\text { Variances } & T & \text { OF } & \text { Probs|T| } \\ \text { Unequal } & -0.9834 & 6.0 & 0.3634 \\ \text { Equal } & -1.0571 & 13.0 & 0.3097\end{array}$

For HO: Variances are equal, F' $=7250.29 \quad$ DF $=(6,7) \quad$ Probsf' $=0.0000$

SIZEWBIG EPLAN=3 FUEL=OIL Voriable: MAC

\begin{tabular}{l|cccc} 
PREPOST & $N$ & Mean & Std Dev & Std Error \\
\hline POS & 23 & 44714.41869565 & 158442.29565950 & 33037.50244130 \\
PRE & 26 & 39778.44730169 & 143644.08329387 & 28170.92245106
\end{tabular}

\begin{tabular}{llll} 
Veriances & T & DF & Probs $\mid \mathrm{T}$ | \\
\hline Unequal. & 0.1937 & 44.8 & 0.9100
\end{tabular}

$\begin{array}{llll}\text { Unequal } & 0.1137 & 44.8 & 0.9100 \\ \text { Equal } & 0.1144 & 47.0 & 0.9094\end{array}$

For HO: Yariances are equal, $F^{\prime}=1.22 \quad$ DF $=(22,25) \quad$ ProbsF' $=0.6321$

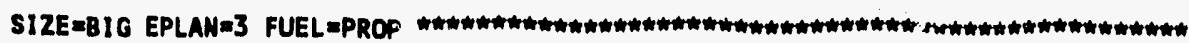
Variable: MAC

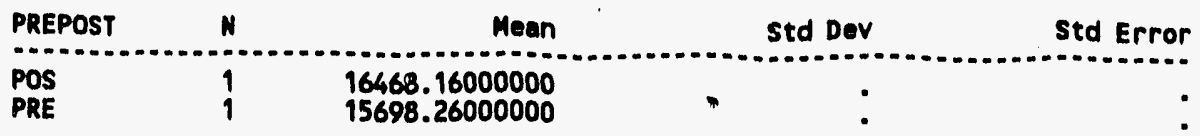

$\begin{array}{lll}\text { Variances } & T & \text { DF Probs }|\mathrm{T}| \\ \text { Unequal } & \text { Equal } & \end{array}$

NOTE: All values are the same for one CLASS level. 


\section{Normalized Annual Consumption of 1990 Participants (by consumption level)}

SIZE=BIG EPLAN=L FUELEELEC Variable: NAC

\begin{tabular}{|c|c|c|c|c|c|}
\hline \multirow{2}{*}{$\begin{array}{l}\text { PREPOST } \\
\text { POS } \\
\text { PRE }\end{array}$} & N & \multicolumn{2}{|r|}{ Mean } & Std Dev & std Error \\
\hline & $\begin{array}{l}6 \\
9\end{array}$ & $\begin{array}{l}16097 . \\
14956 .\end{array}$ & $\begin{array}{l}000000 \\
444444\end{array}$ & $\begin{array}{l}8460.19634199 \\
6310.27680742\end{array}$ & $\begin{array}{l}3453.86069361 \\
2103.42560247\end{array}$ \\
\hline Variances & $T$ & of & Probs $|T|$ & & \\
\hline $\begin{array}{l}\text { Unequal } \\
\text { Equal }\end{array}$ & $\begin{array}{l}0.2823 \\
0.3003\end{array}$ & $\begin{array}{r}8.7 \\
13.0\end{array}$ & $\begin{array}{l}0.7844 \\
0.7687\end{array}$ & & \\
\hline
\end{tabular}

SIZE=BIG EPLAN=4 FUEL=GAS Variable: NAC

\begin{tabular}{|c|c|c|c|c|c|}
\hline PREPOST & N & & Mean & Std Dev & Std Error \\
\hline $\begin{array}{l}\text { POS } \\
\text { PRE }\end{array}$ & $\begin{array}{l}22 \\
25\end{array}$ & $\begin{array}{l}14007 . \\
13764 .\end{array}$ & $\begin{array}{l}181818 \\
280000\end{array}$ & $\begin{array}{l}4624.998746881 \\
6254.83696013\end{array}$ & $\begin{array}{r}986.05304596 \\
1250.96739203\end{array}$ \\
\hline Variances & $T$ & DF & Probs $|T|$ & & \\
\hline $\begin{array}{l}\text { Unequal } \\
\text { Equal }\end{array}$ & $\begin{array}{l}0.1525 \\
0.1497\end{array}$ & $\begin{array}{l}43.8 \\
45.0\end{array}$ & $\begin{array}{l}0.8795 \\
0.8817\end{array}$ & & \\
\hline
\end{tabular}

SIZE=BIG EPLAN=L FUEL=OIL Variable: HAC

\begin{tabular}{|c|c|c|c|c|c|}
\hline PREPOST & N & & Mean & Std Dev & std Error \\
\hline $\begin{array}{l}\text { POS } \\
\text { PRE }\end{array}$ & $\begin{array}{l}36 \\
42\end{array}$ & $\begin{array}{l}14553 . \\
13884 .\end{array}$ & $\begin{array}{l}472222 \\
500000\end{array}$ & $\begin{array}{l}4863.61603518 \\
5465.65613401\end{array}$ & $\begin{array}{l}810.60267253 \\
843.36905122\end{array}$ \\
\hline Variances & $T$ & DF & Probs $|T|$ & & \\
\hline $\begin{array}{l}\text { Unequal } \\
\text { Equal }\end{array}$ & $\begin{array}{l}0.5714 \\
0.5662\end{array}$ & $\begin{array}{l}75.9 \\
76.0\end{array}$ & $\begin{array}{l}0.5694 \\
0.5729\end{array}$ & & \\
\hline
\end{tabular}

SIZE=8IG EPLAN=4 FUEL_PROP Variable: NAC

\begin{tabular}{|c|c|c|c|c|}
\hline PREPOST & $N$ & Mean & Std Dev & std Error \\
\hline $\begin{array}{l}\text { POS } \\
\text { PRE }\end{array}$ & 1 & $\begin{array}{r}10884.00000000 \\
9827.19000000\end{array}$ & $\dot{.}$ & - \\
\hline
\end{tabular}

\begin{tabular}{lll} 
Variances & $T$ & DF Probs $|T|$ \\
\hline Unequal & - &
\end{tabular}

Equal

NOTE: All values are the same for one CLASS level: 


\section{Normalized Annual Consumption of 1990 Participants}

(by consumption level)

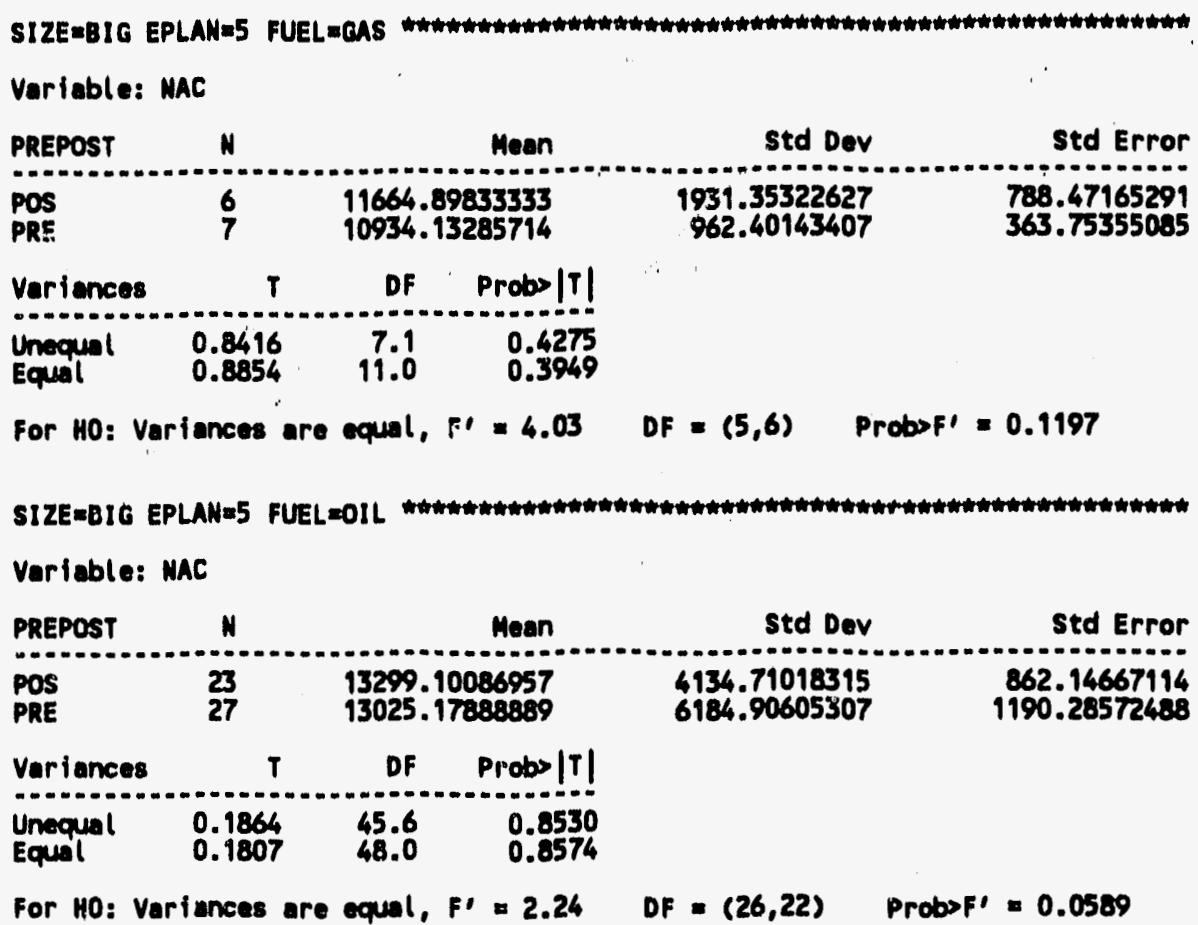




\section{Normalized Annual Censumption of 1990 Participants (by consumption level)}

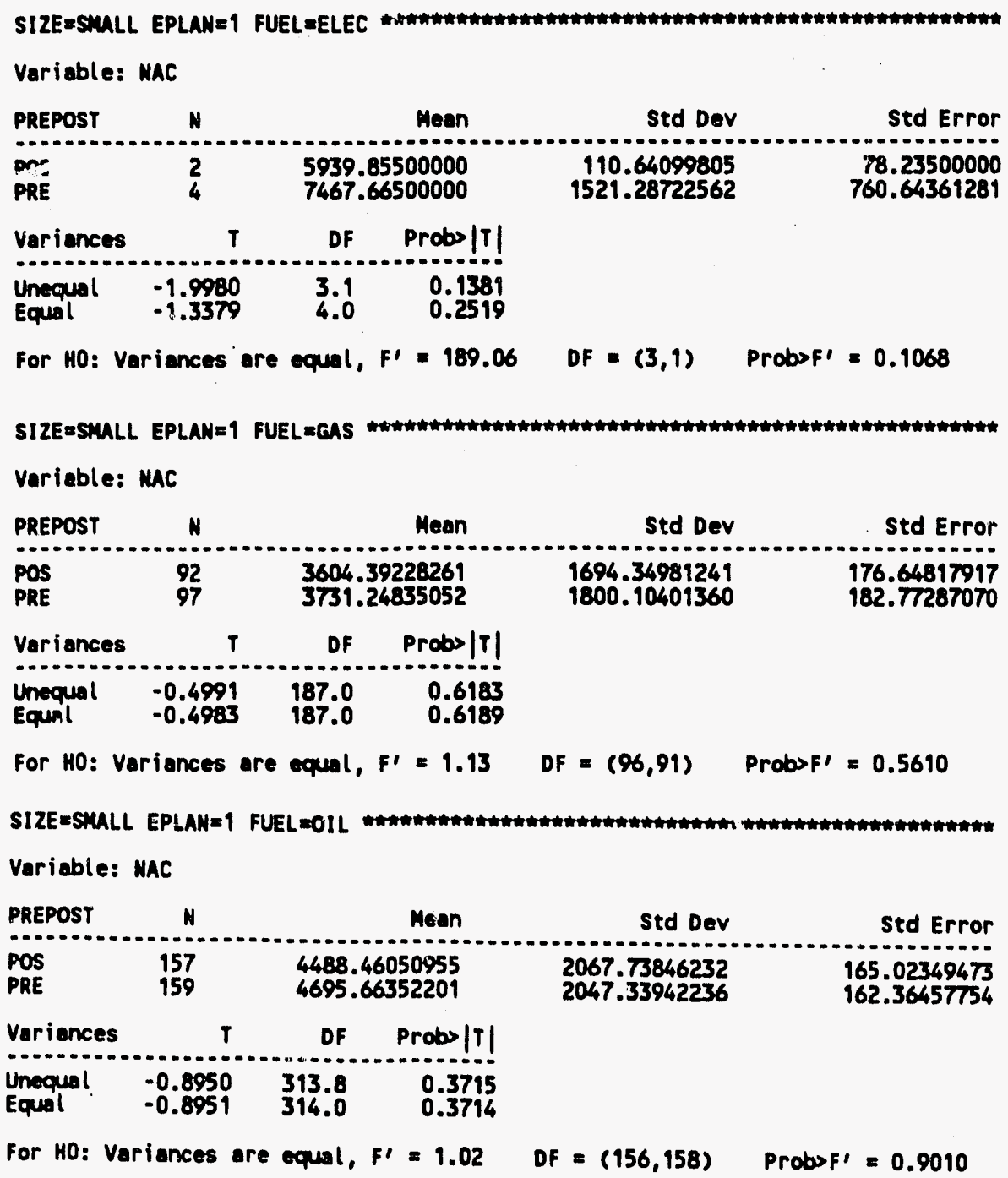


Normalized Annual Consumption of 1990 Participants (by consumption level)

SI2E-SYALL EPLAN=2 FUELEGAS Variable: MAC

\begin{tabular}{llllll} 
PREPOST & $N$ & & Mean & Std Dev & Std Error \\
\hline POS & 14 & 6014.64357163 & 2059.41407228 & 550.40156257 \\
PRE & 15 & 5480.01666667 & 1685.42865462 & 435.17580737
\end{tabular}

Variances

Unequal $0.7620 \quad 25.2 \quad 0.4532$

$\begin{array}{llll}\text { Unoqual } & 0.7620 & 25.2 & 0.4532 \\ \text { Equal } & 0.7674 & 27.0 & 0.44 \% 5\end{array}$

For HO: Veriences are equal, F' $=1.49 \quad$ DF $=(13,16) \quad$ Probsf' $=0.4663$

SIZE=SWALL EPLAME2 FUELOOIL Variable: MAC

\begin{tabular}{|c|c|c|c|c|c|}
\hline PREPOST & $N$ & & Mean & Std Dev & std Error \\
\hline $\begin{array}{l}\text { POS } \\
\text { PRE }\end{array}$ & $\begin{array}{l}119 \\
120\end{array}$ & $\begin{array}{l}4303 \\
4450\end{array}$ & $\begin{array}{l}277311 \\
716667\end{array}$ & $\begin{array}{l}1849.78416986 \\
1904.69521880\end{array}$ & $\begin{array}{l}169.56943683 \\
181.17705685\end{array}$ \\
\hline Variances & $T$ & DF & Probs $|T|$ & & \\
\hline $\begin{array}{l}\text { Unequal } \\
\text { Equal }\end{array}$ & $\begin{array}{l}-0.5949 \\
-0.5968\end{array}$ & $\begin{array}{l}236.1 \\
237.0\end{array}$ & $\begin{array}{l}0.5525 \\
0.5526\end{array}$ & & \\
\hline
\end{tabular}

SIZE=SWHLL EPLAN=2 FUELEPROP Variable: HAC

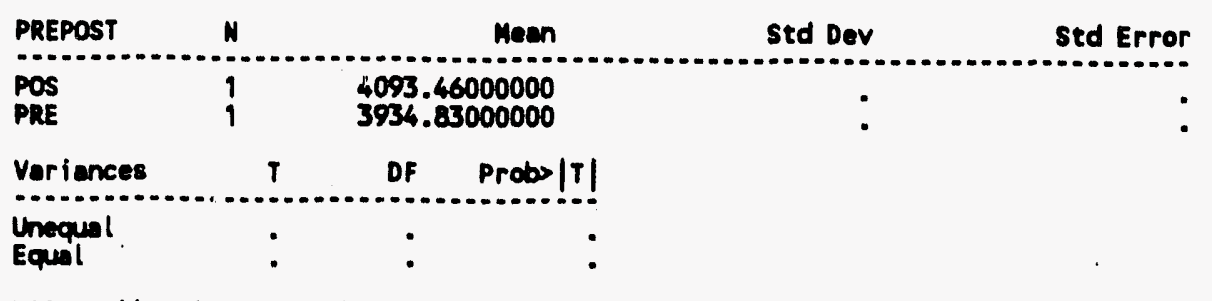

MOTE: All values are the same for one CLASS level. 


\section{Normalized Annual Consumption of 1990 Participants (by consumption level)}

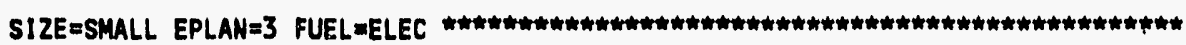
Variable: NAC

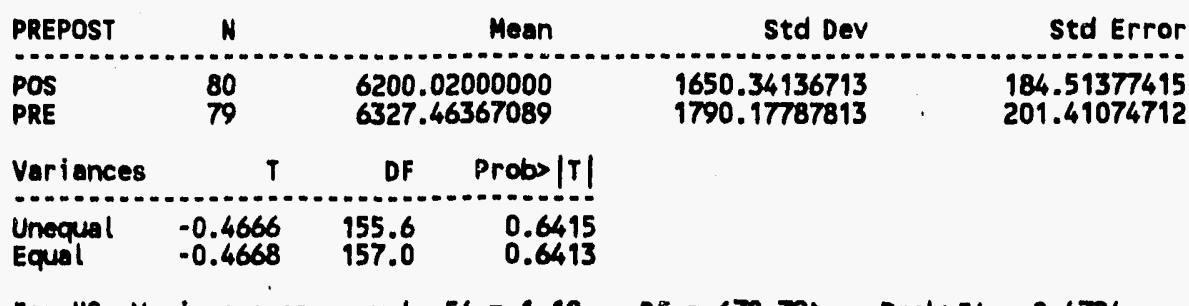

For HO: Variances are equal, $F^{\prime}=1.18 \quad$ DF $=(78,79) \quad$ ProbsF' $=0.4724$

SIZE Variable: MAC

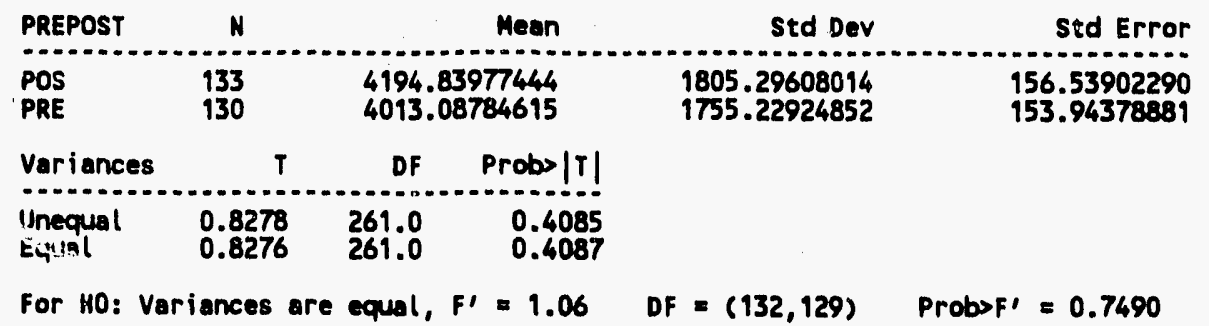

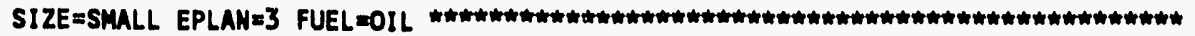
Variable: NAC

\begin{tabular}{|l|cccc} 
PREPOST & $N$ & Mean & Std Dev & Std Error \\
\hline POS & 322 & 4948.14692547 & 1797.00673141 & 100.14326993 \\
PRE & 317 & 4935.44242902 & 1789.33172801 & 100.49888228
\end{tabular}

\begin{tabular}{lccr} 
Variances & $T$ & DF & Probs|T| \\
\hline Unequal & 0.0895 & 636.9 & 0.9287 \\
Equal & 0.0895 & 637.0 & 0.9287
\end{tabular}

For HO: Variances are equal, $F^{\prime}=1.01 \quad$ DF $=(321,316) \quad$ ProbsF' $=0.9394$

SIZE $=S M A L L$ EPLAN=3 FUEL =PROP Varioble: WAC

\begin{tabular}{l|ccrr} 
PREPOST & N & \multicolumn{1}{c}{ Mean } & Std Dev & Std Error \\
\hline POS & 4 & 4085.69250000 & 978.65711154 & 489.32855577 \\
PRE & 4 & 3781.98250000 & 2187.26481757 & 1093.63240878
\end{tabular}

\begin{tabular}{llll} 
Variances & $T$ & DF & Probs|T! \\
\hline Unequal & 0.2535 & 4.2 & 0.8120 \\
Equal & 0.2535 & 6.0 & 0.8084
\end{tabular}

For HO: Variances are equal, $F^{\prime}=5.00 \quad$ DF $=(3,3) \quad$ Probsf' $=0.2194$ 


\section{Normalized Annual Consumption of 1990 Participants}

(by consumption level)

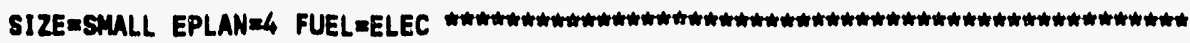
Variable: MAC

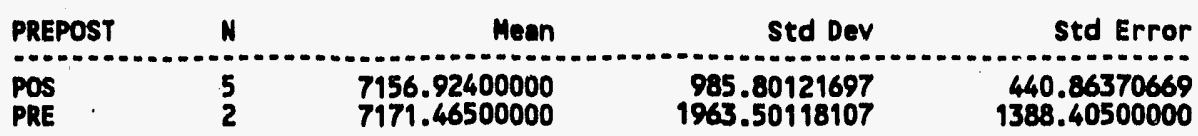

\begin{tabular}{llll} 
Variances & $T$ & DF & Probs $|T|$ \\
\hline Unequal & -0.0100 & 1.2 & 0.9935 \\
Equal & -0.0140 & 5.0 & 0.9894
\end{tabular}

For HO: Variances ore equal, $F^{\prime}=3.97 \quad$ DF $=(1,4) \quad$ Probsf' $=0.2344$

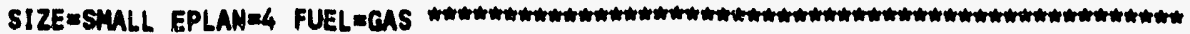
Variable: MAC

\begin{tabular}{lllll} 
PREPOST & $N$ & Mean & Std Dev & Std Error \\
\hline POS & 139 & 4666.99719424 & 1726.37879092 & 146.42953799 \\
PRE & 136 & 4685.57529412 & 1768.83300291 & 151.67617268
\end{tabular}

\begin{tabular}{llll} 
Variences & $T$ & DF & Probs|T| \\
\hline Unequal & -0.0881 & 272.4 & 0.9298 \\
Equal & -0.0881 & 273.0 & 0.9298
\end{tabular}

For HO: Variances are equal, F' $=1.05 \quad$ DF $=(135,138) \quad$ Probsf' $=0.7765$

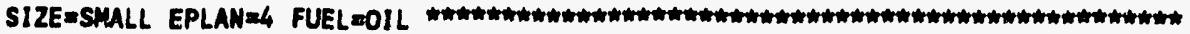
Voribble: MAC

\begin{tabular}{|c|c|c|c|c|}
\hline $\mathbf{T}$ & N & Mean & std Dev & std Error \\
\hline $\begin{array}{l}\text { PUS } \\
\text { PRE }\end{array}$ & $\begin{array}{l}87 \\
82\end{array}$ & $\begin{array}{l}5683.15609195 \\
5722.11487805\end{array}$ & $\begin{array}{l}2080.80302412 \\
1944.37030173\end{array}$ & $\begin{array}{l}223.08550047 \\
214.71977968\end{array}$ \\
\hline
\end{tabular}

\begin{tabular}{llll} 
Variances & $T$ & DF & Probs|T| \\
\hline Unequal & -0.1258 & 167,0 & 0.9000
\end{tabular}

Equal $\quad-0.1256 \quad 167.0 \quad 0.9002$

For HO: Variances are equal, F' $=1.15 \quad$ DF $=(86,81) \quad$ ProbsF' $=0.5387$

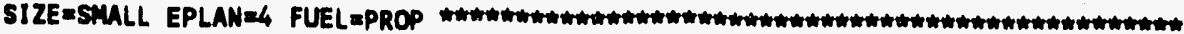
Variable: NAC

\begin{tabular}{l|cccr} 
PREPOST & N & Mean & Std Dev & Std Error \\
\hline POS & 4 & 5151.32500000 & 2847.35846044 & 1423.67923022 \\
PRE & 4 & 5446.41750000 & 2565.64022069 & 1282.82011035
\end{tabular}

\begin{tabular}{llll} 
Voriances & $T$ & DF & Probs |'t | \\
\hline Unequal & -0.1540 & 5.9 & 0.8827 \\
Equal & -0.1540 & 6.0 & 0.8827
\end{tabular}

For HO: Variances are equal, F' $=1.23$ DF $=(3,3) \quad$ Probs $F^{\prime}=0.8681$ 


\section{Normalized Annual Consumption of 1990 Participants (by consumption level)}

SIZE=SMALL EPLAN=5 FUEL=GAS Variable: NAC

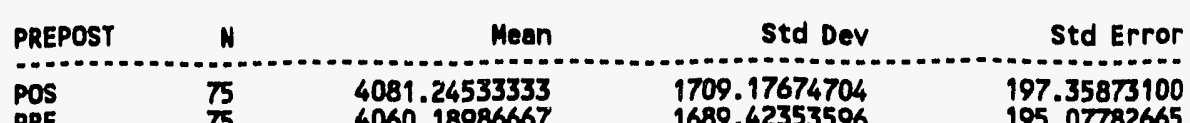

$\begin{array}{lllll}\text { PRE } & 75 & 4060.18986667 & 1689.42353596 & 195.07782665\end{array}$

\begin{tabular}{llll} 
Variances & $T$ & DF & Probs $|T|$ \\
\hline Unequal & 0.0759 & 148.0 & 0.9396 \\
Equal & 0.0759 & 148.0 & 0.9396
\end{tabular}

For HO: Variances are equal, F' $=1.02 \quad$ DF $=(74,74) \quad$ Probsf' $=0.9206$

SIZE=SMALL EPLAN=5 FUEL=OIL Variable: NAC

\begin{tabular}{|c|c|c|c|c|c|}
\hline PREPOST & N & & Mean & Std Dev & Std Error \\
\hline $\begin{array}{l}\text { POS } \\
\text { PRE }\end{array}$ & $\begin{array}{l}152 \\
149\end{array}$ & $\begin{array}{l}4267 \\
4304\end{array}$ & $\begin{array}{l}559211 \\
939597\end{array}$ & $\begin{array}{l}2028.94263075 \\
1958.67323049\end{array}$ & $\begin{array}{l}164.56897848 \\
160.46076323\end{array}$ \\
\hline Variances & T & DF & Probs $|T|$ & & \\
\hline $\begin{array}{l}\text { Unequal } \\
\text { Equal }\end{array}$ & $\begin{array}{l}-0.1596 \\
-0.1595\end{array}$ & $\begin{array}{l}298.9 \\
299.0\end{array}$ & $\begin{array}{l}0.8733 \\
0.8734\end{array}$ & & \\
\hline
\end{tabular}

SIZE=SMALL EPLAN=5 FUEL=PROP Variable: MAC

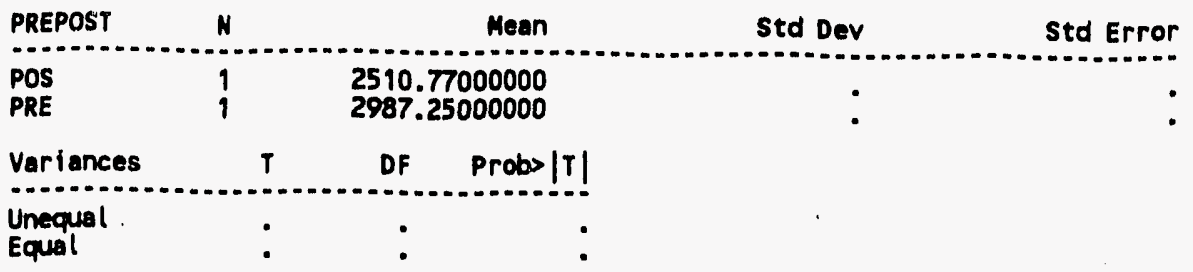

MOTE: All values are the same for one CLASS level. 
Normalized Annual Consumption of 1990 Participants

(by consumption level) 
Normalized Annual Consumption of 1990 Participants

(by consumption level) 
Normalized Annual Consumption of 1990 Participants

(by consumption level) 


\section{Normalized Annual Consumption of 1990 Participants}

(by consumption level) 


\section{Normalized Annual Consumption of 1990 Participants (by R-squared level)}

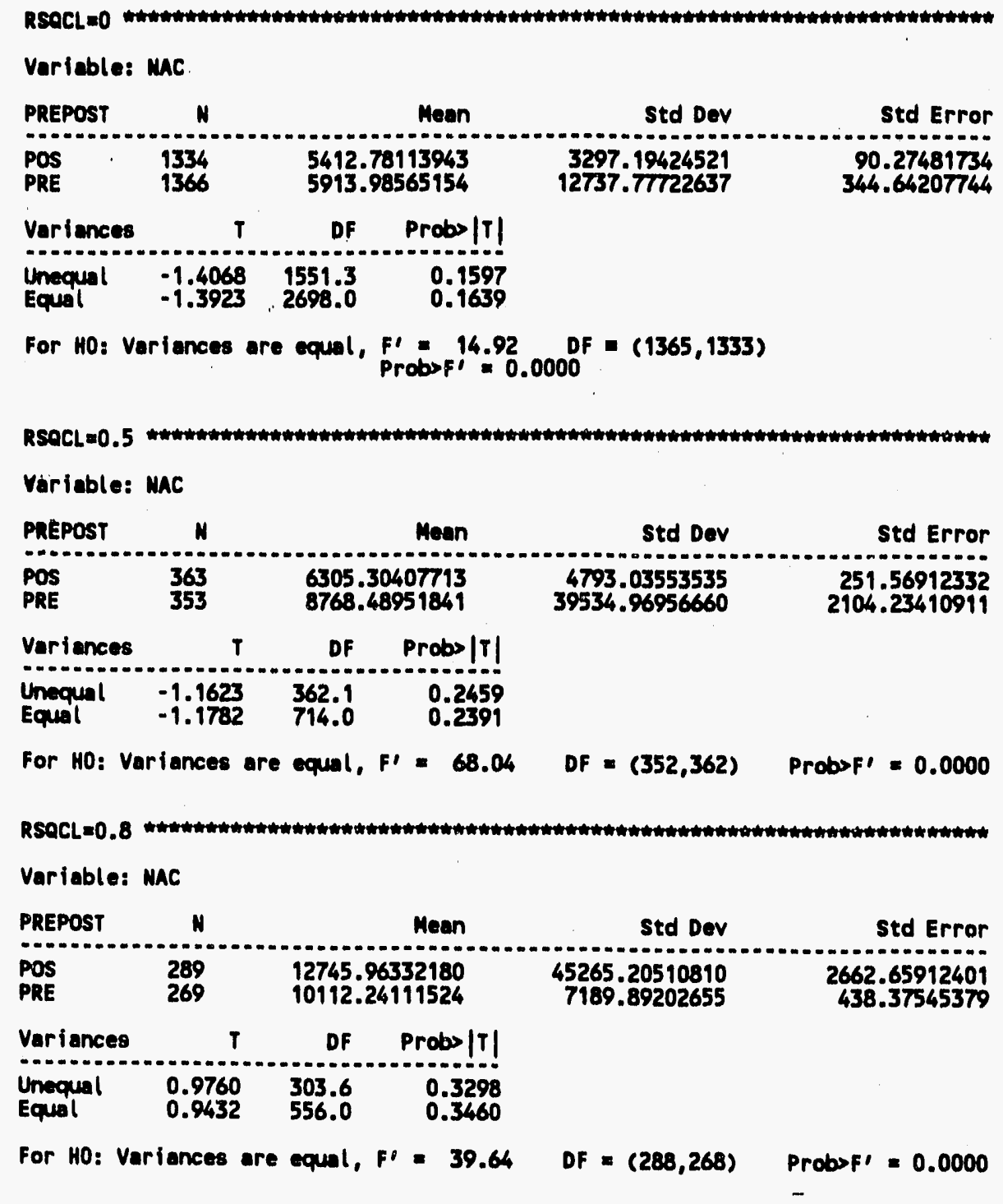




\section{Normalized Annual Consumption of 1990 Participants (by R-squared level)}

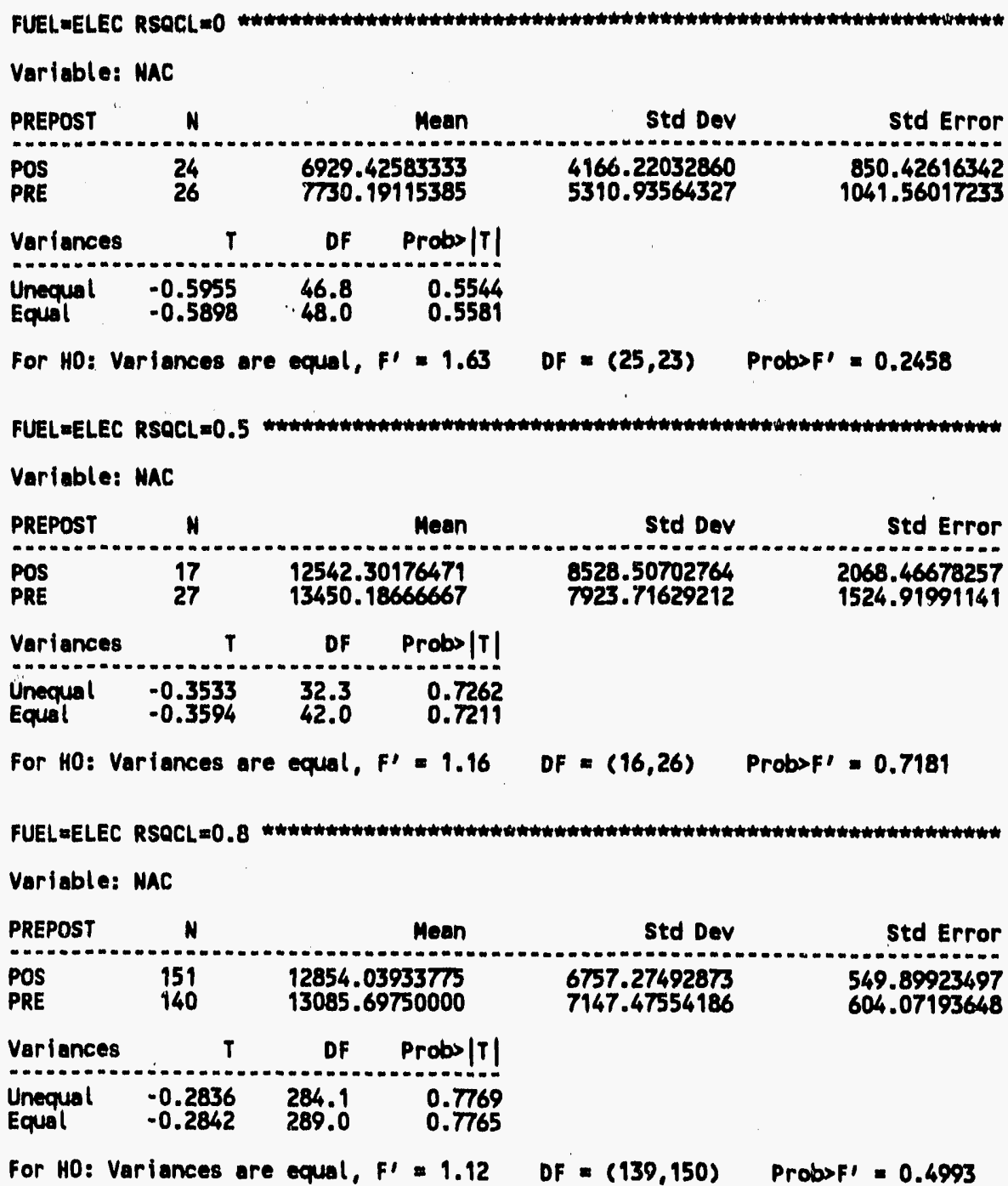




\section{Normalized Annual Consumption of 1990 Participants (by R-squared level)}

FUELECAS REACLEO Variable: MAC

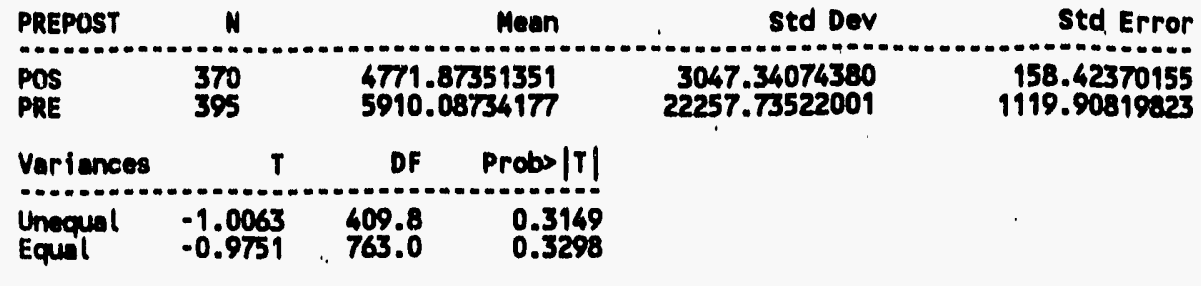

For HO: Variances are equal, FI $=53.35 \quad$ DF $=(394,369) \quad$ Prob>f' $=0.0000$

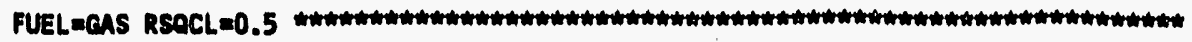
Variable: MAC

\begin{tabular}{lllll} 
PREPOST & $N$ & Meen & Std Dev & Std Error \\
\hline POS & 93 & $5694.0036559 \%$ & 3645.19504308 & 377.98919775 \\
PRE & 79 & 5570.15645570 & 4216.41699489 & 474.38397462
\end{tabular}

\begin{tabular}{llll} 
Variances & $T$ & DF & Probs/T! \\
\hline Unequal & 0.2043 & 155.4 & 0.0584 \\
Equal & 0.2067 & 170.0 & 0.8365
\end{tabular}

For HO: Variances are equal, F' $=1.34 \quad$ OF $=(78,92) \quad$ Probsf' $=0.1794$

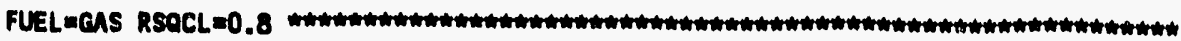
Variable: MAC

PREPOST Meen Std Dev Sror

$\begin{array}{lllll}\text { POS } & 43 & 7635.42232558 & 5352.80968960 & 816.29582493 \\ \text { PRE } & 30 & 7595.34866667 & 5198.45799263 & 949.10423560\end{array}$

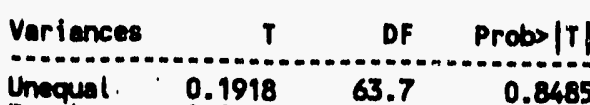

$\begin{array}{llll}\text { Unequal } & 0.1918 & 63.7 & 0.8485 \\ \text { Equil } & 0.1908 & 71.0 & 0.8493\end{array}$

For HO: Varfances are equal, Fo $=1.06 \quad$ DF $=(42,29) \quad$ Probsf' $=0.8816$ 


\section{Normalized Annual Consumption of 1990 Participants}

(by R-squared level)

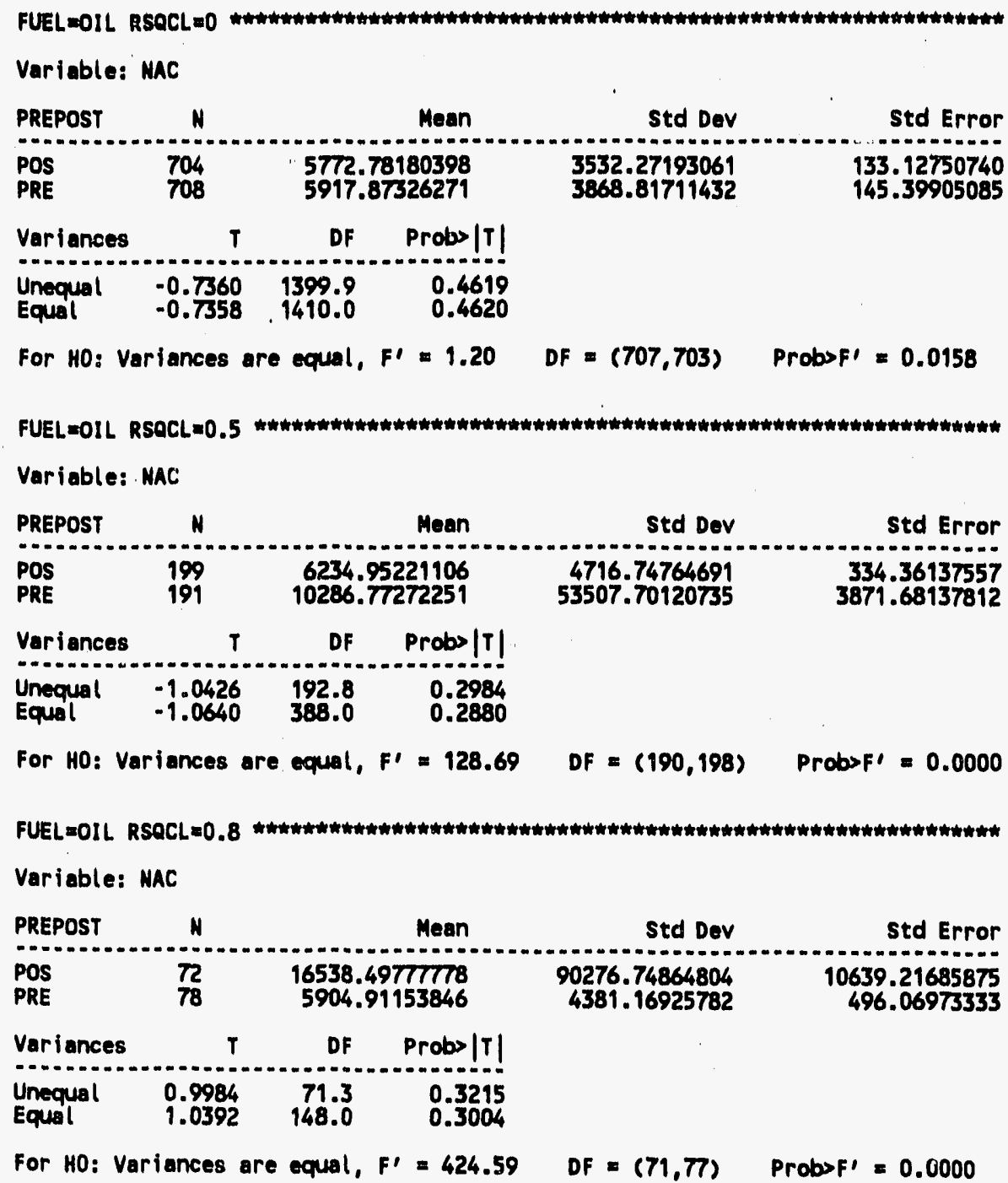


Normalized Annual Consumption of 1990 Participants

(by R-squared level)

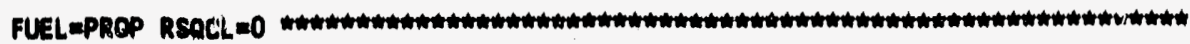
Varicble: Whe

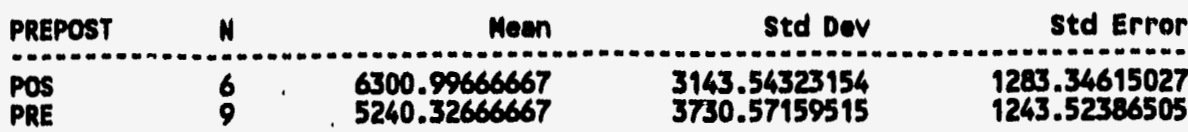

$\begin{array}{llll}\text { Variances } & \text { T } & \text { DF } & \text { Probs }|T| \\ \text { Unequal } & 0.5936 & 12.1 & 0.5637\end{array}$

$\begin{array}{llll}\text { Equal } & 0.5723 & 13.0 & 0.5769\end{array}$

For HO: Variances are equal, $F^{\prime}=1.41 \quad$ OF $\equiv(8,5) \quad$ Probsf' $=0.7345$

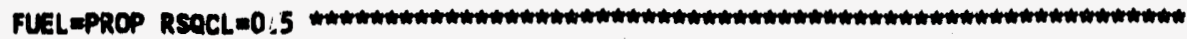
Variable: NAC

\begin{tabular}{lcccc} 
PREPOST & $N$ & Neen & Std Dov & Std Error \\
\hline POS & 7 & 5646.59428571 & 6175.85261854 & 1578.32393433 \\
PRE & 4 & 6998.67250000 & 2895.49232877 & 1447.74616438
\end{tabular}

\begin{tabular}{llll} 
Variances & $T$ & DF & Probs $|T|$ \\
\hline Unequal & -0.6313 & 8.4 & 0.5447 \\
Ecoul & -0.5681 & 9.0 & 0.5839
\end{tabular}

For HO: Variences are equal, $F^{\prime}=2.08 \quad$ DF $=(6,3) \quad$ Probsf' $=0.5849$

FUEL $=P R O P$ RSQCL=0.8 Variable: MAC

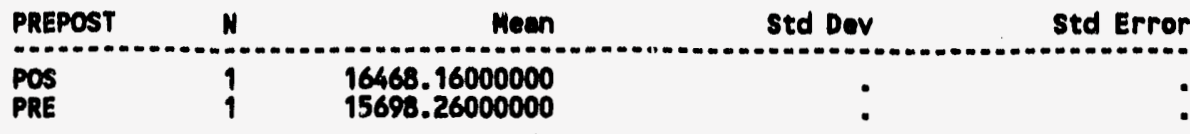

Variances $T$ DF Probs $|\mathrm{T}|$

Unacul

Equal: :

HOTE: All values are the seme for one Class level. 


\section{Normalized Annual Consumption of 1990 Participants (by R-squared level)}

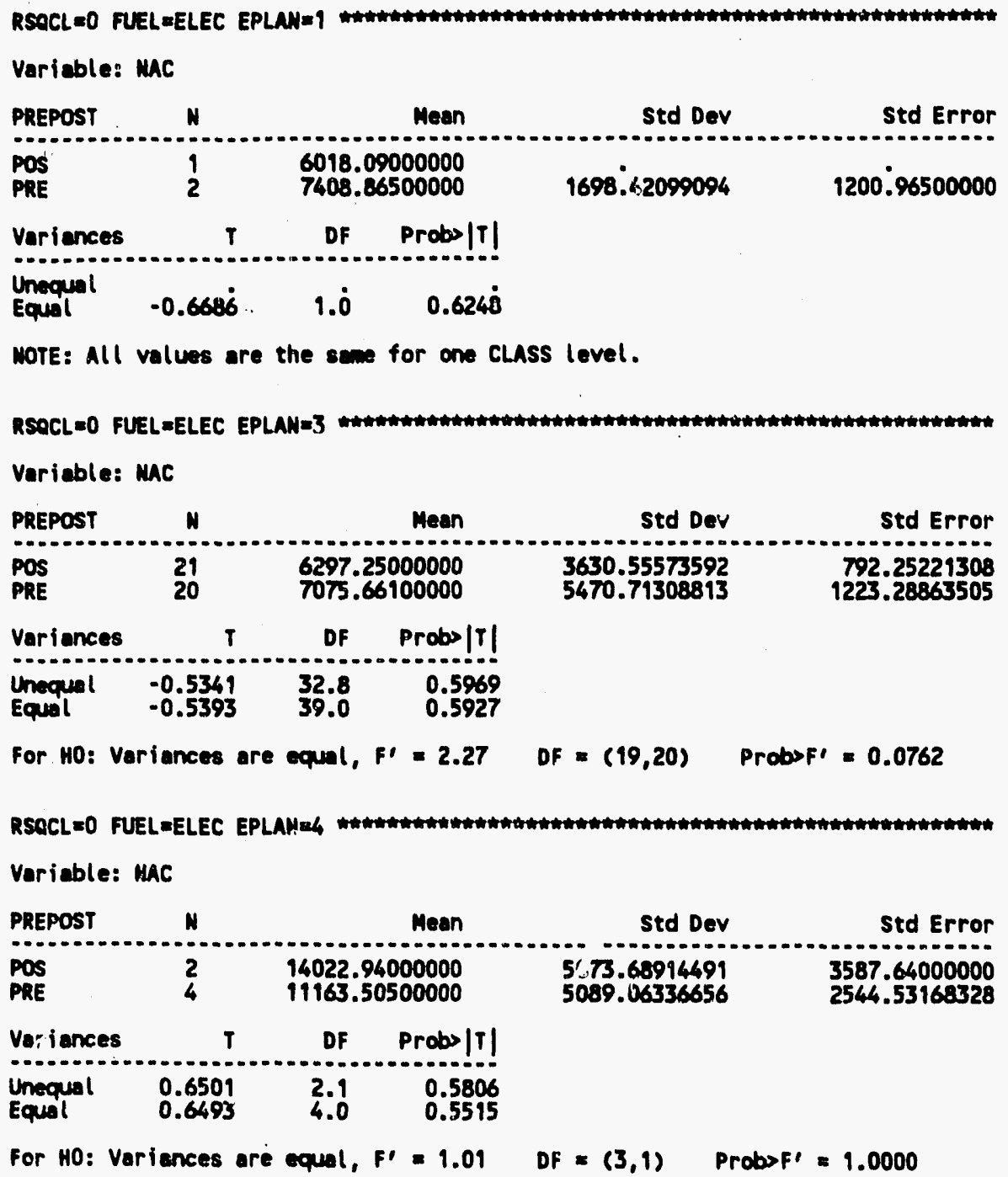




\section{Normalized Annual Consumption of 1990 Participants}

(by R-squared level)

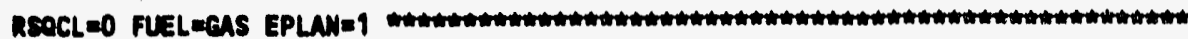
Varioble: MaC

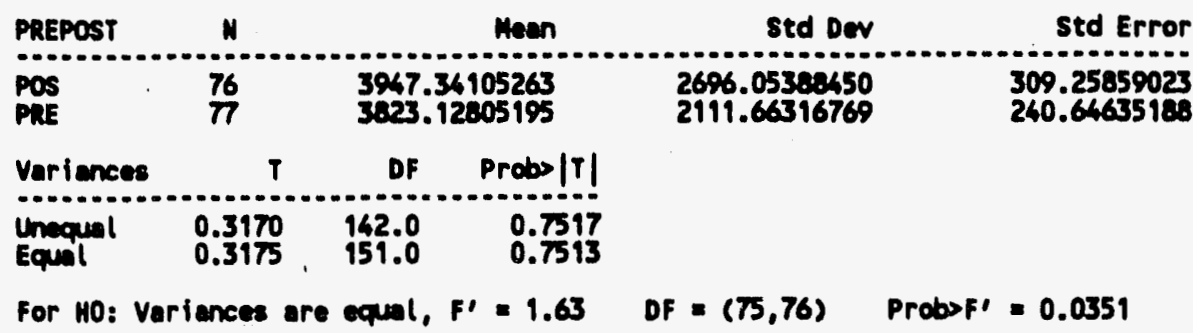

REOCL $=0$ FUELECAS EPLANE2 Variable: MAC

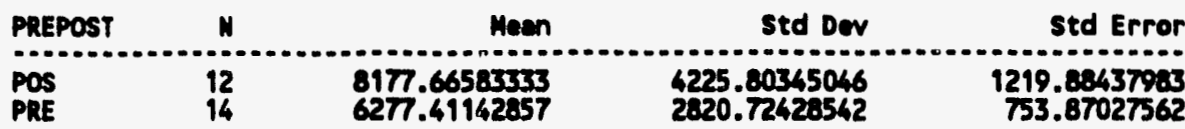

$\begin{array}{llll}\text { Variances } & T & \text { DF } & \text { Probs|T| } \\ \text { Unequal } & 1.3259 & 18.7 & 0.2011\end{array}$

$\begin{array}{llll}\text { Unequal } & \begin{array}{l}1.3251 \\ \text { Equal }\end{array} & 18.7 & 0.2011 \\ .3665 & 26.0 & 0.1846\end{array}$

For HO: Varience ere equal, F' $=2.24 \quad$ DF $=(11,13) \quad$ Probof' $=0.1676$

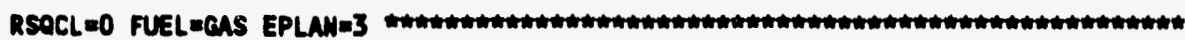
Variable: MAC

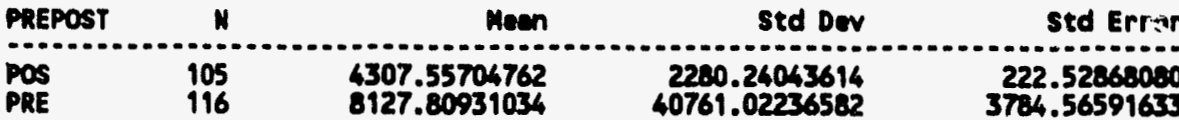

\begin{tabular}{llll} 
Variences & $T$ & DF & Probs/T! \\
\hdashline Unequl & -1.0077 & 115.8 & 0.3157 \\
Equil & -0.9588 & 219.0 & 0.3387
\end{tabular}

For HO: Variances are equal, F' $=319.54 \quad$ OF $=(115,106) \quad$ Probsf' $=0.0000$

RSQCL=0 FUELECAS EPLANEG Variable: MAC

\begin{tabular}{|c|c|c|c|c|c|}
\hline PREPOST & H & & Mean & Std Dev & Std Error \\
\hline $\begin{array}{l}\text { POS } \\
\text { PRE }\end{array}$ & $\begin{array}{l}119 \\
124\end{array}$ & $\begin{array}{l}5482 . \\
5708 .\end{array}$ & $\begin{array}{l}621849 \\
040323\end{array}$ & $\begin{array}{l}3663.43367095 \\
4268.04299172\end{array}$ & $\begin{array}{l}335.82641401 \\
383.28157530\end{array}$ \\
\hline Variences & $T$ & OF & Probs $|T|$ & & \\
\hline $\begin{array}{l}\text { Unequal } \\
\text { Equal }\end{array}$ & $\begin{array}{l}-0.4446 \\
-0.4432\end{array}$ & $\begin{array}{l}238.1 \\
241.0\end{array}$ & $\begin{array}{l}0.6570 \\
0.6580\end{array}$ & & \\
\hline
\end{tabular}




\section{Normalized Annual Consumption of 1990 Participants}

(by R-squared level)

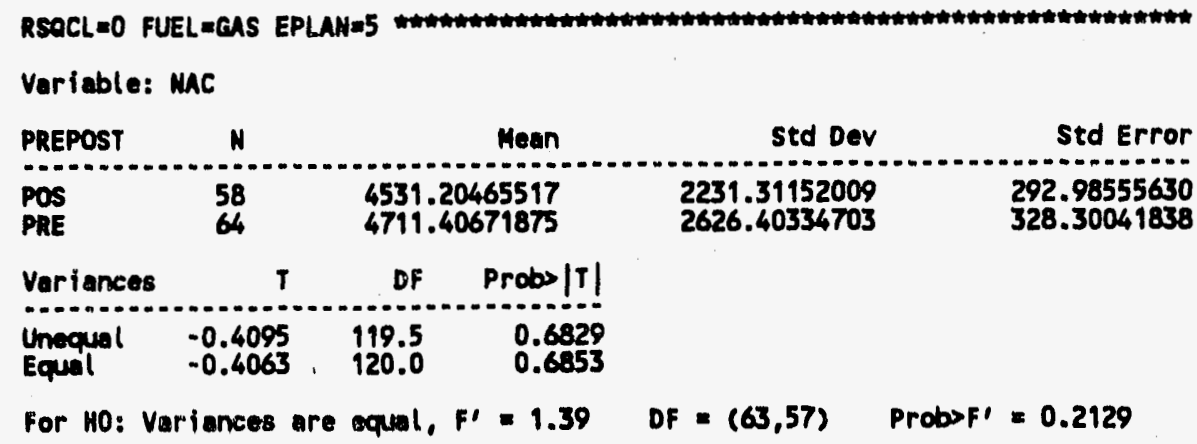




\section{Normalized Annual Consumption of 1990 Participants (by R-squared level)}

RSOCL=O FUELEOIL EPLAN=I Variable: NAC

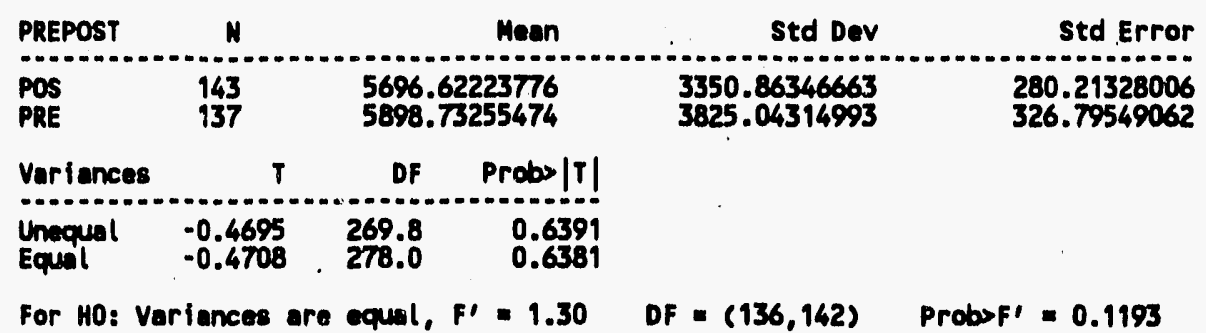

RSQCL=O FUEL=OIL EPLAN=2 Variable: NAC

\begin{tabular}{lccccc} 
PREPOST & $N$ & & Meen & Std DeV & Std Error \\
\hline POS & 99 & 5655.66222222 & 3422.39344434 & 343.96348303 \\
PRE & 101 & 5604.89851485 & 3390.81588458 & 337.39879103
\end{tabular}

$\begin{array}{llll}\text { Variances } & T & \text { DF } & \text { Probs }|T| \\ \text { Unequal } & 0.1054 & 197.8 & 0.9162\end{array}$

$\begin{array}{llll}\text { Unequal } & 0.1054 & 197.8 & 0.9162 \\ \text { Equal } & 0.1054 & 198.0 & 0.9162\end{array}$

For HO: Variances are equal, F' $=1.02 \quad$ DF $=(98,100) \quad$ ProbsF' $=0.9262$

RSOCI:=O FUEL=OIL EPLAN=3 Variable: MAC

\begin{tabular}{lccccr} 
PREPOST & $N$ & & Mean & Std Dev & Std Error \\
\hline POS & 252 & 5263.97289683 & 2275.10889780 & 143.37838927 \\
PRE & 256 & 5408.07894531 & 2545.85891840 & 159.11618240
\end{tabular}

$\begin{array}{llll}\text { Variances } & T & \text { OF } & \text { Probs }|T| \\ \text { Unequal } & -0.6729 & 501.4 & 0.5013\end{array}$

Equal ... $\quad-0.6723 \quad 506.0 \quad 0.5017$

For HO: Variances are equal, FI $=1.25 \quad$ DF $=(255,251) \quad$ ProbsF' $=0.0744$

RSOCL $=0$ FUEL $=O I L$ EPLAN=4 Variable: MAC

\begin{tabular}{|c|c|c|c|c|}
\hline $\begin{array}{l}\text { PREPOST } \\
\end{array}$ & $N$ & Meen & Std Dev & Std Err \\
\hline $\begin{array}{l}\text { POS } \\
\text { PRE }\end{array}$ & $\begin{array}{l}87 \\
86\end{array}$ & $\begin{array}{l}8084.49413793 \\
8305.65709302\end{array}$ & $\begin{array}{l}4926.15389124 \\
5133.06797989\end{array}$ & $\begin{array}{l}528.139133 \\
553.512955\end{array}$ \\
\hline
\end{tabular}

\begin{tabular}{llll} 
Variances & $T$ & DF & Probs|T! \\
\hline Unequal & -0.2891 & 170.5 & $0.7 r 29$
\end{tabular}

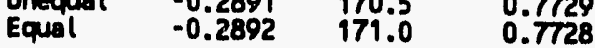

For HO: Variances are equal, F' $=1.09 \quad$ DF $-(85,86) \quad$ Probsf' $=0.7041$ 
Normalized Annual Consumption of 1990 Participants (by R-squared level)

\begin{tabular}{|c|c|c|c|c|}
\hline \multicolumn{5}{|c|}{ Variable: MAC } \\
\hline PREPOST & $\ldots$ & Mean & Std Dev & std Error \\
\hline $\begin{array}{l}\text { POS } \\
\text { PRE }\end{array}$ & $\begin{array}{l}123 \\
128\end{array}$ & $\begin{array}{l}5362.91617886 \\
5600.61281250\end{array}$ & $\begin{array}{l}4138.81787424 \\
4836.34925335\end{array}$ & $\begin{array}{l}373.18464006 \\
427.47691915\end{array}$ \\
\hline Variances & $T$ & Probs|T| & & \\
\hline $\begin{array}{l}\text { Unequal } \\
\text { Equal }\end{array}$ & $\begin{array}{l}-0.4189 \\
-0.4176\end{array}$ & $\begin{array}{l}0.6757 \\
0.6766\end{array}$ & & \\
\hline
\end{tabular}




\section{Normalized Annual Consumption of 1990 Participants (by R-squared level)}

RSOCL=O FUELAPROP EPLAN=1 Variable: MAC

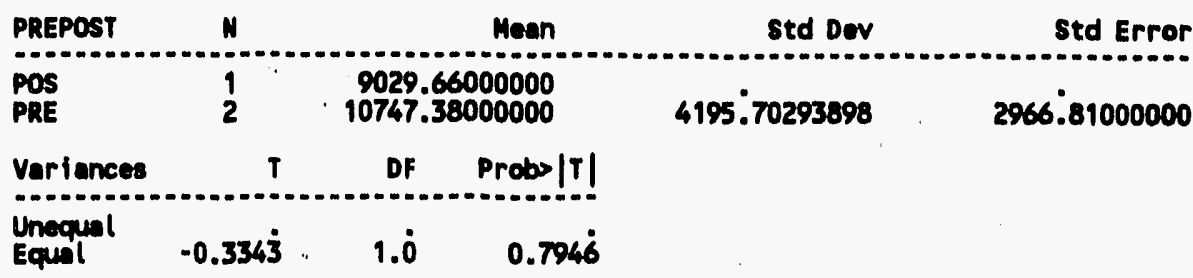

NOTE: All values are the same for one CLASS level.

RSQCL=O FUEL=PROP EPLAN=2 Variable: MAC

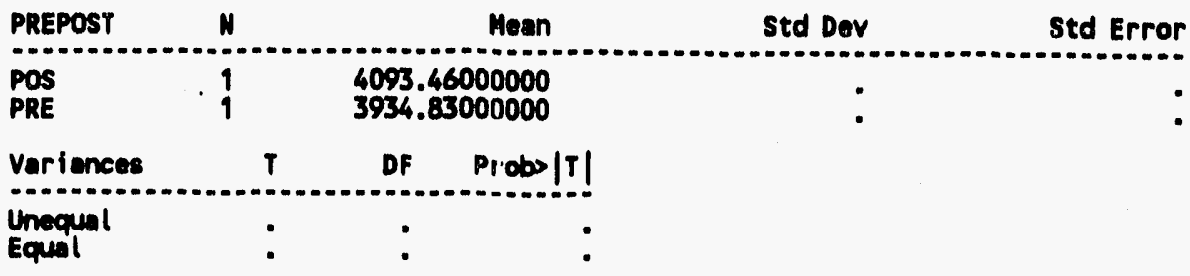

NOTE: All values are the sam for on CLASS level.

RSOCL=O FUELAPROP EPLAN=3 Variable: MAC

\begin{tabular}{|c|c|c|c|c|}
\hline PREPOST & N & Meen & std Dev & std Error \\
\hline $\begin{array}{l}\text { POS } \\
\text { PRE }\end{array}$ & $\begin{array}{l}1 \\
3\end{array}$ & $\begin{array}{l}4834.54000000 \\
3880.04333333\end{array}$ & $2668^{\circ} .05088239$ & 1540.39989516 \\
\hline Variances & $T$ & DF Probs |T & & . \\
\hline $\begin{array}{l}\text { Unequal } \\
\text { Equal }\end{array}$ & 0.3098 & 0.7260 & & \\
\hline
\end{tabular}

MOTE: All values ore the same for one CLASS level.

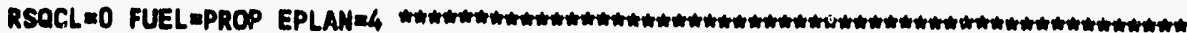
Voriable: MAC

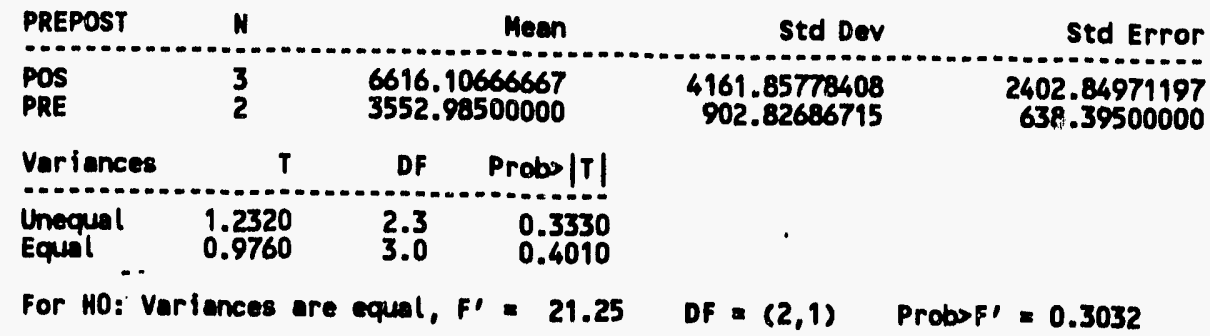




\section{Normalized Annual Consumption of 1990 Participants (by R-squared level)}

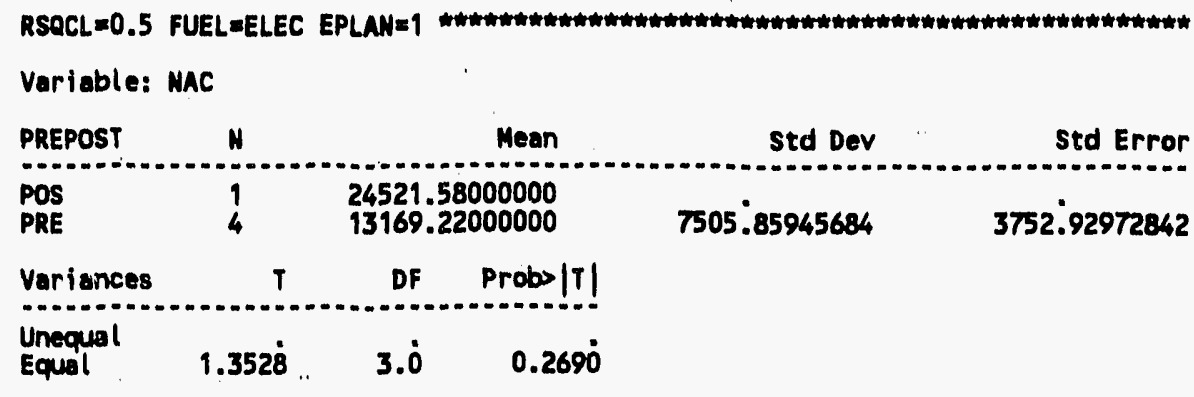

NOTE: All values are the same for one CLASS level.

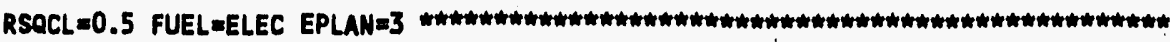
Variable: NAC

\begin{tabular}{|c|c|c|c|c|}
\hline PREPOST & $N$ & Mean & std Dev & Std Error \\
\hline $\begin{array}{l}\text { POS } \\
\text { PRE }\end{array}$ & $\begin{array}{l}12 \\
20\end{array}$ & $\begin{array}{l}12816.28833333 \\
12582.73500000\end{array}$ & $\begin{array}{l}9128.82118489 \\
7768.93796822\end{array}$ & $\begin{array}{l}2635.26368424 \\
1737.18734099\end{array}$ \\
\hline Variances & T & Probs $|T|$ & & \\
\hline $\begin{array}{l}\text { Unequal } \\
\text { Equal }\end{array}$ & $\begin{array}{l}0.0740 \\
0.0771\end{array}$ & $\begin{array}{l}0.9417 \\
0.9390\end{array}$ & & \\
\hline
\end{tabular}

RSACL $=0.5$ FUEL EELEC EPLAN=4 Variable: MAC

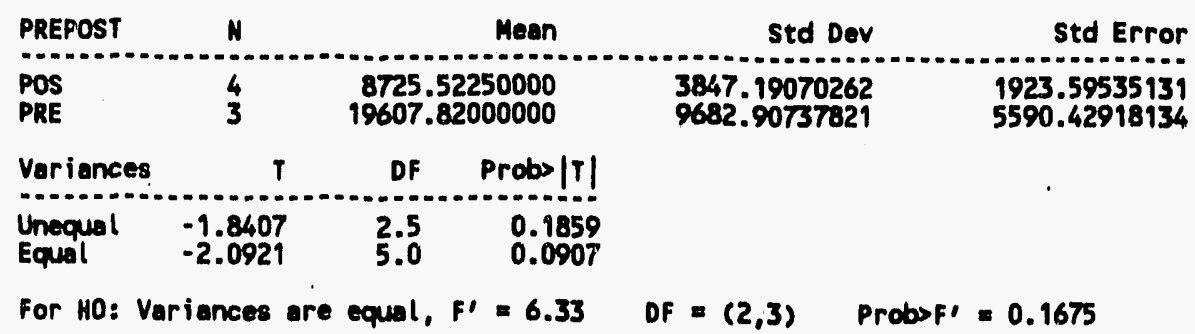




\section{Normalized Annual Consumption of 1990 Participants \\ (by R-squared level)}

RSOCL=0.5 FUEL=CAS EPLAN=1 Variable: MAC

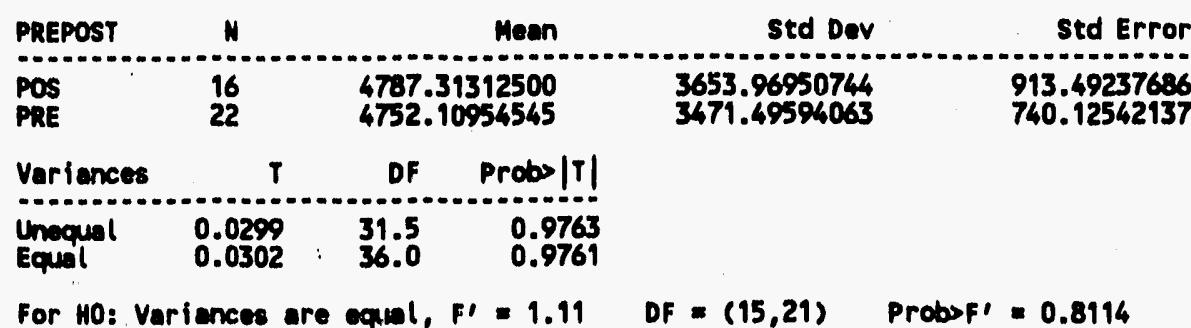

For HO: Variences are equal, F' $=1.11 \quad$ DF $=(15,21) \quad$ Probuf' $=0.8114$

RSQCL $=0.5$ FUEL=CAS EPLAN=2 Variable: MAC

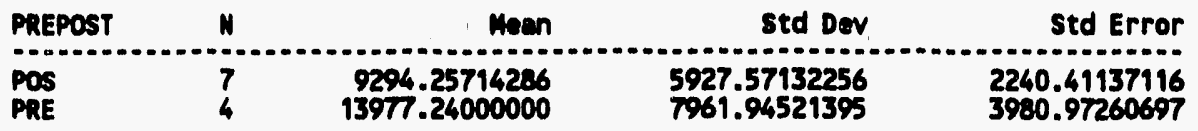

\begin{tabular}{llll} 
Variances & $T$ & DF & Probo $\mid T !$ \\
\hline Unoqual & -1.0251 & 5.0 & 0.3528
\end{tabular}

$\begin{array}{llll}\text { Unoqual } & -1.0251 & 5.0 & 0.3528 \\ \text { Equal } & -1.1193 & 9.0 & 0.2920\end{array}$

For HO: Variances are equal, $F^{\prime}=1.80 \quad$ DF $=(3,6) \quad$ ProbsF' $=0.4931$

RSOCL=0.5 FUEL=CAS EPLAN=3 Variable: MAC

\begin{tabular}{llllll} 
PREPOST & N & & Mean & Std Dev & Std Error \\
\hline POS & 25 & 4993.09320000 & 2230.16510833 & 446.03302167 \\
PRE & 17 & 3637.41058824 & 1718.13233595 & 416.70829999
\end{tabular}

\begin{tabular}{llll} 
Variences & $T$ & DF & Probs|T! \\
\hline Unequal & 2.2210 & 39.3 & 0.0322
\end{tabular}

Equal $\quad 2.1131 \quad 40.0 \quad 0.0400$

For HO: Variances are equal, F' $=1.68 \quad$ DF $=(24,16) \quad$ Probuf' $=0.2832$

RSACL $=0.5$ FUELEGAS EPLAN=4 Variable: MAC

\begin{tabular}{llllll} 
PREPOST & $N$ & & Mean & Std Dev & Std Error \\
\hline POS & 27 & 6380.46000000 & 3396.34037126 & 653.62600920 \\
PRE & 27 & 6803.10111111 & 4173.42223055 & 803.17548275
\end{tabular}

\begin{tabular}{llll} 
Variences & $T$ & DF & Probs $|T|$ \\
\hline Unequal & -0.4081 & 49.9 & 0.6849 \\
Equal & -0.4081 & 52.0 & 0.6848
\end{tabular}

For HO: Variances are equal, F' $=1.51 \quad$ DF $=(26,26) \quad$ Probs F' $=0.2998$ 


\section{Normalized Annual Consumption of 1990 Participants}

(by R-squared level)

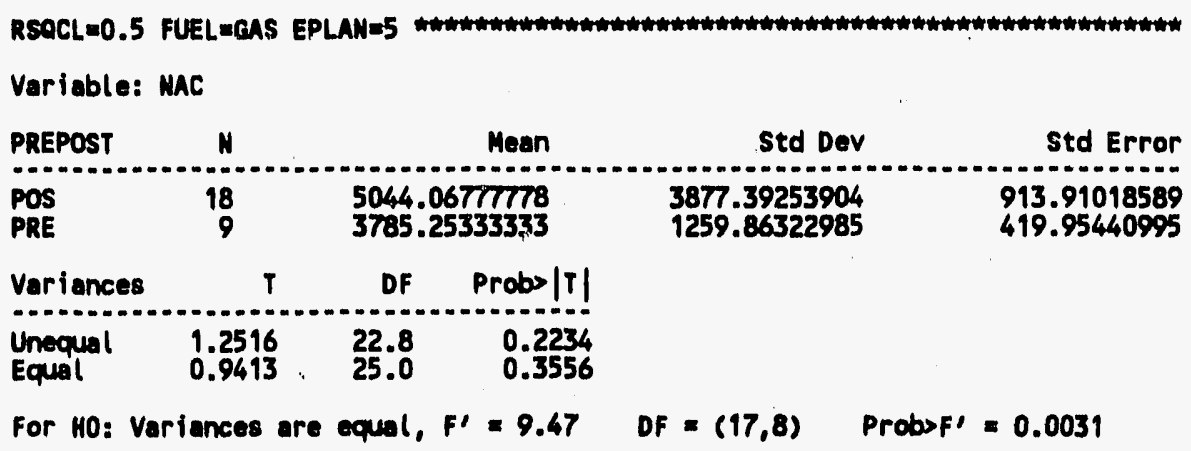




\section{Normalized Annual Consumption of 1990 Participants (by R-squared level)}

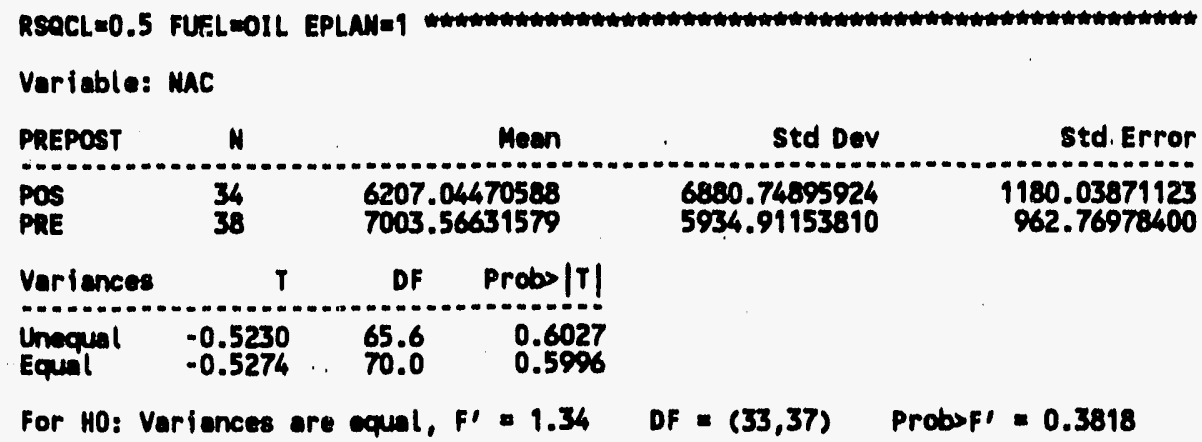

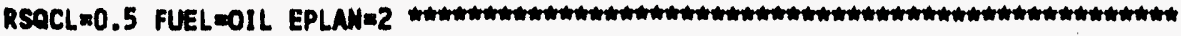
Variable: MAC

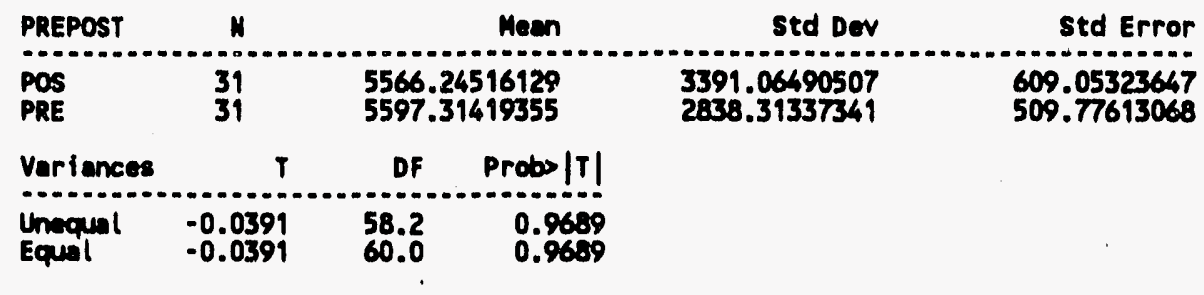

For HO: Variences ore equal, F'=1.43 DF $=(30,30) \quad$ Probsf' $=0.3351$

RSOCL $=0.5$ FUELOOLL EPLANE3 Variable: MAC

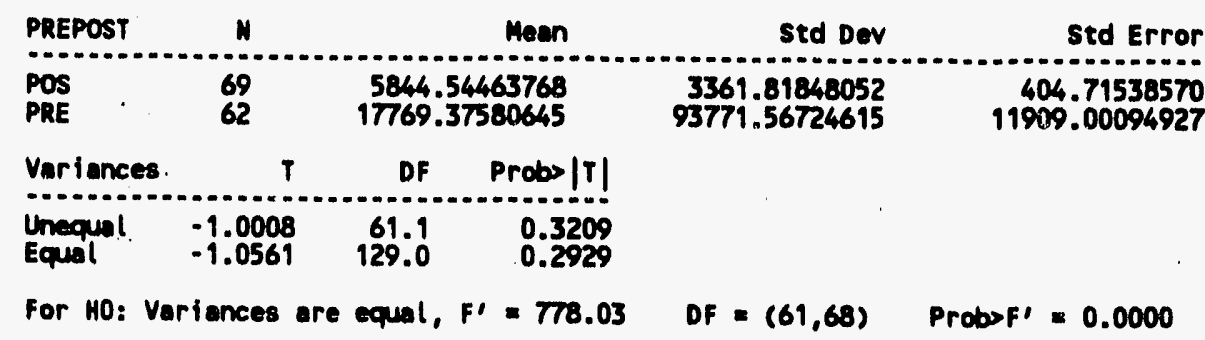

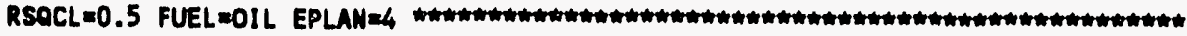
Variable: MAC

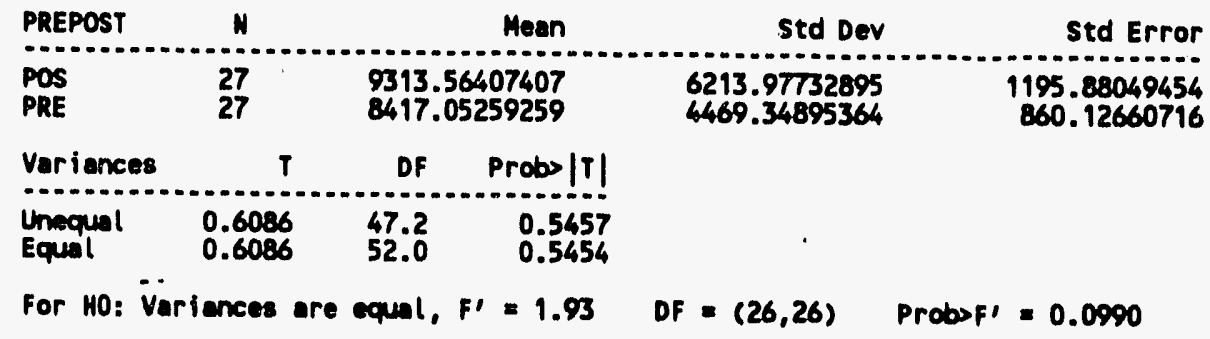




\section{Normalized Annual Consumption of 1990 Participants (by R-squared level)}

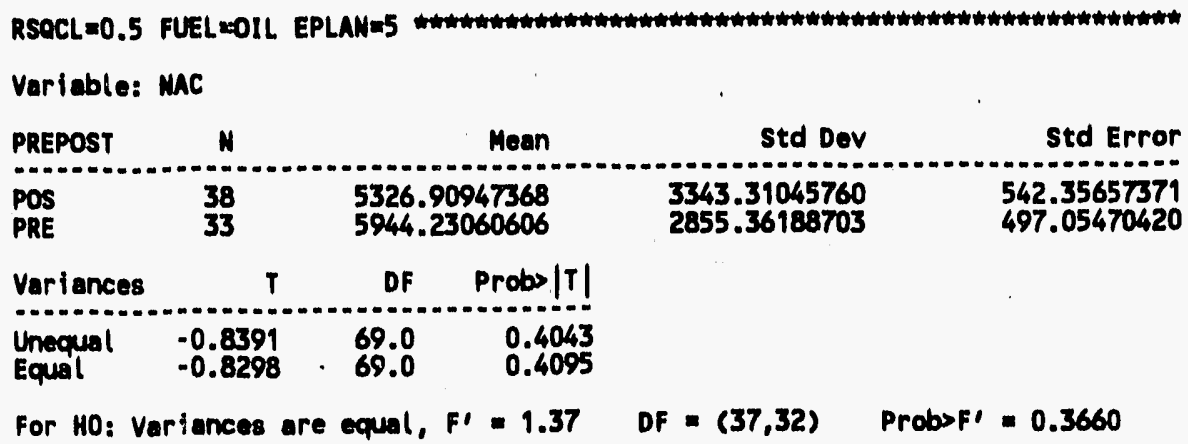


Normalized Annual Consumption of 1990 Participants

(by R-squared level)

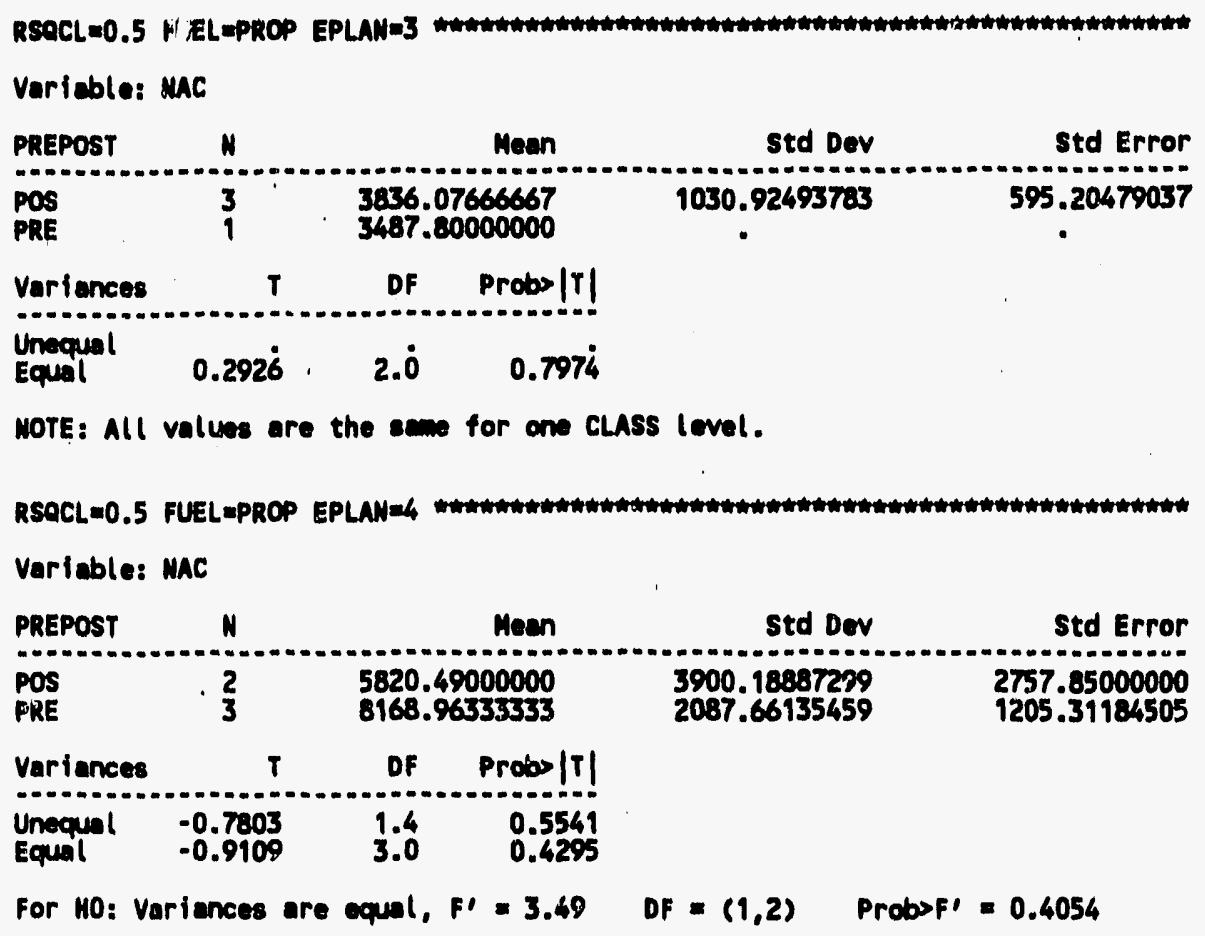




\section{Normalized Annual Consumption of 1990 Participants \\ (by R-squared level)}

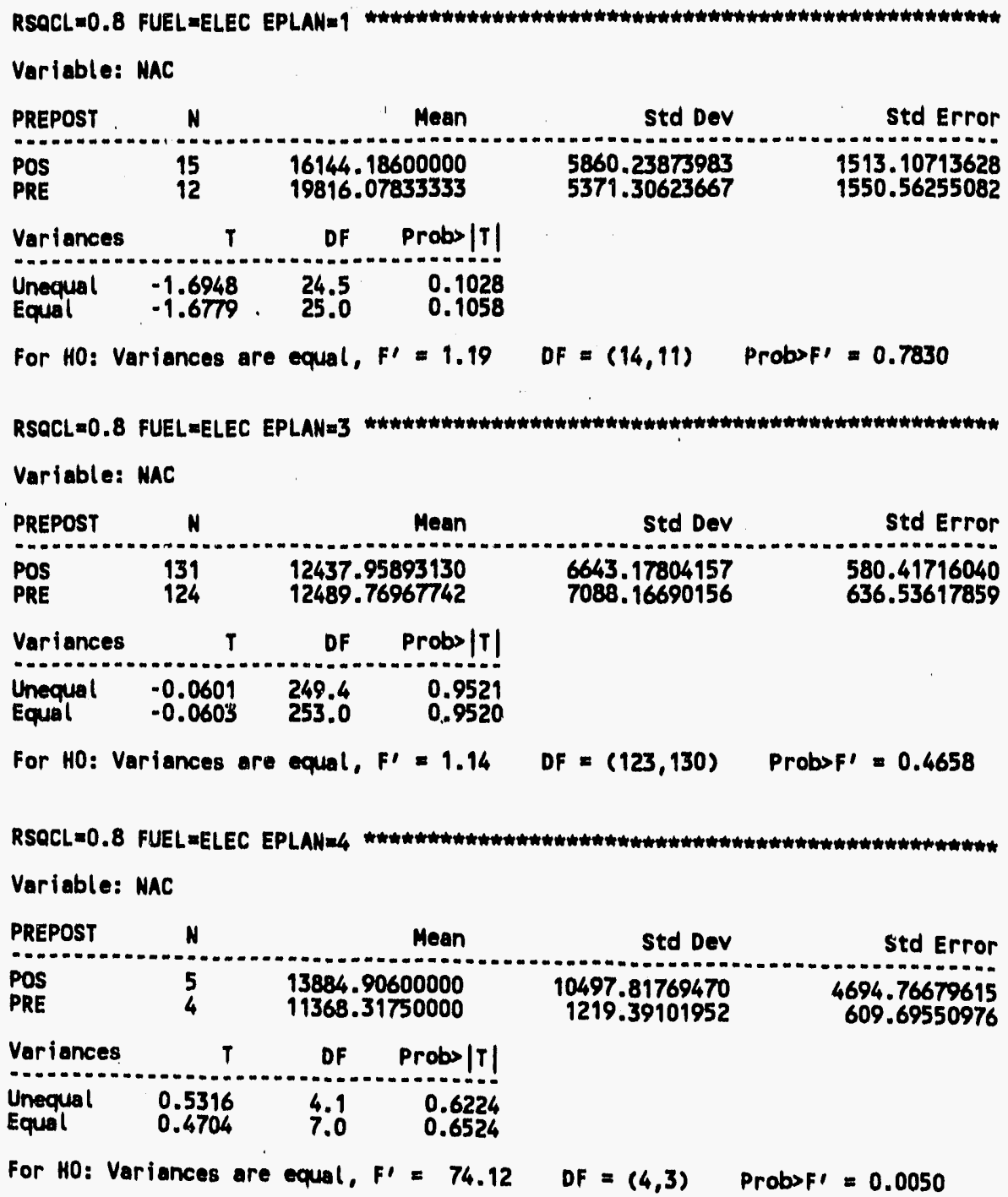




\section{Normalized Annual Consumption of 1990 Participants (by R-squared level)}

RSECL $=0.8$ FUEL=CAS EPLAN=1 Variable: MAC

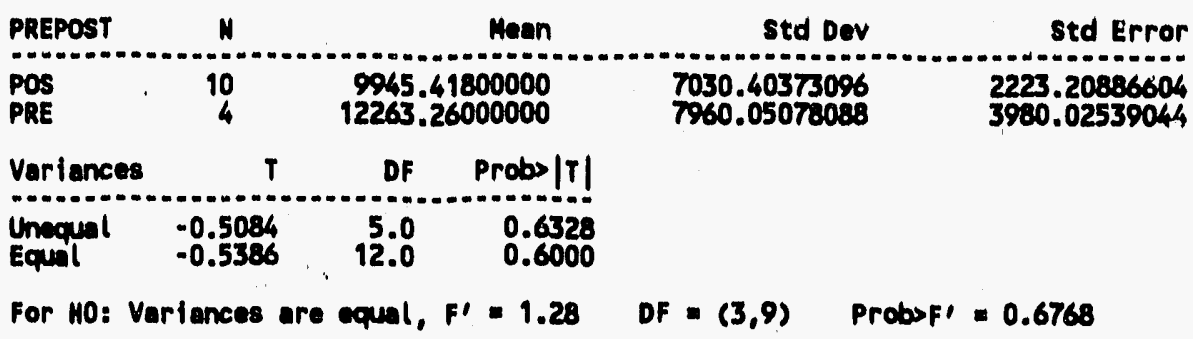

RSOCL $=0.8$ FUEL=CAS EPLAN=2 Variable: MAC

\begin{tabular}{lccccc} 
PREPOST & $N$ & & Moan & Std Dev & Std Error \\
\hline POS & 2 & 6158.90500000 & 2556.21222719 & 1807.51500000 \\
PRE & 3 & 7556.96666667 & 3816.10769095 & 2203.23000748
\end{tabular}

\begin{tabular}{llll} 
Variances & $T$ & DF & Probs $|T|$ \\
\hdashline Unequal & -0.4906 & 2.9 & 0.6583 \\
Equat & -0.4442 & 3.0 & 0.6870
\end{tabular}

For HO: Variences are equal, F'=2.23 DF $=(2,1) \quad$ Probsf' 0.8561

$R S Q C L=0.8$ FUEL=GAS EPLANM3 Variable: MAC

\begin{tabular}{|c|c|c|c|c|c|}
\hline PREPOST & N & & Moan & std Dev & Std Error \\
\hline $\begin{array}{l}\text { POS } \\
\text { PRE }\end{array}$ & 11 & $\begin{array}{l}6401 . \\
5216 .\end{array}$ & $\begin{array}{l}909091 \\
150000\end{array}$ & $\begin{array}{l}3434.77307203 \\
2595.63846149\end{array}$ & $\begin{array}{l}1035.62304727 \\
1297.81923074\end{array}$ \\
\hline Veriences & $T$ & DF & Probs & & \\
\hline $\begin{array}{l}\text { Unequal } \\
\text { Equal }\end{array}$ & $\begin{array}{l}0.7136 \\
0.6224\end{array}$ & $\begin{array}{r}7.2 \\
13.0\end{array}$ & $\begin{array}{l}0.48 \\
0.5\end{array}$ & & \\
\hline
\end{tabular}

For HO: Variances are equal, F'= $=1.75 \quad$ DF $=(10,3) \quad$ Probsfl $=0.7066$

RSOCL $=0.8$ FUEL=GAS EPLAN=4 Variable: MAC

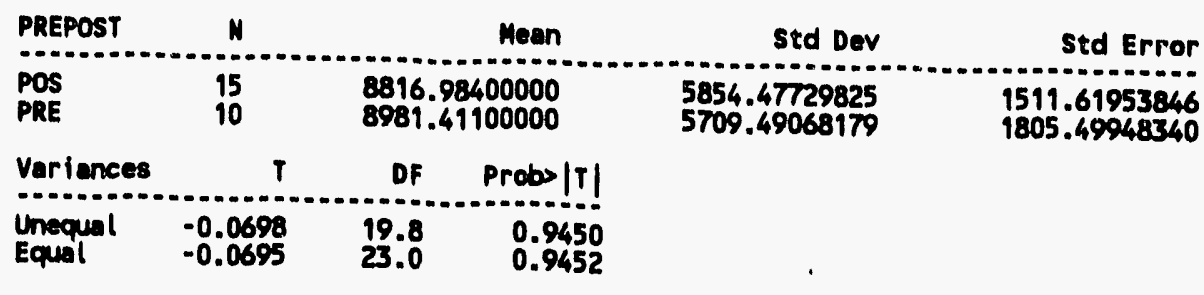

For HO: Veriances are equal, F' $=1.05 \quad$ DF $=(14,9) \quad$ Probsf' $=0.9707$ 


\section{Normalized Annual Consumption of 1990 Participants (by R-squared level)}

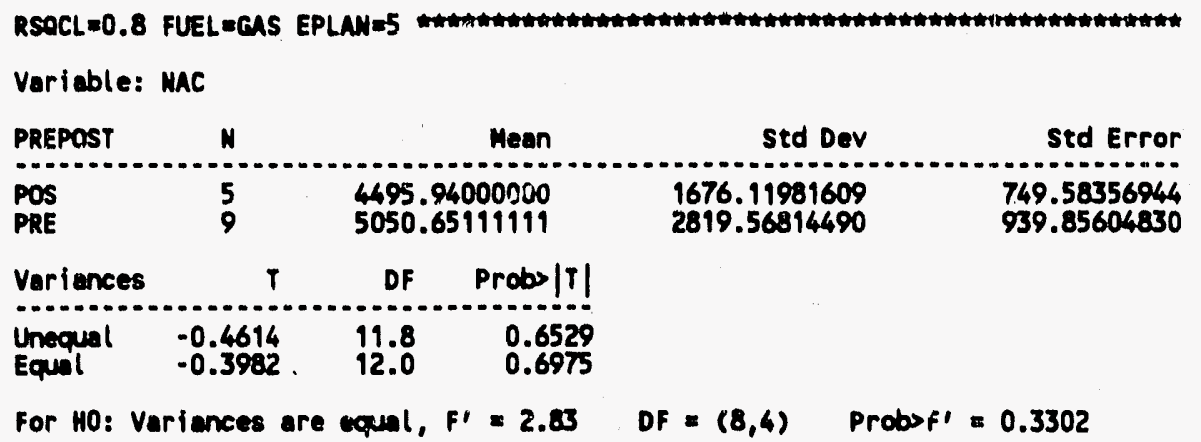




\section{Normalized Annual Consumption of 1990 Participants (by R-squared level)}

RSOCL $=0.8$ FUELEOIL EPLAN=I Variable: MAC

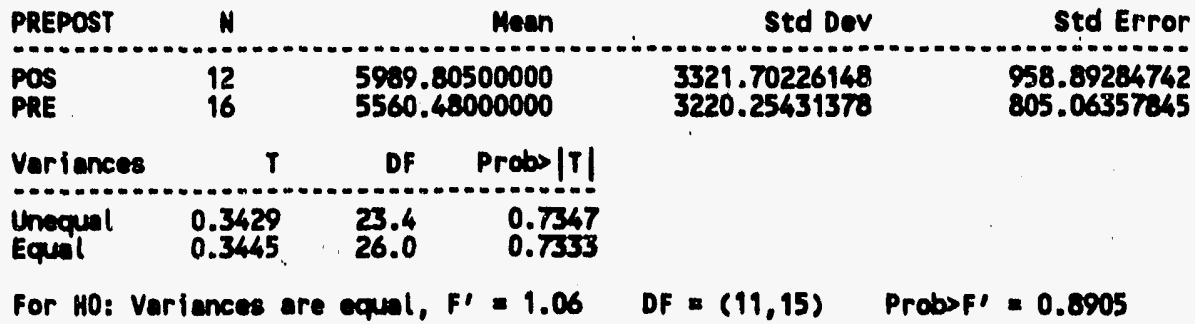

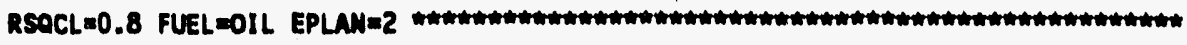
Variable: MAC

\begin{tabular}{|c|c|c|c|c|c|}
\hline PREPOST & N & & Moan & sted Dev & Std Error \\
\hline $\begin{array}{l}\text { POS } \\
\text { PRE }\end{array}$ & $\begin{array}{l}13 \\
11\end{array}$ & $\begin{array}{l}5453 . \\
6197 .\end{array}$ & $\begin{array}{l}615385 \\
.545455\end{array}$ & $\begin{array}{l}5632.73144234 \\
5536.94005126\end{array}$ & $\begin{array}{l}1562.23861818 \\
1669.45023970\end{array}$ \\
\hline Vorience: & $T$ & DF & Probs $|\mathrm{T}|$ & & \\
\hline $\begin{array}{l}\text { Unequal } \\
\text { Equal }\end{array}$ & $\begin{array}{l}-0.3253 \\
-0.3248\end{array}$ & $\begin{array}{l}21.5 \\
22.0\end{array}$ & $\begin{array}{l}0.7481 \\
0.7484\end{array}$ & & \\
\hline
\end{tabular}

RSOCL=0.8 FUELOOIL EPLAME3 Variable: MAC

\begin{tabular}{|c|c|c|c|c|c|}
\hline PREPOST & $\ldots$ & & Mean & Std Dev & std Error \\
\hline $\begin{array}{l}\text { POS } \\
\text { PRE }\end{array}$ & $\begin{array}{l}24 \\
25\end{array}$ & $\begin{array}{r}37164 \\
4504\end{array}$ & 458333 & $\begin{array}{r}156404.94756311 \\
2151.52491097\end{array}$ & $\begin{array}{r}31926.02623136 \\
430.30490219\end{array}$ \\
\hline Variances & $T$ & DF & Probs $|T|$ & & \\
\hline $\begin{array}{l}\text { Unequal } \\
\text { Equal. }\end{array}$ & $\begin{array}{l}1.0229 \\
1.0464\end{array}$ & $\begin{array}{l}23.0 \\
47.0\end{array}$ & $\begin{array}{l}0.3170 \\
0.3016\end{array}$ & & \\
\hline
\end{tabular}

RSOCL $=0.8$ FUEL $=0 I L$ EPLAN=4 Variable: MAC

\begin{tabular}{|c|c|c|c|c|c|}
\hline PREPOST & $\ldots$ & & Mean & Std Dev & Std Error \\
\hline $\begin{array}{l}\text { POS } \\
\text { PRE }\end{array}$ & 99 & $\begin{array}{r}7059 . \\
10075 .\end{array}$ & 909091 & $\begin{array}{l}2899.80576576 \\
7694.12997643\end{array}$ & $\begin{array}{r}966.60192192 \\
2319.86747455\end{array}$ \\
\hline Variences & $T$ & DF & Probs $|T|$ & & \\
\hline $\begin{array}{l}\text { Unequal } \\
\text { Equal }\end{array}$ & $\begin{array}{l}-1.2001 \\
-1.1088\end{array}$ & $\begin{array}{l}13.3 \\
18.0\end{array}$ & $\begin{array}{l}0.2511 \\
0.2821\end{array}$ & & \\
\hline
\end{tabular}




\section{Normalized Annual Consumption of 1990 Participants}

(by R-squared level)

\begin{tabular}{|c|c|c|c|c|c|}
\hline \multicolumn{6}{|c|}{ Variable: MAC } \\
\hline PREPOST & $N$ & & Mean & Std Dev & std Error \\
\hline $\begin{array}{l}\text { POS } \\
\text { PRE }\end{array}$ & $\begin{array}{l}14 \\
15\end{array}$ & $\begin{array}{l}6608 . \\
5333 .\end{array}$ & $\begin{array}{l}714286 \\
8666667\end{array}$ & $\begin{array}{l}2820.68949522 \\
2148.31316416\end{array}$ & $\begin{array}{l}753.86097754 \\
554.69207381\end{array}$ \\
\hline Variances & $T$ & DF & Probs|T| & & \\
\hline $\begin{array}{l}\text { Unequal } \\
\text { Equal }\end{array}$ & $\begin{array}{l}1.3622 \\
1.3752\end{array}$ & $\begin{array}{r}24.3 \\
27.0\end{array}$ & $\begin{array}{l}0.1856 \\
0.1804\end{array}$ & & \\
\hline
\end{tabular}




\section{Normalized Annual Consumption of 1990 Participants}

(by R-squared level)

RSOCL 0.8 FUELAPROP EPLANE3

Variable: MAC

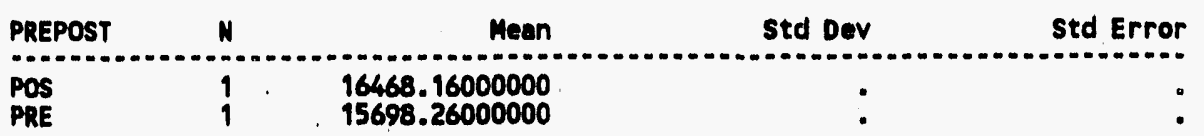

Variances $\quad$ T $\quad$ DF Probs $|\mathrm{T}|$

Unequal

MOTE: All values are the sem for one CLASS level. 


\title{
Normalized Annual Consumption of 1990 Participants
} (by R-squared level)

\author{
RSQCL=O FUEL $=$ BLANK EPLAN=1 URBRUR=RURAL \\ Variable: HAC

\begin{tabular}{l|lllr} 
PREPOST & $N$ & Mean & Std DeV & Std Error \\
\hline POS & 6 & 5708.00333333 & 1411.92556734 & 576.41619913 \\
PRE & 4 & 5809.53750000 & 1507.27091173 & 753.63545587
\end{tabular}

\begin{tabular}{llll} 
Variances & $T$ & DF & Probs|T| \\
\hline Unequal & -0.1070 & 6.3 & 0.9181 \\
Equal & -0.1086 & 8.0 & 0.9162
\end{tabular} \\ For HO: Variances are equal, $F^{\prime}=1.14 \quad$ DF $=(3,5) \quad$ Prob>F' $=0.8356$ \\ RSOCL=O FUELDBLANK EPLAN=1 URBRUR=URBAN \\ Variable: NAC

\begin{tabular}{|c|c|c|c|c|}
\hline PREPOST & $N$ & Mean & Std Dev & Std Error \\
\hline $\begin{array}{l}\text { POS } \\
\text { PRE }\end{array}$ & $\begin{array}{l}4 \\
4\end{array}$ & $\begin{array}{l}4879.07500000 \\
4067.67750000\end{array}$ & $\begin{array}{l}4071.42764879 \\
4318.61732903\end{array}$ & $\begin{array}{l}203 j .71382440 \\
2159.30866451\end{array}$ \\
\hline Variances & $T$ & Probs $|T|$ & & \\
\hline $\begin{array}{l}\text { Unequal } \\
\text { Equal }\end{array}$ & $\begin{array}{l}0.2734 \\
0.2734\end{array}$ & $\begin{array}{l}0.7937 \\
0.7937\end{array}$ & & \\
\hline
\end{tabular}

RSQCL $=0$ FUEL=BLANK EPLAN=2 URBRUR=URBAN Variable: NAC

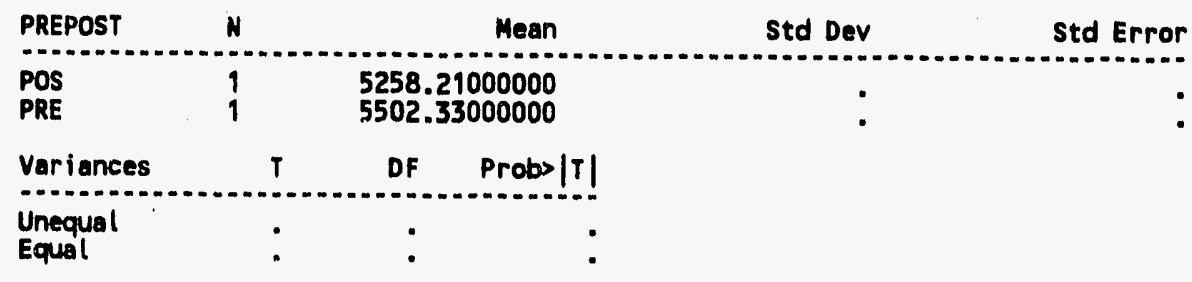

NOTE: All values are the same for one CLASS level.

RSQCL $=0$ FUEL=BLANK EPLAN=3 URBRUR=RURAL Veriable: MAC

\begin{tabular}{|c|c|c|c|c|c|}
\hline PREPOST & $N$ & & Mean & Std Dev & Std Error \\
\hline $\begin{array}{l}\text { POS } \\
\text { PRE }\end{array}$ & $\begin{array}{l}5 \\
8\end{array}$ & $\begin{array}{l}6153 \\
8283\end{array}$ & $\begin{array}{l}600000 \\
000000\end{array}$ & $\begin{array}{l}4597.75973602 \\
5872.90907365\end{array}$ & $\begin{array}{l}2056.18066279 \\
2076.38691563\end{array}$ \\
\hline Variances & $T$ & DF & Probs $|T|$ & & \\
\hline $\begin{array}{l}\text { Unequal } \\
\text { Equa! }\end{array}$ & $\begin{array}{l}-0.7290 \\
-0.6864\end{array}$ & $\begin{array}{l}10.2 \\
11.0\end{array}$ & $\begin{array}{l}0.4824 \\
0.5067\end{array}$ & & \\
\hline
\end{tabular}




\section{Normalized Annual Consumption of 1990 Participants}

(by R-squared level)

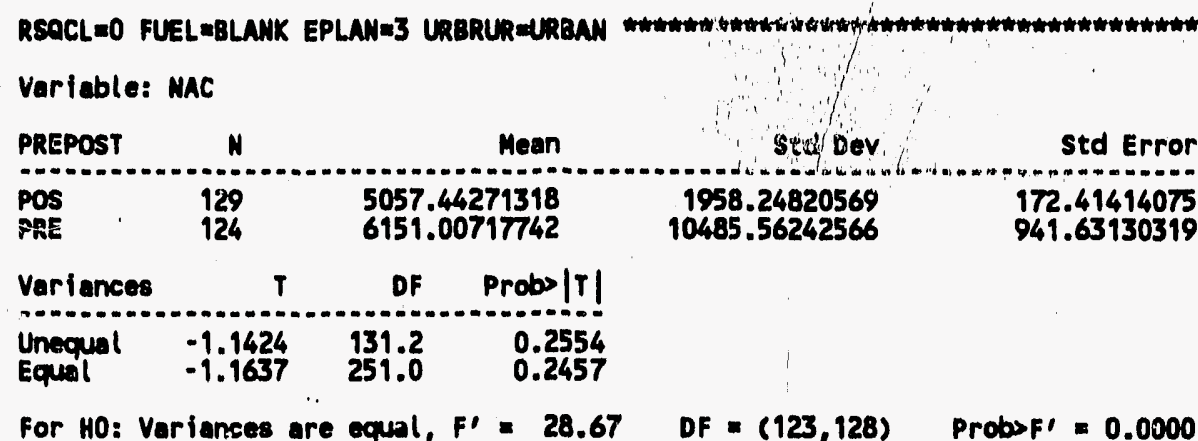

RSOCL=O FUEL $=B L A N K$ EPLAN=4 URBRURELRBKN Variable: HAC

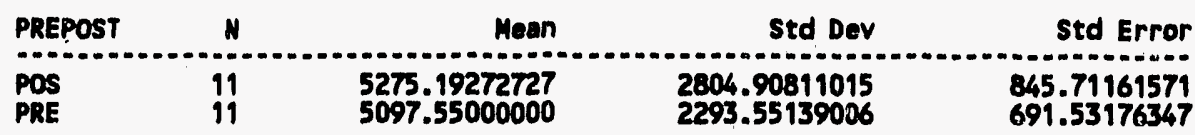

\begin{tabular}{llll} 
Variances & $T$ & DF & Probs $|T|$ \\
\hline Unoqual & 0.1626 & 19.2 & 0.8725 \\
Equal & 0.1626 & 20.0 & 0.8725
\end{tabular}

For HO: Variances are mqual, F' $=1.50 \quad$ DF $=(10,10) \quad$ Probsf' $=0.5361$

RSOCL=O FUEL $=B L A N K$ EPLAN=5 URBRUR=RURAL Variable: MAC

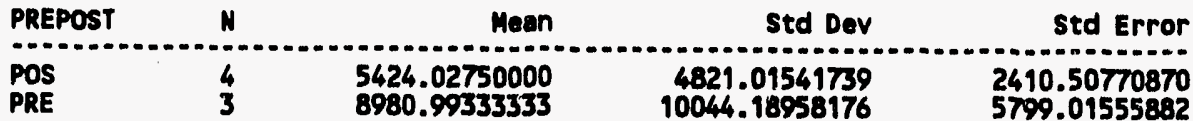

\begin{tabular}{llll} 
Variances & $T$ & DF & Probs $|T|$ \\
\hdashline Unequal & -0.5664 & 2.7 & 0.6160 \\
Equal & -0.6320 & 5.0 & 0.5551
\end{tabular}

For HO: Variances are equal, F' $=4.34 \quad$ DF $=(2,3) \quad$ Probsf' $=0.2603$

RSOCL=O FUEL=BLANK EPLAN=5 URBRURAURBAM Variable: MAC

\begin{tabular}{l|ccccr} 
PREPOST & N & & Mean & Std Dev & Std Error \\
\hline POS & 48 & 4488.01604167 & 1626.05343739 & 234.70059745 \\
PRE & 54 & 4089.24611111 & 1511.10743201 & 205.63567527
\end{tabular}

Veriances $\quad T \quad$ DF Probs|T!

Unequal $\quad 1.2779 \quad 96.5 \quad 0.2043$

Equal $\quad \begin{array}{lll}1.2835 & 100.0 & 0.2023\end{array}$

For HO: _. 


\section{Normalized Annual Consumption of 1990 Participants (by R-squared level)}

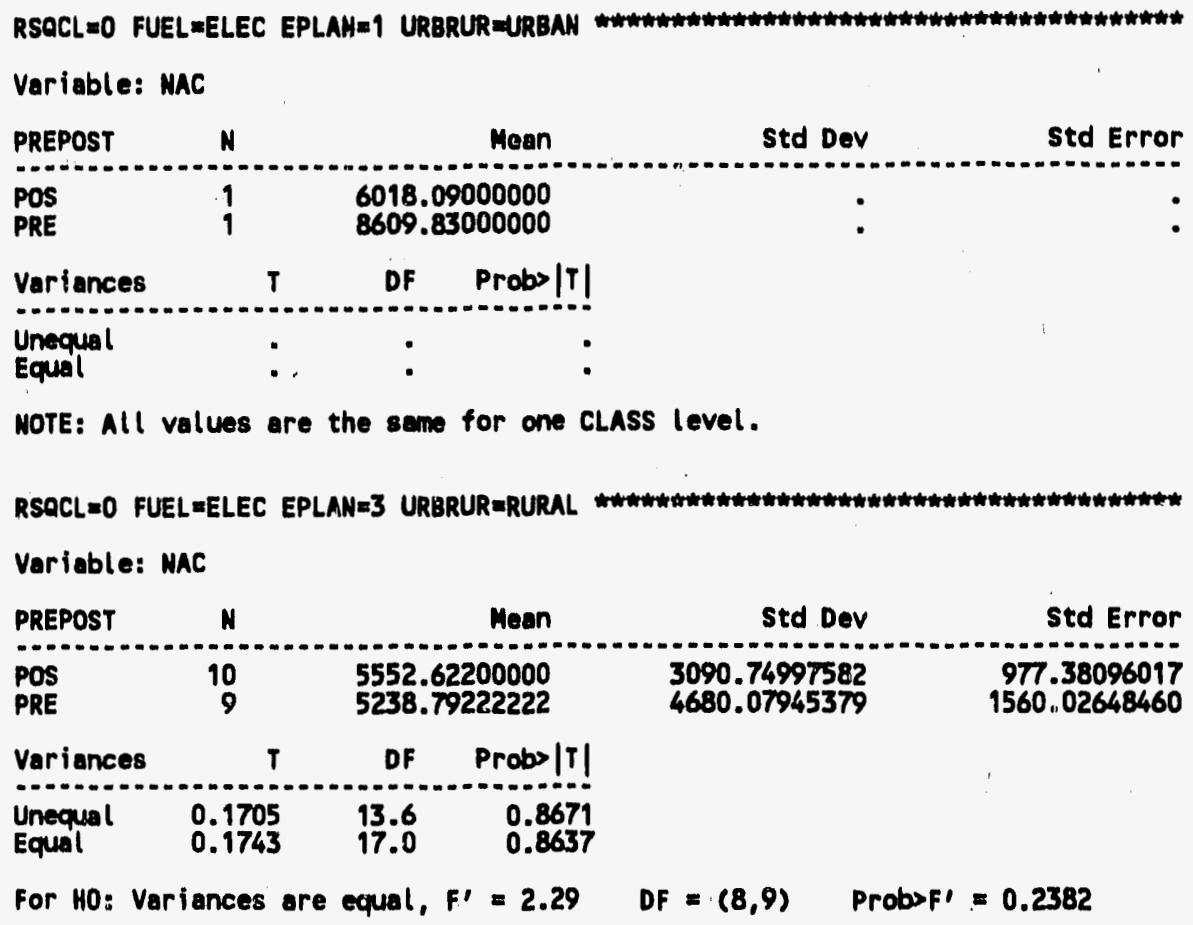

RSQCL=O FUEL=ELEC EPLAN=3 URBRUR=URBAN Variable: NAC

\begin{tabular}{|c|c|c|c|c|}
\hline PREPOST & N & Mean & Std Dev & std Error \\
\hline $\begin{array}{l}\text { POS } \\
\text { PRE }\end{array}$ & $\begin{array}{l}11 \\
11\end{array}$ & $\begin{array}{l}6974.18454545 \\
8578.55363636\end{array}$ & $\begin{array}{l}4087.28182982 \\
5815.56404322\end{array}$ & $\begin{array}{l}1232.36184018 \\
1753.45853415\end{array}$ \\
\hline Variances & $T$ & Probs| & & \\
\hline $\begin{array}{l}\text { Unequal } \\
\text { Equal }\end{array}$ & $\begin{array}{l}-0.7486 \\
-0.7486\end{array}$ & $\begin{array}{l}17.9 \\
20.0\end{array}$ & & \\
\hline
\end{tabular}

For HO: Variances are equal, $F^{\prime}=2.02 \quad$ DF $=(10,10) \quad$ Probsf' $=0.2815$

RSQCL-O FUEL=ELEC EPLAN=L URBRUR=RURAL Variable: NAC

\begin{tabular}{l|ccccr} 
PREPOST & $N$ & & Mean & Std Dev & Std Error \\
\hline POS & 2 & 14022.94000000 & 5073.68914491 & 3587.64000000 \\
PRE & 4 & 11163.50500000 & 5089.06336656 & 2544.53168328
\end{tabular}

\begin{tabular}{llll} 
Variances & $T$ & DF & Probs $|T|$ \\
\hline Unequal & 0.6501 & 2.1 & 0.5806
\end{tabular}

$\begin{array}{llll}\text { Equal } & 0.6501 & 2.1 & 0.5806 \\ & 0.6493 & 4.0 & 0.5515\end{array}$

For HO: -Variances are equal, $F^{\prime}=1.01 \quad$ DF $=(3,1) \quad$ ProbsF' $=1.0000$ 


\section{Normalized Annual Consumption of 1990 Participants (by R-squared level)}

RSOCL=O FUELECAS EPLAN=1 URBRUR=RURAL Variable: MAC

\begin{tabular}{|c|c|c|c|c|c|}
\hline PREPOST & N & & Mean & Std Dev & Std Error \\
\hline $\begin{array}{l}\text { POS } \\
\text { PRE }\end{array}$ & $\begin{array}{l}46 \\
46\end{array}$ & $\begin{array}{l}3809 \\
3693\end{array}$ & $\begin{array}{l}956522 \\
043478\end{array}$ & $\begin{array}{l}2726.94643828 \\
1819.22667466\end{array}$ & $\begin{array}{l}402.06631719 \\
268.23033960\end{array}$ \\
\hline Varience & $T$ & DF & Probs |T| & & \\
\hline $\begin{array}{l}\text { Unequal } \\
\text { Equal }\end{array}$ & $\begin{array}{l}0.2413 \\
0.2413\end{array}$ & $\begin{array}{l}78.4 \\
90.0\end{array}$ & $\begin{array}{l}0.8100 \\
0.8099\end{array}$ & & \\
\hline
\end{tabular}

For HO: Variances are equal, $F^{\prime}=2.25 \quad$ DF $=(45,45) \quad$ Probs $F I=0.0077$

RSQCL=O FUELECAS EPLAN=1 URBRUR=UREAN Variable: NAC

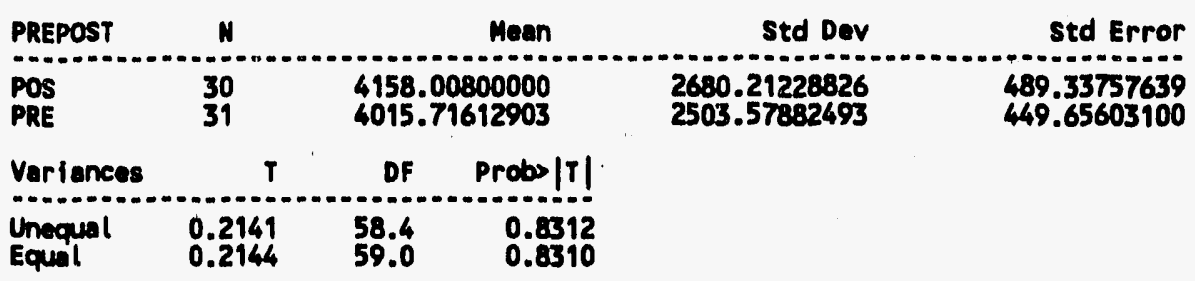

For HO: Variances are equial, F' $=1.15 \quad$ DF $=(29,30) \quad$ ProbsFl $=0.7120$

RSQCL $=0$ FUEL=GAS EPLAN=2 URBRUR=RURAL Variable: MAC

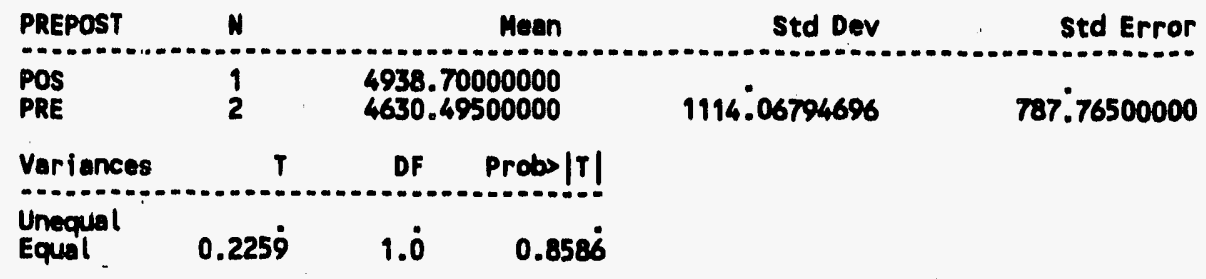

NOTE: All values are the same for one CLASS level.

RSOCL=O FUEL =GAS EPLAN=2 URBRURMURBAN Variable: MAC

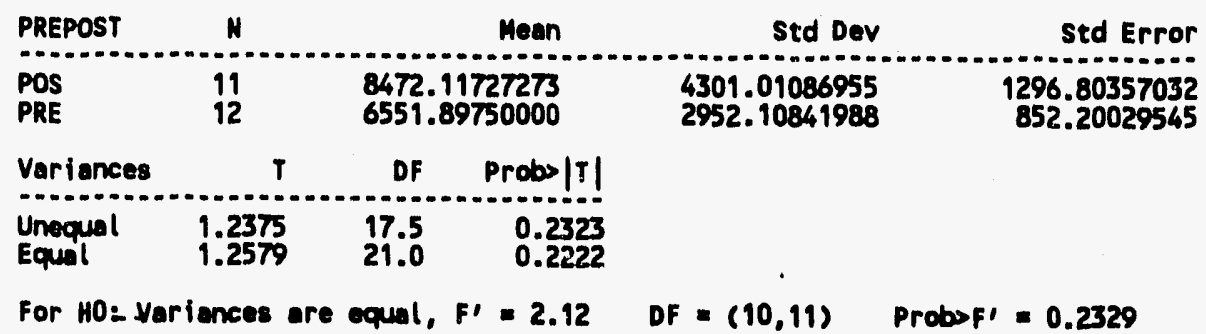




\section{Normalized Annual Consumption of 1990 Participants (by R-squared level)}

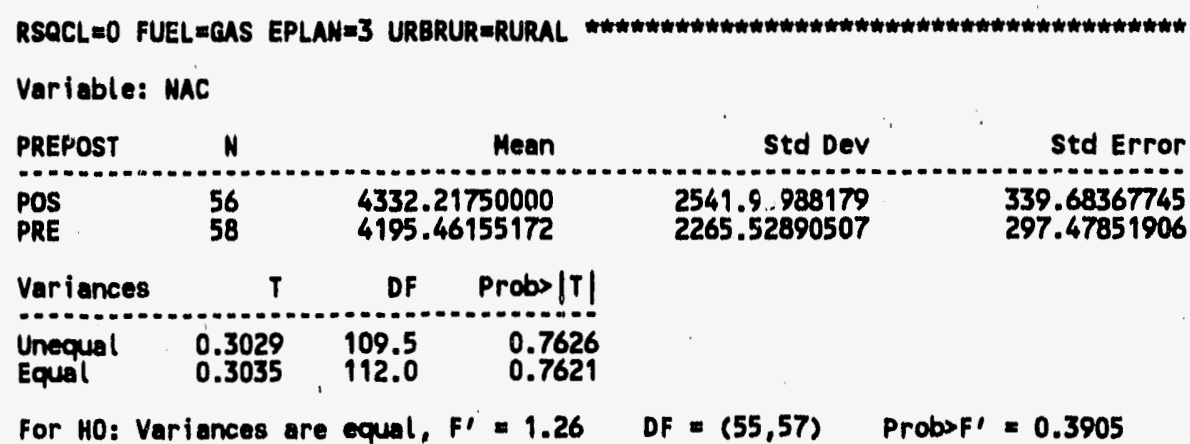

RSQCL=O FUEL=GIS EPLAN=3 URBRUR=URBAN Variable: MAC

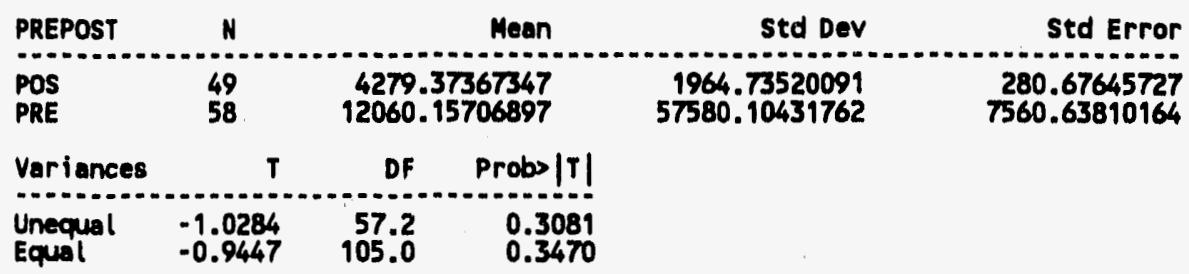

For HO: Variances are equal, $F^{\prime}=858.89 \quad$ DF $=(57,48) \quad$ Probsf' $=0.0000$

RSQCL=O FUEL=GAS EPLAN=4 URBRUR=RURAL Variable: MAC

\begin{tabular}{|c|c|c|c|c|}
\hline PREPOST & $N$ & Mean & Std Dev & Std Error \\
\hline $\begin{array}{l}\text { POS } \\
\text { PRE }\end{array}$ & $\begin{array}{l}49 \\
54\end{array}$ & $\begin{array}{l}5737.39877551 \\
6470.98129630\end{array}$ & $\begin{array}{l}3901.26923613 \\
5168.65169668\end{array}$ & $\begin{array}{l}557.32417659 \\
703.36440639\end{array}$ \\
\hline Variances & $T$ & Probs $|T|$ & & \\
\hline $\begin{array}{l}\text { Unequal } \\
\text { Equal }\end{array}$ & $\begin{array}{l}-0.8175 \\
-0.8065\end{array}$ & $\begin{array}{l}0.4157 \\
0.4218\end{array}$ & & \\
\hline
\end{tabular}

RSOCL $=0$ FUEL =GAS EPLAN=4 URBRUR=URBAN Variable: MAC

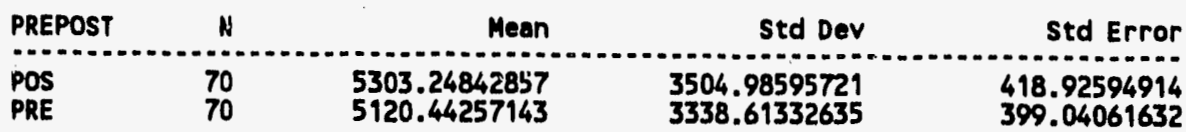

\begin{tabular}{llll} 
Variances & $T$ & DF & Probs|T| \\
\hline Unequal & 0.3160 & 137.7 & 0.7525 \\
Equal & 0.3160 & 138.0 & 0.7525
\end{tabular}

For HO: Variances are equal, $F^{\prime}=1.10 \quad$ DF $=(69,69) \quad$ Probsf' $=0.6874$ 


\section{Normalized Annual Consumption of 1990 Participants (by R-squared level)}

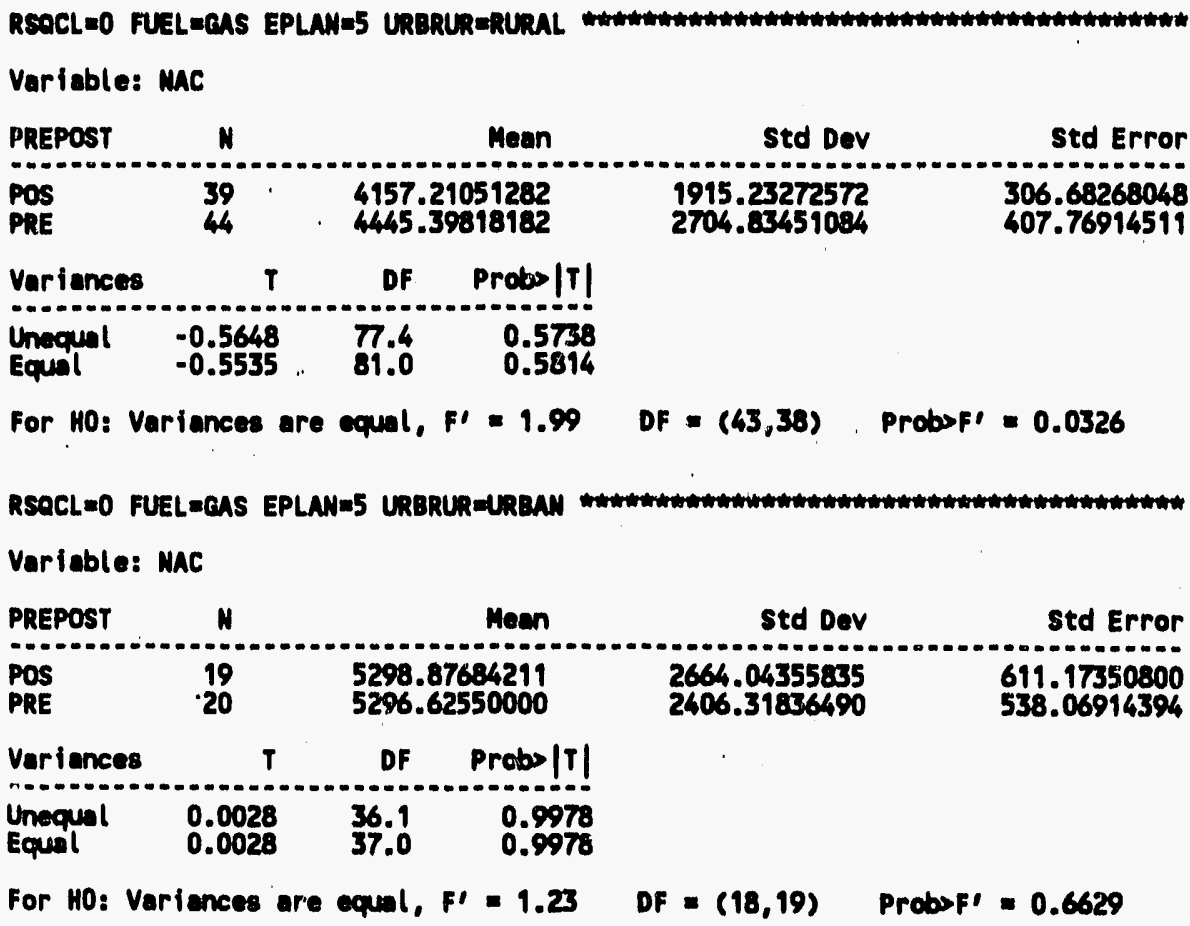




\section{Normalized Annual Consumption of 1990 Participants (by R-squared level)}

RSOCL=O FUEL=OIL EPLAN=1 URBRUR=RURAL Variable: NAC

\begin{tabular}{|c|c|c|c|c|}
\hline & $N$ & Mean & std Dev & -ror \\
\hline OS & $\begin{array}{l}45 \\
40\end{array}$ & $\begin{array}{l}5457.03264444 \\
5726.80025000\end{array}$ & $\begin{array}{l}3252.51504028 \\
4036.03925714\end{array}$ & $\begin{array}{l}4 \\
6\end{array}$ \\
\hline
\end{tabular}

\begin{tabular}{llll} 
Variances & $T$ & DF & Probs $|\mathrm{T}|$ \\
\hdashline Unequal & -0.3366 & 74.9 & 0.7374 \\
Equal & -0.3409 & 83.0 & 0.7341
\end{tabular}

For HO: Variances are equal, $F^{\prime}=1.54 \quad$ OF $=(39,44) \quad$ Prob>F' $=0.1656$

RSQCL=O FUEL=OIL EPLAN=1 URBRUR=URBAN Variable: NAC

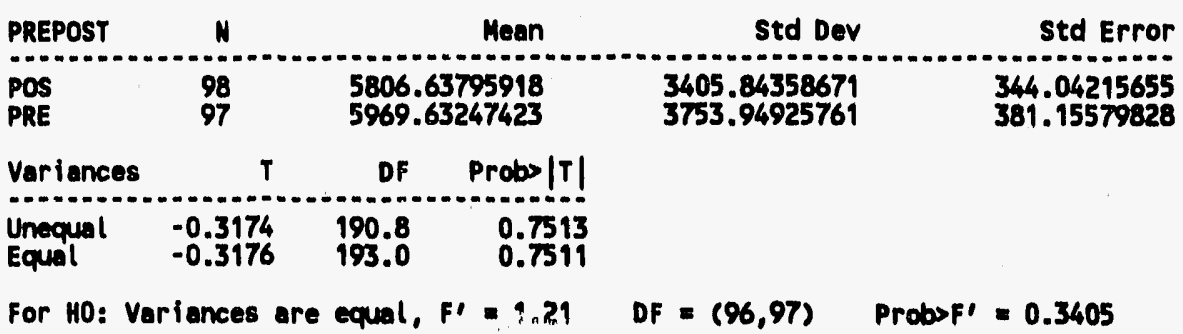

RSQCL=O FUEL=OIL EPLAN=2 URBRUR RRURAL Variable: NAC

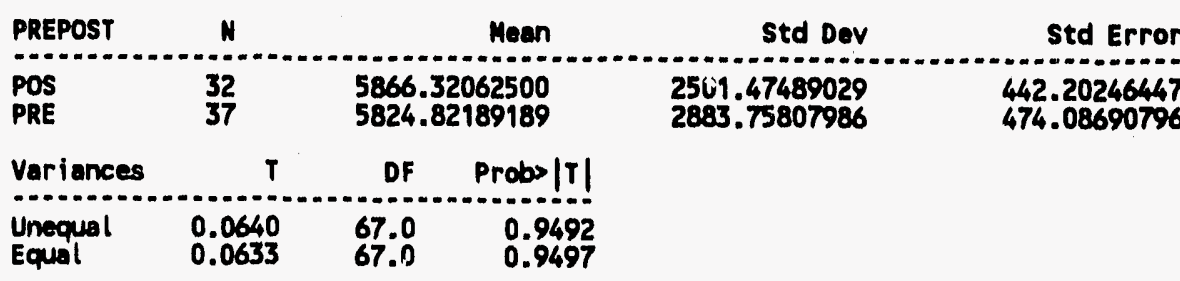

For HO: Variances are equal, F' $=1.33 \quad$ DF $=(36,31) \quad$ ProbsF' $=0.4226$

RSACL $=0$ FUEL=OIL EPLAN=2 URBRUR=URBAN Variable: MAC

\begin{tabular}{|c|c|c|c|c|c|}
\hline PREPOST & N & & Mean & std Dev & Std E'rror \\
\hline $\begin{array}{l}\text { POS } \\
\text { PRE }\end{array}$ & $\begin{array}{l}67 \\
64\end{array}$ & $\begin{array}{l}5555 \\
5477\end{array}$ & $\begin{array}{l}925373 \\
531250\end{array}$ & $\begin{array}{l}3797.47754761 \\
3667.88056624\end{array}$ & $\begin{array}{l}463.93572195 \\
458.48507178\end{array}$ \\
\hline Variances & $T$ & DF & Probs $|\mathrm{T}|$ & & \\
\hline $\begin{array}{l}\text { Unequal } \\
\text { Equal }\end{array}$ & $\begin{array}{l}0.1185 \\
0.1184\end{array}$ & $\begin{array}{l}129.0 \\
129.0\end{array}$ & $\begin{array}{l}0.9059 \\
0.9059\end{array}$ & - & \\
\hline
\end{tabular}




\section{Normalized Annual Consumption of 1990 Participants (by R-squared level)}

RSACL=O FUEL=OIL EPLAN=3 URBRUR=RURAL Variable: MAC

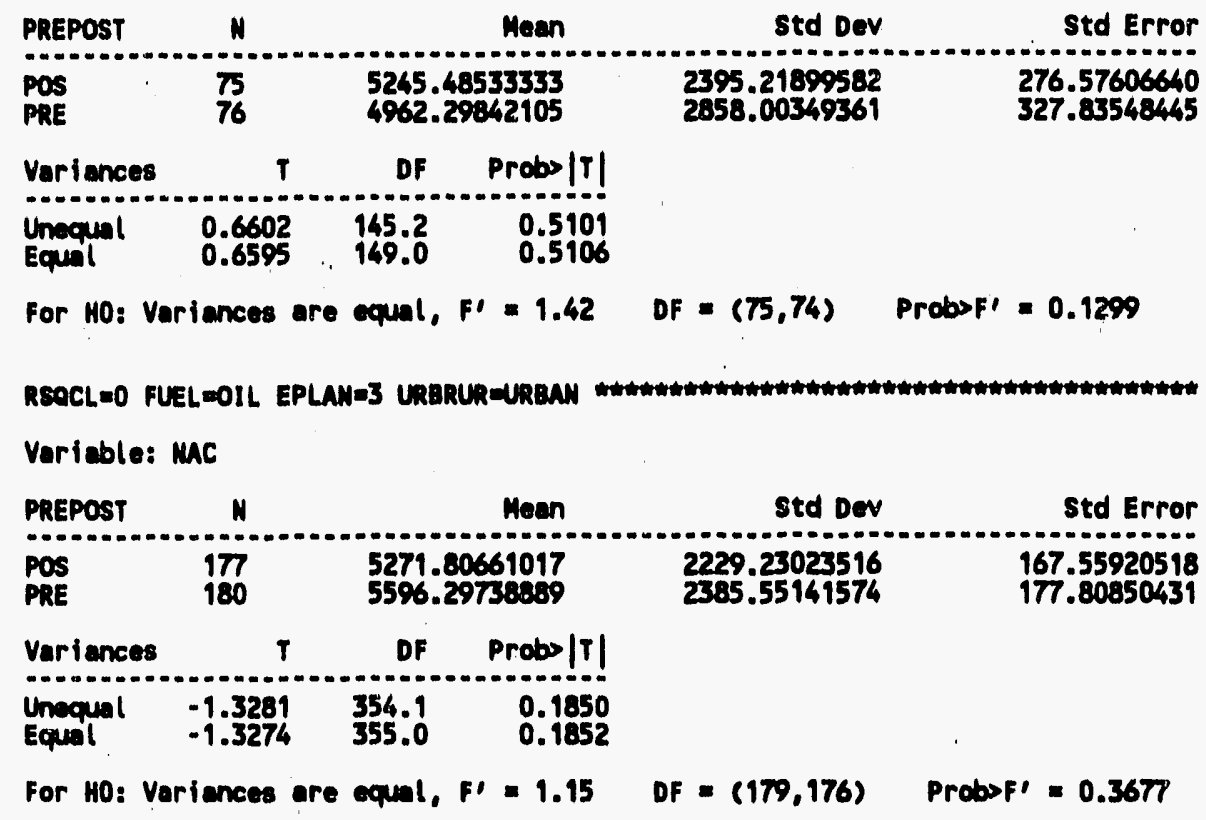

RSOCL=O FUELOOIL EPLAYEL URERUR=RURAL Variable: MAC

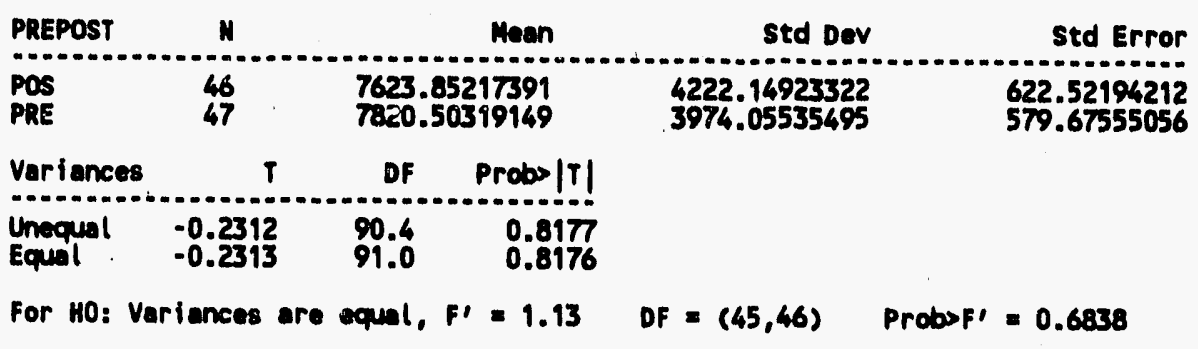

RSACL=O FUEL=OIL EPLAN=4 URBRUREURBAN Variaple: MAC

\begin{tabular}{|c|c|c|c|c|}
\hline PREPOST & $N$ & Mean & Std Dev & Std Error \\
\hline $\begin{array}{l}\text { POS } \\
\text { PRE }\end{array}$ & $\begin{array}{l}41 \\
39\end{array}$ & $\begin{array}{l}8601.31195122 \\
8890.32974359\end{array}$ & $\begin{array}{l}5621.50986284 \\
6259.17246140\end{array}$ & $\begin{array}{r}877.93234277 \\
1002.26973059\end{array}$ \\
\hline Variances & $T$ & Probs $|\mathrm{T}|$ & & \\
\hline $\begin{array}{l}\text { Unequal } \\
\text { Equal }\end{array}$ & $\begin{array}{l}-0.2169 \\
-0.2175\end{array}$ & $\begin{array}{l}0.8289 \\
0.8284\end{array}$ & & \\
\hline
\end{tabular}




\section{Normalized Annual Consumption of 1990 Participants}

(by R-squared level)

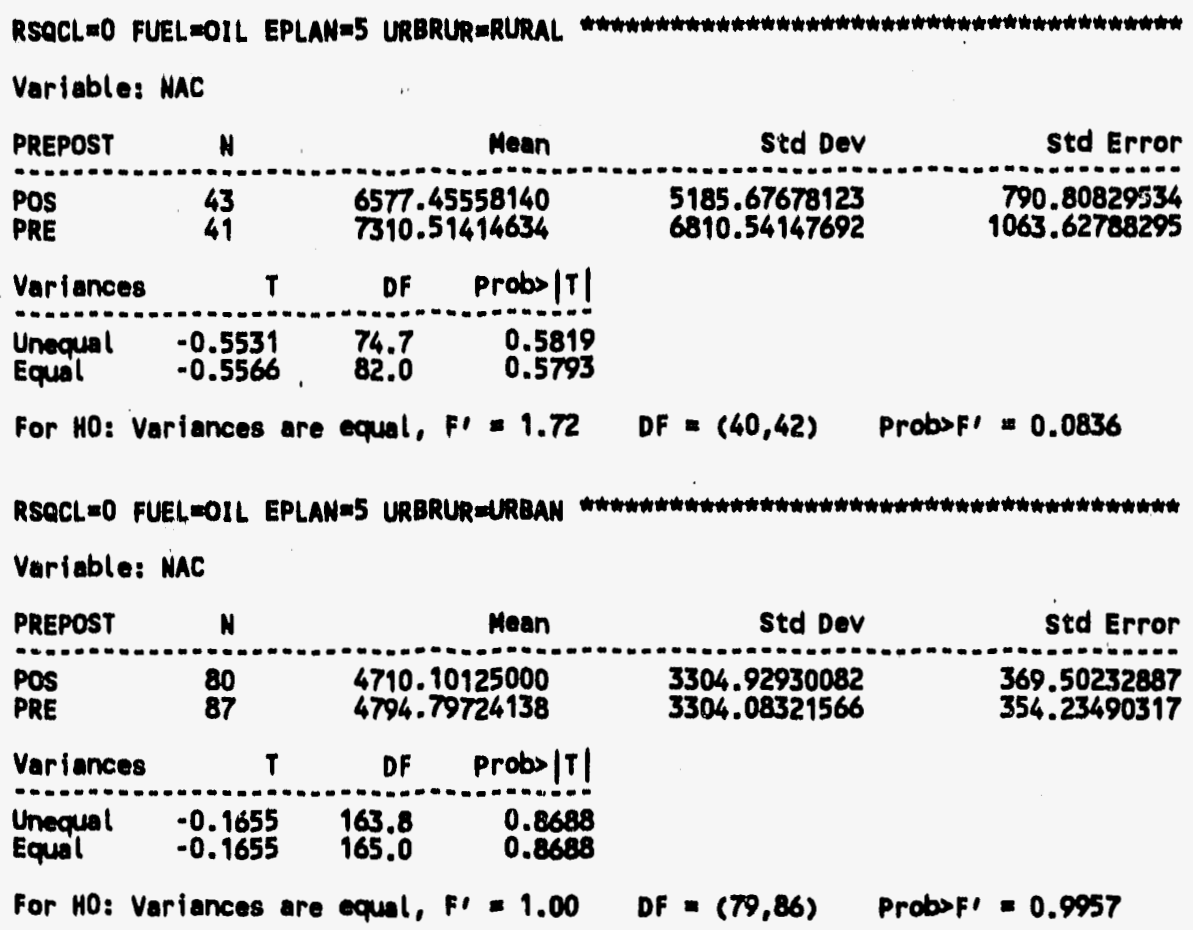




\section{Normalized Annual Consumption of 1990 Participants}

(by R-squared level)

RSOCL=O FUELEPROP EPLAN=1 URBRUR=LREAN Variable: MAC

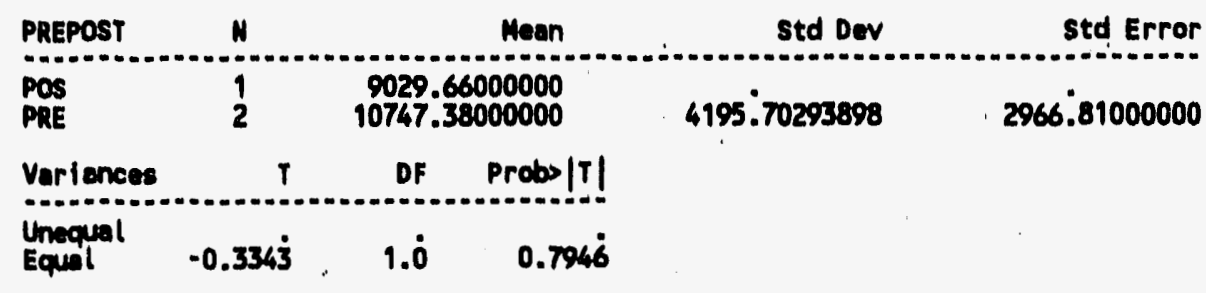

WOTE: All values are the same for on class level.

RSACL $=0$ FUEL APROP EPLANMZ URERURARURAL Variable: MAC

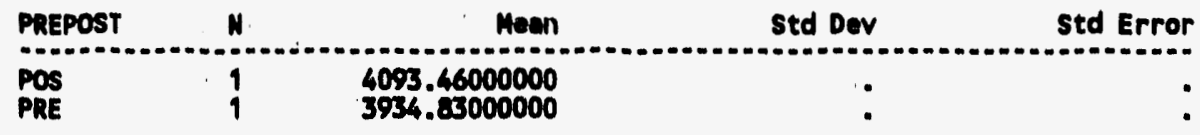

Variences $\quad$ T PF Probs/T!

Unequal : : :

WOTE: All values are the same for one CLASS level.

RSOCL $=0$ FUELAPROP EPLAN=3 URBRURMUREAN Variable: MAC

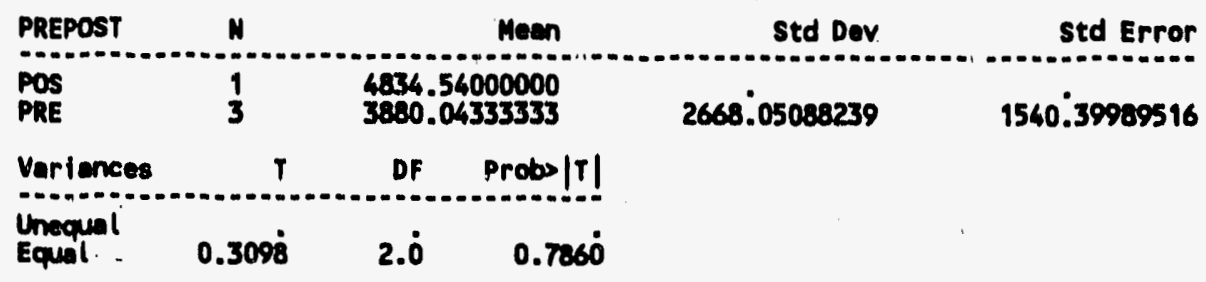

NOTE: All values are the same for one Class level.

RSOCL=O FUEL=PROP EPLANEL URBRUR=RURAL Variable: MAC

\begin{tabular}{|c|c|c|c|c|}
\hline REPOST & $\boldsymbol{N}$ & Mean & std Dev & std Error \\
\hline $\begin{array}{l}\text { POS } \\
\text { PRE }\end{array}$ & 2 & $\begin{array}{l}4482.16000000 \\
3552.98500000\end{array}$ & $\begin{array}{r}2705.50368190 \\
902.82686715\end{array}$ & \\
\hline
\end{tabular}

\begin{tabular}{llll} 
Variances & $T$ & DF & Probs $|T|$ \\
\hline Unequal & 0.4607 & 1.2 & 0.7175 \\
Equal & 0.4607 & 2.0 & 0.6902
\end{tabular}

For HO: Variances are equal, F' $=8.98 \quad$ DF $=(1,1) \quad$ Probsf' $=0.4101$ 


\section{Normalized Annual Consumption of 1990 Participants (by R-squared level)}

RSOCL $=0.5$ FUEL=ELEC EPLAN=1 URBRURMURBAN Variable: MAC

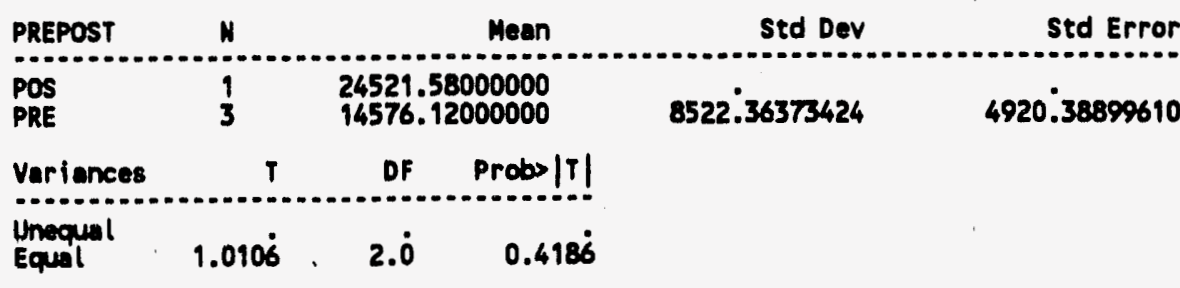

MOTE: All values are thi: same for one CLASS level.

RSQCL $=0.5$ FUEL=ELEC EPLAN=3 URBRUR=RURAL Variable: MAC

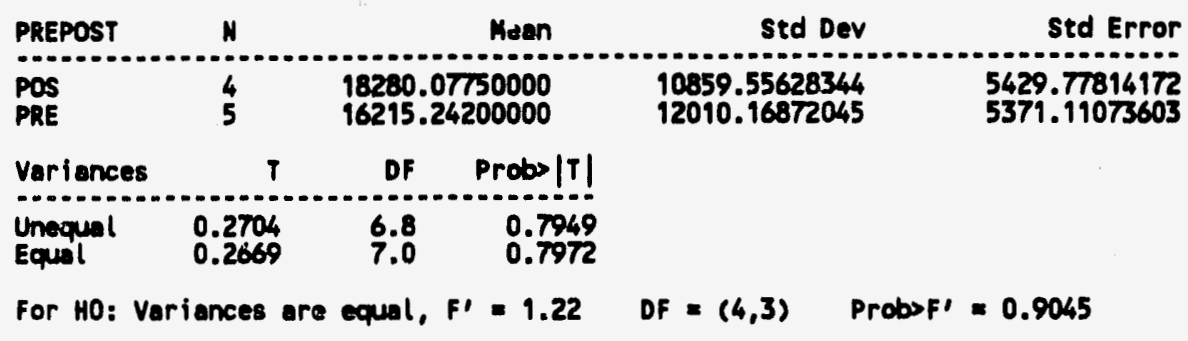

RSOCL $=0.5$ FUEL=ELEC EPLAN=3 URBRUR URBBAN Variable: HAC

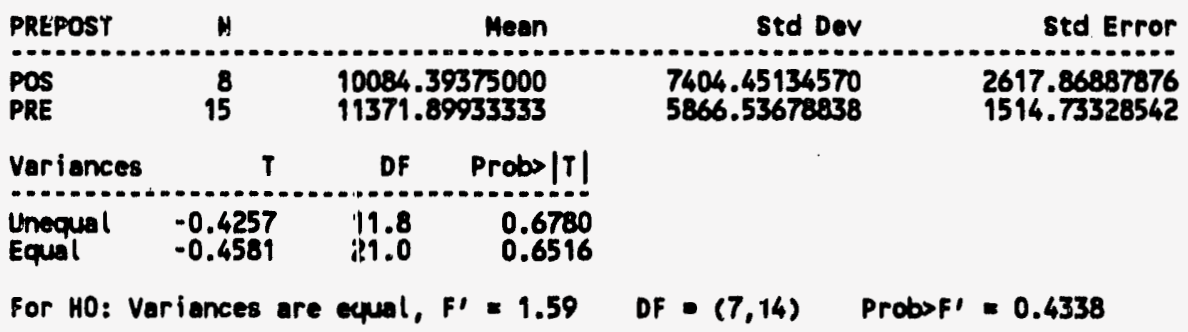

RSOCL $=0.5$ FUEL=ELEC EPLAN=4 URBRUR=RURAL Variable: NAC

\begin{tabular}{|c|c|c|c|c|}
\hline PREPOST & N & Mean & Std Dev & Std Error \\
\hline $\begin{array}{l}\text { POS } \\
\text { PRE }\end{array}$ & $\begin{array}{l}4 \\
1\end{array}$ & $\begin{array}{r}8725.52250000 \\
20315.09000000\end{array}$ & $\begin{array}{c}3847.19070262 \\
\text {. }\end{array}$ & 1923.59535131 \\
\hline Variance & $T$ & Probs $|T|$ & & \\
\hline $\begin{array}{l}\text { Unequal } \\
\text { Equal }\end{array}$ & -2.6944 & $0.074 i$ & . & \\
\hline
\end{tabular}




\section{Normalized Annual Consumption of 1990 Participants (by R-squared level)}

REACL 0.5 FUELECAS EPLAMEI URBRLR=RUAL Varieble: MAC

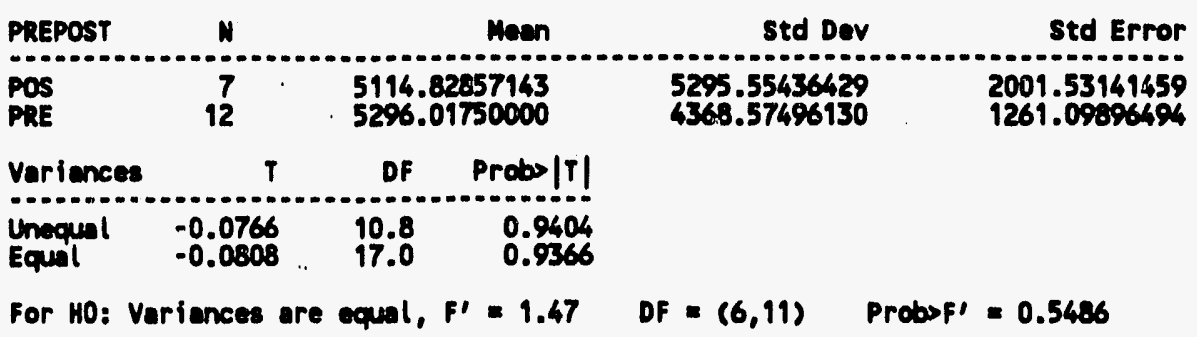

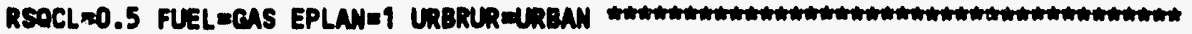
Variable: MAC

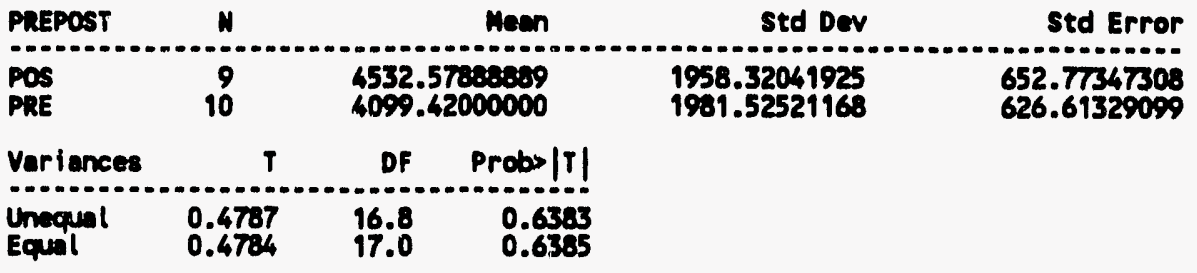

For HO: Variances are cqual, F' $=1.02 \quad$ DF $-(9,8) \quad$ ProbsFl $=0.9844$

RSOCL=0.5 FUEL=CAS EPLANG2 URBRUR=RURAL Varieble: MAC

\begin{tabular}{l|ccccc} 
PREPOST & $N$ & & Mean & Std Dev & Std Error \\
\hline POS & 2 & 14964.92000000 & 8405.80257203 & 594.80000000 \\
PRE & 2 & 12906.22000000 & 6935.13360425 & 4903.88000000
\end{tabular}

\begin{tabular}{llll} 
Variances & $T$ & DF & Probs $|T|$ \\
\hline Unequal & 0.2672 & 1.9 & 0.8157 \\
Equal & 0.2672 & 2.0 & 0.8164
\end{tabular}

For HO: Variances ore equl, F' $=1.47 \quad \mathrm{DF}^{\prime}=(1,1) \quad$ Probsfl $=0.8703$

RSOCL=0.5 FUEL=CAS EPLAHE2 URBRUR=URBAN Variable: MAC

\begin{tabular}{l|crrr} 
PREPOST & $N$ & Mean & Std Dev & Std Error \\
\hline POS & 5 & 7025.99200000 & 3539.81375053 & 1583.05283478 \\
PRE & 2 & 95048.26000000 & 11725.75376252 & 8291.36000000
\end{tabular}

\begin{tabular}{llll} 
Variances & $T$ & DF & Probs $|T|$ \\
\hline Unequal & -0.9504 & 1.1 & 0.5107 \\
Equat & -1.5653 & 5.0 & 0.1783
\end{tabular}

For HO: Veriances are equal, F' $=10.97$ DF $=(1,4) \quad$ ProbsF' $=0.0592$ 


\section{Normalized Annual Consumption of 1990 Participants (by R-squared level)}

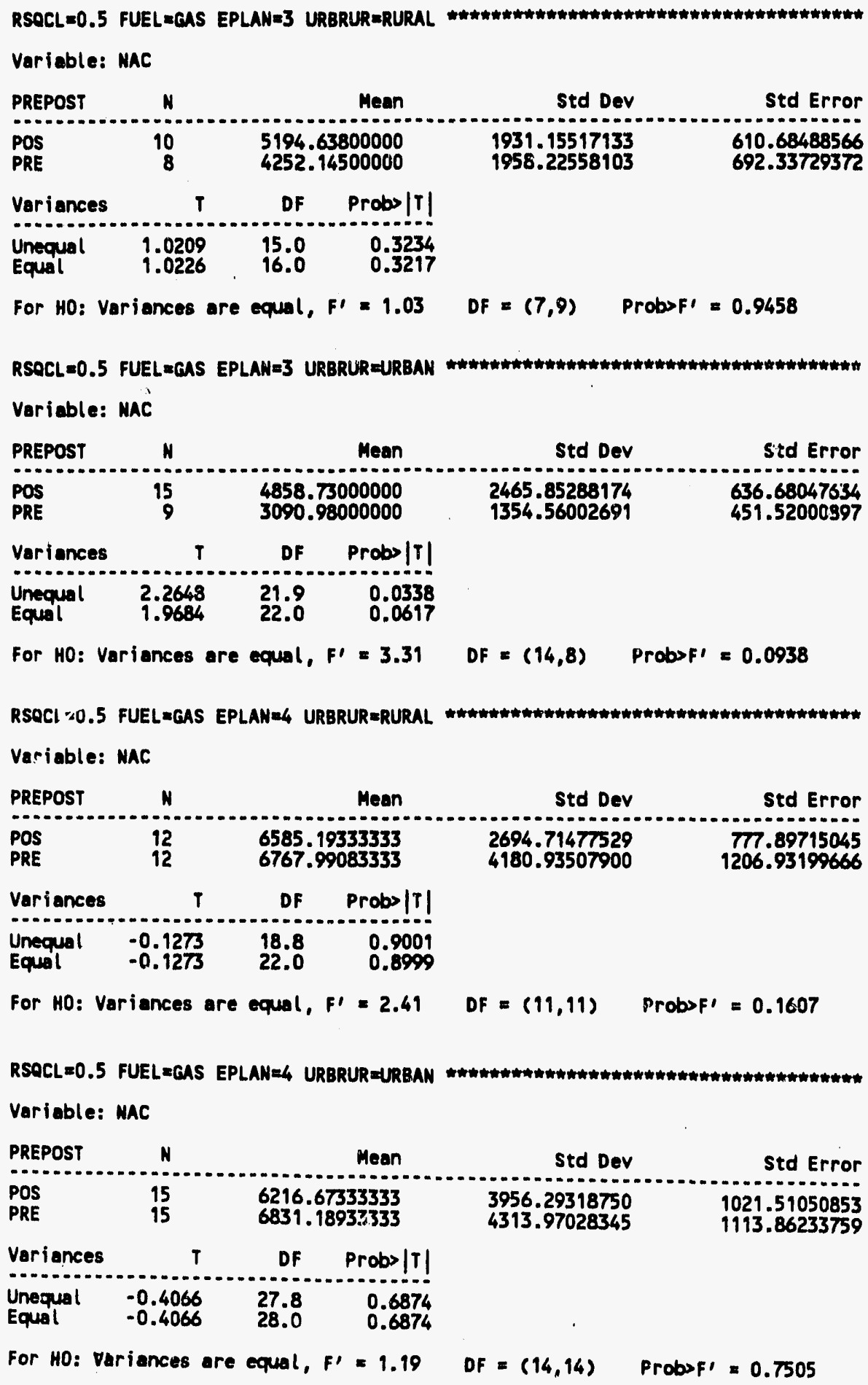




\section{Normalized Annual Consumption of 1990 Participants (by R-squared level)}

RSQCL $=0.5$ FUEL=CAS EPLANIS URQRUR=RURAL Variable: MAC

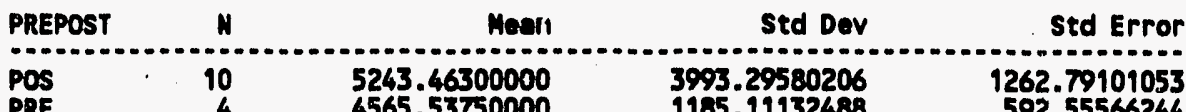

$\begin{array}{lllll}\text { PRE } & 4 & 4565.53750000 & 1185.11132488 & 592.55566244\end{array}$

\begin{tabular}{llll} 
Variences & $T$ & DF & Probs|r|r| \\
\hline Unequal & 0.4860 & 11.7 & 0.6360
\end{tabular}

$\begin{array}{llll}\text { Unequal } & 0.4860 & 11.7 & 0.6360 \\ \text { Equal } & 0.3266 & 12.0 & 0.7496\end{array}$

For HO: Variances are equal, F' $=11.3 ;$ : $\quad$ DF $=(9,3) \quad$ ProbsF' $=0.0704$

RSOCL $=0.5$ FUEL=CAS EPLAN=5 URBRUR=URBAN Voriable: MAC

\begin{tabular}{|c|c|c|c|c|}
\hline PREPOST & N & Mean & Std Dev & Std Error \\
\hline $\begin{array}{l}\text { POS } \\
\text { PRE }\end{array}$ & $\begin{array}{l}8 \\
5\end{array}$ & $\begin{array}{l}4794.82375000 \\
3161.02600000\end{array}$ & $\begin{array}{l}3985.12720421 \\
1012.53443953\end{array}$ & $\begin{array}{r}1408.95523500 \\
452.81916727\end{array}$ \\
\hline Variances & $T$ & Probs $|T|$ & . & \\
\hline $\begin{array}{l}\text { Unequal } \\
\text { Equal }\end{array}$ & $\begin{array}{l}1.1040 \\
0.8853\end{array}$ & $\begin{array}{l}0.3004 \\
0.3949\end{array}$ & & \\
\hline
\end{tabular}




\section{Normalized Annual Consumption of 1990 Participants}

(by R-squared level)

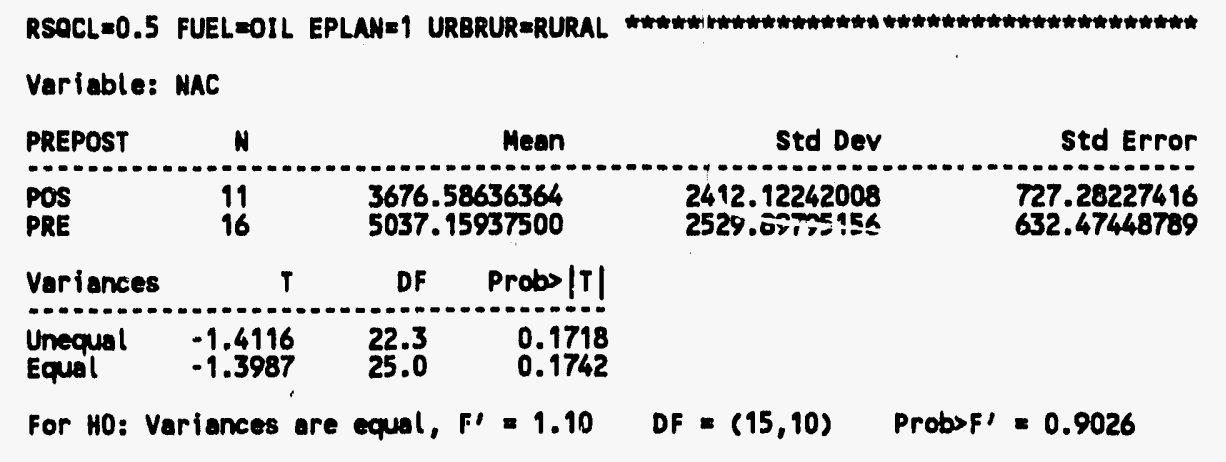

RSOCL $=0.5$ FUEL=OIL EPLAN=1 URBRUR=URBAN Variable: MAC

\begin{tabular}{|c|c|c|c|c|}
\hline PREPOST & $N$ & Mean & Std Dev & Std Error \\
\hline $\begin{array}{l}\text { POS } \\
\text { PRE }\end{array}$ & $\frac{23}{22}$ & $\begin{array}{l}7417.26391304 \\
8433.68045455\end{array}$ & $\begin{array}{l}7977.43990721 \\
7238.74705358\end{array}$ & $\begin{array}{l}1663.41120793 \\
1543.30605734\end{array}$ \\
\hline
\end{tabular}

\begin{tabular}{llll} 
Variances & $T$ & DF & Probs $|T|$ \\
\hline Unequal & -0.4479 & 42.9 & 0.6565 \\
Equal & -0.4470 & 43.0 & 0.6571
\end{tabular}

For HO: Variances are equal, $F^{\prime}=1.21 \quad$ DF $=(22,21) \quad$ ProbsF' $=0.6591$

RSQCL $=0.5$ FUEL=OIL EPLAN=2 URBRUR=RURAL Variable: MAC

\begin{tabular}{l|cccc} 
PREPOST & $N$ & Mean & Std Dev & Std Error \\
\hline POS & 13 & 5710.66384615 & 3368.94426137 & 934.37702143 \\
PRE & 7 & 6081.39857143 & 2324.20315354 & 878.46622009
\end{tabular}

\begin{tabular}{llll} 
Variances & $T$ & DF & Probs $|T|$ \\
\hdashline Unequal. & -0.2891 & 16.6 & 0.7761 \\
Equal & -0.2584 & 18.0 & 0.7990
\end{tabular}

For HO: Variances are equal, F' $=2.10 \quad$ DF $=(12,6) \quad$ Probsf' $=0.3725$

RSOCL $=0.5$ FUEL=0IL EPLAN=2 URBRUR=URBAN Variable: NAC

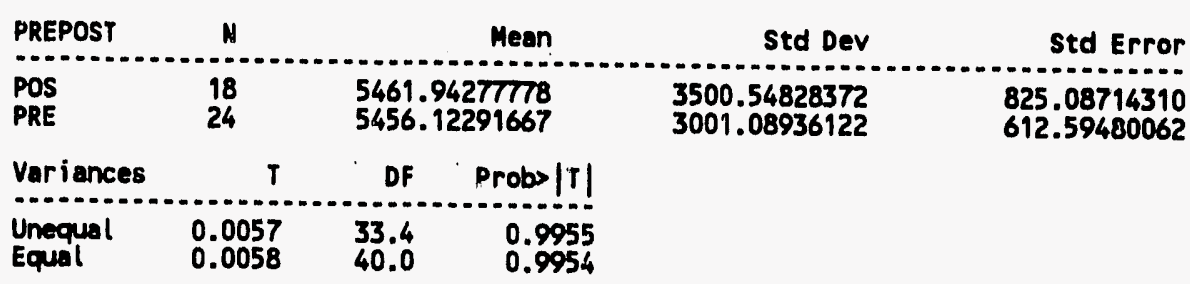

For HO: Voriances ore equal, $F^{\prime}=1.36 \quad$ DF $=(17,23) \quad$ Probs $F^{\prime}=0.4847$ 


\section{Normalized Annual Consumption of 1990 Participants}

(by R-squared level)

RSACL $=0.5$ FUEL=OIL EPLAN=3 URBRUR=RURAL Variable: MAC

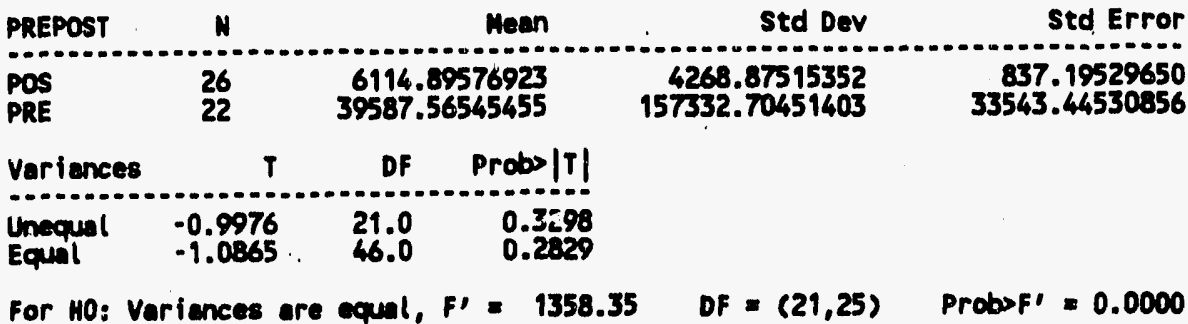

RSACL $=0.5$ FUEL=OIL EPLANE3 URBRUR=LREAN Variable: MAC

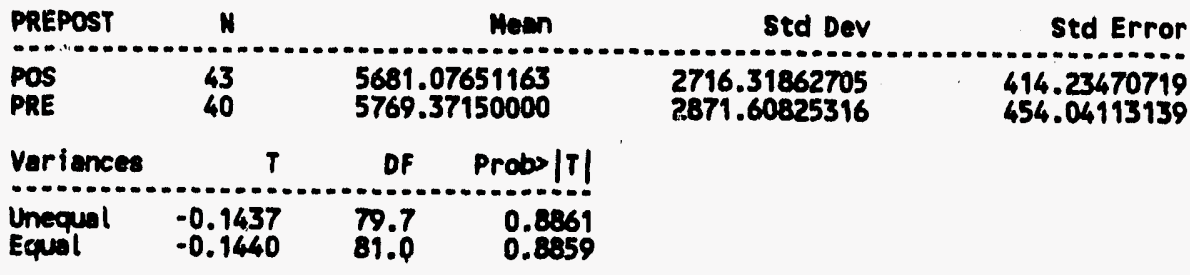

For HO: Variances are equal, F'= $1.12 \quad$ DF $=(39,42) \quad$ ProbsF' $=0.7223$

RSOCL $=0.5$ FUEL $=O I L$ EPLANEL URBRUR=RURAL Variable: MAC

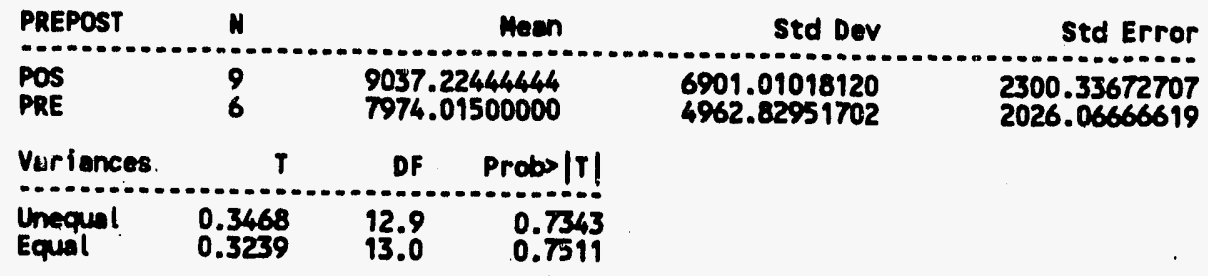

For HO: Variances are equal, F' $=1.93 \quad$ DF $=(8,5) \quad$ ProbsF' $=0.4849$

RSOCL=0.5 FUEL=OIL EPLANEL URBRUR=URBAN Variable: MAC

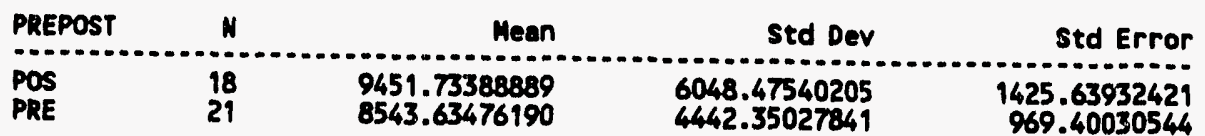

\begin{tabular}{llll} 
Variances & $T$ & DF & Probs|T! \\
\hline Unequal & 0.5267 & 30.8 & 0.6022
\end{tabular}

$\begin{array}{llll}\text { Unequal } & 0.5267 & 30.8 & 0.6022 \\ \text { Equal } & 0.5393 & 37.0 & 0.5929\end{array}$

For HO: Variances are equal, F' $=1.85 \quad$ DF $=(17,20) \quad$ Probsf' $=0.1873$ 


\section{Normalized Annual Consumption of 1990 Participants (by R-squared level)}

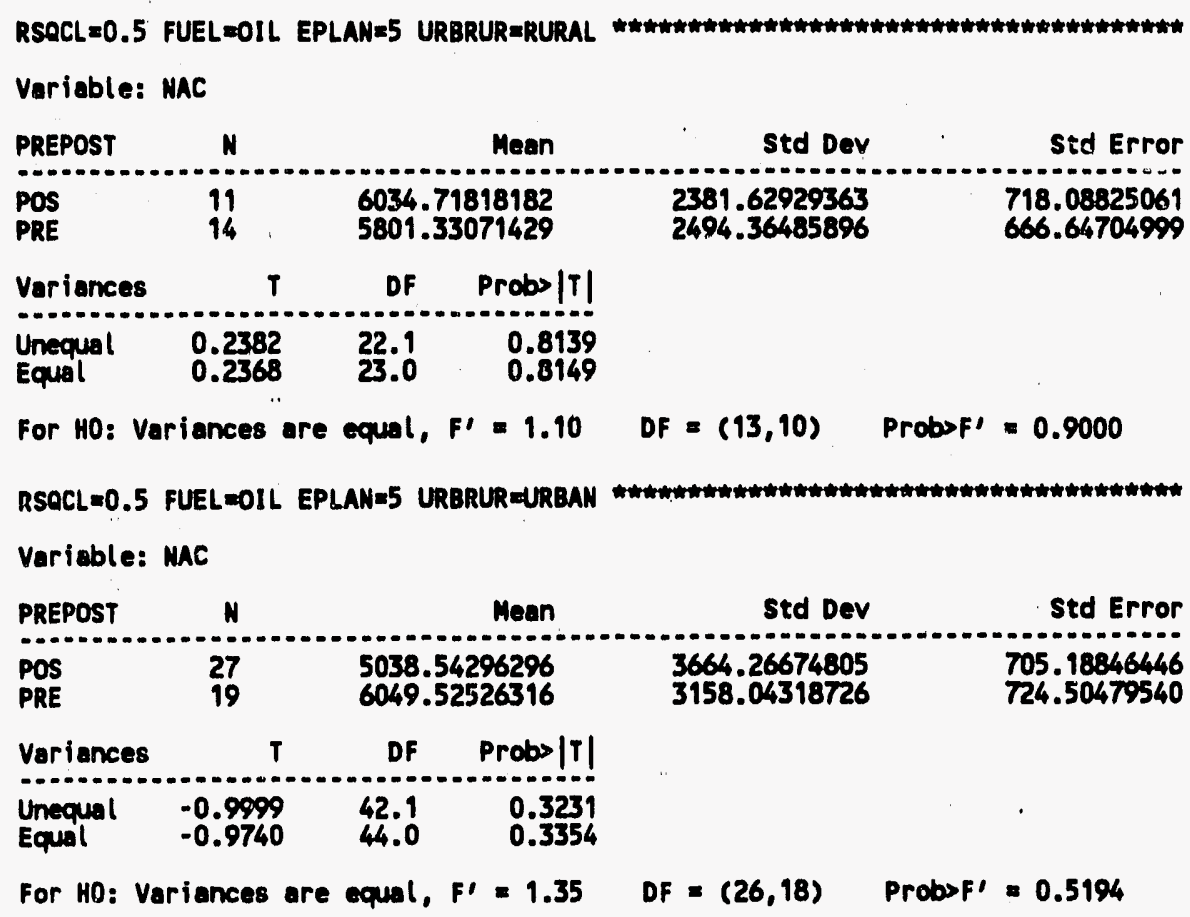




\section{Normalized Annual Consumption of 1990 Participants (by R-squared level)}

REQCL $=0.5$ FUEL $=P R O P$ EPLAN=3 URBRUR=RURAL Vorieble: MAC

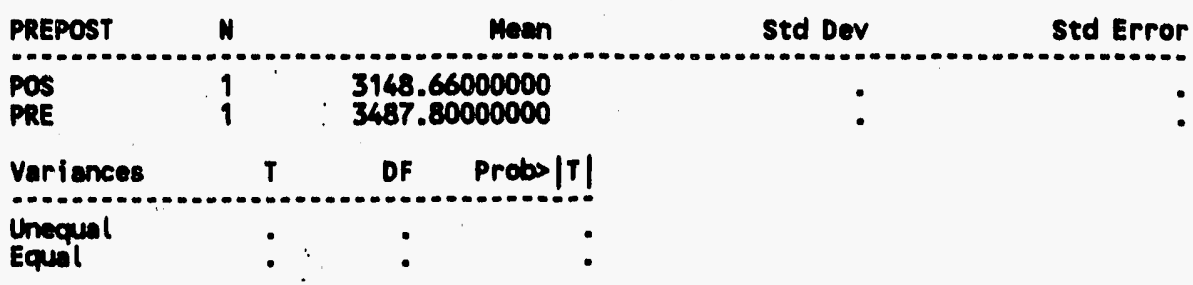

MOTE: All values ore the same for one CLASS level.

RSOCL=0.5 FUEL=PROP EPLANEL URBRUR=RURAL Variable: MAC

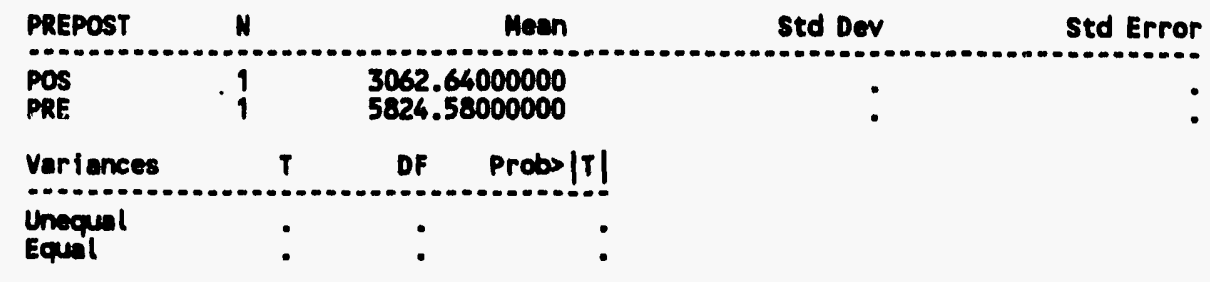

MOTE: All values are the same for one Class level.

RSOCL $=0.5$ FUELEPROP EPLANEL URBRUREURBAN Variable: MAC

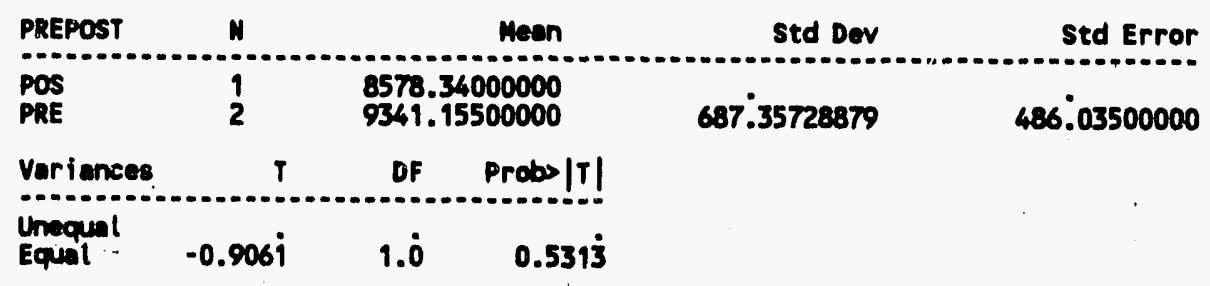

NOTE: All values are the same for one Class level. 


\section{Normalized Annual Consumption of 1990 Participants (by R-squared level)}

RSOCL=0.8 FUEL=ELEC EPLAN=1 URBRUR 0 RURAL Variable: MAC

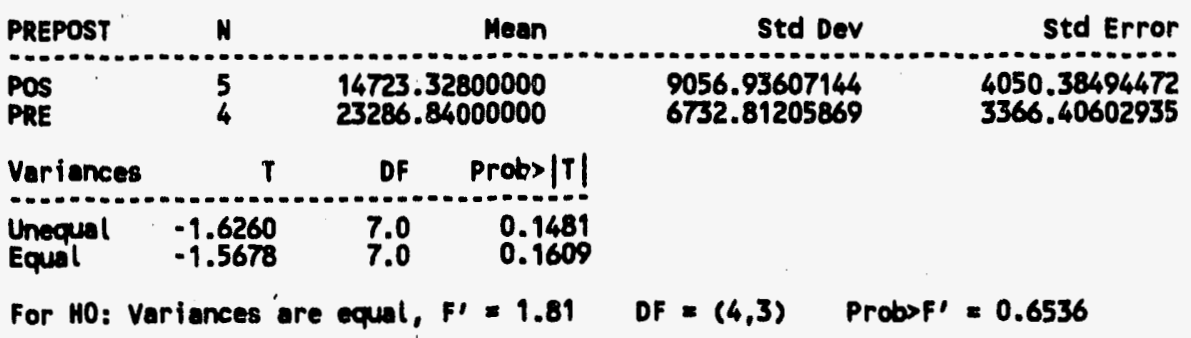

RSOCL=0.8 FUEL=ELEC EPLAN=1 URBRUR=URBAN Variable: MAC

\begin{tabular}{l|ccccc} 
PREPOST & $N$ & & Mean & Std Dev & Std Error \\
\hline POS & 10 & 16854.61500000 & 3909.24727480 & 1236.21253252 \\
PRE & 8 & 18080.69750000 & 3947.70898543 & 1395.72589688
\end{tabular}

\begin{tabular}{llll} 
Variances & $T$ & DF & Probs $|T|$ \\
\hdashline Unequal & -0.6576 & 15.1 & 0.5207 \\
Equal & -0.6584 & 16.0 & 0.5197
\end{tabular}

For HO: Variances are equal, F'=1.02 DF $=(7,9)$. ProbsF' $=0.9547$

RSOCL $=0.8$ FUEL=ELEC EPLAN=3 URBRUR=RURAL Variable: MAC

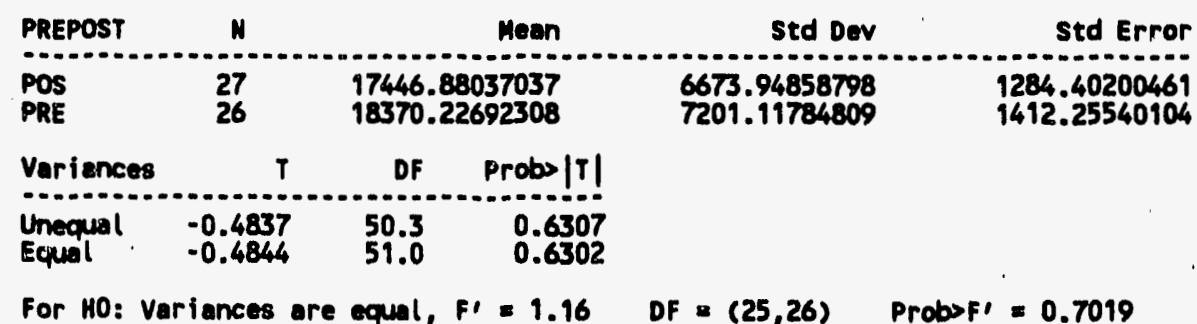

RSQCL $=0.8$ FUEL =ELEC EPLAN=3 URBRUR=URBAN Variable: NAC

\begin{tabular}{l|ccccc} 
PREPOST & $N$ & & Mean & Std bev & Std Error \\
\hline POS & 104 & 11137.56586538 & 6014.36574039 & 589.75708216 \\
PRE & 98 & 10929.64836735 & 6214.19473378 & 627.72846227
\end{tabular}

\begin{tabular}{llll|} 
Variances & $T$ & DF & Probs|T| \\
\hline Unequal & 0.2414 & 198.3 & 0.8095 \\
Equal & 0.2416 & 200.0 & 0.8093
\end{tabular}

For HO: Variances are equal, $F^{\prime}=1.07 \quad$ DF $=(97,103) \quad$ Probs $F \prime=0.7429$ 


\section{Normalized Annual Consumption of 1990 Participants (by R-squared level)}

RSOCL=0.8 FUELEELEC EPLAN=L LRBRUR=URBAN Variable: MAC

\begin{tabular}{l|cccc} 
PREPOST & $N$ & Mean & Std DeV & Std Error \\
\hline POS & 5 & 13884.90600000 & 10497.81769470 & 4694.76679615 \\
PRE & 3 & 11563.63666667 & 1414.73468415 & 816.79745073
\end{tabular}

\begin{tabular}{llll} 
Variances & $T$ & DF & Probs $|T|$ \\
\hline Unequal & 0.4879 & 4.2 & 0.6505 \\
Equal & 0.3692 & 6.0 & 0.7247
\end{tabular}

For HO: Variences are equal, F' $=55.06 \quad$ DF $=(4,2) \quad$ Probsf' $=0.0358$

RSQCL $=0 . R$ FUEL=CAS EPLAN=1 URBRUR=RURAL Variable: MAC

\begin{tabular}{|c|c|c|c|c|}
\hline PREPOST & N & Mean & std Dev & std Error \\
\hline $\begin{array}{l}\text { POS } \\
\text { PRE }\end{array}$ & $\begin{array}{l}7 \\
3\end{array}$ & $\begin{array}{l}10921.44285714 \\
14715.21000000\end{array}$ & $\begin{array}{l}8238.54935044 \\
7679.27469468\end{array}$ & $\begin{array}{l}3113.87896360 \\
4433.63131215\end{array}$ \\
\hline Variences & $T$ & Pross $|T|$ & & \\
\hline $\begin{array}{l}\text { Unequal } \\
\text { Equal. }\end{array}$ & $\begin{array}{l}-0.7002 \\
-0.6785\end{array}$ & $\begin{array}{l}0.5214 \\
0.5166\end{array}$ & & \\
\hline
\end{tabular}

For HO: Variances are equal, F' $=1.15 \quad$ DF $=(6,2) \quad$ ProbsF' $=1.0000$

RSQCL $=0.8$ FUEL=CAS EPLAN=1 URBRUR MURBAN Variable: NAC

\begin{tabular}{|c|c|c|c|c|}
\hline PREPOST & N & Mean & Std Dev & std Error \\
\hline $\begin{array}{l}\text { POS } \\
\text { PRE }\end{array}$ & $\begin{array}{l}3 \\
1\end{array}$ & $\begin{array}{l}7668.02666667 \\
4907.41000000\end{array}$ & 2772.10314354 & 1600.47449615 \\
\hline Variances & T & Probs|T| & & \\
\hline Equal & $0.862 i$ & $0.4793^{\circ}$ & & \\
\hline
\end{tabular}

NOTE: All values are the sume for one CLASS level.

RSOCL $=0.8$ FUEL=GAS EPLAN=2 URBRUR=LRBAN Variable: MAC

\begin{tabular}{|c|c|c|c|c|c|}
\hline PREPOST & N & & Mean & Std Dev & Std Error \\
\hline $\begin{array}{l}\text { POS } \\
\text { PRE }\end{array}$ & $\begin{array}{l}1 \\
3\end{array}$ & $\begin{array}{l}7966 . \\
7556 .\end{array}$ & $\begin{array}{l}900000 \\
6666677\end{array}$ & $38,16^{\circ} \cdot 10769935$ & $2203^{\circ} 23080748$ \\
\hline Variances & $T$ & DF & Probs $|T|$ & & \\
\hline $\begin{array}{l}\text { Unequal } \\
\text { Equal }\end{array}$ & $0.0929^{\circ}$ & $2 . \dot{0}$ & 0.9344 & & \\
\hline
\end{tabular}

NOTE: Aii values are the same for one CLASS level. 


\section{Normalized Annual Consumption of 1990 Participants (by R-squared level)}

RSQCL=0.8 FUEL=GAS EPLAN=3 URBRUR=RURAL Variable: MAC

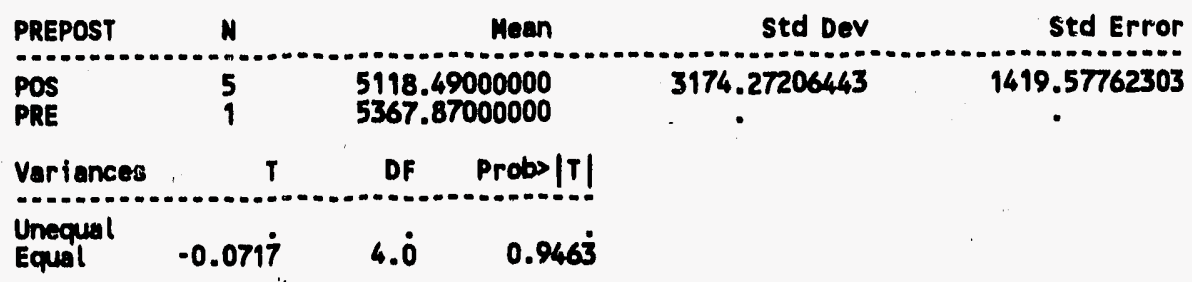

NOTE: All values ore the same for one ClASS level.

RSQCL $=0.8$ FUEL=CAS EPLAN=3 URBRURMLRBAN Variable: MAC

\begin{tabular}{l|cccc} 
PREPOST & $N$ & Mean & Std DeV & Std Error \\
\hline POS & 6 & 7470.71000000 & 3537.87548018 & 1444.33161666 \\
PRE & 3 & 5166.22666667 & 3176.59582280 & 1834.00845340
\end{tabular}

\begin{tabular}{llll} 
Variances & $T$ & DF & Probs $|T|$ \\
\hline Unequal & 0.9872 & 4.6 & 0.3736
\end{tabular}

$\begin{array}{llll}\text { Unequal } & 0.9872 & 4.6 & 0.3736 \\ \text { Equal } & 0.9478 & 7.0 & 0.3748\end{array}$

For HO: Variences are equal, F' $=1.24 \quad$ DF $=(5,2) \quad$ Probof' $=1.0000$

RSOCL $=0.8$ FUEL =GAS EPLAN=4 URBRUR=RURAL Variable: MAC

\begin{tabular}{|c|c|c|c|c|c|}
\hline PREPOST & N & & Mean & std Dev & Std Error \\
\hline $\begin{array}{l}\text { POS } \\
\text { PRE }\end{array}$ & $\frac{12}{7}$ & $\begin{array}{r}8820 . \\
10316 .\end{array}$ & $\begin{array}{l}083333 \\
714286\end{array}$ & $\begin{array}{l}6475.12021006 \\
5590.65701646\end{array}$ & $\begin{array}{l}1869.20619816 \\
2113.06973300\end{array}$ \\
\hline Variance & $\boldsymbol{T}$ & DF & Probs $|T|$ & & \\
\hline $\begin{array}{l}\text { Unequal. } \\
\text { Equal }\end{array}$ & $\begin{array}{l}-0.5302 \\
-0.5091\end{array}$ & $\begin{array}{l}14.3 \\
17.0\end{array}$ & $\begin{array}{l}0.6041 \\
0.6172\end{array}$ & & \\
\hline
\end{tabular}

RSQCL $=0.8$ FUEL $=G A S$ EPLAN=4 URBRUR URBAN Variable: MAC

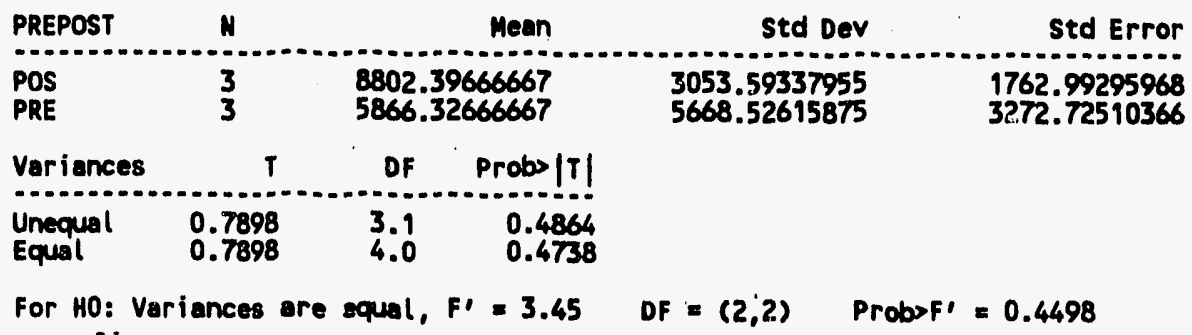




\section{Normalized Annual Consumption of 1990 Participants}

(by R-squared level)

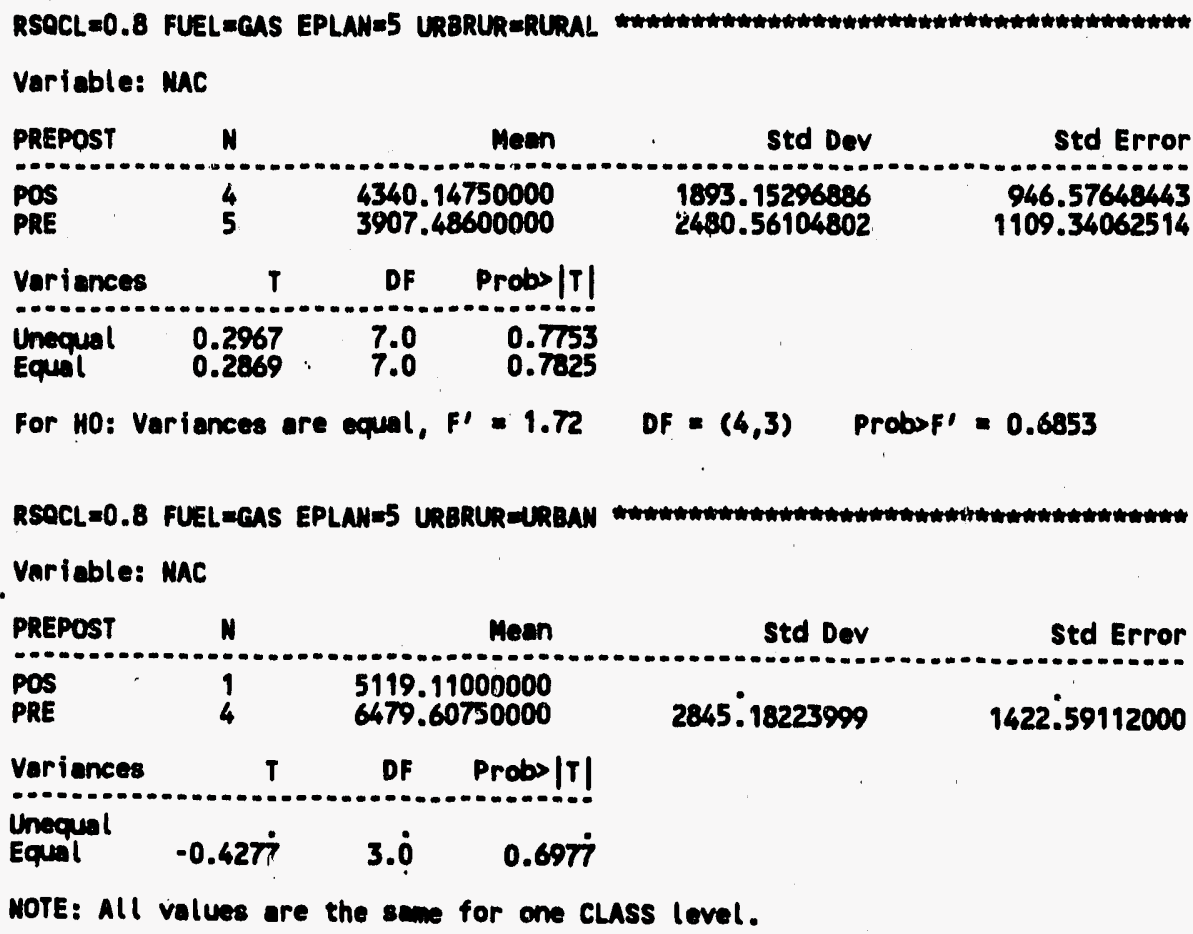




\section{Normalized Annual Consumption of 1990 Participants}

(by R-squared level)

RSOCL=0.8 FUEL=OIL EPLAN=1 URBRUR=RURAL Variable: MAC

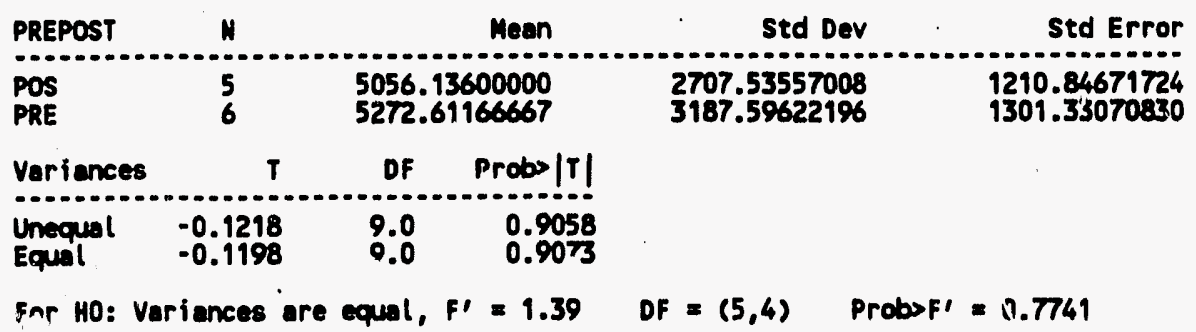

RSOCL $=0.8$ FUEL=OIL EPLAN=q URBRUR=URBAN Variable: MAC

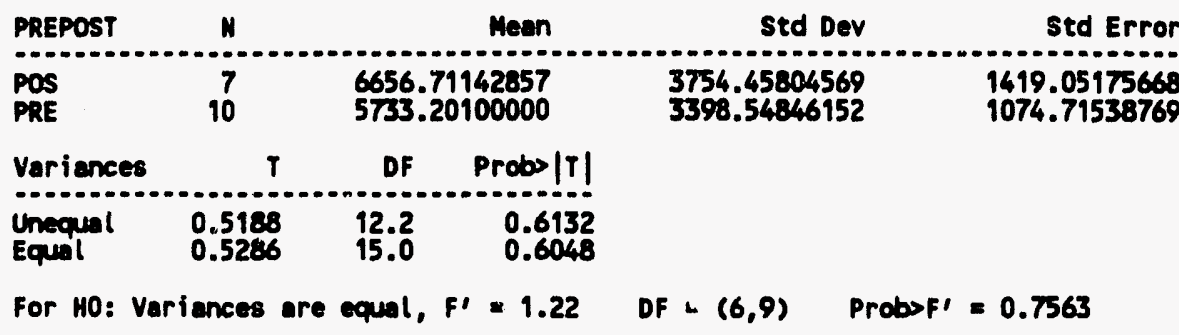

RSOCL $=0.8$ FUEL=OIL EPLAN=2 URBRUR=RURAL Voriable: MAC

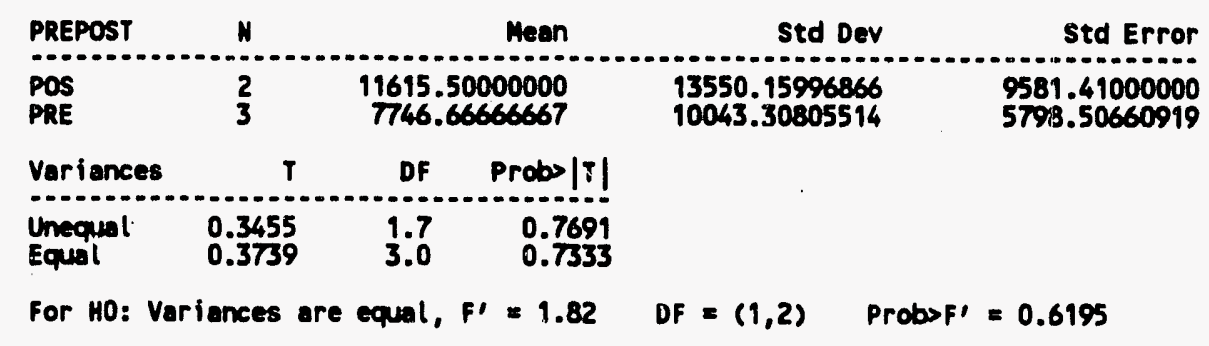

RSOCL=0.8 FUEL,_OOIL EPLAN=2 URBRUR=URBAN Variable: MAC

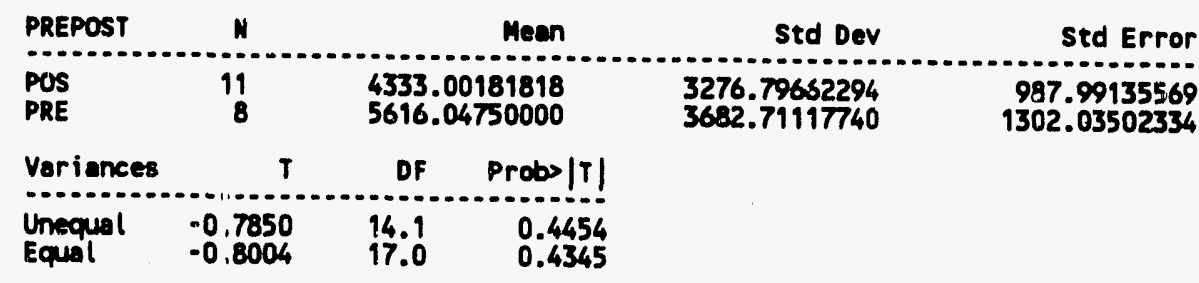

For HO: Varialices are equal, $F^{\prime}=1.26 \quad$ DF $=(7 ; 10) \quad$ Probsf' $=0.7123$ 


\section{Normalized Annual Consumption of 1990 Participants (by R-squared level)}

RSPCL=0.8 FUELDOIL EPLAME3 URBRUR=RURAL Variable: MAC

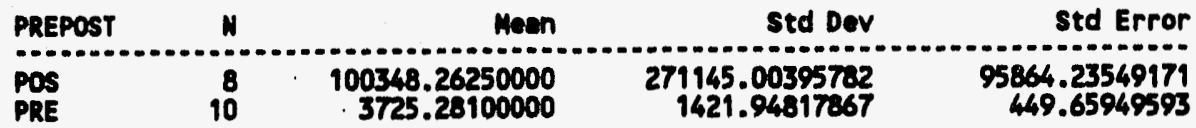

\begin{tabular}{llcc} 
Variances & $T$ & DF & Probs $|T|$ \\
\hline Unequal & 1.0079 & 7.0 & 0.3471 \\
Equil & 1.1358 & 16.0 & 0.2728
\end{tabular}

For HO: Variances ore equal, $F^{\prime}=9999.99 \quad$ DF $=(7,9) \quad$ ProbsF' $=0.0001$

RSOCL=0.8 FUEL $=01 L$ EPLANE3 URBRUR=URBAN Varieble: MAC

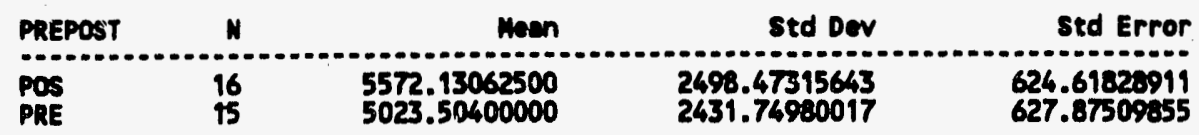

\begin{tabular}{llll} 
Variances & $T$ & DF & Probo| $|T|$ \\
\hdashline Unequal & 0.6195 & 29.0 & 0.5405 \\
Equal & 0.6189 & 29.0 & 0.5408
\end{tabular}

For HO: Variences are equal, F'=1.06 DF $=(15,14) \quad$ ProbsF' $=0.9242$

RSOCL=0.8 FUEL=OIL EPLAN=4 URBRUR=RURAL Variable: MAC

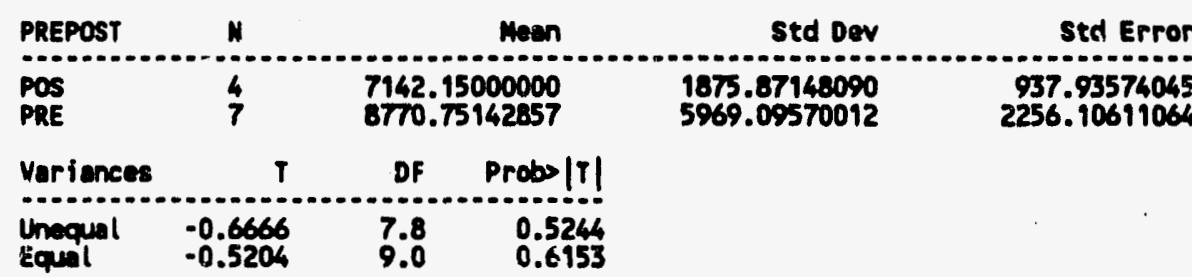

For HO: Variances are equal, F' $=10.13 \quad$ DF $=(6,3) \quad$ Probsf' $=0.0844$

RSOCL=0.8 FUELOIL EPLANE4 URBRURMURBAN Variable: WhC

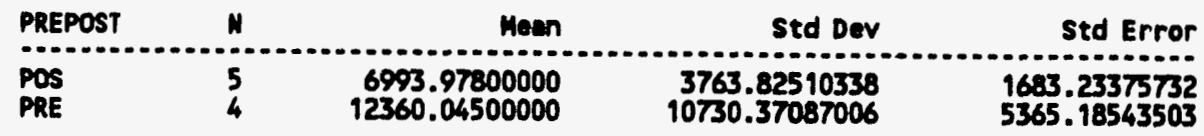

\begin{tabular}{llll} 
Variances & $T$ & DF & Probs|T! \\
\hdashline Unequal & -0.9543 & 3.6 & 0.4006 \\
Equal & -1.0555 & 7.0 & 0.3263
\end{tabular}

For HO: Yariences are equal, F'=8.13 DF $=(3,4) \quad$ ProbsF' $=0.0709$ 


\section{Normalized Annual Consumption of 1990 Participants (by R-squared level)}

RSQCL=0.8 FUEL=PROP EPLAN=3 URBRUR=RURAL Variable: MAC

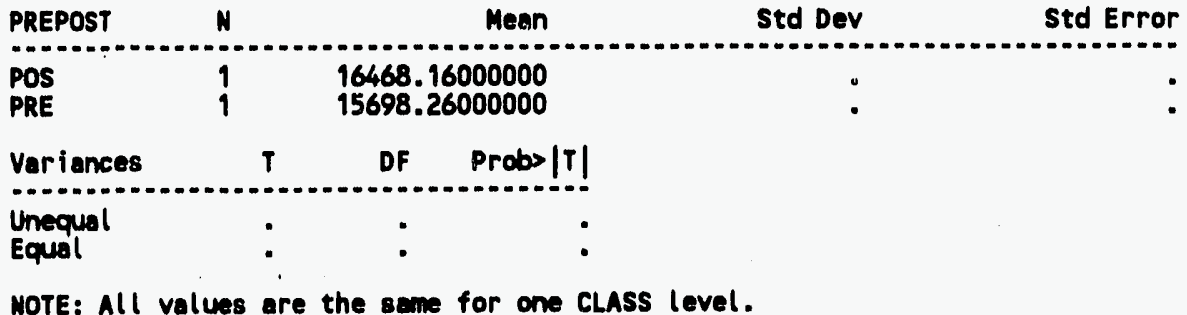

RSOCL=0.8 FUEL=OIL EPLAN=5 URBRUR=RURAL Variable: MAC

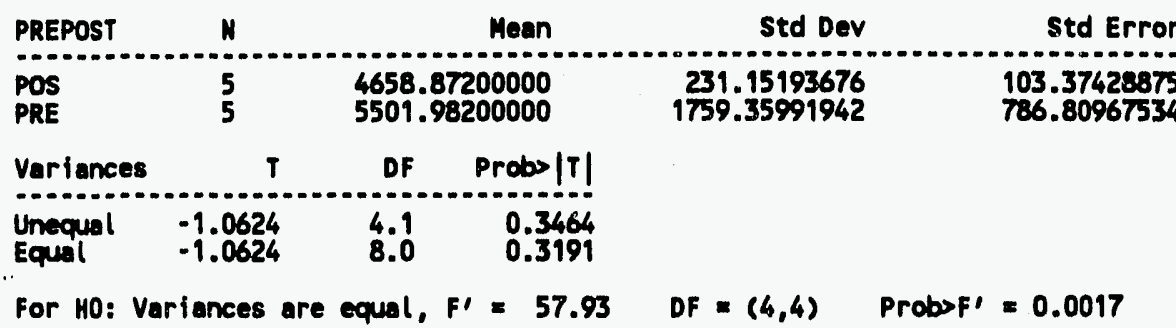

RSOCL $=0.8$ FUEL $=0 I L$ EPLAN=5 URBRUR=URBAN Variable: NAC

\begin{tabular}{|c|c|c|c|c|c|}
\hline PREPOST & $N$ & & Mean & Std Dev & Std Error \\
\hline $\begin{array}{l}\text { POS } \\
\text { PRE }\end{array}$ & $\begin{array}{r}9 \\
10\end{array}$ & $\begin{array}{l}7691 \\
5249\end{array}$ & $\begin{array}{l}222222 \\
200000\end{array}$ & $\begin{array}{l}3034.15856272 \\
2404.15923408\end{array}$ & $\begin{array}{r}1011.38618757 \\
760.26190374\end{array}$ \\
\hline Variences & $\mathbf{T}$ & DF & Probs $|T|$ & & \\
\hline $\begin{array}{l}\text { Unequal } \\
\text { Equal }\end{array}$ & $\begin{array}{l}1.9302 \\
1.9550\end{array}$ & $\begin{array}{l}15.3 \\
17.0\end{array}$ & $\begin{array}{l}0.0724 \\
0.0672\end{array}$ & & \\
\hline
\end{tabular}


Normalized Annual Consumption of 1990 Participants

(by R-squared level) 


\section{Appendix E: Cost Effectiveness}

Appendix $E$ contains installation costs and participant dollar savings used in the cost effectiveness analysis presented in chapter 4, section 7 of the technical report.

Table of Contents:

1989 Installations

Installation Costs $\ldots \ldots \ldots \ldots \ldots \ldots \ldots \ldots \ldots \ldots \ldots \ldots \ldots \ldots \ldots$

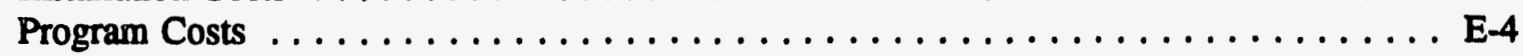

Participant Savings by Urban/Rural Status $\ldots \ldots \ldots \ldots \ldots \ldots \ldots \ldots \ldots \ldots \ldots$ E-5

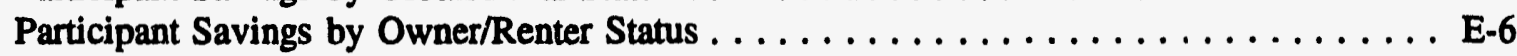

Participant Savings by Primary Space Heating Fuel $\ldots \ldots \ldots \ldots \ldots \ldots \ldots \ldots$ E-7

1990 Installations

Installation Costs $\ldots \ldots \ldots \ldots \ldots \ldots \ldots \ldots \ldots \ldots \ldots \ldots \ldots \ldots \ldots$

Program Costs . . . . . . . . . . . . . . . . . . . . . . . . E-9

Participant Savings by Urban/Rural Status $\ldots \ldots \ldots \ldots \ldots \ldots \ldots \ldots \ldots \ldots \ldots$ E-10

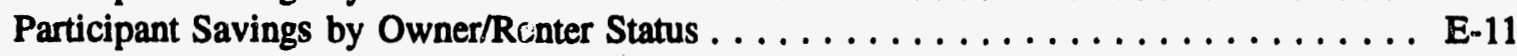

Participant Savings by Primary Space Heating Fuel $\ldots \ldots \ldots \ldots \ldots \ldots \ldots$ E-12 


\section{Installation Costs of 1989 Installations}

1989 TOTAL INSTALLATION COSTS (nOminal dollars)

$\begin{array}{lr} & \text { total } \\ \text { E1 } & 129,798.65 \\ \text { E2 } & 110,483.21 \\ \text { E3 } & 182,137.31 \\ \text { E4 } & 152,230.20 \\ \text { E5 } & 238,378.55 \\ \text { al1 } & 813,027.92\end{array}$

urban
$58,848.85$
$60,108.03$
$110,802.16$
$73,694.83$
$99,101.96$
$402,555.83$

primary space heating fuel

$\begin{array}{lr}\text { E1 } & \text { total } \\ \text { E2 } & 129,798.65 \\ \text { E3 } & 110,483.21 \\ \text { E4 } & 182,137.31 \\ \text { E5 } & 152,230.20 \\ \text { al1 } & 238,378.55 \\ & 813,027.92\end{array}$

elec

$10,996.20$

$1,051.77$

$18,104.77$

$6,680.95$

$13,086.28$

$49,919.97$ rural

$70,949.80$

$50,375.18$

$71,335.15$

$78,535.37$

$139,276.59$

$410,472.09$

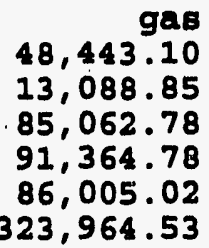

gas

$13,088.85$

, 062.78

$86,005.02$

$323,964.53$

\begin{abstract}
owmers
$64,683.80$

$85,706.03$

$75,062.36$

$55,963.52$

$133,987.47$

$415,403.18$
\end{abstract}

renters $65,079.85$

$24,777.18$ $107,074.95$

$96,266.68$ $104,391.08$ $397,589.74$

1989 NO INSTALIATION COSTS (nominal dollars)

$\begin{array}{lr} & \text { total } \\ \text { E1 } & 81,977.56 \\ \text { E2 } & 94,865.93 \\ \text { E3 } & 132,880.32 \\ \text { B5 } & 60,776.35 \\ \text { al1 } & 149,805.15 \\ & 520,305.30\end{array}$
urban
$44,116.05$
$51,331.43$
$90,780.07$
$29,721.85$
$72,910.40$
$288,859.79$

$64,314.15$

$86,186.48$

$70,043.72$

$54,003.42$

$118,636.54$

$393,184.31$

$$
\begin{array}{r}
\text { prop } \\
114.55 \\
0.00 \\
994.60 \\
90.00 \\
2,804.94 \\
4,004.09
\end{array}
$$

\section{primary space heating fuel}

$\begin{array}{lrrrr} & \text { total } & \text { elec } & \text { gas } & \text { oil } \\ \text { E1 } & 81,977.56 & 10,658.63 & 5,041.20 & 61,289.04 \\ \text { E2 } & 94,865.93 & 1,043.03 & 125.85 & 85,098.37 \\ \text { E3 } & 132,880.32 & 17,806.54 & 40,590.99 & 66,830.41 \\ \text { E4 } & 60,776.35 & 6,597.00 & 775.21 & 53,227.59 \\ \text { E5 } & 149,805.15 & 12,997.72 & 454.65 & 118,418.62 \\ \text { a11 } & 520,305.30 & 49,102.91 & 46,987.91 & 384,864.04\end{array}$

$\begin{array}{rr}\text { rural } & \text { Owners } \\ 37,861.51 & 50,403.00 \\ 43,534.51 & 77,958.60 \\ 42,100.25 & 58,105.64 \\ 31,054.49 & 30,815.74 \\ 76,894.75 & 98,529.98 \\ 231,445.51 & 315,812.95\end{array}$

$37,861.51$

$42,100.25$

$31,054.49$

$231,445.51$
$98,529.98$
$315,812.95$

i1

$61,289.04$

$53,227.59$

$384,864.04$ renters $31,539.56$ $16,907.33$ $74,774.68$ $29,960.61$ $51,275.17$ $204,457.35$

1989 GAS CO. INSTALIATION COSTS (nOminal dollars)

$\begin{array}{lr}\text { E1 } & 47,821.09 \\ \text { E2 } & 15,617.28 \\ \text { E3 } & 49,256.99 \\ \text { E4 } & 91,453.85 \\ \text { E5 } & 88,573.40 \\ \text { al1 } & 292,722.62\end{array}$

$$
\begin{array}{r}
\text { urban } \\
14,732.80 \\
8,776.60 \\
20,022.09 \\
43,972.98 \\
26,191.56 \\
113,696.04
\end{array}
$$
rural
$33,088.29$
$6,840.67$
$29,234.90$
$47,480.88$
$62,381.84$
$179,026.58$

owners $14,280.80$ $7,747.43$ $16,956.72$ $25,147.78$ $35,457.49$ $99,590.23$ prop

98.69

0.00

981.81

90.00

$2,804.94$

$3,975.44$

primary space heating fuel

$\begin{array}{lr} & \text { total } \\ \text { E1 } & 47,821.09 \\ \text { E2 } & 15,617.28 \\ \text { E3 } & 49,256.99 \\ \text { E4 } & 91,453.85 \\ \text { E5 } & 88,573.40 \\ \text { al1 } & 292,722.62\end{array}$

\begin{abstract}
gas
$43,401.90$

$12,963.00$

$44,471.79$

$90,589.57$

$85,550.37$

$276,976.62$
\end{abstract}
oil
$3,025.11$
$1,088.11$
$3,213.31$
775.83
217.92
$8,320.27$

renters $33,540.29$

$7,869.85$ $32,300.27$

$66,306.07$

$53,115.91$

$193,132.39$ 
1989 TOTAL PROGRAM COSTS (nOminal dollarg)

$\begin{array}{lrrrrrr} & \text { total } & \text { urban } & \text { rural } & \text { owners } & \text { renters } \\ \text { E1 } & 166,407.06 & 75,446.58 & 90,960.48 & 82,927.22 & 83,434.97 \\ \text { E2 } & 141,643.89 & 77,060.90 & 64,583.00 & 109,878.56 & 31,765.34 \\ \text { E3 } & 233,507.32 & 142,052.80 & 91,454.52 & 96,232.95 & 137,274.37 \\ \text { B4 } & 195,165.21 & 94,479.72 & 100,685.49 & 71,747.47 & 123,417.73 \\ \text { E5 } & 305,610.84 & 127,052.68 & 178,558.16 & 171,777.30 & 133,833.54 \\ \text { a11 } & 1,042,334.31 & 516,092.68 & \mathbf{5 2 6 , 2 4 1 . 6 4} & \mathbf{5 3 2 , 5 6 3 . 4 9} & \mathbf{5 0 9 , 7 2 5 . 9 5}\end{array}$

\section{primary space heating fuel}

$\begin{array}{lrrrrr} & \text { total } & \text { elec } & \text { gas } & \text { oil } & \text { prop } \\ \text { E1 } & 166,407.06 & 14,097.57 & 62,105.99 & 82,453.31 & 146.86 \\ \text { K2 } & 141,643.89 & 1,348.41 & 16,780.43 & 110,494.51 & 0.00 \\ \text { E3 } & 233,507.32 & 23,211.04 & 109,053.89 & 89,798.85 & 1,275.12 \\ \text { 84 } & 195,165.21 & 8,565.25 & 117,133.30 & 69,234.54 & 115.38 \\ \text { B5 } & 305,610.84 & 16,777.13 & 110,261.88 & 152,096.79 & 3,596.05 \\ \text { al1 } & 1,042,334.31 & 63,999.40 & 415,335.49 & 504,078.01 & 5,133.40\end{array}$

1989 NO PROGRAM COSTS (nominal dollars)

$\begin{array}{lrrrrr} & \text { total } & \text { urban } & \text { rural } & \text { owners } & \text { renters } \\ \text { E1 } & 105,098.51 & 56,558.54 & 48,539.97 & 64,618.66 & 40,434.98 \\ \text { B2 } & 121,621.92 & 65,808.95 & 55,812.98 & 99,946.04 & 21,675.87 \\ \text { B3 } & 170,357.89 & 116,383.68 & 53,974.20 & 74,493.75 & 95,864.13 \\ \text { B4 } & 77,917.71 & 38,104.60 & 39,813.10 & 39,507.01 & 38,410.70 \\ \text { B5 } & 192,056.19 & 93,474.05 & 98,582.15 & 126,319.38 & 65,736.82 \\ \text { a11 } & 667,052.21 & 370,329.81 & 296,722.40 & 404,884.83 & 262,122.50\end{array}$

primary space heating fuel

$\begin{array}{lrrrrr} & \text { total } & \text { elec } & \text { gas } & \text { oil } & \text { prop } \\ \text { E1 } & 105,098.51 & 13,664.79 & 6,463.02 & 78,575.00 & 126.52 \\ \text { E2 } & 121,621.92 & 1,337.21 & 161.34 & 109,099.51 & 0.00 \\ \text { E3 } & 170,557.89 & 22,828.70 & 52,039.27 & 85,679.26 & 1,258.72 \\ \text { E4 } & 77,917.71 & 8,457.62 & 993.85 & 68,239.90 & 115.38 \\ \text { E5 } & 192,056.19 & 16,663.60 & 582.88 & 151,817.41 & 3,596.05 \\ \text { al1 } & 667,052.21 & 62,951.89 & 60,240.38 & 493,411.09 & 5,096.67\end{array}$

1989 GAS CO. PROGRAM COSTS (nominal dollarg)

$\begin{array}{lrrrrr} & \text { total } & \text { urban } & \text { rural } & \text { omers } & \text { renters } \\ \text { B1 } & 61,308.55 & 18,888.04 & 42,420.51 & 18,308.56 & 42,999.99 \\ \text { B2 } & 20,021.98 & 11,251.95 & 8,770.01 & 9,932.52 & 10,089.46 \\ \mathbf{E 3} & 63,149.43 & 25,669.12 & 37,480.31 & 21,739.19 & 41,410.24 \\ \mathbf{B 4} & 117,247.49 & 56,375.12 & 60,872.39 & 32,240.46 & 85,007.03 \\ \mathbf{B 5} & 113,554.64 & 33,578.63 & 79,976.01 & 45,457.92 & 68,096.72 \\ \text { a11 } & 375,282.11 & 145,762.87 & 229,519.24 & 127,678.66 & 247,603.45\end{array}$

primary space heating fuel

$\begin{array}{lrrrrr} & \text { total } & \text { elec } & \text { gas } & \text { oil } & \text { prop } \\ \text { E1 } & 61,308.55 & 432.79 & 55,642.97 & 3,878.31 & 20.33 \\ \text { B2 } & 20,021.98 & 11.21 & 16,619.08 & 1,395.00 & 0.00 \\ \text { E3 } & 63,149.43 & 382.34 & 57,014.61 & 4,119.59 & 16.40 \\ \text { B4 } & 117,247.49 & 107.63 & 116,139.45 & 994.65 & 0.00 \\ \text { B5 } & 113,554.64 & 113.54 & 109,679.00 & 279.38 & 0.00 \\ \text { al1 } & 375,282.11 & 1,047.50 & 355,095.11 & 10,666.92 & 36.73\end{array}$




\section{Dollars Saved by 1989 WRAP Participants \\ (by Urban/Rural Status)}

\begin{tabular}{|c|c|c|c|}
\hline & \multicolumn{2}{|c|}{ Urban/Rural Location } & \multirow[b]{2}{*}{ ALL } \\
\hline & RURAL & URBAN & \\
\hline & $\begin{array}{c}\text { Dollars } \\
\text { Saved by } \\
\text { Participants }\end{array}$ & \begin{tabular}{c|} 
Dollars \\
Saved by \\
Participants
\end{tabular} & $\begin{array}{l}\text { Dollars } \\
\text { Saved by } \\
\text { Participants }\end{array}$ \\
\hline & sin & sum & SuH \\
\hline \multicolumn{4}{|c|}{ E_PLAN } \\
\hline 1 & 146149.11 & 166629.30 & 312778.41 \\
\hline 2 & 137632.08 & 725597.85 & 863229.93 \\
\hline 5 & 171656.30 & 314931.54 & 485787.84 \\
\hline 4 & 368428.55 & 373931.41 & 742359.96 \\
\hline 5 & 422277.50 & 296821.38 & 719098.88 \\
\hline ALL & 1246143.55 & 1877111.48 & 3123255.03 \\
\hline
\end{tabular}


Dollars Saved by 1989. WRAP Participants

(by Owner/Renter Status)

\begin{tabular}{|c|c|c|c|c|}
\hline & \multicolumn{3}{|c|}{ Ouner/Renter Status } & \multirow[b]{2}{*}{ ALL } \\
\hline & H & N & $\mathbf{T}$ & \\
\hline & $\begin{array}{c}\text { Dollars } \\
\text { saved by } \\
\text { Participents }\end{array}$ & \begin{tabular}{|c|} 
Dollars \\
Saved by \\
Participants
\end{tabular} & $\begin{array}{c}\text { Dollars } \\
\text { saved by } \\
\text { Participants }\end{array}$ & $\begin{array}{c}\text { Dollois } \\
\text { saved by } \\
\text { Participants }\end{array}$ \\
\hline & $\operatorname{sun}$ & sur & sun & $\sin$ \\
\hline \multicolumn{5}{|c|}{ E_PLAN } \\
\hline 1 & 138357.78 & 654.39 & 173766.24 & 312778.41 \\
\hline 2 & 723757.09 & $\cdot$ & 79472.84 & 863229.93 \\
\hline 3 & 188013.81 & $\cdot$ & 297774.03 & 485787.84 \\
\hline 4 & 278672.09 & $\cdot$ & 463687.88 & 742359.96 \\
\hline 5 & 395840.73 & $\cdot$ & 323258.15 & 719098.88 \\
\hline ALL & 1784641.50 & 654.39 & 1337959.14 & 3123255.03 \\
\hline
\end{tabular}




\section{Dollars Saved by 1989 WRAP Participants (by Primary Space Heating Fuel)}

\begin{tabular}{|c|c|c|c|c|c|c|c|}
\hline \multirow{4}{*}{ 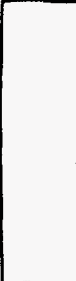 } & \multicolumn{6}{|c|}{ Primary Space Heating Fuel } & \multirow[b]{2}{*}{ ALL } \\
\hline & BLANK & ELEC & aAs & OIL & OTHER & PROP & \\
\hline & \begin{tabular}{c|} 
Dollars \\
Saved by \\
Participants
\end{tabular} & $\begin{array}{c}\text { Dollars } \\
\text { Saved by } \\
\text { Participants }\end{array}$ & $\begin{array}{c}\text { Dollars } \\
\text { Saved by } \\
\text { Participants }\end{array}$ & $\begin{array}{c}\text { Dollars } \\
\text { Saved by } \\
\text { Participants }\end{array}$ & $\begin{array}{c}\text { Dollars } \\
\text { Saved by } \\
\text { Participants }\end{array}$ & $\begin{array}{c}\text { Dollars } \\
\text { Saved by } \\
\text { Participants }\end{array}$ & $\begin{array}{l}\text { Dollars } \\
\text { Soved by } \\
\text { Participant }\end{array}$ \\
\hline & SUM & sur & Sum & SUN & SUN & SUM & sun \\
\hline \multicolumn{8}{|c|}{ E_PLAN } \\
\hline 1 & 754.54 & 104039.54 & 85059.10 & 121776.66 & 791.12 & 357.46 & 312778.4 \\
\hline 2 & 44.03 & 815.26 & 30160.79 & 831753.21 & 456.65 &. & 863229.9 \\
\hline 3 & 2707.78 & 129463.54 & 191336.92 & 157621.09 & 670.04 & 3988.47 & 485787.8 \\
\hline 4 & 1060.15 & $32: 35.29$ & 447705.79 & 260699.21 & $\cdot$ & 359.53 & 742359.9 \\
\hline 5 & 218.75 & 63477.13 & 306472.16 & 317177.49 & 220.18 & 31533.18 & 719098.8 \\
\hline ALL & 4785.26 & 330330.76 & 1060734.75 & 1689027.66 & 2137.99 & 36238.63 & 31232555.0 \\
\hline
\end{tabular}


1990 TOTAL INSTALIAATION COSTS (nominal dollars)

\begin{tabular}{|c|c|c|c|c|}
\hline $\begin{array}{l}1 \\
2 \\
3 \\
14 \\
5 \\
11\end{array}$ & $\begin{array}{r}\text { total } \\
87,545.12 \\
157,922.38 \\
266,294.36 \\
597,538.85 \\
623,163.63 \\
1,732,465.34\end{array}$ & $\begin{array}{r}\text { urban } \\
44,736.72 \\
103,273.46 \\
140,625.40 \\
299,516.41 \\
363,410.70 \\
951,562.69\end{array}$ & $\begin{array}{r}\text { rural } \\
42,809.40 \\
54,648.92 \\
125,668.96 \\
298,022.44 \\
259,752.93 \\
780,902.65\end{array}$ & $\begin{array}{r}\text { owners } \\
40,499.10 \\
103,064.10 \\
89,615.28 \\
212,431.46 \\
382,839.68 \\
828,449.62\end{array}$ \\
\hline
\end{tabular}

\section{prinary apace heating fuel}

\begin{tabular}{|c|c|c|c|c|}
\hline 1 & $\begin{array}{r}\text { total } \\
87,546.12 \\
157,922.38 \\
266,294.36 \\
597,538.85 \\
623,163.63 \\
1,732,165.34\end{array}$ & $\begin{array}{r}\text { elec } \\
4,553.50 \\
2,317.40 \\
30,262.58 \\
13,571.44 \\
1,136.01 \\
51,840.93\end{array}$ & $\begin{array}{r}\text { gas } \\
31,061.25 \\
18,556.71 \\
42,487.19 \\
276,792.16 \\
161,368.75 \\
530,266.06\end{array}$ & $\begin{array}{r}011 \\
42,827.57 \\
127,696.66 \\
162,429.26 \\
285,368.19 \\
403,548.50 \\
1,021,871.12\end{array}$ \\
\hline
\end{tabular}

$$
\begin{array}{r}
\text { prop } \\
757.00 \\
1,537.50 \\
1,964.21 \\
6,376.66 \\
3,282.58 \\
13,917.95
\end{array}
$$

1990 NO INSTALIATION COSTS (nominal dollarB)

$\begin{array}{lr} & \\ \text { E1 } & 57,587.29 \\ \mathrm{E2} & 136,132.88 \\ \mathrm{E3} & 222,987.31 \\ \mathrm{E4} & 324,714.62 \\ \mathrm{E5} & 453,395.06 \\ \mathrm{al1} & 1,194,817.16\end{array}$

$\begin{array}{rr}\text { urban } & \text { rural } \\ 33,316.02 & 24,271.27 \\ 86,569.72 & 49,563.16 \\ 113,031.20 & 109,956.11 \\ 176,860.29 & 147,854.33 \\ 303,265.38 & 150,129.68 \\ 713,042.61 & 481,774.56\end{array}$

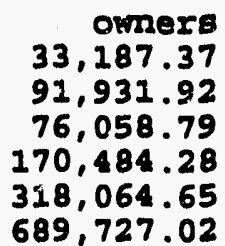

$689,727.02$

$\begin{array}{lrrrrr} & \text { total } & \text { elec } & \text { gas } & \text { oil } \\ \text { E1 } & 57,587.29 & 4,400.00 & 1,373.77 & 40,946.84 \\ \text { E2 } & 136,132.88 & 2,317.40 & 934.53 & 124,720.20 \\ \text { E3 } & 222,987.31 & 29,704.27 & 4,569.97 & 159,114.61 \\ \text { B4 } & 324,714.62 & 13,506.88 & 9,581.11 & 281,880.37 \\ \text { E5 } & 453,395.06 & 1,133.16 & 3,049.10 & 398,966.89 \\ \text { al1 } & 1,194,817.16 & 51,061.70 & 22,508.48 & 1,005,628.92\end{array}$

\section{primary space heating fuel}

1990 GAS CO. INSTALIATION COSTS (nominal dollars)

$\begin{array}{lr}\text { E1 } & \text { total } \\ \text { E2 } & 29,958.83 \\ \text { E3 } & 21,789.50 \\ \text { E4 } & 43,307.05 \\ \text { E5 } & 272,824.23 \\ \text { Al1 } & 169,768.57 \\ & 537,648.18\end{array}$

$\begin{array}{rr}\text { urban } & \text { rural } \\ 11,420.69 & 18,538.13 \\ 16,703.75 & 5,085.76 \\ 27,594.21 & 15,712.85 \\ 122,656.12 & 150,168.11 \\ 60,145.32 & 109,623.25 \\ 238,520.08 & 299,128.09\end{array}$
owmers $7,311.72$ $11,132.18$ $13,556.49$ $41,947.18$ $64,775.03$ $138,722.60$

renters $24,399.91$ $44,200.96$ $146,928.52$ $154,230.35$ $135,330.41$ $505,090.15$

prop
750.00
$1,517.55$
$1,907.98$
$6,341.81$
$3,282.58$
$13,799.92$

renters $22,647.10$

\begin{tabular}{|c|c|c|c|c|c|}
\hline $\begin{array}{l}\text { E1 } \\
\text { E2 } \\
\text { E3 } \\
\text { E4 } \\
\text { E5 } \\
\text { al1 }\end{array}$ & $\begin{array}{r}\text { total } \\
29,958.83 \\
21,789.50 \\
. .43,307.05 \\
272,824.23 \\
169,768.57 \\
537,648.18\end{array}$ & $\begin{array}{r}\text { elec } \\
153.50 \\
0.00 \\
558.31 \\
64.56 \\
2.85 \\
779.22\end{array}$ & $\begin{array}{r}\text { gas } \\
26,687.48 \\
17,622.18 \\
37,917.22 \\
267,211.05 \\
158,319.65 \\
507,757.58\end{array}$ & $\begin{array}{r}011 \\
1,880.73 \\
2,976.46 \\
3,315.58 \\
3,487.82 \\
4,581.61 \\
16,242.20\end{array}$ & $\begin{array}{r}\text { prop } \\
7.00 \\
19.95 \\
56.23 \\
34.85 \\
0.00 \\
118.03\end{array}$ \\
\hline
\end{tabular}
$10,657.32$ $29,750.56$ $230,877.04$ $104,993.54$ $398,925.57$

primary space heating fuel 
1990 TOTAL PROGRAM COSTS (nOminal dollarg)

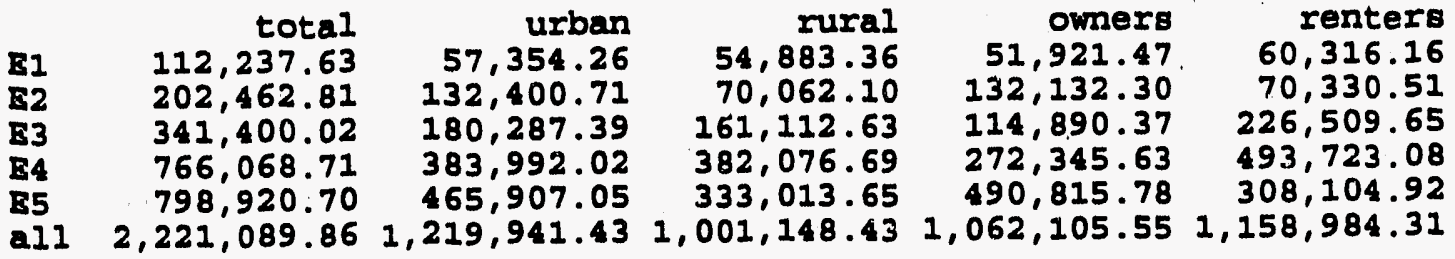

primary space heating fuel

$\begin{array}{lrrrrr} & \text { total } & \text { elec } & \text { gas } & \text { oil } & \text { prop } \\ \text { E1 } & 112,237.63 & 5,837.77 & 39,821.76 & 54,906.66 & 970.50 \\ \text { E2 } & 202,462.81 & 2,971.00 & 23,790.44 & 163,712.23 & 1,971.14 \\ \mathbf{S 3} & 341,400.02 & 38,797.84 & 54,470.28 & 208,240.81 & 2,518.20 \\ \mathrm{E} 4 & 766,068.71 & 17,399.13 & 354,858.62 & 365,853.43 & 8,175.13 \\ \mathrm{E5} & 798,920.70 & 1,456.41 & 206,881.19 & 517,365.32 & 4,208.40 \\ \mathrm{a} 11 & 2,221,089.86 & 66,462.15 & 679,822.30 & 1,310,079.65 & 17,843.37\end{array}$

1990 NO PROGRAM COSTS (nominal dollars)

\begin{tabular}{|c|c|c|c|c|c|}
\hline $\begin{array}{l}1 \\
2 \\
3 \\
4 \\
5\end{array}$ & $\begin{array}{r}\text { total } \\
73,829.21 \\
174,527.80 \\
285,878.65 \\
416,297.13 \\
581,270.60 \\
531,803.39\end{array}$ & $\begin{array}{r}\text { urban } \\
42,712.47 \\
110,985.84 \\
144,910.52 \\
226,741.97 \\
388,798.35 \\
914,149.15\end{array}$ & $\begin{array}{r}\text { rural } \\
31,116.74 \\
63,541.95 \\
140,968.13 \\
189,555.17 \\
192,472.25 \\
617,654.26\end{array}$ & $\begin{array}{r}\text { Owners } \\
42,547.54 \\
117,860.40 \\
97,510.41 \\
218,567.67 \\
407,771.60 \\
884,257.63\end{array}$ & $\begin{array}{r}\text { renters } \\
31,281.66 \\
56,667.40 \\
188,368.24 \\
197,729.48 \\
173,499.00 \\
647,545.78\end{array}$ \\
\hline
\end{tabular}

primary space heating fuel

$\begin{array}{lrrrr} & \text { total } & \text { elec } & \text { gas } & \text { oil } \\ \text { E1 } & 73,829.21 & 5,640.98 & 5,607.35 & 52,495.49 \\ \text { E2 } & 174,527.80 & 2,971.00 & 1,198.10 & 159,896.29 \\ \text { E3 } & 285,878.65 & 38,082.06 & 5,858.88 & 203,991.29 \\ \text { E4 } & 416,297.13 & 17,316.36 & 12,283.37 & 361,381.91 \\ \text { E5 } & 581,270.60 & 1,452.76 & 3,909.07 & 511,491.51 \\ \text { a11 } & 1,531,803.39 & 65,463.14 & 28,856.77 & 1,289,256.50\end{array}$

1990 GAS CO. PROGRAM COSTS (nominal dollars)

$\begin{array}{lrrrrr} & \text { total } & \text { urban } & \text { rural } & \text { Owners } & \text { renters } \\ \text { E1 } & 38,408.42 & 14,641.78 & 23,766.62 & 9,373.92 & 29,034.49 \\ \text { E2 } & 27,935.01 & 21,414.88 & 6,520.15 & 14,271.90 & 13,663.11 \\ \text { E3 } & 55,521.37 & 35,376.88 & 20,144.50 & 17,379.96 & 38,141.41 \\ \mathbf{E 4} & 349,771.58 & 157,250.05 & 192,521.52 & 53,777.96 & 295,993.60 \\ \text { E5 } & 217,650.10 & 77,108.71 & 140,541.39 & 83,044.18 & 134,605.92 \\ \text { a11 } & 689,286.47 & 305,792.28 & 383,494.18 & 177,847.92 & 511,438.54\end{array}$

primary space heating fuel

$\begin{array}{lrrrrr} & \text { total } & \text { elec } & \text { gas } & \text { oil } & \text { prop } \\ \text { E1 } & 38,408.42 & 196.79 & 34,214.42 & 2,411.17 & 8.97 \\ \text { E2 } & 27,935.01 & 0.00 & 22,592.34 & 3,815.94 & 25.58 \\ \text { E3 } & 55,521.37 & 715.78 & 48,611.39 & 4,250.71 & 72.09 \\ \text { E4 } & 349,771.58 & 82.77 & 342,575.25 & 4,471.52 & 44.68 \\ \text { E5 } & 217,650.10 & 3.65 & 202,972.12 & 5,873.81 & 0.00 \\ \text { al1 } & 689,286.47 & 998.99 & 650,965.53 & 20,823.15 & 151.32\end{array}$







Dollars Saved by 1990 WRAP Participants (by Owner/Renter Status)

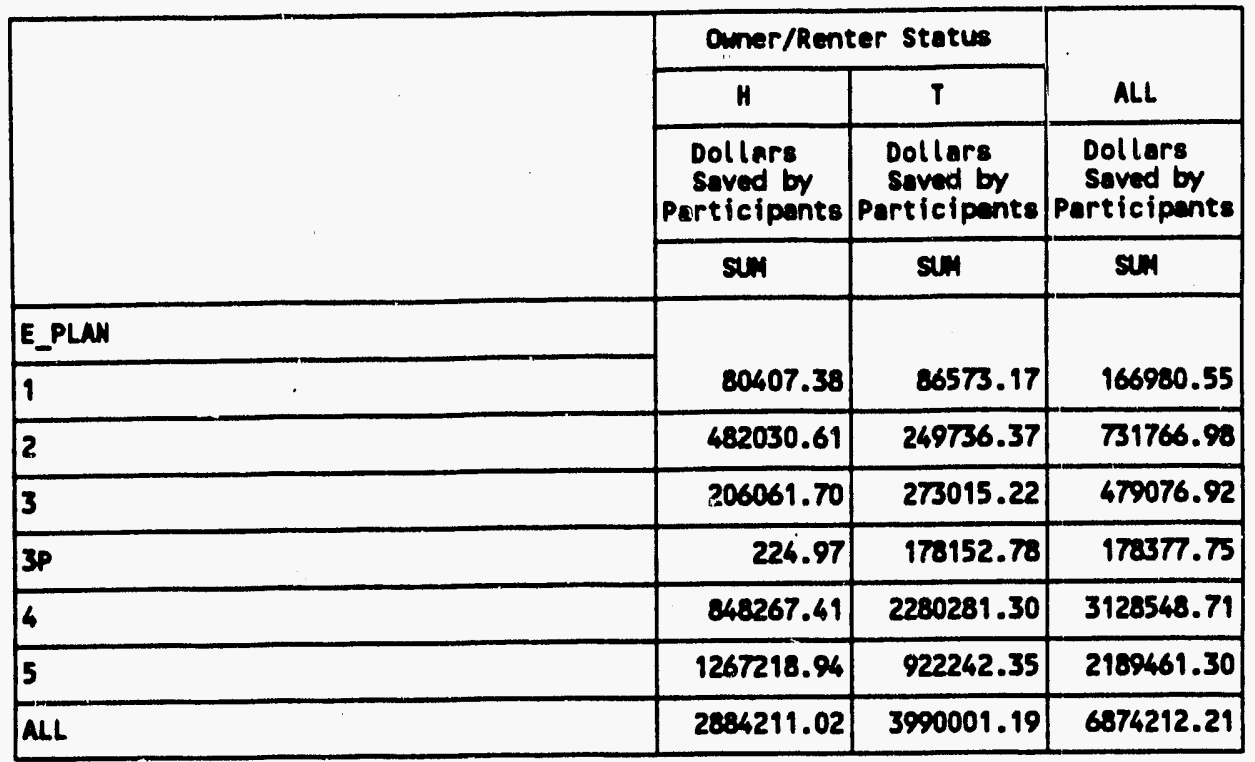




\section{Dollars Saved by 1990 WRAP Participants (by Primary Space Heating Fuel)}

\begin{tabular}{|c|c|c|c|c|c|c|c|}
\hline & \multicolumn{6}{|c|}{ Primary Space Heating Fual } & \multirow[b]{2}{*}{ ALL. - } \\
\hline & BLANK & ELEC & as & OIL & OTHER & PROP & \\
\hline & $\begin{array}{c}\text { Dollars } \\
\text { Saved by } \\
\text { Participants }\end{array}$ & $\begin{array}{c}\text { Dollars } \\
\text { Saved by } \\
\text { Participants }\end{array}$ & $\begin{array}{c}\text { Dollars } \\
\text { Saved by } \\
\text { Participants }\end{array}$ & \begin{tabular}{|c|} 
Dollars \\
Soved by \\
Participants
\end{tabular} & $\begin{array}{c}\text { Dollars } \\
\text { Saved by } \\
\text { Participants }\end{array}$ & $\begin{array}{c}\text { Dollars } \\
\text { Saved by } \\
\text { Participants }\end{array}$ & $\begin{array}{l}\text { Dollars } \\
\text { Saved by } \\
\text { Participents }\end{array}$ \\
\hline & sin & sury & son & $\mathbf{s e m}$ & sum & $\operatorname{sen}$ & $\boldsymbol{s e n}$ \\
\hline \multicolumn{8}{|c|}{ E_PLAN } \\
\hline 1 & 1012.70 & 30300.61 & 43903.57 & 84997.02 & 2036.01 & 4730.63 & 166980.55 \\
\hline 2 & 173.08 & 1060.98 & 128168.98 & 562578.70 & • & 39785.25 & 731766.98 \\
\hline 3 & 6093.26 & 149043.51 & .76169 .46 & 230892.42 & 8656.68 & 8221.59 & 479076.92 \\
\hline $3 p$ & 56586.54 & - & 169.72 & 121621.49 & - & - & 170377.75 \\
\hline 4 & 4699.44 & 51600.89 & 1687658.25 & 1229750.67 & 2555.93 & 152283.54 & 3128568.71 \\
\hline 5 & 21082.66 & 4216.42 & 781649.17 & 1296955.47 & 1167.00 & 82390.58 & 2189461.30 \\
\hline$A L L$ & 89647.68 & 236222.41 & 2717719.16 & 3528795.77 & 14415.62 & 287411.58 & 6874212.21 \\
\hline
\end{tabular}




\section{Appendix F: Arrearage Impacts}

Appendix $F$ presents supporting data for the WRAP arrearage reductions evaluation, included in chapter 4, section 8 of the technical report.

Table of Contents:

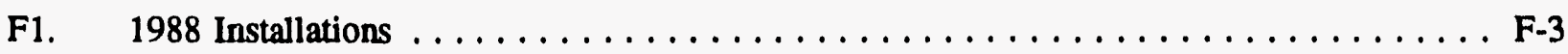

F2. $\quad 1989$ Installations $\ldots \ldots \ldots \ldots \ldots \ldots \ldots \ldots \ldots \ldots \ldots \ldots \ldots \ldots \ldots \ldots \ldots \ldots$

F3. $\quad 1990$ Installations $\ldots \ldots \ldots \ldots \ldots \ldots \ldots \ldots \ldots \ldots \ldots \ldots \ldots \ldots \ldots$ F $\ldots \ldots \ldots$ 


\section{Appendix F: \\ Arrearage Impacts}

\section{Section 1: \\ 1988 Installations}

Table of Contents:

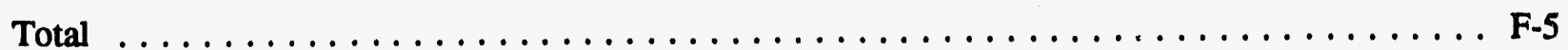

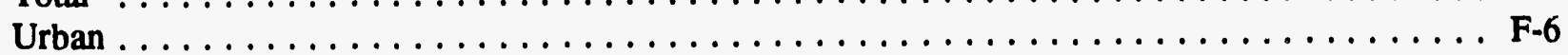

Rural $\ldots \ldots \ldots \ldots \ldots \ldots \ldots \ldots \ldots \ldots \ldots \ldots \ldots \ldots \ldots \ldots \ldots \ldots \ldots \ldots \ldots$

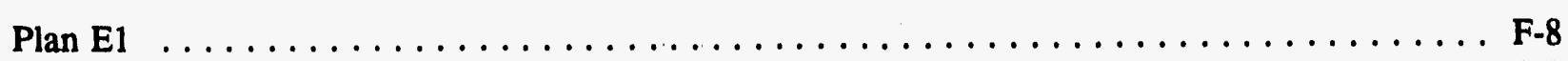

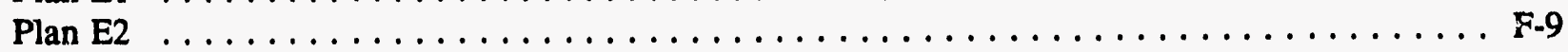

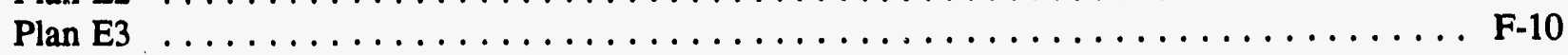




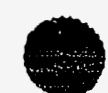

$\bullet$

$\bullet$

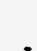
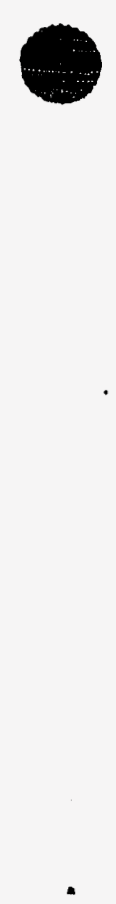
3 


\begin{tabular}{|c|c|c|c|c|c|c|c|c|}
\hline FUEL & EPLAN & $U / R$ & $\begin{array}{l}\text { SALMPLE } \\
\text { SIZEE }\end{array}$ & $\begin{array}{c}-11 \text { To } 0 \\
\text { AVO }\end{array}$ & $1 \underset{\text { AVG }}{T 0} 12$ & $\begin{array}{c}\text { ADJUSTED } \\
1 \text { TO } 12 \\
\text { AVG } \\
3.61 \%\end{array}$ & $\begin{array}{c}\text { REAL } \\
\text { DERTA }\end{array}$ & $\begin{array}{c}\text { REAL } \\
Z \\
\text { DELTA }\end{array}$ \\
\hline ArL & AlL & All & 316 & -18.0 & -4.6 & -4.4 & 13.6 & $-75.4 x$ \\
\hline ALL & All & RURAL & 209 & -18.9 & -0.9 & -0.9 & 18.0 & $-95.3 \%$ \\
\hline AltL & ALL & URAAN & 107 & -16.5 & -11.5 & -11.1 & 5.4 & $-32.7 x$ \\
\hline$\widehat{A L L}$ & 1 & ALL & 26 & -37.5 & -43.8 & -42.2 & -4.7 & $12.6 x$ \\
\hline All & 1 & RURAL & 15 & -41.4 & -45.3 & -43.7 & -2.3 & $5.4 x$ \\
\hline ALL & 1 & URBAN & 11 & -31.9 & -41.8 & -40.3 & -8.4 & 26.37 \\
\hline ALL & 2 & ALL & 1 & -3.2 & 2.8 & 2.7 & 5.9 & -186.42 \\
\hline AIL & 2 & URBAN & 1 & -3.2 & 2.8 & 2.7 & 5.9 & $-186.4 x$ \\
\hline ALI & $\overline{3}$ & Ats & 289 & -16.5 & -1.0 & -1.0 & 15.5 & -94.22 \\
\hline ALL & 3 & RURAL. & 194 & -17.3 & 2.4 & 2.3 & 19.6 & $-113.5 \%$ \\
\hline Als & 3 & URBAN & 95 & -15.0 & -8.1 & -7.8 & 7.2 & -48.08 \\
\hline BLANK & Ald & All & 9 & -33.3 & -33.9 & -32.7 & 0.6 & $-1.8 x$ \\
\hline BLAHK & AlL & RURAL & 5 & -12.8 & -27.1 & -26.1 & -13.3 & 103.78 \\
\hline BLATK & Als & URBAN & 4 & -58.6 & -42.3 & -40.9 & 17.7 & $-30.3 x$ \\
\hline BLANK & 1 & AlL & 1 & -80.6 & -68.6 & -66.2 & 24.4 & -17.98 \\
\hline BLANK & $\overline{1}$ & RURAL & 1 & -80.6 & -68.6 & -66.2 & 24.4 & -17.92 \\
\hline BLANTK & 3 & All & 8 & -27.3 & -29.6 & -28.6 & -1.3 & 4.88 \\
\hline BLARK & 3 & RURAL & 4 & 4.2 & -16.7 & -16.1 & -20.3 & $-486.1 x$ \\
\hline BLARK & 3 & URBAN & 4 & -58.6 & -42.3 & -40.9 & 17.7 & -30.32 \\
\hline ELEC & All & Ald & 15 & 17.8 & -1.5 & -1.4 & -19.3 & $-108.1 x$ \\
\hline ELEC & Allt & RURAL. & 2 & -1.7 & -2.7 & -2.6 & -0.9 & 54.42 \\
\hline ELEC & All & URALH & 13 & 20.6 & -1.2 & -1.1 & -21.7 & $-105.5 x$ \\
\hline ELEC & 1 & All & 2 & 15.1 & -1.7 & -1.6 & -26.7 & -110.78 \\
\hline EILCC & $\bar{i}$ & RURAL & 1 & -1.4 & 3.6 & 3.5 & 4.9 & -344.27 \\
\hline ELEC & $i$ & URBAN & 1 & 31.5 & -7.1 & -6.8 & -98.3 & $-121.7 x$ \\
\hline ELEC & 3 & All & 13 & 28.1 & -1.3 & -1.3 & -19.4 & $-107.1 x$ \\
\hline ELEC & 3 & RURAI & 1 & -1.7 & -8.8 & -8.5 & -6.9 & 411.52 \\
\hline ELEC & 3 & URBAN & 12 & 19.8 & -0.8 & -0.8 & -20.6 & -104.18 \\
\hline GAS & ALL L L & AlL & 122 & -25.7 & -16.5 & -15.9 & 9.7 & -38.02 \\
\hline GAS & All & RURAL & 89 & -18.8 & -13.0 & -12.5 & 6.2 & -33.18 \\
\hline GAS & ALIL & URBAN & 33 & -44.1 & -25.7 & -24.8 & 19.3 & $-43.8 x$ \\
\hline GAS & 1 & ALL & 17 & -55.1 & -62.3 & -60.1 & -5.0 & 9.18 \\
\hline aAs & $\overline{1}$ & RURAL & 8 & -69.3 & -75.3 & -72.7 & -3.4 & 4.92 \\
\hline GAS & 1 & URBAN & 9 & -42.7 & -50.5 & -48.7 & -6.1 & $14.2 x$ \\
\hline GAS & 3 & ALL & 105 & -20.7 & -9.1 & -8.8 & 11.9 & $-57.6 x$ \\
\hline GAS & 3 & RURAL & 81 & -13.7 & -6.9 & -6.7 & 7.0 & $-51.2 x$ \\
\hline GAS & 3 & URBAN & 24 & -44.6 & -16.3 & -15.8 & 28.8 & -64.62 \\
\hline OIL & ALL & ALL & 162 & -15.3 & 5.3 & 5.1 & 20.5 & -133.62 \\
\hline OIL & ALL & RURAL & 108 & -20.2 & 9.8 & 9.4 & 29.6 & -146.72 \\
\hline OIL & All & URBAN & 53 & -5.6 & -3.9 & -3.8 & 1.8 & $-32.3 x$ \\
\hline OIL & 1 & ALL & 6 & 2.9 & -1.8 & -1.7 & -4.6 & $-157.9 x$ \\
\hline ort & 1 & RURAL & 5 & 3.4 & -2.2 & -2.1 & -5.5 & $-161.2 x$ \\
\hline OIL & $\overline{1}$ & URBAN & 1 & -0.2 & -0.2 & -0.2 & 0.0 & $-3.5 x$ \\
\hline OIL & 2 & ALL & $\overline{1}$ & -3.2 & 2.8 & 2.7 & 5.9 & $-180.4 x$ \\
\hline OIL & 2 & URBAN & 1 & -3.2 & 2.8 & 2.7 & 5.9 & -186.48 \\
\hline OIL & 3 & ALL & 155 & -16.3 & 5.6 & 5.4 & 21.6 & $-133.2 x$ \\
\hline OIL & 3 & RURAL & 104 & -21.3 & 10.3 & 10.0 & 31.3 & $-146.7 x$ \\
\hline OIL & 3 & URBAN & 51 & -5.7 & -4.1 & -3.9 & 1.7 & $-30.5 \%$ \\
\hline OTHER & ALL & ALI & 8 & -10.1 & 7.4 & 7.2 & 17.2 & $-171.0 x$ \\
\hline OTHER & ALL & RURAL & 4 & -8.0 & 13.3 & 12.8 & 20.8 & -259.97 \\
\hline OTHER & ALL & URBAN & 4 & -12.5 & 1.5 & 1.4 & 13.9 & $-111.6 x$ \\
\hline OTHER & 3 & ALL & 8 & -10.1 & 7.4 & 7.2 & 17.2 & -171.02 \\
\hline OTEER & 3 & RURAL & 4 & -8.0 & 13.3 & 12.8 & 20.8 & $-259.9 x$ \\
\hline OTHER & 3 & URBAN & 4 & -12.5 & 1.5 & 1.4 & 13.9 & $-111.6 x$ \\
\hline
\end{tabular}




\section{Arrearage Impacts of 1988 Urban Installations}

\begin{tabular}{|c|c|c|c|c|c|c|c|c|}
\hline \multicolumn{9}{|c|}{$\begin{array}{l}\text { MOAIELY CEAKGE IN ARREARACE } 2 \\
\text { URBAN PARTYCIPANIS }\end{array}$} \\
\hline FUEี & EPLAY & $\boldsymbol{U} / \boldsymbol{R}$ & $\begin{array}{l}\text { SAMPLE } \\
\text { SIRE }\end{array}$ & $\begin{array}{c}-11 \text { To } 0 \\
\text { Ave }\end{array}$ & $\begin{array}{l}12 \\
\text { AVO }\end{array}$ & $\begin{array}{l}1 \text { I0 } 12 \\
\text { AVE } \\
3.62 \%\end{array}$ & $\begin{array}{l}\text { REAL } \\
\text { DझLIA }\end{array}$ & $\operatorname{DM}$ \\
\hline Atr. & An & URBAN & 107 & -16.5 & -11.5 & -11.1 & 3.4 & -32.78 \\
\hline Ant & 1 & URBAN & 11 & -31.9 & -41.8 & -40.3 & -8.4 & $26.3 \%$ \\
\hline AnI & 2 & URBAN & 1 & -3.2 & 2.8 & 2.7 & 5.9 & $-186.4 x$ \\
\hline Ant & 3 & URAAN & 95 & -15.0 & -8.1 & -7.8 & 7.2 & $-48.0 \%$ \\
\hline Blnax & ملת & URBA & 4 & -58.6 & -42.3 & -40.9 & 17.7 & -30.34 \\
\hline BLARK & 3 & URBAN & 4 & -58.6 & -42.3 & -40.9 & 17.7 & -30.32 \\
\hline ELEC & All & URBAN & 13 & 20.6 & -1.2 & -1.2 & -21.7 & $-105.5 \%$ \\
\hline Errec & 1 & URBAN & 1 & 31.5 & -7.1 & -6.8 & -38.3 & -121.72 \\
\hline Exc & 3 & URBAN & 12 & 19.8 & -0.8 & -0.8 & -20.6 & $-104.2 \%$ \\
\hline ans & ALL & URBAN & 33 & -44.1 & -25.7 & -24.8 & 19.3 & -48.82 \\
\hline CAs & 1 . & URBAN & 9 & -42.7 & -50.5 & -48.7 & -6.1 & 14.27 \\
\hline ans & & URAAN & 24 & -44.6 & -16.3 & -15.8 & 28.8 & $-64.6 \%$ \\
\hline OIL & ALل & URAAN & 53 & -5.6 & -3.9 & -3.9 & 1.8 & $-32.3 x$ \\
\hline $\begin{array}{l}\text { OIL } \\
\text { ort }\end{array}$ & 1 & URBAA & $\frac{1}{1}$ & -0.2 & -0.2 & -0.2 & 0.0 & $-3.5 \%$ \\
\hline $\begin{array}{l}\text { OIL } \\
\text { OIL }\end{array}$ & & URBAN & 51 & $\begin{array}{l}-3.2 \\
-5.7\end{array}$ & $\begin{array}{r}2.8 \\
-4.1\end{array}$ & $\begin{array}{r}2.7 \\
-3.9\end{array}$ & $\begin{array}{l}3.9 \\
1.7\end{array}$ & $\begin{array}{r}-186.48 \\
-30.5 \%\end{array}$ \\
\hline OTEIER & All & URBAR & 4 & -12.5 & 1.5 & 1.4 & 13.9 & $-111.6 \%$ \\
\hline
\end{tabular}




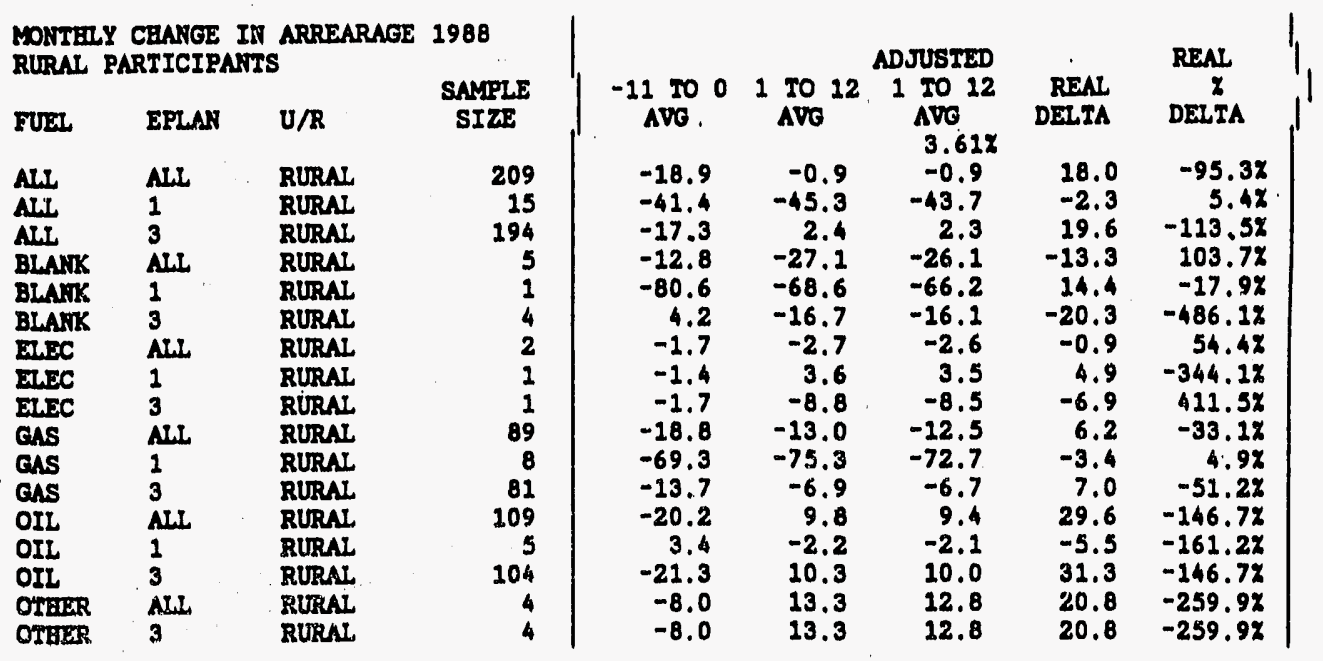




\section{Arrearage Impacts of 1988 Ilan E1 Installations}

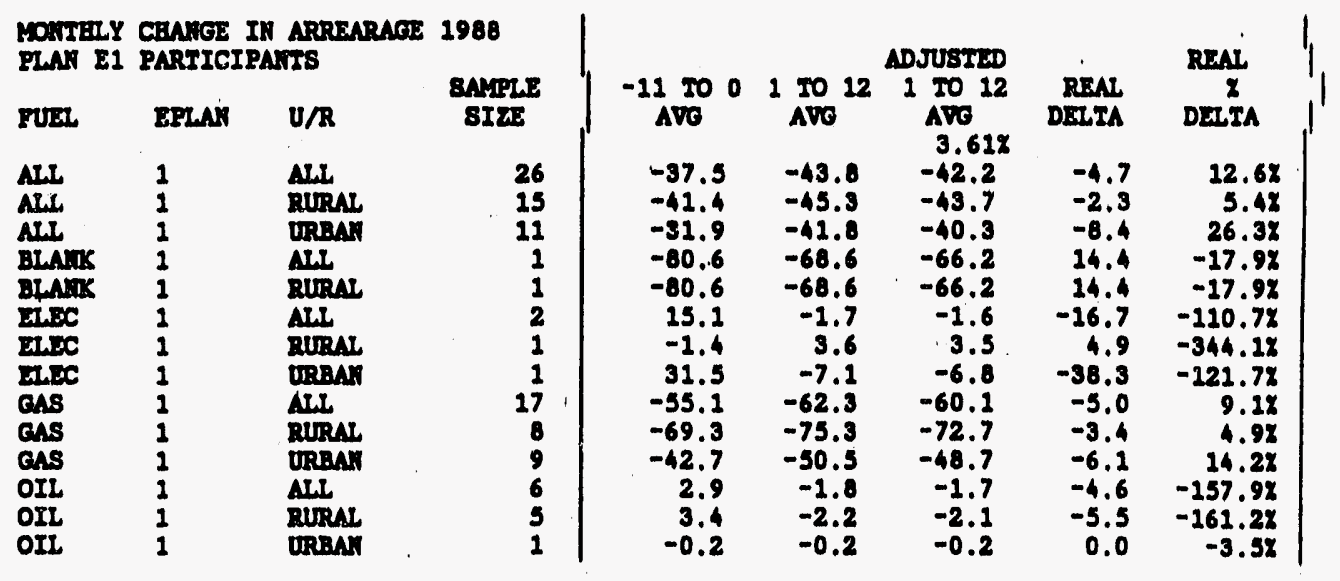




\section{Arrearage Impacts of 1988 Plan E2 Installations}

MONTELY CBANGE IN ARREARAOE 1988 PLAN E2 PARTICIPANTS

FUER EPLAN U/R

All 2 All

All 2 URBAN

OII 2 ALI

OIL 2 URBAB

\begin{tabular}{r|}
1988 \\
SAMPLE \\
SIZE \\
1 \\
1 \\
1 \\
1
\end{tabular} \mid

\begin{tabular}{|c|c|c|c|c|}
\hline $\begin{array}{c}-11 \text { To } \\
\text { AVG }\end{array}$ & $\begin{array}{l}1 \text { TO } \\
\text { AVG }\end{array}$ & $\begin{array}{l}\text { ADJUSTED } \\
1 \text { TO } 12 \\
\text { AVG }\end{array}$ & $\begin{array}{l}\text { REAL } \\
\text { DELTA }\end{array}$ & $\begin{array}{c}\text { REAL } \\
X \\
\text { DELTA }\end{array}$ \\
\hline $\begin{array}{l}-3.2 \\
-3.2 \\
-3.2 \\
-3.2\end{array}$ & $\begin{array}{l}2.8 \\
2.8 \\
2.8 \\
2.8\end{array}$ & $\begin{array}{l}2.7 \\
2.7 \\
2.7 \\
2.7\end{array}$ & $\begin{array}{l}5.9 \\
5.9 \\
5.9 \\
5.9\end{array}$ & $\begin{array}{l}-186 \cdot 4 x \\
-186.4 x \\
-186.4 x \\
-186.4 x\end{array}$ \\
\hline
\end{tabular}




\section{Arrearage Impacts of 1988 Plan E3 Installations}

\begin{tabular}{|c|c|c|}
\hline FUEI & SELAN & $U / R$ \\
\hline ALL & 3 & Ald \\
\hline All & 3 & RUR \\
\hline All & 3 & URBMT \\
\hline BLAKTK & 3 & All \\
\hline BLANTK & 3 & RURAL \\
\hline BLANK & 3 & URBAN \\
\hline ELEC & 3 & Alll \\
\hline Ehre & 3 & RURAL \\
\hline ELEC & 3 & URBAH \\
\hline ans & 3 & Allt \\
\hline GAs & 3 & RURAL \\
\hline GAS & 3 & URBAN \\
\hline OIL & 3 & AtL \\
\hline OIL & 3 & RURAL \\
\hline OIL & 3 & URBAH \\
\hline OTHER & 3 & Ath \\
\hline OTEERR & 3 & RURAL \\
\hline OTHERR & 3 & URBAN \\
\hline
\end{tabular}

\begin{tabular}{|c|}
1986 \\
SAYPLE \\
SIRE \\
209 \\
194 \\
95 \\
0 \\
4 \\
4 \\
13 \\
1 \\
12 \\
105 \\
81 \\
24 \\
155 \\
104 \\
51 \\
8 \\
4 \\
4
\end{tabular}

\begin{tabular}{|c|c|c|c|c|}
\hline $\begin{array}{c}-11 \text { TO } 0 \\
A V 0\end{array}$ & $1 \underset{\text { AVO }}{\text { TO }} 12$ & $\begin{array}{l}\text { ADJUSTED } \\
1 \text { TO } 12 \\
\text { AVO }\end{array}$ & DEDI & $\begin{array}{c}\text { REAL } \\
X \\
\text { DEATA }\end{array}$ \\
\hline $\begin{array}{r}-16.3 \\
-17.3 \\
-15.0 \\
-27.3 \\
4.2 \\
-58.6 \\
18.1 \\
-1.7 \\
29.8 \\
-20.7 \\
-13.7 \\
-44.6 \\
-16.3 \\
-21.3 \\
-5.7 \\
-10.1 \\
-8.0 \\
-12.5\end{array}$ & $\begin{array}{r}-1.0 \\
2.4 \\
-8.1 \\
-29.6 \\
-16.7 \\
-42.3 \\
-1.3 \\
-8.8 \\
-0.8 \\
-9.1 \\
-6.9 \\
-16.3 \\
5.6 \\
10.3 \\
-4.1 \\
7.4 \\
13.3 \\
1.5\end{array}$ & $\begin{array}{r}-1.0 \\
2.3 \\
-7.8 \\
-28.6 \\
-16.1 \\
-40.9 \\
-1.3 \\
-8.5 \\
-0.8 \\
-8.8 \\
-6.7 \\
-15.8 \\
5.4 \\
10.0 \\
-3.9 \\
7.2 \\
12.8 \\
1.4\end{array}$ & $\begin{array}{r}15.5 \\
19.6 \\
7.2 \\
-1.3 \\
-20.3 \\
17.7 \\
-19.4 \\
-6.9 \\
-20.6 \\
11.9 \\
7.0 \\
28.8 \\
21.6 \\
31.3 \\
1.7 \\
17.2 \\
20.8 \\
13.9\end{array}$ & 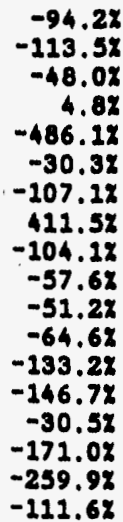 \\
\hline
\end{tabular}




\section{Appendix F: Arrearage Impacts}

\section{Section 2: \\ 1989 Installations}

Table of Contents:

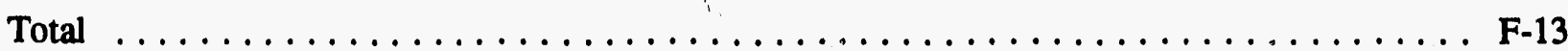

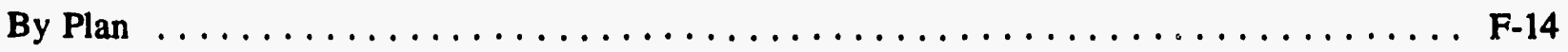

By Urban/Rural Status $\ldots \ldots \ldots \ldots \ldots \ldots \ldots \ldots \ldots \ldots \ldots \ldots \ldots \ldots \ldots \ldots$. . . . . . . . . . . . .

By Urban/Rural Status and Plan $\ldots \ldots \ldots \ldots \ldots \ldots \ldots \ldots \ldots \ldots \ldots \ldots \ldots$

By Owner/Renter Status $\ldots \ldots \ldots \ldots \ldots \ldots \ldots \ldots \ldots \ldots \ldots \ldots \ldots \ldots \ldots \ldots \ldots$ F-23

By Owner/Renter Status and Plan $\ldots \ldots \ldots \ldots \ldots \ldots \ldots \ldots \ldots \ldots \ldots \ldots \ldots \ldots \ldots$

By Primary Space Heating Fuel . . . . . . . . . . . . . . . . . . . . . . . . . . . . F F-29

By Primary Space Heating Fuel and Plan $\ldots \ldots \ldots \ldots \ldots \ldots \ldots \ldots \ldots \ldots \ldots \ldots$ F-31 



\section{Arrearage Impacts of 1989 Installations}

\begin{tabular}{|c|c|c|c|c|}
\hline PREPOST & $\mathbf{N}$ & Mean & Std Dev & Std Erro \\
\hline pre & $\begin{array}{l}2533 \\
2531\end{array}$ & -17767.42992499 & $\begin{array}{l}85684.71260847 \\
89051.76379460\end{array}$ & $\begin{array}{l}1702.4946252 \\
1770.0945018\end{array}$ \\
\hline Variances & $\mathbf{T}$ & Method & erob $>|\mathrm{T}|$ & \\
\hline Equal & 4.7576 & $\begin{array}{l}\text { Satterthwaite } \\
\text { Cochran }\end{array}$ & $\begin{array}{cc}5054.2 & 0.0001 \\
5062.0 & 0.0001 \\
& 0.0000\end{array}$ & \\
\hline
\end{tabular}


EPIAN $=1$

Variable: ARREARAG

\begin{tabular}{lcccc} 
PREPOST & $\mathrm{N}$ & Mean & Std Dev & Std Error" \\
\hline pos & 865 & -24240.36184971 & 117609.30335573 & 3998.85668159 \\
pre & 863 & -32624.26303592 & 88197.28828620 & 3002.27060867
\end{tabular}

Variances $T$ Method DF Prob $|T|$

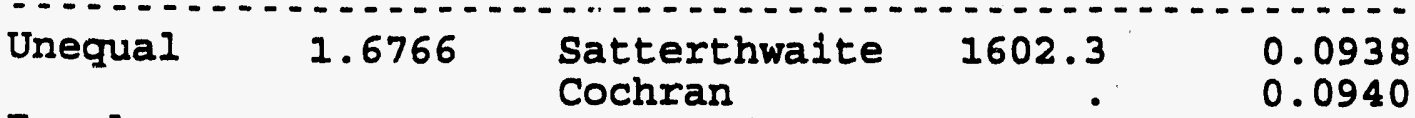

$\begin{array}{llll}\text { Equal } 1.6761 & 1726.0 & 0.0939\end{array}$

For HO: Variances are equal, $F^{\prime}=1.78 \quad D F=(864,862) \quad$ Prob>F' $=0.0000$

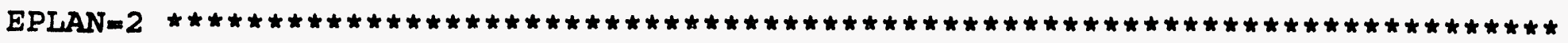

Variable: ARREARAG

\begin{tabular}{|c|c|c|c|c|c|}
\hline PREPOST & $\mathbf{N}$ & Mean & & Std Dev & std E \\
\hline $\begin{array}{l}\text { pos } \\
\text { pre }\end{array}$ & $\begin{array}{l}165 \\
165\end{array}$ & $\begin{array}{l}-26084.00606061 \\
-24470.54545455\end{array}$ & 63 & $\begin{array}{l}.65545455 \\
.75714808\end{array}$ & $\begin{array}{l}4114.02869749 \\
1917.91462406\end{array}$ \\
\hline Variances & $\mathbf{T}$ & Method & DF & Probs $|\mathrm{T}|$ & \\
\hline $\begin{array}{l}\text { Unequal } \\
\text { Equal }\end{array}$ & $\begin{array}{l}-0.2516 \\
-0.2516\end{array}$ & $\begin{array}{l}\text { Satterthwaite } \\
\text { Cochran }\end{array}$ & $\begin{array}{l}318.1 \\
164.0 \\
328.0\end{array}$ & $\begin{array}{l}0.8015 \\
0.8016 \\
0.8015\end{array}$ & \\
\hline
\end{tabular}

For HO: Variances are equal, $F^{\prime}=1.43 \quad \mathrm{DF}=(164,164) \quad$ Prob>F' $=0.0228$ 


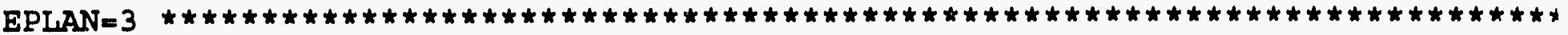

Variable: ARREARAG

\begin{tabular}{|c|c|c|c|c|c|}
\hline PREPOST & $\mathbf{N}$ & Mean & & Std Dev & Std Error \\
\hline $\begin{array}{l}\text { pos } \\
\text { pre }\end{array}$ & $\begin{array}{l}1151 \\
1151\end{array}$ & $\begin{array}{l}-12966.05647263 \\
-20309.12597741\end{array}$ & & $\begin{array}{l}.75588397 \\
1.13160331\end{array}$ & $\begin{array}{l}1656.69717234 \\
2407.0975255\end{array}$ \\
\hline Variances & $\mathrm{T}$ & Method & $\mathrm{DF}$ & Probs $|\mathrm{T}|$ & \\
\hline Unequal & 2.5129 & $\begin{array}{l}\text { Satterthwaite } \\
\text { Cochran }\end{array}$ & $\begin{array}{l}2039.8 \\
1150.0 \\
2300.0\end{array}$ & $\begin{array}{l}0.0120 \\
0.0121 \\
0.0120\end{array}$ & \\
\hline
\end{tabular}

For HO: Variances are equal, $F^{\prime}=2.11 \quad D F=(1150,1150) \quad$ Prob $>F^{\prime}=0.000 C$

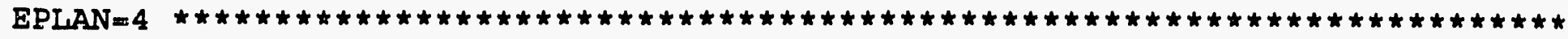

Variable: ARREARAG

$\begin{array}{lllll}\text { PREPOST } & \mathrm{N} & \text { Mean } & \text { Std Dev }\end{array}$

$\begin{array}{llrrr}\text { pos } & 195 & -7739.93333333 & 65346.27088730 & 4679.5436545 \\ \text { pre } & 195 & -56074.82564103 & 115102.89902813 & 8242.6898039\end{array}$

\begin{tabular}{lcccc} 
Variances & $T$ & Method & DF & Probs $|T|$ \\
\hdashline Unequal & 5.0995 & Satterthwaite & 307.3 & 0.0001 \\
Equal & 5.0995 & Cochran & 194.0 & 0.0000 \\
& & & 388.0 & 0.0000
\end{tabular}

For Ho: Variances are equal, $F^{\prime}=3.10 \quad D F=(194,194) \quad$ Prob $>F^{\prime}=0.0000$. 
$E P L A N=5$

Variable: ARREARAG

\begin{tabular}{|c|c|c|c|c|}
\hline PREPOST & $\mathbf{N}$ & Mean & Std Dev & Std Error \\
\hline $\begin{array}{l}\text { pos } \\
\text { pre }\end{array}$ & $\begin{array}{l}157 \\
157\end{array}$ & $\begin{array}{l}-21018.52229299 \\
-51208.87261146\end{array}$ & $\begin{array}{l}102026.91620450 \\
117192.98938037\end{array}$ & $\begin{array}{l}8142.63436855 \\
9353.01877760\end{array}$ \\
\hline Variances & $T$ & Method & Prob $>|\mathrm{T}|$ & \\
\hline Unequal & 2.4345 & $\begin{array}{l}\text { Satterthwaite } \\
\text { Cochran }\end{array}$ & $\begin{array}{l}0.0155 \\
0.0160 \\
0.0155\end{array}$ & \\
\hline
\end{tabular}

For HO: Variances are equal, $F^{\prime}=1.32 \quad \mathrm{DF}=(156,156) \quad$ Prob $>\mathrm{F}^{\prime}=0.0845$ 


\section{Arrearage Impacts of 1989 Installations}

URBRUR=RURAL

Variable: ARREARAG

\begin{tabular}{|c|c|c|c|c|}
\hline PREPOST & $\mathbf{N}$ & Mean & Std Dev & std Erro \\
\hline $\begin{array}{l}\text { pos } \\
\text { pre }\end{array}$ & $\begin{array}{l}1229 \\
1228\end{array}$ & $\begin{array}{l}-19916.38974776 \\
-29037.05211726\end{array}$ & $\begin{array}{r}103133.19064610 \\
89342.39712300\end{array}$ & $\begin{array}{l}2941.8634619 \\
2549.5199656\end{array}$ \\
\hline Variances & $T$ & Method & Probs $|\mathrm{T}|$ & \\
\hline $\begin{array}{l}\text { Unequal } \\
\text { Equal }\end{array}$ & $\begin{array}{l}2.3429 \\
2.3428\end{array}$ & $\begin{array}{l}\text { Satterthwaite } \\
\text { Cochran }\end{array}$ & $\begin{array}{l}2406.6 \\
2455.0\end{array}$ & \\
\hline
\end{tabular}

For HO: Variances are equal, $F^{\prime}=1.33 \quad D F=(1228,1227) \quad$ Prob $>F^{\prime}=0.000$

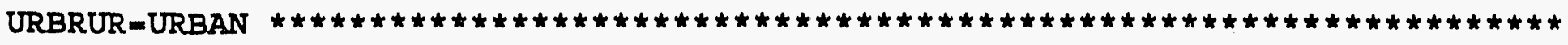
Variable: ARREARAG

\begin{tabular}{|c|c|c|c|c|c|}
\hline PREPOST & $\mathbf{N}$ & Mean & & Std Dev & Std Erro \\
\hline $\begin{array}{l}\text { pos } \\
\text { pre }\end{array}$ & $\begin{array}{l}1304 \\
1303\end{array}$ & $\begin{array}{l}-15742.06825153 \\
-29842.72217959\end{array}$ & & $\begin{array}{l}9.90949975 \\
9.52404239\end{array}$ & $\begin{array}{l}1801.9444853 \\
2460.2958536\end{array}$ \\
\hline Variances & $\mathrm{T}$ & Method & DF & Prob $>|\mathrm{T}|$ & \\
\hline Equal & 4.6238 & $\begin{array}{l}\text { Satterthwaite } \\
\text { Cochran }\end{array}$ & 2387.1 & $\begin{array}{l}0.0001 \\
0.0001 \\
0.0000\end{array}$ & . \\
\hline
\end{tabular}




\section{Arrearage Impacts of 1989 Installations}

EPLAN $=1$ URBRUR $=$ RURAL

Variable: ARREARAG

\begin{tabular}{lcccc} 
PREPOST & N & Mean & Std Dev & Std Error \\
\hdashline pos & 421 & -27345.51306413 & 158959.23568010 & 7747.19911199 \\
pre & 420 & -35568.04761905 & 110754.70136998 & 5404.27605732
\end{tabular}

Variances $\quad T \quad$ DF $\quad$ Probs $|T|$

$\begin{array}{llll}\text { Unequal } & 0.8705 & 750.2 & 0.3843 \\ \text { Equal } & 0.8701 & 839.0 & 0.3845\end{array}$

For HO: Variances are equal, $F^{\prime}=2.06 \quad D F=(420,419) \quad$ Prob $>F^{\prime}=0.0000$

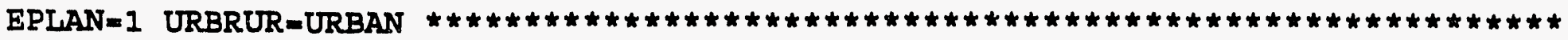

Variable: ARREARAG

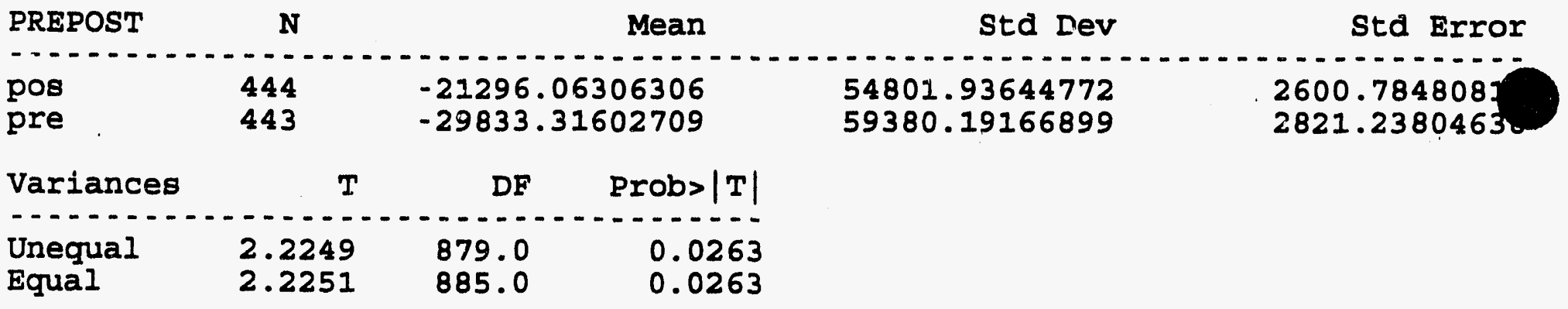

For HO: Variances are equal, $F^{\prime}=1.17 \quad$ DF $=(442,443) \quad$ Prob $>F^{\prime}=0.0918$ 


\section{Arrearage Impacts of 1989 Installations}

EPLAN=2 URBRUR =RURAL

Variable: ARREARAG

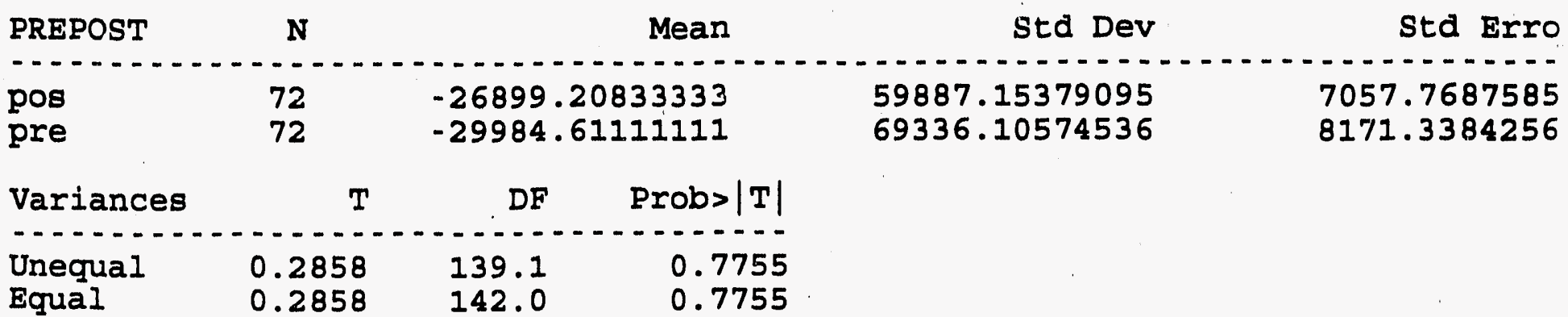

For HO: Variances are equal, $F^{\prime}=1.34 \quad$ DF $=(71,71) \quad$ Prob>F' $=0.2195$

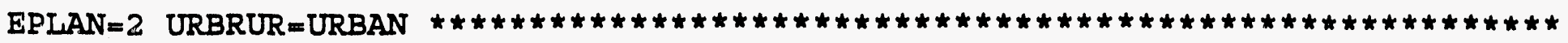
Variable: ARREARAG

$\begin{array}{llll}\text { PREPOST } & \mathbf{N} & \text { Mean } & \text { Std Dev }\end{array}$

$\begin{array}{lllll}\text { pos } & 93 & -25452.88172043 & 47005.13793930 & 4874.2057447 \\ \text { pre } & 93 & -20201.59139785 & 57978.05616562 & 6012.0443598\end{array}$

\begin{tabular}{lccr} 
Variances & T & DF & Prob $>|T|$ \\
\hdashline Unequal & -0.6785 & 176.5 & 0.4984 \\
Equal & -0.6785 & 184.0 & 0.4983
\end{tabular}

For Ho: Variances are equal, $F^{\prime}=1.52 \quad D F=(92,92) \quad$ Prob> $F^{\prime}=0.0455$ 
EPLAN=3 URBRUR=RURAL

Variable: ARREARAG

\begin{tabular}{lcccr} 
PREPOST & $\mathrm{N}$ & Mean & Std Dev & Std Error. \\
\hdashline pos & 544 & -16025.67830882 & 53687.21482044 & 2301.82034549 \\
pre & 544 & -17254.27389706 & 45902.36964626 & 1968.04786226
\end{tabular}

Variances $\quad T \quad$ DF $\quad$ Prob $>|\mathrm{T}|$

$\begin{array}{llll}\text { Unequal } & 0.4057 & 1060.4 & 0.6851 \\ \text { Equal } & 0.4057 & 1086.0 & 0.6851\end{array}$

For HO: Variances are equal, $F^{\prime}=1.37 \quad$ DF $=(543,543) \quad$ Prob $>F^{\prime}=0.0003$

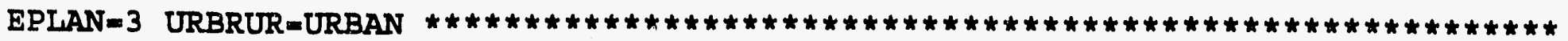
Variable: ARREARAG

PREPOST $\quad$ N $\quad$ Mean Std Dev Std Error

\begin{tabular}{|c|c|c|c|c|}
\hline $\begin{array}{l}\text { pos } \\
\text { pre }\end{array}$ & $\begin{array}{l}607 \\
607\end{array}$ & $\begin{array}{l}-10223.99011532 \\
-23046.91762768\end{array}$ & $\begin{array}{r}58278.31490538 \\
103691.29856306\end{array}$ & \\
\hline
\end{tabular}

\begin{tabular}{lrrr} 
Variances & $T$ & DF & Probs $|T|$ \\
\hline Unequal & 2.6560 & 954.1 & 0.0080 \\
Equal & 2.6560 & 1212.0 & 0.0080
\end{tabular}

For HO: Variances are equal, $F^{\prime}=3.17 \quad$ DF $=(606,606) \quad$ Prob>F' $=0.0000$ 


\section{Arrearage Impacts of 1989 Installations}

EPLAN $=4$ URBRUR $=$ RURAL

Variable: ARREARAG

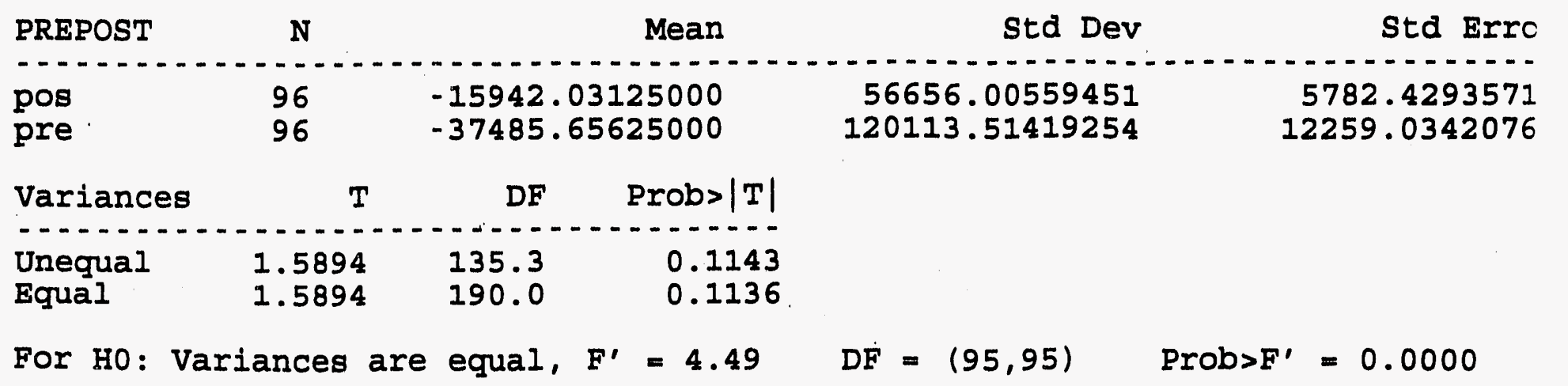

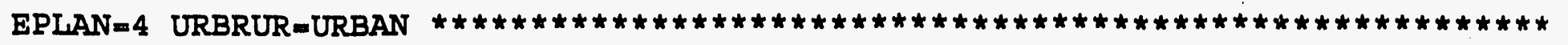
Variable: ARREARAG

PREPOST N Mean $\quad$ std Dev $\quad$ std Erro

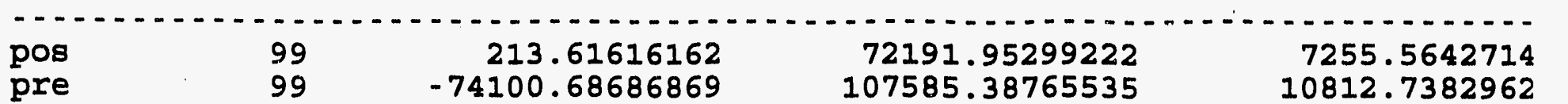

Variances $\quad$ T $\quad$ DF Probs $|\mathrm{T}|$

Unequal $\quad 5.7071 \quad 171.4 \quad 0.0001$

Equal $\quad 5.7071 \quad 196.0 \quad 0.0000$

For HO: Variances are equal, $F^{\prime}=2.22 \quad D F=(98,98) \quad$ Prob $>F^{\prime}=0.0001$ 


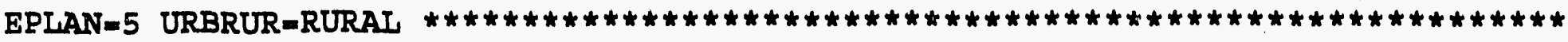

Variable: ARREARAG

\begin{tabular}{|c|c|c|c|c|}
\hline PREPOST & $\mathbf{N}$ & Mean & Std Dev & Std Error \\
\hline $\begin{array}{l}\text { pos } \\
\text { pre }\end{array}$ & $\begin{array}{l}96 \\
96\end{array}$ & $\begin{array}{r}-8121.19791667 \\
-58073.75000000\end{array}$ & $\begin{array}{r}53749.73975156 \\
130462.74640541\end{array}$ & $\begin{array}{r}5485.80984161 \\
13315.29829731\end{array}$ \\
\hline
\end{tabular}

Variances $\quad T \quad$ DF Probs $|T|$

$\begin{array}{llll}\text { Unequal } & 3.4687 & 126.3 & 0.0007 \\ \text { Equal } & 3.4687 & 190.0 & 0.0006\end{array}$

Equal $\quad 3.4687 \quad 190.0 \quad 0.0006$

For HO: Variances are equal, $F^{\prime}=5.89 \quad D F=(95,95) \quad$ Prob> $F^{\prime}=0.0000$

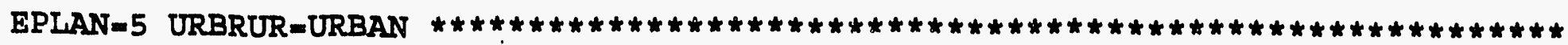

Variable: ARREARAG

\begin{tabular}{|c|c|c|c|c|}
\hline PREPOST & $\mathbf{N}$ & Mean & Std Dev & std Err \\
\hline $\begin{array}{l}\text { pos } \\
\text { pre }\end{array}$ & $\begin{array}{l}61 \\
61\end{array}$ & $\begin{array}{l}-41315.95081967 \\
-40405.13114754\end{array}$ & $\begin{array}{r}147666.43485668 \\
92550.92264829\end{array}$ & $\begin{array}{l}18906 . \\
11849 .\end{array}$ \\
\hline
\end{tabular}

Variances $T$ DF Prob $>|T|$

Unequal $\quad-0.0408 \quad 100.8 \quad 0.9675$

Equal $\quad-0.0408 \quad 120.0 \quad 0.9675$

For HO: Variances are equal, $F^{\prime}=2.55 \quad D F=(60,60) \quad$ Probs $>F^{\prime}=0.0004$ 


\section{Arrearage Impacts of 1989 Installations}

\section{OWNRENT $=\mathrm{H}$}

Variable: ARREARAG

\begin{tabular}{|c|c|c|c|c|}
\hline PREPOST & $\mathbf{N}$ & Mean & & Std De \\
\hline $\begin{array}{l}\text { pos } \\
\text { pre }\end{array}$ & $\begin{array}{l}1171 \\
1170\end{array}$ & $\begin{array}{l}-26235.87959009 \\
-31565.28461538\end{array}$ & & $\begin{array}{l}9.0912426 \\
9.9701429\end{array}$ \\
\hline Variances & $\mathrm{T}$ & Method & $D F$ & Prob $>1$ \\
\hline $\begin{array}{l}\text { Unequa } \\
\text { Equal }\end{array}$ & 1.7601 & $\begin{array}{l}\text { Satterthwaite } \\
\text { Cochran }\end{array}$ & $\begin{array}{l}2047.7 \\
2339.0\end{array}$ & $\begin{array}{l}0 . \\
0 . \\
0 .\end{array}$ \\
\hline
\end{tabular}

For HO: Varlances are equal, $F^{\prime}=2.21 \quad D F=(1169,1170) \quad$ Prob $>F^{\prime}=0.000$

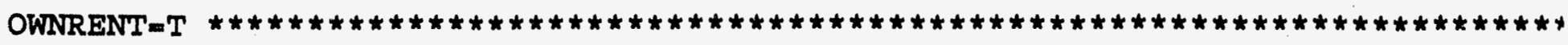
Variable: ARREARAG

\begin{tabular}{|c|c|c|c|c|c|}
\hline PREPOST & $\mathbf{N}$ & Mean & & Std Dev & Std Error \\
\hline $\begin{array}{l}\text { pos } \\
\text { pre }\end{array}$ & $\begin{array}{l}1354 \\
1353\end{array}$ & $\begin{array}{l}-10298.07459380 \\
-27557.82557280\end{array}$ & $\begin{array}{r}10: \\
9\end{array}$ & $\begin{array}{l}7.06079819 \\
.82268600\end{array}$ & $\begin{array}{l}2814.02818977 \\
2495.45856974\end{array}$ \\
\hline Variances & $T$ & Method & DF & Prob $>|T|$ & \\
\hline $\begin{array}{l}\text { Unequal } \\
\text { Equal }\end{array}$ & $\begin{array}{l}4.5890 \\
4.5888\end{array}$ & $\begin{array}{l}\text { Satterthwaite } \\
\text { Cochran }\end{array}$ & $\begin{array}{r}2667.1 \\
2705.0\end{array}$ & $\begin{array}{l}0.0001 \\
0.0001 \\
0.0000\end{array}$ & \\
\hline
\end{tabular}

For HO: Variances are equal, $F^{\prime}=1.27 \quad D F=(1353,1352) \quad$ Prob $>F^{\prime}=0.000 C$ 


\section{Arrearage Impacts of 1989 Installations}

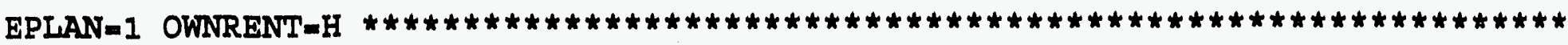
Varlable: ARREARAG

\begin{tabular}{lcccc} 
PREPOST & $\mathrm{N}$ & \multicolumn{1}{c}{ Mean } & Std Dev & Std Error \\
\hdashline pos & 428 & -26985.14953271 & 51990.86054930 & 2513.07309949 \\
pre & 427 & -28467.59953162 & 52813.53865905 & 2555.82627129
\end{tabular}

\begin{tabular}{lccr} 
Variances & $T$ & DF & Prob $>|\mathrm{T}|$ \\
\hline Unequal & 0.4136 & 852.7 & 0.6793 \\
Equal & 0.4136 & 853.0 & 0.6793
\end{tabular}

For HO: Variances are equal, $F^{\prime}=1.03 \quad D F=(426,427) \quad$ Prob $>F^{\prime}=0.7459$

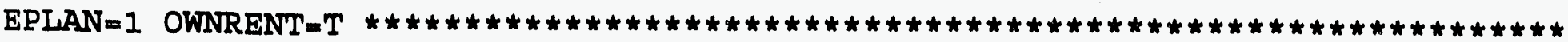
Variable: ARREARAG

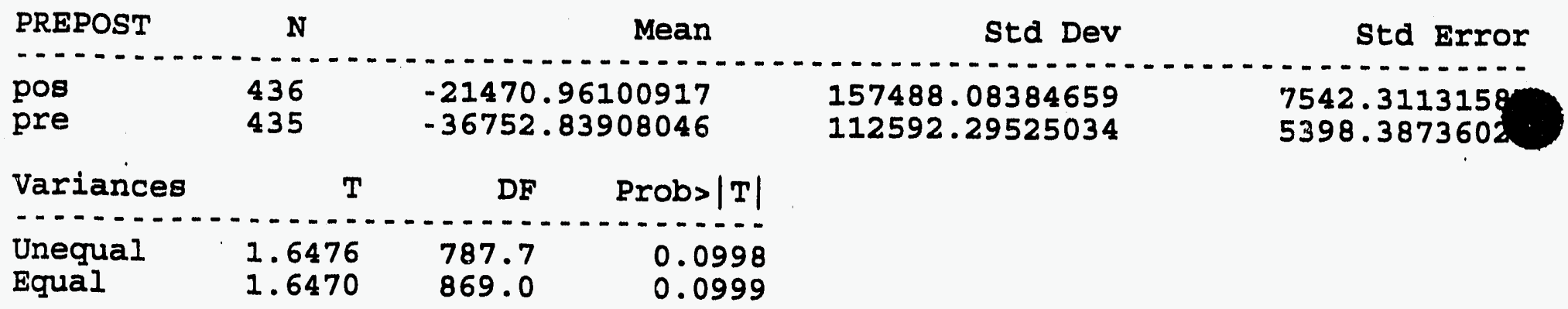

For HO: Variances are equal, $F^{\prime}=1.96 \quad D F=(435,434) \quad$ Prob $>F^{\prime}=0.0000$ 


\section{Arrearage Impacts of 1989 Installations}

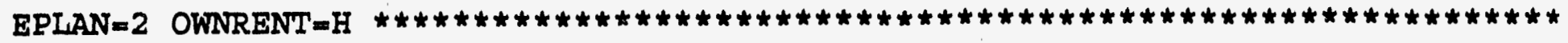
Variable: ARREARAG

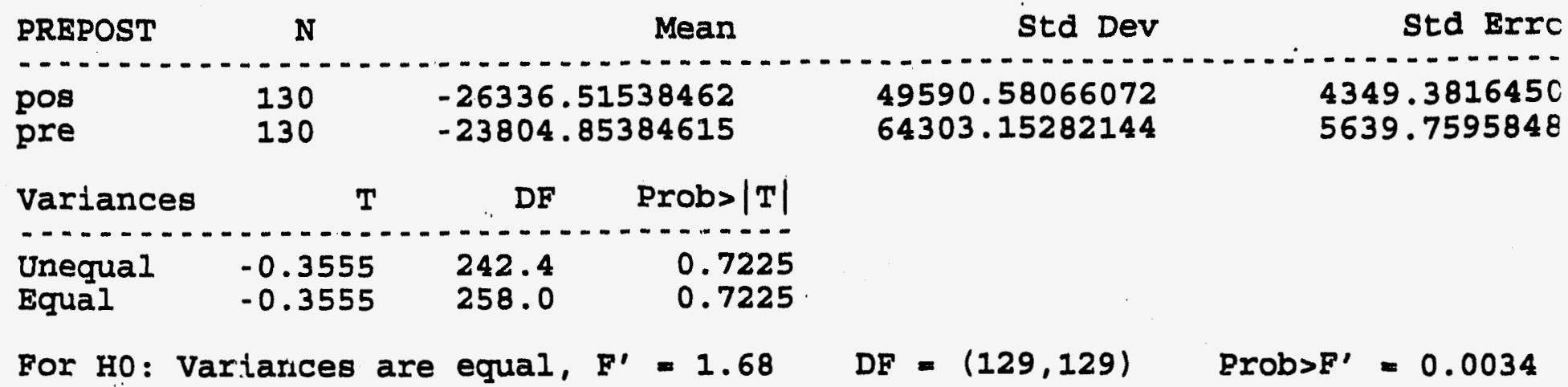

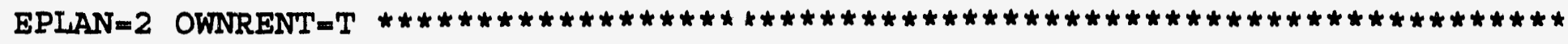
Variable: ARREARAG

\begin{tabular}{|c|c|c|c|c|c|}
\hline PREPOST & $N$ & & Mean & Std Dev & std Errc \\
\hline $\begin{array}{l}\text { pos } \\
\text { pre }\end{array}$ & 35 & $\begin{array}{l}-25146 \\
-26943\end{array}$ & $\begin{array}{l}428571 \\
428571\end{array}$ & $\begin{array}{l}64333.13821442 \\
59605.79529699\end{array}$ & $\begin{array}{l}10874.2850963 \\
10075.2183003\end{array}$ \\
\hline Variances & $T$ & $\mathrm{DE}$ & Probs 1 & & \\
\hline $\begin{array}{l}\text { Unequal } \\
\text { Equal }\end{array}$ & $\begin{array}{l}0.1212 \\
0.1212\end{array}$ & $\begin{array}{l}67.6 \\
68.0\end{array}$ & $\begin{array}{l}0.90 \\
0.90\end{array}$ & & \\
\hline
\end{tabular}




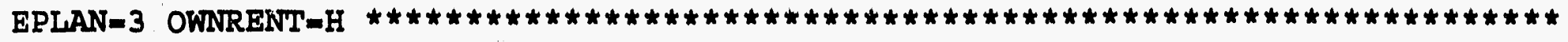
Variable: ARREARAG

\begin{tabular}{lcccc} 
PREPOST & $N$ & Mean & Std Dev & Std Error \\
\hline pos & 445 & -26422.93483146 & 42151.95529361 & 1998.19431694 \\
pre & 445 & -27826.65393258 & 105839.84530626 & 5017.28984869
\end{tabular}

\begin{tabular}{lccr} 
Variances & $T$ & DF & Prob $>|T|$ \\
\hline Unequal & 0.2599 & 581.4 & 0.7950 \\
Equal & 0.2599 & 888.0 & 0.7950
\end{tabular}

For HO: Variances are equal, $F^{\prime}=6.30 \quad$ DF $=(444,444) \quad$ Prob>F' $=0.0000$

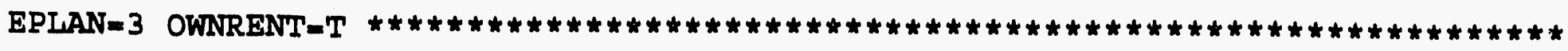
Variable: ARREARAG

PREPOST $\quad$ N $\quad$ Mean Std Dev Stor

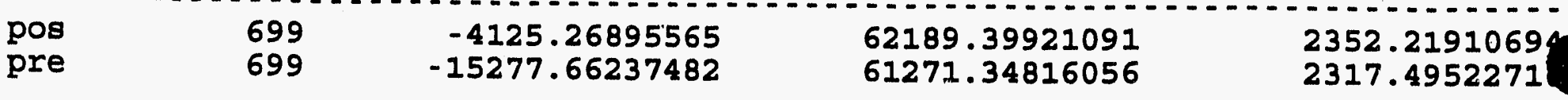

\begin{tabular}{lccr} 
Variances & T & DF & Prob $>|T|$ \\
\hline Unequal & 3.3774 & 1395.7 & 0.0008 \\
Equal & 3.3774 & 1396.0 & 0.0008
\end{tabular}

For HO: Variances are equal, $F^{\prime}=1.03 \quad$ DF $=(698,698) \quad$ Prob>F' $=0.6945$ 


\section{Arrearage Impacts of 1989 Installations}

EPLAN $=4$ OWNRENT $=\mathrm{H}$

Variable: ARREARAG

$\begin{array}{llll}\text { PREPOST } & \mathrm{N} & \text { Mean } & \text { Std Dev }\end{array}$

\begin{tabular}{|c|c|c|c|c|}
\hline $\begin{array}{l}\text { pos } \\
\text { pre }\end{array}$ & $\begin{array}{l}80 \\
80\end{array}$ & $\begin{array}{l}-12942.21250000 \\
-67341.46250000\end{array}$ & $\begin{array}{r}48352.86149576 \\
101282.05710923\end{array}$ & $\begin{array}{r}5406.0142605 \\
11323.678229 \varepsilon\end{array}$ \\
\hline
\end{tabular}

Variances $T$ DF Prob $>|T|$

Unequal $4.3353 \quad 113.2 \quad 0.0001$

Equal $4.3353 \quad 158.0 \quad 0.0000$

For HO: Variances are equal, $F^{\prime}=4.39 \quad D F=(79,79) \quad$ Prob $>F^{\prime}=0.0000$

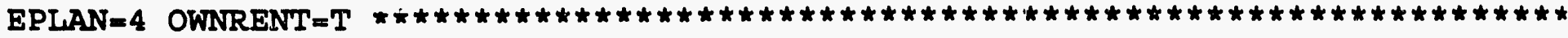

Variable: ARREARAG

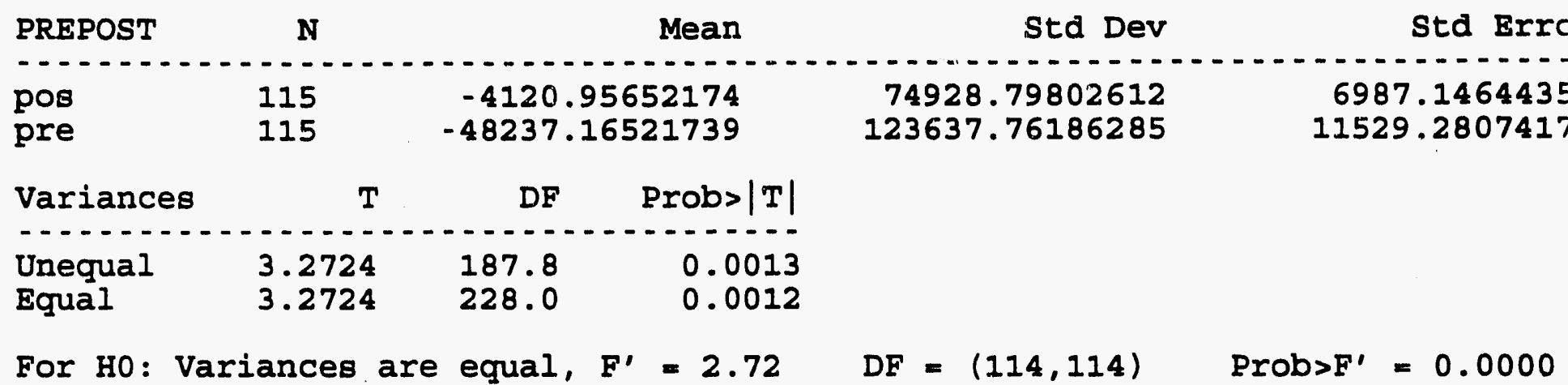




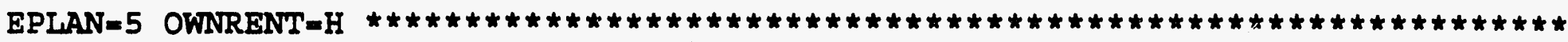
Variable: ARREARAG

\begin{tabular}{|c|c|c|c|c|}
\hline PREPOST & $\mathbf{N}$ & Mean & Std Dev & std Error \\
\hline $\begin{array}{l}\text { pos } \\
\text { pre }\end{array}$ & $\begin{array}{l}88 \\
88\end{array}$ & $\begin{array}{l}-33582.28409091 \\
-44442.14772727\end{array}$ & $\begin{array}{l}129094.53595816 \\
106726.58036724\end{array}$ & $\begin{array}{l}13761.52377194 \\
11377.09169424\end{array}$ \\
\hline
\end{tabular}

Variances T DF, Probs $|\mathrm{T}|$

Unegual

Unequal $\quad 0.6082 \quad 168.1 \quad 0.5439$

$\begin{array}{llll}\text { Equal } & 0.6082 & 174.0 & 0.5438\end{array}$

For HO: Variances are equal, $F^{\prime}=1.46 \quad D F=(87,87) \quad$ Prob>F' $=0.0777$

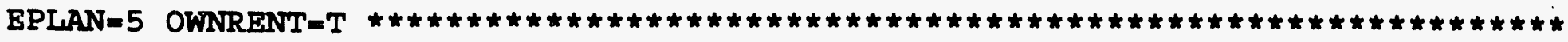

Variable: ARREARAG

PREPOST N Mean Std Dev Std Error

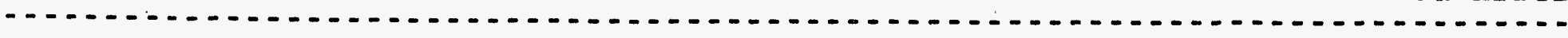

pos 69

pre $\quad 69$

$69 \quad-4995.17391304$

45759.07786953

5508.7456257

129614.09841425

15603.7038095

Variances $\quad T \quad$ DF Prob $|T|$

Unequal $\quad 3.3143 \quad 84.7 \quad 0.0014$

Equal $\quad 3.3143 \quad 136.0 \quad 0.0012$

For HO: Variances are equal, $F^{\prime}=8.02 \quad D F=(68,68) \quad$ Prob>F' $=0.0000$ 


\section{Arrearage Impacts of 1989 Installations}

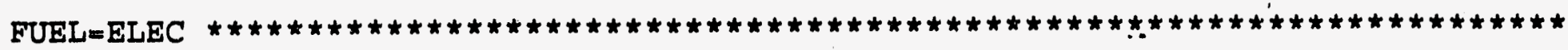

Variable: ARREARAG

\begin{tabular}{lcccr} 
PREPOST & $\mathrm{N}$ & Mean & Std Dev & Std Error \\
\hdashline pos & 325 & -8351.17846154 & 66858.70776043 & 3708.65383141 \\
pre & 324 & -23892.79938272 & 91257.80070773 & 5069.87781710
\end{tabular}

Variances $T$ Method DF Prob $>|T|$

Unequal $\quad 2.4742 \quad$ Satterthwaite $592.1 \quad 0.0136$

$\begin{array}{llll}\text { Equal Cochran } & 0.0139 \\ & 2.4753 & 647.0 & 0.0136\end{array}$

For HO: Variances are equal, $F^{\prime}=1.86 \quad D F=(323,324)^{\circ} \quad$ Prob $>F^{\prime}=0.0000$

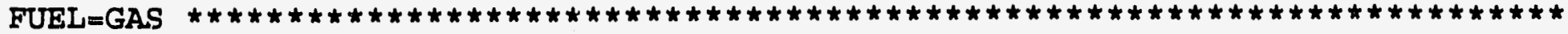

Variable: ARREARAG

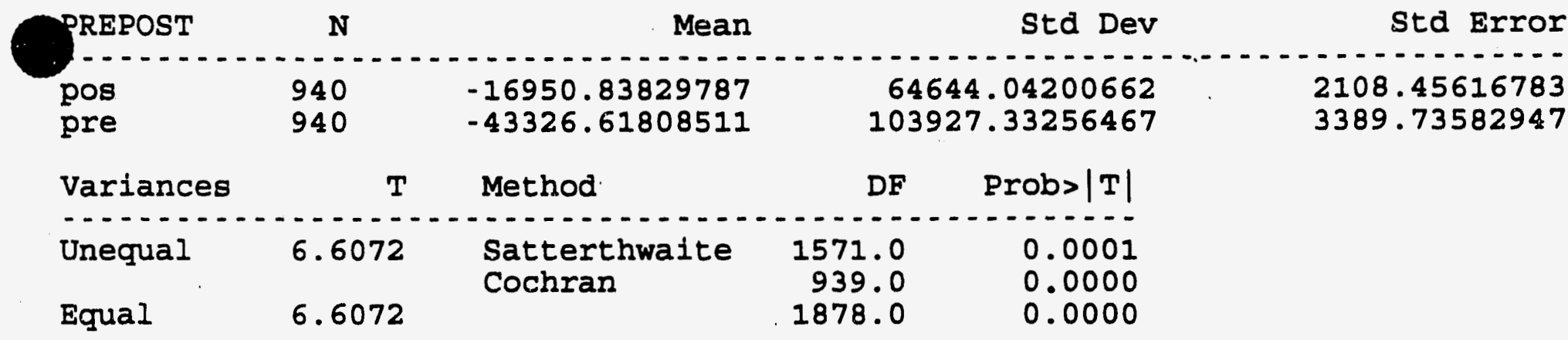

For HO: Variances are equal, $F^{\prime}=2.58 \quad D F=(939,939) \quad$ Prob $>F^{\prime}=0.0000$ 


\section{Arrearage Impacts of 1989 Installations}

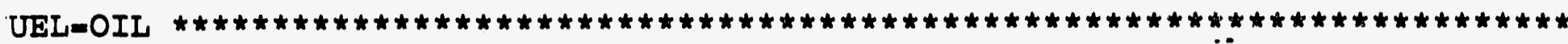
ariable: ARREARAG

\begin{tabular}{|c|c|c|c|c|}
\hline REPOST & $\mathbf{N}$ & Mean & & Std Dev \\
\hline $\begin{array}{l}\text { os } \\
\text { re }\end{array}$ & $\begin{array}{l}1167 \\
1166\end{array}$ & $\begin{array}{l}-21821.04712939 \\
-20955.72641509\end{array}$ & & $\begin{array}{l}.85941 \\
.26719\end{array}$ \\
\hline ariances & $T$ & Method & DF & Prob $>\mid T$ \\
\hline $\begin{array}{l}\text { nequal } \\
\text { qual }\end{array}$ & $\begin{array}{l}-0.2309 \\
-0.2309\end{array}$ & $\begin{array}{l}\text { Satterthwaite } \\
\text { Cochran }\end{array}$ & $\begin{array}{l}2155.6 \\
2331.0\end{array}$ & $\begin{array}{l}0 . \\
0 . \\
0 .\end{array}$ \\
\hline
\end{tabular}

or HO: Variances are equal, $F^{\prime}=1.80 \quad$ DF $=(1166,1165)$ 'Prob $>F^{\prime}=0.0000$

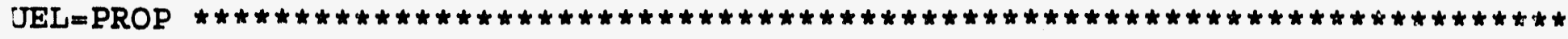
zriable: ARREARAG

REPOST N Mean Std Dev Std Error

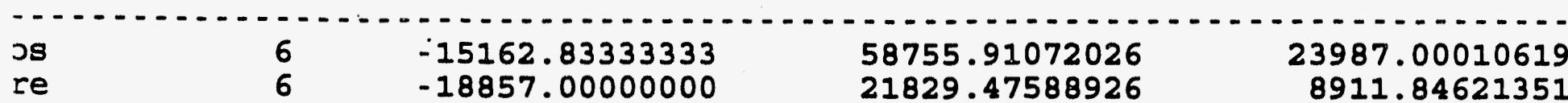

\begin{tabular}{lcccr} 
zriances & $T$ & Method & DF & Prob $>|T|$ \\
\hdashline lequal & 0.1444 & Satterthwaite & 6.4 & 0.8897 \\
& & Cochran & 5.0 & 0.8909 \\
Tual & 0.1444 & & 10.0 & 0.8881
\end{tabular}

Ir HO: Variances are equal, $F^{\prime}=7.24 \quad \mathrm{DF}=(5,5) \quad$ Prob $>\mathrm{F}^{\prime}=0.0486$ 


\section{Arrearage Impacts of 1989 Installations}

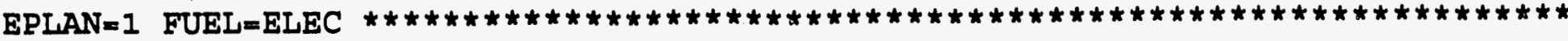
Variable: ARREARAG

\begin{tabular}{|c|c|c|c|c|}
\hline PREPOST & $\mathrm{N}$ & Mean & & Std D \\
\hline pres & $\begin{array}{l}132 \\
131\end{array}$ & $\begin{array}{r}-6730.57575758 \\
-18949.19847328\end{array}$ & & $\begin{array}{l}8.537 \\
0.254\end{array}$ \\
\hline Variances & $\mathrm{T}$ & Method & DF & Prob> \\
\hline $\begin{array}{l}\text { Unequal } \\
\text { Equal }\end{array}$ & 1.7093 & $\begin{array}{l}\text { Satterthwaite } \\
\text { Cochran }\end{array}$ & $\begin{array}{r}261.0 \\
261.0\end{array}$ & \\
\hline
\end{tabular}

For HO: Variances are equal, $F^{\prime}=1.02 \quad D F=(131,130) \quad$ Prob $>F^{\prime}=0.8894$

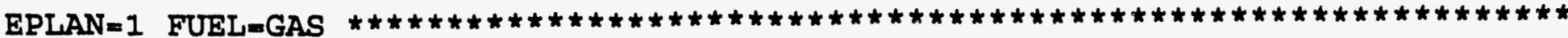
Variable: ARREARAG

\begin{tabular}{|c|c|c|c|c|}
\hline EPOST & $\mathbf{N}$ & Mean & Sta Dev & std Error \\
\hline pos & $\begin{array}{l}288 \\
288\end{array}$ & $\begin{array}{l}-31113.16319444 \\
-53093.99652778\end{array}$ & $\begin{array}{l}75518.67727794 \\
83974.97684963\end{array}$ & $\begin{array}{l}4449.98073412 \\
4948.27296503\end{array}$ \\
\hline
\end{tabular}

\begin{tabular}{lcccc} 
Variances & T & Method & DF & Prob $|T|$ \\
\hdashline Unequal & 3.3030 & Satterthwaite & 567.7 & 0.0010 \\
Equal & 3.3030 & Cochran & 287.0 & 0.0011 \\
& & 574.0 & 0.0010
\end{tabular}

For HO: Variances are equal, $\mathrm{F}^{\prime}=1.24 \quad \mathrm{DF}=(287,287) \quad$ Prob $>\mathrm{F}^{\prime}=0.0727$

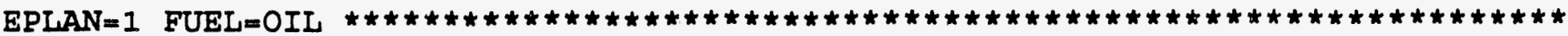
Variable: ARREARAG

$\begin{array}{lllll}\text { PREPOST N } & \text { Mean Std Dev Error }\end{array}$

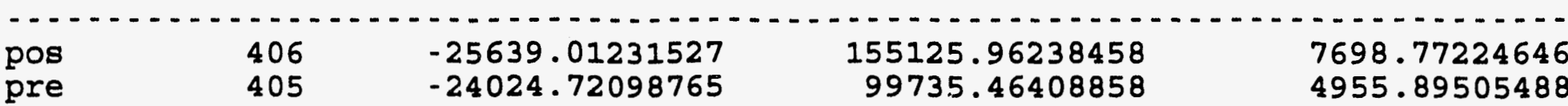
Variances T Method Drob $>|T|$

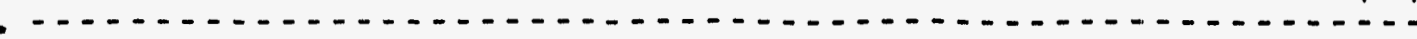

$\begin{array}{lllll}\text { Unequal } & -0.1763 & \text { Satterthwaite } & 691.2 & 0.8601\end{array}$

$\begin{array}{llll}\text { Equal } & -0.1762 & \text { Cochran } & 0.8601 \\ & & 809.0 & 0.8602\end{array}$

For HO: Variances are equal, $F^{\prime}=2.42 \quad D F=(405,404) \quad$ Prob $>F^{\prime}=0.0000$ 


\section{Arrearage Impacts of 1989 Installations}

IPLAN=2 FUEL=GAS

Variable: ARREARAG

$\begin{array}{llll}\text { PREPOST N } & \text { Mean } & \text { std Dev } & \text { Std Error }\end{array}$

\begin{tabular}{|c|c|c|c|c|}
\hline $\begin{array}{l}\text { poss } \\
\text { pore }\end{array}$ & $\begin{array}{l}12 \\
12\end{array}$ & $\begin{array}{l}-38000.33333333 \\
-58240.75000000\end{array}$ & $\begin{array}{l}74248.32103315 \\
90256.70220505\end{array}$ & $\begin{array}{l}21433.64406768 \\
26054.86565713\end{array}$ \\
\hline
\end{tabular}

\begin{tabular}{lcccr} 
Jariances & T & Method & DF & Prob $>|T|$ \\
\hline Jnequal & 0.5999 & Satterthwaite & 21.2 & 0.5549 \\
& & Cochran & 11.0 & 0.5607 \\
Jqual & 0.5999 & & 22.0 & 0.5547
\end{tabular}

For HO: Variances are equal, $F^{\prime}=1.48 \quad$ DF $=(11,11) \quad$ Prob $>F^{\prime}=0.5280$

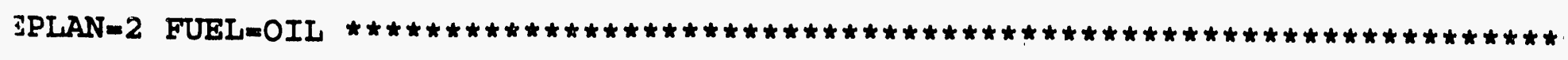
Jariable: ARREARAG

$\begin{array}{lllll}\text { ?REPOST N Nean } & \text { Std Dev } & \text { Std Error }\end{array}$

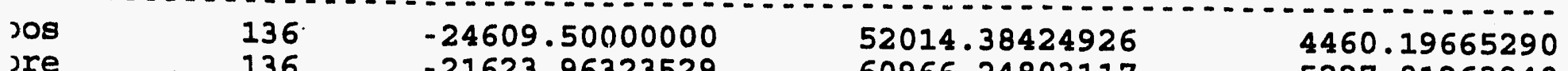

sre $\quad \begin{array}{lll}136 & -21623.96323529 & 60966.24803117\end{array}$

5227.81263940

$\begin{array}{llcrr}\text { Tariances } & T & \text { Method } & \text { DF } & \text { Prob }|T| \\ \text { Inequal } & -0.4345 & \text { Satterthwaite } & 263.5 & 0.6643 \\ \text { Iqual } & -0.4345 & \text { Cochran } & 135.0 & 0.6647 \\ & & & 270.0 & 0.6643\end{array}$

'Or HO: Variances are equal, F' $=1.37 \quad D F=(135,135) \quad$ Prob $>F^{\prime}=0.0661$ 


\section{Arrearage Impacts of 1989 Installations}

EPLAN=3 FUEL=ELEC

Variable: ARREARAG

\begin{tabular}{|c|c|c|c|c|}
\hline PREPOST & $\mathbf{N}$ & Mean & & std \\
\hline $\begin{array}{l}\text { pos } \\
\text { pre }\end{array}$ & $\begin{array}{l}169 \\
169\end{array}$ & $\begin{array}{l}-14383.47337278 \\
-19886.00591716\end{array}$ & & $\begin{array}{l}.4344 \\
5.0297\end{array}$ \\
\hline Variances & $T$ & Method & $D F$ & Prob \\
\hline $\begin{array}{l}\text { Unequal } \\
\text { Equal }\end{array}$ & $\begin{array}{l}0.6480 \\
0.6480\end{array}$ & $\begin{array}{l}\text { Satterthwaite } \\
\text { Cochran }\end{array}$ & $\begin{array}{l}312.7 \\
168.0 \\
336.0\end{array}$ & \\
\hline
\end{tabular}

For Ho: Variances are equal, $F^{\prime}=1.75 \quad D F=(168,168) \quad$ Prob $>F^{\prime}=0.0003$

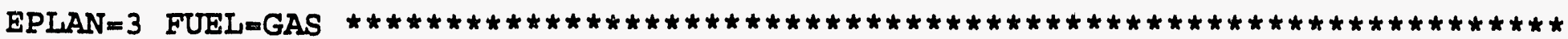
Variable: ARREARAG

PREPOST N Mean Std Dev $\quad$ Std Error

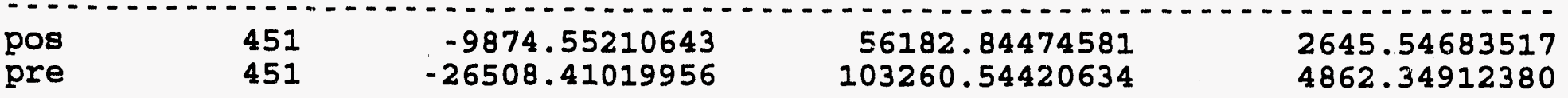

\begin{tabular}{lcccr} 
Variances & $T$ & Method & DF & Probs $|T|$ \\
\hdashline Unequal & 3.0050 & Satterthwaite & 695.0 & 0.0028 \\
Equal & 3.0050 & Cochran & 450.0 & 0.0028 \\
& & & 900.0 & 0.0027
\end{tabular}

For HO: Variances are equal, $F^{\prime}=3.38 \quad D F=(450,450) \quad$ Prob $>F^{\prime}=0.0000$ 


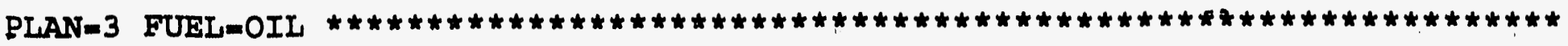
ariable: ARREARAG

\begin{tabular}{|c|c|c|c|c|}
\hline REPOST & $\mathbf{N}$ & Mean & & Std De \\
\hline $\begin{array}{l}\text { os } \\
\text { re }\end{array}$ & $\begin{array}{l}498 \\
498\end{array}$ & $\begin{array}{l}-16858.64658635 \\
-15572.82128514\end{array}$ & & $\begin{array}{l}.1529785 \\
.5987565\end{array}$ \\
\hline ariances & $\mathbf{T}$ & Method & $D F$ & Probs 1 \\
\hline $\begin{array}{l}\text { nequal } \\
\text { qual }\end{array}$ & $\begin{array}{l}-0.4309 \\
-0.4309\end{array}$ & $\begin{array}{l}\text { Satterthwaite } \\
\text { Cochran }\end{array}$ & $\begin{array}{l}872.0 \\
497.0 \\
994.0\end{array}$ & $\begin{array}{l}0.1 \\
0.1 \\
0.1\end{array}$ \\
\hline
\end{tabular}

or HO: Variances are equal, $F^{\prime}=2.20 \quad D F=(497,497) \quad$ Prob>F' $=0.0000$

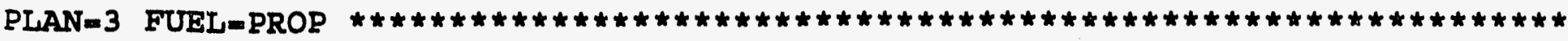
ariable: ARREARAG

REPOST N Mean Std Dev Std Error

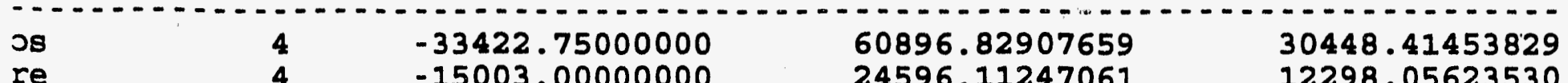

\begin{tabular}{lcccc} 
ariances & $T$ & Method & DF & Prob $>|\mathrm{T}|$ \\
\hdashline nequal & -0.5609 & Satterthwaite & 4.0 & 0.6052 \\
& & Cochran & 3.0 & 0.6140 \\
Tual & -0.5609 & & 6.0 & 0.5952
\end{tabular}

or HO: Variances are equal, $F^{\prime}=6.13 \quad D F=(3,3) \quad$ Prob $>F^{\prime}=0.1706$ 


\section{Arrearage Impacts of 1989 Installations}

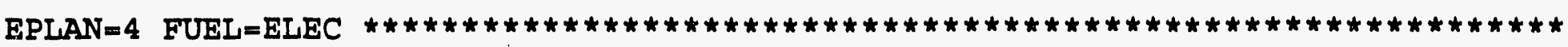

Variabie: ARREARAG

\begin{tabular}{lcccc} 
PREPOST & $\mathrm{N}$ & Mean & Std Dev \\
\hline pos & 12 & 17699.25000000 & 103540.63064335 & Std Error \\
pre & 12 & -77037.33333333 & 112785.93288360 \\
Variances & & Method & DF & Probs|T| \\
\hline Unequal & 2.1435 & Satterthwaite & 21.8 & 0.0435 \\
Equal & 2.1435 & Cochran & 11.0 & 0.0553
\end{tabular}

For HO: Variarices are equal, $F^{\prime}=1.19 \quad \mathrm{DF}=(11,11)$. Probs $=0.7817$

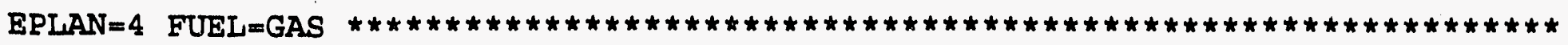

Variable: ARREARAG

PREPOST N Mean Std Dev Std Error

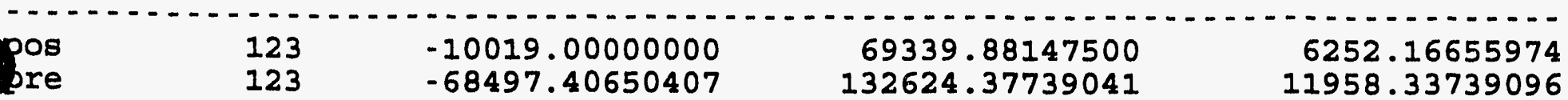

\begin{tabular}{lcccc} 
Variances & $T$ & Method & DF & Probs $|\mathrm{T}|$ \\
\hline Unequal & 4.3336 & $\begin{array}{l}\text { Satterthwaite } \\
\text { Cochran }\end{array}$ & 184.1 & 0.0001 \\
Equal & 4.3336 & & 122.0 & 0.0000 \\
& & 244.0 & 0.0000
\end{tabular}

For HO: Variances are equal, $F^{\prime}=3.66 \quad D F=(122,122) \quad$ Probs $=0.0000$

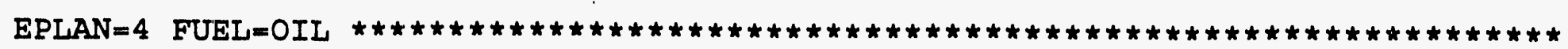

Variable: ARREARAG

$\begin{array}{lllll}\text { PREPOST M N } & \mathrm{N} & \text { Std Dev } & \text { Std Eror }\end{array}$

\begin{tabular}{|c|c|c|c|c|}
\hline $\begin{array}{l}\text { pos } \\
\text { pre }\end{array}$ & $\begin{array}{l}59 \\
59\end{array}$ & $\begin{array}{r}-8180.93220339 \\
-26037.94915254\end{array}$ & $\begin{array}{l}44621.63905816 \\
59725.13921100\end{array}$ & $\begin{array}{l}5809.24259516 \\
7775.55083206\end{array}$ \\
\hline
\end{tabular}

Variances $T$ Method Prob $>|T|$

Unequal $1.8398 \quad$ Satterthwaite $107.4 \quad 0.0686$

- Equal $\quad 1.8398 \quad$ Cochran $\quad 58.0 \quad 0.0709$

for HO: Variances are equal, $F^{\prime}=1.79 \quad D F=(58,58) \quad$ Prob $>F^{\prime}=0.0281$ 


\section{Arrearage Impacts of 1989 Installations}

PLAN=5 FUELI-ELEC

ariable: ARREARAG

\begin{tabular}{|c|c|c|c|c|}
\hline REPOST & $\mathbf{N}$ & Mean & & std Der \\
\hline re & $\begin{array}{l}12 \\
12\end{array}$ & $\begin{array}{r}32726.58333333 \\
-81144.91666667\end{array}$ & & $\begin{array}{r}.87399 \\
1.67971\end{array}$ \\
\hline riances & $T$ & Method & $\mathrm{DF}$ & Probs $|\mathrm{T}|$ \\
\hline nequal & $\begin{array}{l}1.4258 \\
1.4258\end{array}$ & $\begin{array}{l}\text { Satterthwaite } \\
\text { Cochran }\end{array}$ & $\begin{array}{l}14.1 \\
11.0 \\
22.0\end{array}$ & $\begin{array}{l}0.1 \\
0.1 \\
0.1\end{array}$ \\
\hline
\end{tabular}

or HO: Variances are equal, $F^{\prime}=6.99 \quad D F=(11,11) \quad$ Probs $>F^{\prime}=0.0032$

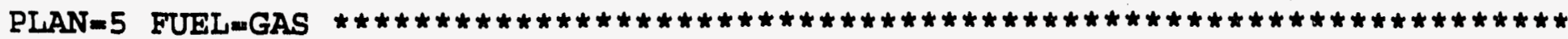
ariable: ARREARAG

REPOST N N Mean Std Dev Std Error

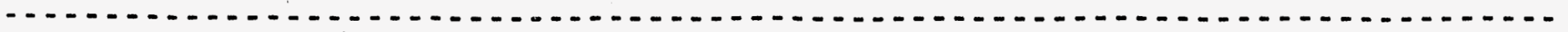

$66 \quad-12597.46969697$

44147.54123730

5434.18667397

re

66

$-66008.89393939$

111964.74860174

13781.90784251

\begin{tabular}{lccrr} 
ariances & T & Method & DF & Probs $|\mathrm{T}|$ \\
\hdashline nequal & 3.6053 & Satterthwaite & 84.7 & 0.0005 \\
& & Cochran & 65.0 & 0.0006 \\
qual & 3.6053 & & 130.0 & 0.0004
\end{tabular}

or HO: Variances are equal, $F^{\prime}=6.43 \quad$ DF $=(65,65) \quad$ Prob $>F^{\prime}=0.0000$ 


\section{Arrearage Impacts of 1989 Installations}

EPLAN $=5$ FUEL $=$ OIL

Variable: ARREARAG

PREPOST N Mean Std Dev Std Error

\begin{tabular}{|c|c|c|c|c|}
\hline $\begin{array}{l}\text { pos } \\
\text { pre }\end{array}$ & $\begin{array}{l}68 \\
68\end{array}$ & $\begin{array}{l}-41625.73529412 \\
-36352.97058824\end{array}$ & $\begin{array}{r}13 \\
8\end{array}$ & $\begin{array}{l}.06000 \\
.27978\end{array}$ \\
\hline Variances & $T$ & Method & DF & Prob $>$ \\
\hline $\begin{array}{l}\text { Unequal } \\
\text { Equal }\end{array}$ & $\begin{array}{l}-0.2618 \\
-0.2618\end{array}$ & $\begin{array}{l}\text { Satterthwaite } \\
\text { Cochran }\end{array}$ & $\begin{array}{r}113.9 \\
67.0 \\
134.0\end{array}$ & $\begin{array}{l}0.2 \\
0 . \\
0 .\end{array}$ \\
\hline
\end{tabular}

For HO: Variances are equal, $F^{\prime}=2.45 \quad \mathrm{DF}=(67,67)$ Prob $>F^{\prime}=0.0003$

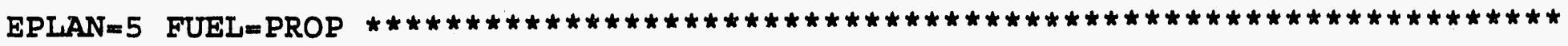
Variable: ARREARAG

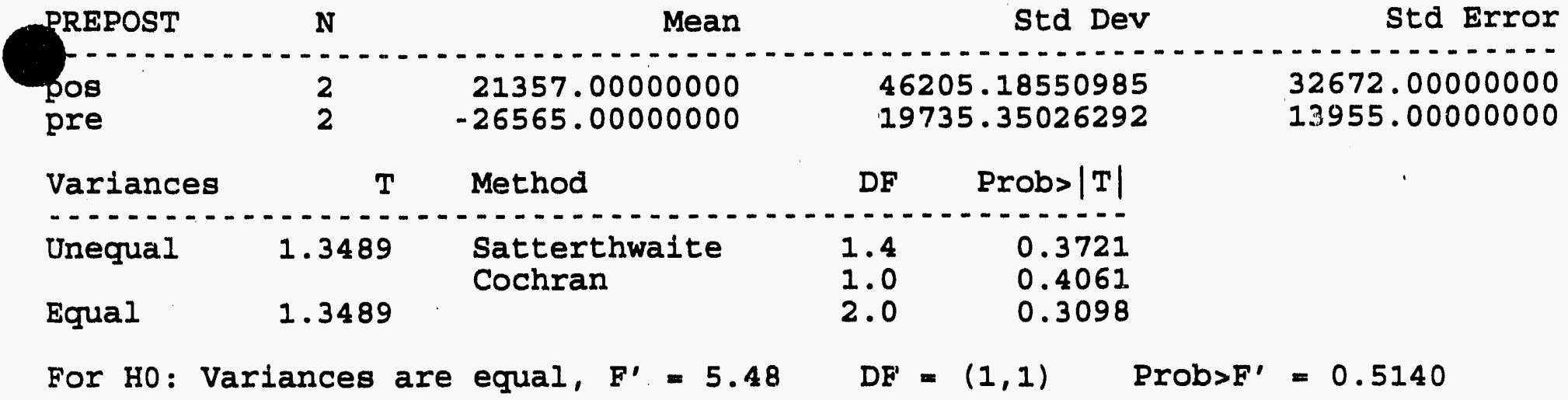




\section{Appendix F: Arrearage Impacts}

\section{Section 3: 1990 Installations}

Table of Contents:

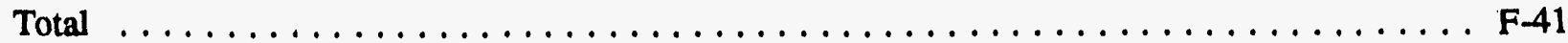

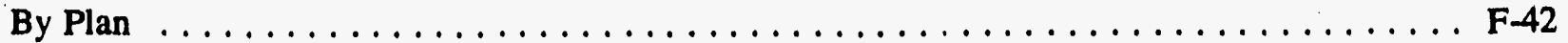

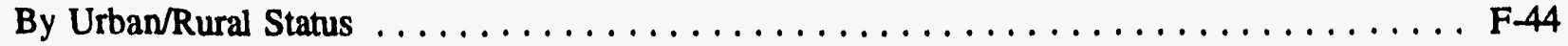

By Urban/Rural Status and $\operatorname{Plan} \ldots \ldots \ldots \ldots \ldots \ldots \ldots \ldots \ldots \ldots \ldots \ldots \ldots$

By Owaer/Renter Status $\ldots \ldots \ldots \ldots \ldots \ldots \ldots \ldots \ldots \ldots \ldots \ldots \ldots \ldots \ldots \ldots \ldots$ F-50

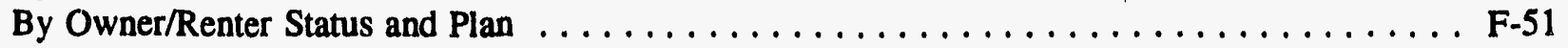

By Primary Space Heating Fuel $\ldots \ldots \ldots \ldots \ldots \ldots \ldots \ldots \ldots \ldots \ldots \ldots \ldots \ldots \ldots$

By Primary Space Heating Fuel and Plan $\ldots \ldots \ldots \ldots \ldots \ldots \ldots \ldots \ldots \ldots \ldots$ 



\section{Arrearage Impacts of 1989 Installations}

Variable: ARREARAG

\begin{tabular}{|c|c|c|c|c|c|}
\hline PREPOST & $\mathbf{N}$ & Mean & & Std Dev & Std Error \\
\hline $\begin{array}{l}\text { pos } \\
\text { pre }\end{array}$ & $\begin{array}{l}2072 \\
2073\end{array}$ & $\begin{array}{r}-1190.20463320 \\
-23706.18282682\end{array}$ & & $\begin{array}{l}25665403 \\
.35788949\end{array}$ & $\begin{array}{r}808.45522467 \\
1566.92354986\end{array}$ \\
\hline ariances & $\mathbf{T}$ & Method & DF & Probs $|\mathrm{T}|$ & \\
\hline $\begin{array}{l}\text { Unequal } \\
\text { Equal }\end{array}$ & $\begin{array}{l}12.7700 \\
12.7682\end{array}$ & $\begin{array}{l}\text { Satterthwaite } \\
\text { Cochran }\end{array}$ & $\begin{array}{l}3102.1 \\
4143 . \dot{0}\end{array}$ & $\begin{array}{l}0.0001 \\
0.0001 \\
0.0000\end{array}$ & \\
\hline
\end{tabular}

For HO: Variances are equal, $F^{\prime}=3.76 \quad D F=(2072,2071) \quad$ Prob $>F^{\prime}=0.0000$ 


\section{Arrearage Impacts of 1990 Installations}

PLAN $=1$ ariable: ARREARAG

\begin{tabular}{|c|c|c|c|c|}
\hline REPOST & $\mathbf{N}$ & Mean & & std D \\
\hline $\begin{array}{l}\text { os } \\
\text { re }\end{array}$ & $\begin{array}{l}370 \\
370\end{array}$ & $\begin{array}{r}-323.12162162 \\
-20156.36756757\end{array}$ & \multicolumn{2}{|c|}{$\begin{array}{l}31271.8009619 \\
49133.4939237\end{array}$} \\
\hline ciances & $\mathbf{T}$ & Method & $\mathrm{DF}$ & Prob $>/ I$ \\
\hline$=40$ & 6.5504 & $\begin{array}{l}\text { Satterthwaite } \\
\text { Cochran }\end{array}$ & $\begin{array}{l}625.8 \\
369.0 \\
738.0\end{array}$ & $\begin{array}{l}0 . \\
0 .\end{array}$ \\
\hline
\end{tabular}

or HO: Variances are equal, $F^{\prime}=2.47 \quad D F=(369,369) \quad$ Prob $>F^{\prime}=0.0000$

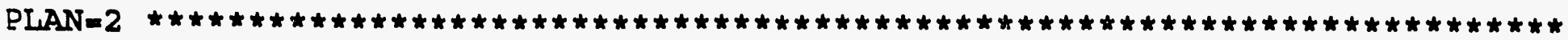
ariable: ARREARAG

\begin{tabular}{|c|c|c|c|c|}
\hline REPOST & $\mathbf{N}$ & Mean & & Std D \\
\hline re & $\begin{array}{l}177 \\
177\end{array}$ & $\begin{array}{r}-972.12429379 \\
-21557.25423729\end{array}$ & & 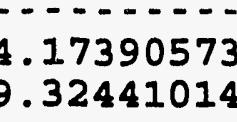 \\
\hline ariances & $T$ & Method & DF & Prob $>|T|$ \\
\hline $\begin{array}{l}\text { nequal } \\
\text { gual }\end{array}$ & $\begin{array}{l}4.0955 \\
4.0955\end{array}$ & $\begin{array}{l}\text { Satterthwaite } \\
\text { Cochran }\end{array}$ & $\begin{array}{l}303.6 \\
176.0 \\
352.0\end{array}$ & $\begin{array}{l}0 . \\
0 . \\
0 .\end{array}$ \\
\hline
\end{tabular}

Ir HO: Variances are equal, $F^{\prime}=2.33$ DF $=(176,176) \quad$ Prob>F' $=0.0000$

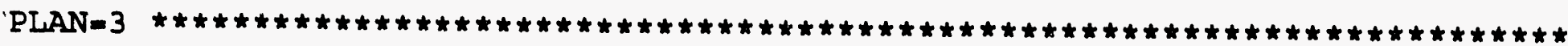
ariable: ARREARAG

\begin{tabular}{|c|c|c|c|c|}
\hline REPOST & $\mathbf{N}$ & Mean & Std Dev & std Erro \\
\hline $\begin{array}{l}\text { os } \\
\text { re }\end{array}$ & $\begin{array}{l}877 \\
878\end{array}$ & $\begin{array}{r}-144.27023945 \\
-22032.14578588\end{array}$ & $\begin{array}{l}36330.31046198 \\
88453.07529052\end{array}$ & $\begin{array}{l}1226.78 \\
2985.14\end{array}$ \\
\hline
\end{tabular}

\begin{tabular}{lcccc} 
ariances & $T$ & Method & DF & Prob $>|T|$ \\
\hline nequal & 6.7819 & Satterthwaite & 1165.0 & 0.0001 \\
qual & 6.7791 & Cochran & 1753.0 & 0.0000
\end{tabular}

or HO: Variances are equal, $F^{\prime}=5.93 \quad \mathrm{DF}=(877,876) \quad$ Prob>F' $=0.0000$ 


\section{Arrearage Impacts of 1990 Installations}

\section{EPLAN $=4$}

- Variable: ARREARAG

\begin{tabular}{|c|c|c|c|c|c|}
\hline PREPOST & $\mathbf{N}$ & Mean & & Std Dev & Std Errol \\
\hline $\begin{array}{l}\text { pos } \\
\text { pre }\end{array}$ & $\begin{array}{l}330 \\
330\end{array}$ & $\begin{array}{r}-3786.52727273 \\
-37387.93333333\end{array}$ & & $\begin{array}{l}0.03813511 \\
5.53326625\end{array}$ & $\begin{array}{l}2585.6155016 \\
3817.89645186\end{array}$ \\
\hline Variances & $\mathrm{T}$ & Method & DF & Prob $>|T|$ & \\
\hline $\begin{array}{l}\text { Unequal } \\
\text { Equal }\end{array}$ & $\begin{array}{l}7.2872 \\
7.2872\end{array}$ & $\begin{array}{l}\text { Satterthwaite } \\
\text { Cochran }\end{array}$ & $\begin{array}{l}578.3 \\
329.0 \\
658.0\end{array}$ & $\begin{array}{l}0.0001 \\
0.0000 \\
0.0000\end{array}$ & \\
\hline
\end{tabular}

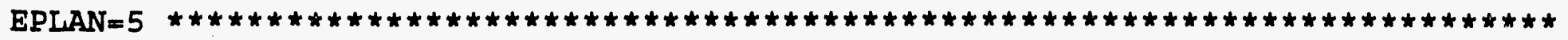

Variable: ARREARAG

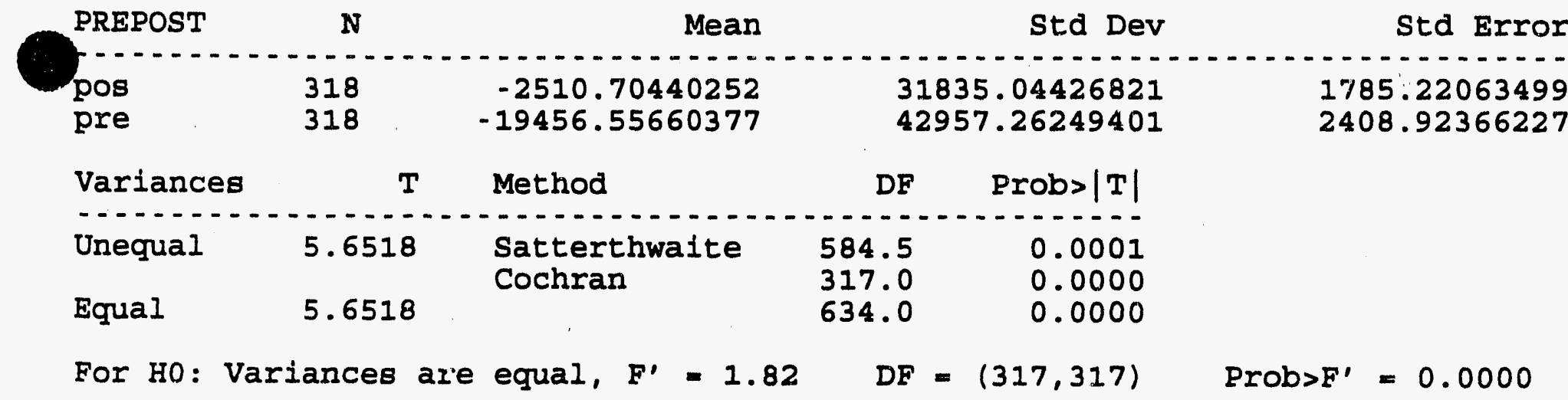




\section{Arrearage Impacts of 1990 Installations}

RBRUR=RURAL ariable: ARREARAG

\begin{tabular}{|c|c|c|c|c|}
\hline EPOST & $\mathbf{N}$ & Mean & & Std De \\
\hline $\begin{array}{l}\text { re } \\
\text { res }\end{array}$ & 721 & $\begin{array}{r}-1181.23439667 \\
-20431.34903047\end{array}$ & & $\begin{array}{l}.5703232 \\
.4125737\end{array}$ \\
\hline ciances & $\mathbf{T}$ & Method & DF & Probs $>$ \\
\hline equal & $\begin{array}{l}5.1131 \\
5.1108\end{array}$ & $\begin{array}{l}\text { Satterthwaite } \\
\text { Cochran }\end{array}$ & $\begin{array}{r}1020.8 \\
1441.0\end{array}$ & $\begin{array}{l}0.1 \\
0.1 \\
0.1\end{array}$ \\
\hline
\end{tabular}

or HO: Variances are equal, $F^{\prime}=4.60 \quad$ DF $=(721,720) \quad$ Prob $>F^{\prime}=0.0000$

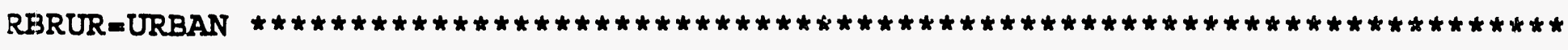
ariable: ARREARAG

$\begin{array}{llll}\text { REPOST N } & \text { Mean Std Dev } & \text { Std Error }\end{array}$

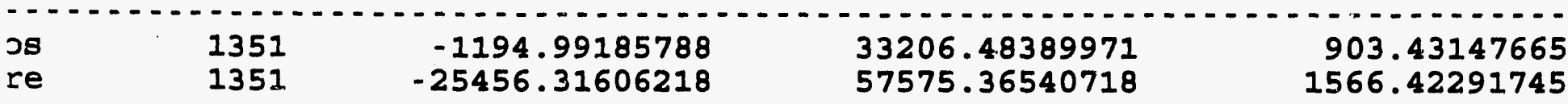

re $\quad 1351 \quad-25456.31606218 \quad 57575.36540718$

\begin{tabular}{lcccr} 
ariances & $T$ & Method & DF & Probs|T| \\
\hdashline requal & 13.4168 & Satterthwaite & 2158.6 & 0.0001 \\
Tual & 13.4168 & Cochran & 1350.0 & 0.0000 \\
& & & 2700.0 & 0.0000
\end{tabular}

or HO: Variances are equal, $F^{\prime}=3.01 \quad$ DF $=(1350,1350) \quad$ Prob $>F^{\prime}=0.0000$ 


\section{Arrearage Impacts of 1990 Installations}

EPLAN= 1 URBRUR=RURAL

- Variable: ARREARAG

\begin{tabular}{|c|c|c|c|c|c|}
\hline PREPOST & $\mathbf{N}$ & Mean & & Std Dev & std Error \\
\hline $\begin{array}{l}\text { pos } \\
\text { pre }\end{array}$ & $\begin{array}{l}152 \\
152\end{array}$ & $\begin{array}{r}574.21710526 \\
-17294.17105263\end{array}$ & & $\begin{array}{l}.58619977 \\
.27225100\end{array}$ & $\begin{array}{l}2348.12150724 \\
3268.54038613\end{array}$ \\
\hline Variances & $T$ & Method & $D F$ & Prob $>|\mathrm{T}|$ & \\
\hline Unequal & 4.4398 & $\begin{array}{l}\text { Satterthwaite } \\
\text { Cochran }\end{array}$ & $\begin{array}{l}274.1 \\
151.0 \\
302.0\end{array}$ & $\begin{array}{l}0.0001 \\
0.0000 \\
0.0000\end{array}$ & \\
\hline
\end{tabular}

For HO: Variances are equal, $F^{\prime}=1.94 \quad D F=(151,151)$ Prob $>F^{\prime}=0.0000$

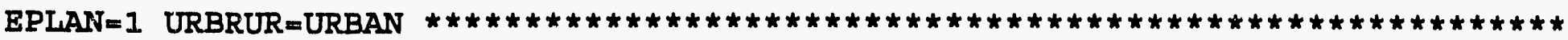

Variable: ARREARAG

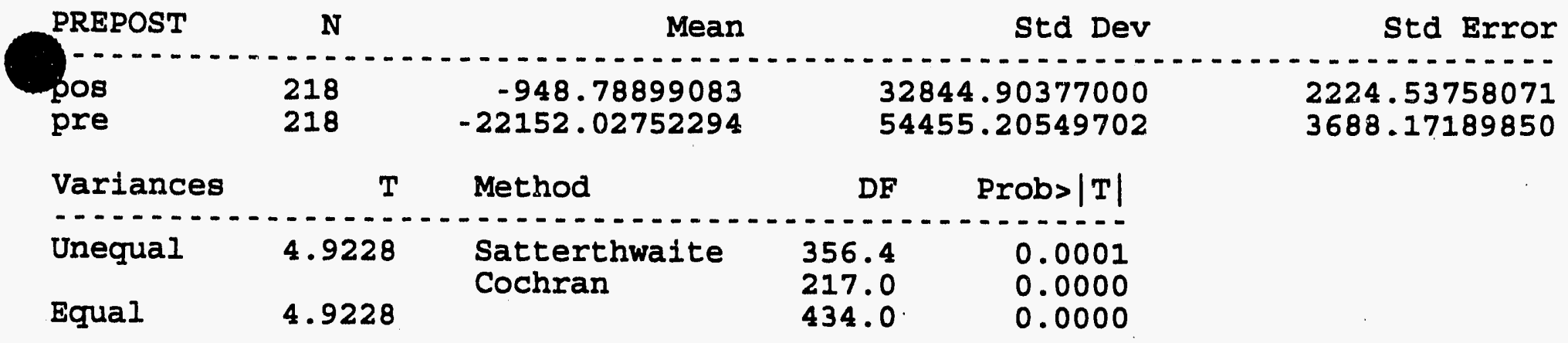

For HO: Variances are equal, $F^{\prime}=2.75 \quad D F=(217,217) \quad$ Prob $>F^{\prime}=0.0000$ 


\section{Arrearage Impacts of 1990 Installations}

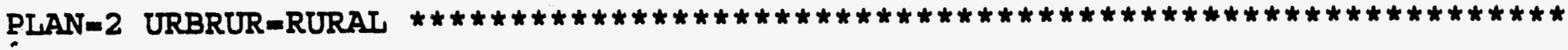
ariable: ARREARAG

\begin{tabular}{|c|c|c|c|c|}
\hline REPOST & $\mathbf{N}$ & Mean & & Std Dev \\
\hline $\begin{array}{l}\text { os } \\
\text { re }\end{array}$ & $\begin{array}{l}53 \\
53\end{array}$ & $\begin{array}{r}-648.92452830 \\
-16113.11320755\end{array}$ & & $\begin{array}{l}5.61017306 \\
9.90114585\end{array}$ \\
\hline riances & $T$ & Method & $D F$ & Prob $>|T|$ \\
\hline $\begin{array}{l}\text { equal } \\
\text { ual }\end{array}$ & $\begin{array}{l}1.7950 \\
1.7950\end{array}$ & $\begin{array}{l}\text { Satterthwaite } \\
\text { Cochran }\end{array}$ & $\begin{array}{r}103.6 \\
52.0 \\
104.0\end{array}$ & $\begin{array}{l}0 . \\
0 . \\
0 .\end{array}$ \\
\hline
\end{tabular}

or HO: Variances are equal, $F^{\prime}=1.13 \quad$ DF $=(52,52) \quad$ Prob>F' $=0.6593$

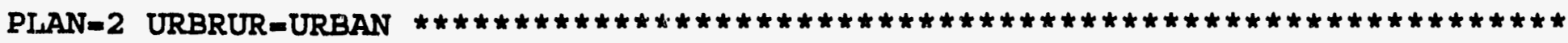
ariable: ARREARAG

\begin{tabular}{lcccc} 
REPOST & $\mathrm{N}$ & \multicolumn{1}{c}{ Mean } & Std Dev & Std Error \\
\hline Os & 124 & -1110.26612903 & 33792.09131150 & 3034.61938306 \\
re & 124 & -23884.18548387 & 59792.86558570 & 5369.55784128
\end{tabular}

\begin{tabular}{lcccr} 
ariances & T & Method & DF & Prob $|T|$ \\
\hline nequal & 3.6924 & Satterthwaite & 194.3 & 0.0003 \\
& & Cochran & 123.0 & 0.0003 \\
qual & 3.6924 & & 246.0 & 0.0003
\end{tabular}

or Ho: Variances are equal, $F^{\prime}=3.13 \quad D F=(123,123) \quad$ Prob $>F^{\prime}=0.0000$ 


\section{Arrearage Impacts of 1990 Installations}

EPLAN $=3$ URBRUR=RURAL

variable: ARREARAG

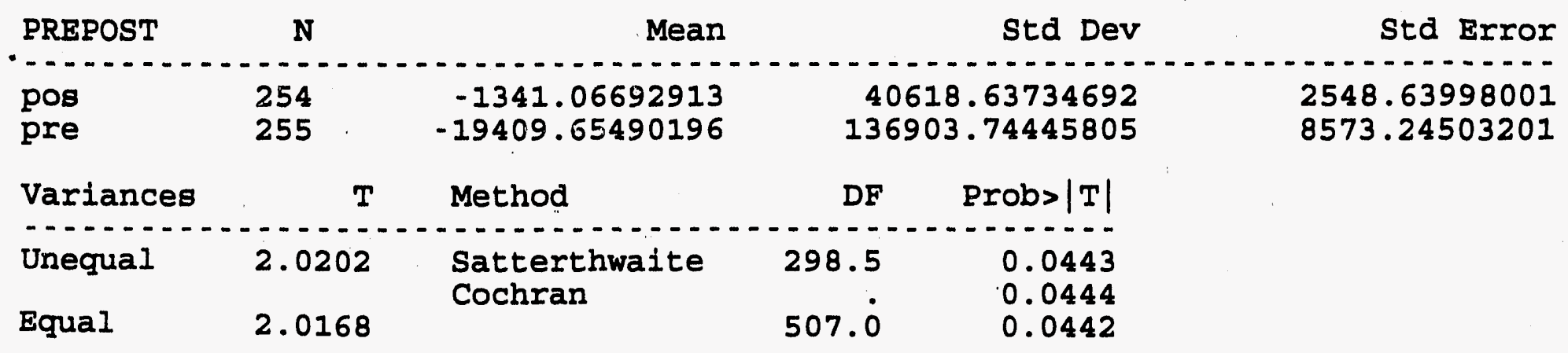

For HO: Variances are equal, $F^{\prime}=11.36 \quad D F=(254,253) \quad$ Prob $>F^{\prime}=0.0000$

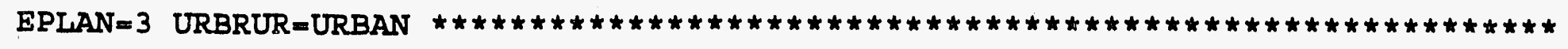
Variable: ARREARAG

\begin{tabular}{|c|c|c|c|c|c|}
\hline REPOST & $\mathrm{N}$ & Mean & & Std Dev & std Error \\
\hline $\begin{array}{l}\text { pos } \\
\text { pre }\end{array}$ & $\begin{array}{l}623 \\
623\end{array}$ & $\begin{array}{r}343.66934189 \\
-23105.55698234\end{array}$ & & $\begin{array}{l}.41684628 \\
.37389127\end{array}$ & $\begin{array}{l}1380.30693457 \\
2327.10130120\end{array}$ \\
\hline Variances & $\mathrm{T}$ & Method & $\mathrm{DF}$ & Prob $>|T|$ & \\
\hline $\begin{array}{l}\text { Unequal } \\
\text { Equal }\end{array}$ & $\begin{array}{l}8.6667 \\
8.6667\end{array}$ & $\begin{array}{l}\text { Satterthwaite } \\
\text { Cochran }\end{array}$ & $\begin{array}{r}1011.5 \\
622.0 \\
1244.0\end{array}$ & $\begin{array}{l}0.0001 \\
0.0000 \\
0.0000\end{array}$ & \\
\hline
\end{tabular}

For Ho: Variances are equal, $F^{\prime}=2.84 \quad D F=(622,622) \quad$ Prob $>F^{\prime}=0.0000$ 


\section{Arrearage Impacts of 1990 Installations}

IPLAN $=4$ URBRUR=RURAL ariable: ARREARAG

\begin{tabular}{|c|c|c|c|c|}
\hline 'REPOST & $\mathrm{N}$ & Mean & & std De \\
\hline $\begin{array}{l}\text { los } \\
\text { ire }\end{array}$ & $\begin{array}{l}154 \\
154\end{array}$ & $\begin{array}{r}-3201.22077922 \\
-28421.79220779\end{array}$ & & $\begin{array}{l}.0842243 \\
.7769416\end{array}$ \\
\hline ariances & $T$ & Method & $\mathrm{DF}$ & Prob $>/ T$ \\
\hline inequal & 3.6886 & $\begin{array}{l}\text { Satterthwaite } \\
\text { Cochran }\end{array}$ & $\begin{array}{l}297.8 \\
153.0 \\
306.0\end{array}$ & 0. \\
\hline
\end{tabular}

'or HO: Variances are equal, $F^{\prime}=1.40 \quad D F=(153,153) \quad$ Prob $>F^{\prime}=0.0391$

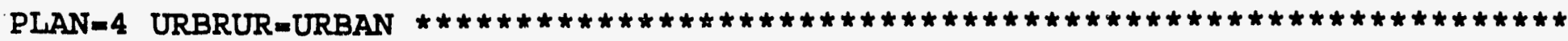
ariable: ARREARAG

REPOST . N Mean Std Dev S Stor

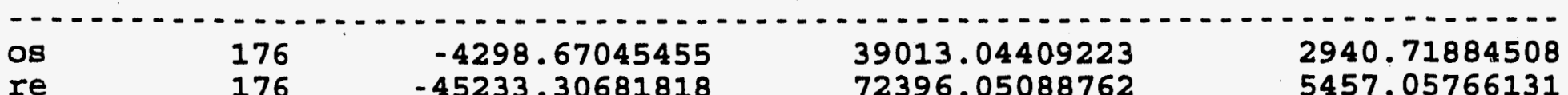

chences

\begin{tabular}{lllll} 
ariances & T & Method & DF & Probs $|T|$ \\
\hline nequal & 6.6035 & Satterthwaite & 268.7 & 0.0001 \\
& & Cochran & 175.0 & 0.0000 \\
qual & 6.6035 & & 350.0 & 0.0000
\end{tabular}

or Ho: Variances are equal, $F^{\prime}=3.44 \quad D F=(175,175) \quad$ Prob $>F^{\prime}=0.0000$ 


\section{Arrearage Impacts of 1990 Installations}

EPLAN $=5$ URBRUR =RURAL

Variable: ARREARAG

PREPOST

N

Mean

Std Dev

Std Error

pos

108

$-656.84259259$

44884.84526841

51983.96699466

4319.04624971

pre

$-17984.32407407$

Variances $\quad T \quad$ Method $\quad$ DF Probs $|\mathrm{T}|$

$\begin{array}{lllll}\text { Unequal } & 2.6219 & \text { Satterthwaite } & 209.5 & 0.0094\end{array}$

Equal 2.6219

Cochran

$107.0 \quad 0.0100$

$214.0 \quad, 0.0094$

For HO: Variances arf equal, $F^{\prime}=1.34 \quad D F=(107,107) \quad$ Prob>F' $=0.1304$

EPLAN $=5$ URBRUR $=$ URBAN

Variable: ARREARAG

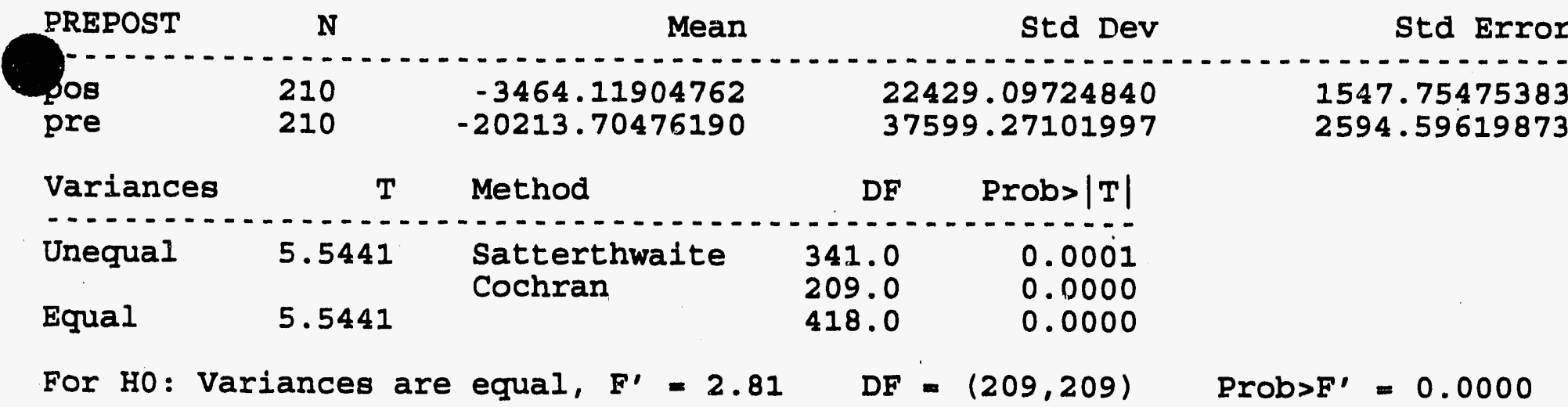




\section{Arrearage Impacts of 1990 Installations}

IWNRENT $=\mathrm{H}$

'áriable: ARREARAG

\begin{tabular}{|c|c|c|c|c|}
\hline EPOST & $\mathbf{N}$ & Mean & & Std De \\
\hline $\begin{array}{l}\text { ios } \\
\text { ire }\end{array}$ & $\begin{array}{l}844 \\
844\end{array}$ & $\begin{array}{r}-7992.97156398 \\
-26057.01658768\end{array}$ & & $\begin{array}{l}6268010 \\
.1424437\end{array}$ \\
\hline riances & $\mathbf{T}$ & Method & DF & Prob $>/ T$ \\
\hline sequal & $\begin{array}{l}8.2424 \\
8.2424\end{array}$ & $\begin{array}{l}\text { Satterthwaite } \\
\text { Cochran }\end{array}$ & $\begin{array}{r}1520.7 \\
843.0 \\
1686.0\end{array}$ & $\begin{array}{l}0 . \\
0 . \\
0 .\end{array}$ \\
\hline
\end{tabular}

'or HO: Variances are equal, $F^{\prime}=1.98 \quad$ DF $=(843,843) \quad$ Prob>F' $=0.0000$

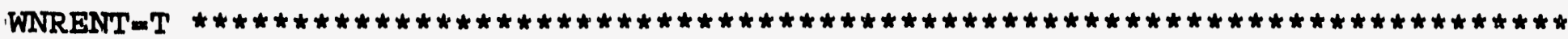
ariable: ARREARAG

\begin{tabular}{|c|c|c|c|c|c|}
\hline PEOST & $\mathbf{N}$ & Mean & & Std Dev & Std Error \\
\hline os & $\begin{array}{l}1228 \\
1229\end{array}$ & $\begin{array}{r}3485.31270358 \\
-22091.77786819\end{array}$ & & $\begin{array}{l}7.45313564 \\
3.97878902\end{array}$ & $\begin{array}{l}1028.38304364 \\
2340.29590243\end{array}$ \\
\hline riances & $T$ & Method & DF & Probs $|\mathrm{T}|$ & \\
\hline $\begin{array}{l}\text { equal } \\
\text { ual }\end{array}$ & 10.0056 & $\begin{array}{l}\text { Satterthwaite } \\
\text { Cochran }\end{array}$ & 2455.0 & $\begin{array}{l}0.0001 \\
0.0001 \\
0.0000\end{array}$ & \\
\hline
\end{tabular}




\section{Arrearage Impacts of 1990 Installations}

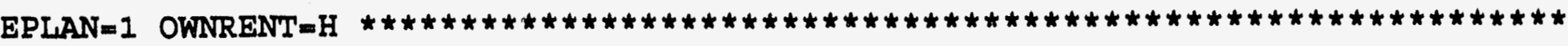
Variable: ARREARAG

\begin{tabular}{|c|c|c|c|c|}
\hline PREPOST & $\mathbf{N}$ & Mean & Std Dev & std Error \\
\hline $\begin{array}{l}\text { pos } \\
\text { pre }\end{array}$ & $\begin{array}{l}171 \\
171\end{array}$ & $\begin{array}{r}-7585.88888889 \\
-21738.09356725\end{array}$ & $\begin{array}{r}30985.36064118 \\
48708.47785215\end{array}$ & $\begin{array}{l}2369.50975025 \\
3724.83039739\end{array}$ \\
\hline $\begin{array}{l}\text { Variances } \\
\text { Unequal } \\
\text { Equal }\end{array}$ & $\begin{array}{r}\mathrm{T} \\
3.2058 \\
3.2058\end{array}$ & $\begin{array}{l}\text { Method } \\
\text { Satterthwaite } \\
\text { Cochran }\end{array}$ & $\begin{array}{cr}\text { DF } & \text { Probs }|\mathrm{T}| \\
288.2 & 0.0015 \\
170.0 & 0.0016 \\
340.0 & 0.0015\end{array}$ & \\
\hline
\end{tabular}

For HO: Variances are equal, $F^{\prime}=2.47 \quad$ DF $=(170,170)$. Prob>F' $=0.0000$

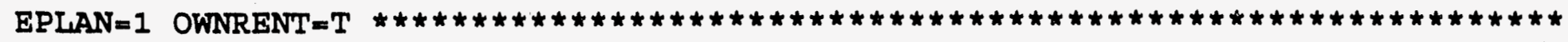
Variable: ARREARAG

\begin{tabular}{|c|c|c|c|c|c|}
\hline PREPOST & $\mathbf{N}$ & Mean & & Std Dev & Std Error \\
\hline pre & 199 & $\begin{array}{r}5917.74874372 \\
-18797.19597990\end{array}$ & & $\begin{array}{l}3.75888617 \\
8.00989418\end{array}$ & $\begin{array}{l}2142.50546191 \\
3514.49193957\end{array}$ \\
\hline Variances & $\mathbf{T}$ & Method & $\mathrm{DF}$ & Probs $|\mathrm{T}|$ & \\
\hline $\begin{array}{l}\text { Unequal } \\
\text { Equal }\end{array}$ & $\begin{array}{l}6.0045 \\
6.0045\end{array}$ & $\begin{array}{l}\text { Satterthwaite } \\
\text { Cochran }\end{array}$ & $\begin{array}{l}327.3 \\
198.0 \\
396.0\end{array}$ & $\begin{array}{l}0.0001 \\
0.0000 \\
0.0000\end{array}$ & \\
\hline
\end{tabular}

For HO: Variances are equal, $F^{\prime}=2.69 \quad$ DF $=(198,198) \quad$ Prob $>F^{\prime}=0.0000$ 


\section{Arrearage Impacts of 1990 Installations}

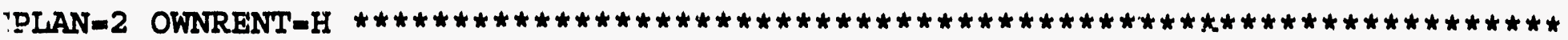
-iable: ARREARAG

\begin{tabular}{|c|c|c|c|c|}
\hline ?REPOST & $\mathbf{N}$ & Mean & & std D \\
\hline $\begin{array}{l}\text { Dos } \\
\text { ore }\end{array}$ & $\begin{array}{l}102 \\
102\end{array}$ & $\begin{array}{r}-5287.80392157 \\
-28897.57647059\end{array}$ & . & .5 \\
\hline ariances & $T$ & Method & DF & Probs /I \\
\hline $\begin{array}{l}\text { Inequa } \\
\text { gqual }\end{array}$ & $\begin{array}{l}3.9192 \\
3.9192\end{array}$ & $\begin{array}{l}\text { Satterthwaite } \\
\text { Cochran }\end{array}$ & $\begin{array}{l}178.8 \\
101.0 \\
202.0\end{array}$ & \\
\hline
\end{tabular}

For HO: Variances are equal, $F^{\prime}=2.12 \quad \mathrm{DF}=(101,101) \quad$ Prob>F' $=0.0001$

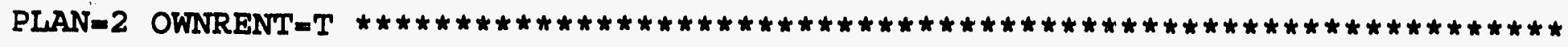
ariable: ARREARAG

$\begin{array}{llll}\text { REPOST N } & \text { Mean Std Dev Error }\end{array}$

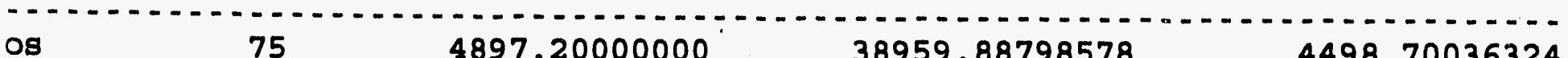

\begin{tabular}{lllll} 
re & 75 & -11574.28000000 & 61880.85814246 & $\mathbf{4 4 9 8 . 7 0 0 3 6 3 2 4}$ \\
\hline & & & 7145.38602125
\end{tabular}

$\begin{array}{lll}\text { ariances } & \text { T } & \text { Method } \\ \end{array}$

nequal $1.9508 \quad$ Satterthwaite $124.7 \quad 0.0533$

gual Cochran 1.9508 74.0 0.0549

or HO: Variances are equal, $F^{\prime}=2.52 \quad$ DF $=(74,74) \quad$ Prob $>F^{\prime}=0.0000$ 


\section{Arrearage Impacts of 1990 Installations}

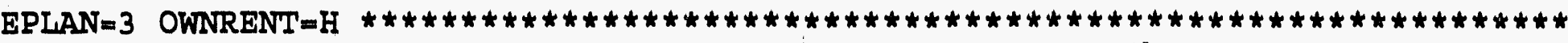

Variable: ARREARAG

PREPOST N Mean Std Dev Std Error

\begin{tabular}{|c|c|c|c|c|}
\hline $\begin{array}{l}\text { pos } \\
\text { pre }\end{array}$ & $\begin{array}{l}292 \\
292\end{array}$ & $\begin{array}{r}-6665.19178082 \\
-18686.75684932\end{array}$ & & $\begin{array}{l}2.9190570 \\
7.2514566\end{array}$ \\
\hline Vartances & $\mathrm{T}$ & Method & DF & Probs $\mid T$ \\
\hline Unequal & 4.0039 & $\begin{array}{l}\text { Satterthwa1te } \\
\text { Cochran }\end{array}$ & $\begin{array}{l}578.3 \\
291.0 \\
582.0\end{array}$ & $\begin{array}{l}0.0001 \\
0.0001 \\
0.0001\end{array}$ \\
\hline
\end{tabular}

For HO: Variances are equal, $F^{\prime}=1.17 \quad \mathrm{DF}=(291,291)^{\circ}$ ProbsF' $=0.1706$

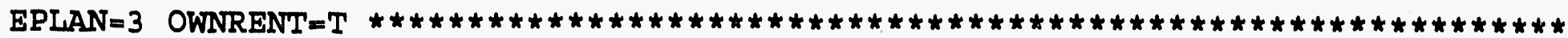

Variable: ARREARAG

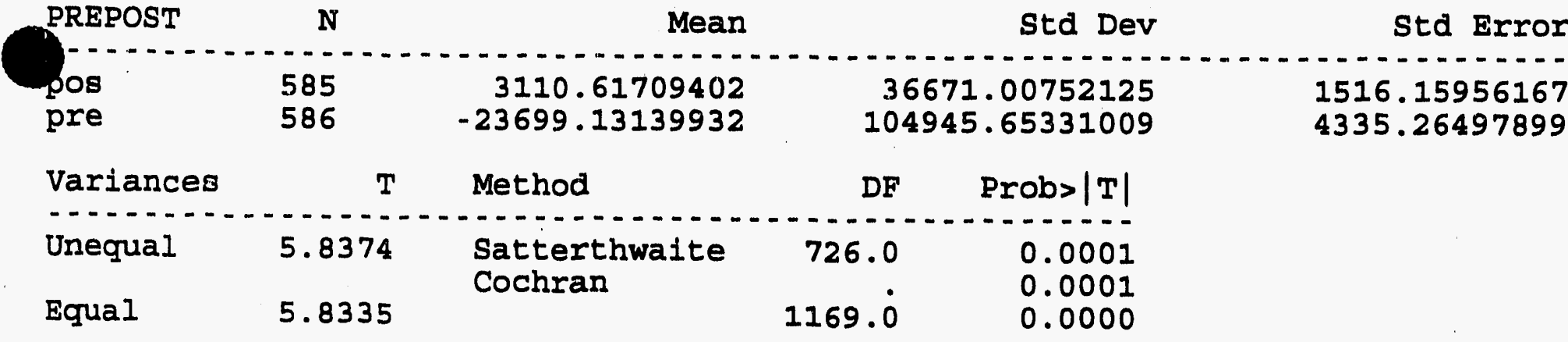

For HO: Variances are equal, $\left.F^{\prime}=8.19 \quad \mathrm{DF}=(585,584) \quad \mathrm{Prob}\right)=\mathrm{F}^{\prime}=0.0000$ 


\section{Arrearage Impacts of 1990 Installations}

PLAN=4 OWNRENT-H iriable: ARREARAG

\begin{tabular}{|c|c|c|c|c|}
\hline REPOST & $\mathbf{N}$ & Mean & & std Dev \\
\hline $\begin{array}{l}\text { og } \\
\text { re }\end{array}$ & $\begin{array}{l}121 \\
121\end{array}$ & $\begin{array}{l}-15252.62809917 \\
-53613.27272727\end{array}$ & & $\begin{array}{l}7.533 \\
2.509\end{array}$ \\
\hline riances & $\mathbf{T}$ & Method & DF & Prob $>\mid T$ \\
\hline $\begin{array}{l}\text { nequal } \\
\text { gual }\end{array}$ & $\begin{array}{r}4.2553 \\
4.2553\end{array}$ & $\begin{array}{l}\text { Satterthwaite } \\
\text { Cochran }\end{array}$ & $\begin{array}{l}209.6 \\
120.0 \\
240.0\end{array}$ & $\begin{array}{l}0 . \\
0 . \\
0 .\end{array}$ \\
\hline
\end{tabular}

or HO: Variances are equal, $F^{\prime}=2.23 \quad \mathrm{DF}=(120,120) \quad$ Prob> $F^{\prime}=0.0000$

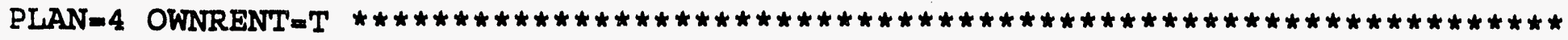
ariable: ARREARAG

REPOST N Mean Std Dev Sror

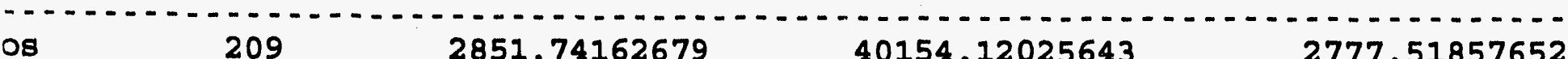

$\begin{array}{llrlr}\text { os } & 209 & 2851.74162679 & 40154.12025643 & 2777.51857652 \\ \text { re } & 209 & -27994.31578947 & 58738.03472603 & 4062.99481991\end{array}$

ariances $T$ Method Prob $>|T|$

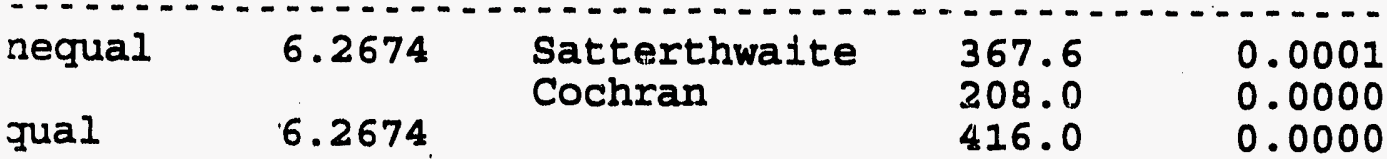

or HO: Variances are equal, $F^{\prime}=2.14 \quad$ DF $=(208,208) \quad$ Prob>F' $=0.0000$ 


\section{Arrearage Impacts of 1990 Installations}

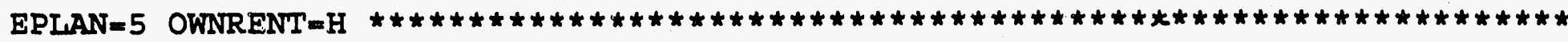

Variable: ARREARAG

$\begin{array}{lllll}\text { PREPOST N Mean } & \text { Stcl Dev } & \text { Std Eror }\end{array}$

-

$-7074.18354430$

29537.57856681

2349.88357857

pre

158

$-21415.2278481 .0$

41550.48135355

3305.57881018

Variances $T$ Method Probs: $|T|$

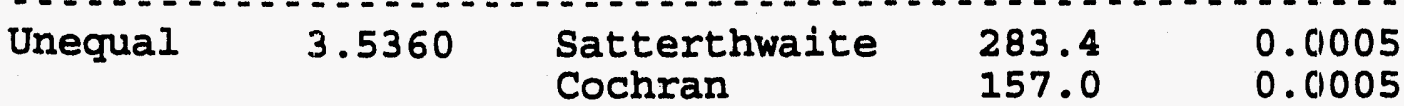

$\begin{array}{lll}\text { Equal } \quad 3.5360 & 314.0 & 0.0005\end{array}$

For HO: Variances are equal, $F^{\prime}=1.98 \quad$ DF $=(157,1.57) \quad$ Prob>F' $=0.0000$

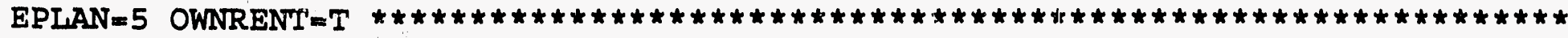

Variable: ARREARAG

\begin{tabular}{|c|c|c|c|c|c|}
\hline RREPOST & $\mathbf{N}$ & Mean & & Sta Dev & Std Error \\
\hline $\begin{array}{l}\text { pos } \\
\text { pre }\end{array}$ & $\begin{array}{l}160 \\
160\end{array}$ & $\begin{array}{r}1995.7312-000 \\
-17522.36875000\end{array}$ & & $\begin{array}{l}5.63833738 \\
7.98593437\end{array}$ & $\begin{array}{l}2643.31930419 \\
3506.01612984\end{array}$ \\
\hline Variances & $\mathbf{T}$ & Method & DF & Prob: $|\mathrm{T}|$ & \\
\hline $\begin{array}{l}\text { Unequal } \\
\text { Equal }\end{array}$ & $\begin{array}{l}4.4452 \\
4.4452\end{array}$ & $\begin{array}{l}\text { Satterthwaite } \\
\text { Cochran }\end{array}$ & $\begin{array}{l}295.6 \\
159.0 \\
318.0\end{array}$ & $\begin{array}{l}0.0001 \\
0.0000 \\
0.0000\end{array}$ & \\
\hline
\end{tabular}

For HO: Variances are equal, $F^{\prime}=1.76 \quad D F^{\prime}=(159,159) \quad$ Prob $>F^{\prime}=0.0004$ 


\section{Arrearage Impacts of 1990 Installations}

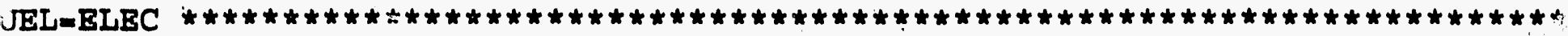
ariable: ARREARAG

\begin{tabular}{lcrrr} 
REPOST & N & \multicolumn{1}{c}{ Mean } & Std Dev & Std Error \\
\hline os & 205 & 4551.28780488 & 58752.04095462 & 4103.42053410 \\
re & 205 & -21525.66829268 & 60657.25751202 & 4236.48663047
\end{tabular}

\begin{tabular}{lcccc} 
ariances & T & Method & DF & Probs $|T|$ \\
\hdashline nequal & 4.4214 & Satterthwaite & 407.6 & 0.0001 \\
& & Cochran & 204.0 & 0.0000 \\
qual & 4.4214 & & 408.0 & 0.0000
\end{tabular}

or HO: Variances are equal, $F^{\prime}=1.07 \quad D F=(204,204)$. Prob $>F^{\prime}=0.6490$

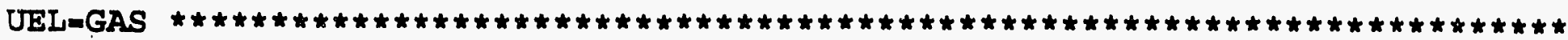
ariable: ARREARAG

REPOST N Mean Std Dev Std Error

\begin{tabular}{|c|c|c|}
\hline $\begin{array}{l}511 \\
511\end{array}$ & $\begin{array}{r}-256.58708415 \\
-26790.75342466\end{array}$ & $\begin{array}{l}35035.02502029 \\
60826.03853861\end{array}$ \\
\hline
\end{tabular}

ariances $T$ Method DF Probs $|T|$

nequal $\quad 8.5450 \quad$ Satterthwaite $\quad 814.8 \quad 0.0001$

Tual $8.5450 \quad$ Cochran $\quad 510.0 \quad 0.0000$

or HO: Variances are equal, $F^{\prime}=3.01 \quad$ DF $=(510,510) \quad$ Prob $>F^{\prime}=0.0000$ 


\section{Arrearage Impacts of 1990 Installations}

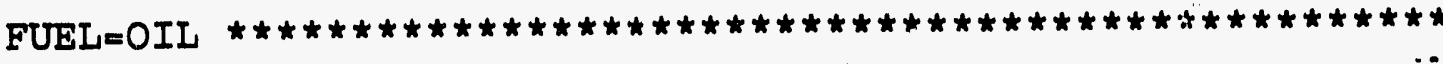

Variable: ARREARAG

\begin{tabular}{|c|c|c|c|c|}
\hline ST & $\mathbf{N}$ & Mean & std Dev & std Error \\
\hline 09 & $\begin{array}{l}1042 \\
1043\end{array}$ & $\begin{array}{r}-2916.39059501 \\
-21238.97411314\end{array}$ & $\begin{array}{l}31905.86255465 \\
78475.21715604\end{array}$ & $\begin{array}{r}988.40886180 \\
2429.91102735\end{array}$ \\
\hline
\end{tabular}

Variances $T$ Method DF Prob $>|T|$

-

$\begin{array}{lllrl}\text { Unequal } & 6.9847 & \text { Satterthwaite } & 1377.6 & 0.0001 \\ \text { Equal } & 6.9823 & \text { Cochran } & 2083.0 & 0.0001 \\ & & & 0.000\end{array}$

For HO: Variances are equal, $F^{\prime}=6.05 \quad D F=(1042,1041) \quad$ Prob $>F^{\prime}=0.0000$

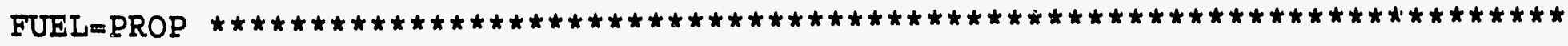

Variable: ARREARAG

$\begin{array}{llll}\text { PREPOST N Nean Std Dev Eror } & \text { Std Eror }\end{array}$

\begin{tabular}{lllll}
\hline os & 1.5 & -9638.53333333 & 49705.81670312 & 12833.98668672
\end{tabular}

$\begin{array}{lllll}\text { se } & 15 & -6033.46666667 & 30919.60985678 & 7983.40893643\end{array}$

Variances $T$ Method Prob $>|T|$

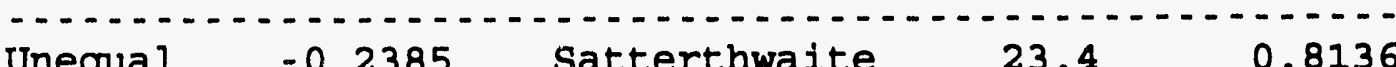

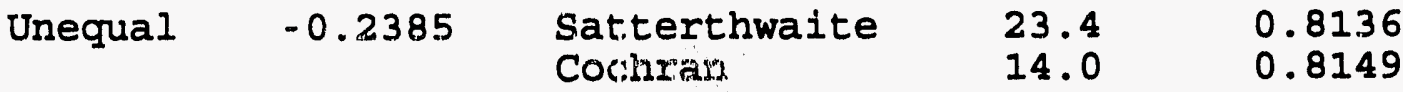

$\begin{array}{llll}\text { Equal } & -0.2385 & 28.0 & 0.8132\end{array}$

For Ho: Variances are equal, $F^{\prime}=2.58 \quad D F=(14,14) \quad$ Prob $>F^{\prime}=0.0865$ 
IPLAN=1 FUEL=ELEC Jariable: ARREARAG

\begin{tabular}{|c|c|c|c|c|}
\hline PREPOST & $\mathbf{N}$ & Mean & & Std D \\
\hline $\begin{array}{l}\text { os } \\
\text { ree }\end{array}$ & $\begin{array}{l}24 \\
24\end{array}$ & $\begin{array}{r}9307.75000000 \\
-29429.08333333\end{array}$ & & $\begin{array}{l}1.22 \\
1.73\end{array}$ \\
\hline Jariances & $\mathbf{T}$ & Method & DF & Prob $>\mid T$ \\
\hline Jnequal & 2.5515 & $\begin{array}{l}\text { Satterthwaite } \\
\text { Cochran }\end{array}$ & $\begin{array}{l}38.6 \\
23.0 \\
46.0\end{array}$ & $\begin{array}{l}0 . \\
0 . \\
0 .\end{array}$ \\
\hline
\end{tabular}

For HO: Variances are equal, $F^{\prime}=2.55 \quad$ DF $=(23,23) \quad$ Prob $>F^{\prime}=0.0288$

BPLAN=1 FUEL=GAS

Tariable: ARREARAG

\begin{tabular}{|c|c|c|c|c|}
\hline REPOST & $\mathbf{N}$ & Mean & std Dev & Std Error \\
\hline $\begin{array}{l}\text { JOS } \\
\text { Jre }\end{array}$ & $\begin{array}{l}111 \\
111\end{array}$ & $\begin{array}{r}3288.61261261 \\
-20853.92792793\end{array}$ & $\begin{array}{l}29167.94611530 \\
60648.85726716\end{array}$ & $\begin{array}{l}2768.49892750 \\
5756.53478084\end{array}$ \\
\hline
\end{tabular}

lariances $\quad$ T Method DF Prob $>|T|$

$\begin{array}{lllll}\text { Inequal } & 3.7796 & \text { Satterthwaite } & 158.3 & 0.0002 \\ & & \text { Cochran } & 110.0 & 0.0003 \\ \text { iqual } & 3.7796 & & 220.0 & 0.0002\end{array}$

ior HO: Variances are equal, $F^{\prime}=4.32 \quad$ DF $=(110,110) \quad$ Prob>F' $=0.0000$ 


\section{Arrearage Impacts of 1990 Installations}

EPLAN $=1$ FUEL $=$ OII

- Variable: ARREARAG

PREPOST N Mean Std Dev S Std Error

\begin{tabular}{|c|c|c|c|c|}
\hline $\begin{array}{l}\text { pos } \\
\text { pre }\end{array}$ & $\begin{array}{l}210 \\
210\end{array}$ & $\begin{array}{r}-3023.90476190 \\
-18393.21904762\end{array}$ & & $\begin{array}{l}5.62199312 \\
.91219067\end{array}$ \\
\hline ariances & $\mathbf{T}$ & Method & $\mathrm{DF}$ & Probs $|\mathrm{T}|$ \\
\hline $\begin{array}{l}\text { Jnequal } \\
\text { gqual }\end{array}$ & $\begin{array}{l}4.5841 \\
4.5841\end{array}$ & $\begin{array}{l}\text { Satterthwaite } \\
\text { Cochran }\end{array}$ & $\begin{array}{l}391.0 \\
209.0 \\
418.0\end{array}$ & $\begin{array}{l}0.00 \\
0.00 \\
0.00\end{array}$ \\
\hline
\end{tabular}

For HO: Variances are equal, $F^{\prime}=1.71 \quad D F=(209,209) . \quad$ Prob $>F^{\prime}=0.0001$

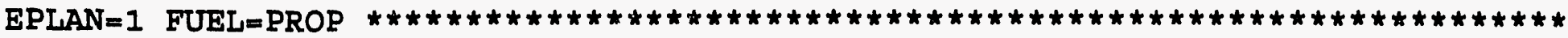

Variable: ARREARAG

$\begin{array}{lllll}\text { PREPOST N } & \text { Mean } & \text { Std Dev } & \text { Error }\end{array}$

bos $\quad 1 \quad 59483.00000000$

pre $\quad 1 \quad 69817.00000000$

Variances $T$ Method DF Probs $|T|$

Unequal . Satterthwaite

Equal

Cochran

NOTE: All values are the same for one Class level. 


\section{Arrearage Impacts of 1990 Installations}

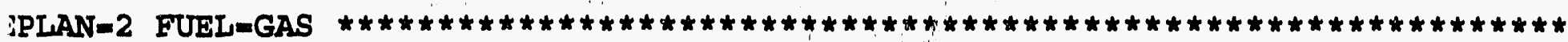
fariable: ARREARAG

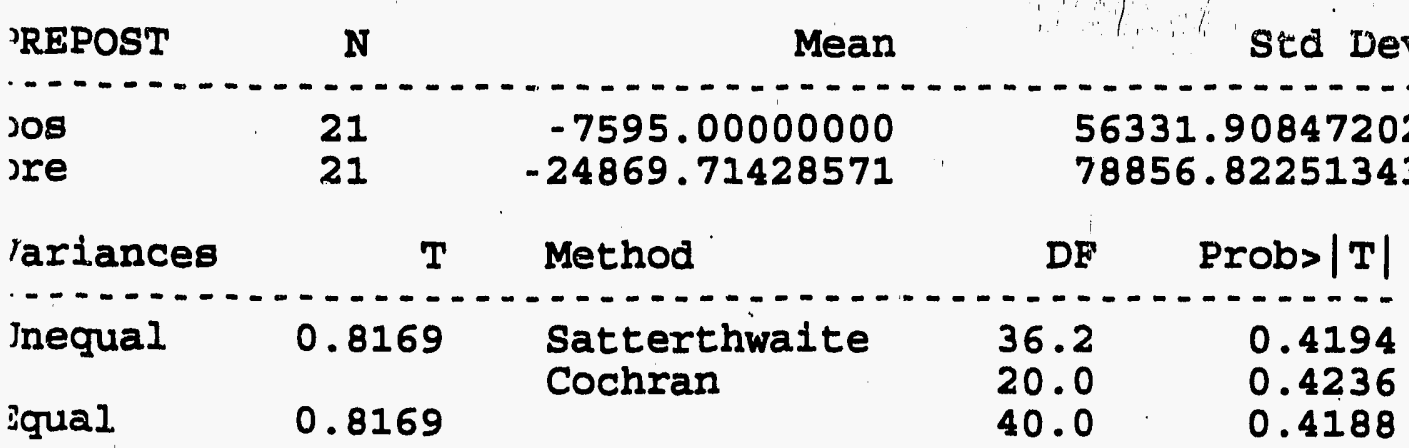

'or HO: Variances are equal, $F^{\prime}=1.96 \quad D F=(20,20) \quad$ Prob>F' $=0.1410$

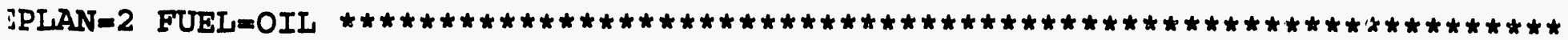
Tariable: ARREARAG

\begin{tabular}{|c|c|c|c|c|}
\hline 'REPOST & $\mathbf{N}$ & Mean & Std Dev & std Error \\
\hline $\begin{array}{l}\text { jos } \\
\text { sre }\end{array}$ & $\begin{array}{l}152 \\
152\end{array}$ & $\begin{array}{r}-1220.17105263 \\
-20162.84210526\end{array}$ & $\begin{array}{l}31952.35319750 \\
52651.05250096\end{array}$ & $\begin{array}{l}2591.6 \\
4270.5\end{array}$ \\
\hline
\end{tabular}

$\begin{array}{lcccc}\text { lariances } & \text { T } & \text { Method } & \text { DF } & \text { Probs }|T| \\ \text { Inequal } & 3.7920 & \text { Satterthwaite } & 248.9 & 0.0002 \\ \text { Iqual } & 3.7920 & \text { Cochran } & 151.0 & 0.0002 \\ & & & 302.0 & 0.0002\end{array}$

'or HO: Variances are equal, $F^{\prime}=2.72 \quad D F=(151,151) \quad$ Prob $>F^{\prime}=0.0000$ 


\section{Arrearage Impacts of 1990 Installations}

EPLAN=2 FUEL=PROP

- Variable: ARREARAG

PREPOST

Mean

Std Dev

std Error

\begin{tabular}{|c|c|c|c|c|}
\hline $\begin{array}{l}\text { pos } \\
\text { pre }\end{array}$ & $\begin{array}{l}1 \\
1\end{array}$ & $\begin{array}{r}-7420.00000000 \\
-52748.00000000\end{array}$ & & \\
\hline Variances & $T$ & Method & $D F$ & Probs $|\mathrm{T}|$ \\
\hline Unequal & • & $\begin{array}{l}\text { Satterthwaite } \\
\text { Cochran }\end{array}$ & $\cdot$ & \\
\hline qual & $\cdot$ & & - & \\
\hline
\end{tabular}

NOTE: All values are the same for one ClaAss level. 


\section{Arrearage Impacts of 1990 Installations}

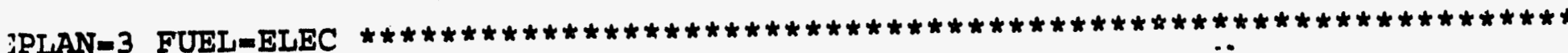
Tariable: ARREARAG

\begin{tabular}{|c|c|c|c|c|c|}
\hline ?REPOST & $\mathbf{N}$ & Mean & & std Dev & Std Erro \\
\hline $\begin{array}{l}\text { Pos } \\
\text { ?re }\end{array}$ & $\begin{array}{l}168 \\
168\end{array}$ & $\begin{array}{r}5384.22619048 \\
-17959.25595238\end{array}$ & & $\begin{array}{l}.57743998 \\
1.87883506\end{array}$ & $\begin{array}{l}4447.22139972 \\
4591.44113339\end{array}$ \\
\hline Jariances & $T$ & Method & DE & Probs $|\mathrm{T}|$ & \\
\hline $\begin{array}{l}\text { Inequal } \\
\text { Equal }\end{array}$ & $\begin{array}{l}3.6519 \\
3.6519\end{array}$ & $\begin{array}{l}\text { Satterthwaite } \\
\text { Cochran }\end{array}$ & $\begin{array}{l}333.7 \\
167.0 \\
334.0\end{array}$ & $\begin{array}{l}0.0003 \\
0.0003 \\
0.0003\end{array}$ & \\
\hline
\end{tabular}

Zor HO: Variances are equal, $F^{\prime}=1.07 \quad D F=(167,167) \quad$ Probs $>F^{\prime}=0.6805$

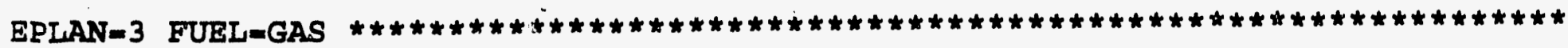
Variable: ARREARAG

PREPOST N Mean $\quad$ std Dev Std Error

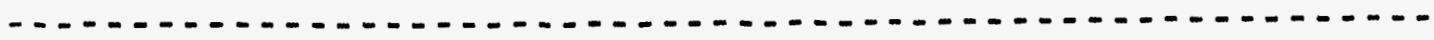
2031.77718973

pos

pre

148

$-18085.13513514$

42834.00245079

3520.93331257

Variances $T$ Method Prob $>|T|$

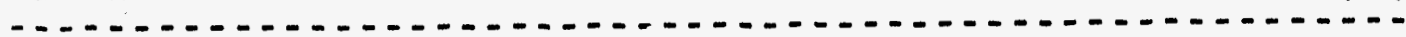

$\begin{array}{lllll}\text { Unequal } & 3.3175 & \begin{array}{l}\text { Satterthwaite } \\ \text { Cochran }\end{array} & 235.1 & 0.0011 \\ \text { Equal } & & 147.0 & 0.0011 \\ & 3.3175 & & 294.0 & 0.0010\end{array}$

For HO: Variances are equal, $F^{\prime}=3.00 \quad$ DF $=(147,147) \quad$ Prob $>F^{\prime}=0.0000$ 


\section{Arrearage Impacts of 1990 Installations}

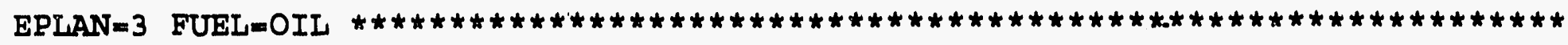
Variable: ARREARAG

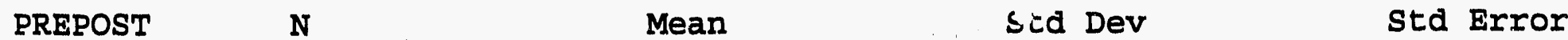

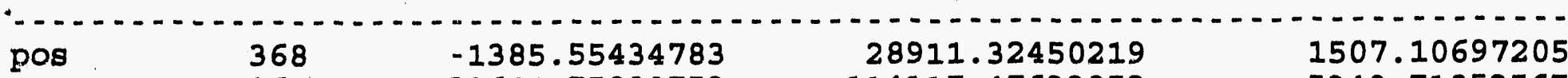

pre $\quad 369 \quad-23644.75880759 \quad 114117.47633852$

5940.71852567

Variances T Method DF Probs $|\mathrm{T}|$

$\begin{array}{lrlrr}\text { Unequal } & 3.6318 & \begin{array}{l}\text { Satterthwaite } \\ \text { Cochran }\end{array} & 415.2 & 0.0003 \\ \text { Equal } & 3.6275 & & 735.0 & 0.0003 \\ & & & & 0.0003\end{array}$

For HO: Variances are equal, $F^{\prime}=15.58 \quad$ DF $=(368,367) \quad$ Prob $>F^{\prime}=0.0000$

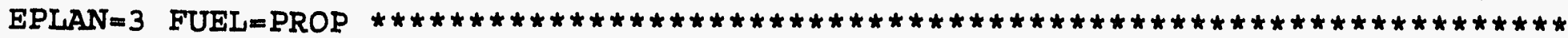
Variable: ARREARAG

\begin{tabular}{|c|c|c|c|c|}
\hline EPOST & $\mathbf{N}$ & Mean & std Dev & std Error \\
\hline $\begin{array}{l}\text { pos } \\
\text { pre }\end{array}$ & $\begin{array}{l}8 \\
8\end{array}$ & $\begin{array}{r}-17464.62500000 \\
-7207.12500000\end{array}$ & $\begin{array}{l}42148.34435636 \\
14320.08299495\end{array}$ & $\begin{array}{r}14901.69005508 \\
5062.91389644\end{array}$ \\
\hline Variances & $T$ & Method & Probs $|\mathrm{T}|$ & \\
\hline $\begin{array}{l}\text { Uhequal } \\
\text { Equal }\end{array}$ & $\begin{array}{l}-0.6518 \\
-0.6518\end{array}$ & $\begin{array}{l}\text { Satterthwaite } \\
\text { Cochran }\end{array}$ & $\begin{array}{l}0.5317 \\
0.5354 \\
0.5251\end{array}$ & \\
\hline
\end{tabular}




\section{Arrearage Impacts of 1990 Installations}

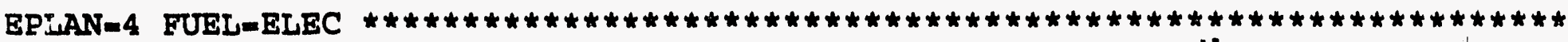
Variable: ARREARAG

\begin{tabular}{|c|c|c|c|c|}
\hline PREPOST & $\mathrm{N}$ & Mean & & std D \\
\hline $\begin{array}{l}\text { pos } \\
\text { pre }\end{array}$ & $\begin{array}{l}12 \\
12\end{array}$ & $\begin{array}{l}-15535.08333333 \\
-54672.75000000\end{array}$ & & $\begin{array}{l}1.2390835 \\
7.0924386\end{array}$ \\
\hline ariances & $T$ & Method & DF & Prob> \\
\hline $\begin{array}{l}\text { inequal } \\
\text { qual. }\end{array}$ & $\begin{array}{l}1.1293 \\
1.1293\end{array}$ & $\begin{array}{l}\text { Satterthwaite } \\
\text { Cochran }\end{array}$ & $\begin{array}{l}19.5 \\
11.0 \\
22.0\end{array}$ & $\begin{array}{l}0 . \\
0 . \\
0 .\end{array}$ \\
\hline
\end{tabular}

For HO: Variances are equal, $F^{\prime}=2.13 \quad D F=(11,11) \quad$ Prob>F' $=0.2268$

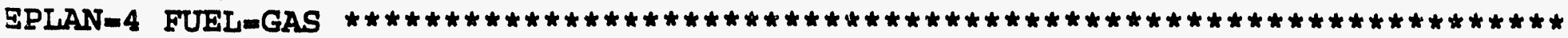
Variable: ARREARAG

\begin{tabular}{|c|c|c|c|c|}
\hline PREPOST & $\mathbf{N}$ & Mean & & std Der \\
\hline $\begin{array}{l}\text { p̧os } \\
\text { ग̧re }\end{array}$ & $\begin{array}{l}158 \\
158\end{array}$ & $\begin{array}{r}3238.03164557 \\
-40880.95569620\end{array}$ & & $\begin{array}{l}3.9515 \\
.5305\end{array}$ \\
\hline Jariances & 1 & Method & DE & Prob $>\mid T$ \\
\hline $\begin{array}{l}\text { Jnequal } \\
\text { Iqual }\end{array}$ & $\begin{array}{l}6.5097 \\
6.5097\end{array}$ & $\begin{array}{l}\text { Satterthwaite } \\
\text { Cochran }\end{array}$ & $\begin{array}{l}244.9 \\
157.0 \\
314.0\end{array}$ & $\begin{array}{l}0 . \\
0 . \\
0 .\end{array}$ \\
\hline
\end{tabular}

For HO: Variances are equal, $F^{\prime}=3.26 \quad$ DF $=(157,157) \quad$ Prob>F' $=0.0000$ 


\section{Arrearage Impacts of 1990 Installations}

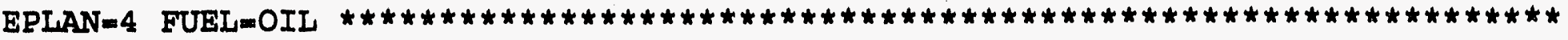
Variable: ARREARAG

\begin{tabular}{lcrrr} 
PREPOST & N & \multicolumn{1}{c}{ Mean } & Std Dev & Std Error \\
\hline pos & 134 & -7382.04477612 & 44513.63896806 & 3845.39272122 \\
pre & 134 & -30229.26119403 & 67053.32245511 & 5792.52480993
\end{tabular}

\begin{tabular}{lcccr} 
Variances & $T$ & Method & DF & Probs $|\mathrm{T}|$ \\
\hline Unequal & 3.2861 & Satterthwaite & 231.2 & 0.0012 \\
Equal & 3.2861 & Cochran & 133.0 & 0.0013 \\
& & 266.0 & 0.0012
\end{tabular}

For HO: Variances are equal, $F^{\prime}=2.27$ DF $=(133,133) \cdot$ Prob>F' $=0.0000$

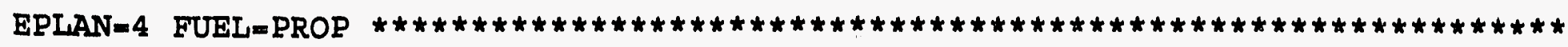
Variable: ARREARAG

PREPOST N Mean

$5 \quad-11384.80000000$

$5 \quad-9982.80000000$

T Method

Variances

(-......-

Unequal -0.0435

Equal

$-0.0435$

For HO: Variances are equal, $F^{\prime}=4.30$

\section{Satterthwaite} Cochran 


\section{Arrearage Impacts of 1990 Installations}

IPLAN $=5$ FUEL=ELEC 'ariable: ARREARAG

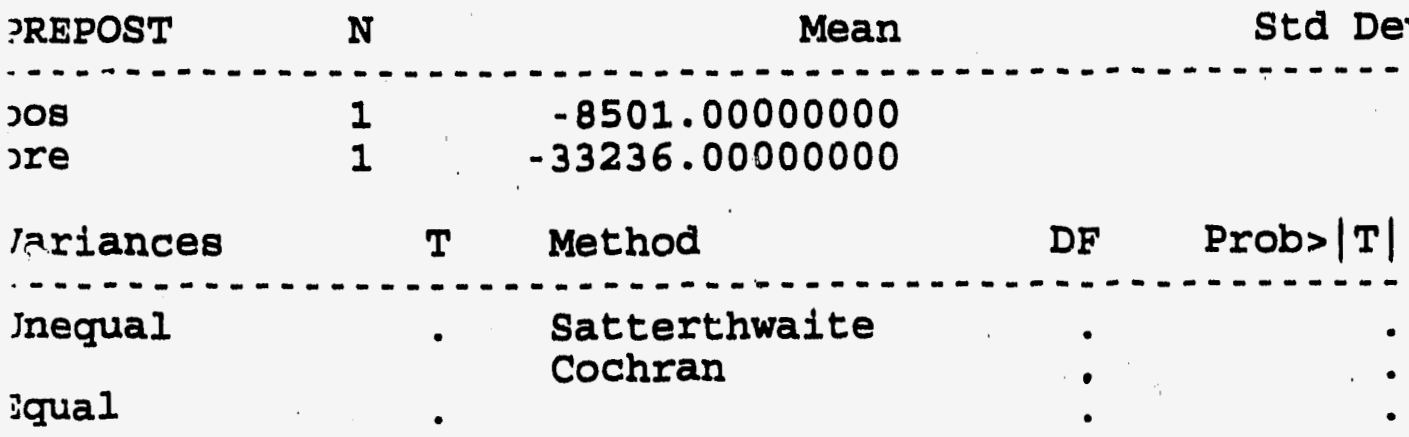

NOTE: All values are the same for one CLASS level.

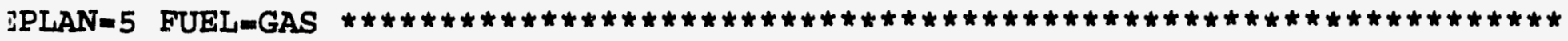
lariable: ARREARAG

?REPOST N Mean Std Dev

Std irror

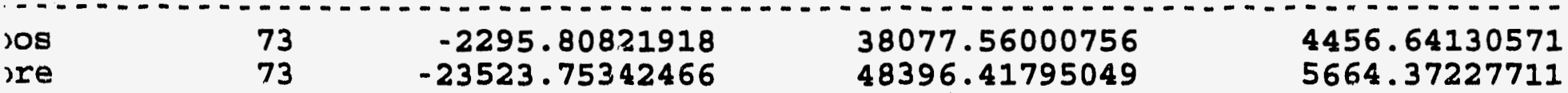

rariances $T$ Method DF Probs $|T|$

Inequal $2.9453 \quad$ Satterthwaite $136.4 \quad 0.0038$

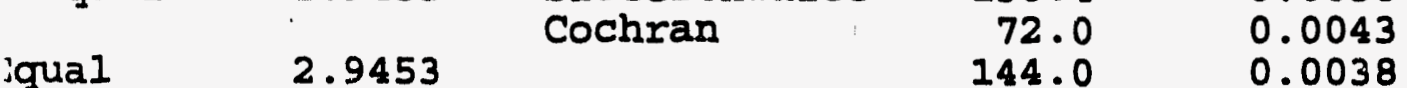

'or HO: Variances are equal, $F^{\prime}=1.62 \quad D F=(72,72) \quad$ Prob $>F^{\prime}=0.0436$ 


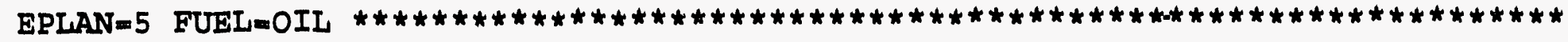
-

Variable: ARREARAG

.PREPOST N Mean $\quad$ Std Dev $\quad$ Std Error

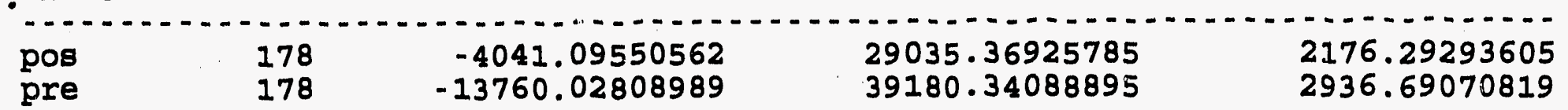

Varlances $T$ Method DF Prob $>|T|$

(1)

\begin{tabular}{|c|c|c|c|}
\hline Unequal & 2.6589 & $\begin{array}{l}\text { Satterthwaite } \\
\text { Cochran }\end{array}$ & $\begin{array}{l}326.4 \\
177.0\end{array}$ \\
\hline
\end{tabular}

$\begin{array}{llll}\text { Equal } 2.6589 & 354.0 & 0.0082\end{array}$

For HO: Variances are equal, $F^{\prime}=1.82 \quad D F=(177,177) \quad$ Prob $>F^{\prime \prime}=0.0000$ 


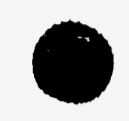

. 


\section{Appendix G: Process Evaluation Documentation}

Appendix $G$ documents the development, design, and process evaluations summarized in chapter 2 of this report. The complete evaluations appear in the two companion documents by Steven Ferrey and Technical Development Corporation.

Table of Contents:

G1. Audit Invoice Forms $\ldots \ldots \ldots \ldots \ldots \ldots \ldots \ldots \ldots \ldots \ldots \ldots \ldots$

Section 1 consists of copies of the actual invoice forms used by auditors to select measures for installation.

G2. Literature Review Bibliography $\ldots \ldots \ldots \ldots \ldots \ldots \ldots \ldots \ldots \ldots \ldots$

Section 2 is the bibliography for the literature search used to evaluate the legitimacy of a low-income weatherization program, NU's screening methodology used in the early WRAP development stages, and the WRAP program design.

G3. Customer Survey Forms

A survey of participants was conducted to evaluate the program from the participants' perspective. Section 3 contains a copy of the survey instrument.

G4. List of Interviewees $\ldots \ldots \ldots \ldots \ldots \ldots \ldots \ldots \ldots \ldots \ldots \ldots$

The proctss evaluation was partially based on interviews with individuals familiar with the design management, and delivery of the WRAP program. Section 5 includes a list of these interviewees. This interview process should not be confused with the interviews conducted to evaluate the collaborative process through which the WRAP program was developed. Individuals who participated in those interviews were guaranteed anonymity. 
G5. Customer Records Analysis $\ldots \ldots \ldots \ldots \ldots \ldots \ldots \ldots \ldots \ldots \ldots \ldots, \ldots \ldots \ldots$

The customer records analysis examines the timeliness of paperflow and installations by several different CAAs, representing the five regions of the WRAP service area. 


\title{
Appendix G: Process Evaluation Documentation
}

\author{
Section 1: \\ Audit Invoice Forms
}




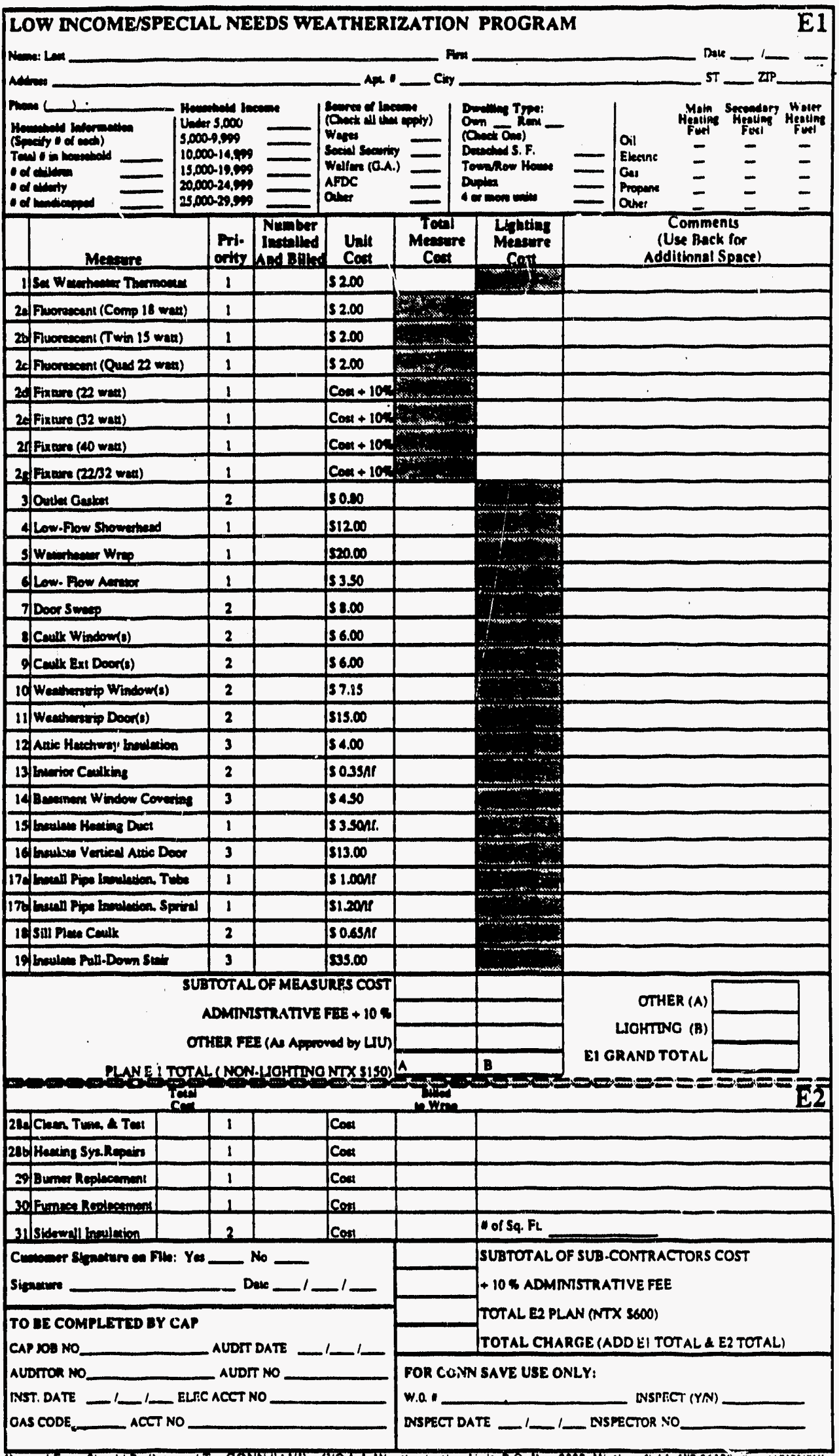

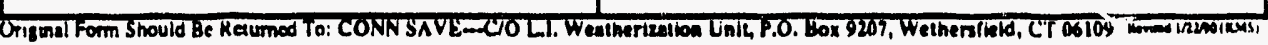




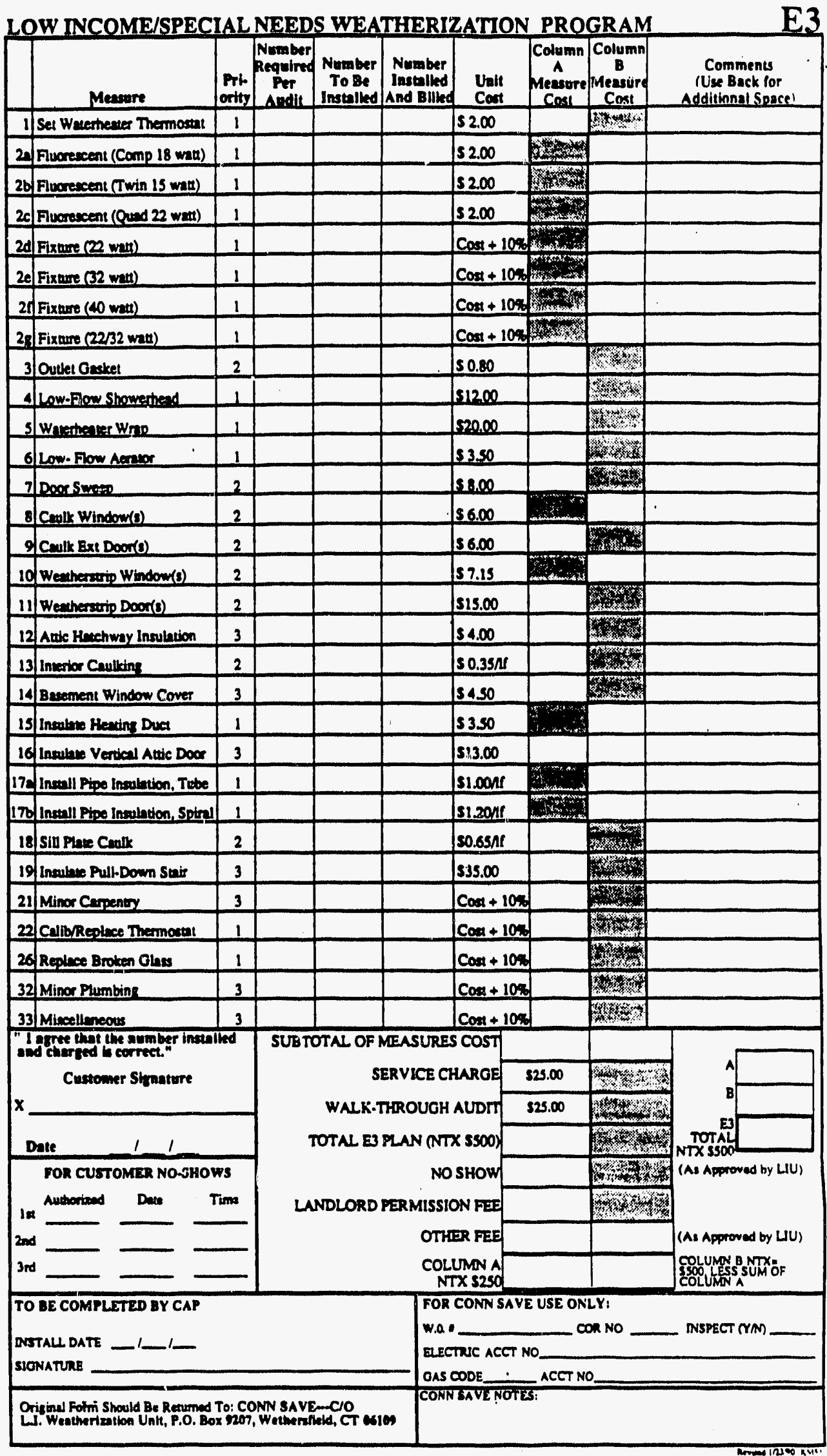




\begin{tabular}{|c|c|c|c|c|c|c|c|}
\hline Meavere & Prt. & 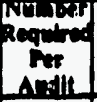 & $\begin{array}{l}\text { Nencer } \\
\text { To Ber } \\
\text { Inetalled }\end{array}$ & $\begin{array}{l}\text { Nomber } \\
\text { inotalled } \\
\text { And Buld }\end{array}$ & $\begin{array}{l}\text { Unit } \\
\text { Ceat }\end{array}$ & $\mid \begin{array}{c}\text { Toul } \\
\text { Meisevere } \\
\text { Cout }\end{array}$ & $\begin{array}{c}\text { Comments } \\
\text { (Use Back for } \\
\text { Additional Sgece) }\end{array}$ \\
\hline 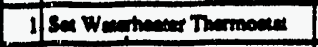 & 1 & & & & 3200 & & \\
\hline 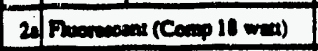 & 1 & & & & 3200 & & \\
\hline 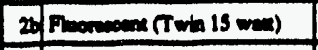 & 1 & & & & 3200 & & \\
\hline 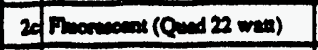 & 1 & & & & 3200 & & \\
\hline 26) Proxues (22 way) & 1 & & & & $\operatorname{con}+100$ & & \\
\hline 2. Frome (102 $\mathrm{man})$ & 1 & & & & $\cos +10 x$ & & \\
\hline 2.] Patue $(10 \mathrm{max})$ & 1 & & & & $\cos +100$ & & \\
\hline 2. Finere $(2232 \mathrm{van})$ & 1 & & & & Con +100 & & 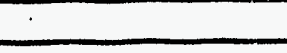 \\
\hline 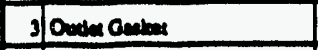 & 3 & & & & 30.00 & & \\
\hline 4 Low How Shominteed & 1 & & & & 31200 & & \\
\hline 9) Wombeom Wres & 1 & & & & 20.00 & & \\
\hline SLow. Flow Anerer & 1 & & & & 5350 & & \\
\hline 7 Door Swepep & 3 & & & & 3200 & & \\
\hline 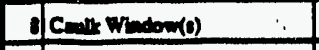 & 3 & & & & 3600 & & \\
\hline 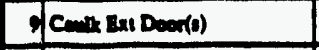 & 3 & & & & 3600 & & \\
\hline 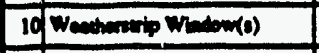 & 3 & & & & 37.15 & & \\
\hline 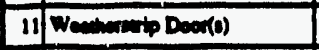 & 3 & & & & $\$ 15.00$ & & \\
\hline 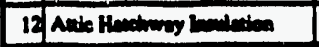 & 4 & & & & 3400 & & \\
\hline 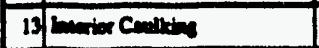 & 3 & & & & 30.35ns & & \\
\hline 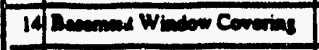 & 4 & & & & 3450 & & \\
\hline 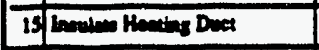 & 1 & & & & 3ssone & & \\
\hline 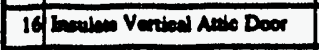 & 4 & & & & 513.00 & & \\
\hline 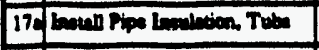 & 1 & & & & \$1.00ns & & \\
\hline 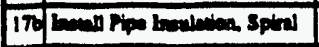 & 1 & & & & 312001 & & \\
\hline 18 $\sin$ new Comsis & 3 & & & & 30.6sn & & \\
\hline 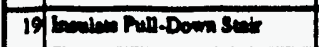 & 4 & & & & 35.00 & & \\
\hline 21 Merer Copengy & 3 & & & & $\cos +100$ & & \\
\hline 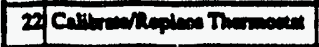 & 1 & & & & $\operatorname{com}+10 \mathrm{~m}$ & & \\
\hline 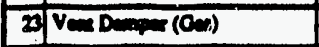 & 1 & & & & $\mathrm{~cm}+10 \mathrm{~m}$ & & \\
\hline 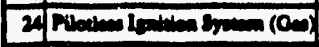 & 4 & & & & $C m+10 m$ & & \\
\hline 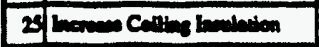 & 3 & & & & $\cos +10 n$ & & \\
\hline 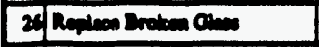 & 1 & & & & $\cos +10 n$ & & \\
\hline 27. Whan Tremen & 4 & & & & $C_{m}+10 m$ & & \\
\hline 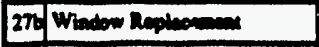 & 4 & & & & $\operatorname{com}+100$ & & \\
\hline 270 Window Locks & 3 & & & & 5250 & & \\
\hline 2ec Com Tme \&u & 2 & & & & $\cos +10 \mathrm{~m}$ & & \\
\hline 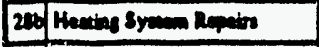 & 2 & & & & $\cos +100$ & & \\
\hline 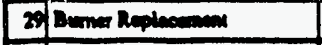 & 2 & & & & $\mathrm{Cos}+10 \mathrm{~s}$ & & \\
\hline 30 Proneos Replecengen & 2 & & & & $\mathrm{Cm}+10 \mathrm{n}$ & & \\
\hline 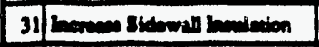 & 3 & & & & $\operatorname{con}+10 n$ & & \\
\hline 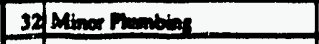 & 3 & & & & Con +100 & & \\
\hline 33] Mimanemen & 3 & & & & $\cos +100$ & & \\
\hline \multicolumn{3}{|c|}{ I I egree that the number betallied } & \multicolumn{4}{|c|}{ SUBTOTAL OF MEASURES COST } & \multirow{4}{*}{$\begin{array}{l}\text { (A) Approved by LUU) } \\
\text { NTX S1,S00 (or } \$ 3,000)\end{array}$} \\
\hline 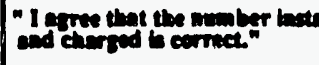 & alled & & \multicolumn{3}{|c|}{ LANDLORD PERMLSSTON FEE } & & \\
\hline \multicolumn{3}{|c|}{ Consomer Signature Date } & \multicolumn{3}{|r|}{ OTHER PEE } & & \\
\hline \multicolumn{3}{|c|}{$x_{2}$} & \multicolumn{3}{|c|}{ PLANE \& TOTALL } & & \\
\hline \multicolumn{4}{|c|}{ 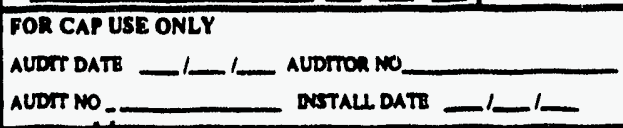 } & \multirow{2}{*}{\multicolumn{3}{|c|}{$\begin{array}{l}\text { FOR CONN SAVE USE ONLY } \\
\text { W.Q. TOWN } \\
\text { REG_- } \\
\text { ELECTRUC ACCT NO_COR NO_ } \\
\text { OAS COOE__ACCT NO_ }\end{array}$}} & WY: DNSPECT (YN) \\
\hline \multicolumn{4}{|c|}{ 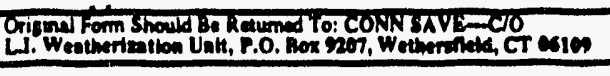 } & & & & \\
\hline
\end{tabular}




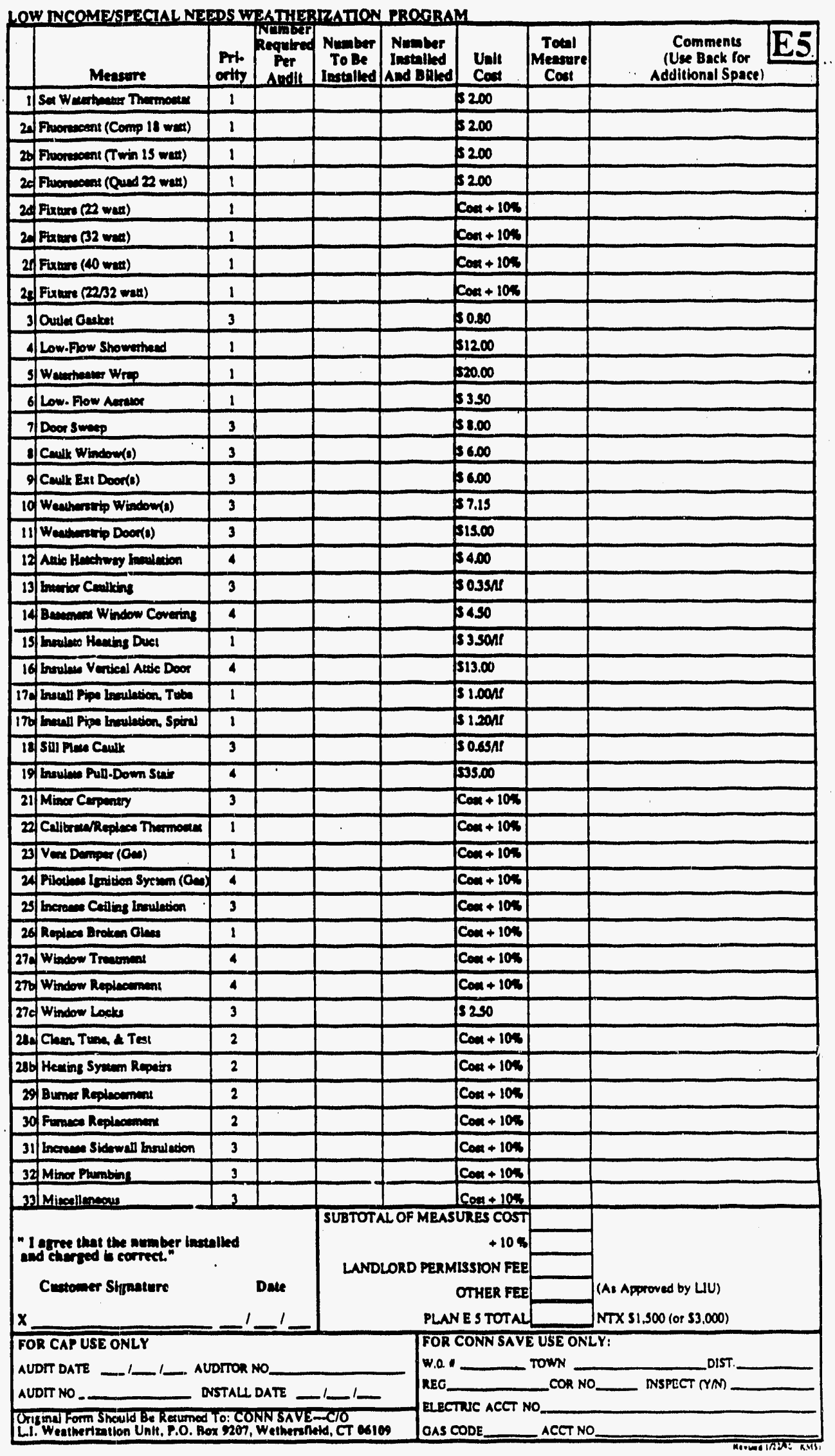





\title{
Appendix G: Process Evaluation Documentation
}

\author{
Section 2: \\ Literature Review \\ Bibliography
}



Berry, L., "Marketing and Design of Residential Energy Conservation Programs for the Elderly." Oak Ridge National Laboratory, ORNL/CON-246, 1988.

Gladhart, P. \& Weihl, J., "The Effects of Low-Income Weatherization on Interior Temperature, Occupant Comfort and Household Management Behavior." ACEEE, 1990.

Gregory, J. \& Williams, L., "Fuel Savings Results: Results of a Consumer Education Pilot Study, 11/863/88." Draft report, Cleveland State University, 1989.

Hammarlund, J., "Marketing Conservation in the Multi-Family Sector: Lessons Learned." ACEEE, 1990.

Haeri, M., "Towards an Optimal Mechanism for the Delivery of Low-Income Residential DSM Services." ACEEE, 1990.

Lent, T., "Cutting Cool Watts: Helping Low-Income Philadelphians Reduce Non-Heating Electricity Use." ACEEE, 1988.

Lent, T., "Improving the Weatherization Assistance Program Through Home Visit Education." Argonne National Laboratory Conference 1987.

Quaid, M., "An Evaluation of the Community Energy Workshop: An Energy Conservation Pilot Program for Low-Income Households." Argonne National Laboratory Conference, 1990.

Quaid, M., "Low-Income Energy Education Programs: A Review of the Evaluation Results and Methods." ACEEE, 1990.

Schlegal, J. \& Pigg, S., "The Potential for Energy Savings and Cost-Effectiveness of Low-Income Weatherization Programs: A Summary of Recent Evaluations." ACEEE, 1990.

Schwartz, D. \& True, B., "What Households Do When Electricity Prices Go Up -- An Econometric Analysis with Policy Implications." ACEEE, 1990.

U.S. General Accounting Office (GAO), forthcoming report which surveys the energy conservation and financial needs of the low-income families in federally assisted housing.

Witts, P. \& Kushler, M., "An Evaluation of the Michigan Low-Income Weatherization Energy Education and Incentives Program." Michigan PSC, 1989. 


\title{
Appendix G: Process Evaluation Documentation
}

\author{
Section 3: \\ Customer Survey Forms
}




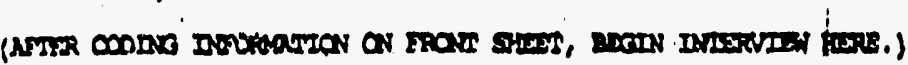

\author{
Intervionesi complete \\ co. 1 Hale 2 sumale
}

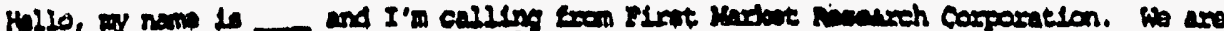

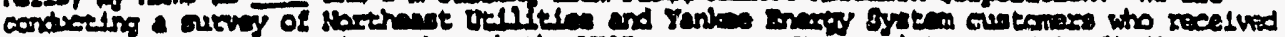

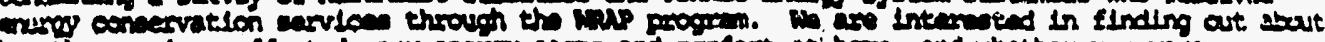

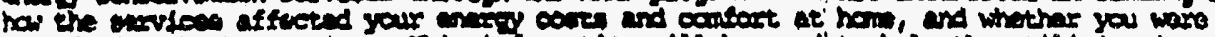

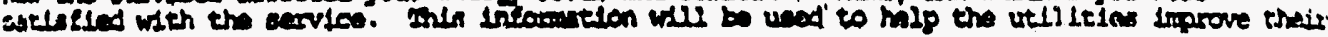
custanase progremen.

1. To begin with, how did you hare abourt the

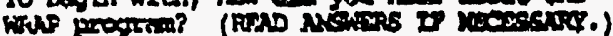

ce.

i contected the cominity dotion

achey

2 contiktend oy drother socinl sarviou Apancy

3 contactad by A Repmenentatilis of the

$$
\begin{aligned}
& 3 \\
& 5 \\
& 8 \\
& 8 \\
& 8 \\
& x \\
& 8
\end{aligned}
$$
vellety

2. Did the aurdror viult your haw on the

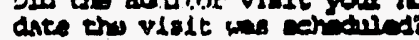

\title{
2
}

ar.

i

3 Dinger

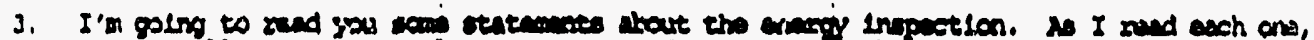

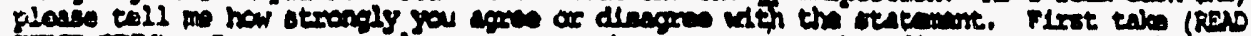

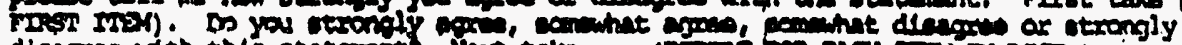

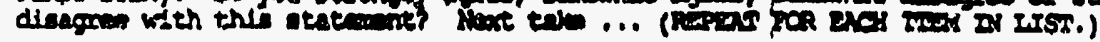

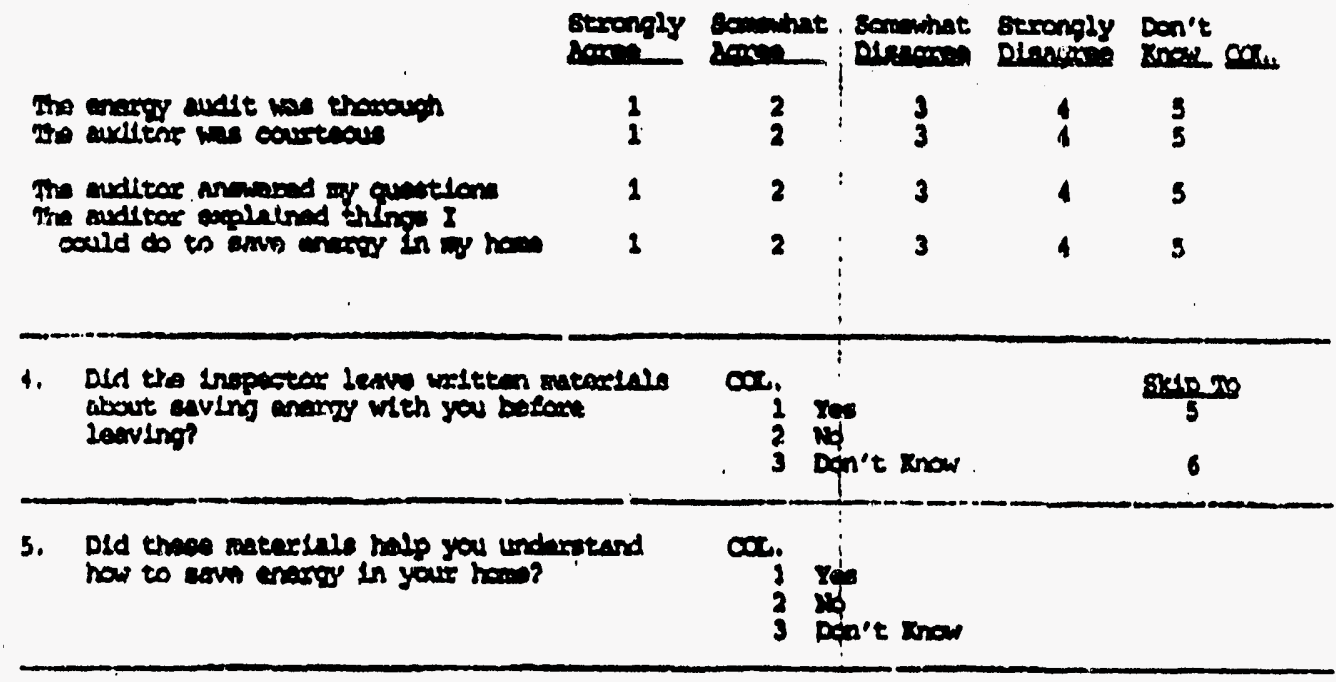




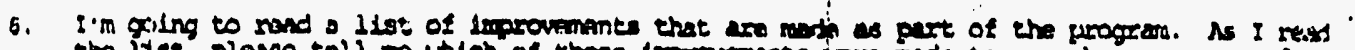

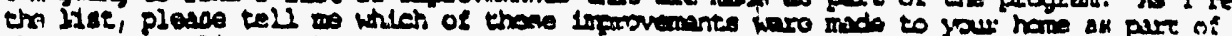

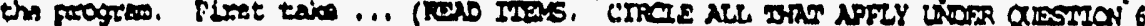
Barsin.)

\begin{tabular}{|c|c|}
\hline$\frac{a g 5 n+6}{s k}$ & Denowayins \\
\hline 1 & Brexpy afflelant Leht bulbe \\
\hline 2 & Water hast wetp \\
\hline 3 & Weather oteripping in coors and window \\
\hline 4 & Stom whendente \\
\hline 5 & Reof Inersation \\
\hline 6 & Iow flow ahoun hasd and/or facat \\
\hline 9 & Clock theomest \\
\hline B & Angthing cles \\
\hline
\end{tabular}

\begin{tabular}{|c|c|c|c|c|}
\hline $\begin{array}{l}\overline{\operatorname{vary}} \\
\cos x\end{array}$ & $\cos \theta$ & $x \times$ & $\begin{array}{l}\text { Very } \\
\text { Bears }\end{array}$ & 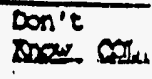 \\
\hline 1 & 2 & 3 & 4 & 3 \\
\hline 1 & $i^{2}$ & 3 & 4 & 5 \\
\hline 1 & 2 & 3 & 4 & 5 \\
\hline 1 & 2 & 3 & 4 & 5 \\
\hline 1 & 2 & 3 & 4 & 3 \\
\hline 1 & 2 & 3 & 4 & 5 \\
\hline 1 & 2 & 3 & 4 & 5 \\
\hline ! & $\because$ & 3 & 4 & 3 \\
\hline
\end{tabular}

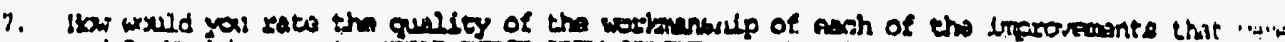

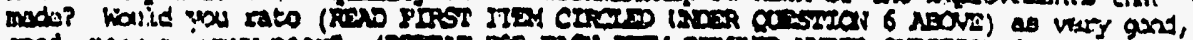

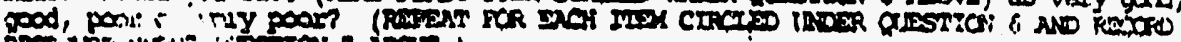

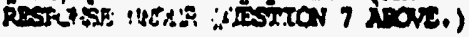

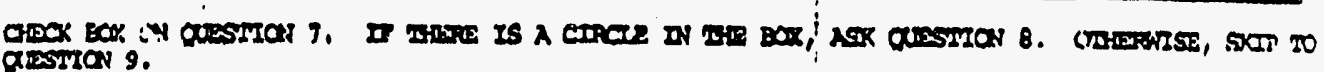

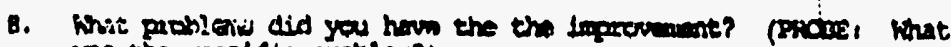
we the upelistr problet?

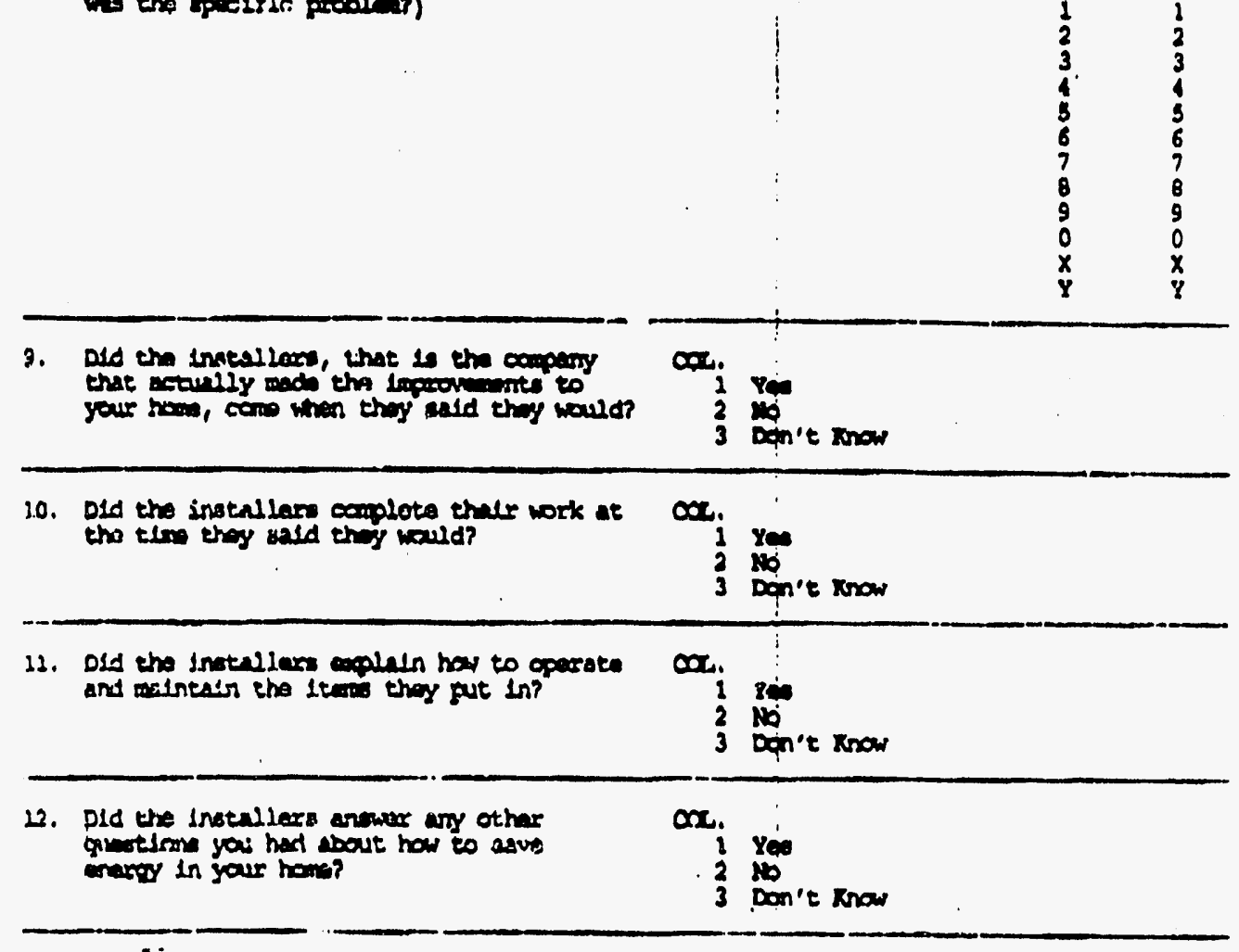


13. Old the Inetrillare clean un to yours artistaption after completing this worte?

$\infty$.

2 so

3 Don't know

21. In gomencl, would you ay you aro vay

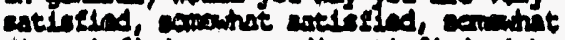

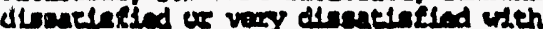
the work dore by the inveallexe?

$\infty$.

i viry satiosied

2 scomine melefled

3 scumint Discatioflex

4 viscartfied

4 bety preve

15. Osd a repremententsw of your loon utillity infopet the Inverlilielon?

$\infty$.

t.
Dive than

(

$$
\text { . }
$$

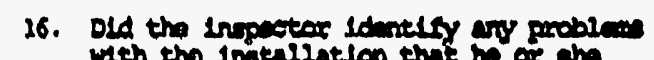

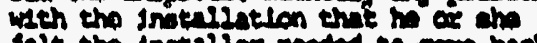

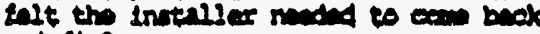
and elx?

3 Doh't nnow 16

19

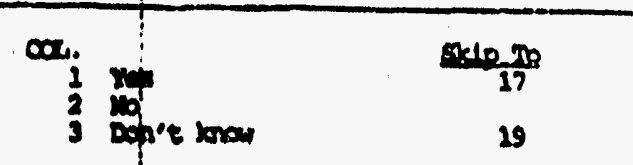

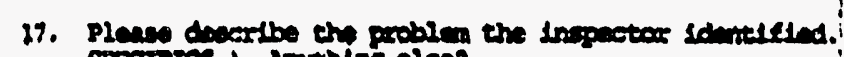
sezcrires.) Nryining aleap

teled.

(Preneres

$\infty$

$\infty$

i

20. Did the Inotaller com beak and tle the probleat Identilied by the inopactex?

a.

i 
22. At what tenprature to you sat your thamosest at night?

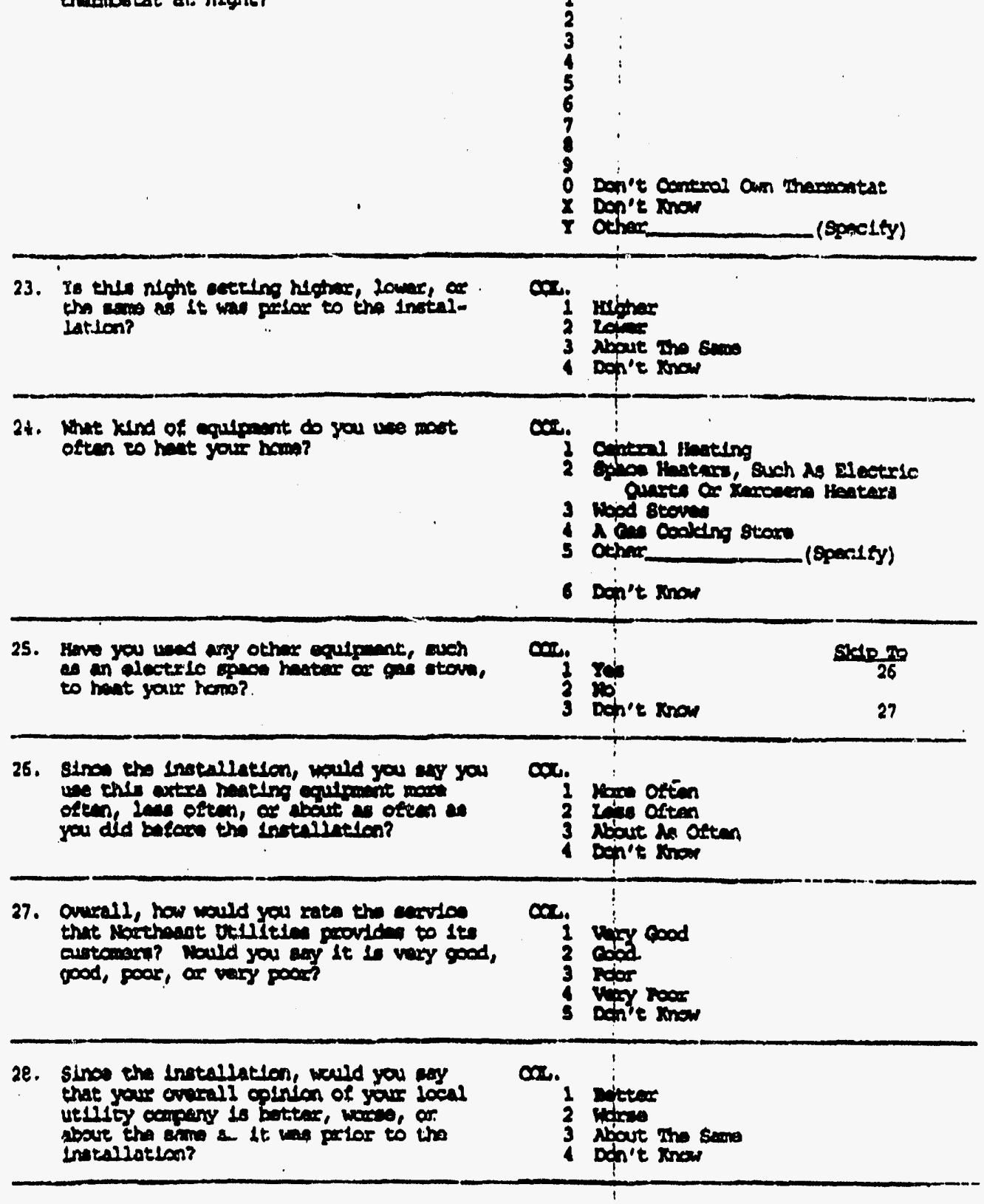

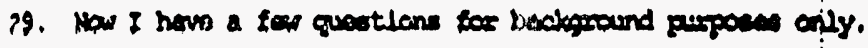

How lang havo you 2 lyed in your curevent.

cos. ham?

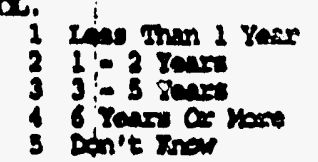

1 I The Than 1 rase

8 ran

Iong or $\mathrm{km}$

3 Din't Inew 



\title{
Appendix G: Process Evaluation Documentation
}

\author{
Section 4: \\ List of Interviewees
}





\section{List of Interviewees}

\section{Northeast Utilities}

Sara Ellison, Community Relations Manager

Marilyn Brossmer, Northern Regional Office

Marge Brannigan, Community Outreach Representative

\section{CONN Save}

Steve Kelly, Low Income Unit Manager

John Greeno,

Pearl Bouchard

Dean Sandstrom

\section{Community Action Agencies (Energy Directors)}

Ron Mattana, WACAP

Joanne Balschak, NOW

Christopher Sardo, TVCCA

Larry Eliot, MCAA

Jim Pistano, CAGM

\section{Department of Human Resources}

Marion Wojick

Public Utilities Commission

Mark Quinlan 


\section{Appendix G: Process Evaluation Documentation}

Section 5:

Customer Records Analysis 

In an effort to determine the extent to which set procedures were followed in serving participants and the elapsed time between the various steps in " providing service, TDC examined customer recorcis for each of five Community Action Agencies. The original focus of this analysis was to track the flow of paper from receipt of a customer application through audit workorder and delivery, to installation of measures and submission of invoice for same. The five CAAs were selected to represent each region of the state and to illustrate the variation among the three top-performing agencies, and between the top performing agencies and two agencies that fell short of their goals for program year 1989:

\begin{tabular}{llcc} 
Agency & Region & $\begin{array}{l}\text { Customers Served as \% } \\
\text { of Agency's 1989 Goal }\end{array}$ & $\begin{array}{r}\text { \# Records } \\
\text { Sampled }\end{array}$ \\
\cline { 3 - 4 } NOW & Western & $167 \%$ & 1,252 \\
TVCCA & Eastern & $144 \%$ & 624 \\
WACAP & Northern & $118 \%$ & 1,104 \\
HRA & Central & $63 \%$ & 388 \\
TEAM & Southern & $21 \%$ & 109
\end{tabular}

Total: 3,477

The objective of this analysis was to identify, for each agency and for the group as a whole, the range of times (measured in days) elapsed between the following key points in the customer service sequence:

(1) preliminary work: from the initial customer application to the issuance of a workorder assigning a Community Action Agency (CAA) to schedule and perform an audit or walk-through energy survey (E3, E4 and E5 only);

(2) audit completion: from the issuance of the workorder to the completion of the audit (E4 and E5 only);

(3) installation: from the completion of the audit to the installation of the recommended measures (E1, E2, E4 and E5);

(4) 90-day period: total time elapsed from the issuance of a workorder to the completion of the installation work, supposed not to exceed 90 days (E3, E4, and E5);

(5) billing time elapsed between completion of the installation work 
The method for identifying these ranges was to perform calculations between selècted date fields within the "WrapTrack" customer service database. The date fields used in these calculations are described below:

- S_DATEISUE = date the WRAP application is processed by an NU Community Outreach Representative (COR). Applications may be sent by a customer either to an NU Representative, or to CONN Save, whose address appears on the application form. If CONN Save receives an application, it forwards it to one of the regional NU offices, where the application is processed by a COR and sent back in to CONN Save for assignment to a Community Action Agency. The date the application is processed by the COR is the date which gets entered into the S_DATEISUE field.

This field applies only to the E3, E4, and E5 subprograms. E1 and E2 customers do not become part of the WRAP customer database until the CAA files an invoice for WRAP measures completed. Thus the first time period TDC sought to analyze (time lapsed between initial application and issuance of a workorder to the CAA) could be analyzed only for E3, E4, and E5 customers.

- DATE_TOCAP = date CONN Save dispatches a workorder to a CAA, requesting that the community agency schedule and perform an audit or walk-through energy survey. Again, this field applies only to the E3, E4, and E5 subprograms.

- P_DATE_AUD = date the audit is performed. This field applies to all but the E3 subprogram, for which a walk-through energy survey is substituted for the more extensive RCS energy audit. In the case of the E4 and E5 subprograms, the audit date may be recorded as soon as the CAA sends the audit in to CONN Save for processing.

In the case of the E1 and E2 subprograms, the customer does not show up in the WrapTrack system until after the installation work has been completed. There is a space on the E1/E2 invoice form for the CAA to record the date of the audit received by customers receiving E1 and E2 services, but the position of this space on the form is ambiguous: its placement on the page suggests that it need only be filled out in the case of an E2 customer. CONN Save has not focused on tracking this date for the E1 and E2 subprograms.

- P_DATE_INS = date the WRAP measures are installed. This field applies to all five of the subprograms. 
- DA TE_BACK = date the invoice is received by CONN Save after all work has be/zn completed. Because the installation date (P_DATE_INS) is not entered until an invoice has been submitted, it is effectively the time elapsed between the initial workorder date (DATE_TOCAP) and the invoice receipt date (DATE_BACK) that triggers an "overdue" when the 90-day limit is reached. As both the P_DATE_INS and the DATE_BACK fields apply to all five subprograms, it is possible to look at the range of times required for CAAs to submit invoices subsequent to completing installations. For the E3, E4, and E5 subprograms only, it is possible to look at how well the various agencies did at completing work and submitting invoices within 90 days of being sent an initial workorder.

\section{Limitations of Customer Service Record Analysis}

The customer service record analysis is limited by two factors:

(1) The structure of the WRAP program limits the most comprehensive analysis to the most comprehensively documented subprograms: E4 and E5. Only the amount of time between audit and installation and between installation and invoice stibmission can be determined for the E1 and E2 subprograms, and only the preliminary work (application to workorder issuance), between workorder and installation (or invoice submission) and the time between installation and invoice submission can be analyzed for the E3 subprogram.

(2) The quality of the data taken from the CONN Save database is inconsistent. In many cases, date fields that should in theory contain dates are empty.

In some cases, the dates entered in a given customer record do not follow the sequence prescribed by the customer service process. There is one instance where a logical explanation can be posited for the reversed date sequence. About a third of one CAA's E4 and E5 subprogram records show the audit date, P_DATE_AUD, preceding the date a workorder was sent to the CAA requesting an audit be done. The most likely explanation for this is that these represent E3 customers for whom the CAA requested an upgrade to E4 or E5 status; in this case, the agency may have received a verbal "o.k." to upgrade the customer to a higher subprogram, and have proceeded with the audit prior to receiving a written workorder from CONN Save. (It is not possible to verify this possibility from the database.) In other instances where date sequences are reversed, or where activities that cannot lngically have 
happened on the same day are recorded as happening on the same date, it is likely a case of inaccurate data.

Within these limitations, it is possible to look at a subset of the records. The findings of this analysis are presented in six tables, described below. 


\section{Findings}

Table 1 Application Processing to Workorder Dispatch: E3, E4 and E5 subprograms.

Sixty-six percent of the 3,477 customer records contain entries in the two date fields (S_DATEISUE and DATE TOCAP) required to calculate the number of days elapsed between the date an NU Community Outreach Representative (COR) processes an application and the date CONN Save dispatches a workorder instructing one of the Community Action Agencies (CAAs) to schedule and perform an energy audit or energy survey. In many cases (anywhere from 3\% to 22\% of a CAA's customers), the workorder was dispatched on the same day the application was processed.

Table 2 Workorder Dispatch to Completion of Audit: E4 and E5 subprograms.

Only $23 \%$ of all customer records in the sample included both a workorder dispatch date (DATE_TOCAP) and an audit completion date (P_DATE_AUD). The proportion of the individual agencies' customer customer load assigned to either the E4 or E5 subprogram ranged from $15 \%$ for one agency to $32 \%$ for another.

The median turn-around time for completion of an audit from the date of workorder dispatch was $\mathbf{4 2}$ days. However, this accounts only for customer records which showed a positive ( $>1$ day) time lapse between workorder dispatch and audit completion. In a total of 248 , or $31 \%$ of the 788 E4 and E5 records examined, the sequence was reversed, with the audit completion date preceding the workorder dispatch date. The practice of upgrading E3 customers to the E4 or E5 subprograms might account for this apparent anomaly, although there is no way to be certain to what extent the sequence reversal is a function of inaccurate data. A subprogram upgrade might result in a CAA completing the audit after receiving a verbal "o.k." to upgrade an E3 customer to E4 or E5. There could be some lag between the date of the verbal o.k. and the official dispatch of a new workc.rdir, requesting a full audit rather than the pared-down energy survey.

Table 3 Completion of Audit to Completion of Installation: E1, E2, E4 and E5 subprograms.

This table should encompass all but the E3 subprogram customers, who do not receive a full energy audit. Only $37 \%$ of the 3,477 records sampled include dates in both the P_DATE_AUD and P_DATE_INS fields, suggesting either some missing dates or a large proportion of customers who received audits but did not have any measures 
installed. It is not possible to determine from the sampled records which of these two possibilities is the case, or whether both factors account for this.

Thirteen percent of the 1,297 records examined show zero days having elapsed between the audit date and the measure installation date. While this would be plausible in the case of the E3 subprogram (for which a walk-through energy survey is completed in lieu of a fulllength audit), E3 customers by definition should not be showing up in this table - for the very reason that the energy survey, unlike the audit, is not tracked by the WrapTrack customer record system.

For those records (85\% of the sub-sample of 1,297$)$ which do show a positive number of days elapsed between audit and measure installation, the median value was 75 days. The individual agency medians ranged from 32 days to 93 days. The agency with the lowest median (TVCCA) also happened to have the lowest percentage $(17 \%)$ of its records included in this subsample. WACAP, with a median audit to installation time of 93 days, had the largest number of records in the sample (510), but HRA another of the smaller agencies, had the largest percentage $(50 \%)$ of its total customer records included in this subsample.

Table 4 Workorder Dispatch to Installation: E3, E4 and E5 subprograms.

The CAAs are expected to completed with their work within 90 days of the initial workorder dispatch date. Approximately $85 \%$, or 1,943 of the 2,297 customer records for which dates were entered in both the application processing and workorder dispatch date fields, have both a workorder dispatch and a measure installation (P_DATE_INS) date. In $18 \%$ of these records at least one of the two dates appears to have been entered inaccurately, resulting in a negative or zero-day period elapsed between the two events.

Of the 1,584 records which show both dates in the proper sequence, $63 \%$ show 90 days or fewer having elapsed between the two events.

Table 5 Workorder Dispatch to Invoice Submission: E3, E4 and E5 subprograms.

As an alternative measure of how well the Community Action Agencies (CAAs) were able to meet the 90-day limit, records featuring dates in both the workorder dispatch and invoice submission (DATE_BACK) date fields were also examined. Only $51 \%$ of the 3,477 record sample had both a workorder dispatch and an invoice 
submission date, as compared with $56 \%$ that had both dispatch and installation dates.

Of the 1,757 records in this subsample, $450(26 \%)$ appeared to have inaccurate data: this includes both records showing zero days elapsed and records which show the sequence of events (initial workorder and final invoice submission) reversed. Of the remaining $74 \%$. $(1,307$ records), $64 \%$ chowed a passage of 90 days or fewer from the workorder dispatch to the date an invoice was received from the CAA.

Table 6 Installiation to Invoice Submission: all subprograms.

Finally, all records showing both an installation date (P_DATE_INS) and an invoice submission date (DATE_BACK) were examined. This subsample amounted to 2,561 records, or $74 \%$ of the total sample. Again, a large number of records $(567$, or $22 \%$ ) were in reversed sequence, the invoice submission date preceding the installation date. Of the $78 \%$ (1,994 records) that were in proper order, the median time elapsed between installation and invoice submission was 22 days.

\section{Conclusions}

The number of invalid entries for the time elapsed from work order dispatch to completion of audit (31\%); from work order dispatch to completion of installation (18\%); from the dispatch to invoice submission (26\%); and from installation to invoice (22\%); makes difficult any generalizations from an analysis of the data. Apparently CONN Save did not demonstrate sufficient or consistent quality control in its data entry activities and/or checking the data submissions from the CAAs. This problem is highlighted by the absence of identifiable trends in the time periods for which valid entries have been recorded.

For example, one would expect that the agencies whose performance surpassed expectations would have shorter elapsed time from work order dispatch to completed installation. There are no such correlations-except in the case of TEAM in Tables 2 and 4 . Table 4 reveals that the agency with the worst record on completions is also the only agency to significantly surpass the ninety day requirement from work order dispatch date to completed installation (110 day median, based on 34 records). TEAM also required an average of 21 days to process applications and receive a work order dispatch from CONN Save--the other four agencies required an average of 11 days. Yet data from the other four agencies-including an "underperforming" CAA--demonstrate no clear trends. Therefore the recommendation which suggests itself from this analysis addresses the quality of the data entry process for record tracking. CONN Save can be more vigilant in monitoring the data entry process and troubleshoot more frequently to detect and 
respond to elapsed times which surpass expectations. More agency-specific recommendations could follow from more extensive interviews between CONN Save staff and CAA program managers. 

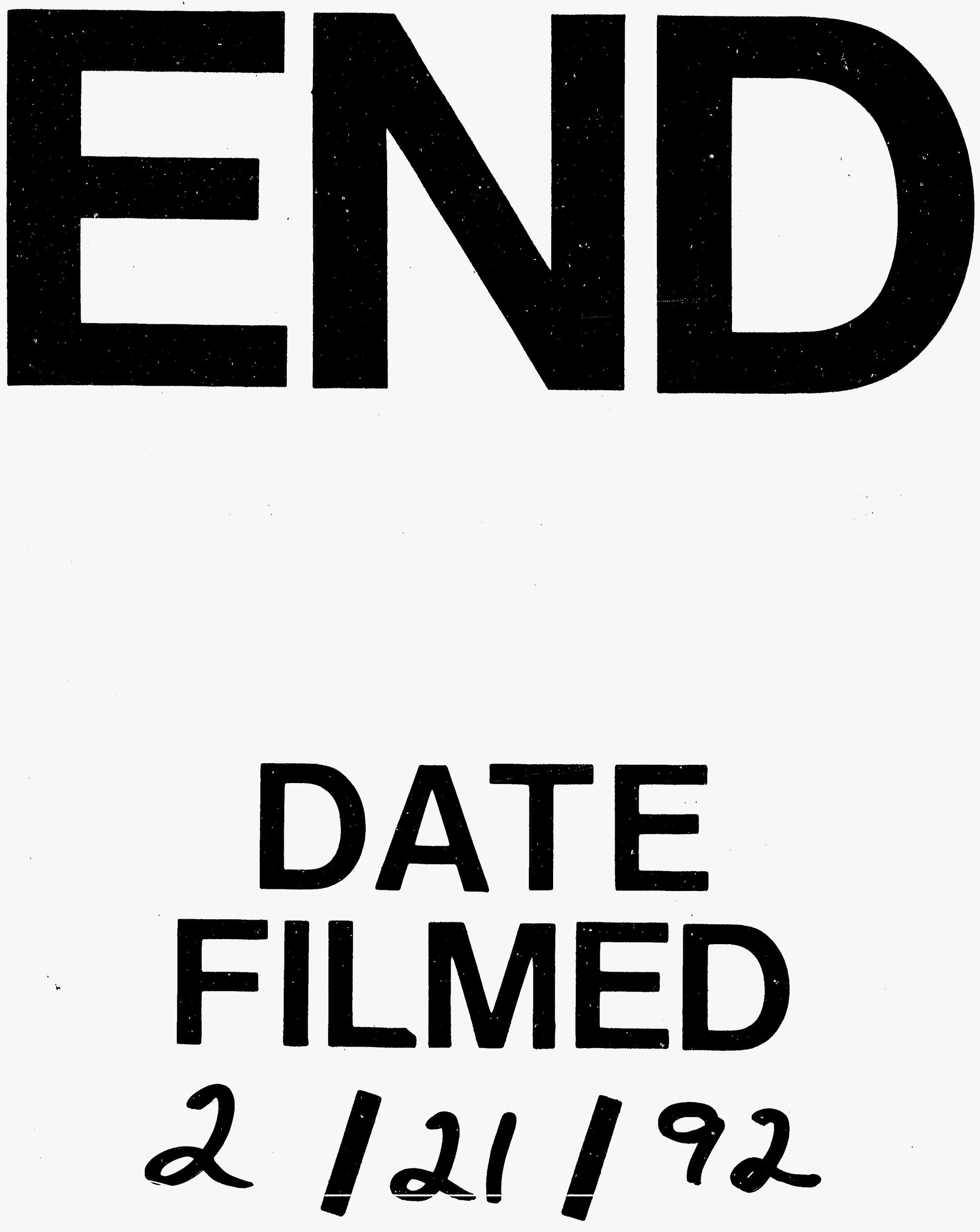
